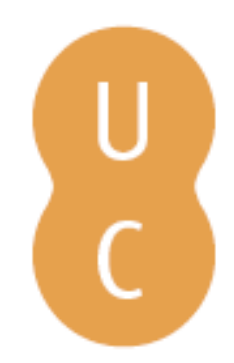

\title{
pommalina
}

\section{Patrimónios de influência portuguesa: modos de olhar}

Autor(es): $\quad$ Rossa, Walter; Ribeiro, Margarida Calafate

Publicado por: Imprensa da Universidade de Coimbra

URL

persistente: URI:http://hdl.handle.net/10316.2/37429

DOI: $\quad$ DOI:http://dx.doi.org/10.14195/978-989-26-1041-2

Accessed : $\quad$ 19-Jan-2017 10:41:39

A navegação consulta e descarregamento dos títulos inseridos nas Bibliotecas Digitais UC Digitalis, UC Pombalina e UC Impactum, pressupõem a aceitação plena e sem reservas dos Termos e Condições de Uso destas Bibliotecas Digitais, disponíveis em https://digitalis.uc.pt/pt-pt/termos.

Conforme exposto nos referidos Termos e Condições de Uso, o descarregamento de títulos de acesso restrito requer uma licença válida de autorização devendo o utilizador aceder ao(s) documento(s) a partir de um endereço de IP da instituição detentora da supramencionada licença.

Ao utilizador é apenas permitido o descarregamento para uso pessoal, pelo que o emprego do(s) título(s) descarregado(s) para outro fim, designadamente comercial, carece de autorização do respetivo autor ou editor da obra.

Na medida em que todas as obras da UC Digitalis se encontram protegidas pelo Código do Direito de Autor e Direitos Conexos e demais legislação aplicável, toda a cópia, parcial ou total, deste documento, nos casos em que é legalmente admitida, deverá conter ou fazer-se acompanhar por este aviso. 


\section{PATRIMÓNIOS de INFLUÊNCIA PORTUGUESA: modos de olhar}

WALTER ROSSA

MARGARIDA CALAFATE RIBEIRO

[ORG.] 
0 uso do plural no título deste livro, Patrimónios de Influêncio Portuguesa: modos de olhar, visa suscitar a pluralidade dos olhares sobre um objeto que resulta da composição de muitos outros. É, digamo-lo, a proclamação de um princípio multidimensional: não há um património com uma só origem, de um agente ou um grupo, que uma vez questionado dê sempre as mesmas respostas. Tudo depende do contexto a partirdo qual se lança o olhar, sendo a influêncio portugueso o operador comum que, com recurso à História, organiza e disciplina os limites, sem contudo os balizar. Influência nos diversos âmbitos e patamares da interculturalidade: formal e informal, administrativa ou espiritual, comercial ou migracional, colonial e pós-colonial.

Eis como, de forma muito sucinta, a problemática contemporânea do património nos apresenta dois desafios basilares: o reconhecimento de alteridades no seio de uma comunidade alargada e o desenvolvimento sustentável. No contexto do projeto que tem como eixo o programa de doutoramento Patrimónios de Influência Portuguesa, e de tudo quanto se tem vindo a constituir em seu redor, isso é material de fundação e inspiração.

in "Modos de Olhar" 
O L H A R E S 


\title{
TÍTULO DO LIVRO
}

Patrimónios de Influência Portuguesa: modos de olhar

\section{EDIÇÃo}

Imprensa da Universidade de Coimbra

Email: imprensa@uc.pt

URL: http://www.uc.pt/imprensa_uc

Vendas online: http://livrariadaimprensa.uc.pt

Fundação Calouste Gulbenkian

URL: http://www.gulbenkian.pt

Vendas online: http://www.montra.gulbenkian.pt

Editora da Universidade Federal Fluminense

\section{ORGANIZAÇÃO}

Walter Rossa

Margarida Calafate Ribeiro

\section{AUTORES}

Ana Maria Mauad, António Sousa Ribeiro, Eduardo Lourenço, Francisco Bethencourt, Francisco Noa, Graça dos Santos, Helder Macedo, José Pessôa, Luísa Trindade, Luís Filipe Oliveira, Margarida Calafate Ribeiro, Maria Fernanda Bicalho, Miguel Bandeira Jerónimo, Mirian Tavares, Renata Araujo, Roberto Vecchi, Sandra Xavier, Sílvio Renato Jorge, Vera Marques Alves e Walter Rossa

\author{
PRODUÇÃO \\ Nuno Lopes \\ REVISÃo \\ Maria da Graça Pericão \\ DESENHO GRÁFICO \\ António Barros
}

CAPA

Helena Rebelo

INFOGRAFIA

Alda Teixeira

EXECUÇÃO GRÁFICA

Norprint - a casa do livro

ISBN

978-989-26-1040-5

ISBN DIGITAL

978-989-26-1041-2

DOI

http://dx.doi.org/10.14195/978-989-26-1041-2

DEPÓSITO LEGAL

$397619 / 15$

(C) SETEMBRO 2015, IMPRENSA DA UNIVERSIDADE DE COIMBRA 


\section{PATRIMÓNIOS de INFLUÊNCIA PORTUGUESA: modos de olhar}

WALTER ROSSA MARGARIDA CALAFATE RIBEIRO [ORG.] 
(Página deixada propositadamente em branco) 


\section{Í N D I C E}

MODOS DE OLHAR ...................... 9 Walter Rossa e Margarida Calafate Ribeiro

1. ${ }^{\mathrm{a}}$ PARTE: CONCEITOS

1. Língua, comunidade e conhecimento . . . . . . . . . . . . . . 39 Helder Macedo

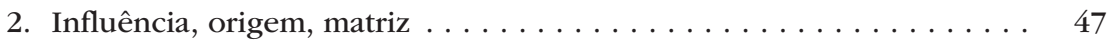
Renata Araujo

3. Identidade, herança, pertença . . . . . . . . . . . . 65 Roberto Vecchi

4. Memória ............................ 81 António Sousa Ribeiro

5. Colonialismo moderno e missão civilizadora . . . . . . . . . . . . 95 Miguel Bandeira Jerónimo

6. Colonização e pós-colonialismo: as teias do património . . . . . . . . . 121 Francisco Bethencourt

ENTREVISTA COM EDUARDO LOURENÇO . . . . . . . . . . . . . . . 149

2. ${ }^{\mathrm{a}}$ PARTE: DISCURSOS E PERCURSOS

1. Patrimónios da palavra: reescritas nas literaturas de língua portuguesa . . . . . . . . . . . . . . . . 173 Margarida Calafate Ribeiro 
2. Literatura, narrativas, discursos: o poder do discurso e a arte da narração............................ 225

Francisco Noa

3. Leitura, citação, tradução . . . . . . . . . . . . . . . . . . . . . . 241 Sílvio Renato Jorge

4. Corpo, voz e língua como patrimónios de emigração . . . . . . . . . . . . 257 Graça dos Santos

5. Territórios e redes na historiografia $\ldots \ldots \ldots \ldots \ldots \ldots \ldots$ Maria Fernanda Bicalbo

6. Dos documentos à história e aos arquivos . . . . . . . . . . . . . . 305 Luís Filipe Oliveira

7. Práticas e materialidades, etnografias e antropologia . . . . . . . . . . 329 Sandra Xavier e Vera Marques Alves

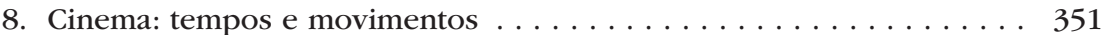
Mirian Tavares

9. Fotografia pública e poder. . . . . . . . . . . . . . . . . . . . . . 377 Ana Maria Mauad

10. Desenho: discurso e instrumento . . . . . . . . . . . . . . . 401 Luísa Trindade

11. A arquitetura como documento . . . . . . . . . . . . . . . 453 José Pessôa

12. Urbanismo ou o discurso da cidade . . . . . . . . . . . . . . . . . . . 477 Walter Rossa 


\section{A G RAD E C IMENTOS}

Agradecemos a:

Fundação Calouste Gulbenkian.

Centro de Estudos Sociais da Universidade de Coimbra.

Instituto de Investigação Interdisciplinar da Universidade de Coimbra.

Débora Santos.

Helena Salgado.

Maria da Graça Pericão.

Maria João Padez.

Nuno Lopes. 
(Página deixada propositadamente em branco) 
MODOS DE OLHAR 
(Página deixada propositadamente em branco) 


\section{MODOS DE OLHAR}

Este livro visa dar conta da proposta científica, teórica e metodológica do projeto Patrimónios de Influência Portuguesa segundo os seus diversos modos. Este texto pretende abrir a sua discussão através do olhar dos seus fundadores. Impõe-se contextualizar e expor as motivações e linhas mestras do pensamento que preside a este projeto científico, académico e de transferência de conhecimento para sociedade. Em seguida detalhamos o processo que conduziu à construção desta obra.

\section{Património e política(s)}

Em Português, Espanhol, Francês e Italiano, línguas novilatinas faladas quotidianamente por cerca de $3,7 \%$ da população mundial, utiliza-se o termo património para o que em Inglês se designa por heritage, forma que, por tal razão, acaba por ser a de uso globalmente mais franco. ${ }^{1}$ Ambos têm étimos latinos que se referem ao que é recebido dos pais, a herança familiar que é uma das garantias basilares proporcionadas pelos sistemas jurídicos de sociedades ocidentais estáveis. Desde logo se impõem, assim, não apenas as condições de identificação e de pertença, mas também as de ava-

${ }^{1}$ Inicialmente, no universo anglo-saxónico, utilizou-se com frequência o termo property, o qual subsiste confinado à designação dos bens em si e já não tanto ao todo temático-disciplinar. 
liação e valorização. Razões suficientes para serem adotados como designação do que constitui o legado cultural integrado que agrega uma comunidade. ${ }^{2}$ A sua utilização, no Brasil, na designação de um dos primeiros organismos com atuação na área, o Serviço do Patrimônio Histórico e Artístico Nacional (SPHAN) criado em 1937, foi singularmente precoce. Com efeito, património (ou heritage) surge raramente e de forma tímida em textos doutrinários anteriores, como na Carta de Atenas de $1931,{ }^{3}$ e só foi plenamente assumido com esse outro significado no crepúsculo da segunda modernidade, sendo sua pedra de toque a Loi Malraux de 1962, que, aliás, a consagra no título. ${ }^{4}$ Essa lei, não só alterou de forma radical e inovadora a atuação do estado francês na área da cultura, como serviu de modelo a outros, como o português, e inspirou diretamente a Carta de Veneza de 1964,5 que permanece como base da doutrina internacional para a conservação e restauro dos monumentos e sítios. Muitas outras convenções, cartas, recomendações internacionais se lhe têm seguido, as quais, entre diversos desenvolvimentos, têm vindo a alargar o conceito de património a outro tipo de bens culturais, que não apenas os tangíveis. ${ }^{6}$

Embora nessa doutrina e fóruns ${ }^{7}$ internacionais do património tenha já sido atingido um patamar de harmonização para as ques-

2 Deve-se ainda assinalar, pois não é este o lugar para discutir a necessidade, ou não, da junção de um ou outro termo, como histórico ou cultural, que explicite essas significações. Aliás, na aceção mais ampla de património, a expressão património cultural não será mais do que uma redundância, e património bistórico uma restrição, também ela redundante.

3 International charters...: 31.

4 "Loi n. ${ }^{\circ}$ 62-903 du 4 août 1962 complétant la législation sur la protection du patrimoine historique et esthétique de la France et tendant à faciliter la restauration immobilière."

5 International charters...: 37.

${ }^{6}$ International charters...

7 United Nations Educational, Scientific and Cultural Organization [UNESCO], International Council of Monuments and Sites [ICOMOS], International Council of Museums [ICOM], entre outros. 
tões e procedimentos mais comuns, nos enfoques, na teorização e conceptualização, na normativa e nas práticas de atuação, entre os diferentes universos culturais - desde logo entre os das culturas latinas e anglo-saxónicas - subsistem desconhecimentos e diferenças sensíveis, cada vez mais ampliadas e questionadas. Estes são a expressão clara da falta de condições e espaço para o diálogo entre formas diversas de olhar, ver, sentir, e pensar. Diferenças que, além das que advêm das componentes objetivas e materiais do que é considerado património em cada cultura, têm ainda origem nas grandes assimetrias de desenvolvimento, nem sempre combatidas de forma solidária ao longo do período em que a temática do património se desenvolveu - e de que se destaca todo o processo colonial - até atingir a relevância e transversalidade que hoje tem. Daí, e desde logo, a impossibilidade de falar com autoridade e propriedade sobre o património do outro, mas também a inutilidade de pensar o meu isoladamente, o que nos leva a concluir sobre a necessidade de dialogar sobre ambos os patrimónios para se incrementar o conhecimento em geral.

No Ocidente, o interesse pelos legados do passado é algo quase tão antigo quanto a civilização (Choay, 1992; Harvey, 2001). Todavia, a sua institucionalização ocorreu apenas na era das revoluções, focalizando-se em bens materiais autonomamente valorizados como monumentos (Riegl, 1903), tendo também sido este o momento do início do interesse pelo património urbano (Choay, 1992). O percurso do monumento ao património correspondeu cronologicamente ao curso da Idade Contemporânea, pois o conceito-ação património só se universalizou, desmaterializou e tornou consequente nas décadas em que se assistiu ao ocaso do colonialismo, ao empenhamento do Movimento dos Não Alinhados, ao sucesso das lutas pelos direitos civis na América do Norte, às lutas anti-apartheid na África do Sul, entre outros marcos sincréticos do fim da segunda modernidade, que determinaram uma concreta redefinição do mapa mundo. 
A construção da consciência da relevância civilizacional integradora do património é uma ação que tem a sua origem no Ocidente, tendo depois seguido o caminho da globalização, assistindo-se agora ao seu reconhecimento geral como um direito e não um privilégio, um ativo sócio-económico e não um fardo. Em suma, tendo nascido no Ocidente com a nostalgia romântica associada ao emergir da era da indústria e do colonialismo moderno, o património é hoje matéria na construção global da terceira modernidade. Já não são as opções, os métodos e técnicas de intervenção física em contextos monumentais o fulcro dos debates sobre património, ${ }^{8}$ mas sim as opções de fundo no âmbito mais nobre da ação política e cidadã, o que abre portas a uma maior participação e ao estabelecimento de plataformas democráticas para o exercício da subsidiaridade.

Todavia, a condição matricial de pertença inerente ao termo património, bem como a matriz romântica dos nacionalismos do Ocidente que levou ao florescimento do conceito de monumento, constituem um pesado lastro com que temos de lidar quando afloramos os antecedentes teóricos e conceptuais das teorias do património. $\mathrm{Na}$ verdade, os sucessivos documentos doutrinários e convenções internacionais ainda não lograram nem erradicá-los nem renová-los, prevalecendo, assim, um apolítico senso comum, que não ignora a essência da questão, mas que não convoca para a discussão todos os atores. Daí a clara e muito pertinente questão formulada no célebre título de Stuart Hall (1999), património de quem? Património partilhado foi a resposta institucionalmente adotada. Naturalmente, ela não podia ter a receção que se pretendia, conduzindo antes a frequentes conflitos e equívocos de interpretação e jurisdição, a

\footnotetext{
${ }^{8}$ Isso não significa que esse tipo de interesses se tenha extinguido. Bem pelo contrário, a evolução científica e tecnológica não para de inovar, disponibilizando soluções cada vez mais desenvolvidas e variadas. Contudo, longe estão os debates sobre o restauro arqueológico, o restauro estilístico, o restauro científico, o restauro crítico, para apenas referir exemplos comuns (Gonzaléz-Varas, 2000).
} 
começar pela ideia de Património Mundial estabelecida na respetiva convenção de 1972 e suas sucessivas atualizações. ${ }^{9}$ Subsistem, assim, sobre o conceito e a ação em património e de formas variadas estigmas de restrição, de exclusividade, de identificação, de não reconhecimento de alteridades que, em contextos globalizados, pós-coloniais e politicamente reconhecidos como inter ou multiculturais, levantam problemas eminentemente políticos, complexos e diversificados. O que é então património e para quem?

Só é património o que suscita o interesse de alguém, preferencialmente de quem, por alguma forma, esteja inserido na comunidade institucionalmente melhor posicionada para o poder proteger, usufruir e desenvolver. É essa a forma mais direta para se entender porque é que o património é essencialmente um problema de poder e, por conseguinte, um problema de matriz política. Interessar implica existir, ter um determinado valor para uma comunidade ou um grupo, o que faz do património um ativo presente e que, como tal, não é fixo, nem seguro, requerendo atenção e gestão permanentes, ou seja, estudo, divulgação, planeamento e desenvolvimento. Isto conduz-nos ao universo de questões relacionadas com a temática da sustentabilidade. Assistimos hoje - designadamente na discussão para a Post 2015 UN Framework - à assunção da cultura como o quarto pilar da sustentabilidade, ou seja, em paridade com as esferas económica, social e ambiental, tal como ao seu reconhecimento universal como motor do desenvolvimento. ${ }^{10}$

Em suma, é já vasto o consenso de que a cultura - e nela necessariamente o património - é crucial para o desenvolvimento sustentável, desempenhando de forma crescente um papel fundamental na construção da paz, na condução de processos de reconciliação, no

9 "Convention Concerning the Protection of the World Cultural and Natural Heritage." in International charters...: 43.

10 Creative economy report $2013 \ldots$ 
estabelecimento de pontes de diálogo e cooperação, incontornavelmente baseadas no entendimento mútuo. Reconhecer a cultura do outro é, basicamente, reconhecê-lo como sujeito da história, como par no desenvolvimento da Humanidade. Ignorar a cultura do outro é aniquilá-la, em suma, destruir a justificação da sua ideia de ser em comunidade, em diálogo com outras.

O património oferece-se, assim, como uma plataforma ideal para a interação das áreas do pensamento e ação política e cultural com os mais diversos estratos sociais, campos de atividade e domínios disciplinares, capazes de desenhar uma cultura de respeito e paz. Património é, portanto, um fenómeno com múltiplas origens e explicações, cujo foco mais florescente está no papel crescente que o lazer - e, com ele, a massificação da cultura, como bem de consumo -, tem vindo a assumir nas atividades e economia da sociedade pós-fordista. O turismo é disso a maior expressão, mas também o seu maior risco. Note-se a relevância sócio-económica que a comunicação, o marketing, o branding, a imagem, a produção de conteúdos, adquiriram no contexto da globalização veiculada pelo desenvolvimento tecnológico, e como tudo isso tem como fundo a ideia de património, começando pela própria língua (Reto, 2012). O património, além de contribuir para a integração e consolidação no seu âmbito de domínios não materiais do legado cultural, ocupa, assim, um lugar central na ação política e diplomática, mesmo que nem sempre consciente ou assumida, o que o torna num instrumento temível, e, por isso, suscetível de escrutínio, seleção e elaboração teórica permanentes nas sociedades de maior solidez e vivência democráticas.

\section{Patrimónios e política}

A perspetiva de trabalho interdisciplinar no âmbito mais lato do património, adquiriu, há poucos anos, a designação de critical 
heritage studies e conta já com uma associação, ${ }^{11}$ eventos regulares e múltiplos textos de referência (Smith, 2012; Harrison, 2013; Waterton e Watson, 2015). Segundo essa forma algo institucionalizada é, contudo, um processo na prática ainda confinado ao tendencialmente hegemónico universo académico e científico anglo-saxónico, o qual, como se sabe, não se restringe aos países de língua inglesa, embora os principais debates, publicações e agentes sejam, de forma expressiva, ingleses, australianos, americanos e canadianos, o que não tem deixado de ser objeto de uma intensa, saudável e profícua autocrítica. Contudo, tal circunstância não só determina os casos empíricos e os temas em debate, como gera autosuficiência e dificuldades à penetração de casos e temas terceiros. É significativo que linhas de reflexão com uma genealogia tão longa e densa, como são os casos italiano e francês, mas também de linhas de reflexão mais recentes, nomeadamente de países herdeiros de grandes legados coloniais, sejam praticamente ignorados, ainda que todos se encontrem e façam ouvir os seus argumentos nos fóruns internacionais de fixação de normas e recomendações comuns.

Laurajane Smith, no seu livro de 2006, defende a ideia de património como discurso, recorrendo a métodos de análise crítica do discurso inspirados em Michel Foucault, ${ }^{12}$ e cunhou o sintagma authorized heritage discourse (que poderemos traduzir como discurso dominante em património) como forma de exprimir o quanto o pensamento sobre património se impõe ao resto do mundo, no âmbito do processo de globalização. Esta denúncia do pensamento sobre o património como eurocêntrico requer, de acordo com a autora, a

\footnotetext{
$11 \mathrm{http}: / /$ criticalheritagestudies.org

12 A autora dá apenas como referência o texto de Stuart Hall (2001), "Foucault: power, knowledge and discourse", in M. Wetherell, S. Taylor and S. J. Yates (ed.), Discourse theory and practice: a reader. London: Sage. Ver ainda Waterton et al. (2006) e o capítulo de Zongjie Wu e Song Hou "Heritage and discourse" in Waterton e Watson (2015: 21-36).
} 
instalação de uma ação crítica permanente, através dos já referidos critical heritage studies. Deixa também claro o quanto esta denúncia tem raízes no pensamento sobre as tradições e comunidades inventadas e imaginadas de Eric Hobsbawm e Terence Ranger (1983) e Benedict Anderson (1983), e posteriores desenvolvimentos de Stuart Hall (1992 e 1999) e alguns outros. Não por acaso são autores contemporâneos que podemos considerar da área dos estudos culturais (cultural studies) ${ }^{13}$ cujo pensamento vemos inspirar outros textos que são referências para os debates atuais sobre património, num alargado universo anglo-saxónico (Lowenthal, 1998; Graham et al, 2000; Graham e Howard, 2008; Harrison, 2013; Waterton e Watson, 2015). Autores que também deixaram a lição da importância de levar a interdisciplinaridade ao diálogo com o pensamento de outras culturas - e, se possível, línguas - ou seja, até à interculturalidade.

De facto, nesses textos chave para os critical heritage studies é algo pálido e indireto, ${ }^{14}$ o recurso às propostas que alargaram a reflexão a outras geografias e culturas, como as elaboradas por Valentin-Yves Mudimbe (1988) para África ou Walter Mignolo (2000) a partir da América Latina. Mas foi, sem dúvida, com o questionamento lançado ao Ocidente, em 1978, por Edward Said, em Orientalism, no âmbito do que foi cunhado como estudos pós-coloniais, que a grande questão, não só sobre os pressupostos de origem da narrativa europeia, mas da sua hegemonia, ficou colocada. Assim se abriu espaço para que outros questionamentos e outras narrativas pudessem ser lançados a partir de várias geografias. Desde o grupo dos subaltern studies da Índia com o icónico texto de Gayatri Spivak, "Can the

13 O Centre for Contemporary Cultural Studies, fundado em 1964 na University of Birmingham por Richard Hoggart, e que desde logo teve como principal propulsor Stuart Hall, foi a casa-mãe deste fecundo movimento científico, académico e político interdisciplinar.

${ }^{14}$ A grande e recente exceção é o capítulo de John Giblin "Critical approaches to post-colonial (post-conflict) heritage" in Waterton e Watson (2015: 313-328). 
subaltern speak?" (1988), ou seja, podem os subalternos contar a história?, aos australianos que em The empire writes back (Ashcroft et al., 1989) - título inspirado no famoso artigo de Salman Rushdie "The Empire writes back with a vengeance" (1982) ${ }^{15}$ - colocaram sob suspeita o cânone literário emanado pelos centros coloniais. É nessa linhagem que se insere o já referido e muito citado "Whose Heritage?", do jamaicano Stuart Hall (1999). Foi assim que o discurso crítico europeu foi levado a (re)questionar-se, não apenas internamente, numa linha que vai de Las Casas e Montaigne a Michel Foucault, mas a partir de outros lugares que a Europa tocou. É, de facto, relevante registar como todos estes autores dos estudos culturais articularam o seu pensamento com a reflexão teórico-metodológica de base ocidental da área do pós-estruturalismo. Como refere Miguel Vale de Almeida, "Foucault e Gramsci influenciando Said, Derrida influenciando Spivak, ou Lacan influenciando Bhabha, por exemplo" (Almeida, 2000: 228).

Nesta aceção, os estudos culturais são a base de reflexão dos critical heritage studies e, para o alargamento destes a uma escala global, torna-se necessário recuperar a sua ligação umbilical com os estudos pós-coloniais e a sua ética política e científica. Num universo académico anglo-saxónico essencialmente composto por investigadores e casos de estudo geograficamente confinados ao norte da Europa e da América e à Oceânia, é compreensível que a discussão de temáticas de património em agenda se centrem em temas como autenticidade, memória, sítio, representação, reconhecimento, tradição, discurso, dissonância, identidade, afetos, emoções, turismo, museologia possa dispensar essa ligação. Todavia para quem, como nós, se propõe fazê-lo sobre e com colegas da América do Sul, de África e da Ásia, isso é inviável, até por que a essa lista impõe-se uma outra agenda de temas de âmbito mais lato sob as categorias

15 Times (Londres), 3 de julho de 1982. 
língua e território, segundo as quais estruturamos a ação do nosso grupo de investigação e, assim, deste livro. São opções políticas que decorrem da necessidade de alicerçar e renovar os debates e teorias sobre património de forma integrada e abrangente, ou seja, sair do mais privilegiado espaço dos países ex-colonizadores para mergulhar naqueles onde o papel da cultura nas políticas nacionais possa ser determinante para o estabelecimento de um desenvolvimento efetivamente sustentável, ou seja, de matriz endógena e não induzida.

Eis como, de forma muito sucinta, a problemática contemporânea do património nos apresenta dois desafios basilares: o reconhecimento de alteridades no seio de uma comunidade alargada e o desenvolvimento sustentável. No contexto do projeto que tem como eixo o programa de doutoramento Patrimónios de Influência Portuguesa (doravante Patrimónios), e de tudo quanto se tem vindo a constituir em seu redor, isso é material de fundação e inspiração.

O uso do plural na designação do objeto Patrimónios, visa suscitar a pluralidade dos olhares sobre um objeto que resulta da composição de muitos outros. É, digamo-lo, a proclamação de um princípio multidimensional: não há um património com uma só origem, de um agente ou um grupo, que uma vez questionado dê sempre as mesmas respostas. Tudo depende do contexto a partir do qual se lança o olhar, sendo a influência portuguesa o operador comum que, com recurso à História, organiza e disciplina os limites, sem contudo os balizar. Influência nos diversos âmbitos e patamares da interculturalidade: formal e informal, administrativa ou espiritual, comercial ou migracional, colonial e pós-colonial.

O espaço de influência portuguesa é culturalmente estruturado pela língua, ${ }^{16}$ mas é territorialmente mais vasto; resulta de processos

\footnotetext{
16 Só os países onde o Português é língua oficial e que ocupam cerca de 7,25\% da superfície continental do planeta, somam mais de 250 milhões de falantes, fazendo do Português a quarta língua mais usada (Reto, 2012).
} 
coloniais, mas extravasa as fronteiras do que integrou o Império; foi ativado por Portugal, mas há muito que o seu desenvolvimento e dinamização são essencialmente produzidos por outros em outras bases territoriais, étnicas e linguísticas. Espaço que geograficamente vai de Deshima em Nagasaki ao Rio da Prata, e da Ferry Street de Newark a Tutuala, em Timor, e no tempo se desenvolve desde a Reconquista Cristã (Fig. 1).

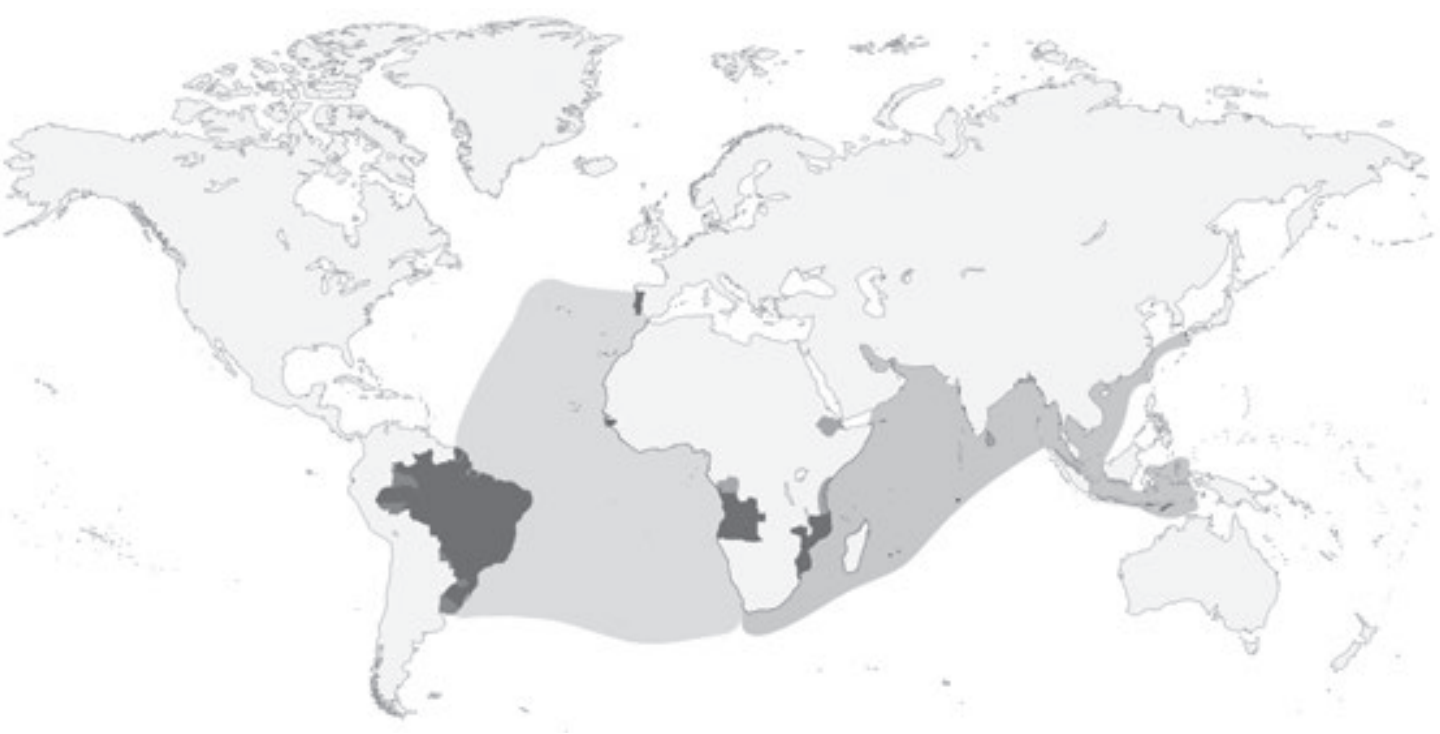

Fig. 1 Espaços de influência portuguesa, sem a produzida pela emigração contemporânea.

A influência portuguesa é, assim, um espaço que extravasou na geografia e no tempo os limites formais das sucessivas configurações geopolíticas do antigo Império, produzindo transculturalidades intensas e difusas, celebradas e ocultas, ostensivas e sensíveis, que o pós-colonialismo vai fragmentadamente absorvendo. O que pretendemos com o Patrimónios é catalisar o desenvolvimento e a integração do conhecimento sobre tudo isso. Procuramos significados, 
representações, alcances, intenções, reconciliação na celebração da diferença com base na identificação do que é comum. E assim vai florescendo o objetivo estratégico da constituição do Patrimónios como um think tank sobre o espaço das culturas de Língua Portuguesa, que potencie o seu desenvolvimento harmonioso, integrado e sustentado.

$\mathrm{Na}$ base desta reflexão, como no próprio programa de doutoramento com o qual iniciamos o processo deste projeto, encontramos duas pedras angulares: língua e território, o que tem tradução não imediata nos dois ramos de titulação dos seus doutorados: Estudos Culturais e Arquitetura e Urbanismo. Não é direta a correspondência entre esses dois eixos e ramos, nem a divisão entre imaterial e material, intangível e tangível, que estrutura os discursos e ações sobre património. Todavia, apesar do caráter difuso de todas as fronteiras implícitas, é tão fácil aceitar a relação de nexo entre esses sucessivos pares, quanto a complementaridade interna de cada um deles. O modo de olhar é interdisciplinar e pós-colonial. Foi sobre essas dualidades difusas que se estabeleceu e desenvolveu este projeto. Uma vez que o desafio central colocado ao longo do processo de preparação deste livro consistiu em elencar ou enumerar, expor e discutir conceitos e instrumentos seminais na investigação sobre patrimónios de influência portuguesa, comecemos por, sumariamente, colocar sobre a mesa como e por que olhamos esse objeto segundo os pares território-língua e arquitetura e urbanismo-estudos culturais.

\section{Território e língua: os dois polos do património vivo}

Nas suas aceções de uso mais comum, território é daqueles termos que utilizamos sem quase refletir sobre eles. Mesmo referido num contexto francamente aberto, território tem integrada uma relação 
de pertença e até de soberania, ou seja, nunca é terra de ninguém, é património de alguém. A relação de pertença do território faz com que seja uma parte importante da identidade. O território ou a terra onde se nasce, de onde se "é natural", é um dado fundamental na identificação do indivíduo, embora há já muito tenha deixado de ser comum fazer do topónimo nome de família. Identidade que se estende às comunidades. Desterrar, deslocar, expatriar são, entre outros, termos que ilustram de forma dramática a relevância da relação entre território e identidade.

Outra característica relevante do território é o limite que, sendo terrestre, é fronteira, até porque do lado de lá está sempre o território de outrem. Limites e fronteiras que, de muitos modos, constituem barreiras que dão forma aos territórios. Mas na realidade o que é, como se nos configura a forma de um território? Sob representação, um território é algo cuja dimensão não nos permite percecioná-lo de forma clara através de um simples olhar. Ninguém forma uma imagem de um território sem o recurso a instrumentos de mediação, ou seja, de representação, escritos ou desenhados. O que, no limite, pode levar a considerar que em termos reais, palpáveis, no seu todo um território só é processável através da abstração. Com ela se operam questões fundamentais, como a escala e a hierarquia. Em síntese, territórios contêm territórios.

Até aqui referimo-nos ao território apenas como infraestrutura primária, que de facto é, e, como tal, ele é a base material para o desenvolvimento da ação humana, que nele se concretiza e manifesta, por regra de forma tão mais intensa e marcada quanto a sua generosidade em recursos. A referida dialética território-identidade é dinamizada por essa ação e vai produzindo registos que, em grau crescente de mutabilidade, estruturam, dão forma e compõem a imagem do território, que frequentemente enfatizamos como "humanizado". O território é a mais viva expressão física das culturas que nele se desenvolvem, o que nos remete para a sua 
organização, expressão e leitura em palimpsesto. É uma analogia frequente, mas que tem como problema o facto de a preexistência interagir sempre com o que lhe advém, assim se transformando em recurso do território. Por isso mesmo, a preexistência nunca se pode apresentar como inerte, neutra perante a passagem do tempo como a mensagem do palimpsesto autêntico, pois nele não é a materialidade que conta.

Essa densidade e complexidade expressiva do território detém uma outra valência por analogia, que lhe é mais própria: a hipertextualidade. Diversos aspetos de um território reportam aos de outros territórios. Neste sentido, a memória tem um papel óbvio de ativação e mediação. É um aspeto da máxima importância para a investigação em patrimónios, pois não só tinge tangível com intangível, como estabelece relações em rede fundamentais para a apreensão e compreensão de séries, influências, diálogos, imaginários. O território de investigação em patrimónios é necessariamente estruturado por essas redes, sendo os nós definidos pelos pontos dessa hipertextualidade, de entre os quais os mais óbvios são as cidades, mas também o espaço rural e todos os demais tipos de paisagem humanizada são compostos por signos que os relacionam com outros próximos e distantes no espaço e no tempo. Por isso, o território é um extraordinário arquivo da ação a que sempre serviu de suporte e recurso. Ativar essa informação é olhar patrimónios. Cruzá-la é encontrar protocolos de seriação e diferenciação, identificar culturas de território.

Trata-se de uma matéria contemporânea que ganha dimensão própria num mundo que, desde a primeira globalização, se foi crescentemente estruturando em redes, que hoje também estruturam os novos espaços, os virtuais, o que nos leva a uma questão importante: Podemos falar de territórios em rede? O espaço da influência portuguesa é isso mesmo, uma rede de territórios com cidades de culturas diversas, mas com coisas em comum. No seu 
todo, podemos considerá-lo um território, um território que contém territórios, que por sua vez contêm cidades que, na essência, são comunidades, pessoas? Pelo meio está quase sempre o mar que, por definição etimológica, não é território, mas por definição política integra territórios. São "águas territoriais" e "áreas económicas exclusivas", como o consagram convenções internacionais que, contudo, deixam livre extensas áreas de "águas internacionais", ou seja, áreas de todos e, assim, de ninguém.

O mar foi o suporte da expansão ibérica, sendo que, no caso português, se pode, de facto, dizer que, parafraseando o título original do clássico de Charles Boxer (1969), o Império viajou por mar. Por extrapolação natural, pode-se estabelecer que a influência portuguesa se veiculou por mar, usando suportes e processos variados, entre os quais as culturas da língua e do território têm papéis centrais e complementares.

Em Os Lusíadas, Luís de Camões descreve o território português como um espaço "onde a terra se acaba e o mar começa", elevando assim aquilo que em Gomes Eanes de Zurara, na primeira crónica da Expansão, a Crónica da Tomada de Ceuta (1450), era ainda uma descrição geográfica real, mas bloqueadora, - "cá nós de uma parte nos cerca o mar e da outra temos muro no reino de Castela" (Zurara, 1992: 52) - à condição de identidade de uma pátria e de um povo em expansão. Na epopeia, os portugueses são o povo eleito do Ocidente para empreender a viagem marítima em busca de uma "outra terra [que] comece" e onde o "mar acabe", ou seja, em busca de territórios que em breve veriam como seus, dando origem ao império. No movimento imprimido pela viagem narrada no poema, está a génese da elaboração de um discurso identitário fundador que Camões, bem longe do seu lugar de origem, colocou no Oriente. Esta descentralização que a epopeia camoniana faz do centro, Lisboa, capital do império a vir, para o Oriente, permite que esse seja o primeiro texto europeu que anuncia a Europa como lugar 
de origem, mas que a olha a partir de fora, pela deslocação da ação dos seus heróis para o Oriente.

Este gesto literário e político, profundamente moderno, explica que este texto seja simultaneamente um discurso de celebração da gesta portuguesa, e um discurso de dúvida pela visão que a vivência de novos quotidianos trazia e que, ao mesmo tempo que desafiava os portugueses, os questionava constantemente sobre quem eram, o que faziam, como faziam e qual o sentido da viagem que realizavam.

Nas sucessivas respostas elaboradas pelos portugueses às questões que lhes vão sendo colocadas, define-se um território de origem, o Ocidente, a que se liga uma religião, uma língua e, simultaneamente, um sentido de demanda, expresso na busca de terras a Oriente. A este aspeto, junta-se um outro elemento fundador da condição moderna de Portugal: o de mediador entre o Ocidente e o Oriente, o que eleva a sua condição de fronteira descrita por Zurara, a um elemento de comunicação e de domínio entre os mundos. A que se devem, portanto, estas duas definições do território português aparentemente tão díspares e quase contemporâneas? Talvez a chamada "questão da língua", nas palavras de Maria Leonor Carvalhão Buescu (1978), como foi vivida pelos gramáticos do século XVI, o possa explicar em termos dos conceitos que aqui nos preocupam: os territórios e o património, enquanto elemento herdado, conquistado e transformado, a que se liga uma cultura, expressa numa determinada língua.

E o que é, afinal, a "questão da língua", no século XVI? Algo de muito semelhante ao território que define uma nação, de facto. Assim, ao mesmo tempo que os gramáticos do século XVI lidam com o final do debate entre o latim e as línguas novilatinas - um eles e nós profundamente intereuropeu - defendendo novas formas de legitimação das línguas e permitindo a estabilização da língua portuguesa no território nacional em disputa e em diferença constante com o castelhano, lidam igualmente com toda a novidade 
que os novos lugares, novos povos, novas línguas e realidades iam trazendo à língua portuguesa, lançada numa viagem planetária.

Como os mapas que desenhavam territórios, permitindo uma visualização do que a viagem trazia, os textos da Expansão, escritos em língua portuguesa, foram outra forma de apreensão e de divulgação dos novos espaços em que escritores, escrivães e anotadores se debatiam com as dificuldades de descrever tudo o que viam e de decidir tudo o que deviam deixar ser visto e apreendido por quem lesse. Assim, ao mesmo tempo que se vai construindo o que João de Barros chamava o "nosso edifício", apelando à necessidade de gramáticas normativas que descrevessem e estabilizassem a língua portuguesa, adaptava-se este "edifício" às novas ideias, terras e coisas que as viagens traziam. Para além do desafio conceptual, tratava-se, também, de um grande desafio de poder não mais e somente na disputa das línguas novilatinas entre si, sobre qual iria substituir o latim na Europa, mas qual seria a língua de evangelização no mundo, atendendo ao sentido religioso que imbuía todas as viagens que desenharam a primeira modernidade europeia.

A língua portuguesa tornava-se, assim, na Europa, um dos instrumentos políticos de emancipação de Roma, pela grandeza que a empresa dos Descobrimentos the ia abrindo e, simultaneamente, um dos instrumentos cruciais de Portugal e de Roma na evangelização dos povos e na divulgação dos novos mundos à Europa. Mais do que um património, mais do que institucionalmente nacionais, as línguas novilatinas tornam-se uma realidade, onde o sentimento e a consciência nacional se afirmava como "pátria" e, no caso português, de uma "pátria" em expansão, como a definição territorial dada por Camões, tão claramente expressa. Assim, ao mesmo tempo que se realizam as grandes inscrições literárias que neste processo significam as obras que vão de Fernão Lopes a Luís de Camões ou Fernão Mendes Pinto, vai-se consolidando a afirmação da portugalidade, por diferença com Castela, e preconizando a prioridade do ensino 
gramatical da língua materna, através de uma nova cartografia da língua. Esta nova cartografia da língua, que desenhava já uma geopolítica da língua, baseava-se não apenas nos valores da gramática e da literatura latina - numa visão da língua como um património herdado, que a liga a uma raiz - mas também contemplava os valores conferidos pelos do uso da língua - o património vivido, dinâmico, em transformação e, portanto, em reutilização por inúmeros sujeitos, que a irão adotar em diversos graus de comprometimento, em relação à norma ou falando-a em diferença.

A celebrada alma portuguesa pelo mundo repartida foi, sobretudo, língua falada, deixada, reusada, reciclada e utilizada como instrumento de comunicação e depois expressão, foi língua espalhada pelo mundo, por territórios tão díspares como pedaços de território no Extremo Oriente e a grande extensão do Brasil. Nas palavras de Eduardo Lourenço, o derramamento, a Expansão, a creoulização da língua portuguesa, foi como a nossa "conquista", mais filha da obra do acaso e da ganância do que uma premeditada "lusitanização", como por vezes imaginamos ou até as premonições dos gramáticos, dos geógrafos, dos escritores e dos navegantes do século XVI nos poderiam hoje sedutoramente induzir.

Também por isso, mas sobretudo por novas relações de forças locais que têm a ver com os processos de colonização e a necessidade de unicidade linguística em sociedades multilingues - pela fragilização do território que essa condição comporta - no momento de luta e de inscrição de um sentimento nacional brasileiro, angolano, moçambicano, cabo-verdiano, guineense, são-tomense foi nessa língua imperial, veiculadora dos costumes, da lei e do rei que a levou, que, subvertida, se foi tornando capaz de brasileiramente falar ou de angolanamente se pronunciar. Desta forma, noutros textos e traçando os mapas de outras histórias, foram começando a ser preenchidos os espaços em branco da história colonial, ou, por outras palavras, começaram a ser colocados sob suspeita os monopólios do conhe- 
cimento e do poder que tinham sido fundamentais no erigir de uma ordem social e política colonial baseada na diferença.

A narrativa dessas outras histórias foi feita na língua imperial, tomada em muitos momentos de luta política e - para usar a expressão de José Luandino Vieira - como "um troféu de guerra", em que a língua de colonização e opressão se transformou numa língua de emancipação. Foi assim que, nesta língua, foram questionados os textos de viagem, como espaços de descrição de uma invasão e rotura, nela foram expressas outras identidades e pronunciada a diferença cultural que se dizia Angola, Moçambique, Guiné-Bissau, São Tomé, Cabo Verde e que justificou os atos políticos das várias independências políticas, sociais e culturais. E, como no século XVI diria o gramático Nunes Lião, "não foi por a bondade de língua, mas por a necessidade que dela têm aquelas gentes que dela usam" (Lião, 1978: 98), o que levou Guimarães Rosa a narrar o sertão brasileiro em Grande Sertâo: Veredas, como Camões tinha narrado o mar dos portugueses em Os Lusíadas; José Luandino Vieira a trazer as vozes dos habitantes dos musseques luandenses para o tecido literário da língua portuguesa; Pepetela a recuperar a História Geral das Guerras Angolanas, de António Oliveira Cadornega, através da imagem de um território em luta que há muito se dizia Angola. Estes e tantos outros regressos a textos portugueses da Expansão, como a Carta de Caminha, por exemplo, a partir de outros lugares de enunciação e de outros contextos políticos, reclamam um património e classificam-nos como membros de uma comunidade linguística e imaginária. A politização da cópia que a reescrita ou revisitação destes textos portugueses implica, gera a emancipação, mostrando que a cópia é política e motivadamente infiel. Esbatia-se, assim, a hierarquia inerente entre a cópia e o original, entre a origem e a influência. Ao mostrar que a cópia não era inferior ao original, mas que o reescreve em diferença, gera-se uma nova conceção de pertença cultural capaz de definir identidades plurais, alicerçadas 
em diferentes memórias culturais e cria-se um outro paradigma cultural em língua portuguesa, gerador de pluralidade, de diálogo e de futuro.

\section{O livro}

A par com a internacionalização e a constituição de um think thank, este livro foi um dos objetivos estratégicos de médio prazo estabelecidos com a criação do Patrimónios. Pretendia-se promover, desenvolver, pôr em relação e publicar o pensamento que investigadores-docentes e colaboradores próximos do programa têm em torno da temática, por forma a tornar explícitas as dimensões metodológicas e interdisciplinares, cujo debate e investigação é oferecido aos alunos, mas também à sociedade em geral, a quem nos dirigimos com um elevado sentido de serviço público. Não podia, contudo, surgir sem algum amadurecimento do projeto, sem que as conexões, os conceitos e a terminologia ganhassem coesão e dimensão, e que também o processo de internacionalização iniciasse o seu percurso. Daí que o projeto do livro tenha sido lançado a par com aquele, o que só foi possível graças ao financiamento que, em concurso, obtivemos da Fundação Calouste Gulbenkian.

Desde logo, ficou claro que não pretendemos produzir uma coletânea de textos, mas sim coligir organicamente e interdisciplinarmente um conjunto de contributos da maioria dos especialistas envolvidos no projeto Patrimónios, o que implicou a formulação e discussão das propostas, por forma a que o texto de cada um se pudesse vir a constituir num capítulo de um livro coletivo. Assim fizemos, promovendo reuniões setoriais e gerais para a discussão dos contributos; a primeira à porta fechada, na Universidade de Bolonha, em dezembro de 2013 (Fig. 2); a segunda num colóquio com boa adesão pública, realizado na Universidade de Coimbra 
em junho de 2014 (Fig. 3). Depois foi a concretização material, a edição e revisão dos textos, a sua conjugação e alinhamento, a consolidação dos títulos e do índice. Agora, a apresentação para a publicação em português, em Portugal e no Brasil, e a preparação da edição em língua inglesa. Este livro é, pois, o produto de um longo trabalho coletivo e interdisciplinar que, por outras formas e em outras oportunidades, irá continuar a ser feito.
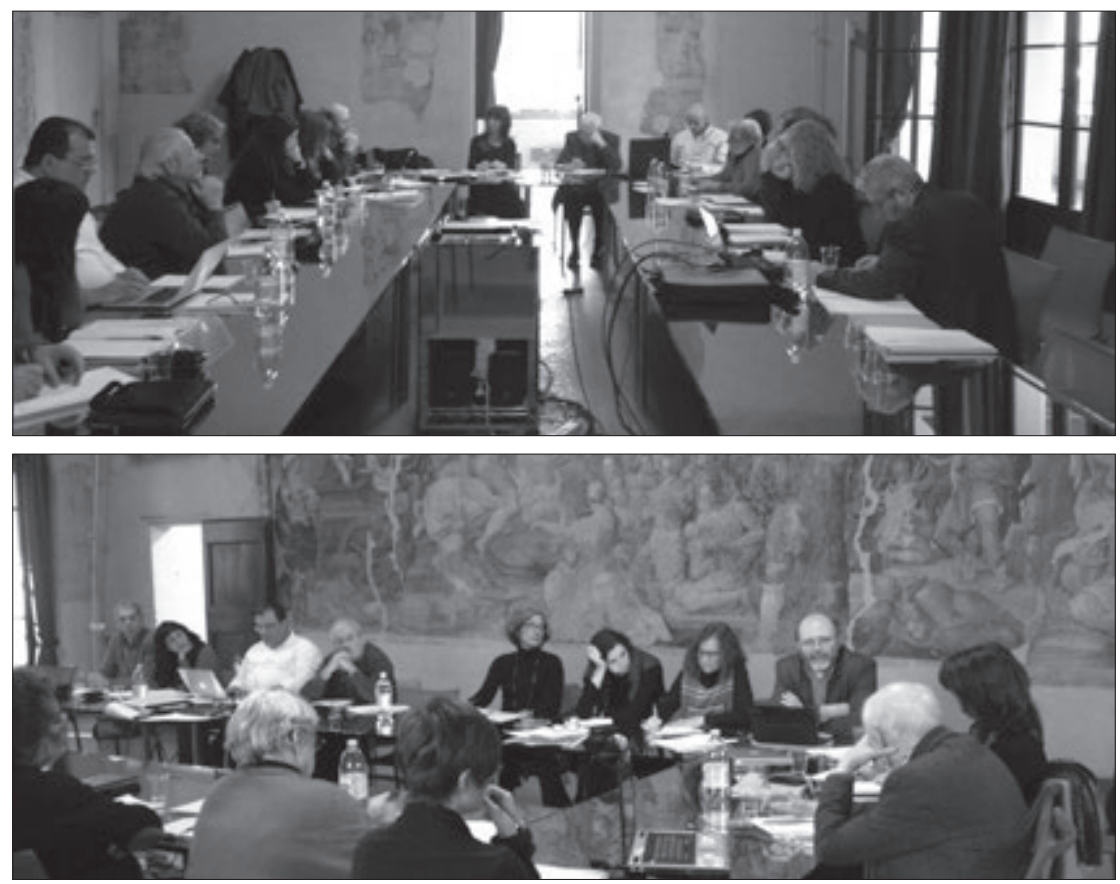

Fig. 2 Reunião de Bolonha.

Patrimónios de Influência Portuguesa, modos de olhar foi um desafio lançado a um conjunto de investigadores para ler e pensar estes espaços a partir de uma perspetiva pós-colonial e, necessariamente, interdisciplinar. Para o fazer, foi objetivamente necessário apelar a um conjunto de conceitos e de contextos que ativam a leitura de patrimónios, conforme podemos olhar na primeira parte 
deste livro. Referimos a conceitos como memória, nas suas várias declinações, herança, identidade e comunidade, que seriam, sem dúvida, os mais imediatos e óbvios, mas também a conceitos mais específicos dos contextos em que estes patrimónios se produziram como colonialismo, missão civilizadora, origem ou influência.
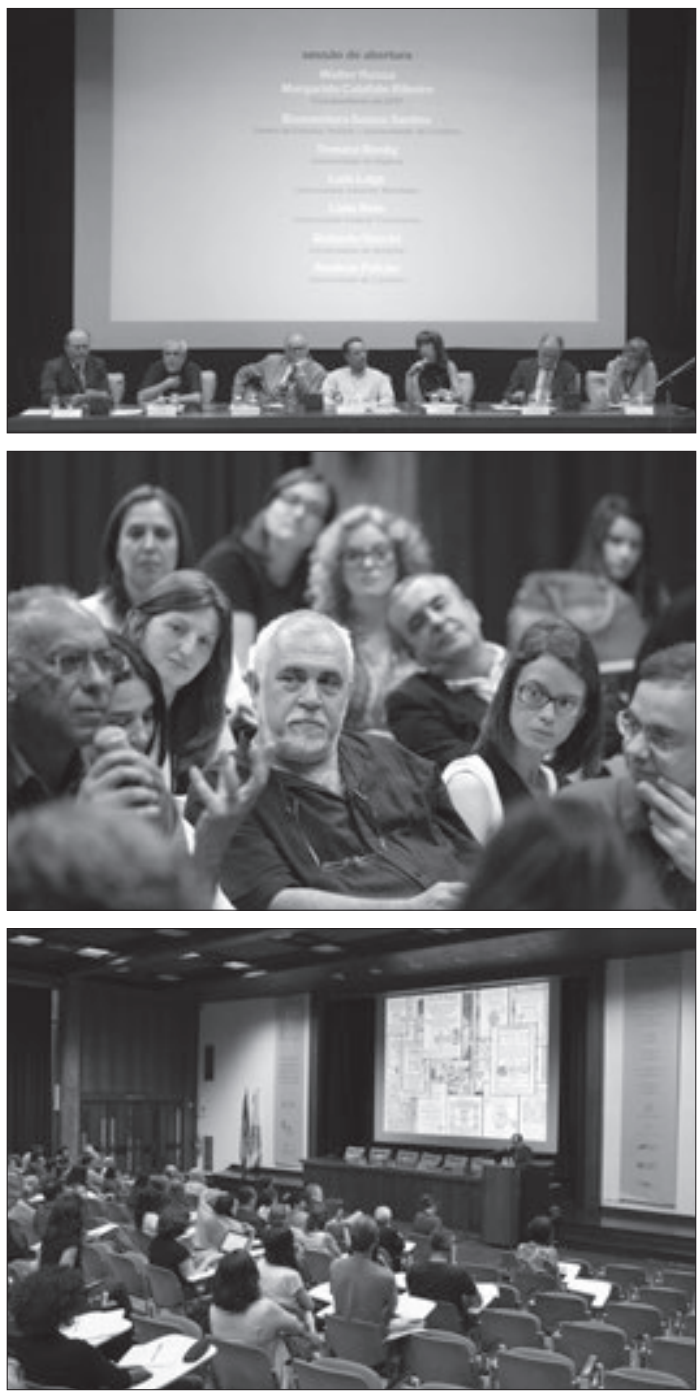

Fig. 3 Colóquio Patrimónios de Influência Portuguesa 
A encerrar a primeira parte e abrindo campos de reflexão para a segunda, apresentamos uma entrevista com Eduardo Lourenço, personalidade central do pensamento contemporâneo sobre Portugal, as suas mitologias, os seus discursos e os seus impensados.

$\mathrm{Na}$ segunda parte, "discursos e percursos", encontramos, em doze capítulos, os principais espaços disciplinares e instrumentais de investigação e ação em Patrimónios. De formas diversas, estes textos realizam um percurso que vai do território à língua, binómio que acima caraterizamos. O percurso empreendido parte das escritas às reescritas das vozes, narrativas e discursos literários em língua portuguesa. Segue-se a mediação historiográfica e antropológica que abre olhares sobre expressões culturais no território, assumidas pela arquitetura e urbanismo, que, por sua vez, dão temas a imagens materializadas em cinema, fotografia, desenho e outros discursos que catalisam e promovem modos de olhar patrimónios de influência portuguesa.

Patrimónios que, como fomos apurando como mote, vemos a propósito da língua no território e sobre o território na língua, pois onde houve território, a língua ficou, muitas vezes como língua não apenas oficial, mas nacional e materna. A língua ficou para além dos padrões, os edifícios e outras coisas que João de Barros não teria previsto. Mas onde não houve território ficaram apenas rastos, marcas no território e nas línguas locais. E assim se foram e vão espalhando e determinando diferentes presenças e representações, baseadas em diferentes compromissos identitários, formando uma rede de diferentes intensidades, que investigamos, interrogamos e olhamos de diferentes modos e lugares como patrimónios de influência portuguesa. 


\section{Referências bibliográficas}

AlMEIDA, Miguel Vale de (2000), Um mar da cor da terra: raça, cultura e política da identidade. Oeiras: Celta.

ANDERSON, Benedict (2012), Comunidades Imaginadas, reflexões sobre a origem e a expansão do nacionalismo (1983). Lisboa: Edições 70.

ASHCROFT, Bill; GRIFFITHS, Gareth; TIFFIN, Helen, (1989). The empire writes back: theory and practice in post-colonial literature. London: Routledge.

BOXER, Charles (1969), The Portuguese seaborne empire, 1415-1825. London: Hutchinson.

BUESCU, Maria Leonor Carvalhão (org.) (1978), Gramáticos Portugueses do Século XVI. Lisboa: Instituto de Cultura Portuguesa.

CHOAY, Françoise (1992), L'allégorie du patrimoine. Paris: Éditions du Seuil.

Creative economy report 2013 special edition: widening local development pathways (2013). Paris: UNDP e UNESCO.

GONZALÉZ-VARAS, Ignacio (2000), Conservación de bienes culturales: teoría, historia, principios y normas. Madrid: Ediciones Cátedra.

GRAHAM, Brian; ASHWORTH, Gregory; TUNBRIDGE, John (2000), A geography of heritage: power, culture, and economy. London: Arnold.

Graham, Brian; HOWARD, Peter (ed.) (2008), The Ashgate Research Companion to Heritage and Identity. Aldershot: Ashgate.

HALL, Stuart (1996), "The question of cultural identity" (1992), in Stuart Hall, David Held e Tony McGrew (ed.), Modernity and its futures. Cambridge: Polity Press and Open University, 273-326.

HALL, Stuart (1999), "Whose Heritage? Un-settling the Heritage, re-imagining the post-nation." Third Text. London: Routledge. n. ${ }^{\circ}$ 49: 3-13.

HARRISON, Rodney (2013), Heritage: critical approaches. Londres: Routledge.

HARVEY, David (2001), "Heritage Pasts and Heritage Presents: temporality, meaning and the scope of heritage studies", International Journal of Heritage Studies. Routledge, n. ${ }^{\circ}$ 7, 4: 319-338.

HOBSBAWM, Eric; RANGER, Terence (1983), The invention of tradition. Cambridge: Cambridge University Press.

International charters for conservation and restoration: monuments and sites I. Munique: ICOMOS, 2004. 
LIÃO, Nunes de (1978), "Não é falta de bondade da língua portuguesa”, in Maria Leonor Carvalhão Buescu (org.), Gramáticos Portugueses do Século XVI. Lisboa: Instituto de Cultura Portuguesa, 98-99.

LOWENTHAL, David (1998), Possessed by the past: the heritage crusade and the spoils of history. Cambridge: Cambridge University Press.

MIGNOLO, Walter (2000), Local Histories/Global Designs: coloniality, subaltern knowledges, and border thinking. Princeton: Princeton University Press. MUDIMBE, Valentin-Yves Mudimbe (1988), The Invention of Africa: gnosis, philosophy and the order of knowledge. Bloomington: Indiana University Press.

RETO, Luís (coord.) (2012), Potencial económico da Língua Portuguesa. Alfragide: Texto.

RIEGL, Aloïs (1984), Le culte moderne des monuments: son essence et sa genèse (1903). Paris: Éditions du Seuil.

SAID, Edward (1978), Orientalism. New York: Pantheon Books.

SMITH, Laurajane (2006), The uses of heritage. London: Routledge.

SMITH, Laurajane (2012), "Editorial”, International Journal of Heritage Studies. London: Routledge, n. ${ }^{\circ}$ 18, 6: 533-540.

SPIVAK, Gayatri Chakravorty (1988), "Can the subaltern speak?" in Cary Nelson e Lawrence Grossberg (ed.), Marxism and the interpretation of culture. Chicago: University of Illinois Press: 271-313.

WATERTON, Emma; SMITH, Laurajane; CAMPBELL, Gary (2006), "The utility of discourse analysis to heritage studies: the Burra charter and social inclusion", International Journal of Heritage Studies. London: Routledge, n. ${ }^{\circ} 12,4: 339-355$.

WATERTON, Emma; WATSOn, Steve (ed.) (2015), The Palgrave handbook of contemporary heritage research. Basingstoke: Palgrave.

ZURARA, Gomes Eanes de (1992), Crónica da Tomada de Ceuta (1450), Reis Brasil (introd. e notas), Mem Martins: Publicações Europa-América. 

1. ${ }^{a}$ PARTE:

CONCEITOS 
(Página deixada propositadamente em branco) 


\section{LÍNG UA, COMUNIDADE E CONHECIMENTO}

O título que me foi proposto - "Língua, Comunidade e Conhecimento" - sugere uma inter-relação ou uma sequência lógica entre esses conceitos: a língua é expressão de uma comunidade e comunidade pressupõe uma partilha de conhecimento. No entanto nem a língua é um elemento indispensável para a definição de uma comunidade (ou mesmo de uma nacionalidade, no clássico exemplo da Suiça) nem a existência de uma comunidade reflete necessariamente um conhecimento partilhado. A nação portuguesa constitui sem dúvida uma comunidade mas, até recentemente, com diferenças económicas, regionais e culturais manifestando-se em modos diferentes de conhecimento - e potencial desconhecimento mútuo - nos diferentes setores da população que falam a mesma língua. A mordaz asserção queirosiana de que "Portugal é Lisboa e o resto é paisagem" sugere também que, da perspetiva de Lisboa, a “paisagem" que é todo o resto do país não é realmente Portugal. Ou que, da inexpressa perspetiva alternativa da "paisagem", Portugal não seria Lisboa. Se tal pode ocorrer num pequeno país com uma longa História, mais facilmente poderá acontecer em grandes comunidades nacionais recentemente formadas como, por exemplo, a Índia, onde a língua alheia da colonização inglesa constitui um fator de hegemonia política, como a língua da colonização portuguesa foi no Brasil e poderá vir a ser em Angola e Moçambique. 
O desenvolvimento económico subsequente à independência das colónias diminuiu consideravelmente os desníveis entre as classes sociais em Portugal e tornou o país numa comunidade culturalmente mais coesa. Mas, fora do país, a língua portuguesa adquiriu uma maior e crescente diversidade através de outras comunidades nacionais noutros continentes. Sendo hoje falada - real ou potencialmente - por mais de duzentos milhões de pessoas em oito países dos cinco continentes, o português já não é apenas, nem sequer dominantemente, a língua de Portugal. É também a língua dos países que a adotaram, tornando-se assim na língua da diferença desses países em relação a Portugal, ainda que seja uma diferença formalmente manifestada numa semelhança linguística. A mesma língua pode veicular tanto uma partilha de conhecimentos quanto uma troca de equívocos entre as diferentes comunidades que a partilham.

A língua portuguesa - como também aconteceu com outras línguas colonialmente impostas - deixou de ser a língua estrangeira da colonização para se tornar na língua do poder político nacional e, consequentemente, num veículo de potencial autoconhecimento para as diferentes comunidades que a tornaram sua nas antigas colónias. Mas permanece como a língua de um poder nacional herdado do poder colonial, com um uso confinado às oligarquias letradas geralmente concentradas nos centros urbanos. É portanto uma herança que, internamente, pode permitir diferentes mas, porventura, maiores equívocos, levando a que a língua do poder político e cultural não seja um veículo de autoconhecimento mas um instrumento de continuada marginalização - e eventual destruição - de outras línguas e culturas que coexistem dentro desses novos países. E não vale o argumento de que os membros das elites urbanas têm geralmente algum conhecimento de línguas e culturas das suas origens étnicas se o oposto não for também verdade e grandes setores da população continuarem a não ter acesso à língua do poder. 
Culturalmente, os escritores africanos e asiáticos que escrevem em línguas europeias têm porventura mais em comum com os seus pares europeus e americanos do que com as comunidades africanas ou asiáticas que coexistem dentro das fronteiras de herança colonial dos seus respetivos países com línguas e parâmetros culturais diferentes. É esse porventura o caso mesmo de escritores que integram, e visam a manifestar nas suas obras, perspetivas culturais nacionais, como, por exemplo, o indiano Salman Rushdie, escrevendo em inglês, e o moçambicano Mia Couto, escrevendo em português. Rushdie recupera a História como metáfora e Couto reconfigura a etnologia como imaginação. A matéria literária de cada um deles é nacional, mas a expressão literária de ambos remete a modelos exteriores: no caso de Salman Rushdie, claramente ao colombiano Gabriel Garcia Marquez (se bem que em tradução inglesa) e, no caso de Mia Couto, sobretudo ao brasileiro João Guimarães Rosa, se bem que em mediação angolana de Luandino Vieira.

Acontece no entanto que Garcia Marquez e Guimarães Rosa provêm eles próprios de tradições literárias coloniais, respetivamente de origem espanhola e portuguesa. Não há, que eu saiba, uma significativa literatura escrita nas línguas nativas da América do Sul e o tupi-guarani, que havia sido a "língua geral" do Brasil até ao século XVIII, deixou de ter qualquer utilização prática. Eram línguas de comunidades que foram culturalmente marginalizadas pelos colonizadores, algumas são línguas extintas. As línguas e as culturas, que levam séculos a formar-se, podem desaparecer bem mais depressa sob o domínio de outras línguas e de outras culturas. Já se perderam muitas ao longo da História e nem sequer podemos saber o que perdemos. Os conceitos "língua, comunidade e conhecimento" estão inevitavelmente vinculados a outro conceito, que designa a realidade política, económica e social de que em larga medida dependem: o "poder". 
No mundo pós-moderno da globalização, a língua multinacional do poder é o inglês. Mesmo as outras línguas da colonização europeia - a despeito do enorme número de falantes - estão a ser marginalizadas pela língua inglesa. Tempo houve em que o latim foi a língua cultural da Europa. Mas como o império romano já havia muito que tinha cessado de existir, o latim não estava especificamente identificado com qualquer poder imperial: o colapso da imperial pax romana permitiu que o latim se integrasse, em maior ou menor grau, no que vieram a ser as línguas nacionais modernas do mundo ocidental. O latim é hoje uma língua morta e o inglês tem uma função equivalente à que o latim teve como língua internacional. Mas o inglês não é apenas a magnífica língua que, na sua expressão simultaneamente nacional e universal, pode ser usada em diálogo com as outras culturas. É também a língua do poder político e económico, a língua vigente da multinacional e globalizante pax americana que tende a marginalizar, quando não a obliterar, as outras culturas, desse modo tornadas periféricas em relação a si próprias.

O próprio conceito sociológico de periferia pressupõe que há um centro exterior do qual se possa ser periférico, o que por sua vez também sugere que o problema não é apenas cultural ou que só por arrastamento o passa a ser. O centro já não é um lugar específico, é a multiplicidade de lugares onde o poder político e económico se exerce, e a periferia é tudo quanto depende desse poder sem ter a possibilidade de influenciá-lo diretamente.

Essas mesmas circunstâncias políticas e económicas ajudam a entender a imagem negativa que as culturas chamadas periféricas têm de si próprias. A periferia, olhando-se com os olhos emprestados do que aceita ser o centro, vê-se como indubitavelmente periférica, e essa perceção passa a ser a imagem que projeta de si própria e que o centro, não sem razão, se vê justificado a aceitar como verdadeira. O resultado é um círculo vicioso, uma tautologia tornada verdade 
factual. Para as culturas do globalizado centro, no entanto, há uma atitude complementar a esta, que é o outro lado da mesma moeda: só serem capazes de se verem a si próprias mesmo quando parecem estar a olhar para as outras, desse modo reduzindo os horizontes da sua perceção num gradual solipsismo que transforma toda a diferença em semelhança. Sem a perceção da diferença, também a língua e as culturas associadas ao poder político e económico ficarão mais pobres. Já está a acontecer. É disso sintomático que, atualmente, apenas 3\% das obras literárias publicadas em inglês são traduzidas de outras línguas.

Seria no entanto errado ver na globalização apenas a expressão de um neo-imperialismo adaptado dos anteriores imperialismos nacionais porque, em contraste com os antigos impérios, o novo império da globalização não tem um centro de poder territorial específico. Os Estados Unidos ocupam atualmente uma posição dominante neste novo imperialismo mas, ao contrário das potências imperialistas do passado, o seu poder não é nacionalmente definido. O centro passou a ser um processo que pode ser exercido a partir do que haviam sido as periferias. Mas se as regras mudaram, também - e por isso - os modos de sobrevivência cultural tiveram de mudar, com a paradoxal consequência de que no mundo pós-nacional da globalização começa a haver um revitalizado lugar para alternativas não centralizadas. Na própria Europa pós-imperial, ao mesmo tempo que as fronteiras nacionais estão a ser abolidas, línguas e culturas que durante séculos tinham sido reprimidas pelos estados-nação começam de novo a emergir com renovada pujança: por exemplo o catalão em Espanha, a languedoc em França, o gaélico no Reino Unido.

Acontece igualmente que, em consequência direta ou indireta da globalização, começam a emergir novas grandes potências nacionais, até recentemente consideradas periféricas, capazes de competir com os descentralizados centros do poder político e económico. Será esse 
talvez o caso do Brasil, da Índia e é certamente o caso da China. Várias décadas antes de Bartolomeu Dias dobrar o Cabo da Boa Esperança, a China iniciara uma viagem marítima rumo ao Ocidente, descendo a costa africana do lado oposto dos portugueses. Houve uma mudança de dinastia na China, a viagem foi interrompida e uma política isolacionista prevaleceu. Mas agora, mais de cinco séculos depois, com diferentes métodos e em diferentes circunstâncias, a China recuperou o seu ímpeto expansionista.

Macau tinha sido concedido aos portugueses no século XVI e, embora com dependência administrativa do vice-reino de Goa, sempre serviu mais os residuais interesses do comércio externo da China do que a política imperial portuguesa. Atualmente de novo sob a jurisdição chinesa, a presença portuguesa é algo fantasmática. Depois de quase cinco séculos de colonização, ninguém fala ou sequer entende a língua portuguesa fora das universidades e de algumas instituições marginais. Não há, portanto, uma relação ativa entre a língua portuguesa e a comunidade macaense. Ainda assim outras formas de conhecimento permaneceram. Restaurantes de chineses frequentados por chineses servem pratos de cozinha tradicional portuguesa. A arquitetura colonial foi preservada na sombra do gigantesco kitsch dos hotéis-casinos do jogo e da prostituição institucionalmente controlada que atraem um plutocrático turismo quase exclusivamente chinês e tornaram Macau numa comunidade excecionalmente afluente. A moeda local mantém a arcaica designação portuguesa de "pataca". Porventura mais significativo, no entanto, é que os nomes das ruas, as instruções de trânsito, a designação de repartições públicas, os diplomas legislativos, continuam todos a ser obrigatoriamente escritos no português que virtualmente ninguém entende, embora transliterados no chinês em que possam ser entendidos. A sobrevivência formal da língua portuguesa está portanto a ser preservada pela administração chinesa de Macau como parte de uma residual herança colonial. Mas é mais do que isso. 
É também - ou sobretudo - um instrumento de política nacional. Usando Macau como base, o ensino da língua portuguesa está a ser implementado em várias universidades ao longo de toda a China, projetando-se a formação de vinte mil professores nos próximos dois anos. Certamente que não para o conhecimento das comunidades locais, incluindo a macaense, mas como um veículo da renovada política expansionista chinesa em África, o crescente comércio com o Brasil e, a partir dos mercados assegurados nos países de língua portuguesa, a conquista de novos mercados nos países vizinhos. Ou seja: uma língua, como a portuguesa, tornada periférica no contexto da globalização pós-colonial está a ser usada pela China como uma alternativa à anglófona pax-americana.

A atitude da China em relação à herança colonial portuguesa contrasta com a ressentidamente miópica política da Índia em Goa, onde o português tinha tido uma penetração muito mais profunda e um uso muito mais generalizado do que alguma vez teve em Macau. Enquanto os chineses entenderam que uma língua de herança colonial alternativa à inglesa pode facilitar o conhecimento de outras comunidades, a Índia virtualmente obliterou o conhecimento do português em Goa após a anexação da antiga colónia portuguesa há pouco mais de cinquenta anos. A língua europeia que substituiu a portuguesa em Goa é a inglesa. Foi uma opção política - e, portanto, também cultural - que pode ter a ver com o facto de a Índia ser um conglomerado de pequenas nações autónomas e linguisticamente diversificadas que foram unificadas pelo colonialismo britânico, enquanto que a China é um vasto país que pré-existia à formação dos estados-nação europeus de futura expansão colonial. Seja como for, o contraste entre a Índia e a China talvez permita concluir que quanto mais integrada - e mais segura da sua própria cultura - for uma comunidade nacional, melhor poderá contribuir para a sobrevivência de outras línguas e para o conhecimento de outras culturas num mundo de coexistentes diversidades. 
(Página deixada propositadamente em branco) 
I N F L U Ê N C IA, ORIGEM, MATR I Z

Discutir conceitos implica questionar as palavras que usamos. As que me couberam em sorte foram influência, origem, matriz. Será melhor começar por analisá-las assim soltas, para depois enfrentar os eventuais problemas de juntá-las umas com as outras e, sobretudo, de lê-las associadas ao próprio conceito de património. Comecemos pelo fim.

Matriz leva-nos a pensar, desde logo, em processos geracionais. Em termos biológicos, a matriz é tanto a mãe, como o órgão dentro dela onde a formação do feto se dá, o útero. É o lugar da gestação e daí a sinonímia com fonte, manancial. Outro dos usos comuns é a relação hierárquica (e implicitamente geográfica) entre a matriz e as respetivas filiais que é utilizada tanto pelas associações comerciais e empresariais como pela organização eclesiástica. Mas a palavra é também associada a sistemas de reprodução de base formal e repetitiva nos quais a matriz é precisamente o molde, ou o modelo a ser utilizado como padrão. Será menos hierárquico neste sentido, mas igualmente, e intimamente, vinculador. Há ainda a matriz matemática, que me parece poder, por ora, ficar fora desta conversa, embora se pudesse estabelecer algumas analogias com as virtualidades das matrizes que servem ao cálculo vetorial, à teoria das probabilidades e sobretudo aos algoritmos computacionais. É interessante pensar que nestas matrizes matemáticas (que se apresentam como conjuntos de números dispostos em linhas e colunas) não cabem de todo 
hierarquias, mas, ao contrário, um sem-número de possibilidades de interações e de operações e um conjunto diverso de resultados (e, literalmente, de formas, dado que as matrizes podem ser lidas como funções).

Origem implica uma leitura que remete quer para uma referência geográfica, que identifica o local de início de alguma coisa, quer para uma ordenação gerativa que tanto pode ser genética, como causal ou cronológico/processual. De todos os modos, a palavra associa relações espáciotemporais e, por regra, exige uma leitura retrospetiva dos processos, invocando a sua génese. Indicar a origem de algo implica remeter ao passado, ou estabelecer percursos, ou ambas as coisas, quase sempre supondo relações implicitamente vinculadoras. Presume-se que a identificação da origem seja potencialmente esclarecedora das características (ou pelo menos de algumas das características) do objeto em causa. Parece ser necessário invocar sempre as origens. Mas se são questionáveis as origens duvidosas, são sobretudo duvidosas as origens inventadas.

Influência é mais ubíqua. Na sua origem a palavra remete para uma espécie de fluxo ou fluído etéreo que se considerava emanado dos astros e que atuava sobre os seres animados e inanimados. Progressivamente, a influência passa a ser entendida como a ação exercida por algo ou alguém sobre um lugar, um fenómeno ou uma pessoa. Supostamente, e aparentemente, esta ação faz-se sem uso de força ou de autoritarismo. A influência será subtil, difusa e prolongada no tempo ou mais direta e direcionada. Mas o que a define e caracteriza é menos o modo e mais o efeito. A influência vê-se pelo resultado, embora não se possa sempre dizer como ele foi obtido. A influência pode ser boa ou má. Pode fazer-se tráfico de influência. Nada implica, na palavra, que a influência seja recíproca. Em princípio, também nada impede, embora a leitura comum veja quase sempre um agente que influencia e um recetor que é influenciado, o que caracteriza senão uma hierarquia, pelo menos um direciona- 
mento. Não há lugar preciso para a ação, nem tempo delimitado. Também não há forma identificada nem padrão reconhecível. Mas há sempre, supostamente, a preexistência de algo que é passível de ser influenciado, daí que o que resulta da influência deverá incluir elementos do agente e do recetor. Não se sabe em que proporção.

Quanto ao património, dispenso-me por agora de entrar diretamente no substantivo e peço licença para fazer um desvio para os verbos. Nas lições de gramática que todos tivemos, ensinaram-nos que o pretérito podia ser perfeito, imperfeito, ou mais-que-perfeito. Penso que a analogia dos tempos verbais com as leituras do património pode ser mais que interessante. Até porque, há ainda um outro tempo verbal, que é quase uma sinonímia do conceito contemporâneo de património que é o futuro do pretérito.

Sem qualquer ironia, importa dizer que, tanto na gramática como no património, o futuro do pretérito é, literalmente, condicional. ${ }^{1}$

$\mathrm{Na}$ gramática, a língua assume a condição fantasmática de uma ação que se projeta num tempo paralelo ao próprio tempo, invocado algo que se poderia realizar, se tivesse sido, ou fosse ainda possível. O futuro do pretérito é, neste sentido, o tempo de uma possibilidade condicionada pela realidade. Contudo, é também o tempo de uma possibilidade desejada, quer no passado, quer no futuro, que se afirma num presente subitamente dilatado por esta amplitude de hipóteses. Há uma clareira que se abre quando se diz simplesmente "eu gostaria..."

No património, o futuro do pretérito é um imperativo categórico. Foi para garantir o futuro do passado que se criou e se afirmou o

${ }^{1}$ A designação de futuro do pretérito é utilizada apenas no Brasil, em todos os outros países lusófonos o mesmo tempo verbal é identificado como condicional. É interessante ter em conta que "a distinção passado/presente (futuro), embora pareça natural, não é de facto universal em linguística" (Le Goff, 1984: 296). Há línguas que não têm tempos específicos para o passado, e outras que não os têm para o futuro. A língua portuguesa é especialmente versátil neste aspeto. 
conceito contemporâneo de património. Na sua origem está, efetivamente, a pretensão de controlar os riscos de perda de um conjunto determinado de objetos herdados do passado colocando-os, de certo modo, também fora do tempo.

Existem, sem dúvida, vários riscos implícitos neste desejo de subtrair as coisas ao tempo. Entre eles, talvez o mais premente seja o da mistificação e construção do próprio passado, que é, como sabemos, perigo desde sempre presente no conceito de património. Sobretudo porque este cedo foi apropriado pelas diversas nações (emergentes ou não) que dele fizeram uso como um dos suportes de afirmação das suas "comunidades imaginadas" (Anderson, 2012), aprisionando os patrimónios em fronteiras nacionalistas que importa discutir. Por outro lado, e embora em aparente paradoxo, em paralelo aos confinamentos nacionalistas, os "patrimónios" não deixaram de se expandir, alcançando quer a escala do património da humanidade, quer a leitura da imaterialidade e do património ambiental.

Contudo, e apesar dos evidentes perigos que podem ameaçar a própria dissolução do conceito pela excessiva abrangência, de resto já denunciados e discutidos em bibliografia reconhecida (Choay, 2000 e 2005); (Guillaume, 2003); (Jeudy, 1900 e 2001), este processo de apropriação do discurso patrimonial é, em si, também já um património do património. Ou seja, a discussão sobre as complexidades inerentes ao conceito faz parte do próprio conceito, o que, de certo modo, o ensaio fundador de Alois Riegl (escrito em 1903) sobre o Culto Moderno dos Monumentos já intuía e anunciava. Dando continuidade ao vaticínio de Riegl, que previu para o século XX a ampliação sucessiva do conceito (Riegl, 2013: 23), podemos prever para o século XXI a sua assimilação cada vez mais lata, como consciência pública e responsabilidade coletiva da continuidade dos elos entre as heranças que recebemos do passado e os legados que deixaremos para o futuro. 
Neste sentido, o conceito de património tanto se pode relacionar com o futuro do passado, como com o passado do passado, e aqui encontrar-se com uma longa linhagem de procedimentos culturais que reiteradamente buscaram conectar o tempo em que se vivia com os que o antecediam. O que é novo no conceito contemporâneo de património é o suposto salto do passado para o futuro, dado que o vínculo do presente com o passado e do passado com o passado é uma constante que remonta, pelo menos, às sociedades neolíticas.

Sobre isso, cabe fazer um breve excurso, para referir uma investigação arqueológica, ainda em curso, que analisa os materiais recolhidos numa gruta-necrópole neolítica, do IV milénio a.C., localizada na Serra de Montejunto, a norte de Lisboa: o Algar do Bom Santo. Segundo o arqueólogo coordenador do projeto, os resultados da investigação são, de certo modo, desconcertantes e contradizem, em parte, o que era dado como adquirido. Supunha-se que aquelas antigas comunidades de agricultores e pastores tinham uma sociedade organizada em função de relações de parentesco e viveriam em territórios mais ou menos amplos, mas com um centro: a necrópole. Aparentemente, a julgar pelos resultados do Algar do Bom Santo, as gentes movimentavam-se mais do que se imaginava. Diz ele que, indivíduos sem qualquer afinidade genética entre si, e vindos de regiões geográficas muito distintas, foram inumados em necrópoles coletivas, como se de "parentes" se tratasse. Estes indivíduos descendiam geneticamente de populações muito diferenciadas, embora todas europeias ou da Ásia ocidental, que a dado momento ter-se-ão misturado. Não há ainda explicações definitivas para o quadro encontrado nas escavações, mas não será, provavelmente, uma exceção (Carvalho, 2014).

Embora possa parecer deslocado, penso que este exemplo pode ser interessante para a reflexão que aqui se quer fazer. Por um lado, esta breve informação, conquanto ultra recuada, não é diferente de outras do mesmo teor, em outras épocas, que atestam a inexorável e 
contínua mescla de que são feitas todas as sociedades humanas. Por outro lado, esta mesma notícia também refere a base, aparentemente inquestionável, da nossa organização primária em termos de relações de parentesco. Assim como evidencia o elo fundamental de vinculação com o passado que se opera por via da morte dos ancestrais.

Convém não esquecer que, na sua base etimológica, o conceito de património é, como todos sabemos, essencialmente, o que nos fica do pai. E o que primeiro nos fica do pai são os seus restos mortais. Toda a operação patrimonial, nalguma instância, incorpora este caráter fúnebre, nem que o faça precisamente para o sublimar. Todos os objetos de rememoração equiparam-se, de certo modo, aos restos mortais (Guillaume, 2003: 90). Guardar os vestígios dos mortos, os seus corpos e os objetos que a eles se associam, implica tanto afirmar a autonomia da morte, como salvaguardar a continuidade da vida. Porque embora se possa supor que a morte possa levar a outros percursos possíveis, o morto separa-se dos vivos, ou melhor, os vivos separam-se dos mortos, enquanto aguardam a morte. A necrópole é, por isso, o primeiro dos monumentos. O monumento por antonomásia, como diria Argan, ${ }^{2}$ porque está ali para continuamente lembrar o seu propósito, que é a própria morte.

Aparentemente, a morte afirmada na necrópole pode ser lida como o reflexo invertido da origem, que se materializa no nascimento. É a morte como destino, como fim da vida. Mas nela está implícita a morte como continuidade, como corte e ao mesmo tempo como sutura da própria vida, quando esta é lida na escala mais vasta da sociedade. Cada morto é um elo de conexão com os mortos todos que o antecederam, e neste sentido é simbolicamente todo o passado. Esse passado, que se espacializa na necrópole, subtrai-se ao tempo,

2 No seu livro A Europa das Capitais (escrito em 1964) Giulio Carlo Argan usa a expressão "monumento por antonomásia” referindo-se à basílica de São Pedro em Roma (Argan, 2004: 78). Noutro texto, utiliza novamente a expressão referindo-se à cidade e afirmando-a como a "obra de arte por antonomásia” (Argan, 1992: 43). 
eterniza-se. No pensamento selvagem, diz Lévi-Strauss, a referência essencial ao passado é a de um tempo mítico de criação ou idade de ouro e o tempo que se supõe ter decorrido entre tal criação e o presente é, em geral, muito "aplanado" (apud Le Goff, 1984: 298). Invisível, como os mortos, o passado pode amalgamar-se e mesclar-se.

$\mathrm{E}$ aqui cabe lembrar que, na expressão do arqueólogo, os nossos antepassados do Algar do Bom Santo inumaram indivíduos de diferentes origens, como se de "parentes" se tratasse. ${ }^{3} \mathrm{O}$ que nos faz pensar se a própria questão da ancestralidade não será, em si, uma leitura sublimada. Ou seja, importa questionar até que ponto a busca de uma linhagem diferenciada, quer seja genética/familiar, ou regional/nacional, não se coloca, necessariamente, desde a origem, como um mecanismo de memória construída.

A família cria-se com os pais mortos e não apenas com os filhos vivos. Mas, enquanto os galhos das árvores genealógicas tendem a crescer e a multiplicar-se, o tronco e as raízes, projetados para o passado, tendem, na maior parte das culturas, a serem aglutinadores, convergindo normalmente para um casal primordial, de que a própria narrativa bíblica é, desde logo, um exemplo.

Lembra-nos, igualmente, Massimo Cacciari que:

quando um grego fala de polis, em primeiro lugar se refere à sede, à morada, ao lugar onde tem sua raiz um determinado genos, uma determinada estirpe, uma gente (gens / genos). [...] A polis é aquele lugar onde uma gente determinada, específica por suas tradições, por seus costumes, tem a sua sede, seu próprio ethos. (Cacciari, 2010: 9)

3 A alusão aos "parentes de diferentes origens" leva-nos a convocar a análise ao totemismo desenvolvida por Sigmund Freud em "Totem y Tabu" (1913). Associando o animal totémico ao pai, Freud pretende demonstrar que só a morte do pai (representada no sacrifício totémico) pode garantir a continuidade social, pois funciona como pacto da comunidade, que assim reprime o incesto e salvaguarda a aliança fraterna. (Freud 2003: 1839) Neste sentido, o pai é o verdadeiro "bode expiatório". 
Para esta construção conceptual da polis contribui a alusão simbólica a um ancestral comum. A pátria é a habitação comum dos descendentes de um único pai. A manutenção deste aspeto arcaico remonta à superação da aldeia e à sua transformação em cidade. Contudo, ainda que possam invocar o pai simbólico, o apanágio das cidades é a mistura de linhagens, o necessário agrupamento e cruzamento genético de populações.

Neste sentido, toda e qualquer pátria parece partilhar desta condição ambígua de ser lugar de uma pertença que é, ao mesmo tempo, intuída e construída. Como, de resto, o é também a apropriação e perceção das cidades. Pois uma cidade é sempre, a priori, um conjunto inapreensível no seu todo, um labirinto, um dédalo de múltiplas possibilidades que se nos apresenta, ao mesmo tempo, como lugar de partilha e de isolamento (Guillaume, 2003: 146). Tudo na cidade remete para a multidão de que ela é constituída, uma multidão potencialmente ameaçadora que é constantemente sublimada numa série de projeções comunitárias que permitem esquecer a estranheza e a ameaça da multidão, convertendo continuamente o eu no outro e o outro no eu.

No verbete "Pátria” do seu dicionário, diz Rafael Bluteau que:

A pátria [...] do sábio é toda a terra onde pode viver honrada e comodamente. [...] Perguntado Sócrates de que terra era, respondeu que era cosmopolita, isto é, habitador do mundo todo. (Bluteau, 1712-1728).

A essência das cidades, na sua síntese e confluência, convoca a imagem do cosmopolita, o habitador do mundo todo. O conceito contemporâneo de património, na sua evocação do passado e do futuro, poderia convocar a imagem do cronopolita, o habitador do tempo todo.

No cerne das operações patrimoniais está uma fantasia, que é também, em mais de um sentido, um fantasma, pois trata-se da 
pretensão de manter o passado visível. Tal não é, contudo, uma mera reação nostálgica acionada pela aceleração do presente, como se poderia, à primeira vista, pensar. Essa convocação do que antes estava sepultado ou invisível funciona como um dos lugares de afirmação da própria modernidade e se inscreve nos seus paradigmas do ver e do saber, que impõem a materialidade e a visibilidade como provas do conhecimento. A modernidade quer ver o passado, quer tocá-lo, quer tê-lo presente. O património materializa e atualiza o passado. Se a obsessão pela materialidade visível comporta o risco de perda da transcendência, ${ }^{4}$ ela também traz consigo um sentido de releitura das alteridades contemporâneas, que passa, necessariamente, pela revisão das narrativas historiográficas tradicionais.

O passado da modernidade contemporânea, este que é constantemente acionado pela omnipresença do património é, também por isso, um passado mais exposto. Corre, inevitavelmente, o risco de se oferecer a usos e abusos de manipulação ideológica ou económica, de que não faltam exemplos, sendo os mais evidentes os que se associam às iniciativas do turismo de massas. Mas, pela mesma hiper exposição, é também um passado menos sujeito a leituras fechadas, ou pelo menos pode ser. Porque estas leituras podem ser criticadas. Porque há mais vozes a reivindicar a sua presença no passado, com diferentes pontos de vista. Porque o passado pode, e está a ser, constantemente revisto e relido. Os fantasmas que se enfrentam deixam de o ser.

Naturalmente, isso não é fácil nem simples. Por um lado, porque esta revisão convoca, muito diretamente, as instâncias de poder e todo o processo de produção de discursos ideológicos que são,

\footnotetext{
${ }^{4}$ Citando Marc Guillaume "se nada mais de transcendente se esconde por trás das coisas e dos corpos, o referente social passa a ser a materialidade visível. É esta que importa conservar do passado e preservar para o futuro. O passado deve tornar-se visível e o futuro previsível. A operação salda-se por uma perda: acabou-se a transcendência, a eternidade." (Guillaume, 2003: 94-95).
} 
genuinamente, refratários a mudanças. Em especial, os discursos nacionalistas, cuja vinculação aos discursos patrimoniais é, como se disse, intrínseca. Por outro lado, esta revisão deve ser associada a um questionamento que está, talvez, a montante dos próprios processos de releitura do passado e que diz respeito ao que Stuart Hall identifica como a "crise de identidade" da modernidade tardia (Hall, 2011).

Na sua leitura, Hall convoca uma série de argumentos que convergem na apresentação de um "sujeito pós-moderno" cuja "identidade se torna uma "celebração móvel": formada e transformada continuamente em relação às formas pelas quais somos representados ou interpelados nos sistemas culturais que nos rodeiam" (Hall, 2011: 13). Uma identidade "definida historicamente, e não biologicamente" (Hall, 2011: 13). Questionando o eventual falso dilema de escolha identitária que se coloca para este sujeito, na contemporaneidade e no futuro, Hall parte do exemplo das múltiplas experiências de diáspora do mundo contemporâneo e propõe a releitura do conceito de "tradução":

Este conceito descreve aquelas formações de identidade que atravessam e intersectam fronteiras naturais, compostas por pessoas que foram dispersadas para sempre da sua terra natal. (...) Elas carregam os traços das culturas, das tradições, das linguagens e das histórias particulares pelas quais foram marcadas. A diferença é que elas não são e nunca serão unificadas no velho sentido, porque elas são, irrevogavelmente, o produto de várias histórias e culturas interconectadas, pertencem a uma e, ao mesmo tempo, a várias 'casas' (e não a uma 'casa' particular). As pessoas pertencentes a estas culturas híbridas têm sido obrigadas a renunciar ao sonho ou à ambição de redescobrir qualquer tipo de pureza cultural 'perdida' ou de absolutismo étnico. Elas estão irrevogavelmente traduzidas. (Hall, 2011: 89) 
Seremos pois todos traduzidos, tradutores e intérpretes das diversas culturas às quais pertencemos. Importa contudo lembrar, como bem aponta António Sousa Ribeiro, que a polissemia contemporânea do conceito de tradução, não nos exime de responsabilidades, mas, ao contrário, exige uma acrescida consciência ética das diferenças.

Pode dizer-se sem qualquer reserva que a tradução se tornou uma palavra chave da nossa contemporaneidade, uma metáfora central do nosso tempo. Potencialmente, toda a situação em que se procura fazer sentido a partir de um relacionamento com a diferença pode ser descrita como uma situação translatória. Nesta acepção ampla, o conceito de tradução aponta para a forma como não apenas línguas diferentes, mas também culturas diferentes e diferentes contextos e práticas políticas e sociais podem ser postos em contacto de forma a que se tornem mutuamente inteligíveis, sem que com isso tenha que se sacrificar a diferença em nome de um princípio de assimilação. O que significa, dito de outro modo, que a questão da ética da tradução e da política da tradução se tornaram tanto mais prementes nos nossos dias. (Ribeiro, 2005: 2 e 8)

O que obriga a voltar às palavras e enfrentar, como dissemos, os problemas de juntá-las umas com as outras, dado que o que aqui está em causa é pensar o património de matriz, de origem, de influência portuguesa.

Desde logo, a questão mais problemática residirá talvez não tanto em cada uma das palavras e mais na junção delas com o adjetivo português. Diz Michel de Certeau que "o outro é o fantasma da historiografia, o objeto que ela busca, o que ela honra, o que ela sepulta" (Certeau, 1982: 9). No passado não há primeira pessoa, o eu não pode ter estado lá, e o suposto nós coletivo é uma mistificação anacrónica e absurda. No passado, todos são outros, e esta alteridade é essencial. Neste sentido, o português aqui invocado, não pode ser senão este outro. É, como bem diz a gramática, o gentílico. 
Embora seja certo e seguro que as palavras, pelo seu próprio mérito enquanto palavras, poderão sempre permitir leituras que as ponham em causa, ainda assim, ou exatamente por isso, importa continuamente questionar as expressões que usamos.

Matriz e origem fazem parte de um léxico até recentemente muito utilizado, sobretudo na história da arte, para dar conta dos processos de difusão das formas. Matrizes italianas, francesas ou flamengas são recorrentemente identificadas na arte peninsular ou noutras áreas da Europa e do mundo. As duas palavras foram invocadas no processo de discussão do título do projeto editorial da Fundação Calouste Gulbenkian. O projeto, dirigido por José Mattoso, coadjuvado por Mafalda Soares da Cunha, e do qual Walter Rossa, Filipe Themudo Barata, José Manuel Fernandes e eu própria participamos como coordenadores dos três volumes, começou por ser pensado dentro da instituição simplesmente como "património português no mundo". O título final ficou, como se sabe, Património de origem portuguesa no mundo (Mattoso, 2010-11), embora na tradução em inglês se tenha suprimido a palavra origem e utilizado a expressão "around the world". Já depois da edição dos livros, no processo de discussão da base de dados que está atualmente on-line (www.hpip.pt) optou-se por utilizar como título Patrimónios de influência portuguesa, que já era a designação utilizada no programa de doutoramento da Universidade de Coimbra.

No projeto da Gulbenkian, quer matriz, quer origem, pretendiam remeter a abordagem para as cronologias em que o património das diversas partes do mundo ali apresentado foi ou esteve ligado a Portugal. Tratava-se de um enquadramento sobretudo cronológico. Contudo, ambas a palavras não negam a intenção de isolar, de certo modo, uma "linhagem" portuguesa. O que poderia ser lido, em parte, como o desejo de Portugal de encarnar o pai, ou a mãe, simbólicos do processo da expansão e dos seus resultados culturais. Em especial 
na ideia de origem, fica implícita a existência de uma genealogia formal que procura afirmar, internacionalmente, uma geografia de difusão que é reivindicada como identitária. Uma geografia direcionada, mais centrífuga que centrípeta. Uma geo-narrativa genésica que invoca o bíblico "crescei e multiplicai-vos" que, se por um lado, afirma o movimento e procura colher, de certo modo, os frutos espalhados, por outro lado, sublima claramente quer o impacto da volta, do retorno do percurso com tudo o que ele implica para o próprio viajante, assim como as resistências e as transformações ocorridas nos vários locais de ancoragem. Corre-se o risco de que, ainda que se saiba a origem, se possa ficar sem destino, porque toda a projeção centra-se na partida e não na chegada.

No caso da matriz, a ideia de um mimetismo formal reforça este sentido de sublimação das vicissitudes dos processos de transposição, mesmo os intencionalmente "repetidores" de padrões. A hierarquia implícita no conceito também não ajuda a ver o quadro mais vasto das inúmeras trocas, negociações e transformações que envolvem quer as pessoas, quer as próprias coisas.

A influência, por sua vez, assenta na ambiguidade, que também não é isenta de riscos. O menor deles será, talvez, a invocação algo esotérica dos astros que, embora aparentemente inócua, há que se admitir que pode ter alguma parcela de ridículo, ou risível, sobretudo porque é um tanto vago. Implícito na fluidez astrológica, pode haver ainda o risco da sublimação ou branqueamento da violência dos processos, que há que acautelar. De igual modo, o direcionamento que se lê na palavra pode conduzir, eventualmente, a um discurso de superioridade talvez ainda mais explícito que nas palavras origem, ou matriz, que também é preciso ter cuidado. Por outro lado, a mesma fluidez da influência permite a hipótese de pensar, se não exatamente, ou não sempre, as trocas, mas pelo menos as resistências e, em especial, as hibridações culturais que dela resultam. Convém ter em conta que, por mais empenhada que 
seja a intenção da influência e por mais coercivos que possam ser os seus métodos, os seus resultados nunca podem ser totalmente previsíveis e nem sempre correspondem às intenções iniciais, o que torna o conceito interessante.

A relação problemática do peso das influências na criação, ainda as tidas como boas e mesmo as eletivas, é lida com alguma ironia por Harold Bloom, que propõe uma teoria da poesia, que intitulou $A$ angústia da influência, onde sustenta que:

A verdadeira história poética é a história de como os poetas enquanto poetas aguentaram outros poetas, tal como qualquer biografia verdadeira é a história do modo como alguém aguentou a sua própria família - ou os seus próprios deslocamentos da família para os amantes e amigos. [...]

A poesia é angústia da influência, é encobrimento, uma perversidade disciplinada. A poesia é mal-entendido, interpretação errónea, aliança desigual.

$[\ldots]$

A influência é influenza - uma doença astral.

$[\ldots]$

A poesia é assim ao mesmo tempo contração e expansão; porque todas as proporções de revisão são movimentos de contração e no entanto o fazer é um movimento de expansão. A boa poesia é uma dialética de movimento de revisão (contração) e de refrescante extravio. (Bloom, 1991: 108-109)

Ironia à parte, e concordando ou não com a sua teoria, o certo é que Bloom toca um ponto central, que é o facto de que não haverá, provavelmente, hipótese de isolar completamente as influências, as boas e as más, as eleitas e as impostas. Contudo, e sem ironia, podem colocar-se as hipóteses que me parecem as mais estimulantes para pensarmos: a hipótese de ler a influência, 
ou mais propriamente as influências, como superação do mito étnico/genético; a hipótese de admitir que são fluidos e vastos os processos de contaminação recíprocos; que não são unicamente genéticos, nem necessariamente redutores a padrões únicos; que não são de todo isentos de violência, mas que implicam vicissitudes as mais variadas; e apesar disso, se podem enterrar os mortos comuns, como se de parentes se tratasse.

Voltando aos "nossos" mortos, e aos patrimónios de influência portuguesa, podemos pensar em partilhas. Não para se decidir a quem cabe cada quinhão, mas para verdadeiramente compartilhar heranças no sentido literal da palavra. No fundo, a questão central que estamos a discutir coloca-se entre a partilha de um suposto passado comum e a partilha comum dos nossos diferentes passados, o que não é a mesma coisa e é importante que não seja. Não será o caso de pretender que o passado tenha sido perfeito, imperfeito, ou mais que perfeito. Seria o caso de discutir como poderemos pensar um futuro para este passado que não seja condicionado por leituras redutoras, que nos possam aprisionar em nichos estreitos, ao invés de possibilidades abertas e questionadoras, embora nunca simples. Porque, de todos os modos, nós precisamos de pensar um futuro do pretérito. O que não implica, de maneira nenhuma, abdicar das diferenças ou das memórias, boas ou más.

\section{Referências bibliográficas}

ANDERSON, Benedict (2012), Comunidades imaginadas: reflexões sobre a origem e expansão do nacionalismo. Lisboa: Edições 70.

ARGAN, Giulio Carlo (2004), “A Europa das Capitais”, in Imagem e Persuasão: Ensaios sobre o Barroco. São Paulo: Companhia das Letras. ARGAN, Giulio Carlo (1992), "A História da Arte" in História da Arte como História da Cidade. São Paulo: Martins Fontes. 
BlOOM, Harold (1991), A angustia da influência: uma teoria da poesia. Tradução Miguel Tamen. Lisboa: Cotovia.

BLUTEAU, Raphael (1712-1728), Vocabulario portuguez e latino, aulico, anatomico, architectonico, bellico, botanico, brasilico, comico, critico, chimico, dogmatico, dialectico, dendrologico, ecclesiastico, etymologico, economico, florifero, forense, fructifero... autorizado com exemplos dos melhores escritores portugueses, e latinos... /. Coimbra: no Collegio das Artes da Companhia de Jesus.

CACCIARI, Massimo (2010), La Ciudad. Barcelona: Gustavo Gilli.

CARvalho, António Faustino, (ed.) (2014), Bom Santo Cave (Lisbon) and the Middle Neolithic societies of Southern Portugal. Faro: Universidade do Algarve (Promontoria Monográfica; 17).

CERTEAU, Michel de (1982), A Escrita da História, Rio de Janeiro: Forense Universitária.

CHOAY, Françoise (2000), Alegoria do Património. Lisboa: Edições 70.

CHOAY, Françoise (2005), Património e Mundialização. Évora: Casa do Sul Editora/Centro de História da Arte da Universidade de Évora.

FREUD, Sigmund (2003), "Totem y Tabu" (1913), in Obras Completas. Madrid: Editorial Biblioteca Nueva, 1745-1850.

Guillaume, Marc (2003), A Política do Património. Porto: Campo das Letras. HALL, Stuart (2011), A identidade cultural na pós-modernidade. Rio de Janeiro: DP\&A Editora.

JEUDY, Henri (dir.) (1990), Patrimoines en folie. Paris: Ed. de la Maison des Sciences de l'Homme.

JEUDY, Henri (dir.) (2001), La machinerie patrimoniale. Paris: Sens \& Tonka.

LE GOFF, Jacques (1984), "Passado/Presente", Enciclopédia Einaudi. Volume 1. Memória-História. Lisboa: Imprensa Nacional - Casa da Moeda, 293-310.

MATTOSO, José (dir.) (2010-11), Património de Origem Portuguesa no Mundo: Arquitetura e Urbanismo. Lisboa: Fundação Calouste Gulbenkian. 
1. ${ }^{\mathrm{a}}$ PARTE: CONCEITOS

RIBEIRO, António Sousa (2005), "A Tradução como Metáfora da Contemporaneidade: Pós-colonialismo, fronteiras e identidades", Eurozine, 2005-07-18.

RIEGL, Alois (2013), O culto moderno dos monumentos e outros ensaios estéticos. Lisboa: Edições 70. 
(Página deixada propositadamente em branco) 
ROBERTO VECCHI

3

I D E N T I A DE, HERANÇA, PERTENÇA

A tríade conceptual aqui apresentada - identidade, herança, pertença - não é redutível a uma série de conceitos justapostos. Pela densa rede de relações que o constituem, este lema múltiplo subentende um macro conceito disseminado e presente, neste como em outros verbetes conceptuais. Falo concretamente do conceito de património, também declinado a partir das suas relações espessas com identidade, herança e pertença que modificam e enriquecem a sua semântica. Mais do que alguns conceitos, é oportuno e mais produtivo pensar com Walter Benjamin numa "constelação crítica" (que faz com que a continuidade da história deflagre e se deixe atravessar por olhares ou tempos plurais, às vezes até opostos, e em conflito, cf. Benjamin, 1991: 83), o que permite pensar não só num aglomerado de conceitos, mas sobretudo nas relações que aproximam ou diferenciam os elementos conceituais entre si. Como se a tríade, na verdade, fosse uma rede de malhas múltiplas de que por exigência de definição não podemos prescindir. Talvez seja também esta perspetiva um modo de acesso menos convencional e mais eficaz ao tema problemático da constelação crítica que é certamente o da identidade.

De certo modo, se assumíssemos integral e estruturalmente o tema da identidade, seria fácil supor que é a identidade triunfante, que substancia a dimensão monumental, efetiva e não só discursiva, que se espelha e se autocomemora. No entanto, a monumentalidade, 
ou o património em que também pensamos, relaciona-se problematicamente com a identidade essencializada, lembrando como ela foi e é matriz de algumas tragédias de um tempo próximo e de qualquer modo nosso. Num livro de Amin Maalouf, a combinação destes elementos, identidade e pertença, são conjugados mostrando o seu lado mais sombrio: como em nome da identidade - no fundo um false friend -, pela sobreposição caótica das muitas pertenças se produz uma violência cega que marca a fratura entre mundos, em particular, entre o Ocidente e Médio Oriente (Maalouf, 2007: 10).

Mas esta reconstrução de uma malha conceptual plural procura antes pensar além e contra as construções identitárias, sobretudo quando os objetos a que se refere são pouco constituídos e, portanto, muito menos identificáveis. A não ser que o jogo seja subvertido de repente e, pela teoria, se possa manter uma imagem de identidade, bruscamente virada do avesso: é o que sugere Edouard Glissant quando em Poétique de la Relation pensa em identidade, mas também no modo como ela se estende na Relação com o outro, abrindo-a, e de certo modo despotencializando-a, daqueles que são os seus limites e potências (negativas) constitutivos. Uma Relação que se enuncia na opacidade (Glissant, 1990).

Através de constelações críticas e plurais, não só é possível associar objetos de outro modo muito distantes um do outro, mas também evidenciar uma relação implicada que torna alguns conceitos o sinal de outras configurações conceituais mais complexas. Por isso, a tríade aqui discutida - identidade, herança, pertença - apoia-se num conjunto - fantasmático, dir-se-ia - de outros conceitos latentes mas capazes de condicionar o sentido do conjunto. Em suma, os conceitos citam-se, implicam-se, e não se esgotam num lema ou numa definição. Vivem pela força das suas relações.

A tríade em questão esclarece o seu emaranhado crítico numa relação com os conceitos de património - que é o eixo de conju- 
gação desta reconstrução - e um outro que, de novo, contorna a constelação que é o de comunidade. O eterno fantasma.

\section{A comunidade que vem?}

Para focalizar de imediato o problema, há, de facto, dentro desta linha de problematização, um outro conceito latente que é preciso convocar, relevante para esboçar a rede de relações - também de força - que permite agregar o conjunto crítico em discussão. Este conceito é o de comunidade. Não é só, como veremos, por uma razão etimológica que é importante conjugar o termo património com o de comunidade, a partir do elemento sufixal "munus", um termo ambíguo e escorregadio que significa ao mesmo tempo dom, doação, mas que pode assumir também a conotação negativa de obrigação, dever. Na modernidade, o que caracteriza uma significação complexa do conjunto da communitas e do seu simétrico oposto da immunitas ou dos "dispostivos imunitários" encontra-se hoje no centro de uma ampla discussão gerada sobretudo a partir do trabalho do filósofo italiano Roberto Esposito (2006: X-XIII). O debate concentra-se em particular na ideia de que a identidade pode ser (ou não) a obra (essencialista, ideológica, retórica) de um trabalho comunitário, que através dela forçosamente se disciplina e configura, alinhando-se por sua vez numa sequência de técnicas de proteção negativa de si própria. É o que atesta larga parte da história trágica do século $\mathrm{XX}$, que pode ser repensada a partir da produção conflituosa de obras identitárias de comunidades de valores e de narrativas, como por exemplo o nacionalismo. Ou também, quando as obras identitárias se combinam com divisores de ordem biológica, como foi com o racismo e a sua versão modernizada que, de acordo com Michel Foucault ao definir o biopoder, foi o colonialismo moderno, ou também a forma extrema de proteção imunitária que foi, fatualmente, a Shoah (Foucault, 1998: 222). 


\section{Em nome do Pai}

Desde logo e com o conforto da etimologia - "o momento poético do pensamento" (Agamben, 2003: 12) - poder-se-ia pensar que património remete para a dimensão privada do círculo familiar. Em quanto "doação do Pai", o património assim como o entendemos modernamente, sobretudo a partir do imenso depósito jurídico que se desdobrou para significá-lo, opera uma deslocação essencial do conceito.

Há de facto uma ambivalência semântica de fundo. Se pensarmos património no contexto familiar, referimo-nos a um conjunto de bens materiais, deixados (como legado ou herança, justamente) aos herdeiros. Mas a sua projeção na dimensão moderna do espaço público modifica o contorno do conceito, mantendo, por um lado, o seu apego a uma realidade material que é transmitida, e, por outro lado e ao mesmo tempo, acentuando o pendor abstrato e plural do conceito assim ressituado. Trata-se de uma mudança significativa, porque ocorre nitidamente no momento em que se afirma a modernidade implicada pelo processo de modernização, a que o significado em jogo se submete. Neste quadro, a instabilidade do conceito deve-se, não apenas ao facto do problema da transmissão dos bens ocorrer dentro e fora do espaço público, mas também neste contexto porque é alimentada pela condição dupla - em negativo e simultaneamente em positivo - do sufixo "munus", presente tanto em património como em comunidade. Por isso, a combinação analítica dos dois termos pelo elemento em comum torna-se particularmente produtiva.

No contraste histórico com o arquivo trágico que a Europa produziu ao longo da sua história onde ideologias comunitárias proporcionaram a forma com que se praticaram as proteções negativas e as providências imunitárias de identificação excludente de grupos e territórios, os modos como a comunidade pode ser repensada criam 
as condições de novas formas de "em-comum", que permitem "ir além" dos impasses gerados pelo "comum" das identidades fortes.

No contexto contemporâneo globalizado, o que a fragilidade e a vulnerabilidade dos tempos atuais expõem (por exemplo, no caso macroscópico da Europa), é a reconfiguração - a re-harmonização - de corpos sociais heterogéneos, marcados por importantes fronteiras internas, como no caso das minorias, que permite deixar amadurecer uma ideia de cidadania que não é parcial ou oblíqua em relação aos direitos.

O que está em jogo, aqui como em muitos outros contextos, é uma redefinição da ideia de comunidade, suspensa, de acordo com a revisão, crítica e antiessencialista, de Jean-Luc Nancy (depois articulada também por Giorgio Agamben, Roberto Esposito e pelo viés da Relação também por Edouard Glissant) entre um ser comum, uma identidade integral e nostálgica, que pressupõe a produção e a realização integral da sua própria essência enquanto obra (identitária), e uma comunidade que não é o fantasma da comunidade perdida, mas é o que nos acontece, a partir da ideia de uma sociedade que incluiu a perda da comunidade como seu elemento constitutivo (Nancy, 1992: 37).

A diferença desta articulação crítica reside no caráter permanentemente incompleto, não homogéneo e dinâmico, da ideia de comunidade: ela não encontraria o seu princípio na construção, mas na incompletude, uma comunidade estruturada pela falta, portanto désœuvrée, pela inoperância, uma comunidade sem obra.

Isto abre o campo para o pensamento de Eduardo Lourenço sobre a Europa para quem a Europa, inclusive na crise atual, é um campo reflexivo decisivo para a construção de um pensamento contemporâneo. Lourenço aponta como potencial da Europa justamente o que uma análise geopolítica exclusivamente exterior criticaria, ou seja, para usar a terminologia do filósofo português, a sua "sublime 
não-identidade", uma "sublime imperfeição", uma "impotente lucidez" (Lourenço, 2005: 240).

É uma imagem de comunidade sem obra, débil, mas que, assumindo conscientemente a sua fragilidade, redesenha o seu papel no mundo que é um papel negocial e de mediação, intermediário e dialógico, necessariamente voltado para a procura de uma polifonia ou de um contraponto, para ficarmos apenas no campo das metáfora musicais.

Qual é o reflexo da reconfiguração da ideia de "força débil", do último Derrida (2003: 195), sobre o conceito de património? Aqui a discussão sobre a reinscrição do conceito deve ser ampla. O património que não se funda mais numa essência identitária - o que seria problemático - pode refundar-se como potência, sobre elementos parciais, fragmentos, silêncios que modifiquem o conceito de contemplação e escuta da doação metaforicamente paterna. Por exemplo, talvez isso possa ocorrer na Literatura como campo do impossível que se pode tornar possível e que deveria ser, por definição, a política. Na superfície encrespada do texto literário torna-se possível reconfigurar o projeto de um património que não gera mais narrativas comunitárias - exposto na sua vulnerabilidade e limites, na sua erosão e ruína - mas na inscrição do fragmento como indicador (como no caso da fotografia ou da imagem) que aponta para os sinais de uma comunidade potencial e não histórica, como a comunidade ideal de Bataille que é a dos amantes (cfr. Blanchot, 1984: 84).

Um património possível, articulado em rede, que não se reproduz como tal, mas que subsiste só em função da relação de uma singularidade com outras singularidades, de uma insuficiência com outras insuficiências. E incompletudes. É isso na comunidade despotencializada da força de autoidentificação que põe as singularidades "em-comum", mostrando a comunidade que vem, como um "ser singular plural" (Nancy, 2001: 43) ou uma "singularidade 
qualquer" (Agamben, 2001: 67) que não é mediada por um sentido de pertença ou uma identidade homogénea.

\section{Tempo de heranças}

Antonio Candido, numa definição clássica que condensa várias camadas de interpretações modernas do processo de formação do Brasil por parte dos grandes nomes fundadores em particular da década de 1930, observa: "Na nossa cultura há uma ambiguidade fundamental: a de sermos um povo latino, de berança cultural europeia, mas etnicamente mestiço, situado no trópico, influenciado por culturas primitivas, ameríndias e africanas" (Candido, 1980: 119, itálico meu).

O termo "herança cultural", aproveitado por Candido e associado a um problema não tanto de origem quanto de inícios (para continuarmos na vertente do discurso de Candido com que estrutura o quadrante fundamental da Formação da literatura brasileira) é bastante acertado e leva a reformular uma ideia alternativa de tradição. Situa-a na linha horizontal do presente, valorizando a sua atualidade e o seu funcionamento dentro do Brasil contemporâneo, embora assinalando as dificuldades (as "ambiguidades") que se associam a estas complexas raízes identitárias e ao seu processo de formação. No seu entendimento, herança de facto não remete para uma ideia museificada - ou de relíquia - de permanência da cultura europeia, mas o próprio conceito acentua um processo inesgotável de transformação da imagem da Europa, numa outra imagem de que o Brasil se apropriou, em particular nos anos seminais do Modernismo novecentista.

É oportuno lembrar aqui a contribuição relevante de Ernst Bloch e do seu artigo de 1935 (escrito, no entanto, em 1932) em que reconceitualiza a herança, inscrevendo-a justamente numa perspetiva de 
Erbschaft dieser Zeit, de "herança do nosso tempo", uma herança portanto atual. De facto, distanciando-se de uma ideia de homogeneidade ou de interpretação contemplativa e limitada da presença do passado no presente, o filósofo capta o caráter não sincrónico caracterizando o conceito de herança, estruturado numa pluralidade de tempos, a partir de um incipit famoso da reflexão: "Not all people exist in the same Now. They do so only externally, by virtue of the fact that they may all be seen today. But that does not mean that they are living at the same time with others" (Bloch, 1977: 22).

A contemporaneidade-do-não-contemporâneo assim configurada torna-se uma ferramenta conceitual importante para ler os processos culturais da "semiperiferia" (como ilustra Franco Moretti, 1994: 47) e serve a Bloch também para mostrar que além do esquema hegeliano é possível encontrar espaços utópicos e de mudança e que, na reformulação de uma herança atual, da riqueza incompleta do passado, é possível derivar uma "additional revolutionary force" (Bloch, 1977: 38) no Agora.

É interessante, nesta perspetiva, qualificar o tipo de força que articularia a herança atual e que modifica de maneira radical a ideia de tradição, substituindo o seu traço conservador por um traço transformador: a ideia que a tradição é sempre uma inexaurível tradução. É uma força, que decorre da desconstrução do elo de relação (que convencionalmente se chamaria tradição), que pela sua disseminação em multíplices ângulos da cultura e das praxes sociais dos "espaços da língua portuguesa" não possui uma homogeneidade ou um centro, mas que se substancia pela dispersão, o que poderá tornar problemática a noção de "lusofonia". É uma força que se pode definir, oximoricamente, como uma "força débil", sem nenhuma conotação reducionista da figura retórica - o oxímoro - que a constitui.

Para esclarecer a função desta força débil é fundamental recorrer ao pensamento do último Jacques Derrida, preocupado em desconstruir o paradigma do poder soberano, um poder que, de acordo 
com o filósofo, tem sempre a ver com um phantasma, em particular em antítese com outros paradigmas de certo modo dominantes no debate atual, como por exemplo o elaborado por Giorgio Agamben a partir da conexão entre soberania e biopolítica. No contexto das ameaças e das catástrofes do começo do milénio, Derrida elabora um novo pensamento político estruturado à volta da ideia de uma força débil ou uma força da debilidade, ou seja, sem poder, mas não por isso desprovida de força. O filósofo franco-argelino aproveita para a redefinição dessa ideia-chave uma famosa tese sobre o conceito de história de Walter Benjamin, a segunda, de acordo com a qual "a nós, como a cada geração que foi antes de nós, foi entregue uma débil força messiânica ("eine schwache messianische Kraft"), a que o passado tem direito. Este direito não se elude" (Benjamin, 1997: 23). Nesta rearticulação do conceito de poder - um poder do menos, esvaziado, mas não anulado - pode surgir uma metáfora conceptual interessante para repensar a relação entre passado e presente, mediado pela "herança", fora das forças hegemónicas que dominam a nação e suas narrativas (as identidades). A partir deste conceito podem elaborar-se outros modos para construir projetos compartilhados sobre bens culturais "em-comum", a partir de uma força mínima mas efetiva e afetiva, enterrada na herança do presente.

Pensar nessas relações, hoje, é interrogarmo-nos sobre a potência cultural e não necessariamente apenas histórica que este "em comum" alternativo implica.

\section{Pertença e estátuas que tombam}

Pertença é um conceito que se inscreve num quadro complexo, remetendo para um sentido pelo menos duvidoso, como vimos também nos outros casos. Sobretudo entra numa "constelação crítica" de que outros termos como propriedade e posse são partes. 
A pertença é essencialmente uma relação, subjetiva ou objetiva, ou seja, implica ou é implicada ao mesmo tempo - a pertença de alguém, o que remete para o tema da identidade, ou a algo que pertence. Nesse sentido, a pertença é política, o que decorre da dualidade da força da relação pela qual a pertença se exerce.

Deste ponto de vista, sempre a partir de uma ideia de força, podem ser pensadas também as categorias de propriedade e de posse. A primeira, a propriedade, é uma noção jurídica (afirmada como direito natural) que sanciona o direito legal e real e que se afirma por força da lei; a posse configura-se como um poder - com todas as nuances que tal condição comporta, no sentido que pode ser um domínio mas também uma atribuição, efetiva ou simbólica - sobre um objeto.

Nos processos de desapropriação e apropriação, reestruturam-se as relações e, consequentemente, rearticulam-se as identidades em jogo. Por exemplo, na relação colonial, a propriedade, sancionada pelo domínio que se institui juridicamente, pode remeter para outros sentimentos de posse ou de pertença, fora do círculo da identidade dominante. De igual modo, nas descolonizações o conflito de forças reestrutura outros sentidos de posse e pertença relativos a objetos anteriormente não reconhecidos como próprios.

Sobre esta trama de poderes e forças, mais do que qualquer conceptualização abstrata, a pertença, na crise do além-colónia relativa aos monumentos coloniais, é magnificamente dissecada numa narrativa de Cronicando, de Mia Couto, "A derradeira morte da estátua de Mouzinho". Trata-se da cena da remoção do monumento equestre de Mouzinho de Albuquerque da praça homónima que, com a independência, começará a chamar-se Praça da Independência. A questão pós-colonial, a sua indecidibilidade, está em pleno representada entre narrador e personagens - moçambicano e portugueses - que vivem distintas melancolias, "na ilusão de um só golpe derrubar todo o sofrimento" (Couto, 1988:162) mas também 
na consciência de que uma fratura irreversível se produziu, o que explica porque "a sua tristeza não é igual à minha".

Mas é também, a crónica, um fragmento de um tratado antimonumentalizador, que separa a história do mito e capta a emanação trágica da matéria "Dói a estátua ser pedra indefesa" (Ibidem: 161). Por isso, a destruição que deveria significar a mudança da pertença, o resgate de uma posse dominada, a reapropriação, pelo nome, de um espaço simbólico, de um centro ideal, mostra o paradoxo da impossibilidade de reinscrição. Ou de reescrita: "Há um mundo que termina, um luto que não é meu mas que me ensombra o peito. Eu estou só, ninguém me pode ajudar a recompor dessa morte. Porque nenhuma morte nos é alheia, mesmo a do insuficiente inimigo" (Ibidem: 163).

A tentação seria assim a de abolir todas as estátuas, mas quais seriam as alternativas para abandonar o passado? O sentimento de propriedade (colonial) do passado abre espaço a uma outra relação de posse, também insuficiente, que se esvazia no gesto do velho português que segura nas mãos uma pedra da estátua antes de jogá-la no chão. Pedra que se estilhaça e se torna poeira: ruína que se destrói e não deixa margem a nenhum sentido possível porque é indecidível, no vazio, tanto na pertença (de quem era, de quem é) como na disputa da memória.

\section{Coda}

A partir de um quadro tão instável de referências que conjugam a tríade de conceitos, é possível definir um campo novo para repensar as relações entre património, herança, identidades e pertença, sobre as quais se projeta o problema central do ser "em comum", no desmoronamento das grandes narrativas e que consiste no seguinte: promover uma leitura radical e desconstelizadora de património. 
Porque como foi observado, em contextos monumentais, há sempre o risco acrescido que "a dor, reificada, morre exilada na pedra" (Calimani, 2002: 32).

Um exemplo, talvez extremo, sobre o silêncio das ruínas, dos despojos, dos monumentos, ocorre num dos romances mais radicais da modernidade portuguesa, isto é, Viagens na minha terra, de Almeida Garrett, que funciona como um epítome dos problemas aqui enumerados e proporciona um campo conceptual vasto para repensar o património.

A consciência trágica que surge pela experiência moderna da viagem é que os restos do passado, monumentalizados e museificados, não produzem mais nenhuma narração com que a comunidade se possa identificar (Mendes, 1999: 136), apesar da ideologia romântica garantir uma força simbólica entre presente e passado. Eles, os restos, revelam-se pelo esvaziamento da força simbólica, pelo fetichismo das narrações que originaram, caracterizando uma faceta da grande literatura romântica portuguesa, que é o seu lado mais subversivamente anti-romântico.

O que resta é o silêncio das pedras, no deserto da história que não se deixa simbolizar. A sensação é aquela que talvez se tenha experimentado visitando o monumento do campo de Treblinka, perto de Varsóvia: um mar de pedras - uma por cada comunidade exterminada - que não substituem mas suplementam a catástrofe sem testemunhas do que ali ocorreu. Escombros, não ruínas. Ou com Garrett: "Mas em vão interrogo pedra a pedra, laje a laje: o eco morto da solidão responde tristemente às minhas perguntas, responde que nada sabe, que esqueceu tudo, que aqui reina a desolação e o abandono, e que se apagaram todas as lembranças de outro estado" (Garrett, 1983: 301).

No entanto e aqui, no "horror e maldição" do vazio que não simboliza, opaco e mudo como o trauma, podemos assumir como elo a força ténue, débil "a que o passado tem direito", força que pode 
rearticular (sem estrutura, sem constituição) tanto a comunidade, como a herança e a pertença. A partir daqui pode surgir uma revisão da ideia de património como uma arte residuária das sobrevivências, por imagens e não por horizontes, pelo brilho de uma alternativa humanizadora de um saber resistencial, que se contrapõe à luz feroz do poder, ou à soberania autoritária. Estou aqui a glosar a metáfora dos vaga-lumes com que Georges Didi-Huberman lê o tempo da desumanização denunciado por Pasolini e pensado por Agamben (Didi-Huberman, 2010: 26).

Pela subtração da força das narrativas identitárias, pelo seu enfraquecimento, a ideia de património que sobrevive é aquela do outro lado, pelo rastro, pela ausência, não constituída, residuária, de perdas, resistências, sobrevivências, aspetos que não remetem para qualquer narração deslumbrante e eloquente, mas só para uma arte modesta e possível de sinais e indícios.

Não devo concluir a abordagem ao conjunto de conceitos aqui em jogo mostrando que a tríade de partida - identidade herança pertença - mesmo pensada numa constelação crítica mais ampla que remete para o tema-problema do "em comum", se esfarela em poeira sem coagular em qualquer sentido.

Talvez o problema - ou a aporia - seja mesmo este: como pensar a monumentalidade fora de categorias apaziguadoras, mas de facto violentas, como identidade, tradição, herança e pertença e que apagaram, até quase à extinção, a força ou a potência que as caracterizavam?

Aqui a própria ideia de relação deve ser repensada a partir de um esvaziamento que se aproxima da perda ou do silêncio. Por isso o desafio de repensar o património a partir do avesso de uma monumentalidade que se reconhece pela retórica, pela hipertrofia, pelo seu traço hierático ou eloquente, é um campo novo a estruturar, uma vez que todas as categorias fundamentais mostram os seus limites. 
O desafio que surge a partir de um reconhecimento teórico e subversivo em relação aos cânones da monumentalização é como reformular de modo radical o património a partir da subtração do que histórica e ideologicamente o fundamentou, e que corresponde ao desafio lançado por Garrett e que atravessa, sem solução, toda a nossa modernidade: uma tradição que renova - pensando em Pasolini - a força do passado assumindo a sua debilidade, a condição e o seu risco de impercetibilidade e perda. Se o coração, o objeto do século que passou, como lembra Gérard Wajcman, colocando no centro deste século a Shoah, é a construção da invisibilidade, a invenção da "destruição sem ruína" (Wajcman, 1998: 21) das vítimas absolutas - onde a construção do nada, do escombro, da poeira deixa de desempenhar qualquer possível ou eventual função evocativa em relação ao passado que a produziu -, talvez seja então pela ausência ou pelo negativo (Zevi, 2014: 71) capazes de inverter a consistência e o sentido da força, que a monumentalidade pode, mas talvez deva, ser repensada.

Um património que retém fisicamente o que está em risco de perder-se para sempre, nunca será base possível de alguma fundação futura. Como o murmúrio, o grito ou o sofrimento.

De forma diversa estas perdas parciais ou quase totais que são as sobrevivências e resistências perante forças bem mais poderosas e totalizadoras, criam outro "em-comum" em que se espelharam e se reconheceram numa outra delicadeza pela sua transmissão em risco: um património dilacerado e precário mas que talvez possa finalmente dar conta - mais do que qualquer outra falsa narrativa supostamente homogénea, mais do que qualquer monumentalização retórica - da dor do tempo e das suas imensuráveis e definitivas perdas. Uma outra memória, uma contramemória em suma: um património da Relação, um património do outro. 


\section{Referências bibliográficas}

AgAmBEN, Giorgio (2001), La comunità che viene. Torino: Bollati Boringhieri. AgAmben, Giorgio (2003), Stato di eccezione: Homo sacer, II, I. Torino: Bollati Boringhieri.

BENJAMIN, Walter (1991), L'opera d'arte nell'epoca della sua riproducibilità tecnica. Arte e società di massa. Trad. de Enrico Filippini. Torino: Einaudi. BENJAMIN, Walter (1997), Sul concetto di storia. Trad. de Giafranco Bonola e Michele Ranchetti (eds.). Torino: Einaudi.

BLANCHOT, Maurice (1984), La comunità inconfessabile. Trad. de Mario Antomelli. Milano: Feltrinelli.

BLOCH, Ernst (1977), "Nonsynchronism and the Obligation to Its Dialectics", New German Critique, 11, 22-38. Versão eletrónica, consultada a 31.12.14, em http://www2.warwick.ac.uk/fac/arts/english/currentstudents/postgraduate/masters/modules/postcol_theory/bloch.pdf

CAlimani, Dario (2002), "La memoria e il suo esilio", in Maria Sechi et al. (orgs.), L'ombra lunga dell'esilio. Ebraismo e memoria. Firenze: Giuntina.

CANDIDO, António (1980), Literatura e sociedade. São Paulo: Companhia Editora Nacional.

CouTO, Mia (1988), Cronicando. Lisboa: Caminho.

DERRIDA, Jacques (2003), Stati canaglia. Due saggi sulla ragione. Milano: Cortina.

DIDI-HUBERMAN, Georges (2010), Come le lucciole. Una politica delle sopravvivenze. Torino: Bollati Boringhieri.

ESPOSITO, Roberto (2006), Communitas. Origine e destino della comunità. Nuova edizione ampliata. Torino: Einaudi.

FOUCAUlT, Michel (1998), Bisogna difendere la società. Mauro Bertani e Alessandro Fontana (eds.). Milano: Feltrinelli.

GARRETT, Almeida (1983), Viagens na minha terra. Lisboa: Estampa. Glissant, Édouard (1990), Poétique de la Relation. Paris: Gallimard. LOURENÇO, Eduardo (2005), A Europa desencantada. Para uma mitologia europeia (1994). Lisboa: Gradiva. 
MAALOUF, Amin (2007), L'identità. Trad. de Fabrizio Ascari. Milano: Bompiani. MENDES, Victor (1999), Almeida Garrett. Crise na Representação nas Viagens na Minha Terra. Lisboa: Cosmos.

MORETTI, Franco (1994), Opere mondo. Saggio sulla forma epica dal Faust a Cent'anni di solitudine. Torino: Einaudi.

NANCY, Jean-Luc (1992), La comunità inoperosa. Trad. de Antonella Moscati. Napoli: Cronopio.

NANCY, Jean-Luc (2001), Essere singolare plurale. Trad. de Davide Tarizzo. Torino: Einaudi.

WAJCMAN, Gérard (1998), L'objet du siècle. Lagrasse: Verdier.

ZEVI, Adachiara (2014), Monumenti per difetto. Dalle Fosse Ardeatine alle pietre. Roma: Donzelli. 
Se há um consenso que tem vindo a instalar-se com cada vez maior clareza e mais ampla aceitação no âmbito dos estudos sobre o património, ele está na perceção de que, para citar a definição de um manual de referência, o património constitui "o uso seletivo do passado para fins contemporâneos", "uma agregação de mitos, valores e legados determinada pelas necessidades da sociedade no presente e definida por estas" (McDowell, 2008: 37). É bom de ver, evidentemente, que estas necessidades no presente e aqueles fins contemporâneos podem ser definidos de modo muito diverso, numa escala que vai de um uso instrumental condicionado por interesses económicos ou ideológicos a modos contra-hegemónicos de afirmação comunitária ou reivindicação crítica. A conjunção entre memória, identidade e património revela-se, em qualquer dos casos, indissociável e constitui uma articulação decisiva para entender os usos culturais do património e os processos complexos de negociação e conflito que lhes estão associados nos nossos dias.

Estas considerações iniciais permitem balizar minimamente o breve percurso que me proponho fazer sobre algumas declinações atuais do conceito de memória. Já nos anos 80, a abrir os seus Lieux de mémoire, Pierre Nora afirmava que, se falamos tanto de memória, é porque sobrou tão pouco dela, apontando assim para a tensão entre a lógica devoradora das culturas do presente e a resistência a essa hegeliana "fúria do desaparecimento" ("Furie des 
Verschwindens") característica de um processo histórico concebido da perspetiva de um tempo linear. A verdade é que este paradoxo de uma simultânea crise da memória, por um lado, e hipertrofia da memória e dos estudos sobre a memória, por outro, aponta para a dimensão de essencial conflitualidade de um contexto social e cultural em que a memória se constitui, em aspetos determinantes, como crítica do presente e concomitante estratégia de produção do contemporâneo, no sentido captado pela definição já quase clássica de Giorgio Agamben:

Pertence verdadeiramente ao seu tempo, é verdadeiramente contemporâneo, aquele que não coincide perfeitamente com este nem está adequado às suas pretensões e é, portanto, nesse sentido, inactual; mas, exactamente por isso, exactamente através desse deslocamento e desse anacronismo, ele é capaz, mais do que os outros, de perceber e apreender o seu tempo.” (Agamben, 2009: 58-59)

É no fio da navalha de um contemporâneo assim definido que poderemos captar algumas dimensões fundamentais de um conceito que, nas últimas três décadas, se foi afirmando com cada vez maior centralidade. A dificuldade do conceito é evidente, como é evidente o facto de que só uma visão transdisciplinar - das neurociências aos estudos culturais e aos estudos literários - pode aspirar a captá-lo nos seus múltiplos aspetos. Cabe constatar que, em muitos casos, esta transdisciplinaridade permanece mais um desiderato do que uma realidade, mas é cada vez mais visível como o potencial migratório do conceito lhe tem vindo a assegurar um lugar crescentemente central. É indesmentível que o campo dos estudos da memória está, hoje em dia, firmemente estabelecido - a fundação, em 2008, da revista Memory Studies é prova cabal da solidez do processo de legitimação académica e de canonização institucional. 
Em retrospetiva, não será simples acaso que os estudos da memória tenham começado a afirmar-se depois da Primeira Grande Guerra, nos anos 20, a partir do contributo basilar de Maurice Halbwachs, com as obras Les cadres sociaux de la mémoire, de 1925, e os estudos reunidos postumamente em La mémoire collective. ${ }^{1} \mathrm{Na}$ verdade, seja pelo emergir da forma do testemunho, consagrada, em 1929, com a publicação da obra Témoins, compilada por Jean Norton Cru a partir de testemunhos de antigos combatentes, seja pela importância conquistada pela noção de trauma e do que viria a chamar-se stress pós-traumático, a partir da necessidade de confrontação da medicina militar com o impacto psicológico da escala monstruosa da guerra moderna, o chamado "shell shock" ou "neurose de guerra", seja, finalmente, pelas inúmeras formas de culto dos mortos e de memorialização pública, nos mais recônditos lugares, da lembrança da guerra, também neste aspeto o primeiro conflito mundial constitui um momento decisivo de charneira.

Não vou aqui recapitular as teses de Halbwachs, bem conhecidas pelo menos nas suas linhas gerais. Destacarei apenas o que podem considerar-se três aquisições que lançam pontes ainda hoje decisivas para vertentes essenciais dos estudos da memória:

1. De acordo com Halbwachs, em rigor, não existe nem pode existir uma memória puramente individual, já que essa memória se constrói sempre em contextos socioculturais precisos - os indivíduos são incapazes de recordar de forma consistente fora de contextos grupais. O estudo da memória pressupõe, assim, a investigação dos quadros sociais da memória.

2. A atenção dada por Halbwachs às memórias familiares abre caminho para a teoria e metodologia da história oral e, em

1 Halbwachs morreu em março de 1945 no campo de concentração de Buchenwald - em A escrita e a vida, Jorge Semprún deixou-nos um relato comovente dos seus últimos momentos (Semprún, 1994: 27-28). 
certos aspetos, mesmo para o conceito de pós-memória, a que irei referir-me mais adiante.

3. Sobretudo com os seus estudos sobre a memória de comunidades religiosas, Halbwachs põe em relevo a importância de aspetos topográficos da memória cultural, abrindo assim caminho, com essa acentuação da dimensão espacial, para o conceito de lugar de memória.

O conceito de memória colectiva, tal como teorizado por Halbwachs, é controverso. Já Marc Bloch chamava a atenção numa recensão da época para o facto, entre outros aspetos, de esse conceito poder representar a simples transposição para o plano social de um conceito individual, postulando-se uma noção de sujeito coletivo, em última análise, de extração romântica (Bloch, 1998). Independentemente da posição de Halbwachs, é verdade que a noção do coletivo parece remeter para uma ideia de partilha igual, obliterando dimensões de conflito e a presença de relações de poder e, por conseguinte, correndo o risco de remeter para um conceito essencializado de comunidade no âmbito do qual a própria noção de memória como construção e como negociação de sentidos passa inevitavelmente para segundo plano. Em estudos desenvolvidos no Centro de Estudos Sociais, nomeadamente no âmbito de um projeto de investigação sobre a transmissão intergeracional do trauma que intitulámos "Os filhos da guerra", preferimos, assim, opor ao conceito de memória individual ou privada o conceito de memória pública, a que voltarei ainda. ${ }^{2}$

Aleida Assman, uma das protagonistas mais destacadas dos estudos de memória contemporâneos, tem vindo a propor uma

2 Sobre o conceito de Halbwachs, cf., nomeadamente, Olick, 2008. Para alguns resultados do projeto em referência, cf. Ribeiro e Ribeiro, 2011; 2013; Ribeiro, Vecchi e Ribeiro, 2012. 
distinção operativa que me parece ter especial relevância para os estudos do património - a distinção entre o cânone e o arquivo. De acordo com Assman (2008), o cânone é a memória em circulação ativa, constituindo um modo de articulação do passado no presente; o arquivo é a memória simplesmente "armazenada", em estado de latência, que mantém o passado como passado. Os dois conceitos são, naturalmente, dinâmicos, isto é, a todo o momento, em contextos sociais e políticos específicos, o que estava no cânone pode ser remetido para o arquivo, e vice-versa, por ação de grupos ou forças sociais que, num determinado momento, tenham a capacidade de protagonizar esse processo.

No texto que tenho vindo a citar, Assman relaciona esta distinção entre o cânone e o arquivo com duas categorias trabalhadas por Jakob Burckhardt: a mensagem e o traço (ibid.: 98-99). Burckhardt, um dos pais da historiografia de língua alemã, desconfiava do valor histórico daquilo a que chama mensagens, isto é, aquilo que foi produzido para ser legado à posteridade perpetuando, nomeadamente, uma memória oficial e que, portanto, transporta o signo do poder e da manipulação institucional. O conceito de traço, por contraste, aproxima-se tendencialmente do testemunho num sentido amplo, abrangendo o não-intencional, aquilo que, não transmitindo uma visão estruturada, pode servir de base a uma história alternativa que não se deixe engodar pelas lógicas dominantes.

Note-se como esta noção de traço, apontando para o que sobreviveu do passado, mas de modo não estruturado e, muitas vezes, pouco visível ou mesmo invisível para o olhar comum, faz lembrar o programa de Walter Benjamin de "escovar a história a contrapelo", isto é, valorizar o reverso das narrativas dominantes e pesquisar os interstícios ocultos nas dobras dessas narrativas. Este é um programa, é bom lembrá-lo, formulado da perspetiva da contemporaneidade, a que Benjamin chama "Jetztzeit", literalmente, o tempo-do-agora, que faz explodir o continuum indiferente do tempo da modernidade 
e permite a reconquista de uma posição de sujeito e uma possibilidade de sentido. É verdade que acordar os mortos e recompor o que foi destroçado, a ambição impossível do Anjo da História de Benjamin, não está ao alcance do trabalho da memória. Este, na verdade, faz-se pelos vivos e para os vivos, isto é, por nós e para nós, mas, justamente, é a capacidade de lembrar, não apenas na esfera privada, mas na esfera pública, que permite que nos situemos no âmbito daquela semântica densa do tempo histórico a que, como vimos há pouco através da citação de Agamben, podemos chamar o contemporâneo.

Estas parcas reflexões visam lembrar que o atual boom dos estudos da memória se deve em parte considerável à consciência da história catastrófica do século XX. Sejam os estudos sobre o Holocausto ou, mais em geral, os estudos sobre a violência, sejam os estudos pós-coloniais, do que se trata é de recuperar a memória do sofrimento concreto de seres humanos concretos, de escutar a voz daquele subalterno que, mesmo quando pôde falar, o fez quase sempre num espaço de enunciação que o condenava ao silêncio. Lembra Primo Levi, a abrir o prefácio a Os que sucumbem e os que se salvam, que muitos relatos autobiográficos de sobreviventes do Holocausto fazem referência ao modo como os guardas SS dos campos se compraziam em torturar os prisioneiros dizendo-lhe que não apenas estavam fisicamente condenados, mas também a máquina concentracionária se encarregaria de assegurar que nada ficasse da sua memória - mesmo que, por um qualquer acaso, alguma coisa sobrasse, ninguém se disporia a acreditar em história tão inverosímil (Levi, 1989: 1).

É, em boa parte, a tarefa de desmentir os assassinos que alimenta hoje em dia a vertente crítica dos estudos da memória. Dito de outra forma: trata-se de refletir sobre um património do silêncio e do sofrimento, um património que não é apenas imaterial, nos termos da equívoca distinção convencionalmente estabelecida, mas se 
materializa igualmente de múltiplas formas, desde a musealização e memorialização até às práticas estéticas ou a diferentes modos de discurso público. Sublinhe-se que a construção desse património do silêncio passa, em aspetos essenciais, também pela investigação histórica - na verdade, a distinção entre história e memória, sendo necessária, não tem que traduzir de modo nenhum uma dicotomia estanque. Veja-se, por exemplo, a questão do nome. Há alguns anos, um grupo de investigação austríaco, o Dokumentationsarchiv des österreichischen Widerstands (Arquivo Documental da Resistência Austríaca), conseguiu completar o projeto, moroso e difícil, de identificação nominal caso a caso de todos os judeus de Viena deportados pelos nazis. Perguntar-se-á o que é que isto acrescenta ao nosso conhecimento da história do Holocausto, seguramente um dos temas da história do século XX mais exaustivamente investigados. A resposta talvez seja que não acrescenta nada ou acrescenta muito pouco. Mas, a meu ver, a restituição do nome e, concomitantemente, da identidade e da condição de sujeito às vítimas da violência genocida acrescenta muito do ponto de vista daquilo a que chamaria uma ética da memória - não em nome dos mortos, que ninguém poderá já restituir à vida, mas, justamente, em nome dos vivos, enquanto património de memória essencial para a produção de uma consciência crítica do contemporâneo.

É bom de ver que estamos a falar de um património da memória que está longe de ser consensual, de constituir uma memória coletiva no sentido de Halbwachs, mas é atravessado por tensões e conflitos inerradicáveis. O levantamento de uma vala comum da Guerra Civil de Espanha representa um momento de um trabalho de memória inevitavelmente marcado por relações de antagonismo, na medida em que quebra décadas se não de esquecimento, de silêncio (Silva, 2005; Ferrándiz, 2008; Vincent, 2010; Colmeiro, 2011). Ou pense-se na memória da Guerra Colonial entre nós e na dificuldade extrema de fazer confluir as miríades de memórias 
privadas naquilo a que poderíamos chamar uma memória pública - em boa parte, justamente pelas múltiplas tensões que ainda hoje atravessam essa memória.

Tendo tudo isto em mente, e tendo em mente o carácter, por definição, essencialmente polémico dos conceitos basilares dos estudos culturais em geral, podemos perguntar quais são as declinações do conceito de memória que nos podem ser mais úteis, em particular quando queremos pensar esse conceito em articulação com o de património. Enumerarei, sem preocupação de exaustividade e de modo inevitavelmente sucinto, algumas dessas declinações, que sinalizam outras tantas dimensões polémicas do conceito.

A primeira questão diz respeito, precisamente, à relação entre o privado e o público. Quando, e como, é que o privado se torna socialmente relevante e leva a uma rearticulação da memória pública, se torna património público? Esta era uma das perguntas condutoras do projeto Os Filhos da Guerra: Pós-Memória e Representações, a que já fiz alusão e que, entre outros aspetos, partia da constatação de que um excesso de memória privada da Guerra Colonial no Portugal dos nossos dias corresponde a um défice da memória pública. As respostas possíveis terão de envolver uma investigação em múltiplos planos, capaz de pôr em correlação dimensões como a da política do Estado, nomeadamente a política educativa, o papel dos media, ${ }^{3}$ mas também a relevância do campo das artes, do cinema, das artes plásticas e da literatura, no estabelecimento de modos de representação que criam espaços de articulação da memória suscetíveis de serem partilhados na esfera pública.

Uma outra questão cada vez mais premente diz respeito aos processos do que poderíamos chamar a transnacionalização da memória.

3 Seria necessário avaliar, por exemplo, o impacto público de um trabalho documental com a excelência da série A Guerra, de Joaquim Furtado, apresentada pela RTP de 2007 a 2013. 
Transnacionalização não apenas no sentido, por exemplo, em que um país historicamente colonizador partilha memórias e patrimónios - nomeadamente, desde logo, o da língua - com países que são suas ex-colónias, mas também noutros sentidos, em que os limites nacionais se revelam demasiado estreitos. Refiro-me a situações, por exemplo, em que um acontecimento local vem a obter repercussão global. Hoje em dia, é legítimo afirmar que a memória do Holocausto é uma memória global, no sentido em que, enquanto desmentido irrevogável de qualquer crença ingénua na ordem das coisas na modernidade, Auschwitz constitui um paradigma de violência absoluta que serve de metanarrativa para a compreensão de outros fenómenos de violência sistemática e em larga escala (Assman, 2010).

Mas a questão da transnacionalização da memória tem também outras vertentes, relacionadas com os fenómenos de mobilidade que marcam as sociedades contemporâneas. As memórias sempre viajaram e isso hoje em dia é mais verdade do que nunca. Mas o que é que acontece às memórias quando viajam? Os processos de deslocalização e de translocalização que constituem as memórias diaspóricas acarretam consigo, inevitavelmente, a desestabilização dos quadros de referência e geram modos de turbulência que fazem com que os quadros sociais da memória se transformem e ganhem dimensões de ambivalência crescentemente sujeitas a lógicas interculturais.

Neste quadro, ganha relevância um conceito relativamente recente e que, originalmente desenvolvido no âmbito dos estudos sobre o Holocausto, pode bem aplicar-se igualmente a situações como as vividas, por exemplo, na relação de uma segunda geração emigrante com um país de origem que, muitas vezes, não é sequer diretamente conhecido. Marianne Hirsch, que propôs o conceito de pós-memória no seu livro Family Frames, publicado em 1997, define pós-memória como "a relação da segunda geração com experiências poderosas, frequentemente traumáticas, que são anteriores ao seu nascimento mas, não obstante lhes foram transmitidas de modo tão profundo 
que constituem memórias dignas desse nome" (Hirsch, 2008: 103). Estamos, há que reconhecê-lo, perante um conceito subteorizado e que necessita de ser trabalhado e testado sobretudo em contextos empíricos. Entre os vários problemas que lhe estão associados há um particularmente difícil, a meu ver, o facto de pós-memória se referir em primeira linha à esfera privada ou, em rigor à esfera familiar. Na verdade, é nesta esfera que, por excelência, acontece a "transmissão profunda" de acontecimentos muitas vezes traumáticos a que se refere Hirsch. É possível projetar esta experiência privada para uma dimensão pública? Ou, dito de outro modo, existe ou pode existir uma pós-memória pública? Esta é uma pergunta que está verdadeiramente por responder, muito embora, nomeadamente no plano das artes, muita coisa aponte para essa possibilidade.

No âmbito do projeto Os Filhos da Guerra, a que tenho vindo a fazer referência, e que tinha por objeto investigar a possibilidade da transmissão intergeracional do trauma, obtiveram-se resultados, ainda só muito parcialmente publicados, que confirmam claramente a hipótese de uma vulnerabilidade ao trauma muito superior por parte dos filhos da guerra, isto é, de uma segunda geração nascida de pais ex-combatentes vítimas de stress pós-traumático. Essa vulnerabilidade acrescida situa-se com idêntica clareza no quadro de uma pós-memória da guerra, alimentada por uma vivência familiar difícil, mas também pelo contacto mais ou menos secreto com traços e rastos da história paterna, por exemplo, de modo particularmente importante, através de fotografias, mas também de cartas, diários ou outras formas de um testemunho tornado silencioso, mas que o gesto de memória do membro da segunda geração arranca ao silêncio. Pode a pós-memória assim construída tornar-se pública? Estamos, nitidamente, no âmbito daquilo a que poderíamos chamar a política das emoções, perante a questão de saber se é possível uma dialética do reconhecimento e da compaixão suscetível de atravessar tão profundamente a esfera pública que gere constelações 
de memória tão intensamente vividas socialmente que justifiquem a designação de pós-memória.

Para compreender questões como as que esbocei, duas outras declinações do conceito de memória crescentemente utilizadas se afiguram especialmente importantes. Refiro-me, em primeiro lugar, ao conceito de memória prostética, isto é, uma memória que é construída a partir de próteses, da mediação de objetos de diferente tipo, com proeminência especial para as imagens fotográficas ou, noutro plano, cinematográficas (Lury, 1998; Landsberg, 2004). E refiro-me, em segundo lugar, ao conceito de memória multidirecional, que tem vindo a ser proposto com especial fundamentação por Michael Rothberg, no âmbito dos estudos sobre o Holocausto. De facto, entre as várias controvérsias que atravessam esses estudos, pode encontrar-se aquilo a que Jean-Michel Chaumont, numa obra de 1997, chamou La concurrence des victimes, a concorrência das vítimas, isto é reivindicações concorrentes que, muitas vezes, assumem a forma da acusação de que a insistência na memória do Holocausto obscurece a memória de muitas outras violências e deixa na sombra as vítimas dessas violências ou também a acusação, por exemplo, de que sublinhar o genocídio dos judeus remete para segundo plano ou mesmo silencia outras dimensões dos crimes nazis como o genocídio dos ciganos. Uma outra forma de concorrência, que o grupo de investigação do projeto Os Filhos da Guerra experimentou diversas vezes em primeira mão, em ocasiões marcadas por uma elevada exacerbação emocional e mesmo algum nível de conflitualidade, traduz-se na recusa do direito à memória da segunda geração: deste ponto de vista, só as vítimas verdadeiras, os detentores exclusivos de uma memória "autêntica", no caso vertente, os ex-combatentes da Guerra Colonial, "sabem como foi" e, portanto, têm direito à memória e ao testemunho.

A tese de Rothberg, demonstrada pelo autor a partir de múltiplos exemplos, é muito simples: a existência de memórias concorrentes 
não se traduz nem tem necessariamente que traduzir-se em menos, mas sim em mais memória. Por outras palavras, a memória não é unidirecional, mas sim multidirecional, isto é, tem a capacidade de constituir-se em múltiplas vertentes, que não se anulam mutuamente, antes se potenciam na interrelação que estabelecem entre si (Rothberg, 2009).

Guardei para o fim deste rápido elenco uma questão particularmente difícil. Se é verdade que uma perceção fundamental das teorias do património está em que o desaparecimento do passado equivale ao roubo do futuro, como pensar a questão da memória num universo dominado pela lógica presentista da cultura de massas? $\mathrm{Na}$ verdade, esta, mesmo quando a roupagem é a da reconstituição histórica, como em séries televisivas de sucesso ou em feiras medievais ou parques temáticos, vive numa espécie de presente intemporal de que está ausente a profundidade da memória. Sem que possa aqui desenvolver este aspeto, sirvo-me dele para chegar à minha conclusão: sublinhar o papel da memória no horizonte do nosso presente significar lutar pela recomposição da esfera pública num sentido que permita o emergir de referências agregadoras suscetíveis de projetar esse presente na dimensão plena do contemporâneo, isto é, lembrando a definição de Agamben, que permita a produção daquela inatualidade que nos permite perceber e apreender o nosso tempo e sermos verdadeiramente do nosso tempo.

\section{Referências bibliográficas}

AGAmBen, Giorgio (2009), O que é o contemporâneo e outros ensaios. Chapecó: Argos.

ASsman, Aleida (2008), "Canon and Archive", in Astrid Erll; Ansgar Nünning (orgs.), Cultural Memory Studies. An International and Interdisciplinary Handbook. Berlin: de Gruyter, 97-107. 
Assmann, Aleida (2010), "The Holocaust - A Global Memory? Extensions and Limits of a New Memory Community", in Aleida Assmann; Sebastian Conrad (orgs.), Memory in a Global Age: Discourses, Practices and Trajectories. Palgrave MacMillan: Basingstoke, 97-117.

BLOCH, Marc (1998), "Memória colectiva, tradição e costume: a propósito de um livro recente", in M. Bloch, História e Historiadores. Textos reunidos por Étienne Bloch. Lisboa: Teorema.

CHAUmont, Jean-Michel (1997), La concurrence des victimes: génocide, identité, reconnaissance. Paris: La Découverte.

COLMeIro, José (2011), “A Nation of Ghosts?: Haunting, Historical Memory and Forgetting in Post-Franco Spain", $452^{\circ} \mathrm{F}$. Electronic Journal of theory of literature and comparative literature, 4, 17-34.

CRU, Jean Norton (1993), Témoins. Nancy: Presses Universitaires de Nancy. FERRÁNDIZ, Francisco (2008), "Cries and Whispers: Exhuming and Narrating Defeat in Spain Today", Journal of Spanish Cultural Studies, 9(2), 177-92. HALBWACHS, Maurice (1925), Les cadres sociaux de la mémoire. Paris: Lib. Félix Alcan.

HIRSCH, Marianne (2008), "The Generation of Postmemory”, Poetics Today, 29(1), 103-28.

LANDsberg, Alison (2004), Prosthetic Memory: The Transformation of American Remembrance in the Age of Mass Culture. New York: Columbia University Press.

LEVI, Primo (1989), The Drowned and the Saved. Trad. R. Rosenthal. London: Abacus.

LURY, Celia (1998), Prosthetic Culture. Photography, Memory and Identity. London/New York: Routledge.

MCDOWELL, Sara (2008), "Heritage, Memory and Identity”, in B. J. Graham; Peter Howard (orgs.), The Ashgate Research Companion to Heritage and Identity. Burlington: Ashgate, 37-53.

NORA, Pierre (1993), Les lieux de mémoire. Paris: Gallimard.

OLICK, Jeffrey K. (2008), "From Collective Memory to the Sociology of Mnemonic Practices and Products”, in Astrid Erll; Ansgar Nünning 
(orgs.), Cultural Memory Studies. An International and Interdisciplinary Handbook. Berlin: de Gruyter, 151-61.

Ribeiro, António Sousa; RiBeiro, Margarida Calafate (2011), "Zeit, die stillsteht: Postgedächtnis und Trauma unter Kindern von Kriegsteilnehmern”, in Dietmar Goltschnigg (org.), Phänomen Zeit. Dimensionen und Strukturen in Kultur und Wissenschaft. Tübingen: Stauffenburg, 313-18.

RIBEIRO, Margarida Calafate; VECCHI, Roberto; RIBEIRO, António Sousa (2012), "The Children of the Colonial War: Post-Memory and Representations”, in Isabel Capeloa Gil; Adriana Martins (orgs.), Plots of War. Modern Narratives of Conflict. Berlin: De Gruyter, 2012, 11-23. RIBEIRO, Margarida Calafate; RIBEIRO, António Sousa (2013), “Os netos que Salazar não teve: Guerra Colonial e memória de segunda geração”, Abril - Revista do Núcleo de Estudos de Literatura Portuguesa e Africana da UFF, 5(11), 25-36.

ROTHBERG, Michael (2009), Multidirectional Memory: Remembering the Holocaust in the Age of Decolonization. Stanford: Stanford University Press.

SILVA, Emilio (2005), Las fosas de Franco. Crónica de un desagravio. Madrid: Ediciones Temas de Hoy.

VINCENT, Mary (2010), "Breaking the Silence? Memory and Oblivion since the Spanish Civil War", in Ben-Ze'ev, Efrat et al. (org.), Shadows of War. A Social History of Silence in the Twentieth Century. Cambridge: Cambridge University Press. 


\section{5}

\section{COLONIALISMO MO DERNO}

\section{E M IS S ÃO CIVILIZADORA}

No seu Política Ultramarina de Portugal, de 1955, Francisco Bahía dos Santos argumentava que a elevação moral dos "povos atrasados" fora a pedra angular da política colonial portuguesa, a "preocupação tradicional" de uma política sempre capaz de conciliar o "interesse material" com a realização de uma tarefa de "sentido universal". A antiguidade dos traços humanitários da colonização portuguesa seria inegável, um "processo acidental", ditado por princípios "morais e sentimentos religiosos", que se tornou uma política nacional, visando "a unidade política e a assimilação espiritual". Contrariamente ao que sucedia com outras "nações colonizadoras", a excecionalidade da colonização portuguesa era fácil de compreender e demonstrar. As políticas indígenas que governaram a constituição do terceiro império seriam mais "espontâneas que deliberadas", inscrevendo, codificando-as e formalizando-as, tendências naturais num conjunto de doutrinas que apontavam para a constituição de uma prova legal da constante missão civilizadora. Contudo, a retórica de uma doutrina institucionalizada da missão civilizadora foi sempre mais um princípio declarado do que uma prática efetiva, foi sempre mais um expediente que uma política, como James Duffy sintetizou com perspicácia. ${ }^{1}$

1 Francisco Bahia dos Santos (1955), Política Ultramarina de Portugal. Lisboa: Sociedade de Geografia de Lisboa, 181. Veja-se ainda James Duffy (1959), Portuguese Africa. Cambridge: Harvard University Press, 292-293. 
A assimilação nunca foi uma política de facto, ou sequer um desiderato significativo. A assimilação foi, no essencial, uma política marcadamente "seletiva", mais determinada pelas circunstâncias e por interesses conjunturais do que por um projeto de incorporação cultural, integração social ou promoção civilizacional que tivesse como meta a universalização e uniformização de direitos e deveres dentro do espaço imperial, não obstante as proclamações retóricas nesse sentido. Ou seja, foi antes o resultado das necessidades de um estado imperial e colonial com inúmeras limitações políticas, administrativas, económicas e militares e um produto da situação colonial, do que consequência de um complexo de idiomas e repertórios efetivamente planeado e aplicado nos territórios coloniais. Foi central na imaginação política do império, nos esforços da sua legitimação ideológica, mas não nos seus processos dominantes. Não foi certamente o produto da aplicação da torrente de medidas legislativas que visavam regular a natureza, o momento e os objetivos da suposta incumbência civilizadora. As leis imperiais foram, no essencial, leis de relações raciais; isto é, a legislação incorporou no seu cerne as gramáticas de um racismo institucionalizado, como o regime do Indigenato foi demonstrando até à sua abolição em 1961. Foram instrumentos de perpetuação, e não poucas vezes de agudização, e não de correção das condições objetivas de discriminação política, social, cultural e económica. Por exemplo, as leis que procuraram suprimir, de modo gradual, o tráfico de escravos e a escravatura foram, no essencial, instrumentos para legitimar e legalizar o trabalho forçado e novas formas económicas de dominação colonial. Não eram, seguramente, instrumentos com o fim de moralizar, por assim dizer, os termos das relações económicas e sociais coloniais. Ocuparam um lugar central nas modalidades 
ideológicas de justificação e legitimação do império colonial, mas pouco contribuíram para uma transformação mais profunda. ${ }^{2}$

Como qualquer sistema político, as estruturas imperiais e coloniais (e os projetos a estas associados) precisaram sempre de idiomas e repertórios ideológicos - plurais, contestados, com múltiplas origens sociais - de legitimação da sua existência e dos seus modi operandi administrativos. Como em qualquer ideologia, os argumentários das ideologias imperiais visaram sempre a autoperpetuação, a justificação da existência e da imperiosa preservação do império, assim como a legitimação dos modos de governação e administração imperial, dos seus idiomas e dos seus repertórios (não só instituições de governo mas também os sistemas e práticas de administração e regulação da vida das populações). ${ }^{3}$ De justificações valorizando os benefícios económicos do império a fundamentações sublinhando o seu imperativo civilizacional, passando por razões que apontavam para os seus benefícios cívicos - caráter, honra, glória -, foram (e são) várias as articulações (e rearticulações) da ideologia imperial. ${ }^{4}$ Estas foram, claro, quase sempre acompanhadas por argumentários de

2 Miguel Bandeira Jerónimo (2012), "The "Civilization Guild": Race and Labour in the Third Portuguese Empire c.1870-1930", in Francisco Bethencourt e Adrian Pearce (eds.), Racism and Ethnic Relations in the Portuguese Speaking World, 173-199. Londres: Oxford University Press.

3 É importante sublinhar a necessidade de se escrutinar a constituição histórica das ideologias imperiais para lá da mera decifração de textos escritos. A centralidade da análise das práticas sociais e da produção, circulação e receção de cultura material e visual deve ser reconhecida. Por outro lado, devemos ainda sublinhar o papel de justificação, de legitimação, de transformação e de contestação de uma dada ordem social e política que as ideologias desempenham. Para uma reflexão importante veja-se, entre outros, Michael Freeden (2004), "Ideology, political theory and political philosophy", in Gerald Gaus e Chandran Kukathas (eds.), Handbook of Political Theory, 173-199. London: Sage.

${ }^{4}$ Duncan Bell isola cinco tipos-ideais de modalidades de justificação ideológica das formações imperiais; comercial-explorador; realista-geopolítico; liberal-civilizacional; republicano; marcial. Duncan Bell (2013), "The ideologies of Empire", in Michael Freeden, Lyman Tower Sargent \& Marc Stears (eds.), The Oxford Handbook of Political Ideologies. Oxford: Oxford UP, maxime 543 e ss. 
resistência, associados à contestação da (des)ordem e da dominação imperial, tanto os que advogaram a necessidade da sua reforma como os que reclamaram o seu desmantelamento. ${ }^{5}$

Muito está por fazer no que concerne à identificação e estudo da substância plástica das ideologias imperiais no dito "terceiro império português", sobre os seus contextos de produção (nacionais e internacionais), sobre as redes e instituições da sua disseminação e sobre as redes e práticas da sua apropriação e da sua contestação. ${ }^{6}$ As modalidades ideológicas dominantes que procuraram legitimar os imperialismos de benevolência, de obrigação, de inevitabilidade, de tutela ou de desenvolvimento/modernização estão ainda por estudar em profundidade. ${ }^{7}$ Em Portugal, o imperialismo de benevolência essencialmente centrado na supressão da escravatura e do tráfico de escravos, alicerçado em competitivas motivações religiosas (o objetivo da conversão ao cristianismo e, em grande medida, proveniente de setores protestantes) e humanitárias (defendendo a melhoria das condições de vida das populações não-europeias) - foi fortemente condicionado pela persistência de uma ideologia da escravatura. ${ }^{8}$

5 Jonathan Derrick (2008), Africa's 'Agitators': Militant Anti-Colonialism in Africa and the West, 1918-1939. London: Hurst.

${ }^{6}$ Considere-se, contudo, a síntese de Valentim Alexandre (2005) "O Império Português (1825-1890): ideologia e economia”, Análise Social, Vol. XXXVIII, n. ${ }^{\circ}$ 169, 959-979, e Miguel Bandeira Jerónimo e António Costa Pinto (2015), "Ideologies of Exceptionality and the Legacies of Empire in Portugal", in Dietmar Rothermund (ed.), Memories of Post-imperial Nations: The Aftermath of Decolonization, 1945-2013. Cambridge: Cambridge University Press, 97-119.

7 Para os primeiros três tipos de imperialismos veja-se Andrew Porter (2011), O Imperialismo Europeu, 1860-1914. Lisboa: Coleção História\&Sociedade, Edições 70. Para os de tutela e de desenvolvimento veja-se, entre outros, Neta Crawford (2002), Argument and Change in World Politics: Ethics, Decolonization, Humanitarian Intervention. Cambridge: Cambridge University Press; Michael Callahan (2004), A Sacred Trust: The League of Nations and Africa, 1929-1946. Brighton: Sussex Academic Press; e Joseph Hodge, Gerald Hodl e Martina Kopf (eds.) (2014), Developing Africa: Concepts and Practices in Twentieth Century Colonialism. Manchester: Manchester University Press.

8 Miguel Bandeira Jerónimo, "The "Civilization Guild”. Veja-se ainda João Pedro Marques (2006), The Sounds of Silence: Nineteenth-Century Portugal and the Aboli- 
Já o imperialismo de obrigação, marcado por conceções utilitaristas radicadas em perspetivas evolucionistas explicativas da diferenciação racial e da diversidade cultural, deteve um inegável protagonismo, como sucedeu com o imperialismo de inevitabilidade, caracterizado pela justificação da expansão colonial e do associado projeto civilizacional enquanto consequência natural da superioridade europeia e ocidental, num processo revelador de uma espécie de variante social, política e económica das teorias e esquemas da seleção natural. Igual ressonância tiveram os vários imperialismos de tutela e de desenvolvimento, associados à progressiva internacionalização das questões imperiais e coloniais, desde finais do século XIX até ao momento descolonizador. Todos estes contextos, discursos e processos históricos envolveram múltiplas teorias, ideologias e imaginários imperiais9 e tiveram a participação de múltiplos saberes (com destaque para as ciências sociais e humanas ${ }^{10}$ ), participando

tion of the Slave Trade. Oxford: Berghahn Books. Para uma análise global de longa duração veja-se o seminal trabalho de Francisco Bethencourt (2013), Racisms: from the Crusades to the Twentieth Century. Princeton, Oxford: Princeton University Press.

9 As teorias desempenham um papel central na formação histórica de ideologias mas não esgotam este processo. A existência de imaginários sociais concretos e minimamente partilhados, que funcionem como enquadramentos culturais propiciadores de conhecimento e comunicação, são fundamentais. De outro modo, as formas legítimas de legitimação das ideologias são pouco prováveis. Para a necessária distinção entre ideologias, imaginários e teorias imperiais, veja-se Duncan Bell, "The ideologies of Empire", maxime 538-543. Bell recupera a noção de imaginário social proposta por Charles Taylor (2014) em Modern Social Imaginaries. Durham, NC: Duke University Press, em si fortemente devedora da noção de comunidade imaginada de Benedict Anderson (1991). Veja-se Benedict Anderson (2012), Comunidades Imaginadas. Lisboa: Coleção História\&Sociedade, Edições 70.

10 A história dos idiomas e repertórios de legitimação imperial e a história da evolução das ciências sociais e humanas são histórias profundamente interligadas. A imaginação (geo)política dos impérios coloniais europeus só pode ser compreendida explorando as suas interseções. David Long e Brian Schmidt (eds.) (2005), Imperialism and Internationalism in the Discipline of International Relations. Albany: SUNY Press; Georges Steinmetz (ed.) (2013), Sociology and Empire: The Imperial Entanglements of a Discipline. Durham, NC: Duke University Press; Miguel Bandeira Jerónimo (2015), "Geografias vitais: A imaginação (geo)política do novo imperialismo europeu (1870-1920)", in Francisco Colom González, (ed.), El espacio político. Aproximaciones al 'giro espacial' en la teoría política. Madrid: Editorial Anthropos. 
na constituição de inúmeras doutrinas de uma missão civilizadora, baseadas numa codificação da desigualdade civilizacional e racial, geradora de um conjunto de políticas da diferença que eram, simultaneamente, políticas que visavam demonstrar e legitimar o esforço colonizador e civilizador. ${ }^{11}$

De facto, a racialização do mundo imperial e colonial, baseada num corpus de representações sobre a "psicologia" e a "cultura" das comunidades nativas e do seu estado de desenvolvimento sociocultural, constituiu um poderoso instrumento de legitimação das políticas imperiais e coloniais, sobretudo as politicas indigenas. ${ }^{12}$

A racialização da imaginação imperial, das formas de conhecimento e entendimento da situação colonial e das respetivas formações sociais, dos códigos e das práticas culturais, dos sistemas económicos e educacionais e, como referimos, dos enquadramentos legais da colonização (incluindo as leis que regulavam as relações sociais coloniais) criou condições favoráveis à persistência de práticas coloniais conducentes à lógica de assimilação "seletiva”, ao regime formal e informal de cidadania dual, à institucionalização de formas múltiplas de discriminação racial, económica, política e social. As políticas indígenas constituíram a codificação jurídica da

11 Para a noção de politicas da diferença veja-se Frederick Cooper e Jane Burbank (2010), Empires in world history. Princeton: Princeton University Press, 11-13. Para o catálogo de conceções de civilização no interior de ideologias imperiais explore-se Brett Bowden (2009), The Empire of Civilization: The Evolution of an Imperial Idea. Chicago: University of Chicago Press.

12 Por racialização entendemos a combinação entre dimensões ideológicas - o uso da ideia de raça para estruturar a perceção sobre grupos ou populações, ou seja, a sua categorização a partir de uma perspetiva racial, definindo e construindo coletividades sociais diferenciadas; e o uso destas categorias e visões raciais para racializar interações e relações sociais entre coletividades sociais diferenciadas e dimensões práticas ou institucionais - o processo de institucionalização destas categorias e visões raciais no interior do aparelho de Estado, ou seja, o processo de organização das divisões raciais (e das desvantagens associadas) por parte do Estado, um racismo institucional patrocinado pelo Estado. Veja-se Rohit Barot e John Bird (2001), "Racialization: The Genealogy and Critique of a Concept", in Ethnic and Racial Studies, vol. 24, n. ${ }^{\circ}$, 601-618; Karim Murji e John Solomos (eds) (2005), Racialization: Studies in Theory and Practice. Oxford: Oxford University Press. 
diferença racializada (diferenciação a partir de critérios raciais): na categorização e classificação das populações nativas, na sua administração e controlo diferenciados, na definição do seu estádio de desenvolvimento "civilizacional" e das subsequentes "necessidades", direitos e deveres, ou seja, na definição discriminada do seu papel político e económico (por exemplo, no uso prolongado do trabalho forçado e obrigatório). A construção do Estado-império português e das suas inúmeras políticas da diferença foi um processo histórico intimamente ligado a processos históricos de racialização, com óbvias dissemelhanças em relação a outros casos mas partilhando, no entanto, inegáveis similitudes. ${ }^{13}$

Um exemplo claro deste processo, e também causa evidente da sua centralidade, reside no pragmatismo colonial de finais de oitocentos (imbuído de uma considerável genealogia histórica, claro está), que contribuiu de modo decisivo para a racialização da imaginação e das práticas políticas centradas na formação imperial. A institucionalização de um pragmatismo colonial racializado - protagonizado, em oitocentos, por figuras como Oliveira Martins, António Ennes ou Mouzinho de Albuquerque, entre outros - prolongou-se, de diferentes modos e com várias articulações mas com inegáveis continuidades, ao longo do século XX. O pensamento, também ele diverso mas com afinidades incontornáveis, dos principais especialistas imperiais e coloniais - utilitaristas e pragmáticos na sua imaginação das funções políticas, económicas e socioculturais do império colonial - foi recuperado por personalidades como Sampayo e Mello, José Gonçalo Santa Rita, Marnoco e Souza, Rui Ennes Ulrich. Este pragmatismo colonial racializado estimulou elaborações científicas (que justificaram e legitimaram o seu pensamento), foi

13 Veja-se, a este propósito, David Theo Goldberg (2002), The Racial State. Oxford: Blackwell; idem (2002a), "Racial States", in David Theo Goldberg e John Solomos (eds), A Companion to Racial and Ethnic Studies, 233-258. Oxford: Blackwell. 
incorporado pelos sistemas de educação colonial (sobretudo na metrópole, tanto a um nível rudimentar como superior), alimentou a propaganda colonial que visou a imperialização da nação (nos jornais e em eventos como a Semana das Colónias de 1920 em diante), formou os curricula e os manuais de administração colonial que educaram gerações de burocratas coloniais, e cristalizou-se em formas de imaginação (geo)política do Estado-império (pense-se nas posições portuguesas na defesa internacional dos sistemas de trabalho colonial no interior do seu império). O argumentário pragmático e utilitarista, fortemente racializado, repita-se, predominou ainda na intensa produção legislativa, caracterizando o enquadramento legal da missão civilizadora e das suas políticas indígenas. Ou seja, o pragmatismo colonial racializado tornou-se o elemento central na formulação de modalidades de dominação colonial - laborais, fiscais, educativas, religiosas ou missionárias - e das respetivas estratégias de legitimação imperial num plano interno e externo. ${ }^{14}$

O caso da educação é assaz ilustrativo a este propósito. ${ }^{15} \mathrm{Se}$ existiu um consenso relativo à necessidade de educar a nação sobre as questões imperiais e coloniais - com objetivo de alargar e racionalizar a soberania e a estrutura administrativa do império (na metrópole e nos territórios coloniais), de acrescentar cientificidade aos programas e às políticas coloniais (por exemplo, por via da

\footnotetext{
14 Miguel Bandeira Jerónimo, "Civilization guild".

15 João Carlos Paulo (1992), "A Honra da Bandeira". A Educação Colonial no Sistema de Ensino Português (1926-1946). Lisboa: Dissertação de Mestrado, FCSH-UNL; idem (1999), "Da Educação Colonial Portuguesa ao Ensino no Ultramar", in Francisco Bethencourt e Kirti Chadhuri (dir.), História da Expansão Portuguesa, vol. 5, 304-333. Lisboa: Círculo de Leitores; Miguel Bandeira Jerónimo (2006), "Os Missionários do Alfabeto nas Colónias Portuguesas (1880-1930)”, in Diogo Ramada Curto (ed.), Estudos de Sociologia da Leitura em Portugal no Século XX, 29-67. Lisboa: Fundação Calouste Gulbenkian; Ana Isabel Madeira (2007), Ler, Escrever e Orar: uma análise histórica e comparada dos discursos sobre a educação, o ensino e a escola em Moçambique, 1850-1950. Lisboa: Tese de Doutoramento, Universidade de Lisboa.
} 
formulação de uma sciência da colonização ${ }^{16}$ ), de socializar certos setores do país numa ideologia proimperial através da produção e disseminação de propaganda de forma sistemática sobre a história colonial e imperial, num esforço para reforçar a legitimidade interna da continuação dos projetos imperiais -, o mesmo sucedeu quanto aos escassos benefícios da educação colonial, nomeadamente no que diz respeito aos indígenas. A própria produção de conhecimento colonial esteve intimamente associada à criação de condições para responder a necessidades políticas, militares e administrativas (delimitação de fronteiras, definição de estratégias securitárias, controlo das populações nativas, formação da burocracia colonial) e a necessidades económicas (nomeadamente a identificação dos recursos naturais a explorar, a organização de um mercado laboral nativo o mais estável possível e o desenho das geografias da taxação). ${ }^{17}$

A educação, formal e literária, do nativo não foi a prioridade. $\mathrm{O}$ facto de terem sido especialistas militares e administradores coloniais, e não pedagogos ou especialistas educativos, a definir o lugar da educação no interior das políticas coloniais, ajuda por certo, a compreender esta situação. ${ }^{18}$ As reflexões sobre a educação colonial surgiram sempre como um epifenómeno de debates sobre a necessária reforma das burocracias metropolitanas e coloniais, sobre a natureza, os princípios e os repertórios da missão civilizadora (sobre a sua retórica e sobre as suas concretizações), sobre questões demográficas e migratórias associadas à necessidade de

16 Veja-se, por exemplo, Lourenço Cayolla (1912), Sciencia da colonização. Lisboa: Tipografia da Cooperativa Militar.

17 Miguel Bandeira Jerónimo (2013), "The States of Empire (1880-1975)", in Luís Trindade (ed.), The Making of State Power in Portugal, 65-101. Cambridge: Cambridge Scholars Press. Veja-se ainda, num outro plano, Bernardo Cruz (2015), Proto-totalitarismo de gabinete: A génese e consolidação do Gabinete dos Negócios Políticos do Ministério do Ultramar. Lisboa: Tese de Mestrado, FCSH-UNL.

18 João Carlos Paulo (2001), "Cultura e Ideologia Colonial”, in António Henrique de Oliveira Marques (ed.), Nova História da Expansão Portuguesa. Lisboa: Editorial Estampa, 34-35. 
desenhar programas de colonização étnica, e sobre como alcançar a imperativa modernização dos sistemas de desenvolvimento económico das colónias.

A educação do indígena não deixou de ser debatida. No Congresso Colonial de 1901, por exemplo, António Cabreira procurava acrescentar a educação do nativo ao catálogo de projetos civilizadores. Mas a educação colonial continuou a ser essencialmente pensada a partir de outras questões consideradas mais importantes e prementes, desde a necessidade de se pensar a instrução do colono (e oficiais, missionários, comerciantes e homens de negócio, trabalhadores) até à necessidade de vulgarização das ideias e representações sobre o império entre as populações metropolitanas. As necessidades inexoráveis de ocupar e colonizar, de controlar e administrar e de legitimar o império constituíram as razões para conhecer e educar. ${ }^{19}$ Contudo, e mesmo assim, a instrução dos futuros colonos, incluindo missionários e militares, revelou sempre enormes debilidades, tendo assentado, essencialmente, na disseminação de noções - cursos sobre noções de higiene tropical ou noções sobre etnografia e psicologia do indígena, estes últimos sempre baseados em noções de "indolência", "vadiagem", "barbárie", "bestialidade", um amplo catálogo de preconceitos raciais e etnoculturais - e no ensino de conhecimentos assaz rudimentares sobre as línguas locais.

Claro que as palavras cristalinas de António Ennes ou Oliveira Martins foram gradualmente substituídas por outro tipo de considerações, assentes em lógicas de diferenciação e hierarquização racial e cultural mais elaboradas e (supostamente) científicas. Se se foi tornando cada vez mais difícil proferir frases como a escrita por Oliveira Martins - "a ideia de uma educação dos negros é absurda não só perante a História, mas também em virtude da capacidade mental dessas raças inferiores" -, o seu sentido não deixou de ser

19 António Cabreira (1902), o Ensino Colonial e o Congresso de Lisboa, 3. 
partilhado socialmente, detendo um lugar central nos imaginários e nas ideologias imperiais e coloniais. Se afirmações como as que argumentavam que o suposto esforço civilizador não passava de uma "simpática ilusão" começaram a rarear (e já na altura não esgotavam as ideias sobre o assunto), o consenso relativo sobre os métodos que deviam materializar esse esforço não incluíam a promoção de projetos educativos em contexto colonial, especificamente dirigidos às populações colonizadas. Representações e discursos semelhantes, associados a uma tradição de pragmatismo colonial racializado, foram gradualmente abandonados ou mitigados, mas as práticas deles decorrentes nem tanto. A educação do africano foi sempre menosprezada. A missão civilizadora passava por outros princípios, instrumentos e objetivos. ${ }^{20}$

Neste contexto, a educação para e pelo trabalho, sobretudo o compelido, tornou-se predominante. ${ }^{21}$ A "civilização rudimentar" que caracterizaria as populações coloniais a isso obrigava, segundo a justificação de António Enes. O estado colonial, "soberano de populações semibárbaras", não devia ter "escrúpulo de obrigar e, sendo preciso, de forçar" os "rudes negros de África" a trabalhar, "a melhorarem-se pelo trabalho, a adquirirem pelo trabalho meios de existência mais feliz, a civilizarem-se pelo trabalho". Paiva Couceiro concordava, sublinhando os perigos da educação primária enquanto "pedagogia essencial ou dominante": devia ser apenas um complemento subordinado do "ensino do trabalho". De outro

20 Joaquim Pedro de Oliveira Martins (1978), O Brasil e as Colónias Portuguesas. Lisboa: Guimarães Editores, 175-179, 213 e 255; Valentim Alexandre (2000), "Questão Nacional e Questão Colonial em Oliveira Martins", in Velho Brasil, Novas Áfricas. Portugal e o império (1808-1975), 174-179. Porto: Edições Afrontamento; Miguel Bandeira Jerónimo (2010), Livros Brancos, Almas Negras. Lisboa: Imprensa de Ciências Sociais.

21 Sobre este assunto veja-se Miguel Bandeira Jerónimo (2010), Livros Brancos, Almas Negras. 
modo, contribuiria para que os nativos se tornassem "avessos às actividades produtivas". ${ }^{22}$

A questão educativa foi sempre enquadrada pela questão do trabalho e pela necessidade de criar um sistema efetivo e eficiente de regulação, administração e distribuição da mão de obra nativa. A educação pelo trabalho foi a questão central, o instrumento privilegiado para civilizar as populações nativas, para que estas entrassem no "grémio da civilização". ${ }^{23}$ Apesar da existência de formas distintas de o justificar, umas mais utilitaristas e pragmáticas (a exploração colonial devia proceder "sem escrúpulos, preconceitos nem quimeras", como dizia Oliveira Martins), outras mais crentes nos benefícios e na exequibilidade da civilização, este argumentário e as correspondentes políticas foram constantes da política colonial portuguesa. Como garante de uma exploração económica sem "escrúpulos" do império ou como uma obrigação civilizacional, a educação para e pelo trabalho foi um dos pilares inabaláveis da história do terceiro império. Nem a educação, laica ou religiosa, providenciada pelas estruturas eclesiásticas, sobretudo missionárias, foi uma alternativa séria, pelo menos até aos anos de 1940. A legislação de João Belo, o Estatuto Orgânico das Missões Católicas Portuguesas da África e Timor (1926), já prenunciara a delegação do programa civilizador para a alçada das missões católicas. Entre as suas várias responsabilidades, estava o objetivo de desenvolver no seu interior a educação agrícola, com o objetivo de aprimorar os processos laborais, "primitivos" e "rudimentares". A indispensável "disciplina social" nos mundos coloniais só poderia resultar da educação para e pelo trabalho: “a empresa misericordiosa de salvar

22 António Ennes (1946), "A Colonização Europeia de Moçambique", in Antologia Colonial Portuguesa, Vol I. Lisboa: Agência Geral das Colónias, 27-28; Paiva Couceiro (1910), Angola: dois anos de governo, 1907-1909. História e Comentários. Lisboa: Editora Nacional, 205-206.

23 Miguel Bandeira Jerónimo, "Civilization guild". 
almas para Deus tem de se conciliar com a de educar corpos para o trabalho", escreveu Ennes. Qualquer alternativa era assim uma "quimera", um mero simulacro de civilização, com consequências consideradas perigosas. ${ }^{24}$

As realidades educativas em contexto colonial eram um corolário óbvio destes discursos tornados políticas. Em 1908, o Grémio Africano de Lourenço Marques publicou um jornal intitulado $O$ Africano, cujo subtítulo, bastante significativo, era Número de Propaganda a Favor da Instrução. Nele podia ler-se que a colonização não oferecia "nem estradas, nem fontes, nem oficinas, nem escolas!", sendo que o propósito era o de exigir a construção de uma "escola" onde se ensinasse "a verdade e o horror ao vício" às "crianças - os homens de amanhã". ${ }^{25}$

Em 1922 e 1925, dois relatórios organizados por Thomas Jesse-Jones (sociólogo da Universidade de Columbia e diretor do famoso Hampton Institute) para a Phelps-Stokes Foundation não deixavam dúvidas, confirmando, aliás, relatórios produzidos no interior da própria burocracia colonial, como aquele feito por Mário Costa para Moçambique, apresentado por António Barradas, ou aqueloutro assinado por Joaquim Vaz Solipa Norte, primeiro relator da Inspecção Escolar da Província de Moçambique. ${ }^{26}$ A apreciação de Solipa Norte era clara, denunciando a distância entre o oficialmente declarado e as realidades coloniais: supostamente existiam " 153 escolas com o nome pomposo de técnicas, profissionais, agrícolas, primárias” mas "o maior número das quais é impossível fiscalizar ou saber com

24 Miguel Bandeira Jerónimo (2010), Livros Brancos, Almas Negras, 163. Veja-se ainda Joaquim Pedro de Oliveira Martins (1978), O Brasil e as Colónias Portuguesas, 257. Lisboa: Guimarães Editores; António Ennes (1913), Moçambique. Lisboa: Sociedade de Geografia de Lisboa, 175-178, 181-186 e 189.

25 Miguel Bandeira Jerónimo (2010), Livros Brancos, Almas Negras, 166-167.

26 Para uma análise mais detalhada destas questões veja-se Miguel Bandeira Jerónimo (2015a), The 'Civilising Mission' of Portuguese Colonialism, 111-121. Basingstoke: Palgrave Macmillan, Cambridge Imperial and Post-Colonial Studies Series. 
precisão onde demoram". Do mesmo modo, a análise de Barradas não deixava dúvidas: "Escolas a valer, não chega a haver na colónia duas dúzias delas. As outras são palhotas em que um indígena quase analfabeto ensina a outros indígenas o Padre-Nosso e finge que os ensina a rabiscar quarto palavras e a soletrar outras tantas". A estatística contabilizava escolas onde os alunos saíam a falar "árabe, landim e talvez inglês", não português. Fazia o mesmo com palhotas onde se ensinavam os "sorates do Alcorão", não o verbo da missão do império. Como em muitas outras situações, incluindo em períodos históricos mais tardios, a razão estatística obscurecia as realidades coloniais locais. ${ }^{27}$

Os relatórios de Jesse-Jones (1922 e 1925) aludiam a situações semelhantes em Angola e Moçambique. ${ }^{28}$ No caso de Angola, a escassez e a inadequação da instrução pública, a indiferença da administração colonial em relação aos problemas dos indígenas, o parco desenvolvimento material e cultural destes e os "desafortunados métodos utilizados pelos empregadores para obter mão de obra nativa barata" eram os aspetos salientados. Moçambique, por seu lado, "apresentava problemas educativos e coloniais que parecem impossíveis de ser resolvidos". As debilidades da administração colonial e o caráter "desorganizado, desconexo e contraditório" da legislação colonial eram notadas. A arbitrariedade reinava. A inexistência de um programa civilizador e emancipatório através da educação era óbvia. Como se concluía no relatório, com inegável ironia e perspicácia, as autoridades portuguesas não podiam con-

27 Joaquim Vaz Solipa Norte (1920), Relatório do Inspetor da Instrução Primária da Provincia de Moçambique. Lourenço Marques: Imprensa Nacional, 6-13; Mário Barradas (1928), "Relatório", in Boletim Económico e Estatístico, série especial n. 5. Lourenço Marques: Imprensa Nacional, Repartição Estatística da Colónia de Moçambique, 56-57. Para o contexto veja-se ainda Miguel Bandeira Jerónimo (2010), Livros Brancos, Almas Negras, maxime 183-193.

28 Para a sua história veja-se Miguel Bandeira Jerónimo (2015), The 'Civilising Mission' of Portuguese Colonialism, 109-133. 
tinuar a invocar um passado glorioso como se isso solucionasse as "reais perplexidades do presente". ${ }^{29}$

Os princípios da civilização para e pelo trabalho e da educação para e pelo trabalho, ambos marcadamente caracterizados por múltiplos processos de racialização, foram pilares centrais da ação colonial. A escassez, real e percebida, de mão de obra nativa e a abundância de preconceitos raciais, mais ou menos explícitos, contribuiu para que esta realidade perdurasse, com variações geográficas e temporais importantes, até aos anos finais do império colonial, continuando a gerar contrariedades significativas à política externa nacional. ${ }^{30}$ As retóricas, as ideologias e as propagandas da missão civilizadora e do lusotropicalismo dificilmente podem obscurecer estas realidades, ontem como hoje.

Estas ideologias detiveram um lugar central nos processos de imperialização da nação, ou seja, na emergência histórica de discursos e práticas, incluindo institucionais, que colocavam o império no âmago de projetos políticos, económicos e identitários. O império (re)afirmou-se como recurso simbólico e cultural fundamental para a (re)formulação da identidade nacional e como instru-

29 Thomas Jesse Jones (ed.) (1922), Education in Africa. A Study of West, South, and Equatorial Africa by the African Education Comission, under the Auspices of the Phelps-Stokes Fund and Foreign Mission Societies of North America and Europe. New York: Phelps-Stoke Fund, 224-232, 236, 245-247; idem (1925), Education in Africa: a study of East, Central and South Africa by the Second African Commission under the auspices of the Phelps-Stokes Fund, in cooperation with the International Board. New York: Phelps-Stoke Fund.

30 Miguel Bandeira Jerónimo e José Pedro Monteiro (2014), "O império do trabalho. Portugal, as dinâmicas do internacionalismo e os mundos coloniais", in Miguel Bandeira Jerónimo e António Costa Pinto (eds.), Portugal e o fim do Colonialismo. Dimensões internacionais. Lisboa: Edições 70, 15-54. Para um exemplo de uma contrariedade - a queixa que o Gana depositou na Organização Internacional do Trabalho contra Portugal pelo incumprimento das suas obrigações internacionais - veja-se: José Pedro Monteiro (2013), Portugal, a Organização Internacional do Trabalho e o problema do trabalho nativo: a queixa do Estado do Gana. Lisboa: Tese de Mestrado, FCSH. 
mento político e económico da ambicionada regeneração nacional. A elaboração e disseminação pública de ideologias que veiculavam uma missão histórica e uma excecionalidade imperial - as missões históricas de colonizar e de civilizar, acompanhadas por processos de sacralização do império - desempenharam um papel crucial na imperialização da nação, sobretudo a partir dos anos de 1870, com a gradual consolidação de um nacionalismo de tipo imperial, sempre acompanhado por uma historiografia essencialista. ${ }^{31}$ O contexto internacional de competição interimperial contribuiu, por certo, para este fenómeno, tanto em finais de oitocentos como na fase tardia do império colonial. Estas ideologias foram igualmente importantes para a definição de uma política externa que enfatizava, de um ponto de vista retórico, a sua dimensão identitária, como sucedeu nas inúmeras conferências internacionais desde o último quartel do século XIX. A defesa do império - do seu presente mas também do seu futuro, do seu significado político, religioso, económico e cultural-identitário - era a defesa da nação, como o famoso Ao Povo Português em Nome da Honra, do Direito, do Interesse e do Futuro da Pátria de 1881 argumentava. Para que tal fosse possível, a nação, as suas elites, o seu povo tinham de ser imperializados, o projeto imperial legitimado, através de comemorações de mitos da expansão colonial, na sua longue durée, da disseminação de um populismo imperial, da formulação e disseminação de várias teorias

31 Miguel Bandeira Jerónimo e António Costa Pinto (2015), "Ideologies of Exceptionality and the Legacies of Empire in Portugal", in Dietmar Rothermund (ed.), Memories of Post-imperial Nations: The Aftermath of Decolonization, 1945-2013. Veja-se ainda Valentim Alexandre (2000a), "A Política Colonial em Finais de Oitocentos: Portugal e a Sacralização do Império", in Velho Brasil, Novas Áfricas. Portugal e o Império (1808-1975), 147-162. Porto: Edições Afrontamento. Sérgio Campos Matos (2002), "História e Identidade Nacional. A formação de Portugal na historiografia contemporânea", in Lusotopie. Lisboa: FLUL, 123-139. Veja-se ainda o recente estudo de Márcia Gonçalves (2015), Beyond the "Imperial Mystique": Empire and National Identity in the Portuguese Estado Novo (c. 1930-1951). Florence: PhD Thesis-European University Institute. 
explicativas da excecional capacidade civilizadora dos portugueses, da difusão de imaginários e de ideologias imperiais racializadas. A necessidade de promover idiomas e repertórios de legitimação do projeto imperial no contexto do novo imperialismo gerou inúmeros debates e propostas de demonstração da natureza e missão histórica de colonizar e civilizar de que eram supostamente dotados os portugueses. O mesmo sucedeu nas décadas terminais do império. ${ }^{32}$

Este processo de quase ininterrupta imperialização da nação, sempre relacionado com doutrinas de uma excepcional missão civilizadora, criou condições para a nacionalização de ideologias racialistas - por exemplo, o chamado darwinismo social - e para a racialização estrutural do projeto imperial, que foi justificando os processos de diferenciação e exclusão social das populações colonizadas, mesmo tendo em conta a gradual mitigação, obscurecimento ou mera codificação dos princípios racialistas, sobretudo com a promoção de retóricas assimilacionistas ou das vulgatas lusotropicalistas. ${ }^{33}$ A imperialização da nação tornou-se uma constante da

32 Ao Povo Português em Nome da Honra, do Direito, do Interesse e do Futuro da Pátria a Comissão do Fundo Africano Criada pela Sociedade de Geografia de Lisboa para Promover uma Subscrição Nacional Permanente Destinada ao Estabelecimento de Estações Civilizadoras nos Territórios Sujeitos e Adjacentes ao Domínio Português em África. Lisboa: Imprensa Nacional, 1881. Para todo o contexto veja-se Miguel Bandeira Jerónimo (2012a), A Diplomacia do Império. Política e Religião na Partilha de África (1820-1890). Lisboa: Edições 70. Para o período terminal veja-se Miguel Bandeira Jerónimo e António Costa Pinto (2015), "A Modernizing Empire? Politics, Culture and Economy in Portuguese Late Colonialism", in Miguel Bandeira Jerónimo e António Costa Pinto (eds.), The Ends of European Colonial Empires: Cases and Comparisons, 51-80. Para uma análise do debate coevo sobre relações raciais, veja-se Diogo Ramada Curto (2013), "O debate político sobre as raças", versão portuguesa, desenvolvida, de "The Debate on Race Relations in the Portuguese Empire and Charles R. Boxer's Position", e-Jounal of Portuguese History, vol. 11.

33 Para o exemplo da necessidade de se pensarem as condições históricas de produção do lusotropicalismo e interrogarem as intenções do seu principal pensador, veja-se Diogo Ramada Curto (2015), "Casa-grande \& Senzala de Gilberto Freyre: Quatro Constatações em torno das Intenções do Autor", in Cláudia Castelo e Marcos Cardão (eds.), Gilberto Freyre. Novas leituras do outro lado do Altântico. São Paulo: Edusp. Este conjunto de textos reaprecia o lusotropicalismo de Freyre e a sua vulgarização. Veja-se ainda Marcos Cardão (2012), Fado Tropical: o Luso-Tropicalismo na Cultura de Massas (1960-1974). Lisboa: Tese de Doutoramento, ISCTE-IUL. 
definição de regimes políticos (e respetivos atores e instituições), de culturas políticas domésticas, de políticas e enquadramentos legislativos, de formas de imaginação da identidade nacional, de orientação da política externa. Apesar de significativas diferenças de contexto e substância, tornou-se um elemento de continuidade histórica que ainda hoje condiciona os debates historiográficos e os debates políticos. ${ }^{34}$

Claro que as realidades coloniais contrastaram quase sempre com as projeções da civilizada missão civilizadora. Os usos e abusos do trabalho nativo em contexto colonial; a já referida racialização das sociedades coloniais e as associadas políticas da diferença; a quase ausência de estruturas educativas (sendo que as existentes eram quase exclusivamente dirigidas para as populações urbanas, "brancas"); a escassez da presença eclesiástica e missionária (com uma deficiente preparação); um estado colonial fraco, com uma débil capacidade de territorialização política, económica (incluindo fiscal) e militar; e o insuficiente desenvolvimento económico das colónias até à última década da sua existência; todos estes aspetos foram contradizendo as doutrinas de excecionalidade do imperialismo e do colonialismo português. ${ }^{35}$ Colocam ainda inúmeros problemas

34 Miguel Bandeira Jerónimo e António Costa Pinto (2015), "Ideologies of Exceptionality and the Legacies of Empire in Portugal", in Dietmar Rothermund (ed.), Memories of Post-imperial Nations: The Aftermath of Decolonization, 1945-2013.

35 Idem. Para cada um destes tópicos veja-se ainda James Duffy (1967), A Question of Slavery: Labour Policies in Portuguese Africa and the British Protest 1850-1920. Oxford: Oxford University Press; Patrícia Ferraz de Matos (2013), The colours of the empire: racialized representations during Portuguese colonialism. New York: Berghahn; Michael Samuels (1970), Education in Angola, 1878-1914: A history of cultural transfer and administration. New York: Teachers College Press; Hugo Gonçalves Dores (2015), A Missão da República: Política, religião e o império colonial português (1910-1926). Lisboa: Edições 70; Miguel Bandeira Jerónimo (2013), "The States of empire", in Luís Trindade (org.), The Making of Modern Portugal, 65-101; William Clarence-Smith (1985), The Third Portuguese Empire (1825-1975). Manchester: Manchester University Press; Jorge Pedreira (1998), "O Sistema de Trocas", in Francisco Bethencourt and Kirti Chaudhuri (eds.), História da Expansão Portuguesa. Do Brasil para África, Vol. IV. Lisboa: Círculo de Leitores, 214-299. 
por resolver a todos os que pretendem refletir judiciosamente (e empiricamente) sobre os patrimónios linguísticos e culturais e os legados plurais das trajetórias imperial e colonial portuguesas. Por exemplo, os patrimónios e os usos da língua portuguesa e as disputas sobre o grau da sua disseminação social e sobre a sua relevância na ordem cultural, tanto no período colonial como pós-colonial, têm de ser interrogados sem cair nas armadilhas retóricas e historiográficas produzidas pelas ideologias da excecionalidade. Mais do que uma demonstração de capacidade colonizadora ou de adesão a um suposto programa civilizador, a procura e o uso generalizado da língua portuguesa em contexto colonial foram essencialmente instrumentos de mobilidade social num contexto dominado por políticas da diferença, fortemente racializadas, que reproduziam e reforçavam desigualdades de várias espécies. ${ }^{36}$ Apesar destas realidades, contudo, ontem como hoje, continuam a ser obscurecidas ou desvalorizadas pela continuada proclamação, por políticos, propagandistas ou académicos, nem sempre sendo fácil distingui-los, de uma putativa forma especial de promoção de contactos e de trocas culturais (as tendências naturais posteriormente codificadas), de uma putativa predominância de traços humanitários da história colonial e imperial lusa, de um putativo enfoque na civilização, na assimilação, na evangelização, na promoção do modo português de estar no mundo e da lusofonia, aspetos estes que, desta forma propagandeados, condicionam, quando não impedem, um debate menos etéreo sobre as consequências económicas e (geo)políticas do império e das suas colónias, ou dos seus legados. ${ }^{37}$

36 Miguel Bandeira Jerónimo (2006), "Os Missionários do Alfabeto nas Colónias Portuguesas (1880-1930)", in Diogo Ramada Curto (ed.), Estudos de Sociologia da Leitura em Portugal no Século XX, 33. Lisboa: Fundação Calouste Gulbenkian.

37 Alfredo Margarido (2000), A Lusofonia e os Lusófonos: Novos Mitos Portugueses. Lisboa: Universitárias Lusófonas. 


\section{Referências bibliográficas}

ALEXANDRE, Valentim (2000), "Questão Nacional e Questão Colonial em Oliveira Martins", in Velho Brasil, Novas Áfricas. Portugal e o império (1808-1975), 174-179. Porto: Edições Afrontamento.

AleXANDre, Valentim (2000a), “A Política Colonial em Finais de Oitocentos: Portugal e a Sacralização do Império", in Velho Brasil, Novas Áfricas. Portugal e o Império (1808-1975), 147-162. Porto: Edições Afrontamento.

ALEXANDRE, Valentim (2005) "O Império Português (1825-1890): ideologia e economia", Análise Social, Vol. XXXVIII, n. ${ }^{\circ}$ 169, 959-979.

ANDERSON, Benedict (2012), Comunidades Imaginadas. Lisboa: Coleção História\&Sociedade, Edições 70.

BAROT, Rohit; BIRD, John (2001), "Racialization: The Genealogy and Critique of a Concept", in Ethnic and Racial Studies, vol. 24, n. ${ }^{\circ} 4,601-618$. BARRADAS, Mário (1928), "Relatório", in Boletim Económico e Estatístico, série especial n. ${ }^{\circ}$ 5. Lourenço Marques: Imprensa Nacional, Repartição Estatística da Colónia de Moçambique, 56-57.

BELL, Duncan (2013), "The ideologies of Empire”, in Michael Freeden, Lyman Tower Sargent \& Marc Stears (eds.), The Oxford Handbook of Political Ideologies. Oxford: Oxford University Press, maxime 543 e ss.

BETHENCOURT, Francisco (2013), Racisms: from the Crusades to the Twentieth Century. Princeton, Oxford: Princeton University Press.

BOWDEN, Brett (2009), The Empire of Civilization: The Evolution of an Imperial Idea. Chicago: University of Chicago Press.

CABreira, António (1902), O Ensino Colonial e o Congresso de Lisboa, 3.

CAllahan, Michael (2004), A Sacred Trust: The League of Nations and Africa, 1929-1946. Brighton: Sussex Academic Press.

CARDÃO, Marcos (2012), Fado Tropical: o Luso-Tropicalismo na Cultura de Massas (1960-1974). Lisboa: Tese de Doutoramento, ISCTE-IUL.

CAYOLla, Lourenço (1912), Sciencia da colonização. Lisboa: Tipografia da Cooperativa Militar. 
CLARENCE-SMITH, William (1985), The Third Portuguese Empire (1825-1975). Manchester: Manchester University Press.

COOPER, Frederick; BURBANK, Jane (2010), Empires in world history. Princeton: Princeton University Press, 11-13.

COUCEIro, Paiva (1910), Angola: dois anos de governo, 1907-1909. História e Comentários. Lisboa: Editora Nacional, 205-206.

CRAWFORD, Neta (2002), Argument and Change in World Politics: Ethics, Decolonization, Humanitarian Intervention. Cambridge: Cambridge University Press.

CRUZ, Bernardo (2015), Proto-totalitarismo de gabinete: A génese e consolidação do Gabinete dos Negócios Políticos do Ministério do Ultramar. Lisboa: Tese de Mestrado, FCSH-UNL.

CURTO, Diogo Ramada (2013), "O debate político sobre as raças”, versão portuguesa, desenvolvida, de "The Debate on Race Relations in the Portuguese Empire and Charles R. Boxer's Position", e-Jounal of Portuguese History, vol. 11.

CURTO, Diogo Ramada (2015), "Casa-grande \& Senzala de Gilberto Freyre: Quatro Constatações em torno das Intenções do Autor", in Cláudia Castelo e Marcos Cardão (orgs.), Gilberto Freyre. Novas leituras do outro lado do Altântico. São Paulo: Edusp.

DERRICK, Jonathan (2008), Africa's 'Agitators': Militant Anti-Colonialism in Africa and the West, 1918-1939. London: Hurst.

DORES, Hugo Gonçalves (2015), A Missão da República: Política, religião e o império colonial português (1910-1926). Lisboa: Edições 70.

Duffy, James (1959), Portuguese Africa. Cambridge: Harvard University Press, 292-293.

DUFFY, James (1967), A Question of Slavery: Labour Policies in Portuguese Africa and the British Protest 1850-1920. Oxford: Oxford University Press. ENNES, António (1913), Moçambique. Lisboa: Sociedade de Geografia de Lisboa, 175-178, 181-186 e 189.

ENNES, António (1946), "A Colonização Europeia de Moçambique”, in Antologia Colonial Portuguesa, Vol I. Lisboa: Agência Geral das Colónias, 27-28. 
FREEDEN, Michael (2004), "Ideology, political theory and political philosophy", in Gerald Gaus e Chandran Kukathas (eds.), Handbook of Political Theory. London: Sage, 173-199.

GOLDBERG, David Theo (2002), The Racial State. Oxford: Blackwell.

GoldBerg, David Theo (2002a), "Racial States", in David Theo Goldberg e John Solomos (eds), A Companion to Racial and Ethnic Studies. Oxford: Blackwell, 233-258.

HODGE, Joseph; HODL, Gerald e KOPF, Martina (eds.) (2014), Developing Africa: Concepts and Practices in Twentieth Century Colonialism. Manchester: Manchester University Press.

JERÓNIMO, Miguel Bandeira (2006), "Os Missionários do Alfabeto nas Colónias Portuguesas (1880-1930)", in Diogo Ramada Curto (org.), Estudos de Sociologia da Leitura em Portugal no Século XX, 29-67. Lisboa: Fundação Calouste Gulbenkian.

JERónimo, Miguel Bandeira (2010), Livros Brancos, Almas Negras. Lisboa: Imprensa de Ciências Sociais.

JERÓNIMO, Miguel Bandeira (2012), "The "Civilization Guild": Race and Labour in the Third Portuguese Empire c.1870-1930", in Francisco Bethencourt e Adrian Pearce (eds.), Racism and Ethnic Relations in the Portuguese Speaking World. Londres: Oxford University Press, 173-199. Jerónimo, Miguel Bandeira (2012a), A Diplomacia do Império. Política e Religião na Partilha de África (1820-1890). Lisboa: Edições 70.

JERónimo, Miguel Bandeira (2013), “The States of Empire (1880-1975)”, in Luís Trindade (ed.), The Making of State Power in Portugal. Cambridge: Cambridge Scholars Press, 65-101.

Jerónimo, Miguel Bandeira; Monteiro, José Pedro (2014), “O império do trabalho. Portugal, as dinâmicas do internacionalismo e os mundos coloniais”, in Miguel Bandeira Jerónimo e António Costa Pinto (orgs.), Portugal e o fim do Colonialismo. Dimensões internacionais. Lisboa: Edições 70, 15-54.

JERÓNIMO, Miguel Bandeira (2015), "Geografias vitais: A imaginação (geo) política do novo imperialismo europeu (1870-1920)”, in Francisco Colom 
González, (ed.), El espacio político. Aproximaciones al 'giro espacial' en la teoría política. Madrid: Editorial Anthropos.

JERónimo, Miguel Bandeira (2015a), The 'Civilising Mission' of Portuguese Colonialism. Basingstoke: Palgrave Macmillan, in Cambridge Imperial and Post-Colonial Studies Series, 111-121.

JERónimo, Miguel Bandeira; PINTO, António Costa (2015), "Ideologies of Exceptionality and the Legacies of Empire in Portugal", in Dietmar Rothermund (ed.), Memories of Post-imperial Nations: The Aftermath of Decolonization, 1945-2013. Cambridge: Cambridge University Press, 97-119.

JONES, Thomas Jesse (ed.) (1922), Education in Africa. A Study of West, South, and Equatorial Africa by the African Education Comission, under the Auspices of the Phelps-Stokes Fund and Foreign Mission Societies of North America and Europe. New York: Phelps-Stoke Fund, 224-232, 236, 245-247.

JONES, Thomas Jesse (ed.) (1925), Education in Africa: a study of East, Central and South Africa by the Second African Commission under the auspices of the Phelps-Stokes Fund, in cooperation with the International Board. New York: Phelps-Stoke Fund.

LONG, David; SCHMIDT, Brian (eds.) (2005), Imperialism and Internationalism in the Discipline of International Relations. Albany: SUNY Press. MADEIRA, Ana Isabel (2007), Ler, Escrever e Orar: uma análise histórica e comparada dos discursos sobre a educação, o ensino e a escola em Moçambique, 1850-1950. Lisboa: Tese de Doutoramento, Universidade de Lisboa.

MARGARIDO, Alfredo (2000), A Lusofonia e os Lusófonos: Novos Mitos Portugueses. Lisboa: Universitárias Lusófonas.

MARQUES, João Pedro (2006), The Sounds of Silence: Nineteenth-Century Portugal and the Abolition of the Slave Trade. Oxford: Berghahn Books. MARTINS, Joaquim Pedro de Oliveira (1978), O Brasil e as Colónias Portuguesas. Lisboa: Guimarães Editores, 175-179, 213 e 255. 
MATOS, Patrícia Ferraz de (2013), The colours of the empire: racialized representations during Portuguese colonialism. New York: Berghahn. MATOS, Sérgio Campos (2002), "História e Identidade Nacional. A formação de Portugal na historiografia contemporânea”, in Lusotopie. Lisboa: FLUL, 123-139.

MONTEIRo, José Pedro (2013), Portugal, a Organização Internacional do Trabalho e o problema do trabalbo nativo: a queixa do Estado do Gana. Lisboa: Tese de Mestrado, FCSH.

MURJI, Karim; SOlOMOS, John (eds) (2005), Racialization: Studies in Theory and Practice. Oxford: Oxford University Press.

NORTE, Joaquim Vaz Solipa (1920), Relatório do Inspetor da Instrução Primária da Provincia de Moçambique. Lourenço Marques: Imprensa Nacional, 6-13.

PAUlo, João Carlos (1992), "A Honra da Bandeira". A Educação Colonial no Sistema de Ensino Português (1926-1946). Lisboa: Dissertação de Mestrado, FCSH-UNL.

PAulo, João Carlos (1999), "Da Educação Colonial Portuguesa ao Ensino no Ultramar", in Francisco Bethencourt e Kirti Chadhuri (dir.), História da Expansão Portuguesa. Lisboa: Círculo de Leitores, vols. 5, 304-333.

PAUlo, João Carlos (2001), "Cultura e Ideologia Colonial”, in António Henrique de Oliveira Marques (org.), Nova História da Expansão Portuguesa. Lisboa: Editorial Estampa, 34-35.

PEDREIRA, Jorge (1998), "O Sistema de Trocas", in Francisco Bethencourt and Kirti Chaudhuri (orgs.), História da Expansão Portuguesa. Do Brasil para África. Lisboa: Círculo de Leitores, vol. IV, 214-299.

PORTER, Andrew (2011), O Imperialismo Europeu, 1860-1914. Lisboa: Coleção História\&Sociedade, Edições 70.

SAMUELS, Michael (1970), Education in Angola, 1878-1914: A bistory of cultural transfer and administration. New York: Teachers College Press. SANTOS, Francisco Bahia dos (1955), Política Ultramarina de Portugal. Lisboa: Sociedade de Geografia de Lisboa, 181. 
1. ${ }^{\mathrm{a}}$ PARTE: CONCEITOS

STEINMETZ, Georges (ed.) (2013), Sociology and Empire: The Imperial Entanglements of a Discipline. Durham, NC: Duke University Press.

TAYLOR, Charles (2014), Modern Social Imaginaries. Durham, NC: Duke University Press. 
(Página deixada propositadamente em branco) 


\title{
6 \\ COLONIZAÇÃO E PÓ S-COLONIALISM O : \\ AS TEIAS DO PATRIMÓN I O
}

\begin{abstract}
Sim, valeria a pena estudar, clinicamente, em pormenor, os métodos de Hitler e do Hitlerismo e revelar ao muito distinto, muito humanista, muito cristão burguês do século XX, que ele traz consigo um Hitler que se ignora, que Hitler o habita, que Hitler é o seu demónio, que se ele o vitupera é por falta de lógica, porque no fundo o que ele não perdoa a Hitler não é o crime em si, o crime contra o bomem, não é a bumilhação do homem em si, é o crime contra o homem branco, é a humilhação do homem branco, é ter aplicado à Europa procedimentos colonialistas que só diziam respeito, até agora, aos árabes da Argélia, aos trabalhadores da Índia e aos negros de África (Césaire, 2004: 13-14).
\end{abstract}

A comparação da política de Hitler com o colonialismo, ou melhor, do colonialismo externo europeu com o colonialismo interno, foi, talvez, a arma ideológica mais poderosa dos movimentos de libertação no período da descolonização. A equivalência dos procedimentos de violência permitiu levar mais longe a desconstrução dos pressupostos do colonialismo e desafiar a hipocrisia da consciência europeia, falsamente estabelecida sobre si própria na ignorância do outro. A linguagem explosiva de Aimé Césaire, tão produtiva em 1955, continha uma outra ideia fundamental: a coisificação (ou reificação) do colonizado pelo colonizador. 
Esta ideia foi igualmente utilizada por Frantz Fanon sob a fórmula "o colono faz o colonizado", num quadro compartimentado, onde o mundo dos colonos e dos colonizados se define de forma separada e exclusiva, com escolas para os indígenas e escolas para os europeus, cidades europeias e aldeias indígenas, ao cabo de um processo sistemático de destruição das formas culturais nativas. A separação entre colonizador e colonizado é lida por Fanon em chave existencialista e psicanalítica, conduzindo a uma abordagem inovadora da mentalidade do oprimido, que interioriza a repressão e os valores do opressor (Fanon, 1952 e 2002).

Esta linguagem, ainda hoje fascinante, não resistiu incólume à crítica pósmoderna, interessada nos interstícios da negociação e da resistência, nas formas de sobrevivência cultural e social, nas trocas, certamente desiguais, mas não ausentes, entre colonizadores e colonizados, na articulação entre formas tradicionais e modernas de dominação. Contudo, a crítica pós-colonial trouxe consigo uma reavaliação do marxismo em chave não europeia, destinada a analisar as consequências objetivas e subjetivas do domínio colonial, em linha com o pensamento de Fanon (Young, 2001).

Os problemas de dupla identidade impostos pelo colonialismo, analisados por Fanon depois da reflexão oferecida por Frederick Douglass e William Du Bois, tiveram um longo impacto (Douglass, 1979 e Du Bois, 2003). A ideia crucial de emancipação dos povos colonizados da mentalidade de oprimido modelada pelo colonizador foi desenvolvida, entre outros autores, pelo brasileiro Paulo Freire, pelo queniano Ngũgĩ Wa Thiong'o e pela maori Linda Tuhiwai Smith (Freire, 1981; Thiong'o 1986; Smith, 1999).

Entretanto, os caminhos da independência trouxeram ao de cima, simultaneamente, os legados dos impérios e as formas tradicionais de patrimonialização do poder, que vieram complicar as visões decapantes de Aimé Césaire e Frantz Fanon. Jean-François Bayart propôs uma análise radical das realidades do exercício do poder nos 
novos países independentes, onde os fenómenos de apropriação do aparelho de estado, neopatrimonialismo e gestão de clientela figuram em posição cimeira (Bayart, 1989). Esta perspetiva foi desenvolvida por outros autores, nomeadamente Patrick Chabal e Jean-Pascal Daloz, que procuraram compreender o agenciamento gerado pelas novas realidades sociais e políticas africanas (Chabal e Daloz, 1999).

É neste jogo permanente entre memória e ação política, diferentes conjunturas e legados históricos, período colonial e pós-colonial, que situamos esta abordagem do património estimulado pela presença portuguesa nos outros continentes. O primeiro problema diz respeito à terminologia, necessariamente contaminada pelo passado colonial. Daí começarmos por esclarecer o significado dos principais substantivos com que trabalhamos - colónia, colonialismo, império, imperialismo, descolonização, pós-colonialismo, património - para definir melhor as possibilidades deste projeto intercontinental e interdisciplinar. Proponho a expressão "estímulo de presença" de modo a tornar mais evidente o agenciamento nativo, embora não queira com isto escamotear o poder de imposição de artefactos, construções, monumentos e formas de pensar pelo poder colonial. Como Georges Balandier bem sublinhou, a situação colonial deve ser considerada como um facto social total, definida por relações de poder derivadas de um complexo de significados sociais, económicos, políticos e culturais (Balandier, 1951). Abordarei em seguida os modelos e práticas de colonização e descolonização, para finalmente tratar do respetivo impacto no património.

\section{Terminologia}

No Vocabulário de Raphael Bluteau, publicado em 1712, colónia é referida como "gente que se manda para alguma terra novamente descoberta, ou conquistada, para a povoar" e colono é "um dos 
fundadores de uma colónia", mas também "agricultor" (Bluteau, 1712: 379). A primeira edição do Dicionário da Língua Portuguesa, de Morais Silva, em 1789, explicita as origens clássicas, referindo que "os romanos descarregavam a república enviando colónias aos países que conquistavam" (Morais, 1789: 287). É evidente o sentido rural e interno destes substantivos no período moderno, embora o sentido de expansão e de criação de novas comunidades seja também visível. A noção original latina de colonus deriva de colere (cultivar). Daí a noção de colonato agrícola e de colónia como propriedade rural na Idade Média, embora a noção de colono como habitante de uma povoação nova fundada por uma cidade grega ou por Roma tenha sido integrada no mesmo período (Rey, 1992: 805; Shorter, 2002: 451). Colónia significa, simultaneamente, propriedade rural e referência histórica aos estabelecimentos romanos em regiões controladas por Roma.

A terminologia fixada por Bluteau reflete explicitamente a experiência colonial portuguesa. Nos séculos XVI e XVII, o substantivo colónia começou a designar território dominado e administrado por um poder estrangeiro. O sentido de migração e povoamento domina nessa altura e prolonga-se até aos nossos dias, designando comunidades deslocadas. No século XVIII, o conceito torna-se mais denso com o debate filosófico das conquistas europeias promovido pela Encyclopédie, por Raynal e pelo debate abolicionista inglês, embora este debate não tenha tido impacto no caso português (Forbonnais, 1753; Raynal, 1774; Equiano, 2003; Marques, 1999). É nessa altura que aparecem expressões derivadas, como colonial (relativo às colónias, incluindo direito, economia e clima), colonizar e colonização, empregues sobretudo nos séculos XIX e XX.

Bluteau fixa o conceito de Império como "Monarquia, ou região muito ampla, dominada por um Príncipe. O Império do Mogol. O Império do Monomotapa. O Império de Trebisonda. O Império do Oriente. Hoje com mais individual acepção se toma por Alema- 
nha, e pelos Estados do Emperador". Em seguida introduz o conteúdo semântico latino de Império: "Mando. Autoridade. Senhorio. Domínio" (Bluteau, 1713: 68-69). Esta visão está em geral centrada na soberania, na definição do poder e da autoridade do Príncipe. O Dicionário de Morais Silva, dada a formação do autor, é mais centrado nos aspetos jurídicos, sendo salientados os direitos sobre o território e os vassalos do imperador. A delegação de jurisdição em magistrados está ali indicada com os vários tipos de penas. O Dicionário compreende ainda "o domínio ou grande influência que têm em nós as pessoas a quem somos sujeitas por direito, ou por amor, ou vontade, ou por reconhecimento de superioridade, etc. O domínio forte que têm em nós as paixões. § poet. Dizemos império da morte, pôr a sepultura, etc.” (Morais, 1789: 698).

Neste caso, a ideia de império contempla de forma mais desenvolvida a noção de jurisdição, declinada consoante o grau de delegação de poder do imperador. O mais interessante é a emergência de uma dimensão psicológica inexistente no dicionário de Bluteau. O império é aqui entendido como submissão pessoal a quem tem direitos sobre nós (implícito o direito paternal ou marital da época), a quem somos sujeitos por amor ou vontade, ou a quem nos submetemos por reconhecimento de superioridade. A relação jurídica de poder é assim estendida à relação interpessoal, implicitamente entendida no seio das famílias, entre amigos, entre profissionais. A referência poética ao império da morte corresponde ao mesmo sentido dos afetos, desta vez império como inclinação, sedução, subjugação ou fatalidade.

Estas perceções não são novas. No caso francês, o substantivo empire está atestado desde meados do século XI, derivado do latim imperium, entendido como poder soberano do pai sobre os filhos e do mestre sobre os escravos, tendo também o conteúdo de poder supremo, comandante em chefe. A noção de estado submetido ao imperador vem deste período medieval, com destaque para a auto- 
ridade e poder do soberano. A equivalência de império a soberania régia é prolongada em Inglaterra. Nos séculos XVI e XVII a noção de domínio torna-se mais vincada, relativo a poder sobre extensos territórios e populações, surgindo no meio literário a ideia de império da morte inscrita por Morais Silva. A aplicação da noção de império aos territórios coloniais difunde-se nos séculos XVIII e XIX, ao mesmo tempo que se consagra a noção de indivíduo sob o império (ou sob o domínio) das emoções (Rey, 1992: 1224; Shorter, 2002: 816-817).

A noção de colonialismo só emerge no século XIX, para exprimir a noção de dominação de outros povos, sendo objeto da crítica marxista e anarquista (Marx e Engels, s.d). Os adjetivos anticolonial e anticolonialista estão atestados em Inglaterra, desde o final do século XVIII, tendo sido introduzidos em França cerca de um século mais tarde (Rey, 1992: 805; Shorter, 2002: 451). No caso português, as primeiras críticas anticolonialistas à opressão de povos nativos só são formuladas, tanto quanto sei, por jornais anarquistas nos anos de 1910. Colonização mantém um conteúdo semântico aparentemente neutro, que sublinha povoamento, implicitamente europeu, pelo que a sua utilização se perpetua até à descolonização.

A relação genética entre capitalismo e colonialismo, já analisada por Marx, foi desenvolvida por John Atkinson Hobson num livro crucial sobre o imperialismo, entendido como desenvolvimento financeiro baseado na exploração económica e política de povos coloniais pelas potências europeias (Hobson, 1905). Este livro teve uma enorme influência em Lénine, cujo livro sobre o imperialismo, publicado em 1917, marcou o início da passagem do eixo do movimento comunista das suas origens europeias para as colónias e países em vias de desenvolvimento (Lénine, 2010). A crítica anti-imperialista criou uma nova dinâmica que só começou a ter impacto em Portugal no movimento de oposição ao regime de Salazar, nos anos de 1950. 
Se o termo colonização acentua o povoamento e domínio de territórios pela potência em expansão, ofuscando o papel desempenhado a vários níveis pelas populações submetidas, o termo descolonização prolonga e enraiza na memória essa mesma dominação, exatamente quando a recuperação da independência das populações nativas parecia ter representado uma viragem histórica no sentido da afirmação dos direitos iguais de todos os povos. Descolonização significa, no Oxford English Dictionary, em primeiro lugar "a retirada de um Estado das suas antigas colónias, deixando-as independentes”, e só em segundo lugar a "aquisição de independência por uma antiga colónia" (Shorter, 2002: 618). No Robert o sentido de "décoloniser" é idêntico: "fazer cessar o estado de colónia” (Rey, 1981: 269). O dicionário Houaiss integra estes sentidos: "processo ou efeito de descolonizar; aquisição gradual de independência política, económica e cultural por parte das antigas colónias" (Houaiss, 2001: 967).

A acentuação da noção de retirada perpetua uma visão da história centrada nas potências colonizadoras - e aqui estou de acordo com Isabel Castro Henriques (Henriques, 2014). No momento decisivo da independência, os povos coloniais veem-se desapossados do seu orgulho de conquista ou reconquista de autonomia, pois o vocabulário dos povos dominantes inculca a noção de retirada, ou seja, sugere de forma perversa a decisão do colonizador, como se se tratasse de um abandono, não um ganho de lutas, por vezes, seculares e que custaram milhares e milhares de vidas. A noção crítica de dispossession, tão bem elaborada por Judith Butler e Athena Athanasiou, encontra aqui plena aplicação (Butler e Athanasiou, 2013). A independência é, assim, esvaziada de força intrínseca, simulacro de capricho do colonizador, que parece entregar à sua sorte populações dominadas. A semântica encarrega-se da compensação histórica, neste caso dupla, pois o arcaísmo colonial parece assumido com ambiguidade pelas populações metropolitanas, que exprimem simultaneamente 
desdém e nostalgia por projetos de outros tempos, como nos surge no filme Tabu, de Miguel Gomes, de 2012.

A corrente crítica do pós-colonialismo, desenvolvida nos anos de 1990, não viu a nova expressão imediatamente integrada nos dicionários ingleses e franceses. O dicionário Houaiss define póscolonial como "posterior à época colonial; posterior ao colonialismo; relativo ao período que sucedeu ao fim do regime colonial; Lit. concernente a uma corrente crítica de inspiração pós-estruturalista que se especializa em buscar traços de dominação colonial no pensamento e no texto literário" (Houaiss, 2001: 2268). Esta não é uma má definição, dado o pressuposto da perpetuação subjetiva da dominação colonial patente em Robert Young, mas perde as diversas dimensões da imbricação entre passado e presente, bem como a perspetiva marxista adaptada ao contexto não-europeu através da denúncia das formas de opressão e dominação neocolonial. A maior criatividade cultural dos últimos quarenta anos situa-se justamente nas áreas da literatura e da cultura visual, que permitem estabelecer uma relação profunda entre transformação política e mentalidade social, comportamento individual e subconsciente coletivo. A reflexão de numerosos escritores e artistas sobre relações sociais e culturais antes e depois da independência dá-nos um leque extremamente diversificado de visões de mudança radical, onde continuidades e adaptações se produzem subrepticiamente.

Finalmente, precisamos de esclarecer o conceito de património, fixado no Dicionário Houaiss como herança familiar, conjunto dos bens familiares, bens naturais ou culturais de importância reconhecida num determinado lugar, região, país ou de interesse para a humanidade, cadastrados para proteção e conservação. A etimologia latina é indicada, patrimonium, ii patrimonio, bens de família, herança, posses, haveres, com raiz em pater (pai), sendo atestados usos do termo nos séculos XII e XIV (Houaiss, 2001: 2151). Esta definição está em linha com o que nos dizem outros dicionários. 
Na França medieval, patrimonium populi designa o tesouro público (século XII), enquanto na mesma época, em Itália, os bens eclesiásticos são designados como patrimonium Crucifixi e os bens dos pobres patrimonium pauperum (Rey: 1992: 2614). No caso inglês, património é a propriedade que pertence por direito antigo a uma instituição, a antiga dotação de uma igreja, a propriedade herdada do pai ou de antepassados, herança (Shorter, 2002: 2122). A especificidade inglesa é que o termo que designa património público é heritage, um substantivo francês que manteve o sentido pessoal e familiar de origem (Shorter, 2002: 1230).

\section{Modelos e práticas}

Os modelos grego e romano estão presentes nas raras referências etimológicas. O caso grego é definido pela criação de novas cidades em locais distantes na orla marítima, que se desenvolvem de forma autónoma, mas mantendo várias formas de associação com a cidade-mãe. A constante interação promovida pelo comércio e pela guerra entre as diversas cidades gregas e as restantes civilizações no Mediterrâneo faz parte deste modelo (Graham, 1964). O caráter seminal do poema épico homérico Odisseia representa a tragédia do conflito, as consequências da guerra e os problemas do retorno (Homero, 1996). A influência no mundo romano e no mundo ocidental, com a Eneida de Virgílio, as Aventuras de Telémaco, de Fénelon ou o Ulisses, de James Joyce, é bem conhecida (Virgílio, 1989; Fénelon, 1995; Joyce, 2000).

O caso romano é diferente, com conquista de extensos territórios e integração num vasto império com atribuição seletiva de cidadania às populações dominadas. O caráter original do povo romano e o seu papel crucial na construção do império são acentuados na Eneida, embora o processo de integração de outras populações 
tenha contribuído para matizar a relação entre fundadores e indígenas, colonizadores e colonizados (Gardner, 1993; Giacomini, 1996). É esta a diferença fundamental entre o modelo grego e o modelo romano, a capacidade de integração e posteriormente de implosão do império romano, baseado não em cidades autónomas mas em territórios relativamente integrados.

A experiência colonial europeia dos séculos XV a XVIII, embora tenha baseado a sua reflexão política e jurídica nos precedentes grego e romano, diverge fundamentalmente destes modelos. Os casos inglês e holandês, com exclusão, regra geral, de cidadania dos povos nativos, é aquele que mais se afasta do modelo romano. O modelo grego poderia ter tido alguma pertinência no caso holandês, embora este seja um império relativamente centralizado, sem cidades autónomas. O modelo grego poderia relacionar-se melhor com o caso inglês de colonização da América do Norte e das Caraíbas, dada a relativa autonomia das colónias até ao início do século XVIII, embora a configuração do habitat local tenha sido fundamentalmente rural até ao final desse século (Elliott, 2006; Marshall, 2005; Bayly, 1988; Emmer, 1998; Boxer, 1990).

O caso ibérico, com integração das populações nativas de forma subordinada, é talvez aquele que se relaciona mais com o modelo romano. A colonização das ilhas atlânticas tem alguns traços da colonização grega, embora sem o caráter autónomo das novas cidades. A mediação medieval dos modelos de expansão genovesa e veneziana no Mediterrâneo desempenhou um papel significativo na expansão ibérica, embora as condições locais tenham desempenhado um papel ainda mais importante. Esta variável é fundamental no caso português, dadas as formas diversas de dominação e integração (ou exclusão) de populações locais no Norte de África, Ásia, África e América (Bethencourt e Curto, 2007; Lucena, 1990).

O caso português está, assim, mais próximo do modelo romano que do modelo grego. Contudo, o projeto de evangelização das popu- 
lações nativas define uma rutura com estes modelos, bem expressa pela tensão entre os antigos e os novos moldes nos Lusíadas, de Camões, como se sabe inspirado pela Eneida (Camões, 1989). Este projeto tornou obsoleta a referência aos modelos da Antiguidade Clássica, pois o quadro de conversão religiosa acabou por criar uma dinâmica de integração subordinada das populações nativas e de vassalagem generalizada que alterou os quadros legais herdados. Para além disso, a noção de transferência das "qualidade nacionais” para as colónias, sugerida por Cortés, logo no século XVI e desenvolvida por David Hume no século XVIII, triunfante na visão histórica eurocêntrica dos séculos XIX e XX, tem sido abalada nos últimos vinte anos, dada a nova atenção às formas de resistência e de negociação desenvolvidas pelos povos coloniais (Cortés, 1986: 445; Hume, 1996; Bethencourt, 2013: 159-162).

Jürgen Osterhammel define colonização como um processo de aquisição territorial, colónia como um tipo particular de organização sociopolítica, e colonialismo como um sistema de dominação por uma sociedade fora do seu habitat original (Osterhammel, 1997). Estas definições podem funcionar como pano de fundo da pesquisa, mas o que se ganha em clareza perde-se em perceção da diversidade. As formas de estabelecimento e exercício do domínio envolveram conquista, pressão militar, negociação para a cessão de territórios, como no caso de Diu, imposição do reconhecimento da suzerania portuguesa a príncipes locais, como no caso de Ternate nas Molucas, ou conversão de príncipes que inclusive legaram os seus territórios ao rei português, como aconteceu com o príncipe Dharmapala no reino de Kotte, Sri Lanka. Na mesma linha, penso que a visão esquemática e tipológica das colónias - de exploração, de enclave marítimo e de povoamento - não tem pertinência, sobretudo no caso português, onde se verificou uma complementaridade ou mesmo a substituição de uma por outra destas formas no espaço e no tempo (Bethencourt, 2007). Finalmente, a separação entre colo- 
nialismo (séculos XVI-XVIII) e imperialismo (séculos XIX-XX) faz sentido no quadro da extraordinária expansão europeia dos últimos dois séculos, que culmina no controlo direto ou indireto da maior parte dos territórios e dos povos do mundo nos anos de 1920 e 1930, mas obscurece as continuidades dos processos de domínio (Cooper, 2005; Burbank e Cooper, 2010).

Importa refletir agora sobre a prática da colonização e sobre as relações concretas entre portugueses e populações nativas que ajudam a situar historicamente uma realidade certamente flexível, mas que obedece a constrangimentos estruturais. Concretamente, como é que os complexos urbanos coloniais foram utilizados na relação entre portugueses e populações locais? Como é que eles refletiram, influenciaram, facilitaram ou impuseram quadros de integração, segregação ou discriminação nas relações interétnicas?

A violência da conquista deve ser reconhecida historicamente como um meio fundamental de redistribuir propriedade, reconstituir a geografia étnica e criar novas relações de poder. No caso do Norte de África, entre 1415 e 1514 os portugueses constituiram comunidades relativamente homogéneas etnicamente, em enclaves resultantes de evacuação da população muçulmana residente. A existência de escravos no interior daquelas urbes, testemunhada pela extraordinária receção de vocábulos de origem árabe pela língua portuguesa ao longo do século XVI, indica um constante vai-vem de populações impulsionadas pelo ambiente de guerra. Se o século XV foi marcado pelo extraordinário número de degredados enviados para as fortalezas, o século XVI foi marcado pelo significativo número de renegados reconciliados e pela indústria do resgate de cativos de ambos os lados. A escala do contrabando português com cidades marroquinas, em meados do século XVI, sugere uma persistente rede de mercadores com ligações inter-religiosas, apesar da derrota e abandono das praças portuguesas entre 1541 e 1550 (Bethencourt, 1998). 
As ilhas atlânticas da Madeira e dos Açores, inabitadas antes da chegada dos portugueses, evidenciam uma composição étnica homogénea, embora a utilização de escravos do Norte de África, sobretudo nas plantações de açúcar da Madeira, esteja documentada. Nas ilhas tropicais e equatoriais de Cabo Verde e São Tomé, a miscigenação foi regra desde o início, dado o papel de Cabo Verde como plataforma de tráfico de escravos da África Ocidental ou de São Tomé como adaptação do sistema de plantação de cana de açúcar, baseado em mão de obra escrava (Caldeira, 2013). A conversão sistemática dos escravos criou uma relação vertical de patronagem refletida nas confrarias do Rosário promovidas pelos dominicanos. A rarefação das elites de origem portuguesa nestas regiões de mortalidade anual europeia da ordem dos $66 \%$, justificou a aceitação régia de mulatos nas vereações, contrária à regra de pureza de sangue. O único caso de inserção dos portugueses numa realidade urbana africana ocorreu na cidade de Mbanza-Kongo, posteriormente chamada São Salvador, onde partilharam a zona alta da cidade com o rei e a corte congolesa junto às fontes de água.

A cidade de Luanda, criada em 1576 na costa da África Central, cedo se transformou num dos mais importantes portos de tráfico de escravos. O enclave sofreu notáveis vicissitudes ao longo dos séculos, mas o domínio dos portugueses foi temperado pela existência de uma sociedade africana envolvente que só veio a ser efetivamente controlada nas primeiras décadas do século XX. O contraste entre a cidade alta e a cidade baixa, com a concentração das instituições políticas, religiosas e assistenciais na primeira, estabeleceu um paradigma branco que não excluiu o serviço de inúmeros escravos e mulatos emancipados. Em 1781, residiam em Luanda 9861 pessoas, das quais 1516 europeus, 1770 euro-africanos e 6575 africanos. Entre os euro-africanos e africanos, 5683 eram escravos e 2662 livres (Venâncio, 1996: 45-47). As realidades do tráfico criaram uma configuração multiétnica que sobreviveu até aos nossos dias, 
contrariamente aos restantes aglomerados urbanos da África colonial, onde as realidades da mestiçagem reverteram, em geral, para a sociedade global africana.

Este é o caso da presença de portugueses em Moçambique nos séculos XVI a XVIII, definida pelos prazos do Zambeze, ou seja, forais por três vidas, reconhecidos simultaneamente por portugueses e autoridades africanas. O sistema matrilinear subjacente, não só revela a dominante africana nesta relação de intrusão e autonomia, como expressa a miscigenação que tornou possível a presença portuguesa num quadro que só veio a dominar nas primeiras décadas do século $\mathrm{XX}$, com as novas possibilidades de campanhas militares (Newitt, 1995: 217-242). O contraponto dos prazos do Zambeze é dado pela presença dos lançados portugueses na Senegâmbia, que se inseriram nas chefaturas locais e criaram uma identidade africana, longe dos constrangimentos urbanos de matriz europeia (Green, 2012). Os enclaves europeus no Golfe da Guiné viveram uma realidade de dupla segregação, simultaneamente definida pelos europeus e imposta pelas autoridades africanas, baseada num isolamento tributário conveniente para o tráfico de escravos. A transformação étnica e social de alguns destes entrepostos, no século XIX, é bem representada pelo caso de São João Baptista de Ajudá, no Dahomey, onde Francisco Félix de Sousa (1754-1849) desempenhou um papel destacado como traficante de escravos e apoiante do pretendente ao trono Ghezo, em 1818.

A criação de cidades coloniais no Brasil foi feita a partir do zero: não existiam ali verdadeiras estruturas urbanas. A proteção dos habitantes europeus tornou-se predominante, mas as cidades fortificadas organizaram-se contra a ameaça de outros poderes europeus que competiam na zona - franceses e holandeses. As cidades brasileiras definiram-se pelo poder da comunidade branca, aberta à mistura com índios e escravos africanos. A visão que nos deixaram os artistas do primeiro terço do século XIX, sobretudo Debret e 
Rugendas, mostram o Rio como uma cidade multiétnica, dominada por brancos, mas permeada por uma maioria de escravos em todos os setores de atividade artesanal, comercial e doméstica (Debret, 1834-1839). As outras cidades revelavam características semelhantes, sobretudo na orla marítima e na região de Minas, embora em diferentes escalas. A segregação espacial não era tão pronunciada como na América espanhola, sem falar no caso mais extremo da América inglesa (Bethencourt, 2013: 216-223).

As cidades portuguesas na Ásia resultam de uma dinâmica totalmente distinta, dada a existência de uma complexa realidade urbana milenar. Os fortes criados pelos portugueses transformaram-se em núcleos intitucionais e habitacionais dominados por europeus, cuja propriedade foi devidamente cadastrada, embora as cidades nativas próximas se tenham transformado em espacos multiétnicos com residência de portugueses (Rossa, 1997; Felner, 1868). A (relativa) segregação espacial é, contudo, anterior à chegada dos portugueses. A divisão de Malaca em bairros étnicos, nomeadamente de javaneses e chineses, espelha a prática tradicional dos portos da região. A monopolização do espaço da fortaleza com instituições portuguesas faz parte do modelo geral, penetrado por relações multiétnicas. Macau é um caso ainda mais interessante, pois não resultou de conquista, mas de concessão de espaço pelas autoridades chinesas de Guangdong. A situação insular da comunidade portuguesa era confortável para os dois lados, pois dava protecção, ao mesmo tempo que permitia controlo de atividade. Esta situação de subordinação refletiu-se no controlo da comunidade chinesa pelas autoridades de Guangdong, enquanto os portugueses gozaram de proteção dessas mesmas autoridades nos conflitos com os holandeses. Tratava-se, de novo, de uma situação de monopolização do espaço do forte e de penetração interétnica, desta vez subordinada a um poder não paralelo, mas reconhecido como superior no continente. 
A situação dos portugueses em Nagasaki durante o século cristão foi complexa, devido aos diversos períodos de favor e repressão por parte do daimyo local e do shogun. A jurisdição temporal do território foi concedida, em 1580, aos Jesuítas, pelo cristão Omura Sumitada, tendo sido recuperada sete anos mais tarde por Toyotomi Hideyoshi, que unificou o território do Japão. A cidade só pode ser considerada portuguesa, ou melhor, jesuíta, nesse curto período de tempo, mas, mesmo assim, foi desenhada e habitada por japoneses (Elisonas, 2008). O crescimento exponencial da cidade - em 1614 teria 25.000 habitantes - atraiu sobretudo japoneses, mas também coreanos trazidos das guerras de 1592-98, cuja conversão levou à criação de uma confraria específica. A influência cristã foi erradicada com a expulsão mas, para termos uma ideia da realidade interétnica, é preciso salientar que o Japão foi, com a China, o país onde a Companhia de Jesus ordenou nativos. A presença dos portugueses no Ceilão, expressa pela série de portos/fortalezas na orla marítima, complementada pelo domínio da maior parte do território entre 1597 e 1630, conduziu a um domínio espacial centrado nos portos que implicou extensa miscigenação. O domínio sucessivo holandês deu origem aos "black burghers", de origem portuguesa e aos "white burghers", de origem holandesa.

A situação de conquista permitia estabelecer um padrão de segregação mais claro, que processos de negociação e tratados com poderes locais geralmente excluíam. Contudo, a relação de forças a nível local, acabou por definir os limites destes propósitos de monopolização do espaço urbano. Em Goa, capital do Estado da Índia, a aliança dos portugueses com os hindus contra os muçulmanos no poder, quando da conquista, manteve uma situação de tolerância religiosa durante trinta anos, rompida com a nova política de destruição de templos hindus nos anos de 1540 e 1550. Esta política foi ensaiada noutras cidades, mas não pode ser implementada da mesma maneira, dada a diferente relação de forças locais. As perdas 
territoriais com a expansão marata, nos anos de 1730 , foi seguida de uma concentração de esforços na conquista de um território significativo em torno de Goa, nos anos de 1740 a 1770 (Lopes, 1996). Esta estratégia militar, acompanhada das alterações introduzidas por Pombal no centro do império, conduziu a uma rutura com a intolerância religiosa do passado, pois as novas comunidades indígenas deixaram de ser submetidas à pressão evangelizadora. Goa, que se tinha transformado numa cidade relativamente homogénea, não do ponto de vista étnico, mas do ponto de vista religioso, viu essa situação deteriorar-se a partir da segunda metade do século XVIII, mas o declínio populacional tinha precedido em mais de um século o declínio religioso.

A característica mais saliente das comunidades portuguesas no Oriente é que elas eram constituídas fundamentalmente por luso-descendentes, ou seja, uma linhagem de portugueses misturados com populações locais, orgulhosos da origem europeia, cuja identidade era estruturada pela religião católica e pela relação distante com o rei de Portugal. Na relação de Bocarro sobre o Estado da Índia, em 1635, o inventário das receitas e despesas de cinquenta comunidades distingue "casados brancos" e "casados negros" (Bocarro, 1992). A particularidade é que os casados classificados como "brancos" são, na verdade, lusodescendentes de raça mista, enquanto os "casados negros" são indígenas convertidos ao cristianismo, sem sangue português. Trata-se da relação inversa da que prevaleceu depois do século XIX nos Estados Unidos, onde uma gota de sangue negro define a classificação de negro. No Oriente, uma gota de sangue português equivalia a uma definição de linhagem portuguesa.

A segregação espacial não foi institucionalizada. Processou-se de maneira informal, estruturada pelo espaço privilegiado das fortalezas dominadas pela propriedade régia. Em todo o caso, nunca foi a característica dominante do império português, melhor definido pela discriminação que pela segregação. No caso do Oriente, o 
reconhecimento dos lusodescendentes como "casados brancos" junta uma peça essencial neste puzzle complexo das realidades urbanas interétnicas, onde as realidades locais têm um peso dominante. No tempo longo, a segregação económica teve um papel mais importante que a segregação política: o custo das casas definiu a estratificação social dos bairros. Gilberto Freyre, tão (justamente) criticado pela sua visão lusotropicalista, teve uma intuição fundamental ao opôr casa e senzala no contexto das grandes plantações, tendo estendido de forma pertinente esta observação social à oposição entre sobrados e mucambos no meio urbano brasileiro (Freyre, 1992 e 2003).

Poderíamos estender esta divisão à África colonial portuguesa, com a divisão entre cidade e musseque que se desenvolveu ao longo dos séculos XIX e XX, tendo deixado traços até à atualidade. A divisão étnica era então duplicada pela divisão social, que assumiu novas dimensões no contexto pós-colonial. Mas as realidades da segregação de bairros podem ser complicadas pela segregação arquitetónica nos bairros de colonos, com as zonas de serventia reservadas aos criados. Em todo o caso, a segregação informal prevaleceu, num complexo interétnico onde a definição de vassalo do rei, seguida pela definição (mais restrita) de cidadão, conheceu contornos diversos e as elites do império integraram diferentes configurações de lusodescendentes nas realidades urbanas da Ásia e do Brasil.

\section{Património}

O problema do património, estimulado pela presença portuguesa no mundo, resulta dos diferentes níveis de construção, de produção de sentido e de identidade coletiva na qual se insere a resistência nativa e a afirmação da identidade nacional pós-independência. O que é património para os portugueses não é necessariamente 
património (no sentido de herança coletiva) para as novas populações independentes. As estátuas de descobridores e reis portugueses (como Afonso Henriques) disseminadas por diversos lugares de África e Ásia, por exemplo, foram justamente desmontadas depois da independência por não serem consideradas parte do património coletivo dos novos países independentes. Igualmente discutíveis são as fortalezas deixadas pelos portugueses, pois, em muitos casos, destinavam-se a protegê-los dos competidores europeus, mas noutros casos das revoltas e das guerras nativas. A integração da herança colonial é mais visível no Brasil, dada a ausência de rutura ao nível das elites, embora o movimento negro e a reorganização social decorrente da imigração tenham produzido diferentes dinâmicas.

O desafio é analisar o património colonial num contexto pós-colonial. O que supõe uma sequência de questões importantes: qual é o estatuto original deste património ? Quais as suas variadas funções no tempo e no espaço? Como foi afetado pela descolonização? Como foi rejeitado ou adaptado no período pós-colonial? Deixaremos o estudo do património construído (arquitetura e urbanismo) para os especialistas que colaboram neste volume.

O património móvel oferece um enorme campo de pesquisa, pois os usos de objetos e artefactos variaram de forma significativa ao longo do tempo. As colheres, garfos, píxides e olifantes do Benim e da Serra Leoa, por exemplo, foram produzidos para uma clientela europeia cujas coleções acabaram por ser acolhidas pelos gabinetes de curiosidades. O caráter híbrido destes objetos é muito marcado, com a matriz africana vincada nas formas, mas integrando imagens e elementos decorativos europeus. Caso contrário é o das cruzes do Congo, que reproduzem a forma original europeia mas estão recheadas de figuras africanas acostadas ao objeto religioso. As arcas, secretárias e caixas de marfim ou tartaruga do Gujarate ou do Sri Lanka mantiveram as formas e as técnicas tradicionais, mas adicionaram a gramática decorativa e a estrutura narrativa euro- 
peia. As porcelanas chinesas tão pouco modificaram a sua técnica tradicional, adaptando igualmente emblemas de pertença e motivos ocidentais para a clientela europeia (Sobral, 2007). O impacto desta técnica na Europa é bem conhecido, mas o papel mediador dos portugueses e a difusão de manufaturas pode ser mais estudado. $\mathrm{Na}$ mesma linha de raciocínio, a influência dos tapetes persas na Europa, no caso português através dos ateliers de Arraiolos e Portalegre, é outra das áreas cujo conhecimento não está esgotado. No sentido contrário, foram introduzidos móveis de origem europeia na Índia, nomeadamente cadeiras e mesas; a influência do vocabulário português em carpintaria é uma das marcas visíveis desta troca cultural. É nesta área da cultura material que novas descobertas podem ser feitas, nomeadamente na área dos têxteis, dada a troca de técnicas e padrões entre diversos países asiáticos e africanos com a mediação portuguesa, particularmente entre a Índia e o Japão.

A troca gastronómica, manifesta através da transferência de plantas e de animais, ganha hoje uma nova acuidade na área da cozinha experimental, dada a explosão dos conceitos de fusão e de pesquisa criativa baseada em diferentes tradicionais culinárias lançadas por Alice Waters, na Califórnia, nos anos de 1970. A troca de receitas entre a Europa, a América, a África e a Ásia mediada pelos portugueses, mostra uma extraordinária capacidade de adaptação e experimentação em diversos sentidos, da Malásia para a Índia, da Índia para o Brasil ou de Portugal para outros continentes (Rocha, 1998). Já há algum trabalho feito neste domínio, mas sem dúvida que existe espaço para um trabalho de pesquisa aprofundado. É também nesta área que as ruturas da descolonização podem ser discutidas e os processos de reconstituição das continuidades pós-coloniais podem apresentar maiores surpresas.

A arte pública é, talvez, a área em que a descolonização se tornou mais visível, com a inevitável destruição, desmontagem ou remoção de estátuas de reis, heróis ou navegadores portugueses, 
representando os colonizadores. O único caso de relativa simbiose de perspetivas esteve na relação entre Portugal e Brasil, com oferta recíproca de estátuas de heróis partilhados, como Pedro Álvares Cabral, mas o Brasil representa, em larga medida, a continuidade da herança colonial até às últimas décadas do século XIX. A intervenção modernista no centenário da independência (Semana da Arte Moderna) introduziu uma rutura nesta perspetiva, enquanto a promoção de Palmares nos últimos trinta anos gerou, propositadamente, um elemento de conflito que tem a ver com a reapropriação do passado pela população de origem africana. Património é, obviamente, memória coletiva e a luta pela memória exprime lutas sociais em torno de projetos políticos divergentes. A toponímia é outra área de óbvia depuração do passado colonial, conduzida pela mesma lógica de criação de uma narrativa nacional de raiz.

O património colonial, neste período pós-colonial é, assim, um motivo de debate, desafio e disputa. A artista plástica Adriana Varejão, que recebeu, em 2013, o prémio da Associação Brasileira dos Críticos de Arte, transformou os azulejos portugueses numa referência constante ao passado colonial, como uma moldura rasgada onde se expõem carnes e entranhas, numa encenação de universo barroco, marcado por uma violência incontida. É talvez o projeto artístico pós-colonial mais consistente, num país acusado de perpetuar o passado colonial. O território ou o lugar de onde se cria, em todo o caso, dilui-se: a condição colonial e pós-colonial é conduzida para a esfera do corpo feminino, por Paula Rego, que transforma a pintura numa narrativa de poder e contrapoder, onde a mulher passa a ter uma presença dominante. Numa linha de subversão de formas e técnicas tradicionais situa-se Joana Vasconcelos, que utiliza tachos, bordados, rendas, missangas e outros elementos decorativos femininos tradicionais para desconstruir o respetivo sentido pela mudança de escala. 
A religião, o direito e a língua, são talvez os maiores legados do período colonial. A religião católica está agora em situação de concorrência com as igrejas evangélicas no Brasil, embora mantenha uma intervenção dominante. A sua presença em países africanos e asiáticos foi promovida por uma enorme renovação das hierarquias, com visível intervenção pública, como no caso de Timor. O direito colonial refletiu a integração sistemática de formas locais que se revelavam úteis ao poder. A codificação legislativa de inspiração napoleónica do século XIX veio nivelar o carácter plural do direito colonial, que passou a estar mais distante das tradições locais. As vicissitudes dos processos de descolonização prolongaram, no caso de Goa, a vigência do código civil de 1865, entretanto reformado em Portugal. Na esfera constitucional, as trocas entre Portugal e os diferentes países lusófonos, particularmente o Brasil, foram significativas. A língua constitui o elemento de comunicação primordial, utilizado para a afirmação de literaturas anticolonialistas e de afirmação das independências. É esse um dos maiores legados cuja transformação permanente mostra o carácter aberto e de desafio virado para o futuro.

\section{Referências bibliográficas}

BALANDIER, Georges (1951), "La situation coloniale: approches théoriques", Cabiers Internationaux de Sociologie, 11, 44-79.

BAYLY, Christopher Alan (1988), Indian Society and the Making of the British Empire. Cambridge: Cambridge University Press.

Bethencourt, Francisco (1998), "Contrabando: um estudo de caso", in Francisco Bethencourt e Kirti Chaudhuri (orgs.) História da expansão portuguesa. Lisboa: Círculo de Leitores, vol. 1, 387-392.

Bethencourt, Francisco e CurTo, Diogo Ramada (orgs.) (2007), The Portuguese Oceanic Expansion, 1400-1800. Cambridge: Cambridge University Press. 
BETHENCOURT, Francisco (2007), "Political Configurations and Local Powers", in Francisco Bethencourt e Diogo Ramada Curto (ed.), The Portuguese Oceanic Expansion, 1400-1800. Cambridge: Cambridge University Press, 197-254.

BETHENCOURT, Francisco (2013), Racisms from the Crusades to the Twentieth Century. Princeton: Princeton University Press.

BOCARRO, António (1992), O livro das plantas de todas as fortalezas, cidades e povoações da Índia Oriental (1635), Isabel Cid (org.), 3 vols. Lisboa: Imprensa Nacional.

BlUTEAU, Raphael (1712-1713), Vocabulario Portuguez e Latino. Coimbra, vols. B-C e F-I.

BOXER, Charles Ralph (1990), The Dutch Seaborne Empire, 1600-1800 (1965). London: Penguin.

BURBANK, Jane e COOPER, Frederick (2010), Empires in World History. Power and Politics of Difference. Princeton: Princeton University Press. BuTler, Judith e ATHANASIOU, Athena (2013), Dispossession: the Performative in the Political. Cambridge: Polity Press.

CALDEIRA, Arlindo M. (2013), Escravos e traficantes no império português: o comércio negreiro português no Atlântico durante os séculos XV a XIX. Lisboa: A Esfera dos Livros.

CAMÕeS, Luís de (1989), Os Lusíadas (1572). Lisboa: Instituto de Cultura e Língua Portuguesa.

CÉSAIRE, Aimé (2004), Discours sur le colonialisme suivi de Discours sur la négritude (1955). Paris: Présence Africaine.

CHABAL, Patrick e DALOZ, Jean-Pascal (1999), Africa Works: Disorder as Political Instrument. Oxford: James Currey.

COOPER, Frederick (2005), Colonialism in question: theory, knowledge, history. Berkeley: Universirty of California Press.

CORTÉS, Hernán (1986) Letters from Mexico, Anthony Pagden (trad. e ed.). New Haven: Yale University Press.

DEBRET, Jean-Baptiste (1834-1839), Voyage pictoresque et historique au Brésil, 3 vols. Paris: Firmin Didot et Frère. 
DOUGLAS, Frederick (1979-), The Frederick Douglas Papers, John W. Blassingame et al., (eds.), 3 séries em 9 volumes. New Haven: Yale University Press.

DU BOIS, William (2003), The Souls of Black Folk (1903), Dolan Hubbard (ed.). Columbia: University of Missouri Press.

ELISONAS, Jurgis Saulius Algirdas (2008), "Nagasaki: The Early Years of an Early Modern Japanese City", in Liam Matthew Brockey (org.), Portuguese Colonial Cities in the Early Modern World. Farnham: Ashgate, 63-102.

ELLIOTT, John Huxtable (2006), Empires of the Atlantic World. Britain and Spain in America, 1492-1830. New Haven: Yale University Press.

EMMER, Pieter (1998) The Dutch in the Atlantic Economy, 1580-1880. Trade, Slavery and Emancipation. Aldershot: Ashgate.

EQUIANO, Olaudah (2003), The Interesting Narrative and Other Writings (1789), Vincent Carretta (ed.). Londres: Penguin.

FANON, Franz (1952), Peau noire, masques blancs. Paris: Seuil.

FANON, Franz (2002), Les damnés de la terre (1961), editado com textos de Jean-Paul Sartre, Alice Cherki e Mohammed Harbi. Paris: La Découverte. FELNER, Rodrigo José de Lima (org.) (1868), Subsídios para a bistória da Índia portuguesa. Lisboa: Real Academia das Sciências.

FÉNELON, François (1995), Les Aventurers de Télémaque (1699), Jacques Le Brun (ed.). Paris: Gallimard.

FORBOnNAIS, François Véron de (1753), "Colonie”, in Encyclopédie, Diderot e D'Alembert (eds.). Paris, vol. 3, 648-651.

FreIre, Paulo (1981), Pedagogia do oprimido. Rio de Janeiro: Paz e Terra. FREYRE, Gilberto (1992), Casa-Grande e Senzala (1933), Rio de Janeiro: Record.

FREYRE, Gilberto (2003), Sobrados e Mucambos (1936), Roberto DaMatta (org.). São Paulo: Global.

GARDNER, Jane F. (1993), Being a Roman Citizen. Londres: Routledge.

Giacomini, Paola Donati (1996), Cittadini e non cittadini nel mondo romano. Bolonha: CLUEB. 
GRAHAM, Alexander John (1964), Colony and Mother City in Ancient Greece. Manchester: Manchester University Press.

GREEN, Toby (2012), The Rise of the Trans-Atlantic Slave Trade in Western Africa, 1300-1589. Cambridge: Cambridge University Press.

HENRIQUES, Isabel Castro (2014), "Colónia, colonização, colonial, colonialismo", in Livio Sansone e Cláudio Alves Furtado (orgs.), Dicionário crítico de ciências sociais dos países de fala oficial portuguesa. Salvador: EDUFBA, 45-58.

HOBSON, John Atkinson (1905), Imperialism: a Study (1902), revised edition. Londres: Archibald and Constable.

HOMERO (1996), The Odyssey, tradução de Robert Fagles. Londres: Penguin.

HOUAISS, Antônio et al. (2001), Dicionário Houaiss da Língua Portuguesa. Rio de Janeiro: Objetiva.

HUME, David (1996), "Of National Characters" (1741), in Stephen Coplkey e Andrew Edgar (eds.), Selected Essays. Oxford: Oxford University Press, 113-125.

JOYCE, James (2000), Ulysses (1922), Declan Kiberd (ed.). Londres: Penguin. LÉNINE, Vladimir Ilich (2010), Imperialism: the highest stage of capitalism (1917). Londres: Penguin.

LOPES, Maria de Jesus Mártires (1996), Goa Setecentista: tradição e modernidade, 1750-1800. Lisboa: Universidade Católica Portuguesa.

LuCENA SAlmoral, Manuel et al. (1990), Historia de Iberoamerica. Madrid: Catedra, tomo II.

MARQUeS, João Pedro (1999), Os sons do silêncio: o Portugal de oitocentos e a abolição do tráfico de escravos. Lisboa: ICS.

MARSHALL, Peter J. (2005), The Making and Unmaking of Empires: Britain, India and America, c.1750-1783. Oxford: Oxford University Press.

MORAIS SILVA, António de (1789), Diccionario da lingua portugueza. Lisboa: Officina de Simão Thaddeo Ferreira, tomo I.

NEWITT, Malyn (1995), A History of Mozambique. Bloomington: Indiana University Press. 
OSTERHAMmel, Jürgen (1997), Colonialism: a Theoretical Overview, Shelley L. Frish (trad.). Princeton: M. Wiener.

RAYNAL, Guillaume-Thomas (1774), Histoire philosophique et politique des établissements et du commerce des européens dans les deux Indes, 7 vols. Haia: Chez Gosse Fils.

REY, Alain (org.) (1992), Dictionnaire bistorique de la langue française, 3 vols. Paris: Le Robert.

REY, Alain et al. (1981) Dictionnaire du Français Primordiale. Paris: Robert. ROCHA, Rui (1998), A viagem dos sabores. Lisboa: Inapa.

ROSSA, Walter (1997), Cidades indo-portuguesas: contribuições para o estudo do urbanismo português no Hindustão ocidental. Lisboa: CNCDP.

Shorter Oxford English Dictionary on Historical Principles (2002) (1964) Oxford: Oxford University Press.

SMITH, Linda Tuhiwai (1999), Decolonizing Methodologies: Research and Indigenous People. Londres: Zed Books.

SOBRAL, Luís Moura (2007), “The Expansion and the Arts: Transfers, Contaminations, Innovations", in Francisco Bethencourt e Diogo Ramada Curto (eds.), The Portuguese Oceanic Expansion, 1400-1800. Cambridge: Cambridge University Press, 390-459.

THIONG'O, Ngũgĩ Wa (1986), Decolonising the Mind: the Politics of Language in African Literature. Londres: Currey.

VENÂNCIO, José Carlos (1996), A economia de Luanda e binterland no século XVIII. Um estudo de sociologia histórica. Lisboa: Estampa.

VIRGílio (1989), Eneida (19 a.C.). Risa Calzecchi Onesti (ed.). Turim: Einaudi. YOUNG, Robert (2001), Postcolonialism. An Historical Introduction. Oxford: Blackwell. 
ENTREVISTA COM

EDUARDO LOURENÇO

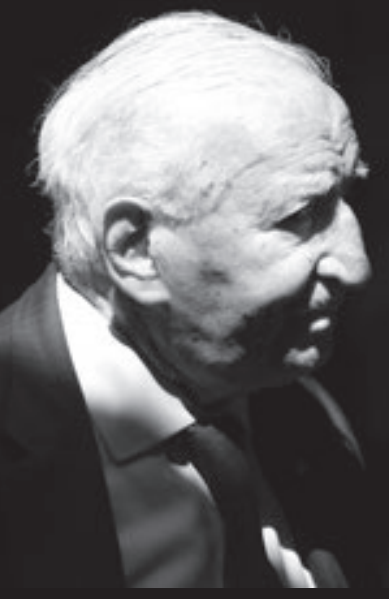


(Página deixada propositadamente em branco) 


\section{Entrevista a Eduardo Lourenço | 12 de março de 2015}

(conduzida e editada por Margarida Calafate Ribeiro e Walter Rossa, com a colaboração de Roberto Vecchi)

Eduardo Lourenço tem sido uma presença assídua nas atividades extracurriculares do programa de doutoramento Patrimónios de Influência Portuguesa, nomeadamente proferindo conferências e participando no colóquio de 13 e 14 de junho de 2014, Patrimónios de Influência Portuguesa: conceitos e instrumentos, que decorreu no Auditório da Reitoria da Universidade de Coimbra. Esta entrevista, realizada a 12 de março de 2015 na sede da Fundação Calouste Gulbenkian, em Lisboa, revela o comprometimento de Eduardo Lourenço com estes temas da cultura portuguesa que sempre nos interrogam. Para uma melhor leitura as perguntas foram formuladas de modo simplificado evidenciando em negrito as palavaras chave de cada uma, inclusive para um melhor aproveitamento didático desta lição.

- Património é o conceito chave do nosso projeto e ecoa neste livro. Mas, como verificámos, em vários momentos e contextos é também um conceito riquíssimo e, às vezes, polémico ou controverso. Como poderíamos então enquadrar o tema dos patrimónios de influência portuguesa a partir de uma perspetiva culturalista?

Património é algo que incluímos numa esfera que tem a ver com a nossa própria identidade. Os símbolos, os sinais, os modos, o discurso que nos identifica, todo esse género de coisas que nos dizem respeito. Património é uma coisa que nunca mais tem fim. 
Para mim, pensando patrimónios de influência portuguesa como propõem, a Índia é o lugar. Para o que nós fomos, aquele é um sítio único, porque foi ali que começou a nossa definição como maiores do que nós. A nossa primeira capital verdadeira foi no Oriente, a capital do mundo foi Goa, durante quase cento e cinquenta anos. E tanto mais capital que, mesmo quando se perdeu a independência, as estruturas do nosso império real e imaginário, segundo o Tratado de Tordesilhas, nunca foram alteradas. Os espanhóis cumpriram à letra a separação que se fazia. O rei era o mesmo, Filipe II de Espanha e Filipe I de Portugal, e quando havia conflitos, de tipo administrativo, entre as partes do império que pertenciam a um lado ou a outro, o rei resolvia segundo os interesses culturais. Há um caso famoso. A determinada altura, aos filipinos, ou seja, os que estavam do lado de Espanha, interessava ir para Macau e aproximarem-se da China. Queriam-se instalar em Macau e o Senado de Macau escreveu ao rei a explicar que aquilo fazia parte de Portugal. E o rei proibiu os filipinos de irem para Macau. Era assim. Quando a América foi descoberta, aquela América descoberta a título por Colombo, pago pela rainha Isabel e, portanto, com Castela ainda separada - ou antes de aliar Castela e Aragão e as outras províncias - os castelhanos não podiam ir para a América sem a autorização pessoal deles, eram ações muito patrimoniais.

Creio que não é por acaso que Camões escreveu o poema que escreveu, embora o meu amigo Vasco Graça Moura tenha escrito que, de qualquer modo, Camões teria escrito os mesmos poemas, mesmo que não tivesse ido à Índia. Eu não acredito, de maneira nenhuma. Não acredito porque não só Camões fez o percurso, fez o trajeto, como se informou do que se estava lá a viver naquela altura, do que se escrevia sobre o assunto, sobre Goa, as descrições da Ásia, os Castanhedas e os Barros. Todas essas informações Camões conhecia. No poema, Camões está a falar de algo que lhe é próximo, não é por acaso que ele experimentou descrever o mundo a partir de um 
sítio que não é Lisboa, mas de um lugar cujo centro é o Oriente. Os Lusíadas é mesmo o primeiro poema europeu, o primeiro poema que verdadeiramente merece esse nome. O primeiro poema em que a Europa é vista de fora. E as coisas só existem quando são vistas de fora e não de dentro.

- O império é objeto de uma considerável análise na sua obra. A dimensão histórica, cultural e conceitual impede, por vezes, uma apreciação de conjunto. Ninguém melhor do que o Professor para esboçar brevemente, para um volume de reflexão crítica como este, o que nos seus textos se chamaria a "ontologia do império português".

As primeiras terras do período imperial - onde não havia ninguém - foram a Madeira e os Açores e é ali que se começa a ver qualquer coisa. Ainda hoje, normalmente o açoriano tem uma visão de Portugal - já não falo do Antero de Quental - diferente deste cantinho, porque os açorianos estão no meio do mundo, estão num outro espaço, estão no Portugal arquipélago. A nossa verdadeira definição é essa, isto é uma espécie de arquipélago, um arquipélago estranho, barroco, mas muito coerente do ponto de vista das nossas possibilidades da época até hoje, no sentido da marca imperial, se bem que nós só fomos império a título póstumo, no Brasil. Nunca o rei de Portugal reivindicou o título de imperador, esses títulos estavam codificados na esfera europeia. Não há imperadores em França, a não ser Carlos Magno, que é uma herança do Império Romano, depois quem reivindica o Império é a Alemanha... até hoje.

Na história do nosso império, desde o princípio do nosso futuro império, ou do virtual império, tudo se fez empiricamente, pouco a pouco, não há um projeto porque não havia uma possibilidade de considerar que a Índia fosse uma coisa que estivesse ao nosso alcance, imediatamente... A Índia era conhecida, a China, Marco Polo e a Antiguidade..., mas eram informações por terra, das quais 
nós, particularmente, não tínhamos experiência. O rei D. João II enviou esses nossos famosos missionários à Abyssinia, para ver se se sabia qual era a passagem mais direta por terra e mais fácil para ir à Índia, para não dar aquela volta, até pelo investimento que requeria. Depois chegou-se à Índia.

Mas a Índia foi essa expressão de realização, de poder. Talvez o mais espantoso daquilo que aconteceu no caso português - e Camões foi o primeiro que lhe deu uma figura poética, mítica e visível - é o contraste entre a pequena casa lusitana e esses espaços novos que se iam descobrindo e que passavam a ser importantes para nós, não só importantes mas os mais importantes. Portugal, durante cem anos, viveu desse comércio que vinha do Oriente para aqui, Portugal só entrou no olhar europeu, de fora - embora Portugal tenha sido uma nação sempre muito europeia, na sua relação com a Inglaterra, com a França - mas só entrou verdadeiramente nessa época nova e a partir daí.

- A Índia foi o limiar de uma mitologia colonial que, apesar dos séculos, ainda não se apagou. O que é que ainda representa em termos de pensamento?

A centralidade da Índia, o tal lugar na nossa definição, foi também um programa oficial. Todas as aventuras espanholas são empreendedores, de comércio, que levam as pessoas para o outro lado, com patrocínios, é necessária a autorização da rainha para navegar e para pagar a viagem, é tudo desenvolvido pelos privados. No caso português, foi um empreendimento da nação, não o rei, mas um príncipe com autorização, que se lançou nessa empresa, que fez de empresário - ele que não tinha alma de empresário, ele é um homem da Idade Média - quase um místico. Pelo lado espanhol não, são mercadores de Sevilha, habituados ao Mediterrâneo e, portanto, são homens que já têm uma longa prática do comércio europeu interno. 
Nós não, e tudo isso se tornou necessário pensar quando se chegou à Índia, com os enviados do rei - os Almeidas, os Albuquerques, que se sucedem lá como vice-reis - estão como se o Big Brother estivesse ali sempre a olhar para eles, porque se controlam uns aos outros. Todos aqueles problemas que houve com Albuquerque e estes "ciúmes à portuguesa", tudo isso, lá era evidente porque estavam em causa coisas poderosas - dinheiro, influência, presença, estar mais tempo. E é espantoso como Camões percebeu e celebrou - porque ele esteve lá e viu-os - a fidelidade portuguesa: o rei manda uma reprimenda e os tipos morrem de tristeza; os Cortés mandam passear o rei e inventam outro reino, se for preciso, como fizeram outros, vários, na América Latina. De Portugal não há caso nenhum de sublevação de alguém que quisesse um bocado de território onde estivessem naus, não temos exemplo nenhum disso. É uma coisa extraordinária, esta coesão profunda, como se fosse uma missão quase sagrada.

- Há uma dimensão comprometida nos temas patrimónios, império, colónia que se interseta numa dimensão identitária para Portugal: a viagem. Como pode ser conjugada a viagem, e os encontros que por ela se determinaram - inclusive nos seus desdobramentos teóricos - com os patrimónios a vir?

A viagem portuguesa é uma viagem extraordinária porque, tirando aqueles que tinham uma cultura - e a cultura pode-se considerar um estado de exceção duplo - a maioria das pessoas que ia nos barcos nessa época era analfabeta. Tivemos a sorte da pessoa que acompanhou a ida para o Brasil, Pêro Vaz de Caminha, saber ler e escrever, era uma espécie de jornalista da época, mas a maioria das pessoas que ia naqueles barcos, saía de Lisboa e tanto lhes importava ir para a Austrália, para o Canadá ou para qualquer sítio, por causa desta espécie de analfabetismo ontológico da maioria do povo português até aos tempos mais recentes. É muito diferente, aqui de 
um ponto de vista europeu, o relacionamento com os novos mundos que começam a ser conhecidos e visitados. Isso marcou sempre o nosso encontro, bem como a temporalidade. Nós levámos cem anos para chegar à Índia, não foi um tropeção, e isto deu-nos um conhecimento profundo, resultado dos contatos que fomos tendo com os outros povos, antes dos outros europeus, embora muitos dos nossos navegadores fossem italianos e de outras nacionalidades, ao serviço do rei de Portugal. Esse primeiro conhecimento da dimensão do mundo é português e é empírico. Contando, obviamente, também com os Duartes Pachecos e todos esses homens mais sábios, que iam tendo uma ideia mais adequada da geopolítica, da geohistória, uma formação humanística. Esses têm um código de leitura, mas o resto foi vendo e estando, sem grandes admirações, grandes espantos, a todos os níveis. Este é um elemento importante que marcou muito o nosso relacionamento - sem o mitificar - com os outros, na primeira grande escala de tipo planetário. Chegámos ao Japão - e os japoneses não se esquecem disso porque fomos os primeiros que os vimos, do exterior - e isso é uma marca fantástica. Mas, provavelmente, a marca é mais profunda neles do que em nós, porque nós estávamos dispostos a aceitar toda a diferença que aparecesse. Daí resulta algo de muito interessante: na carta de Pêro Vaz de Caminha não há espanto diante dos novos povos. Ninguém esperava que eles fossem os Levi Strauss da época, mas parecia quase uma coisa natural... A nudez é uma coisa da humanidade, mas a nudez no estado natural, isso nunca tinham visto. As mulheres não só não os espantam, mas acham-nas mais bonitas do que as mulheres daqui do Minho e de Trás-os-Montes. Não há nada da reflexão desse género do Colombo, quando ele chega ao outro lado.

No encontro com a América do Sul, nós não tivemos nenhum problema por causa do encontro com o Brasil, não foi um encontro problematizado, a não ser tardiamente e de outra maneira. Reflete-se no século XVII, através do Padre António Vieira e outros, mas sobre- 
tudo Vieira - mas a Espanha problematizou imediatamente. Porquê? Porque encontrou novos países, novas culturas, que eram culturas que eles não podiam ler, não tinham leitura senão em função do conhecimento que se tinha de culturas mais antigas. $O$ paradigma que havia mais relevante era as lembranças do Império Romano, por um lado, e sobretudo as mais antigas do Egito. Quando Cortés conquistou o México, o Bernal Díaz del Castillo - que era uma espécie de soldado, que fez um diário, um livro famoso - escreveu que o que via lhe lembrava as pirâmides, o Egito, e que, provavelmente, aquela gente teria vindo de alguma maneira misteriosa, que na altura não se podia imaginar, e que tinham sido eles que tinham ido para a América. Mas, quando começou a colonização, no sentido forte do termo, a conquista, no sentido férreo do termo, os problemas colocaram-se. O que o Cortés fez foi uma loucura, mas ele conquistou aquele território imenso com quatrocentas pessoas, ou coisa parecida. Era uma espécie, quase, de terror metafísico, levavam os cavalos, os índios não sabiam o que era aquilo, se eram verdadeiros, se eram centauros, não faziam ideia nenhuma... até que descobriram que eram simplesmente homens e aí, realmente, as coisas mudaram. E começaram a discutir, na famosa querela acerca da natureza dos índios, no famoso colóquio de Valladolid, entre o humanista Sepúlveda e Las Casas, que era um dominicano de formação tomista, natural, curiosamente com menos prejuízos do que tinha o humanista, porque o humanista tinha os textos que faziam recordar Aristóteles - embora Aristóteles fosse o próprio filósofo de referência dos dominicanos - mas na verdade, naquela altura, esse humanista considerável, que era Sepúlveda - tinha dito que havia escravos, por natureza, e outros não, segundo uma descrição fenomenológica típica de um pagão e explicava as razões. São coisas hoje tipo... quase pré-marxistas, em relação ao trabalho, ao seu lugar, sobre o que eram realmente escravos. Las Casas, que era mais cristão, de formação clássica, de recorte medieval, achou que não, que os índios eram não só seres humanos 
como também uns seres quase sublimes, porque estavam próximos de um paradigma paradisíaco. Houve, portanto, um conflito, uma discussão a que não se assistiu em Portugal e, curiosamente, nunca se assistiu a propósito da África.

- O império, talvez como infraestrutura material poderia, em termos marxistas, ter criado superestruturas, ou seja, ideologias particulares. Num plano histórico, isto não se deu e é mais um elemento que alimenta a reflexão sobre Portugal e os mares. Ao mesmo tempo, o património não se pode desconectar de uma componente ideológica fundamental da expansão, ou seja, a dilatação da fé, a vertente religiosa. A relação monumental entre património e fé é evidente ou até macroscópica, mas como poderia ser melhor enquadrada?

O que talvez seja mais extraordinário é que Portugal não tem nenhuma ideologia imperial no sentido profano do termo, só tem uma ideologia, que é a ideologia religiosa, que é, na verdade, a ideologia natural da humanidade, as ideologias religiosas... Estamos agora a ser de novo confrontados com uma. Religiosidade no sentido não das formas de viver o religioso, no sentido dos místicos, mas religioso no sentido dos valores que condicionam todas as práticas, o bem, o mal, o que é que é correto, o que é que salva. E neste aspeto não há diferença nenhuma entre os muito cultos e não cultos. E isto é extraordinário, do ponto de vista do património simbólico de uma nação e da sua ação.

A viagem portuguesa é fruto dessa ideia de missão religiosa, até porque, no tempo, toda a sanção política era, ao mesmo tempo, religiosa. A ONU da época era o Vaticano, a Santa Sé. E tudo isto vai de 1415 até à chegada à Índia. A Reforma não está ainda no horizonte. Havia muitos movimentos, mas nunca da dimensão do que vai ser a futura Reforma, que vai separar a Europa em duas, para sempre. Foi o acontecimento mais importante na Europa da época, Lutero. 
Com outros propósitos e outro conteúdo, tratava-se de uma religião mais individualizada, mais individualista, menos familiar do que era a religião tal como o cristianismo a viveu até à Reforma. Para nós, portugueses, o religioso é desde sempre, até hoje, familiar: de todas as imagens que nós nos servimos com mais frequência é o "ai jesus" para a esquerda e para a direita, continuamente, estamos sempre envoltos neste quotidiano religioso. Agora, não conseguimos sequer imaginar como é que esse tipo de fé aumenta para um sujeito que vai nesses barquinhos por aí fora e a tremer de pânico, de medo, de horror. É também esta entrega que uma parte da nossa literatura vai registar. Embora não fossem autores fora de série, eram grandes relatores, dos naufrágios, dos perigos, dos medos e da religiosidade. Essas grandes epopeias pagaram-se caro, como todas as grandes epopeias exigentes. O que é fantástico, eu penso, é como é que nós devíamos ser uns interlocutores privilegiados das novas grandes civilizações do Oriente.

Por exemplo, no Japão nós temos uma visibilidade natural, porque eles consideram que foi um momento importante deles, de encontro do outro... É a coisa ao contrário, eles descobrem os outros continentes através dum sujeito que vem de outro "planeta". A China não, a China sempre lá esteve e sempre estará e já o mundo desapareceu e ainda lá estará a China... Agora, a China, em relação a nós, é algo de paradoxal: imaginar que o homem mais representativo dessa espécie de aventuras - deste lado religioso propriamente dito - é Francisco Xavier, que se desencantou e sofreu um certo desencontro no encontro com a Índia, com aquela proliferação de religiões, para as quais ele não tinha, e não havia, do nosso lado, possibilidade de leitura. O que Francisco Xavier apreciou muito nos Japoneses foi a questão que eles lhe colocaram: "Por que é que aparecem agora?"

Francisco Xavier pensava, tinha ouvido dizer, que os chineses ainda eram mais terríveis, na sua perspicácia e que lhe fariam ques- 
tões fantásticas, mas morreu à beira da China, não chegou a entrar. Tardiamente percebemos que, para além de alguma mercadoria ocidental que lhes pudesse interessar, eles eram mais ricos do que nós. A Europa só se impôs verdadeiramente ao Oriente, quando começou o princípio da era dos relógios, todos esses instrumentos de observação do céu, que eles não tinham ainda. Quando vamos a Pequim podemos ver as ofertas que foram levadas aos imperadores. Mas nós não tínhamos meios para enquadrar aquela visão do mundo, que era a deles, era preciso séculos para integrar uma coisa daquelas e eu não sei se algum dia se integrará ou se eles integrarão os outros. Nós estamos convencidos de que, durante estes séculos todos, o domínio científico, da visão das coisas - do tipo europeu - foi de tal forma dominante, que dá a impressão que englobou todos, mas isto é superficial. Por enquanto é assim, por enquanto todos os relógios do mundo marcam o Greenwich, daqui a cem anos não sei... não sei se estará tudo escrito em chinês...

- Há uma espécie de dualismo na genealogia colonial portuguesa entre um império presente, em embrião desde a fundação de Portugal (como magnificamente analisa em "Psicanálise mítica do destino português") e a sua declinação moderna, que parece atenuar-se na sombra dos impérios históricos. No entanto, a opacidade encobre ou atenua o caráter moderno que também teve o imperialismo português, sobretudo na sua última estação africana. Como pode ser repensado este caráter?

A partir da Conferência de Berlim há uma mudança de paradigma. O século XIX é um século em que toda a Europa se tornou viajante ou colonizadora e estamos em disputa com um novo tipo de imperialismo, mais eficaz do que o nosso, e que vende coisas que nós não temos para vender, como as armas. As armas com que vão fazer as primeiras guerras sociais do século XIX são armas que os 
ingleses vendem aos outros - um pouco como se passou na América do Norte, embora por outros motivos. Aí estarão os imperialismos europeus em luta uns com os outros pela posse de África - o que ainda não acabou. Mas há uma mudança, nessa época são continentes que são percebidos como objeto de pregação, de conversão religiosa, quer de origem protestante, quer de origem católica, mas são também os locais do grande negócio.

Mas entretanto, a surpresa fantástica - principalmente para as gentes da Europa - é outra: é que enquanto nós dávamos a volta para chegar à Índia, há séculos, o Islão tinha ocupado praticamente toda a África... E isso era uma coisa profunda. A "África fetichista”, propriamente dita, era uma presa mais fácil, ou sentia-se um contraste maior do que numa religião unitária, simplificadora e simples e que promete o paraíso real e erótico, “do lado de lá”. Quando se procede a um pequeno processo de laicização, que se faz ao longo do século XIX aqui, depois do Liberalismo, a Igreja vai atuar por sua própria conta e isso vai-se acentuar ainda mais com a República numa certa fase, durou pouco. A Igreja foi objeto de alguma recusa no seu ofício religioso, mas não nos impérios, pois os missionários têm uma função particular e que se conserva até ao fim dos impérios e permanece.

Isto é um património, claro que é um património! Eu tenho uma irmã que é Carmelita, que professou em Fátima, em 64 . Em 64 já tinha começado a rebelião africana... e em Moçambique, um senhor muito importante, um engenheiro católico que era um homem muito influente, decidiu fazer um pedido a Fátima para que enviassem para lá freiras, porque ele fez lá um convento, um Limpopo Carmelita. E a minha irmã e mais doze ou treze freiras foram para Moçambique. Lembro-me de dizer à minha irmã: "Mas o que é que vocês vão fazer para lá? Uma ordem contemplativa? Mais contemplativo que aquilo não há, vocês não lhes podem ensinar nada”. E estiveram lá até 74 . Tiveram muita sorte, porque em 74 a guerrilha tomou conta 
de metade do convento. E dali, não sabiam o que haviam de fazer, e receberam uma proposta, um convite vindo do Brasil, da Amazónia, dum bispo, para elas, se quisessem, irem para a Amazónia. E foram, para grande aborrecimento do Bispo D. Sebastião de Resende, que queria que elas tivessem ficado lá, para assegurar a continuidade da pregação cristã tradicional, que se tinha feito durante os últimos séculos. O religioso deixa muitas marcas. Segundo me consta, em Malaca, ainda hoje há partes de orações, pequenas comunidades religiosas que ficaram e que estão lá há mais de quinhentos anos. Era preciso pensar que este país, que fez essas coisas todas, não tinha dois milhões de habitantes. Também devia ser um dos países mais pobres da Europa, portanto, não sei se a ideia de Joel Serrão é justa, que a nossa história é um subproduto do fenómeno da emigração; a força, por necessidade, é uma explicação poética e marxista.

- Como é que o conceito de cultura, em particular no plano diacrónico, pode moldar e substanciar a conceptualização do património?

A cultura é uma confiscação europeísta de um dado universal. A Humanidade é cultura. Não há humanidade sem cultura. Mas depois, cultura foi sendo considerada como o que se distingue, o que é superior em relação àquilo que é uma espécie de caoticidade, algo sem leitura. Tornou-se uma maneira de separar aquilo que é verdadeiro daquilo que é falso, aquilo que é aparente daquilo que é não aparente, aquilo que é justo daquilo que é injusto, apelando a um quadro de valores que nós pensamos que foi uma conquista de séculos, das culturas que nos precederam, e que são, ao mesmo tempo, o paradigma da cultura, hoje. Alguém religioso falava recentemente a propósito da Grécia, desta Grécia, fazendo uma espécie de saudação a dizer "a Grécia é a cultura! A ciência da cultura ocidental é grega". E é, para nós, no Ocidente, mais 
não fosse pela sua forma mais sofisticada - que não é outra que a Filosofia. A cultura, pouco a pouco, foi tomando outra dimensão. A definição mais interessante de cultura deverá ser aquela inventada pelo discurso de Lévi-Strauss. Quando fiz estudos não havia "a cadeira" de Sociologia, estudava-se "Filosofia da História", e estava muito em voga naquela altura. Deram-me uma espécie de axioma museológico da separação entre pensamento lógico e pensamento pré-lógico, ou pensamento primitivo. E isso era recebido como um certo "óbvio": nós éramos sobretudo "do lógico", os outros eram para o "primitivo", e isso fazia-se na maior das inocências. O teórico desse assunto era um homem chamado Lévy-Bruhl, que tinha um livro famoso, La pensée logique et la pensée prélogique. Havia ainda uns ensaios de um outro grande filósofo da época, chamado Léon Brunschvics, Les Âges de l'intelligence. É uma tradição sociológica, que vinha do positivismo. Lévi-Strauss introduz um pensamento revolucionário que é, naturalmente, na continuidade dos Rousseaux, etc. Mas é estruturado a partir de um conhecimento de um certo tipo de humanidade, considerada como "menos humana" ou "humana de outra maneira" ou coisa parecida. Lévi-Strauss mostra que as técnicas simbólicas de representação de outras culturas têm uma inteligibilidade, uma leitura e, portanto, têm um outro tipo de inteligibilidade.

Neste momento, provavelmente a crise que estamos a viver não é senão a crise da nossa imagem da Europa, ou do papel que a Europa teve nos últimos milénios, praticamente desde a Grécia até hoje. Mesmo se o cristianismo introduziu uma dimensão diferente na herança greco-romana - mas ao mesmo tempo na herança judaica, propriamente dita, porque o cristianismo é essa revolução no interior do mesmo - a verdade é que já não é o discurso dessa ordem, que vivemos desde a Grécia até hoje, que está em discussão. É o discurso da área das ciências, sobretudo das ciências com um grau de abstração realmente maior em que a continuidade está assegurada, e que continua a discutir o assunto e que através de novas descobertas está a 
rever a imagem, digamos, einsteiniana do mundo, que é aquela sobre a qual nós vivemos. Nós vivemos, quer dizer, uma pequena minoria... No tempo do Einstein havia quatro ou cinco pessoas que se entendiam umas às outras sobre o assunto, agora há mais de quatro, certamente, mas não são mais de quarenta. No Ocidente, temos confiança que este tipo de conhecimento que é tão sofisticado, tão difícil de apreender, que se aceita com uma certa fé - não é fé religiosa, propriamente dita, mas é uma fé intelectual - e ao qual não temos nenhum outro discurso que se possa opor, com o mínimo de coerência, aceitamos que é verdadeiro, como algo que parece autoevidente, mas não se sabe. Nós estamos num ponto da História do Mundo em que não sabemos o que é que as gerações futuras vão pensar daquilo, ou o que é que vão dispensar, para ficarem ainda mais entenebrecidos do que nós já estamos neste momento. É evidente que o conhecimento científico moderno, de Galileu, Copérnico, alterou a visão que se tinha do mundo, para eles. Para o comum do cidadão, os problemas são tão difíceis de perceber como Einstein, hoje.

- O Professor falou da crise atual que é a crise (já há muito tempo adiantada na sua reflexão) da Europa. Como abordar a atual interpelação da Europa no quadro das suas complexas raizes?

Hoje há uma diferença muito grande. É a primeira vez que a Europa é interpelada de fora. Interpelada não, posta em causa como modelo, mas "posta em causa”, por vezes, de formas não argumentadas.

Penso que, neste momento, em termos que têm a ver com o passado europeu, mas também com outra expressão desse passado, que é todo o mundo anglo-saxónico que está sob questão. O mundo anglo-saxónico é a Europa, só que sem fixação mística de qualquer espécie de natureza. São muito fiéis a uma leitura empírica das coisas, a uma leitura da experiência. Fora disso, as coisas 
não têm sentido, se são neopositivistas ou neoempiristas, não têm sentido para os anglo-saxónicos. Foi sempre assim, desde muito cedo. Foram eles os primeiros, que fizeram a grande separação de águas, filosoficamente falando, como uma gnosiologia realista. Antigamente havia uma fé mais natural de que as palavras que nós inventamos - correspondem a uma essência dessas coisas, que é o que está implícito nas famosas passagens da Bíblia, em que é muito parecido, porque a nomeação não é feita por Deus, nós não temos um código de leitura... o ser humano que nomeou as coisas. Porque se fosse com um alfabeto divino, então de facto seria a luz, como se todas as coisas fossem iluminadas: é assim e é assim e não é outra coisa. E os ingleses são os mais fiéis a essa leitura das coisas. A famosa Querela dos Universais, que andam séculos a discutir "e nem para trás nem para diante" foi decidida depois, por uma espécie de consequência de decisão teórica: "é assim e acabou". Mas teve consequências extraordinárias, porque como isso se aplicava igualmente à realidade das realidades, a que nós chamamos Deus, foi aí que começou a desconfiança de que nós podíamos nomear convenientemente. E, em última análise, isto vai bater a Lutero, Lutero pertence a essa escola, que veio da Inglaterra, que entrou na Europa sob o nome de nominalismo.

- 2015 é, para Portugal, o ano do aniversário das descolonizações africanas. Nos ensaios deste livro, o conceito de pertença é estudado a partir deste momento fraturante e ainda por pensar que foi as descolonizações. Como repensar o património a partir das independências africanas? O tema é vastíssimo mas, depois da publicação do seu livro Do colonialismo como Nosso Impensado, é uma pergunta de que não nos podemos eximir...

Não sei se não teremos de colocar a questão "quem era património de quem?”, uma espécie de questão excêntrica, aparentemente 
exterior. Nós podemos falar, com alguma autoridade, do que foi esse império como património, porque assim o tivemos, mesmo se só um pouco onírica ou virtualmente. A maneira de o ter deve ter sido muito diferente, para os diversos portugueses. Aqueles para quem o império existiu verdadeiramente como coisa vivida e aqueles para quem não existiu, para quem foi uma inexistência, uma coisa tipo mítica, da qual se sabia se se tivesse o mínimo de consciência do que tinha sido o percurso histórico dos portugueses. Claro que a certa altura o império aparece-nos, porque este país pequenino não estava destinado, em princípio, a ser um império, fosse do que fosse, dadas as suas dimensões, a sua situação na Europa e no quadro da Península Ibérica. O império foi uma espécie de surpresa contínua, para nós próprios algo de ordem mítica, que já se tinha mitificado antes que houvesse alguma mitologia consistente interna. E essa dimensão expressou-se na chegada ao Oriente, sem dúvida nenhuma. No quadro europeu, esta apresentação à Europa foi feita com a embaixada a Roma (1514). Roma era o centro do mundo ocidental e isso não passou desapercebido. Passamos a ser gente porque "Roma ainda é Roma”, embora estivéssemos nas vésperas de entrar num período que iria modificar toda a relação que o próprio Vaticano, o catolicismo, tinha consigo próprio. A verdade é que, no tempo, a embaixada a Roma foi um passo importante e essa era a primeira grande revolução interna, numa Europa, até então, organicamente cristã. E é assim que o nosso estatuto se percebe e é apreendido na Europa.

Falamos assim de Património, que primeiro é conhecimento e depois o gozo do diferente. O diferente com o qual nós comunicamos desde cedo e isso, provavelmente, é o maior património, um património que nós não conquistamos - no sentido próprio do termo - mas que se produziu do contacto de nós com povos que conhecemos, uns com presença guerreira - o caso do Albuquerque na Índia - mas também com uma certa naturalidade, de povos diferentes que se encontram e que encontram maneira de ficarem aí vários séculos 
uns com os outros, e onde deixámos as nossas marcas, pela mistura que proporcionaram. A avaliação dessas marcas incumbe a quem viveu ou sofreu essa presença, a diversos níveis. Quanto à nossa, é toda a nossa literatura. Entre as coisas mais extraordinárias temos a historiografia, mas a nossa historiografia, em geral, tem um certo handicap, ainda tem os reflexos de estar sempre a descrever uma epopeia, sempre no centro das coisas. Nós não temos é um olhar do outro, que descreva o que é que nós representamos para eles. Deve haver várias versões disso... e deve haver uma literatura nesse capítulo incomparável, pela sua precocidade, pela novidade, pelo insólito desse contacto, que não foi só superficial, mas foi profundo.

Por exemplo, em relação à China, a quantidade de livros nossos, da época, que há sobre a China é uma coisa que para os chineses - e cada vez mais - não são livros mortos, não são relatos mortos, são o passado que eles vão reler outra vez, para se conhecerem a eles próprios e para conhecerem aquela gente com quem eles entraram em contacto. É muito curioso porque, de há uns anos para cá, essa coisa que aqui em Portugal deixou de ter visibilidade - há muito tempo, se é que alguma vez a teve, à altura do que está em causa - mas que Michel Chandeigne, editor francês que é financiado pela Fundação Gulbenkian, tem vindo a produzir e a publicar em edições estupendas em francês sobre o Japão, a China, o Oriente. Uma quantidade de livros absolutamente fantásticos e nenhum povo, naquele momento, tem nada parecido. O único que poderia ter alguma coisa parecida era a Holanda, que seguiu os traços de Portugal, mas representando já outro momento, o momento das "duas Europas". Foram, aliás, os nossos inimigos; não teriam sido tanto se não tivessem sido inimigos de Espanha, por um lado, e ao mesmo tempo nós, inimigos deles, por causa da Espanha. Eles depois também lá os combateram, porque de um lado são os calvinistas ou luteranos e nós somos os cristãos e pagamos a conta toda de uma vez. 
O que é curioso é como uma parte da história europeia se desloca, de repente, para um outro espaço, que é uma coisa que nunca é muito sentida. É mais vista agora do que naquele momento, em que não havia leitura para este movimento, para esta deslocação. Eram acontecimentos importantes e que tinham visibilidade na Europa. Provavelmente um dos mais extraordinários deve ter sido todas as tentativas de conquistar Diu e da defesa dos portugueses de Diu, que foram celebradas, aqui, com grande pompa, quando essas notícias vieram e foram celebradas no centro da cristandade porque, naturalmente, então a Igreja Católica já estava na fase contrarreformista ou de Pós-reforma e estava na defensiva. Começa aí em espaço europeu, mas também extraeuropeu, uma espécie de muralha da China, de outro género, e nós, agora, percebemos o que isso pode dizer. A Companhia de Jesus é uma espécie de resposta teológica, religiosa, a uma outra formulação da tradição cristã, e ao mesmo tempo compensada na realidade pela evangelização dum tipo novo. É a novidade da evangelização, desde que é uma evangelização "prática", muito moderna, que faz dos jesuítas uma ordem cosmopolita. Eles "treinaram-se" primeiro com a Índia, com o Japão e depois, curiosamente, com a América do Sul, sobretudo no Brasil e nos territórios que pertenciam a Espanha, para compensar a perda de influência na Europa. Portanto, as nossas coisas passaram a ter significados diferentes em função de uma outra história, que já não é uma história só europeia, porque as coisas se passam noutros espaços. Isto é uma expressão de património diferenciada.

Quando foi da Batalha de Alcácer Quibir, Portugal chorou muitas lágrimas reais, verdadeiras, e realizou as cerimónias do Portugal que era, porque ficou órfão do seu rei. Mas o poema mais extraordinário sobre a morte de D. Sebastião é de um espanhol, Fernando Herrera, que é um belo poema. Nele é evocada uma perda como símbolo da cristandade, não como uma coisa local. De resto, nós não nos podemos queixar da Espanha, inclusive de D. Filipe. 
D. Filipe avisou claramente D. Sebastião de que ele ia para o desastre e mandou um homem importante acompanhá-lo. E foi de facto uma catástrofe, não só nacional, mas uma catástrofe do mundo católico. O representante máximo do catolicismo, nessa época, era a Espanha e nós estávamos numa frente que, quer quiséssemos, quer não, a nossa figura matricial, enquanto pequena nação que nós somos, foi desde a origem a de estado-cruzada. Nascemos de um contexto de reconquista e de cruzada. A missão dos nossos primeiros reis, na luta pela independência, foi fazer recuar os árabes o mais possível, conquistar mais espaço em função de uma ordem política, que tinha consequências no triunfo ou não triunfo de uma religião sobre outra, ou de uma cultura sobre outra. As religiões têm a sua autonomia própria, mas são as formas culturais diferentes que distinguem e condicionam o futuro e a cultura dos países onde esses fenómenos se produzem. Somos cruzados, a última cruzada - a Guerra Colonial, no entendimento do regime de então - foi já sem objeto e sem causa legitimante, transcendente. Ainda houve uma tentativa de englobar a defesa do Ocidente na defesa do Império, mas não tivemos eco nenhum, já tinha passado o tempo. Estávamos em plena descolonização, a universalidade das coisas era um fenómeno irresistível e, portanto, a cegueira era nossa, que foi paga cara, muito mais cara do que nós imaginávamos.

Os últimos livros que eu escrevi, como Do Colonialismo como Nosso Impensado, são livros que não sei classificar, são livros que me doem. Não os escrevi com o intuito de os publicar, se não fosse a Margarida Calafate Ribeiro e o Roberto Vecchi, estes livros nunca tinham aparecido à superfície. Eu próprio, quando me deparei com eles, fiquei surpreso, porque eu não teria coragem de os publicar. Aqueles textos doem-me e eu escrevi-os para que isso não acontecesse, mas entretanto as coisas já aconteceram. São textos póstumos a tudo e têm um peso, esse peso do irrevogável. Eu nem me atreveria, nem estarei em condições de imaginar minimamente, só eles, 
do outro lado. Lerão as mesmas coisas, mas de outra maneira e em função não só do que já passou, mas do futuro que eles se imaginam para legitimar, virtualmente, pois a insurreição foi criadora de novos países. Paradoxalmente, eu escrevi isso para me convencer a mim próprio de que não perdemos aquilo que já tínhamos perdido. É a mesma atitude que eu tenho em relação ao Brasil. Mas o Brasil é mais fácil, porque nós não podemos perder o Brasil, porque o Brasil não nasceu de uma insurreição contra nós, como os outros países. É uma situação em que, realmente, fomos vencidos, quando pensávamos que tínhamos um tipo de relacionamento que podia ter impedido essa tragédia brutal e caramente paga do nosso lado e pelo outro lado, e ainda em tudo o que está por vir... Pode ser que consigam resolver as coisas, com mais eficácia do que a América Latina fez durante quase duzentos anos... ditadores que sucedem uns aos outros, a permanência da desigualdade e sobretudo o sofrimento para os povos. Neste momento, dos países europeus que colonizaram o mundo, o único país que não está em acusação nítida europeia - embora pudesse estar, tanto como os outros e às vezes até mais do que todos, porque era maior, porque era verdadeiramente imperialista, no sentido forte mas eficaz do termo - é a Inglaterra. Mas a Inglaterra é uma espécie de Estados Unidos do passado, não só porque nunca perdeu nada que fosse verdadeiramente importante para ela, como se retirou dos sítios onde dominou, ficando lá, de outra maneira. É incontornável. O que a Europa fez no mundo - do tipo inglês, e o que nós fizemos, na versão portuguesa - são coisas que deixam uma marca inapagável. O pecado capital da cultura europeia, enquanto tal, moderna, é o facto de que o reino longo se promoveu da escravidão dos povos com os quais a Europa entrou em contacto - os que ela pôde escravizar, não pôde escravizar a Índia, não pôde escravizar a China, mas há outras maneiras de subordinar.

A Inglaterra teve sempre a sabedoria fantástica de não reinar por discursos teóricos e transcendentes e ofensivos das coisas. Antes, 
pelo contrário, a Inglaterra já andava na altura com um grande fascínio "pelo outro". É um paradoxo dos ingleses, porque eles têm uma identidade tão forte que não pode ser afetada, mas têm o fascínio dos outros. Nós devemos aos ingleses o retrato dos feitos por onde eles andaram e toda uma cultura, que é uma parte da literatura moderna inglesa, que está cheia do fascínio do espírito indiano, das aventuras, de aprofundar o que aquele pensamento elabora. Nós não entrámos em contacto com culturas com esse conteúdo, com essa profundidade, a nossa troca com essas culturas foi muito anterior e, na modernidade europeia do século XIX, foi uma troca superficial. Além do mais, nós nunca pudemos conquistar tanto, ficamos sempre na beirinha das coisas, dado que éramos muito poucos. O espanto é como é que tão pouca gente deixou tanta marca e com pouca organização. O segundo colonialismo - que é o verdadeiro e o grande, sobretudo o segundo imperialismo - é muito diferente do primeiro. O primeiro é ainda quase um subproduto da emigração de um outro género, por razões óbvias - ir procurar vida noutro sítio, mas sem nenhum conteúdo dominante, ideológico, para além do religioso, que se traduzia em "salvar as almas", num prolongamento do espírito cruzadístico. A verdade é que, apesar desta nossa fraqueza, deixámos essas marcas, que são marcas de diferença dos outros - aos olhos dos outros e aos nossos próprios olhos. Os agentes da nossa civilização, em geral, não tinham grande cultura humanística. No fundo, a nossa presença é de dois géneros, uma missionária, que se interessa por questões que dizem respeito às formas de religião diferentes, impondo e defendendo um certo património que é nosso, para quem os ídolos são qualquer coisa que não tem leitura positiva.

Camões, nesse aspeto, é a grande marca. Em primeiro lugar, numa famosa expressão do Fernando Pessoa, Camões "errou para certo". "Errou para certo", porque há ali uma objetividade quase técnica de um objeto que tem uma tal solidez de construção - mesmo se 
o sujeito é um outro de uma outra época e com outras conotações - que há um fascínio objetivo da qualidade propriamente técnica daquele objeto, como um palácio diferente, que é construído, que tem uma solidez que poucas obras na literatura têm. Em cada linha, tudo está feito de uma maneira que não há réplica, não precisa de ter réplicas, exerce um fascínio estético quase puro. Talvez os outros que este poema também tocou não tenham provavelmente ainda a alma camoniana, mas tem a expressão que lhes faz crer que estão à altura de produzir um "Camões deles", ou qualquer coisa que se identifique e que tenha a mesma função mítica e simbólica de um poema, como aquele em relação à nossa própria tradição. Mas terão, embora não precisem, e penso em particular nos angolanos ou moçambicanos - porque para mim estão próximos - em que os quadros culturais em termos literários escritos não são muito diferentes. Quanto ao caso dos brasileiros, as coisas são diferentes. Diferentes porque a continuidade aí é muito afirmada. Não precisam de Camões, o culto do Camões é comum ao brasileiro, provavelmente até é mais cultuado lá, como uma espécie de resumo a tudo quanto devem, ou não devem, às raízes de onde eles saíram e que lhes oferece um passado que eles não tiveram, mas onde também estão incluídos. De uma forma ou de outra todos serão os Homeros de si próprios. 
2. ${ }^{\text {a PARTE : }}$

DISCURSOS E PERCURSOS 
(Página deixada propositadamente em branco) 


\section{PATRIMÓ́n IOS DA PALAVRA: REESCRITAS NAS LITERATURAS DE LÍNGUA PORTUGUESA}

Já disse a Fernão Mendes Pinto que eu mais ou menos como ele, não minto, sugiro um implante e ele responde com um gargalhar tricotado pela falta de dentes, digo-lhe que, numa imensidão de tornados por contar, a viagem da língua passou a língua de viagem, pois, meteu-se Pero Vaz de Caminha, o grande tornado foi ter acabado o império e eu retomei a palavra enfatizando que viajar antes de todas as viagens é ter sido embrião, feto, depois gestação até à novidade das palavras, a língua mãe, a minha mãe, a minha língua materna depois de ter sido padrasta da metade mais sofrida de meus antepassados, isso foi outra peregrinação, mais trágica e mais épica de lágrima marítima, falei e estou a verificar que Álvaro Velho, o do diário da viagem de Vasco da Gama, se deslumbra em ver passar o colorido que se movimenta na rua, frente à esplanada aqui na baixa de Luanda e comecei assim porque nós conversávamos tudo e desconversávamos de bom humor e sem regras como se com as palavras conseguíssemos delas próprias achamentos.

MANUEL RUI, "Língua de Viagem num Parágrafo" 1

1 Texto apresentado por Manuel Rui numa sessão da UCCLA - União das Cidades Capitais de Língua Portuguesa, em 2011. Gentilmente cedido pelo escritor à autora deste texto. 


\section{A abrir}

Quando no início do século XVI, João de Barros escrevia na sua Gramática de Língua Portuguesa que os padrões e os monumentos o tempo se encarregaria de levar, mas que a língua ficaria como testemunho do encontro, ou Fernão de Oliveira na sua "primeira anotação de língua portuguesa", afirmava que "melhor é que ensinemos a Guiné que sejamos ensinados de Roma" (Oliveira, in Buescu, 1978: 96) marcavam uma determinação política, religiosamente motivada, um propósito cultural e enunciavam uma premonição. A língua portuguesa, vista neste primeiro momento imperial como língua mais nobre para a evangelização católica, começava assim a sua peregrinação por outras terras, imbuída de um ideal ainda muito medieval na sua motivação religiosa, no seu imaginário, mas moderno pela sua projeção à escala planetária. A língua portuguesa, até aqui fixada no interior da Península através da gramática, dicionários ou prontuários e em confronto com as outras línguas novilatinas, como bem aponta Maria Leonor Buescu, surgia agora projetada para os quatro cantos do mundo com diferentes gramáticas, pensadas para estrangeiros, dicionários para as línguas orientais e nativas ameríndias, prontuários e outros métodos do ensino de português para estrangeiros (Buescu, 1978: 15-16). Evangelização e educação em língua portuguesa, e, mais tarde, com legislação vigorosa que impunha a língua portuguesa em todo o império (nomeadamente no Brasil através da lei do Marquês de Pombal que proibiu o uso de outras línguas no território) a língua portuguesa, com as suas obras fundadoras da nação - como as crónicas de Fernão Lopes e a sua epopeia moderna, Os Lusíadas -, a sua linguagem codificada em lei nas Ordenações Manuelinas, a sua vertente científica registada nas grandes obras do Renascimento, foi-se impondo como língua da Europa e da cristandade fora da Europa, moldando-se às culturas com as quais entretanto contactava, até ao ponto de nela se 
inscrever a diferença cultural que a prazo determinou as diferentes identidades políticas, primeiro no Brasil e depois, mais tardiamente em África, já no século XX. E quantas línguas morreram para que o português vingasse? Quantas culturas assim ficaram sem voz? E como se foram desenvolvendo outras culturas em língua portuguesa no interior dos contextos coloniais? E, finalmente, de que forma é que uma língua que foi a voz e a lei do poder colonial se transformou em espaço de inscrição de resistência e diferença e, portanto, em instrumento de emancipação?

\section{Primeiro andamento - corsi e recorsi}

Foi o historiador napolitano Giovan Vico que primeiramente falou da história como um movimento de corsi et recorsi, de fluxos e refluxos, e de que eram os seres humanos que faziam a sua própria história estendendo esta ideia a todas as geografias, como Said o irá ler em Orientalism. Uma obra, uma ideia, não pertence assim a um lugar específico, ela emerge de outros lugares, viaja e veicula outros sentidos dependendo dos locais de enunciação e de receção e dos contextos temporais e geográficos dos seus recetores.

A ideia portuguesa da Descoberta, inscrita na Europa pelas suas viagens e fundadora da modernidade, como propôs Fernando Pessoa $^{2}$, trazia de uma forma inequívoca, como tem sido apontado por vários críticos, a questão da identidade - a identidade dos europeus e a identidade dos "Outros" e, particularmente, dos europeus por oposição aos "Outros". Como resultado imediato, ao proporcionarem o encontro com o "Outro", os Descobrimentos, na sua elaboração europeia, proporcionaram a definição da Europa como centro de identidade (Ramalho, 1993: 96), de poder e de irra-

\footnotetext{
${ }^{2}$ Cfr. "a primeira descoberta foi a descoberta da ideia de descoberta", Pessoa, 1978: 43.
} 
diação cultural face a esse "Outro", que os europeus interpretaram, imaginaram e construíram em sucessivas metáforas de contraste, conforme os locais em que aportavam, as épocas e as respetivas perceções e políticas de diferença.

As narrativas fundadoras que dão conta dos primeiros encontros e que assim mapearam o que veio a ser colonial e imperialmente designado como "mundo português", são cartas, diários, relações de viagem, poemas, tratados, crónicas de autores portugueses cuja escrita é tecida entre o espaço narrado no imaginário e os relatos factuais das descrições das terras, das pessoas, dos recursos, das viagens, das glórias e das tragédias. São narrativas marcadamente eurocentradas e religiosamente motivadas pelo seu constante apelo à fé cristã e à missão que orientava as viagens e integram-se numa vaga europeia de representação e visão do espaço da Renascença, de feição veneziana, florentina, mas também, mais tarde, alemã ou flamenga. Mas, ao contrário destas visões que são geradas no interior da Europa e assim a refletem, os textos portugueses são gerados algures no mundo e portanto, ao mesmo tempo, que descrevem os "novos mundos", são também os primeiros textos que vêem a Europa de fora. Nestes textos definem-se identidades, atribuem-se identidades, rasuram-se identidades, questionam-se identidades, traduzem-se, bem ou mal, as impressões do encontro. Neste aspeto o olhar português é um olhar em busca da universalidade, inerente à ideia imperial manuelina, ainda que muito medieval na sua conceção de poder, nas suas obsessões, na sua fantasmagoria e nas suas fantasias, na sua religiosidade, mas muito moderno por a sua estratégia simbólica e cultural se projetar à escala planetária unindo o Ocidente com o Oriente e descentrando Jerusalém para todo o mundo não cristão, ampliando assim a dimensão do espírito de Cruzada medieval (Thomaz, 1990). Este elemento religioso caracteriza os discursos da primeira modernidade europeia como discursos de salvação que, aliás, irão tomar outras cambiantes nas 
diferentes modalizações que os Descobrimentos vão assumindo. Num primeiro momento esta modernidade caracterizou-se pela profunda novidade, pela profunda religiosidade e por várias ambiguidades, nomeadamente aquela que se prende com a alteridade humana ser simultaneamente revelada e recusada pela expulsão do Outro do interior na Península - judeus, berberes, árabes - numa espécie de pré-Contra-Reforma para que houvesse uma purificação da missão inerente à viagem/ peregrinação - e o descobrimento do Outro exterior - africanos, índios, asiáticos - como afirma Luís de Albuquerque em O Confronto do Olhar (1991). Olhando para as primeiras narrativas destes encontros verificamos que nelas se fixam imagens de "reconhecimento do desconhecido", nas palavras de Helder Macedo (1992), nelas se fixam alguns olhares que vão perdurar e criar estereótipos simplificadores da complexidade do mundo e nelas se registam grandes equívocos do olhar (Macedo, 1992; Gil e Macedo, 1998). Como refere Helder Macedo (1992) no seu grande ensaio de interpretação destes primeiros textos, "Reconhecer o Desconhecido", os portugueses levaram consigo a sua língua e, dentro dela, os seus conhecimentos, desejos, medos, ideais, sonhos, fantasmas, em suma, o património que funda o imaginário de um povo. Viam por comparação com o que conheciam, mas quando o que se lhes deparava excedia o conhecido, recorriam a metáforas; e quando estas ameaçavam subverter a ordem da sua razão, havia a fé para lidar com o ininteligível. Assim vê Camões quando fala das coisas que existem, mas não são cridas e das coisas cridas que não existem, para concluir que "o melhor de tudo é crer em Cristo" (apud Macedo, 1998: 203). O processo de visão por semelhança ou efabulação era, portanto, a regra. As fronteiras entre o visto e o imaginado face às indescritíveis novidades do mundo são ténues e mais seriam para aqueles que "viam" e que tiveram o poder de decidir quais eram as coisas que havia e em que não se acreditava e as coisas que não havia, mas em que se devia acreditar. Assim, se 
por um lado, a analogia produzida pela comparação neutralizava a diferença, e tornava semelhante e portanto inteligível, por outro lado, a descrição de coisas que não existiam e que, por isso, ninguém viu, agudizava a diferença entre os mundos e as pessoas que os habitavam. Por isso, nestes primeiros textos os mundos vistos têm a marca do olhar europeu, nas suas limitações e no seu desconhecimento, no seu imaginário e na sua retórica descritiva, e é a partir deste olhar que ficam inscritas as maiores e mais assumidas ambiguidades e enganos do olhar (Macedo e Gil, 1998).

Conhecidos exemplos, entre outros, surgem logo no Roteiro de Viagem de Vasco da Gama, atribuído a Álvaro Velho. No entendimento europeu da época, o mundo estava dividido entre cristãos e muçulmanos, e portanto, na perspetiva europeia, nas terras vistas pela primeira vez pelos portugueses, tudo o que não fosse de aparência muçulmana era cristão, não sendo assumida sequer a possibilidade de outras vias. Mas o curioso é que este equívoco é assumido de um lado e de outro. Assim, no primeiro encontro com um soberano africano os portugueses são tomados por turcos, como aliás nos reaparece em Os Lusíadas, no encontro com o rei de Melinde:

E isto foi enquanto lhes parecia que nós eramos turcos ou mouros de alguma outra parte, porque eles nos perguntavam se vinhamos da Turquia e que lhes mostrássemos os arcos da nossa terra e os livros da nossa lei. E, depois que souberam que nós eramos cristãos, ordenaram de nos tomarem e matarem à traição.

(Velho, 1960: 24)

Mas este seria até um equívoco esperado no entendimento mútuo do mundo de então, que só contemplava duas ordens. Deste modo, os hindus, habitantes da cidade de Calecute, foram assumidos como cristãos e o seu templo como uma igreja com santos com muitos 
braços e uma Nossa Senhora, que só os portugueses viram, para agradecer a chegada e rezar:

Esta cidade de Calecute é de cristãos os quais são homens baços. E andam (parte) deles com barbas grandes e os cabelos da cabeça compridos, e outros trazem as cabeças rapadas e outros tosquiadas; e trazem em a moleira uns topetes, por sinal que são cristãos; e nas barbas bigodes. (...) Primeiramente o corpo da igreja é da grandura de um mosteiro, toda lavrada de cantaria, telhada de ladrilho. E tinha à porta principal um padrão de arame, da altura de um mastro, e em cima deste padrão está uma ave, que parece galo; e outro padrão, da altura de um homem, e muito grosso. E em o meio do corpo da igreja está um coruchéu, todo de cantaria; e tinha uma porta, (larga) quanto um homem cabia, e uma escada de pedra, porque subiam a esta porta, a qual porta era de arame; e dentro estava uma imagem pequena, a qual eles diziam que era (de) Nossa Senhora. E diante da porta principal da igreja, ao longo da parede, estavam sete sinos pequenos. Aqui fez o capitão-mor oração, e nós com ele. (...)

E outros muitos santos estavam pintados pelas paredes da igreja, os quais tinham diademas; e a sua pintura era em diversa maneira, porque os dentes eram tão grandes que saiam da boca uma polegada, e cada santo tinha quatro ou cinco braços."

(Velho, 1960: 41 e 43-44)

Para além do equívoco cultural e religioso aqui assinalado, interessa também marginalmente sublinhar a descrição de estruturas muito similares àquelas que um ocidental poderia reconhecer, entre as quais a definição de cidade na sua organização, a grandeza da igreja como um mosteiro e as suas sofisticadas decorações, a nobreza dos seres e o seu vestuário. Aqui estamos num mundo de diálogo e de equivalências muito reconhecíveis, o que não acontece, por exemplo, na descrição do não diálogo entre o negro da costa 
atlântica africana e os portugueses, na epopeia camoniana, que de certa forma transpõe esta viagem contada por Álvaro Velho, para o ritmo nobre da epopeia.

Neste passo abaixo transcrito, passamos de uma aparente relação de equivalência, que reflete o momento do extasiamento e das primeiras dificuldades e perplexidades na descrição desse "Outro" - "Nem ele entende a nós, nem nós a ele" - para uma posição de valorização do próprio, por desvalorização do "Outro":

\author{
Nem ele entende a nós, nem nós a ele, \\ Selvagem mais que o bruto Polifemo. \\ Começo-lhe a mostrar da rica pele \\ De Colcos o gentil metal supremo, \\ A prata fina, a quente especiaria: \\ A nada disto o bruto se movia. \\ (Camões, 1992: V, 28: 270)
}

Esta visualização do Outro como inferior passa dos sujeitos para as terras que habitam, impondo uma ordem política e religiosa baseada na "nossa" superioridade, como aliás desde logo ficou patente na apresentação do mundo, oferecida por Tétis a Vasco da Gama:

Vês Europa Cristã, mais alta e clara

Que as outras em polícia e fortaleza.

Vês África, dos bens do mundo avara,

Inculta e toda cheia de bruteza;

Co Cabo que até 'qui se vos negara,

Que assentou pera o Austro a Natureza.

Olha essa terra toda, que se habita

Dessa gente sem Lei, quási infinita.

(Camões, 1992: X, 92: 130) 
No entanto, este olhar não seria inevitavelmente unidimensional. Desde cedo se deu o "confronto do olhar", trazendo não só as visões europeias dos povos encontrados, mas também, ainda que em pequeno número, as visões desses povos sobre os europeus $^{3}$ e talvez, acima de tudo, como hoje, retrospetivamente nos é possível observar, uma nova visão sobre a humanidade, sobre os valores ditos europeus, sobre a sua assumida superioridade e o seu questionamento. No caso português com Luís de Camões na sua epopeia, escrita setenta anos depois da chegada de Vasco da Gama à Índia e portanto já em tempo de dúvida e decadência, a crítica é evidente, o que faz do poema simultaneamente uma celebração dos feitos passados (como compete à epopeia clássica), um corretivo do presente e um projeto do futuro, como seria de esperar de uma epopeia moderna, em que a dúvida sistemática sobre as realizações imperiais e o modo como elas estão a ser desenhadas e obtidas é constante. Isto é desenvolvido no poema, não apenas pela conhecida figura do Velho do Restelo, mas também em todos os finais de canto e, como bem assinala Helder Macedo, no plano metafórico, pela fala de Baco que é simultaneamente o pai ancestral dos portugueses, o antigo senhor da Índia que os portugueses demandavam, e o veemente opositor ao projeto imperial. É Baco que "avisa" as populações da terra africana de Moçambique contra as "gentes roubadoras" que eram "estes homens que passavam" e "que com pactos de paz sempre ancoravam". As acusações de Baco são qualificadas no poema como "falsidades". A verdade, no entanto, é que as incómodas palavras que lhe são atribuídas dificilmente poderiam ter sido entendidas como falsas pelos portugueses contemporâneos de Camões" (Macedo, 2013)

- E sabe mais (lhe diz) como entendido

3 Ver Albuquerque et al., (1991). 


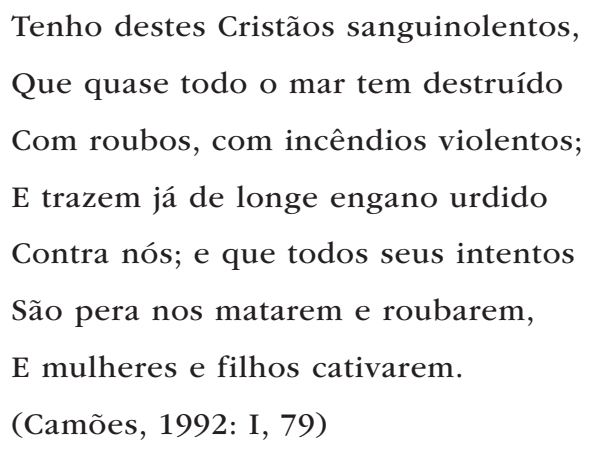

No caso francês, este questionamento vem pela voz de Montaigne que tão bem inscreve esta dúvida no discurso europeu em pleno Renascimento. Ao pedir, nos Essais (1969: 251-263), aos seus leitores, naturalmente europeus, para tentarem ver os costumes dos povos do Novo Mundo através dos olhos dos indígenas, para assim reexaminar as definições europeias de "barbarismo" ou "civilização", Montaigne abria as portas para a angústia da Europa em relação a si própria, ao colocar no terreno da dúvida, a ação política e religiosa colonizadora, sugerindo mesmo que este Novo Mundo iria, mais tarde ou mais cedo, antropofagizar a velha Europa. No caso português, também Camões o tinha exprimido ao longo do Canto $\mathrm{X}$, de Os Lusíadas, ao confrontar a pequena nação portuguesa com a imensidão da terra incógnita que as Descobertas traziam, coroando os reis portugueses como senhores "da Conquista, da Navegação, do Comércio, da Etiópia, da Arábia, Pérsia e Índia”. No entanto, a "missão civilizadora" cristã de que a Europa, a partir de então, ficou imbuída, face ao Outro, inculto, bruto e sem lei, nas várias modelações em que se foram prolongando as Descobertas ao longo dos séculos (Ramalho, 1993:103), não teve os mesmo contornos no Oriente e no extremo Oriente, como ficou mostrado nas grandes obras que descreveram essas terras e viagens desde a Peregrinação aos Os Lusíadas, a que volto, para observar a sofisticação do diálogo entre os povos e as revelações feitas. 
No caminho da viagem para a Índia narrada no poema, a frota de Vasco da Gama aporta nos ditos territórios de Moçambique para descansar e saber novas da Índia que procurava. Os marinheiros vendo aquela "gente estranha" que em batéis os acompanhava na entrada da baía, perguntavam-se sobre quem seriam aqueles homens, a que terra pertenceriam, que cultura, que crença, que poder representariam, pronunciando assim a questão fundadora que enforma Os Lusíadas, aquando do encontro (ou talvez melhor do "encontrão", para evocar as palavras de Eduardo Lourenço) entre os navegantes e os Outros:

- «Que gente será esta?» (em si diziam)

"Que costumes, que Lei, que Rei teriam?»

(Camões, 1992: I, 45, 2003: 12)

A curiosidade daqueles que na ordem da história narrada pelo Ocidente ficaram designados como "os descobridores" encontra-se, de modo especular, na curiosidade desconfiada dos nativos, já previamente avisados por Baco. Recebidos a bordo, perguntavam

Pela Arábica língua, donde vinham,

Quem eram, de que terra, que buscavam,

Ou que partes do mar corrido tinham?

(Camões, 1992: I, 50: 13)

Independentemente da pertinente questão de saber quem descobre quem, que estes passos desde logo sugerem, interessa-me sobretudo sublinhar que as questões levantadas, de forma aparentemente simples, são na verdade elementos centrais no que diz respeito à identidade dos povos que pela viagem se encontravam. Por outras palavras, em que língua se expressam estas gentes, que conhecimentos possuem, que religião seguem, que poder é que 
os conduz e que os move? O que representa esta humanidade em relação a nós, ou dito de outra maneira, quem somos nós afinal? A resposta dos portugueses vai dar lugar, nas palavras de Eduardo Lourenço, a uma primeira identificação global (1994: 90), que indica simultaneamente uma origem e um desejo de poder e de expansão:

Os Portugueses somos do Ocidente,

Imos buscando as terras do Oriente.

(Camões, 1992: I, 50: 13)

Nesta descrição lapidar, a origem funciona como um elemento estático que define uma zona geográfica identificada com valores cristãos, determinando os valores identitários desta comunidade embarcada. Mas estes valores aparecem conjugados com um elemento dinâmico, "a busca" de outra geografia e de tudo o que lhe é inerente no imaginário a que pertencem. Esta definição que, desde logo, coloca Portugal no centro dos mundos conhecidos - o Ocidente que representam e o Oriente que procuram - posta por Camões na boca dos marinheiros, vai ser ampliada na conversa subsequente entre Vasco da Gama e o rei desta "gente estranha”, o rei de Melinde. Neste encontro Vasco da Gama e, com ele, o povo por si representado, geográfica, moral e religiosamente, como português, europeu, cristão, inscreve pela primeira vez a aventura nacional portuguesa no círculo mais alargado da Europa e, consequentemente, a narração dos feitos de Os Lusíadas, como a "primeira epopeia europeia moderna”, como o definiu Eduardo Lourenço (1994: 87). Mas ao colocar na Europa este discurso símbolo da identidade nacional, Vasco da Gama coloca também o Reino Lusitano como "cabeça” dessa "Europa toda" que os portugueses ali representavam e anuncia uma nova ordem instalada pela religião e pelas armas de que é portador. É certo que, como notou Eduardo Lourenço, trata-se da Europa saída da Reforma, portuguesa, ibérica, defensora fervorosa 
do catolicismo saído do Concílio de Trento, em nome do qual os dois países ibéricos, unidos na sua fé e geografia, empreenderam as suas gestas marítimas de conquista e fé (1994: 92). Daí que, de acordo com o ensaísta, na descrição mágica que Vasco da Gama faz da Europa ao Rei de Melinde, destaque a pátria comum a Portugueses e Espanhóis, em contraste com a outra Europa, aqui subentendida, mas posteriormente apresentada no Canto VII, como a de "gente insana", cega e sedenta do seu próprio sangue em contraste com os "cristãos atrevimentos" encabeçados pelo Reino Lusitano e pela Espanha em breve lançados na expansão para a América do Sul.

Eis aqui se descobre a nobre Espanha,

Como cabeça ali de Europa toda,

Em cujo senhorio e glória estranha

Muitas voltas tem dado a fatal roda;

(...)

Eis aqui, quasi cume da cabeça

De Europa toda, o Reino Lusitano,

Onde a terra se acaba e o mar começa

(Camões, 1992: III, 17: 63)

No entanto, estas diferenças entre as nações europeias são inacessíveis para os outros povos, mas o que me interessa aqui realçar é que é através deste discurso, traçado na base da diferença que o contacto com o Outro proporcionou, que Camões reflete sobre a condição da nação portuguesa no concerto das nações europeias. A revelação da identidade a um Outro, feita por Vasco da Gama, e elaborada na base do confronto, confessa-se como uma autoanálise, mostrando assim como o processo da descoberta é simultaneamente um processo de autodescoberta e de crítica que, ora é transmitida pela interrogação dos próprios, ora vem sob a máscara do Outro (Gil e Macedo, 1998; Lourenço, 1994: 94). Mas enquanto Camões alarga 
os parâmetros da cultura europeia para incluir nela a diferença e a partir daí a crítica ou, Fernão Mendes Pinto, em Peregrinação, usa a diferença que observa no Oriente como um modelo crítico da Europa. E é esta capacidade de descentramento do centro - Lisboa, Europa - para o Oriente que estas obras oferecem, que permite uma visão totalmente diferente da Europa e dos portugueses que começam a ter uma existência noutro lugar, o que vai caracterizar os protocolos narrativos da epopeia.

Parece, portanto, ser o movimento imprimido pela viagem que liga a origem - o Ocidente - ao mundo desconhecido - o Oriente que está na génese da elaboração deste discurso identitário fundador, que tem por base os elementos reais e simbólicos do mundo original dos navegantes e que no contacto com o Outro se consagram como seus, enquanto matéria diferenciadora e dialogante com os Outros. A este aspeto junta-se portanto um outro elemento fundador da condição moderna de Portugal: o seu papel pioneiro de mediador dos mundos, que eleva a condição de fronteira de Portugal a um elemento de comunicação e de domínio entre os mundos, veiculado por uma imagem duplamente central de Portugal. Por um lado, de Portugal face à Europa, como o descobridor dos novos mundos, que perante ela, através de si, ganham existência, e, por outro lado, de Portugal face aos variados Outros, como representante da Europa, espécie de "cabeça" bifronte olhando para a Europa e para o Atlântico em que em breve se vai lançar criando - quase em oposição, mas também complementaridade, ao seu encontro com o Oriente - um novo Ocidente.

\section{Segundo andamento - um novo Ocidente?}

No momento em que, após o prolongado contacto dos portugueses com o Oriente, de que resultou um património literário absolutamente único, os reinos ibéricos se lançavam nas Américas com 
grande apoio das políticas do Vaticano para a expansão da fé cristã, a Europa dita central, vivia guerras religiosas intestinas entre si e contra os muçulmanos. Esta opção geopolítica dos reinos ibéricos e do Vaticano, ou seja, de uma Europa do sul, periférica em relação à outra Europa, uma "extrema Europa", nas palavras de Roberto Vecchi (2011), criadora de um Ocidente a Ocidente de matriz cristã, moderno, mas baseado ainda num mundo antigo, é quem desenvolve, pela circulação, pela mobilidade, pela ciência, pelo conhecimento, pelo cosmopolitismo, as bases do mundo capitalista contemporâneo. Este desenho de Portugal e Espanha para além de si mesmos, e de que ainda hoje vivemos os reflexos reais e míticos, vai conjugar-se na ideia de uma frente atlântica que nunca mais nos abandonou e que nos definiu como europeus, ora numa jangada de pedra, como viu José Saramago, extremo ocidental da Europa deslocando-se na deriva marítima para o Atlântico ou no Portugal navio-nação, como o vê Eduardo Lourenço, a partir das lentes pessoanas, de costas viradas para a Europa, fitando o Atlântico, ora ainda numa relação compensatória de grandeza para iludir a relação complexa e complexada com a Europa dita central. Aos olhos dos Outros - em África e nas Américas que trouxeram à Europa uma "nova humanidade", sobre a qual se iria discutir na polémica que opôs Sepúlveda a Las Casas em Valladolid - esta era a Europa, como Portugal tinha sido no encontro com o Oriente. Mas, dentro da Europa em si cabe hoje perguntar se esta "navegação" da Península, não foi em si, mesma uma procura de uma outra condição europeia, baseada no Atlântico Sul e nos seus movimentos, de que hoje resta a proximidade cultural a um Sul Global.

O problema da interpretação de um movimento desta amplitude e das suas consequências a partir de visões eurocêntricas, mas também afro-cêntricas ou americo-cêntricas é que, de facto, nenhuma delas é totalmente capaz de descrever a complexidade do fenómeno da mobilidade e da circulação gerada pela modernidade, sendo contudo 
todas verdadeiras, ou seja, não são contraditórias em si, nem se excluem, são antes narrativas que se completam. (Naro, Sansi-Roca e Treece, 2007: 1-18). O Novo Mundo não foi apenas o resultado da intervenção europeia, pela colonização e pela evangelização, nem do tráfico negreiro. Estas terras eram uma terra nova para quem lá chegou, mas outra humanidade as habitava. Contudo, a mistura liderada pelo movimento europeu cria algo de absolutamente novo ${ }^{4}$.

Não se trata portanto do Velho Mundo transladado para o Novo Mundo, mas transfigurado, como o evoca Eduardo Lourenço (2005), pois não se trata apenas e também de um novo Ocidente nas Américas (em contraste com o Oriente encontrado pelos portugueses), mas também de uma nova África no Brasil, desencadeada pelo tráfico negreiro. Não é apenas uma questão de genética, mas de história, de cultura, de línguas, de geografias que se misturam. A Europa, não é assim e apenas o agente desta transformação, mas também o resultado disso. Ou seja, a Europa também é profundamente mudada pelo Novo Mundo e por todas as partes do mundo em que passa a estar. Por isso, e como defendem Naro, Sansi-Roca e Treece (2007), os mares em que se circula, e o Atlântico sul em particular no caso português, não é só passagem, separação entre o novo e o velho, mas espaço de intensa circulação em que todos os atores, sem esquecer as suas diferenciadas posições de ação, poder

\footnotetext{
${ }^{4}$ Darcy Ribeiro numa versão um pouco romanceada fala de um "género humano novo", na sua obra O Povo Brasileiro (1996:19). Novo porque surge como uma etnia nacional, diferenciada culturalmente de suas matrizes formadoras, fortemente mestiça, dinamizada por uma cultura sincrética e singularizada pela redefinição de traços culturais delas oriundos. Também novo porque se vê a si mesmo e é visto como uma gente nova, um novo género humano diferente de quantos existam. Povo novo ainda, porque é um novo modelo de estruturação societária, que inaugura uma nova forma singular de organização sócio económica, fundada num tipo renovado de escravismo e numa servidão continuada ao mercado mundial. Novo, inclusive, pela inverosímil alegria e espantosa vontade de felicidade, num povo tão sacrificado, que alenta e comove a todos os brasileiros.
} 
e audição, saíram transformados da travessia. Assim se compreende que a narrativa europeia seja a narrativa da modernidade e a da diáspora negra, a da contramodernidade, ou do seu negativo, como a vê Paul Gilroy em Black Atlantic e vários outros estudiosos. Mas também não é só isso. Será que esta narrativa é sempre, como foi vista a partir de certa altura pelos europeus, apenas uma narrativa de interpelação e resistência? Não é de facto também uma nova narrativa transformadora, como a da modernidade também o foi para os europeus? E aqui chegamos à questão do narrador. Quem faz a narração da história, em que língua e a partir de que lugar? Quais são as condições de receção destes discursos e de possibilidade de encetamento de um diálogo entre estes discursos?

O texto fundador desse Novo Mundo para os portugueses é seguramente a "Carta a El-Rei Dom Manuel sobre o Achamento das Terras de Vera-Cruz", de Pêro Vaz de Caminha que é um texto descritivo e a expressão de um não diálogo. Como assinala Helder Macedo, no ensaio acima referido, "Reconhecer o Desconhecido", os equívocos na Carta são hoje uma evidência, mas o não diálogo não é, como no passo de Os Lusíadas, acima referido, pela inferiorização do Outro, mas pura e simplesmente pelo espanto e pela dificuldade de leitura da sua diferença. Tal como Colombo, Pêro Vaz de Caminha parece ter encontrado o Paraíso, mas enquanto Colombo o vê como o sonho que alimentava a sua viagem, Pêro Vaz de Caminha sente-se no Paraíso para poder descrever o que vê e para poder lidar com a nudez dos índios, que o seu imaginário religioso não tolera. É assim que vê na nudez dos índios a inocência anterior ao pecado, como assinala Helder Macedo no referido ensaio. Os homens e as mulheres, diz Caminha:

andam nus, sem nenhuma cobertura, nem estimam nenhuma cousa cobrir nem mostrar vergonhas. E estão acerca disso com tanta inocência como têm em mostrar o rosto. (...) Também andavam entre eles quatro 
ou cinco mulheres moças, assim nuas, que não pareciam mal, entre as quais andava uma com uma coxa, do joelho até ao quadril e a nádega, toda tinta daquela tintura preta e o resto todo da sua própria cor. Outra trazia ambos os joelhos com as curvas assim tintas e também os colos dos pés. E as suas vergonhas tão nuas e com tanta inocência descobertas que não havia aí nenhuma vergonha.

(Caminha, 2000: 21-23)

Como sabemos pelo andamento histórico, esta ideia de Paraíso rapidamente se inverte e os sinais da imposição são dados logo na própria carta em que o homem religioso hesita entre a sua visão idílica e o seu comprometimento religioso, concluindo que o melhor era tapar a nudez e distribuir camisas para os homens e panos para as mulheres pois "a esta gente não lhes falta outra cousa para ser toda cristã que entenderem-nos". Em que língua então se iria comunicar nestas paragens? Como se traduziriam estes dois mundos sem aparente ligação?

Língua, e com ela, poder e conhecimento é, como é sabido, a estrutura sobre a qual repousou grande parte do ideário imperial e do ato colonial imposto pelas potências navegantes da primeira modernidade e depois pelas potências coloniais europeias no final do século XIX e ao longo de boa parte do século XX. Esse poder e esse conhecimento, veiculado numa certa língua imperial, representou um poderoso elemento estruturador e unificador dos territórios coloniais em si, entre si e com as suas metrópoles. Basta remontar a João de Barros, acima referido, para entender que - como ele tão premonitoriamente insinua na introdução - a língua ficaria como testemunho do encontro; ou basta recordar politicamente Helder Macedo para perceber que a língua seria, não apenas a expressão mais distintiva do espírito da nação imperial - composta de múltiplas nações e de múltiplos povos ignorados - mas também uma das 
formas através da qual a nação, saída das várias lutas pelas várias emancipações, se poderia expressar.

É nesta medida que Os Lusíadas se assumem como o discurso fundador da identidade de uma pátria em expansão que dinamicamente se procura entre a Europa a que pertence e "as novas partes do Oriente" que deseja, entre o arrojo e heroísmo dos seus homens e a consciência das suas fraquezas e perversidades, entre a celebração das glórias das conquistas e das armas e a angústia e a dúvida sobre as ações realizadas. Por isso, Os Lusíadas simbolizam a gloriosa voz onde a imagem nacional e a imagem imperial se fundem, e, ao mesmo tempo, a primeira voz de um escritor regenerador da pátria, de que Vieira viria a ser o profeta até à instalação do discurso de regeneração, não só do tempo ideal celebrado no poema, mas da própria pátria, discurso que percorre todo o século XIX e que só com Fernando Pessoa se projeta na modernidade europeia.

O sentido profundo do diálogo, estabelecido por gerações de políticos e poetas de língua portuguesa com Os Lusíadas, é dado pela dimensão humana, nacional e estética que a interrogação nele contida nos dirige, fazendo com que nas diferentes épocas em que o poema é lido, cada leitor retire dele um olhar interrogativo que se dirige a si, não tanto enquanto reflexo necessariamente retórico da nossa interrogação temporal, mas como interrogação essencial que vem ao nosso encontro e nos insta a responder. Revelando-nos a beleza do que fomos, de que o poema é registo, no que arriscávamos tornar-nos, como o poema nos avisa, e sugerindo-nos o que poderíamos vir a ser na celebração dos impérios, o poema interroga-nos a partir da nossa contemporaneidade e do nosso lugar de enunciação. Responder-lhe foi o grande desafio que, a partir de então, se instalou, e que se revelou sempre aquém do mundo inicialmente oferecido. Responder-lhe foi reconfigurar, nos vários momentos históricos, a imagem de Portugal como centro, que o poema nos oferece em diversas "imaginações do centro" (Ribeiro: 2004) que tiveram, na 
imagem de Portugal como nação imperial, a sua construção balsâmica, para assim iludir uma vivência de periferia. Na verdade, não se estava a responder ao poema, estava-se a usá-lo como resposta. Mas o que aqui mais me interessa mostrar - pensando na herança deste património literário que descreve e inscreve os "Outros" na história dos portugueses e, consequentemente os portugueses na história dos "Outros" - foi como é que esses "Outros" a partir dos seus lugares de origem e de luta, responderam ao poema, exprimiram a rejeição da situação política em que viviam, e reivindicaram o seu lugar de vítimas, mas também de sujeitos de uma história comum.

É trabalho hoje dos historiadores, críticos literários e outros estudiosos resgatar esses outros discursos que nas margens do discurso colonial asseguraram a existência de outras histórias. Histórias que estão na origem dos primeiros textos escritos em língua portuguesa pelas literaturas brasileira, são-tomense, guineense, angolana, moçambicana, cabo-verdiana, textos que registaram a inscrição da diferença cultural que visava o resgate das identidades rasuradas e das histórias silenciadas. Por isso, os estudiosos destas literaturas, normalmente designadas por literaturas africanas de lingua portuguesa refletem nos seus estudos sobre a profunda relação entre esta literatura e a história, entre a literatura e política, desde o momento de aportagem e do longo momento colonial até às lutas, às independências e ao momento contemporâneo. E o que fazem estas primeiras vozes destas literaturas?

Movendo os africanos das margens para o centro das narrativas e fazendo do seu território o centro das suas identidades, os movimentos anticoloniais foram inscrevendo nas suas narrativas e poemas as suas diferenças em língua portuguesa, contando a história da intervenção colonial a partir de um ponto de vista africano. Leram os grandes textos de viagens dos portugueses, não como textos de glorificação e de conquista, mas de invasão e interrogação sobre si mesmos. Por isso, estas primeiras narrativas africanas denunciam 
o "perigo de uma história única", de que fala a escritora nigeriana Chimamanda Adchie Ngozi (2009) e, consequentemente quebram a hegemonia narrativa europeia sobre a gesta colonial. Foram, na sua origem, plataformas para um diálogo possível, mas na ordem colonial então vigente, rapidamente se tornaram objeto de censura e perseguição dos seus autores lidos como antiportugueses, quando tantas vezes eram homens e mulheres de cultura expressa em língua portuguesa, mas que colocavam o centro da sua identidade no seu território e denunciavam a situação imoral que viviam. Por isso, estas narrativas foram também objeto de leitura para muitos membros da comunidade colonial e metropolitana, que muitas vezes assim iniciaram caminhos de grande ambiguidade identitária, com diversas motivações, reconfigurações e transformação de identidades pessoais e nacionais. No caso da África de língua portuguesa estas narrativas trazem para a cena do texto Angola, Moçambique, Guiné-Bissau, S. Tomé e Príncipe, Cabo Verde, apelando a heranças e gerando mecanismos de pertença e identidade múltiplos que colocam sob suspeita a aparente hegemonia cultural gerada pelo colonialismo. A falta de diálogo e o impasse político radicalizou posições e levou a cenários de grande violência nomeadamente de guerras coloniais. No fundo, eram narrativas e poemas que procuraram responder, séculos mais tarde, às insidiosas perguntas dos navegantes camonianos, dizendo-nos quem são, de onde vêm e como são as suas terras, em que é que acreditam. Ao mesmo tempo que se explicam e afirmam as suas identidades, questionam-nos profundamente.

\section{Terceiro andamento - reescritas, a cópia infiel}

Teríamos de esperar cinco séculos para que pela voz poética de uma moçambicana - Noémia de Sousa, em Sangue Negro - viesse a mais profunda resposta à pergunta lançada cinco séculos atrás pelos navegantes camonianos: 
Se me quiseres conhecer,

estuda com os olhos bem de ver

esse pedaço de pau preto

que um desconhecido irmão maconde

de mãos inspiradas

talhou e trabalhou

em terras distantes lá do Norte.

Ah, essa sou eu:

órbitas vazias no desespero de possuir a vida, boca rasgada em feridas de angústia, mãos enormes, espalmadas, erguendo-se em jeito de quem implora e ameaça, corpo tatuado de feridas visíveis e invisíveis pelos chicotes da escravatura...

Torturada e magnífica

altiva e mística,

África da cabeça aos pés,

- ah, essa sou eu:

Se quiseres compreender-me

vem debruçar-te sobre minha alma de África,

nos gemidos dos negros no cais

nos batuques frenéticos dos muchopes

na rebeldia dos machanganas

na estranha melancolia se evolando

duma canção nativa, noite dentro...

E nada mais me perguntes,

se é que me queres conhecer...

Que não sou mais que um búzio de carne, onde a revolta de África congelou seu grito inchado de esperança.

(Sousa, 1988: 49-50) 
O processo de ocupação e colonização que se seguiu à viagem narrada no poema camoniano, vai sendo, ao longo da história, ilustrado por múltiplas narrativas escritas em língua imperial e emitidas a partir da nação imperial, narrativas essas que edificaram, retificaram, codificaram e finalmente reproduziram o pensamento colonial. Esta história colonial escrita pelos caçadores, para recorrer às categorias definidas por um provérbio africano - "Também o leão deverá ter quem conte a sua história. As histórias não podem glorificar apenas o caçador" - converteu esses outros em seres sem história, sem lei, sem Rei como se diz na História da Província de Santa Cruz a que vulgarmente chamamos Brasil, de Pêro de Magalhães Gândavo. Passarão muitos anos, haverá muitas lutas, correrá muito sangue para que se entenda o mundo colonial em resposta às perguntas camonianas a partir do outro lado.

Levará muitos anos depois da chegada de Pero Vaz de Caminha para que os brasileiros assumam esta carta como o seu certificado de batismo e a reescrevam de forma incessante nos momentos de grande reflexão sobre a nação a ponto de quase se poderem configurar como refundações, como foram as múltiplas cartas escritas em 1922, no centenário da independência e no contexto do Modernismo de 22, a Carta de Darcy Ribeiro, aquando da fundação de Brasília, em 1960 ou a de Luís Veríssimo, em 2000, aquando das comemorações da descoberta do Brasil. Neste momento, como refere Eduardo Lourenço (2005), pela primeira vez Portugal tomou consciência que os filhos de Colombo "não queriam comemorar", mostrando assim os detalhes hipersignificativos das histórias coloniais: uma história comum, mas de memórias muito diferentes e, portanto, a necessidade de uma pluralidade de narrativas, feitas a partir de um processo de reescrita e de tradução de um património comum para portugueses e brasileiros, como é a Carta de Caminha, operacionalizado por os instrumentos que Sílvio Renato Jorge tão bem identifica no seu texto publicado neste livro, "Só a Antropofagia nos Une". 
Em África outro será o processo de resposta e reescrita. Haverá muitas lutas, muitas insurreições, muitas mortes para que se entenda o mundo colonial em Angola em tensão e fratura entre brancos, negros, mulatos como nos mostrou Castro Soromenho na sua obra ficcional, particularmente a partir de Terra Morta (1949), ou em Moçambique para que José Craveirinha publique Xibugo (1964) ou Noémia de Sousa o poema acima citado, de 1947. Como aponta Laura Padilha, na senda de Cornejo Polar, nas margens dos discursos eurocêntricos, existiram sempre outras vozes, outras nomeações da terra e das coisas, senhoras de outras versões nunca escutadas e, portanto, por vezes, nem sequer silenciadas, mas antes nunca ouvidas (Padilha, 2006a). Não se tratava portanto de defender a ideia, cara a alguns teóricos do pós-colonialismo, de que os subalternos não falavam ou não podiam falar, mas de, como defende Spivak, mostrar que o seu lugar de enunciação, no seio da diferença colonial, condenava o seu discurso à irrelevância por o oferecer a interpretações que o silenciavam (Spivak, 1988).

Mas lendo e sobretudo escutando textos como os de Ruy Duarte de Carvalho ou os de Ana Paula Tavares em que todas essas vozes-outras são convocadas, assistimos a um confronto do olhar, que pode não ser necessariamente conflituoso, mas que nos revela não só os enganos dos olhares europeus, mas também a má fortuna dos seus olhares e o pouco amor ardente. Nestas vozes, outros sujeitos históricos e etno-culturais se revelam, mostrando assim outras formas de falar, de estar, de sentir e de enunciar o mundo, de ser, de viver a vida e de organizar a cultura, a memória e a história, como as mulheres que amassam o pão, como os homens dos bois, senhores da transumância do planalto de Huíla.

Vieram muitos

à procura de pasto 
traziam olhos rasos da poeira e da sede e o gado perdido.

Vieram muitos

à promessa de pasto

de capim gordo

das tranquilas águas do lago.

Vieram de mãos vazias

mas olhos de sede

e sandálias gastas

da procura de pasto.

(...)

Partiram com olhos rasos de pasto

limpos de poeira

levaram o gado gordo e as raparigas.

(Tavares, 1999: 27-28)

Vestindo outras peles, outros conhecimentos e imbuída de outros poderes, foi portanto nessa língua imperial - que muitas outras rasurou no processo de colonização - que se começaram a preencher os espaços em branco da história colonial (Padilha, 2006a: 29-49), ou, por outras palavras, se começaram a colocar sob suspeita os monopólios do conhecimento e do poder que tinham sido fundamentais no erigir de uma ordem social, política e cultural baseada na diferença e na economia do conhecimento que valoriza o "conhecimento autorizado" e socialmente reconhecido, em detrimento (por rasura) de outros conhecimentos expressos muitas vezes noutras línguas nacionais.

Quando estas narrativas do então definido como o Outro, para o europeu, se enunciaram como um "enfrentamento" pronunciado em línguas imperiais, nelas se inscreveu a diferença cultural que reclamava o ato político da independência. Em Moçambique, com José 
Craveirinha ou Noémia de Sousa, em Angola, com Luandino Vieira, António Jacinto, Viriato da Cruz, Agostinho Neto e tantos outros, ou Amílcar Cabral, em Cabo Verde e Guiné-Bissau, revelavam-se as vozes que vinham falar no que o poder colonial queria continuar a ver como "dialetos" de um folclórico poder africano local. Nas suas escritas, não mais assumidas como marginais, regista-se a semente da diferença, em tensão com o modelo linguístico colonial. Essa linguagem fundadora de um conhecimento outro, de um poder outro e, finalmente, de uma língua outra, veicula e narra, como bem observou Laura Padilha, uma "outra viagem", não mais mar abaixo rumo ao sul, como a viagem camoniana em demanda das novas terras que o império traria, mas para "dentro" e por "dentro" (Padilha, 2006b). A viagem que o desejo de descolonização determinava - lembrando aquela viagem narrada na literatura portuguesa por Almeida Garrett em Viagens na Minha Terra, Tejo arriba e portanto para dentro da terra e reclamando descolonizações de outra ordem - parecia procurar e tentar recuperar os laços dilacerados pelo poder colonial e, desta forma, outros enunciados se começaram a estruturar em torno da luta e do confronto, a enunciar e a fixar para dar respostas às questões dos navegantes, usando a mesma língua, mas que era já outra. Neste aspeto, tanto o processo colonial, como, mais tarde, o processo de independência e construção da nação, ainda que por razões e motivações políticas diferentes, promoveram sempre a hegemonia da língua portuguesa em relação às línguas nacionais, fomentando de certa forma algum colonialismo linguístico interno, veiculado pela língua portuguesa como a língua do poder.

Em 1946, após toda a onda de libertação que varreu a Europa em ruínas no pós Segunda Guerra Mundial, Amílcar Cabral, amargurado pelas fomes que assolavam Cabo Verde e o abandono da Guiné-Bissau, exprimia essa dor local abarcando em si o desejo de libertação de um continente inteiro. No poema, publicado só três décadas mais tarde, dizia: 
No fundo de mim mesmo

eu sinto qualquer coisa que fere a minha carne, que me dilacera e tortura...

qualquer coisa estranha (talvez seja ilusão), qualquer coisa que eu tenho não sei onde, que faz sangrar o meu corpo, que faz sangrar também

a Humanidade inteira!

(apud Semedo, in Ribeiro e Semedo, 2011: 30-31)

Em 1949 Alda Espírito Santo, a partir de S. Tomé e Príncipe, em "Luares de África”, publicado na revista Mensagem, alude também ao desconhecimento de África presente no imaginário colonial, questionando-o:

África, esse grande continente de calor, essa terra de gente escura, de flora ridente e esquisita, de clima tropical, é África de histórias, de lendas, de mistérios, de selvas e selvas sem fim, para muita gente que vê África através dos livros de aventuras e de páginas da imaginação. Eu não vejo essa África. Vejo a África real e abraço no meu problema os luares escondidos dessa terra prodigiosa, de séculos de esquecimento. (Espírito Santo, 1949: 1)

Em 1964, José Craveirinha publicava Xibugo. Em 1963, José Luandino Vieira escrevia Luuanda a partir da prisão. Nestes contos, como já em Cidade da Infância do mesmo autor é denunciada a linha que separa a cidade colonial, do musseque, onde vivem negros, mulatos e os brancos pobres. Mas a opção de José Luandino Vieira não segue a esperada dicotomia na senda do neorrealismo entre exploradores e explorados. O cenário escolhido é o musseque, com as suas personagens, a sua linguagem, as suas línguas, os seus 
conhecimentos, as suas ordens sociais e de justiça. A opção foi portanto mostrar não o que o musseque não tem em relação à cidade colonial, mas de mostrar o que o musseque também tem e a cidade colonial não conhece. Todos os textos são basicamente histórias de pobreza e de fome e a questão que os perpassa anuncia o projeto político e literário do autor, epitomizado na pergunta - de quem são as riquezas de Angola?

A dar corpo a estas visões dos poetas estariam muitos dos camaradas da Casa dos Estudantes do Império, que desde esta altura tiveram um papel fundamental na construção de uma visão plurifacetada de África, que vai pôr em causa as imagens construídas pelo Estado Novo e registadas no imaginário colonial português, nomeadamente na sua literatura colonial, ao mesmo tempo que vai ver o problema africano a partir de fora, ou seja, a partir da experiência metropolitana de desenraizamento dos seus autores, gerando novos mecanismos de formação identitária e de pertença.

Mas a estas representações de África que, a seu tempo, iriam evoluir para a construção de uma identidade cultural e nacional, que seria o pano de fundo das lutas de libertação (que me levaria a reflexões fora do âmbito deste pensamento), associamos, relativamente à representação de outras Áfricas, autores como o já citado Castro Soromenho de Terra Morta, José-Augusto França de Natureza Morta, alguma poesia de Ruy Cinatti e de Francisco José Tenreiro, e tantos outros. Não quero com isto dizer que todos estes livros, vindos de África ou sobre África, são contra o regime ou contra a ideia de uma África portuguesa, mas são certamente narrativas que dentro de um inicial paradigma de literatura colonial apontam para uma desmistificação da ideia de África cheia de heróis épicos de pacotilha e sonhos de fortuna, a que se juntava a cor local do exotismo e mistério, como aparece nos romances colonialistas afetos à ideologia do Estado Novo e são sobretudo, nas suas várias representações simbólicas, espaços que refletem a ambiguidade da ideologia colonial 
salazarista. Assim, sob o título "Eu Não Vejo Essa África” podemos também colocar os textos que revelam outras imagens de África que a ambiguidade da situação colonial foi a seu tempo gerando, demonstrando assim que, como defende Bhabha $(1994)^{5}$, a hegemonia do poder colonial nunca é completa, nem mesmo naqueles espaços que estão rodeados de muros de silêncio, como era o caso das colónias portuguesas, nas palavras de Amílcar Cabral. Trata-se portanto de um múltiplo movimento participado por muitos e com diferentes graus de comprometimento e empenhamento político, mas o importante é que sobretudo a partir dos meios urbanos são convocados para a cena do texto sujeitos etno-culturais não valorizados pelo regime colonial, mas importantíssimos na outra ordem do mundo que o mundo colonial não atingia. Nela se trazem as línguas e a vozes de outros sujeitos, os gestos e os atos e os sinais produzidos por esse mundo outro, senhor de outras leis, de outros conhecimentos e de outros poderes que aparentemente o regime colonial parecia não ter tocado e as de outros profundamente atingidos pela violência do processo de assimilação, que se baseia no sacrifício e anulação da diferença sem reparação, ao mesmo tempo que, pela educação formal, dota os sujeitos de conhecimento e possibilidade de pensamento crítico, o que levou muitos africanos a repensar a sua própria condição. E assim vozes, nomes, territórios, corpos são convocados em títulos de alguns dos poemas que vão desfilando à frente dos nossos olhos de leitores, como fotografias que vão dando rosto ao que antes só tinha um nome. Poemas que projetam percursos de vida ao longo de uma paisagem natural, social e humana que coloca sob suspeita os valores ocidentais a partir de uma vivência múltipla de uma terra/território sentido como terra-mãe que acolhe

5 Homi Bhabha defende que o terreno colonial é "uma incubadora de fraturas, ambivalências e uma série de ansiedades [...] e imagens de marginalidade", Bhabha, 1994: 66- 84 . 
e integra os seus filhos, como uma casa-nação que se torna o espaço de um pronunciamento político capaz de revelar e de exercer um poder-outro, por um conhecimento-outro imanente da relação com a própria terra, com as pessoas que a habitam e pronunciando noutras línguas: as línguas dos negros, o ronga, o macua, o suaíli, o changana, o oxitsua e o bitonga, articuladas sempre como sempre estiveram com a natureza e o desenho do país violentado por séculos de ocupação estrangeira. É assim o mapa do país gritado pelo poeta José Craveirinha nos anos 60 , no poema "Hino à minha Terra”, onde se renomeia a terra, se faz a identificação do país, e se transforma e remodela a língua portuguesa para a celebração visceral dum Moçambique plural em processo de reconhecimento, de libertação e de sonho de um futuro.

O sangue dos nomes

é o sangue dos homens.

Suga-o tu também se és capaz

tu que não nos amas.

\author{
Amanhece \\ sobre as cidades do futuro. \\ E uma saudade cresce no nome das coisas \\ e digo Metengobalame e Macomia \\ e é Metengobalame a cálida palavra \\ que os negros inventaram \\ e não outra coisa Macomia. \\ E grito Inhamússua, Mutamba, Massangulo!!! \\ E torno a gritar Inhamússua, Mutamba, Massangulo!!! \\ E outros nomes da minha terra \\ afluem doces e altivos na memória filial \\ e na exacta pronúncia desnudo-lhes a beleza.
}


Chulamáti! Manhoca! Chinhambanine!

Morrumbala, Namaponda e Namarroi

e o vento a agitar sensualmente as folhas dos canhoeiros

eu grito Angoche, Marrupa, Michafutene e Zóbuè

e apanho as sementes do cutlho e a raíz da txumbula

e mergulho as mãos na terra fresca de Zitundo.

$\mathrm{Oh}$, as belas terras do meu áfrico País

e os belos animais astutos

ágeis e fortes dos matos do meu País

e os belos rios e os belos lagos e os belos peixes

e as belas aves dos céus do meu País

e todos os nomes que eu amo belos na língua ronga

macua, suaíli, changana,

xitsua e bitonga

dos negros de Camunguine, Zavala, Meponda, Chissibuca

Zongoene, Ribáuè e Mossuril.

- Quissimajulo! Quissimajulo! - Gritamos

nossas bocas autenticadas no hausto da terra.

- Aruángua! - Responde a voz dos ventos na cúpula das micaias.

E o luar de cabelos de marfim nas noites de Murrupula

e nas verdes campinas das terras de Sofala a nostalgia sinto

das cidades inconstruídas de Quissico

dos chindjinguiritanas no chilro tropical de Mapulanguene

das árvores de Namacurra, Muxilipo, Massinga

das inexistentes ruas largas de Pindangonga

e das casas de Chinhanguanine, Mugazine e Bala-Bala

nunca vistas nem jamais sonhadas ainda.

Oh! O côncavo seio azul-marinho da baía de Pemba

e as correntes dos rios Nhacuaze, Incomáti, Matola, Púnguè

e o potente espasmo das águas do Limpopo.

Ah! E um cacho das vinhas de espuma do Zambeze coalha ao sol 
e os bagos amadurecem fartos um por um amuletos bantos no esplendor da mais bela vindima.

E o balir pungente do chango e da impala

o meigo olhar negro do xipene

o trote nervoso do egocero assustado

a fuga desvairada do inhacoso bravo no Funhalouro

o espírito de Mahazul nos poentes da Munhuana

o voar das sécuas na Gorongoza

o rugir do leão na Zambézia

o salto do leopardo em Manjacaze

a xidana-kata nas redes dos pescadores da Inhaca

a maresia no remanso idílico de Bilene Macia

o veneno da mamba no capim das terras do régulo Santaca

a música da timbila e do xipendana

o ácido sabor da nhantsuma doce

o sumo da mampsincha madura

o amarelo quente da mavúngua

o gosto da cuácua na boca

o feitiço misterioso de Nengué-ua-Suna.

Meus nomes puros dos tempos

de livres troncos de chanfuta umbila e mucarala

livres estradas de água

livres pomos tumefactos de sémen

livres xingombelas de mulheres e crianças

e xigubos de homens completamente livres!

Grito Nhanzilo, Eráti, Macequece

e o eco das micaias responde: Amaramba, Murrupula,

e nos nomes virgens eu renovo o seu mosto em Muanacamba

e sem medo um negro queima as cinzas e as penas de corvos de agoiro 
não corvos sim manguavavas no esconjuro milenário do nosso invencível Xicuembo!

E o som da xipalapala exprime os caninos amarelos das quizumbas ainda mordendo agudas glandes intumescidas de África antes da circuncisão ébria dos tambores incandescentes da nossa maior Lua Nova.

(Craveirinha, 1980: 21- 23)

Interessa sublinhar que estes pronunciamentos - como desde a primeira citação de vozes africanas feita neste texto - nas suas várias configurações são textos que respondem às perguntas colocadas por Camões a partir de outras geografias, outros lugares políticos e sociais e outros lugares culturais, profundamente identificados com uma língua comum e um património literário inicialmente imposto, mas depois tomado como parte de si. Como não ouvir neste poema o eco camoniano da nomeação do mundo feita por Luís de Camões no canto $\mathrm{X}$ de Os Lusíadas? Assim estes são textos que só poderiam exercitar a resposta e promover o diálogo, pelo esclarecimento e pela paz como se apela neste poema da FRELIMO, "Irmão do Ocidente", escrito já em cenário de guerra:

Irmão do ocidente...

(como explicar-te que és nosso irmão?)

O mundo não acaba à porta de tua casa

nem no rio que limita o teu país

nem no mar

em cuja vastidão às vezes pensas teres descoberto

o sentido do infinito

para além da tua porta para além

do mar 
o grande combate continua

homens de olhar quente e mãos

duras como a terra

à noite abraçam os seus filhos

E partem ao nascer do sol

muitos não voltaram. Que importa!

Somos homens cansados de algemas

Para nós a liberdade

vale mais do que a vida

de ti, irmão, nós esperamos,

não a mão caridosa

que humilha e mistifica

mas a mão solidária,

cometida, consciente.

Como podes recusar,

Irmão do Ocidente?

(FRELIMO - 1973)

E para concluir perguntaria ainda: e como é que uma língua de colonização se torna instrumento de promoção do diálogo a partir do outro lado e de inscrição da sua emancipação? Como é que as literaturas africanas vão combinar, por um lado, a herança de um património cultural europeu e português, veiculado pela língua escrita, e a oralidade das histórias que descrevem as suas terras, a suas gentes, as suas vidas, crenças e sonhos? Que distorção dos campos literários destas nações terá havido pela imposição, essencialmente urbana, da língua portuguesa como língua literária em detrimento das línguas nacionais? Que omissões e esquecimentos esta hegemonia terá provocado? Como é que as literaturas africanas vão negociar com esta língua e este património literário as relações de poder desiguais e impostas, nomeadamente pelo violento processo da assimilação tão marcante no processo de educação formal 
dos africanos? A questão da língua no desenhar da luta e depois na estruturação da nação independente é um elemento essencial de união e de combate à fragmentação que compõe muitas nações africanas e, portanto, a questão da língua deixa de ser uma questão colonial e portuguesa para ser uma questão nacional, como ainda hoje é, nas suas diversas formulações nomeadamente face à hegemonia da língua portuguesa nas cidades e nos organismos políticos e educacionais - outra forma de colonização ou de colonialismo interno? - subalternizando as outras línguas nacionais. É claro que as várias dimensões políticas a que a questão da língua está associada levanta problemas de representatividade dos outros possíveis tecidos literários face à hegemonia imposta pela língua portuguesa, mas a nacionalização da língua portuguesa como instrumento angolano, moçambicano, são-tomense, guineense, cabo-verdiano foi e continua a ser um elemento essencial para a descolonização política, que só se realizará verdadeiramente pela descolonização cultural. Mas nada melhor do que as palavras de um escritor angolano para perceber o longo processo, as adaptações e os resultados sempre em constante reidentificação.

Quando chegaste mais velhos contavam estórias. Tudo estava no seu lugar. A água. O som. A luz. Na nossa harmonia. O texto oral. E só era texto não apenas pela fala mas porque havia árvores, parrelas sobre o crepitar de braços da floresta. E era texto porque havia gesto. Texto porque havia dança. Texto porque havia ritual. Texto falado ouvido e visto. É certo que podias ter pedido para ouvir e ver as estórias que os mais velhos contavam quando chegaste! Mas não! Preferiste disparar os canhões.

A partir daí, comecei a pensar que tu não eras tu, mas outro, por me parecer difícil aceitar que da tua identidade fazia parte esse projeto de chegar e bombardear o meu texto. Mais tarde viria a constatar que detinhas mais outra arma poderosa além do canhão: a escrita. E que 
também sistematicamente no texto que fazias escrito intentavas destruir o meu texto ouvido e visto. Eu sou eu e a minha identidade nunca a havia pensado integrando a destruição do que não me pertence. Mas agora sinto vontade de me apoderar do teu canhão, desmontá-lo peça a peça, refazê-lo e disparar não contra o teu texto não na intenção de o liquidar mas para exterminar dele a parte que me agride. Afinal assim identificando-me sempre eu até posso ajudar-te à busca de uma identidade em que sejas tu quando eu te olho em vez de seres o outro. Mas para fazer isto eu tenho que transformar e transformo-me. Assim na minha oratura para além das estórias antigas na memória do tempo eu vou passar a incluir-te. Vou inventar novas estórias.

(Rui, 2008: 27)

Tal como a descolonização política não implica a rasura total do Estado, do direito, da religião e de outros sistemas desenhados pela colonização, ou seja de um património, também a cultura e a língua em que ela se exprime e toma forma literária não será rasurada, apesar dos necessários processos conjunturais de purga e de revolução. E é desta forma que tantos anos depois serão as palavras iniciais de Peregrinação, de Fernão Mendes Pinto, reescritas por José Luandino Vieira no seu mais recente livro, O Livro dos Guerrilheiros, de 2009, que servirão ao escritor angolano para refletir sobre as conquistas e as dores da luta de libertação em Angola muitos anos depois. Uma reescrita que implica um assumir de um património literário comum escrito na sua língua e cujo processo implica seguramente uma seleção, um arranjo, uma escrita em diferença que, ao mesmo tempo que pela intertextualidade gerada, reinterroga o texto inicial, o reatualiza num outro contexto e numa outra expressão linguística do português.

Quando, às vezes, ponho diante de meus olhos aos grandes errores e tribulações, aos muitos sofrimentos que por nós passaram e vejo a figura 
de tantas vidas, e não menos mortes, no livro da nossa luta, pergunto saber: vivem, nossos mortos, se vivos os vejo em meus sonhos? (Vieira, 2009: 97)

Como afirmava Chinua Achebe relativamente ao inglês como a língua em que escrevia - quando escrevo em inglês a língua inglesa é africana - quando José Luandino Vieira escreve em português ou qualquer angolano, moçambicano, são-tomense, cabo-verdiano ou guineense fala ou escreve em português a língua portuguesa é angolana, moçambicana, são-tomense, cabo-verdiana, guineense.

\section{Quarto andamento - patrimónios}

A partir de vários olhares disciplinares e interdisciplinares, os estudos pós-coloniais têm vindo a sublinhar que a interpenetração cultural resultante do processo colonial - que hoje entendemos como interculturalidade, ao pensarmos nas culturas a partir das suas interrelações, das suas interseções - não se pode pensar sem ter em conta as relações de poder inerentes à situação colonial. Dito de outra forma, devido à situação de profunda desigualdade em que a relação colonial teve lugar, o processo de interpenetração entre as várias culturas em contacto nunca foi horizontal, mas desenhado na maior verticalidade e baseado num princípio de exclusão e de uma não leitura da diferença, de que o violento processo de assimilação é talvez o exemplo mais ilustrativo. Nestas condições, como é que a partir de vários lugares de enunciação, por vezes em conflito, partilhamos um património literário a ponto de o reusarmos? Ou por que razão em certas alturas há gerações que contratualizam recusar um determinado património literário para, mais tarde, outras gerações o recuperarem? Do ponto de vista do país anteriormente colonizado, o processo de descolonização coloca-se exatamente na fratura 
entre a constituição de "uma habilitação de herdeiros", em que se elenca o património a herdar, e uma possível redação da "renúncia de herança”, em que, como classifica juridicamente a expressão, rejeitamos a herança que supostamente deveríamos herdar. $\mathrm{O}$ ajuste entre estes dois termos da herança é controverso e lento e constrói-se dia a dia numa espécie de plebiscito não assumido, muito marcado por contingências políticas de um quotidiano de transição pleno de urgências, dúvidas e indefinições. Mas neste aspeto é importante pensar com Homi Bhabha (1998) e com vários pensadores latino-americanos que, a partir do anos 30 do século passado refletiram sobre as suas vivências e negociações identitárias a partir de mescladas heranças coloniais, e assumir que não há culturas puras, e portanto não é mais possível escrever a "hora zero" da história. Na verdade, todas as culturas estão envolvidas umas nas outras e o processo colonial é decisivo nesse aspeto, para um lado e para o outro, ou seja, para a nação que conquista a independência e para a nação descolonizadora. Portanto a impossibilidade de reinvenção de uma tradição africana perdida ou de uma mística saudosamente imperial, por um lado, e a impossibilidade de rejeição da cultura do antigo colonizador e do antigo colonizado, por outro lado, promove uma "dimensão transnacional de transformação cultural ligada a processos de migração, diáspora, deslocamento, relocação" (Bhabha, 1998: 241), que torna o processo de descolonização, transição e plena soberania um sucessivo processo não mais de rejeição e ou aceitação do património atribuído ao ex-colonizador, mas num processo de tradução de intensidades diversas.

A questão do património, material e imaterial liga-se, portanto, a uma marca de poder, mas de um poder que é contratualizado pelas circunstâncias políticas de exceção que caracterizam um processo de descolonização e de geração em geração, sendo que esta escolha não é inteiramente livre, e, no caso particular da situação colonial, obedece a uma série de fatores objetivos e subjetivos ligados à pos- 
sibilidade de criação de um conceito de comunidade e de nação e a uma outra série mais habitual de condicionantes, nomeadamente aquelas que se prendem com a noção de propriedade (intrinsecamente ligada à questão de património no mundo ocidental), com as instituições, particularmente a escola e os curricula por ela veiculados, (e que em contexto colonial é duplamente interveniente), e outras situações políticas, sociais e culturais.

Assim qual é o grande desafio lançado a estas novas literaturas relativamente à noção de um património comum em língua portuguesa? Como "arquivar" em histórias da literatura, em cânones literários ou em programas escolares este património?

Recupero aqui as palavras de Ana Paula Tavares, numa entrevista que lhe fiz há alguns anos sobre a literatura angolana.

"Em Angola a nossa relação com o passado histórico-literário não é esse mar manso e arrumado das histórias da literatura europeia, com uma data de nascimento e certificado de baptismo. Há várias hipóteses de certificado de nascimento, e a discussão inicia-se: será mil oitocentos e quarenta e tal, quando Maia Ferreira publicou Espontaneidades da Minha Alma - às Senhoras Africanas? Ou será antes 1680, com Cadornega, que escreveu a História Geral das Guerras Angolanas? E o que muitos angolanos, ainda hoje, dizem seria: "Não, não: Cadornega tem um olhar de fora, para dentro". Cadornega chegou a Angola com 17 anos, e nessa altura, ninguém olha de fora para dentro - aprende a olhar no lugar onde se insere, e sobretudo aprende a olhar pelos olhos dos angolanos, a quem ele chamava os seus pretos informantes." (...)

"Após a independência, em 1975" - dizia-me ainda Ana Paula Tavares - "houve a necessidade de arranjar uma mitologia de referência e praticou-se o exercício clássico, que já todos os teóricos exploraram, de matar o pai e a mãe, excluir uns, incluir outros na literatura, na história, na nação. Foi assim que recuperámos para a história da literatura angolana, Castro Soromenho, que tinha nascido em Moçambique, vivido 
em Angola como administrador colonial, e depois expulso de todos os territórios então ultramarinos, acabou por morrer no Brasil. E foi assim que também rapidamente excluímos Mário António - um poeta notável em alguns dos seus poemas - mas que pagou caro a diáspora que escolheu. E até hoje, ainda não foi recuperada toda a sua contribuição para a literatura angolana, nem a sua enorme contribuição para a história de Angola. Escrevendo e publicando documentozinhos, um atrás do outro, ele foi juntando "Angolana", que constitui, à falta de melhor, uma grande parte da nossa história escrita."

(Ribeiro, 2007: 147)

Posteriormente, ouvindo de novo Ana Paula Tavares e José Luandino Vieira no curso sobre literatura angolana que decorreu em 2007 no Centro de Estudos Sociais da Universidade de Coimbra, o escritor lançava na sua intervenção, um pronunciamento sereno, mas potencialmente revolucionário sobre a escrita da história da literatura do seu país ${ }^{6}$. Após falar do que designou como "buracos negros" da literatura angolana, trazendo a lume o que classificou como o primeiro texto escrito em Angola registado sobre uma pedra, onde se anunciava a chegada das "naus do esclarecido rei D. João II", as cartas do Rei Afonso do Congo, a História Geral das Guerras Angolanas, de António Oliveira Cadornega, as cartas de D. Francisco Sottomayor, governador de Massangano, ao Conselho Ultramarino e dos seus poemas referidos no espólio pelo padre que lhe deu a extrema-unção, Luandino Vieira perguntava: "Não é isto testemunho, de trezentos e tal anos da nossa História? Quer queiramos quer não, é a nossa História!” E continuava identificando outros "buracos negros" na historiografia da literatura angolana mais

${ }^{6}$ Colóquio-curso de Literatura Angolana, Centro de Estudos Sociais, Universidade de Coimbra, 22 e 23 de junho de 2007, partes transcritas no ensaio de José Luandino Vieira, 2008. 
recente: "Quem é que fala dos escritores ditos coloniais? Alguém leu um romance chamado Sangue Kuanhama, de um senhor natural de Angola chamado António Pires?" E ainda na historiografia mais recente relativamente às Brigadas da Literatura questionava: "Fala-se das Brigadas Jovens da Literatura de Luanda ou de Benguela, mas também houve as Brigadas Jovens da Literatura de N'dalatando, ou em Mbanza Koongo". (Vieira, in Padilha e Ribeiro, 2008:33)7.

Finalmente citando um belo trecho de Cadornega sobre as batalhas nas terras dos Muxicongos em que Angolanos lutavam em defesa do seu reino, Luandino lançava mais um desafio à historiografia literária angolana ao citar, de seguida, um discurso de 1982, proferido pelo General António dos Santos França, sobre a importante batalha contemporânea de Quifangondo.

Esta subtil aproximação de dois textos cronologicamente distantes - trezentos e dez anos separam estes textos - e de géneros diferentes - uma crónica de batalha e um discurso político circunstancial - revela porém um mesmo lugar de enunciação interior: Angola, e a luta de um povo identificado com um território. O problema que este gesto de Luandino Vieira levanta liga-se a algumas questões fundamentais para a definição de um património literário e a sua seleção na elaboração das histórias da literatura e, consequentemente, do cânone que elas constroem: a questão do princípio de inclusão e exclusão que está na base da conceção das histórias da literatura, das antologias ou das coletâneas de textos; a permeabilidade do género literário ao poder incluir como textos fundadores de uma literatura, textos historiográficos, mas que em si, como disse Luandino, são momentos únicos de literatura, e basta pensarmos, na literatura brasileira com a Carta de Caminha, para ver que assim é; a questão da temporalidade cultural e literária ligada à identidade política e cultural de um país; e finalmente, a questão de determinar

\footnotetext{
7 Parte desta discusão está convertida em texto no livro indicado.
} 
a partir de que espaço social e geo-cultural a literatura em análise fala, ou seja, qual é o seu lugar de enunciação. No fundo, Luandino Vieira mais do que chamar a atenção para o questionamento do cânone do género literário, estava de facto a chamar a atenção para o paradoxo dos nacionalismos literários, que se caracterizam por incluir e excluir autores e obras, misturando razões políticas e económicas com razões de ordem histórica, literária e estética, sob pena de assim estarem a eliminar algo que, do ponto de vista histórico-cultural, é constitutivo da sua identidade. Leyla Perrone-Moisés (1997), falando a partir dos nacionalismos literários latino-americanos, reconhece que este paradoxo matricial, que se caracteriza pela inclusão e exclusão de certos constituintes identitários, é típico de uma situação pós-colonial, entendo aqui com Elikia M' Bokolo (2006), na esteira de Balandier, o pós-colonialismo com uma "situação" e portanto uma fase, da qual eventualmente se poderá sair8. Assim, o momento pós-colonial latino-americano situar-se-ia no século XIX, como aliás defendem vários teóricos reagindo à homogeneização do conceito e da situação, promovida pelas escolas norte-americanas relativamente ao Sul Global como um mundo pós-colonial. Basta pensar nas situações político-culturais da América Latina e a multiplicidade de situações em África, para perceber que assim não é. Mas voltando à questão lançada por Luandino Vieira, trata-se portanto de conceber a literatura angolana como uma literatura com quatrocentos anos, cujo certificado de nascimento, para voltar às palavras de Ana Paula Tavares seria, a História Geral das Guerras Angolanas, de Cadornega, ou até, como sugere Luandino Vieira, o texto anónimo inscrito junto com as cruzes em Ielala, anunciando

8 Elikia M' Bokolo, (2006). Georges Balandier fala em 1951 de "situation coloniale", como uma situação razoavelmente estável que se poderia reproduzir durante algum tempo de uma forma idêntica; M'Bokolo fala de "situação pós-colonial", na esteira de Balandier, acrescentando-lhe a noção de temporalidade, de dinâmica, de fratura, de corte, e portanto de possível saída, como aliás, da situação colonial. 
a chegada das naus do rei D. João II, ou ainda as conhecidas cartas do Rei Afonso do Congo, também anteriores a Cadornega, considerando-se assim fundador, e portanto constitutivo da historiografia literária angolana, o período de encontro com os europeus, a ocupação litoral, o tráfico esclavagista e a colonização europeia moderna; ou, de outro modo, e como até aqui se tem procurado fazer, considerar a literatura angolana como uma literatura com mais ou menos um século, o tempo em que se começa a esboçar uma identidade literária, de matriz europeia e africana, conectável com um desejo de autonomia proto-nacionalista e depois nacionalista, retrospetivamente percecionado.

Daí que, e para voltar às palavras de Ana Paula Tavares, a geração de críticos angolanos ou moçambicanos pós-independência e de outros estudiosos destas literaturas se tenha dedicado não apenas a narrar a história destas literaturas, à maneira das histórias da literatura europeias tradicionais, ou seja, cronologicamente por períodos ou fases, mas sobretudo a identificar o objeto literário das novas nações. Artigos como "Literatura moçambicana o que é?", de Fátima Mendonça, Império, Mito e Miopia. Moçambique como invenção literária, de Francisco Noa, as crónicas de Luís Carlos Patraquim, em Moçambique ao longo da década de 80, a atividade da União dos Escritores Angolanos, sob a direção de José Luandino Vieira até aos anos 90 do século passado, os ensaios seminais de Mário António, Gerald Moser, Manuel Ferreira, Russell Hamilton, Michel Laban, Laura Padilha, Pires Laranjeira, Luis Kandjimbo, Inocência Mata entre outros, ou as mais recentes tentativas de sínteses de Patrick Chabal, Hilary Owen ${ }^{9}$ e outros estudiosos, refletem arduamente, e de forma diversa, sobre o possível cânone destas literaturas e para ele contribuem, ao identificarem aquilo que Antonio Candido, refe-

\footnotetext{
9 No caso do trabalho de Hilary Owen refiro-me apenas ao estabelecimento de um cânone de literatura escrita por mulheres em Moçambique, veja-se em Owen (2007).
} 
rindo-se à literatura brasileira, designou como o "sistema literário". Mas a pedra de toque desta narrativa histórico-literária reside ainda na questão que Luandino subtilmente levanta, e que Ana Paula Tavares tão bem enuncia: qual é o certificado de nascimento, quando e como se começa a narrar a história literária de Angola, quem são os seus atores?

Assim aquando deste apelo dos estudos pós-coloniais se os latino-americanos tinham avançando para o que vieram a designar por "La Razon Postcolonial", nas palavras de Walter Mignolo (2005), a África de língua oficial portuguesa encontrava-se na fase que Elikia M' Bokolo (2006) designou como "situação pós-colonial", uma fase de inscrição no seu imaginário literário da diferença cultural que justificara e reclamara a independência política, formalmente obtida, mas não culturalmente sentida. E é este facto que leva a que nesta "situação pós-colonial" só sejam reconhecidos como textos canónicos da literatura angolana, por exemplo, textos que em si inscrevem essa diferença cultural imediatamente conectada com a emancipação política, e sejam rejeitados textos que liguem o território angolano à antiga potência colonizadora, gerando assim aquilo a que Luandino Vieira chamou de alguns dos "buracos negros" da história da literatura angolana, que desta forma rasura partes constitutivas da sua identidade.

Será que, por sua vez, a "razão pós-colonial" latino-americana contempla esta série de questões? Podemos dizer generosamente que está atenta a elas, mas não faz delas o seu centro de preocupações. A "razão pós-colonial" latino-americana por oposição à razão moderna, revela o pensamento daqueles que vivem sobre fortes heranças coloniais, mas, na verdade, não se opõe à razão moderna, apenas reclama a sua inclusão na modernidade que define a Europa como centro das periferias que lhe conferem esse estatuto, ou seja, pretende a inclusão das periferias como parte da definição, como defende Enrique Dussell (2001). Um outro ponto 
importante da "razão pós-colonial" é o da deslocação não só do lugar da enunciação, mas também do sujeito da enunciação do conhecimento do primeiro mundo para o terceiro mundo, para finalmente concluírem que a "razão pós-colonial" surge de uma aliança entre a produção cultural do terceiro mundo e a imaginação teórica do primeiro. Ora esta ideia de que, por um lado, não há modernidade sem colonialidade e, por outro lado, da deslocação do sujeito de enunciação, mas nem sempre do local de enunciação, leva estes pensadores a refletirem sobre a geopolítica do conhecimento, nos termos que António Quijano, filósofo mexicano, define como a "colonialidade do saber" e a "colonialidade do poder", ou seja do domínio do conhecimento do norte sobre o sul, reflexão que é hoje um dos objetos centrais do pensamento pós-colonial de inspiração latino-americana (Quijano, 2000). Ora todas estas questões trazem fundamentalmente outros aspetos da descolonização. Trata-se de uma descolonização do saber e do poder e de uma descolonização das representações dos sujeitos, ou seja, uma descolonização da representação do ex-descolonizado e da representação do ex-descolonizador, como, noutro contexto, prefiguram Hesse e Sayyid (2006: 19-20). Consequentemente, estamos a falar de outro tipo de pós-colonialismo. Por isso, como bem adverte Roberto Morales (2007), precisamos de refletir sobre se somos todos pós-coloniais e em que sentido ou sentidos diferentes o somos pois isso tem os seus profundos reflexos nas narrativas que produzimos, sejam elas histórias literárias ou de qualquer outra matéria.

Neste princípio de século em que o tempo europeu não é mais sinónimo de tempo universal, em que as teorias pós-coloniais e as práticas literárias de Garcia Marquez, Vargas Llosa, Guimarães Rosa, Assia Djebar, Salman Rusdhie, V. S. Naipaul, Chinua Achebe, Simbene Ousmane, José Luandino Vieira, Manuel Rui, Mia Couto, Ana Paula Tavares, Conceição Lima e tantos outros têm transformado, não só a nossa visão dos processos coloniais, como estão 
também desafiando o conceito ocidental de conhecimento, ao estabelecer ligações epistemológicas entre o lugar geocultural e a produção teórica, ao contar o outro lado da história europeia, ao apresentar afinal toda a história da modernidade europeia como uma história local que se desenvolveu à escala planetária. Como poderemos nós, europeus, continuar a não ouvir o barulho do mundo e a construir mansamente as nossas histórias da literatura quando, afinal, grande parte da nossa história se passou fora da Europa, como nos dizem todos os desafios teóricos, narrativos e epistemológicos do Sul global?

O desafio lançado por José Luandino Vieira à historiografia literária angolana, e ao seu possível cânone, não se limita, portanto, à historiografia literária angolana. Ele funciona também como uma espécie de "the empire writes back to the centre", na célebre expressão de Salman Rusdhie tão cara aos teóricos do pós-colonialismo. Genuinamente interessado em perseguir as criações desse lugar que se enuncia como Angola, onde há muito se começam a tecer outras vozes em língua portuguesa escrita, Luandino Vieira subtilmente e, ao mesmo tempo, pisca o olho e parodia o 'olhar sphyngico e fatal' de Fernando Pessoa, pelo que também ele deixa de fora, questionando-nos a nós portugueses: como poderemos continuar a contemplar quase num capítulo à parte, como um apêndice incómodo e não constitutivo da nossa identidade, a literatura designada de colonial, que afinal nos conta grande parte da história de Portugal passada noutras paragens? Onde também nós portugueses colocaremos Cadornega, os poemas de D. Francisco Sottomayor ou os escritores ditos coloniais?

Como dizia Angel Rama referindo-se às histórias da literatura latino-americanas de inspiração europeia, "a organicidade rápida e mecânica das histórias da literatura europeia" - que geram a tal imagem de mar manso evocada por Ana Paula Tavares - "impediram-nos de avançar logo para uma interpretação local, própria e original dos sistemas literários designados como nacionais" (Rama, 1974: 38), mas 
foi esse o caminho traçado pelas gerações seguintes. No entanto, pós-colonialmente falando, ele enriquecer-se-á e produzirá novos sentidos quando em diálogo com um imaginário mais abrangente em que a língua e a tal história comum de memórias diferentes nos devolvam as imagens múltiplas de rostos pretensamente singulares. Cartografar o retrato destes rostos fundadores da nossa pós-colonialidade não pode prescindir da abertura de outros arquivos literários, históricos e culturais e de outras leituras geograficamente deslocadas onde, para voltar a Camões, se vivem outros "costumes", onde se guardam outras "leis" e de onde se regista o poder de outros "reis" e de outros "conhecimentos", que nos compõem a todos, como nos mostra a dimensão transnacional destes patrimónios literários escritos e reescritos em língua portuguesa num sistema de fluxos e refluxos que nos identificam e interrogam a todos.

\section{Referências bibliográficas:}

AlBUQUERQUe, Luís de et al. (1991), O Confronto do Olhar: o encontro dos povos na época das navegações portuguesas, séculos XV e XVI: Portugal, África, Ásia, América. Lisboa: Caminho.

CÂNDIDO, Antonio (1995), Textos e Comentários. São Paulo: FCE.

BARRos, João de (1978), "Declarar, Mover, Deleitar e Exortar”, in Maria Leonor Carvalhão Buescu (org.), Gramáticos Portugueses do Século XVI. Lisboa: Instituto de Cultura Portuguesa/Secretaria de Estado da Cultura/ Ministério da Educação e Cultura, 87-91.

BНАВНА, Homi K. (1994), The Location of Culture. Routledge: London and New York. Tradução para português (1998), O Local da Cultura, Belo Horizonte: Ed. UFMG.

BUESCU, Maria Leonor Carvalhão (1978), Gramáticos Portugueses do Século XVI. Lisboa: Instituto de Cultura Portuguesa/Secretaria de Estado da Cultura/Ministério da Educação e Cultura. 
CAMÕES, Luís de (1992), Os Lusíadas (1572). Lisboa: Instituto Camões. (Leitura, prefácio e notas de Álvaro Júlio da Costa Pimpão; apresentação de Aníbal Pinto de Castro).

CraVEIRINHA, José (1980), Xibugo. Lisboa: Edições 70.

CAminha, Pêro Vaz (2000), "Carta de Pêro Vaz de Caminha para Dom Manuel”, in José Manuel Garcia (org.), O Descobrimento do Brasil nos textos de 1500 a 1571. Lisboa: Fundação Calouste Gulbenkian, 15-34.

DUSSEL, Enrique (2001), "Eurocentrismo y modernidad", in Walter Mignolo (ed.), Capitalismo y geopolitica del conocimiento. Buenos Aires: Ediciones del Signo.

GÂndAvo, Pero de Magalhães de (2004), A Primeira História do Brasil. História da província Santa Cruz a que vulgarmente chamamos Brasil. Lisboa: Assírio e Alvim, 41-45.

GILROY, Paul (1993), The Black Atlantic: Modernity and Double Consciousness. Londres: Verso.

GIL, Fernando e MACEDO, Helder (1998), Viagens do Olhar-Retrospecção, Visão e Profecia no Renascimento Português. Porto: Campo das Letras. HESSE, Barnor; SAYYID, Salmon (2006), "Narrating the Postcolonial Political and the Immigrant Imaginary", in N. Ali; V.S. Kalra; S. Sayyid (eds.), $A$ Postcolonial People: South Asians in Britain. Londres: Hurst \& Company, 13-31.

LOURENÇO, Eduardo (1994), Nós e a Europa ou as Duas Razões. Lisboa: INCM. LOUREnÇO, Eduardo (2005), A Morte de Colombo: A Metamorfose e Fim do Ocidente como Mito. Lisboa: Gravida, 9-17.

MACEDO, Helder (1992), "Reconhecer o desconhecido", in C. Berardinelli; G. Santos; T. Cerdeira (orgs.), XIII Encontro de Professores Universitários Brasileiros de Literatura Portuguesa. Rio de Janeiro: Universidade Federal do Rio de Janeiro, 100-103.

MACEDO, Helder (2013), "Camões sob o signo da incerteza”, conferência de encerramento do colóquio "Camões - crise e superação", no âmbito de Guimarães, Capital da Cultura 2013. Manuscrito gentilmente cedido à autora deste texto. Brevemente em publicação em "Camões - crise 
e superação". Coimbra: Centro de Estudos Camonianos, Faculdade de Letras, Universidade de Coimbra.

M'BOKOLO, Elikia (2006), "Culturas Políticas, Cidadania e Movimentos Sociais na África Pós-colonial", aula inaugural do Programa "Pós-Colonialismos e Cidadania Global”, Centro de Estudos Sociais/Faculdade de Economia, Universidade de Coimbra, 3 de fevereiro de 2006, in Cabo dos Trabalhos - Revista electrónica dos Programas de Mestrado e Doutoramento do Centro de Estudos Sociais, Universidade de Coimbra, n. 2 (http:// cabodostrabalhos.ces.uc.pt/) http://www.igadi.org/te/pdf/te_se13/ te25_13_131mario_roberto_morales.pdf Acedido a 15 de agosto de 2014 . MignolO, Walter (2005), "La Razón Postcolonial: Herencias Coloniales y Teorías Postcoloniales", Adversus, Ano II, n. 4, Diciembre.

Montaigne, Michel de (1969), Essais. Paris: Garnier-Flammarion.

MORALES, Roberto (2006), “Modernidade periférica e mestizaxe diferencial en America Latina", Tempo Exterior, n. ${ }^{\circ}$ 13, julho/dezembro, 131-154. NARO, Nancy Priscilla; SANSI-ROCA, Roger; TREECE, David (eds.) (2007), Cultures of the Lusophone Black Atlantic. Nova Iorque: Palgrave Macmillan. NGOZI, Chimamanda Adichie (2009), "The danger of the only story" http:// www.ted.com/talks/chimamanda_adichie_the_danger_of_a_single_story. html Acedido a 15 de agosto de 2014.

OliveirA, Fernão de (1978), "Melhor é que ensinemos a Guiné" in Maria Leonor Carvalhão Buescu (org.), Gramáticos Portugueses do Século XVI. Lisboa: Instituto de Cultura Portuguesa/Secretaria de Estado da Cultura/ Ministério da Educação e Cultura, 94-95.

OWEN, Hilary (2007), Mother Africa, Father Marx. Women's Writing of Mozambique, 1948-2002. Bucknell University Press/Associated University Presses.

PERRONE-MOISÉS, Leyla (1997), "Paradoxos do nacionalismo literário na América Latina”, Estudos Avançados, vol. 11, n. ${ }^{\circ}$ 30, maio/agosto.

PADILHA, Laura (2006a), "O espaço colonial e sua paginação em branco na cartografia ficcional de Eça de Queiroz", in Manuela Ribeiro Sanches 
(org.), Portugal não é um país pequeno - Contar o império na póscolonialidade. Lisboa: Cotovia, 29-42.

PADILHA, Laura (2006b), "Protocolos de apresentação". Metamorfoses. (Revista da Cátedra Jorge de Sena/UFRJ), v. 7, 147-158.

PESSOA, Fernando (1978), Sobre Portugal - introdução ao problema nacional (org. Joel Serrão). Lisboa: Ática.

PINTO, Fernão Mendes (sd), Peregrinação. Lisboa: Sá da Costa.

QUIJANO, Aníbal (2000), "Colonialidad del poder, eurocentrismo y América Latina”, in Edgardo Lander (ed.), La colonialidade del saber: eurocentrismo y ciencias sociales. Perspectivas latinoamericanas. Buenos Aires: CLACSO Y UNESCO.

RAMA, Angel (1974), “Um Processo Autonômico das Literaturas Nacionais”, Revista Argumento, janeiro, 37-49 (disponível em Banco de Dados Literários, org. César Giusti. Catalogação: BDL:CUL-4-008).

RAMALHO, Maria Irene (1993), "A poesia e o sistema mundial”, in Boaventura de Sousa Santos (org.), Portugal: Um Retrato Singular. Porto: Afrontamento/Centro de Estudos Sociais, 91-128.

RIBEIRO, Darcy (1995), O Povo Brasileiro. São Paulo: Companhia das Letras. RIBEIRO, Margarida Calafate (2004), Uma História de Regressos: Império, Guerra Colonial e Pós-Colonialismo. Porto: Afrontamento.

RIBEIRO, Margarida Calafate (2007) “A Heritage of One's Own: a conversation with Ana Paula Tavares", Ellipsis - Journal of the American Portuguese Studies Association, vol. 5, 147-152.

RIBEIRO, Margarida Calafate; SEMEDO, Odete Costa (2011), Literaturas da Guiné-Bissau - cantando os escritos da história. Porto: Afrontamento. RUI, Manuel (2008), "Eu e o Outro - o invasor ou em poucas três linhas uma maneira de pensar o texto", in Laura Cavalcante Padilha e Margarida Calafate Ribeiro, Lendo Angola. Porto: Afrontamento, 27-29.

RUI, Manuel (2011), Língua de viagem num parágrafo. Apresentado na reunião da UCCLA. Cedido à autora por gentileza do autor.

SAID, Edward (1978), Orientalism. Nova Iorque: Pantheon Books. 
SANTO, Alda Espírito (1949), "Luares de África", in Mensagem, Ano I, janeiro, 7, 1-3. (Reeditado in Mensagem - Boletim da Casa dos Estudantes do Império, coleção para a História das Literaturas Africanas de Expressão Portuguesa, direção de Manuel Ferreira, nota prévia de Orlanda Amarílis e introdução de Pires Laranjeira, ALAC, vol. I, 1996).

SOUSA, Noémia de (1988), Sangue Negro. S1: Associação de Escritores Moçambicanos, 49-50 e 109.

SPIVAK, Gayatri C. (1988), "Can the Subaltern Speak?”, in Cary Nelson e Lawrence Grossberg (eds.), Marxism and the Interpretation of Culture. Urbana: University of Illinois Press.

TAVARES, Paula (1999), O Lago da Lua. Lisboa: Caminho.

THOMAZ, Luís Filipe (1990), "L' idée impériale manuéline", in La Découverte, Le Portugal et L'Europe - Actes du Colloque. Paris: Fondation Calouste Gulbenkian, 35-103.

VECCHI, Roberto (2011), Excepção Atlântica: pensar a literatura da Guerra Colonial. Porto: Afrontamento.

Velho, Álvaro (1960), Roteiro da Primeira Viagem de Vasco da Gama (1497-99). Lisboa: Agência Geral do Ultramar (Prefácio, notas e anexos de A. Fontoura da Costa).

VIEIRA, José Luandino (2008), "Literatura Angolana: estoriando a partir do que não se vê", in Laura Padilha e Margarida Calafate Ribeiro (orgs.), Lendo Angola. Porto: Afrontamento, 31-37.

VIEIRA, José Luandino (2009), O Livro dos Guerrilheiros. Lisboa: Caminho. 
(Página deixada propositadamente em branco) 
LIT E RAT URA, NAR RATIVAS, D I S C URS OS : O PODER DO DISCURSO EA ARTE DA NARRAÇÃO

\section{Introdução}

Assumindo que as literaturas africanas modernas, isto é, enquanto fenómeno de escrita, têm uma existência relativamente curta, cerca de um século, portanto, dificilmente elas poderão ser dissociadas de perspetivas de representações onde prevalecem questões de poder. Basta, para isso, termos em conta que estas literaturas nasceram na vigência da presença colonial, em África, exatamente no momento em que essa mesma presença adquiria contornos mais pronunciados e mais estruturados, depois da Conferência de Berlim, em 1884-1885.

Se é verdade que por essa altura, finais do século XIX, princípios do século XX, surgiu uma literatura deliberadamente celebratória da ação colonial portuguesa, começa a emergir, em paralelo, uma outra escrita esgrimida pelos nativos mas que traduzia, nem sempre de modo muito evidente, consistente e coerente, a ansiedade pela afirmação estética de um território cultural, que se contrapunha ao que era representado pelo imaginário colonial. Ou, pelo menos, à perspetiva nele dominante.

Mais do que pretendermos explorar a confrontação lógica que esses dois universos literários significam, ou, noutra hipótese, rastrear as figurações de poder neles presentes, interessa-nos, nesta 
reflexão, analisar os discursos, sobretudo os da narrativa, enquanto eles próprios emanações de poder.

Se é verdade, e à luz de uma paradigmática perceção foucaultiana, que o poder do discurso decorre das próprias palavras, importa identificar tais marcas na narrativa moderna moçambicana e perceber em que medida elas se inscrevem numa perspetiva mais ampla da literatura africana.

Em suma, esta é uma tentativa de mapeamento, ainda preliminar, de um património que encontra na arte de narrar, enquanto modo de fabricar mundos, o seu fundamento estruturante e de afirmação.

\section{O discurso como poder}

No prefácio a uma das suas obras mais emblemáticas, As Palavras e as Coisas, Michel Foucault (1998: 49-50) afirma a dado passo:

As heteropias inquietam, sem dúvida, porque minam secretamente a linguagem, porque impedem de nomear isto e aquilo, porque quebram os nomes comuns ou os emaranham, porque de antemão arruínam a "sintaxe", e não apenas a que constrói as frases mas também a que, embora menos manifesta, faz «manter em conjunto» (ao lado e em frente umas das outras) as palavras e as coisas. É por isso que as utopias permitem as fábulas e os discursos: elas situam-se na própria linha da linguagem, na dimensão fundamental da fábula: as heteropias [...] dissecam o assunto, detêm as palavras sobre si mesmas, contestam, desde a sua raíz, toda a possibilidade de gramática: desfazem os mitos e tornam estéril o lirismo das frases.

Seguindo a linha de pensamento aqui proposta, encontramos expressa a ideia de que toda a ordem, ou aquilo que pressupomos ser a ordem e a regra, significa, em última instância, um valor 
social dominante, isto é, uma forma de poder. Um poder, por isso, ordenador, que se impõe e que, inevitavelmente, subjuga. E o que discursivamente nega essa ordem, numa voluntária ou involuntária desconstrução do que prevalece, é como se se instituísse como um contrapoder, que inscreve outras lógicas que são, afinal, a sua razão de ser.

Por outro lado, é como se nada acontecesse para além das palavras que nos surgem como expressão de atos de consciência. As coisas e os seres existem, os factos sucedem-se, os contornos e os movimentos do mundo adquirem nitidez, a vida ganha sentido porque há um discurso que os nomeia, que os anuncia e que os enuncia e, mais do que isso, que os legitima ao dar-lhes inteligibilidade.

Mas o poder maior do discurso decorre do facto de ele ser a condição de conhecimento que, por sua vez, resulta sobretudo de uma capacidade do sujeito de interpretar e representar os fenómenos. Facto que se sublinha, ao mesmo tempo, a sua singularidade e a sua centralidade, não deixa, mesmo assim, de revelar a sua precariedade. A linguagem feita discurso institui-se, assim, como uma plataforma que, por um lado, projeta a potência e, por outro, e de modo quase paradoxal, os limites da condição humana.

Em A Ordem do Discurso, Foucault (1999: 9) considera que é nas regiões da sexualidade e da política onde, através das interdições, são exercidos alguns dos poderes mais temíveis ou, se quisermos, "as grades da interdição são mais cerradas".

$\mathrm{E}$, diríamos nós, sem necessariamente nos contrapormos a este incontornável pensador do nosso tempo, que é no espaço da cultura, em particular da literatura, enquanto devir recriado, espaço de ilimitadas possibilidades, onde superiomente são afrontadas e rompidas essas mesmas grades.

Enquanto exercício da imaginação e de liberdade interior, enquanto lugar de representação e de reinvenção do mundo, a literatura, na esteira dos protocolos que lhe são intrínsecos, é ver- 
dadeiramente um dos poderes mais temíveis por, exatamente, fazer estremecer qualquer grade, por mais cerrada que ela seja.

As literaturas foram surgindo nas antigas colónias, num contexto onde as manifestações de poder, fossem elas de carácter jurídico-administrativo, político, socioeconómico, ideológico ou discursivo, se faziam sentir de forma profunda, aviltante e dolorosa no quotidiano das pessoas. Por outro lado, as marcas reativas a essa dominação tanto se caracterizavam pela insurgência e pela denúncia, implícita ou explícita, como por uma exuberante necessidade de afirmação identitária. Não surpreende pois que, se durante a vigência da dominação colonial vários foram os poetas e escritores perseguidos e encarcerados, mas não silenciados, no pós-independência, não deixam, mesmo assim, de ser indisfarçáveis zonas de desconforto e de ambiguidades entre os que escrevem e os poderes do dia.

Quer no processo de apropriação das linguagens, dos valores e das lógicas da força dominante, quer nas estratégias de representação e de nomeação, o discurso dos insurgentes era, por conseguinte, ele também uma inequívoca expressão de poder. A este propósito, Ashcroft et al. (1989: 8) entendem que a linguagem das periferias, onde a rebelião se desenhava, era formada por um discurso opressivo de poder. Isto é, essas mesmas periferias que, em algum momento, instituíram a sua própria centralidade, têm sido, segundo eles, fonte de algumas das literaturas mais instigantes e mais inovadoras do nosso tempo. Resultado, portanto, das energias reveladas pelo jogo permanente de tensões e de harmonizações entre uma língua-norma, no nosso caso, o português continental, e as variedades dos usos locais. Estes usos, por sua vez, profundamente determinados tanto por necessidades comunicacionais específicas, como por condicionalismos de vária ordem. Este pode ser, afinal, um facto revelador de que a apropriação da língua do colonizador e de alguns dos seus valores participou da base patrimonial que caracteriza o universo 
das literaturas e das sociedades africanas que se foram projetando como repositório, afinal, de múltiplas e diversificadas influências.

Se a poesia, pela sua vocação para focar-se na materialidade das palavras, isto é, para a autorreflexão discursiva, terá, neste particular, levado ao limite essas interações, a narrativa, enquanto representação tendencialmente multidimensional, acabou por incorporar a pluralidade e diversidade do mundo de onde ela emergia.

\section{O poder da narrativa}

No romance Anthills of the Savannah (1987: 153), de Chinua Achebe, uma das personagens, Ikem, falando para um grupo de estudantes conclui, a dado passo:

Storytellers are a threat. They threaten all champions of control, they frighten usurpers of the right-to-freedom of the human spirit - in state, in church or mosque, in party congress, in the university or wherever / Os contadores de histórias são uma ameaça. Eles ameaçam todos os campeões do controlo, eles intimidam os usurpadores do direito à liberdade do espírito humano - no estado, na igreja, nas mesquitas, no partido, na universidade ou onde quer que seja.

Seriam inúmeros os exemplos para fundamentar esta afirmação, mas ela, por si só, pela carga significativa e expressiva que transporta, é bastante para ilustrar, ou, pelo menos, sugerir o poder da narrativa. Porém, uma questão que, de imediato, nos assalta é como é que esse poder se realiza efetivamente, sobretudo quando sabemos que essas narrativas são dominantemente ficções, portanto, produto da imaginação. Eventualmente socorrendo-nos da assertiva aristotélica de a literatura ser mais filosófica do que a história. Isto é, o possível é sempre mais amplo, mais desafiador e mais perturbador 
que o real, o que existe. Talvez a essência desse poder se encontre precisamente aí, como assevera uma perceção pascaliana, de que a razão, por mais que grite, não pode negar que a imaginação estabeleceu no homem uma segunda natureza.

É essa espécie de segunda natureza que, poderosa e desafiadoramente, se encontra instalada na narrativa como discurso e não necessariamente enquanto história em si. Facto que nos obriga, metodologicamente, a considerar três dimensões estruturantes: primeiro, a do enunciado, que estabelece a relação com os acontecimentos, isto é, se quisermos, o enredo; segundo, a da história, o conjunto de acontecimentos potencialmente no seu estado original, e que constituem o objeto ou o efeito desse discurso e, finalmente, a enunciação, ou seja o ato de narrar em si.

É, pois, esta última dimensão que irá prender a nossa atenção para procurarmos perceber a forma como a narrativa moçambicana, seja conto, novela ou romance, se realiza como discurso de poder. Para isso, teremos como instrumentos tanto o modo como a voz, que se destacam na narração. Quando falamos do modo, seguimos a sugestão de Genette (1995: 184) de querer saber quem vê? e quanto à voz, de querer saber quem fala?

A narrativa é, no essencial, a arte de contar uma história e grande parte da sedução de um conto ou de um romance reside fundamentalmente na forma como essa arte é exercida. Aliás, nos universos africanos onde a força da oralidade ainda prevalece, mesmo que de forma residual ou transfigurada, não é qualquer um que pode contar histórias à comunidade, mas aquele que é iniciado, que é detentor de talento, que domina superiormente as técnicas da narração e que pode, assim, prender o auditório. Aliás, é diante das pausas calculada e habilmente interpostas pelo contador da história, que a irreprimível pergunta presa de uma ânsia infantil, irrompe amiúde de quem o escuta: e depois? Afinal, é também deste património oral que se funda e se alimenta parte substancial da literatura africana. 
Em sintonia com esta milenar tradição de contar que tem, infelizmente, perdido e, de forma acelerada, a sua fascinante validade, parece estar Jorge Luis Borges (1987), que defende que os autores devem intervir o menos possível na elaboração da sua obra. Devem, segundo ele, procurar ser amanuenses do Espírito ou da Musa e não das opiniões deles próprios, que são o que de mais superficial neles existe.

Mais do que a fábula, a narrativa em si é o domínio das técnicas de contar que assegura a comunicação e a apreensão da mensagem. Isto é, o modo como uma história é contada é um requisito essencial para a sua transmissão, receção, memorização e divulgação. Na arte de contar se subsumem elementos de natureza estética, lúdica, pedagógica e ética, daí a enorme responsabilidade e prestígio de que se reveste a função de contador de histórias.

E, ao colocarmos a ênfase na narração, queremos sobretudo evidenciar os pontos de vista ou perspetivas dominantes em associação com uma voz determinada. Por outro lado, trata-se de explorar a forma como a visão e a voz configuram histórias e temáticas e, concomitantemente, engendram o poder na narrativa moçambicana e na narrativa africana, em geral.

Numa intervenção, em setembro de 2010, dois anos antes da sua morte prematura e trágica, Emmanuel Reed Manirakiza (c.1993-2012), um jovem refugiado ruandês, num discurso proferido na African Leadership Academy, na África do Sul, deixa-nos um testemunho penetrante e eloquente, a partir da sua curta, mas significativa experiência de vida, sobre o poder da narrativa:

Inside stories lies transformational power,/ Dentro das histórias encontra-se um poder transformacional

Power that moves the invisible us,/ poder que move invisiveis nós Power that stirs our emotions,/ poder que mexe com as nossas emoções 
To experience the experiences of others;/ de modo a experimentar as experiências de outros

Stories allow us to imagine and live momentarily the lives of others./ As histórias permitem-nos imaginar e viver momentaneamente as vidas dos outros

And thereafter set a different course and perspective for the life we seek to live./ E dai fixar um curso e uma perspectiva diferente para a vida que procuramos viver.

O reconhecimento de um poder comunicacional e transformador, neste caso intrínseco à própria narrativa, é também confirmado por uma voz autorizada e experiente como a de Chinua Achebe (2000: 38-39), que defende que há três razões para se ser escritor: primeiro, há, em cada um de nós, uma poderosa urgência em contar uma história; segundo, há pressões de uma história à espera de sair; e, finalmente, há um projeto digno de um esforço considerável que se terá de suportar para transformá-lo em fruição. Daí que, conclui ele, o homem é um animal contador de histórias e que raramente deixa passar uma oportunidade para acompanhar os seus trabalhos e suas experiências com histórias apropriadas.

É assim que, tendo como foco a narração, enquanto exercício de manifestação de poder, esboçamos um mapeamento breve e experimental da narrativa moçambicana, com a ressalva dos elementos narracionais que se evidenciam num e noutro caso. Esta opção não significa compartimentar nem as obras nem os autores aqui identificados, nem retirar a pluralidade de sentido dos textos, onde fica sempre aberta a possibilidade de encontrarmos os diferentes elementos que, num e noutro caso, concorrem para um determinado enquadramento identificativo, como o aqui proposto.

Uma das mais expressivas linhas de força da narrativa africana é a moçambicana, em particular, é a de ela afrontar os poderes instituídos, seja no contexto colonial, seja no pós-independência. 
Trata-se de uma literatura cuja especificidade decorre da sua profunda e estruturante interlocução com o meio de onde ela provém e onde as demonstrações de poder, sobretudo político, são notórias e envolventes. Portanto, temos, neste caso específico, a narração funcionando tanto como um mecanismo de denúncia quando não mesmo de confrontação.

É assim que, num romance como Portagem de Orlando Mendes, pela voz do narrador que está muito longe de uma atitude neutral, acompanhamos não só os conflitos interiores do protagonista, como também as tensões sociais e raciais resultantes da dominação colonial. Tensões que nos são também traduzidas pela voz pretensamente infantil e aparentemente cândida do narrador e que atravessa os diferentes contos que corporizam a obra Nós Matámos o Cão Tinhoso de Luís Bernardo Honwana. E é através desse olhar, quase inocente, mas sobretudo através da visão de dentro, onde a ferocidade dos desequilíbrios, das injustiças e das arbitrariedades gerados pela colonização se desenrola diante do leitor. $\mathrm{E}$ a este apenas the resta manter-se contemplativo, ou indignar-se, mesmo que impotente, ou, então, sentir-se culpado por nada poder fazer para mudar o curso dos acontecimentos. Ou, se quisermos, dos discursos, em que a marca ominosa do preconceito se torna quase insustentável. Afinal, como explica Roland Barthes (1980: 14), o "discurso de poder [é] todo o discurso que engendra a culpa e, por conseguinte, a culpabilidade daquele que o ouve". E, neste caso, o poder da narração em Nós Matámos o Cão Tinhoso acaba por ser tremendamente perverso, tal o potencial de fruição que acaba por envolver o leitor.

Curiosamente, será no pós-independência, onde a irreverência de algumas consciências literárias encontrará na arte da narração um poderoso meio de interpelar, muitas vezes de forma sarcástica, alguns desvarios do poder político. Tais são os casos, entre outros, de Ualalapi ou Orgia dos Loucos de Ungulani Ba Ka Khosa. E, em ambos os casos, trata-se de uma confrontação efetiva, tal a virulência 
da ironia, por exemplo, no conto "A revolta". Gerida com cálculo, a narração conduz-nos gradual e intencionalmente ao clímax da história, fazendo-nos perceber, através da interioridade desvelada do administrador local, as discrepâncias e fragilidades do poder que ele próprio representa. A concentração da narração na figura do administrador, sobretudo através da focalização interna, concorre fortemente não só para desmistificar alguns dos fundamentos ideológicos do sistema, mas também para colocar em questão a hiperbolizada sintonização entre governantes e governados.

Macacos, cães, filhos mal-paridos, agora vão ver quem sou eu, dizia para si, o senhor administrador, à medida que caminhava em direcção à sede, perante o silêncio céptico da população em ver o herói do distrito com as pantufas arrastando a areia solta... (p. 86).

Entretanto existe toda uma arte de narrar, cujo poder radica no seu sentido fundacional, neste caso, da nação, seja ela pedagógica, mais englobante e ordenadora, seja ela performativa, mais descontínua e refratária. Trata-se de uma vocação quase transversal à narrativa moçambicana, diríamos mesmo à narrativa africana, em geral. Por um lado, pela forte e intensa relação dialógica com a realidade envolvente e, por outro, por uma espécie de missão assumida por grande parte dos escritores. Se é verdade que autores já consagrados como Mia Couto e Aldino Muianga traduzem fortemente essa vocação, jovens escritores como Clemente Bata, com Retratos do Instante, Hélder Faife, com Contos de Fuga, ou, ainda, Lucílio Manjate, com O Contador de Palavras revitalizam e prolongam essa vocação.

O conto, colocando-se assim ao lado daquela que me parece a marca mais expressiva da literatura moçambicana, a poesia, através da narrativa curta e fragmentária, afirma a sua performatividade que assenta, segundo Bhabha, na representação da vida social, nos seus 
aspetos mais comezinhos, marginais e imprevisíveis e aparentemente esvaziados de um sentido mais profundo.

E a narração faz-se essa nação poderosa dos que até aí não tinham voz, mas faz-se sobretudo nação plural, diversa, desafiadora e palpitante dos prédios carcomidos, das ruelas obscuras, dos labirintos suburbanos, dos campos por desbravar, dos conflitos interpessoais, dos olhares perdidos num futuro vazio, dos choros das crianças que rasgam a noite, dos amores furtivos, das gargalhadas em cascata das mulheres, da morte inesperada do pai de família, do gesto solidário da vizinhança de caniço, das traições perdoadas, enfim...

O poder de não esquecer é, seguramente, outra das marcas mais reivindicadas pela narrativa moçambicana. Trata-se, afinal, de resgatar um tempo outro, um tempo épico ou desastroso, um tempo de proibições, de omissões, de múltiplas sujeições, de promessas não cumpridas, de paraísos perdidos, de alegrias suspensas. Curiosamente, os tempos que a narração como memória traz são variados: desde o tempo da ancestralidade, passando pela experiência colonial, até um tempo mais próximo, o do pós-independência. No essencial, qualquer dos tempos, apesar das referências cronológicas e topográficas, parece poder ser medido apenas pela própria ficção que o emoldura e lhe dá existência.

Aqui, nesta vertente, em particular, é como se as narrativas buscassem a sua própria inteligibilidade e o sentido da existência na relação dos seres com a temporalidade. Aldino Muianga é um dos autores onde os três tempos podem ser encontrados, isto é, o ancestral (veja-se, entre outros, A Noiva de Kebera e Contos Rústicos), o colonial (Magustana, Meledina (ou a história duma prostituta)) e o pós-independência (Nghamula, o homem do tchova (ou o eclipse de um Cidadão)). Obras como Ninguém matou Subura de Lília Momplé, O Olho de Hertzog ou Duas Sombras do Rio de João Paulo Borges Coelho são outros exemplos que, na inscrição de diferentes temporalidades, são emblemáticas da glorificação da memória 
como narração. Isto é do poder, da arte, do direito e do dever de não esquecer. Daí que, para Marc Augé (2001: 179), a "memória e o esquecimento mantêm de algum modo a mesma relação que existe entre a vida e a morte".

Passemos agora, neste nosso rápido excurso pela ficção moçambicana, a uma outra hipótese de categorização, que é a da narração da catástrofe coletiva. Em A Sensibilidade Apocalíptica, Frank Kermode considera que não existe nada de mais antiutópico que as ficções escatológicas, onde a obsessão com a ideia do fim é intensa. A dado passo, afirma ainda que "Não é que sejamos conhecedores do caos, mas estamos, sim, rodeados por ele, e equipados para coexistirmos com ele apenas através dos nossos poderes de ficção" (1997: 73). Tanto a ideia de finitude, como o poder da narração para lidar com essa mesma ideia e com o caos que nos cerca, e que muitas vezes é, afinal, uma projeção do caos que lavra dentro de nós, parece estar intensamente representada nas narrativas da catástrofe coletiva. Tendo como pano de fundo a guerra civil que fustigou o país, durante década e meia, Ventos do Apocalipse, de Paulina Chiziane e Terra Sonâmbula, de Mia Couto, são duas experiências do poder de narração sobre o caos coletivo. Significativamente, enquanto que Ventos do Apocalipse é escrito durante a vigência da referida guerra, Terra Sonâmbula é um relato a posteriori, num rastreio implacável das suas consequências a todos os níveis: físico, psicológico, social e infraestrutural. Aliás, o quadro descritivo que faz a abertura do romance não poderia ser mais elucidativo:

Naquele lugar, a guerra tinha morto a estrada. Pelos caminhos só as hienas se arrastavam. A paisagem se mestiçara de tristezas nunca vistas, em cores que pegavam à boca. Eram cores sujas, tão sujas que tinham perdido toda a leveza, esquecidas da ousadia de levantar asas pelo azul. Aqui, o céu se tornara impossível. E os viventes se acostumaram ao chão, em resignada aprendizagem da morte. 
A guerra aqui, sobretudo pelo seu caráter profunda e absurdamente fratricida - pois trata-se de uma guerra civil - é uma expressão suprema de violência sobre o outro, pois não se trata de aniquilar uma pessoa, mas todas aquelas e tudo aquilo que constitui, ou pode constituir, ameaça. Romance de dupla narração, Terra Sonâmbula implica também a multiplicação de pontos de vista em relação à história contada, o que não só lhe dá configuração e ritmo narrativos particulares, como também acentua e aprofunda os dramas vividos pelas personagens.

A violência, e seguindo Hannah Arendt, opõe-se a discurso, ou, se quisermos, ao próprio sentido de poder como Foucault já o tinha definido. O que significa que narrar a violência é, por conseguinte, uma afirmação de poder. É negar-lhe a lógica e denunciar toda a irracionalidade que lhe está subjacente. Facto que levará o sul-africano Ndjabulo Ndebele a desenvolver toda uma reflexão numa intervenção intitulada "Should literature be political" (2012) onde fundamenta a inevitabilidade de a literatura, em África, ter de ser política, face às pressões e ameaças generalizadas do presente e às incertezas em relação ao futuro coletivo dos africanos.

Terminamos este abreviado rastreio da narrativa moçambicana detendo-nos na narração que tem a morte como tema e motivo. Julgo que duas obras, curiosamente do mesmo autor, são superiormente representativas desta vertente narrativa: trata-se de $O$ Regresso do Morto e Palestra para um Morto, de Suleiman Cassamo. Enquanto que em O Regresso do Morto, a narração, com uma tensa e intensa cadência cinematográfica, nos coloca perante a ideia tradicional da morte como perda, como ausência e como fator fraturante e desestruturante, Palestra para um Morto, faz da narração, mesmo com o seu pendor monologante, um jogo que desafia as crenças do leitor, tanto em relação à própria literatura, como também em relação à própria morte. 
A narração impõe-se aqui mais como uma estratégia discursiva que projeta o poder da escrita, uma celebração da literatura, como superação da ideia da morte como desfecho trágico, como chegada a um vazio, mas, sobretudo, como um espaço de interação com a vida, de intermitências diversificadas e de múltiplas possibilidades existenciais e interpretativas.

Isto é, cumpre-se com este filão necrológico da narrativa moçambicana, a função transformacional anteriormente referida pelo jovem Manirakiza e por Chinua Achebe. A voz, ora monologante, ora dialogante do narrador e as perspetivas narrativas plurais e desconcertantes instauradas, jogando, não sem ironia, com os horizontes de expectativa tanto dos imaginários africanos como de outros, são como que uma demonstração de que a morte não é uma situação limite, mas que o é, sim, a própria vida pelos muitos sinais que ela apresenta de estar a esgotar-se. Trata-se, pois, e uma vez mais, da reafirmação do pressuposto foucaultiano de que o poder do discurso reside na sua capacidade de poder nomear, representar e interpretar os fenómenos.

\section{Conclusão}

Em jeito de conclusão, poderíamos afirmar que a literatura moçambicana, à imagem de outras literaturas africanas, releva a sua condição de património particular, pela sua inscrição no património universal da humanidade, através do poder do discurso que, nas suas variadas realizações, the permitiu definir a sua própria singularidade. Singularidade que decorre da capacidade de realizar apropriações, rejeições e sínteses e de establecer um diálogo permanente e estruturante com o meio que imediatamente o cerca e com tempos, lugares e imaginários determinados. 
No caso específico das literaturas africanas, este património respalda-se na assunção de um território simbólico e identitário assente, por um lado, no resgate de representações, tradições, práticas e linguagens ligadas a uma ideia de origem e, por outro, à apropriação e transfiguração dos valores e dos símbolos (caso concreto da língua) do colonizador, numa síntese dinâmica, mas muitas vezes conflituante entre identidade e alteridade.

É assim que, através da arte da narração, e pelo viés da voz e do olhar, que nos transportam pelas histórias, nos é permitido aceder à pluralidade e diversidade das manifestações do poder patrimonial da literatura e da imaginação, nas suas infinitas interações com a linguagem, com a condição humana e com a vida, no que ela tem de mais comezinho e de mais nobre.

\section{Referências bibliográficas}

ACHEBE, Chinua (1987), Anthills of the Savannah. London: Heinneman. ACHEBE Chinua (2000), Home and Exile. Oxford: University Press.

ARENDT, Hannah (2009), Sobre a Violência. Rio de Janeiro: Civilização Brasileira.

ASHCROFT et al. (1989), The Empire Writes Back: Theory and Practice in Post-Colonial Literatures. London \& New York: Routledge.

AUGÉ, Marc (2001), As Formas do Esquecimento. Almada: Iman Edições. BARTHES, Roland (1980), Aula. São Paulo: Cultrix.

BATA, Clemente (2010), Retratos do Instante. Maputo: AEMO. CASSAMO, Suleiman (1989), O Regresso do Morto. Maputo: AEMO. CASSAMO, Suleiman (1999), Palestra para um Morto. Maputo: Ndjira. Chiziane, Paulina (1993), Ventos do Apocalipse. Maputo: Ed. da Autora. COUTO, Mia (1992), Terra Sonâmbula. Lisboa: Caminho.

FAIfE, Hélder (2010), Contos de Fuga. Maputo: TDM.

FOUCAUlT, Michel (1998), As Palavras e as Coisas. Lisboa: Edições 70. 
FOUCAUlT, Michel (1999), A Ordem do Discurso, (1971). São Paulo: Edições Loyola.

GENETTE, Gerard (1995), Discurso da Narrativa, (1972). Lisboa: Vega.

HonwanA, Luis Bernardo (2000), Nós Matámos o Cão Tinhoso, (1964). Porto: Afrontamento.

KERMODE, Frank (1997), A Sensibilidade Apocalíptica. Lisboa: Século XXI. KHOSA, Ungulani Ba Ka (1987), Ualalapi. Maputo: AEMO.

KHOSA, Ungulani Ba (1990), Orgia dos Loucos. Maputo: UEM.

MANIRAKIZA, Emmanuel Reed in Alexander Atkins, "The power of literature", Consultado a 23 de maio de 2014 em: http://atkinsbookshelf.wordpress. com/2012/12/02/the-power-of-literature/

MANJATE, Lucílio (2011), O Contador de Palavras. Maputo: Alcance Editores. MUIANGA, Aldino (2012), Nghamula, o bomem do tchova (ou o Eclipse de um Cidadão). Maputo: Alcance Editores.

NDEBELE, Ndjabulo, "Should Literature be political", Consultado a 17 de abril de 2014 em: http://www.theguardian.com/books/2012/oct/04/ njabulo-s-ndebele-should-literature-be-political. 
L E I T U R A , C I TAÇ Ã O, T RA D U Ç Ã O

Só a Antropofagia nos une. Socialmente. Economicamente. Filosoficamente.

Única lei do mundo. Expressão mascarada de todos os individualismos, de todos os coletivismos. De todas as religiões. De todos os tratados de paz.

Tupi, or not tupi that is the question.

Contra todas as catequeses. E contra a mãe dos Gracos. Só me interessa o que não é meu. Lei do homem. Lei do antropófago.

(OSWALD DE ANDRADE)

A epígrafe com que inicio esse texto é retirada do já bastante conhecido "Manifesto antropófago" (1983¹), de Oswald de Andrade, e enuncia um questionamento fundamental a atravessar a literatura produzida no Brasil desde meados do século dezanove e que será a base de muito do que os nossos escritores modernistas, já no século vinte, pensaram sobre o ato de criação literária: "Tupi, or not tupi, that is the question"... A paráfrase de Shakespeare, quando ensaiada ao lado do verso com que o poema se inicia - "Só a antropofagia

1 O manifesto foi publicado originalmente no primeiro número da Revista de antropofagia, São Paulo, em $1^{\circ}$ de maio de 1928. 
nos une" -, permite elaborar uma análise acerca do profundo deslocamento que atravessa nosso processo de formação cultural, convocando o leitor a perceber que, unidos pela antropofagia, caberia aos colonizados pelejar pela "revolução caraíba" e "deglutir" o corpo estrangeiro para, a partir dele, constituir-se em diferença. $\mathrm{O}$ que talvez tenha faltado a Oswald perceber, naquele momento, foi o quanto de estrangeiro haveria já em nós mesmos, o que torna mais complexa e sedutora a sua perceção e abre portas para uma futura discussão acerca do caráter fronteiriço da nossa sociedade mestiça. Por agora, todavia, é suficiente destacar que as palavras do autor modernista brasileiro, mesmo sem estarem diretamente preocupadas com a prática da tradução, antecipam muito do que circulará mais tarde sobre o tema nos estudos de tradutologia, vindo a embasar, de forma significativa, a proposta de tradução como transcriação, veiculada em termos de teoria e prática nos escritos em torno da "poética da destruição" 2 dos poetas concretistas brasileiros, ou na teoria antilogocêntrica de Jacques Derrida, conforme referida por Haroldo de Campos (2004: 43).

O que nos preocupa, pois, já não é a tradução pensada nos limites estreitos dos processos de transferência interlinguísticos, que pressupõem a unidade entre as línguas, recorrendo a uma utópica crença na possibilidade de transposição completa de sentidos e formas, mas, sim, nas palavras de António de Sousa Ribeiro, a sua deslocação para "o eixo dos estudos culturais e, concomitantemente, (su)a crescente configuração como uma interdisciplina" (Sousa Ribeiro, 2005: 1). Se, para uma certa tradição, o conceito de tradução está ligado à ideia de fidelidade, numa estratégia servil, que privilegia o texto de partida, ao atribuirmos maior peso à tarefa do tradutor, ao seu lugar de enunciação, estamos a considerar sobretudo a impossibili-

2 Conferir análise sobre o tema desenvolvida por Susana Kampff Lages (2007), em específico nas páginas do número 88 a 92 . 
dade de se abolir a diferença entre o eu e o outro, entre o próprio e o estrangeiro, o que nos encaminha para a perceção de que não se pode chegar a um absoluto linguístico, em que as línguas sejam marcadas por equivalências plenas. Se a referência à Babel seria aqui possível, mais significativo e correto é indicar, todavia, que o ato de traduzir implica perda, ou melhor dizendo, diferença; implica descobrir "a multiplicidade irredutível das línguas", nas palavras de Patrícia Lavelle, que, ao prefaciar uma reunião de artigos de Paul Ricoeur sobre o tema, enfatiza o quanto o pensamento do filósofo francês subverte o contraponto entre fidelidade e traição para pensar o ato tradutório como a busca de "correspondências sem adequação" ou de "equivalências sem identidade" (in Ricoeur, 2012: 8). O processo do traduzir aponta, dessa forma, para um modo específico de constituição de uma imagem cultural e literária que revela o jogo de poder entre forças inovadoras e conservadoras, constituindo-se não como um evento isolado, mas como processo determinado por contingências históricas e sociais. É esse o sentido proposto por André Lefevere, ao afirmar que:

A tradução pode falar-nos muito sobre o poder de imagens e as formas com que tais imagens são forjadas, sobre as formas com que a autoridade manipula as imagens e emprega especialistas para sancionar aquela manipulação e para justificar a confiança de uma audiência - é esse o motivo pelo qual o estudo da tradução pode nos ensinar algumas coisas não apenas sobre o mundo da literatura, mas também sobre o mundo em que vivemos. (Lefevere, 1992: 26-27)

Ciente da importância que o ato de traduzir pode vir a ter na cena político-literária, marcada pela imposição e/ou construção de novos paradigmas, a discussão proposta pelo teórico belga ilumina e, de certa forma, abre-se ao diálogo com o pensamento de Lawrence Venuti (1995), quando este problematiza a transparência das tradu- 
ções, para reclamar maior visibilidade para aquele que as produz no corpo de seu trabalho. A inscrição deste como ser historicamente determinado é fundamental, portanto, para que se perceba mesmo a impossibilidade de harmonia entre consciência e linguagem, pois, nas palavras de Susana Kampff Lages, ao comentar Venuti,

Alguma espécie de conflito, de violência é inerente ao processo de tradução, por estar ele, de um lado, assentado sobre um gesto interpretativo que necessariamente privilegia um aspecto em detrimento de muitos outros possíveis, e, de outro, intrinsecamente constituído como alteridade linguística e cultural. (Lages, 2007: 80)

Ora, se a tradução se vincula a um gesto interpretativo, ler e traduzir são faces de uma mesma moeda, faces essas que necessariamente atravessam processos de contato intercultural para constitui-los como espaços de negociação e fricção, em que se gera a própria ideia de liminaridade ou, nas já repetidas palavras de Silviano Santiago (1978), posteriormente usadas por Bhabha (1998), em desdobramentos de sentido, a ideia de entre-lugar. Em termos mais específicos de uma abordagem cultural, não seria demais recorrermos, novamente, ao pensamento sempre lúcido de Sousa Ribeiro, quando este afirma que a tradução é uma "metáfora central de nosso tempo" e que,

Nesta acepção ampla, o conceito de tradução aponta para a forma como não apenas línguas diferentes, mas também culturas diferentes e diferentes contextos e práticas políticos e sociais podem ser postos em contacto de forma a que se tornem mutuamente inteligíveis, sem que com isso tenha que se sacrificar a diferença em nome de um princípio de assimilação. (Sousa Ribeiro, 2005: 2)

Seguindo por essa trilha, como já afirmei, talvez não seja difícil estabelecer a linha que une leitura, tradução e citação como termos 
que pressupõem a inserção ativa de um sujeito nos processos a que dão origem, visto que, se efetivamente os três termos trabalham em busca da constituição de sentidos, na forma como pretendemos considerá-los a própria ideia de sentido não é um pressuposto, mas, ao contrário, deriva do trabalho constante de construção, desconstrução e reconstrução, trabalho esse que só admite revelar-se no provisório de sua existência. Para além do sonho assimilacionista ou do pesadelo racista - e já agora retomando Bhabha - há o processo ambivalente de cisão e hibridização, que marca a diferença da cultura e ao qual não nos podemos furtar. É nesse espaço de fricção que talvez se possa pensar, de forma produtiva, a própria ideia de um património de influência portuguesa, seja em seu viés arquitetónico, seja na articulação de um conjunto de obras literárias que compõem aquilo que Margarida Calafate Ribeiro nomeia, publicamente, como um património da palavra. Essas ambivalências, próprias do espaço liminar ocupado por todos os envolvidos no sistema colonial - e insiro, nesse processo, a própria cultura portuguesa na forma como se desenhou na antiga metrópole do império português, e não apenas porque esteja a referir-me à adequada proposta de Boaventura de Sousa Santos de pensar Portugal como semiperiferia, mas, e sobretudo, porque, como sabemos, o Brasil e a África também lá estão, há mais tempo do que possa parecer à primeira vista, friccionando a ideia de uma tradição estável e isenta de influências -, propiciam uma poética de descontinuidades, em que uma camada se interpõe à outra para deslocá-la produtivamente. Se falamos em permanência, e sobre ela efetivamente falamos quando nos referimos aos conceitos de património e influência, é porque, nessa contabilidade, não nos negamos a "reconhecer a importância fundamental da perda, do distanciamento, da separação, para a constituição de uma identidade, seja ela cultural ou pessoal" (Lages, 2007: 83), pois, da mesma forma que a tradução se manifesta como uma escrita "que não esconde a duplicidade de sua autoria" (Lages, 2007: 82), ao percebermos a 
importância que esse conceito tem para a nossa investigação literária e cultural, não nos podemos furtar à necessidade de constituir uma abordagem que permita problematizar tanto a simples negação do outro quanto a sua assimilação acrítica. Trata-se, aqui, portanto, de um sistemático jogo de descontextualização e recontextualização, em que o texto/objeto - no sentido barthesiano - é domado, após a sua apropriação/interpretação, para recriar-se em novas condições.

Nesse sentido, é importante considerarmos o valor e a função da citação, por exemplo, em qualquer produção textual. A referência necessária é a Antoine Compagnon e ao seu O trabalho da citação, quando o autor afirma, recuperando os passos de Laurent Jenny, no já clássico "A estratégia da forma", publicado na revista Poétique de número 27 , que "a citação não tem sentido em si, porque ela só se realiza em um trabalho, que a desloca e a faz agir" (Compagnon, 1996: 35). A ideia de deslocamento é, nesse conjunto reflexivo, fundamental, pois, quando recortamos um fragmento do seu texto original, para o inserirmos num novo espaço, seja ele literário ou crítico, esse fragmento, ao trabalhar na sintaxe que o recebe, não apenas abre o novo texto a uma leitura que seguirá a refletir o texto original, como também instaura um processo inverso, em que o original, sendo citado num novo corpo, começa a ser lido de nova forma, passando necessariamente pelo já referido processo de descontextualização e recontextualização. Assim, não é apenas o poema de Oswald de Andrade aqui tomado como epígrafe que será lido em diálogo com Shakespeare, pois, para o leitor do poeta paulista, a volta ao texto do dramaturgo inglês se dará, inexoravelmente, de uma nova forma. Ou, mesmo, para pensarmos outros instrumentos e, além disso, recuperarmos as reflexões de Francisco Bethencourt presentes nesse livro, como tornar aos azulejos tradicionais portugueses depois de os ver citados em trabalhos da artista plástica Adriana Varejão, como "Varejão acadêmico - heróis" (1997) ou "Pele tatuada à moda de azulejaria" (1995/1996)? Que leitura tornaremos 
a construir diante das famosas peças de cerâmica em azul e branco, depois de as encontrarmos dilaceradas por imagens de vísceras ou de pedaços de corpos esquartejados? Corpos de inconfidentes? Corpos de colonizados? Ao nos depararmos com uma citação, mais do que encontrarmos um desvio, somos transportados a um entroncamento de diversas vias que jamais retornarão a um sentido único ou primordial. Mais uma vez, volto ao texto de Compagnon, para com ele dizer que:

Isso se aplica maravilhosamente bem à citação: ela não tem sentido fora da força que a move, que se apodera dela, a explora e a incorpora. O sentido da citação depende do campo das forças atuantes: ele é essencialmente variável, como escreveu Gilles Deleuze sobre o sentido, segundo Nietzche, "sempre uma pluralidade de sentidos, uma constelação, um complexo de sucessões mas também de coexistências". (Compagnon, 1996: 35, citando Deleuze de Nietzsche et la philosophie, p.4)

A citação é, assim, um operador de leitura que, ao apelar para a competência do leitor, produz um desvio, uma "diferença de potencial", um curto-circuito produtivo e amplificador. Ao citar um livro lido, estabeleço com ele uma relação em que progressivamente nos aproximamos e distanciamos, transformando-se o objeto em eu e não-eu, uma "not-me possession", segundo o autor de $O$ demônio da teoria. Mais uma vez, a ideia de liminaridade apresenta-se para nós, o que reforça o movimento anteriormente descrito em que busquei articular leitura, tradução e citação como procedimentos profundamente marcados pela intervenção de um sujeito, que neles irá assinalar o percurso da sua própria existência e o lugar que ocupa numa rede de relações. São experiências de fronteira, que demarcam pontos de passagem e de enfrentamento, e só podem ser concebidas como formas dinâmicas, tal qual a própria fronteira o é. 
Nesse sentido, cabe aqui retomar o que diz Roberto Vecchi (2010), em artigo acerca da relação entre citação e memória pública. Ao recuperar a linha de pensamento acima referida, em que a citação é vista como um fragmento de discurso que se inter-relaciona de forma significativa com um novo corpo textual, o investigador italiano destaca, contudo, a sua presença como fração de uma totalidade que se perde ou se elimina, manifestando-se, portanto, como o gatilho de uma dialética que aproxima memória e esquecimento, o resto e a falta. Evidencia-se a citação, no seu pensamento, não apenas como um instrumento destinado a dizer (lembrar) aquilo que é citado, mas também a silenciar (esquecer) o que se deixou para trás, em repouso, sem emergir no novo texto. Numa relação tensa, portanto, ela traz o passado ao presente mas, ao mesmo tempo, denuncia o esquecimento desse passado e a própria impossibilidade de sua elaboração. As palavras de Vecchi são esclarecedoras:

No entanto a própria citação, no anacronismo que supõe, poder-se-ia articular tanto como déjà-vu, ou seja, um presente duplicado pelo pseudopassado, como também um anacronismo oposto, formal e não real, que se realiza coadunando a forma-passado - por exemplo, a língua - com o presente em curso. Então, entre perdas e possibilidades, a citação como modo para a formação da memória por uma repetição diferencial - uma tradução, de certo modo - evoca sempre, numa relação tensa e às vezes contraditória entre passado e presente, o fantasma de um tempo outro, que não se deixa inteiramente elaborar ou apreender, como pressupõe a dimensão espectral. (Vecchi, 2010: 601)

A citação, assim desenhada como um espectro, abre no presente uma brecha pela qual podemos ler o passado, mas apenas e sempre de forma incompleta, tensionada pelo novo corpo a que se entrega e pelo novo autor que a manipula diante de seus receios e desejos. Mais uma vez, apresentamos os verbos citar, traduzir e ler como 
ações tangenciais, que se aproximam de forma significativa, quando consideramos o peso que deve ser atribuído aos seus agentes e à perspetiva política, em sentido pleno, que os conduz. Se o ponto de partida para cada um desses atos - a fonte, o original em língua estrangeira e texto/tecido sobre o qual nos debruçamos - é um marco incontornável, o ponto a que se chega dependerá sempre dessa articulação, dessa também incontornável tensão dialética que os envolve, impossibilitando qualquer crença na transposição fiel de sentidos. Quando leio o texto - ou o mundo, ou o mapa da cidade por habitar - leio nele(s) aquilo que é, para mim, o texto, o mundo e o mapa e mais ainda: a minha própria consciência daquilo que cada um é, como objeto da atividade que exerço e do lugar de onde opero essa atividade: não o lugar físico, palpável, em que a experiência se dá, mas a confluência social, política e cultural que habilita a minha condição de leitor. Já não há qualquer possibilidade de restituição ao texto de um sentido primordial, único, perdido para sempre no próprio esforço de apreensão a que dou vazão. Importante destacar, é claro, o conceito de texto é aqui entendido como qualquer sistema de produção de sentidos, como o são a tapeçaria ou a moda, e não apenas o que é fruto do trabalho da escrita. Já lemos todos Barthes e as considerações que sobre isso tece o semiólogo francês, não sendo esse o espaço adequado para discorrer sobre tal assunto. Todavia, não seria demais lembrar que, onde digo leitura, digo, ainda, tradução e citação, para além das especificidades de cada termo e de forma a demarcar a abertura presente no modo como hoje são compreendidos.

Pensar tal quadro teórico no âmbito dos Patrimónios de Influência Portuguesa é, necessariamente, refletir sobre o dinâmico processo fronteiriço de constituição cultural por nós experimentado para percebermos, mais uma vez em diálogo com Sousa Ribeiro, que analisar a heterogeneidade interna das culturas nos obriga a entender a tradução como um processo marcante tanto nas relações 
interculturais quanto no plano intracultural (Sousa Ribeiro, 2005: 3). Pensar a cultura brasileira, por exemplo, é pensar uma multiplicidade de matizes, não necessariamente dialogantes entre si - e não me estou a referir às mais de vinte línguas que também compõem o nosso panorama nacional, como as diversas línguas indígenas e o pomerano -, que demandam constantes reagenciamentos e aproximações, leituras e traduções, em que se manifestam não apenas os patrimónios materiais e imateriais legados por portugueses, indígenas e africanos da diáspora, mas também as sucessivas camadas de apropriação que os transformaram em diversos níveis, para neles se assinalarem de forma mais ou menos visível.

Parece-me que estamos a retornar à antropofagia oswaldiana, para dizermos mais uma vez que "Só a Antropofagia nos une. Socialmente. Economicamente. Filosoficamente.” Estamos e não estamos, pois interessa agora enfatizar a forma como o conceito modernista foi relido pelo movimento da Poesia Concreta, na sua radical busca do que haveria de mais próprio na poesia, a partir de um investimento que valorizou o seu aspeto material e sua configuração como uma linguagem própria. Se para tal processo os concretistas recorreram ao conceito de função poética, conforme proposto por Jakobson, também nele buscaram o conceito de "transposição criativa", o qual, segundo Susana Lages, seria "a tradução capaz de reproduzir na outra língua o elemento especificamente poético, por uma atenção sobretudo a elementos da estrutura, da articulação entre significantes e, em especial, ao recurso poético da paranomásia33." (Lages, 2007: 89). É esse conceito de transposi-

3 Figura de linguagem que consiste no emprego de parônimos, palavras com a sonoridade semelhante, mas de sentidos diferentes; é o que podemos observar, por exemplo, nos versos da canção "Qualquer coisa", do compositor brasileiro Caetano Veloso: "Berro pelo aterro pelo desterro b e r r p o r s e u b e $\mathrm{rro} \quad \mathrm{pe} l$ o $\mathrm{s}$ e u e r r o quero que você ganhe que voce me a pan e sou o seu bezerro gritando mamãe." 
ção criativa que determina o termo utilizado por tais poetas para designar a sua teoria e prática de tradução, ou seja, a transcriação. Nesse caminho, podemos afirmar que o elemento a definir o projeto poético concretista apoia-se numa aplicação radical do conceito modernista de antropofagia, já por nós percebido como estratégia singular de leitura das tradições. Materializa-se, assim, como uma tomada de atitude tanto diante da tradição poética brasileira, em um processo de tradução intracultural, quanto diante das diversas literaturas estrangeiras, como, no nosso caso especifico, a portuguesa, já agora em processo de tradução intercultural. Tal tomada de atitude, não se deixa definir nos termos tradicionais da influência, no sentido de uma assimilação passiva de elementos externos, mas, ao contrário, "trata-se de um processo de violenta apropriação que se constitui a partir de uma releitura conscientemente seletiva do substrato literário passado e contemporâneo" (Lages, 2007: 90), o que nos levaria a referi-la como uma "poética da destruição". Leia-se nesse processo - na inteireza da sua violência - a homologia entre destruição e desconstrução, para que assim se revele o intenso diálogo entre a reflexão poética dos concretistas, principalmente de Haroldo de Campos, e o pensamento antilogocêntrico do filósofo francês Jacques Derrida.

A proposta concretista de "destruição" de uma forma tradicional de perceber e assimilar a influência pode, paradoxalmente encaminhar-nos a uma perceção produtiva do termo no contexto dos patrimónios, pois o que aqui se busca é, talvez e enfaticamente, um processo de ressignificação, em que o detalhe arquitetónico, o planeamento urbano, o texto literário deixam de ser lidos em si, no isolamento espectral de um passado que só se faz presente como ruína - para dialogarmos um pouco mais com Walter Benjamin (2012) -, para se articularem numa outra dinâmica, atravessada pela diferença e, por isso mesmo, mais produtiva, porque renovada. Ao considerarmos o sentido profundo que a tradução ganha nesse pro- 
cesso, veremos que, quando relemos os vestígios da cidade colonial de Lourenço Marques na Maputo do século XXI, ao identificarmos aquilo que pode ser citado como traço de sua existência, não estamos necessariamente seguindo na contramão do direito inalienável que todo moçambicano tem de se apropriar do território por ele tão arduamente conquistado, para nele enfatizarmos a presença alienante do colonizador. Ao contrário de tal pensamento, partimos da consciência de que o património que lá está já é inevitavelmente outro, ainda que aparentemente o mesmo, traduzido pelas novas fronteiras que o atravessam, re-referenciado pela diferença que o circunda. Outro exemplo significativo desse ponto de vista é o que posso observar na literatura, quando busco ler Camões em Carlos Drummond de Andrade: o poeta que encontro, mesmo que ainda ostente o indefetível tapa olho com que a posteridade o reconhece em qualquer imagem, já agora traz em si a luzidia calvície do poeta mineiro, a atravessar o seu semblante centenário; cito um pequeno fragmento de "A máquina do mundo", poema publicado originalmente por Carlos Drummond de Andrade no livro Claro enigma, de 1951, em que o poeta relê a tradição clássica, sem abrir mão da busca por uma nova dicção poética:

E como eu palmilhasse vagamente uma estrada de Minas, pedregosa, e no fecho da tarde um sino rouco

se misturasse ao som de meus sapatos que era pausado e seco; e aves pairassem no céu de chumbo, e suas formas pretas

lentamente se fossem diluindo na escuridão maior, vinda dos montes e de meu próprio ser desenganado, 


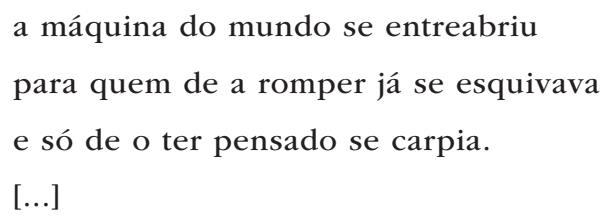

Se a máquina camoniana é aqui citada, abrindo um espaço de leitura em que o texto de Os Lusíadas (1982), em seu canto décimo, não pode, e nem deve, ser obliterado, é importante perceber que o seu sentido passa de forma irrecorrível pelas indagações existenciais do poeta brasileiro, em um projeto que de forma alguma reitera o percurso heroico de apropriação dos mares e da mitificação do homem por seus feitos, mas, sim, explicita a perceção cética da existência humana. Ao citar a máquina do mundo, o poeta de Claro enigma efetua um processo de tradução que potencializa a leitura de Camões, propondo a constituição de distintos pactos de leitura. Diria Oswald que Drummond antropofagicamente deglutiu Camões... E, nesse ato, o que passamos a encontrar é uma estratégia de composição que, efetivamente, interseciona leitura e escrita como faces de uma mesma moeda, pois o ato de escrever pode ser visto aqui, de modo concreto, como uma resposta ao ato de ler. De certa forma, o poeta brasileiro traduz o português para um contexto outro, próprio, em que a sua heroicidade épica é deixada de lado para que se possa validar, na sua poesia, a aguda reflexão acerca das vicissitudes existenciais do homem, esse "bicho da terra tão pequeno", e o fortuito conhecimento da vida que em raros momentos se pode contemplar.

A leitura drummondiana de tal património - e Camões, numa certa visão de mundo, como já o disse Eduardo Lourenço, é o património português por excelência - exercita-se como um processo de reconhecimento/apagamento, que desdobra a leitura possível do património português numa nova clave, distinta, revelando a sua 
existência para denunciar a sua ultrapassagem. O tempo de Drummond é outro - e não apenas seu espaço ou sua cultura - e essa diferença é fundamental para compreendermos a diferença do seu discurso, as novas linhas lançadas por seus versos. Ao apropriar-se de Camões - da sua escrita e do seu tempo -, dá ao património português uma feição que rasura a sua existência, convocando-a, todavia, em diferença. Por outro lado, se o poema brasileiro, ao demandar a presença do texto camoniano, revela um fragmento do que foi o passado colonial português, vívido na dicção épica do seu princípio, não se furta, porém, a estampar o seu possível apagamento, como um tempo que, necessariamente, se escorre por entre versos que o deixam para trás. Ler o fragmento de Os Lusíadas é assinalar duplamente a sua lembrança e o seu esquecimento, a sua presença como ruína e a sua ausência fantasmática, espectro de uma epopeia que, não tendo mais tempo ou lugar, ainda assim lá está a indagar por nós.

Lembro-me de um ensaio de Maria Alzira Seixo, publicado num já distante 1977, logo a seguir à Revolução dos Cravos, em que, a título de refletir acerca de "Literatura, processo revolucionário e comunicação", a professora portuguesa dizia:

Só se escreve porque se lê, e a primeira palavra escrita nasceu do desejo de informação que se leu no outro - o outro, imagem, pintura, ideograma. Assim, escrever é responder à leitura - fundamento de todos os exercícios, de todas as pedagogias. E a pedagogia da literatura (em sentido amplo e restrito) deverá portanto assentar na escrita, na leitura como reescrita, que só assim é prática de sentido. Por-se-ão de parte, pois, todos os critérios de repetição como reveladores de má assimilação, e todos os critérios de glosa como denunciadores de percepção míope. Escrever é dar a medida daquilo que se leu. (Seixo, 1977: 33) 
De certa forma, em diálogo com Seixo, creio que não seria demais afirmar que "Só se cita porque se lê" ou então que "Só se traduz porque se lê"... Tais sentenças revelam a minha perceção de que tanto o ato de traduzir quanto o de citar, fundados necessariamente na leitura, revelam a importância do debruçar-se sobre o outro para, a partir dele, se dar início a uma prática de reescrita. Se, de forma efetiva, "escrever é dar medida do que se leu" e, nesse caminho, tanto a prática da tradução quanto o uso da citação podem ser considerados processos nascidos do desejo pelo outro, é importante ter-se a medida de que as duas ações partem do embate com um processo lacunar, da perceção de uma diferença irredutível e necessária, responsável por inscreve-las num espaço de liminaridade constante. É a consciência desse espaço sempre presente que estaria na base da proposta antropofágica de Oswald. Propor a revolução caraíba era, a seu tempo, revolucionar a perceção da forma como a cultura brasileira poderia - deveria, para melhor dizer - relacionar-se com a estrangeira, sobretudo a do colonizador. Hoje, mais do que isso, é descrever o modo como os atos fundamentais de ler, citar e traduzir permeiam diversas formas de produção cultural, revelando não só jogos políticos de poder e autoridade, mas também estratégias de subversão e enfrentamento. Por isso, lembrar do poeta paulista e da sua invetiva irónica para problematizar tais atos é, também, um modo de estimular o leitor a perceber que, em todo o processo de contato cultural, a par do desejo de inteligibilidade, permanece a diferença como traço de resistência e como princípio fundador.

\section{Referências bibliográficas}

ANDRADE, Carlos Drummond de (2012), Claro enigma. São Paulo: Cia das Letras. 
ANDRADE, Oswald (1983), Manifesto antropófago, in Teles, Gilberto Mendonça (org), Vanguarda europeia e modernismo brasileiro, (1928). Petrópolis: Vozes, 353-360.

BENJAMin, Walter (2012), O anjo da história, João Barrento (org. e trad). Belo Horizonte: Autêntica.

BHABHA, Homi K (1998), O local da cultura, Myriam Ávila, Eliana Lourenço Reis e Gláucia Renate Gonçalves (trad.). Belo Horizonte: Editora UFMG. CAMÕes, Luís de (1982), Os Lusíadas (1572). Porto: Porto Editora.

CAMPOS, Haroldo de (2004), "Da tradução como criação e como crítica", in Metalinguagens e outras metas. São Paulo: Perspectiva, 31-48.

COMPAGnON, Antoine (1996), O trabalbo da citação, Cleonice Mourão (trad.). Belo Horizonte: Editora UFMG.

LAGES, Susana Kampff (2007), Walter Benjamin: tradução e melancolia. São Paulo: EdUSP.

LEFEVERE, Andre (1992), Translation, rewriting and the manipulation of literary fame. London/New York: Routledge.

RICOEUR, Paul (2012), Sobre a tradução, Patricia Lavelle (trad. e pref.). Belo Horizonte: Editora UFMG.

SANTIAgO, Silviano (1978), Uma literatura nos trópicos. São Paulo: Perspectiva.

SEIXO, Maria Alzira (1977), "Literatura, processo revolucionário e comunicação", in Discursos do texto. Amadora: Livraria Bertrand, 31-48.

SOUSA RIBEIRO, António (2005), "A tradução como metáfora da contemporaneidade: pós-colonialismo, fronteiras e identidades". http://www.euro zine.com/articles/2005-07-18-ribeiro-pt.html, acesso em 15/maio/2014. VECCHI, Roberto (2010), "História de nomes, memórias sem nome. Citação e estado de excepção nas actualizações da memória pública”, in Fernanda Mota Alves, Sofia Tavares, Ricardo Gil Soeiro, Daniela Di Pasquale (orgs.), ACT 20: Filologia, memória e esquecimento. Lisboa: Humus, 593-609. VENUTI, Lawrence (1995), The translator's invisibility. A bistory of translation. London/New York: Routledge. 
4

CORPO, VOZ E LÍ NGUA

COMO PATRIMÓn IOS DE EMIGRAÇ Ão

Partir, morrer um pouco,

Morrer para o que amamos

De nós mesmos um pouco vai-se

A toda bora, em qualquer parte

(Edmond Karaucourt, "Rondel de l'adieu", Seul, 1890)

(Trad. de Cunha e Silva Filho)

\section{O vestígio das "separações"}

Quando se parte, nunca se regressa verdadeiramente, o que se deixou para trás não será reencontrado da mesma maneira; à recordação traumatizante da extirpação do espaço-tempo, definitivamente deixado, junta-se a constatação do regresso impossível. Esta constatação, que é também a do tempo que passa irremediavelmente, diz respeito a cada migrante, a cada exilado que tem de abandonar um território, voluntariamente ou não. As condições específicas de cada partida distinguem as experiências de cada um e determinam, a partir destes episódios, memórias íntimas muito diversificadas.

Quando se parte, o que se deixa? O que se leva? Sim, o que deixou o meu pai, em 1961, quando emigrou clandestinamente para França, para aí procurar uma vida melhor? Antes de mais, a sua famí- 
lia - e é terrível deixar o que conta mais -, aqueles que contam mais, ainda que o objetivo seja precisamente procurar, para os membros da célula familiar próxima, algo diferente de uma existência em que se está condenado a se submeter a um quotidiano sem alternativas. Uma partida assim é um ato de amor extremo. Ao mesmo tempo, uma escolha e uma não escolha. O Portugal ditatorial desses anos empurrava uma boa parte da população para a emigração. Era impossível ficar e esgotar-se em tarefas sem outro proveito, a não ser a fadiga crescente, sem que fosse previsível qualquer melhoria da condição social. Impossível decidir reproduzir o mesmo futuro para os filhos. É, porque os amamos, que abandonamos quem amamos, acima de tudo. O sofrimento inevitável que esta situação provoca apenas é imaginável por causa do desafio da partida, fonte de uma possível felicidade inerente à que se vai proporcionar aos seus próximos.

No momento de fazer a relação entre língua e património, parto da síntese do meu trabalho em áreas que vão da minha atividade artística à atividade profissional, dado não poder abstrair-me do que conduziu às minhas escolhas de objetos, tanto de pedagogia como de criação muito particulares. O que levo a cabo é uma prática e uma reflexão postas em conexão com uma história pessoal relacionada com a emigração de Portugal para França nos anos 60. Este elemento autobiográfico foi fundamental nas escolhas do meu percurso artístico e científico.

"A tentação existe", diz Jean-Claude Ameisen,

na abordagem científica, de se abstrair do discurso sobre essa abordagem: poucos cientistas escrevem "eu", é como se a ciência se escrevesse sozinha. Parece-me, pelo contrário, que reinscrever nos textos científicos quem os inventa, os observa e especula, permite um acréscimo de objetividade. Há um ponto de vista, faço parte do que digo, não existe discurso sem que eu seja parte interessada. [...] Um narrador nunca 
está ausente da sua narração, há quase uma espécie de honestidade em não o dissimular

(Crom, 2014).

Assim, escrevo deliberadamente "eu" e não utilizarei o "nós" habitual das publicações especializadas.

A questão da língua, e posteriormente da linguagem, colocou-se-me diretamente aquando da minha chegada a França, em fevereiro de 1965, após uma escolarização de dois anos na aldeia em que nascera. Abdelmalek Sayad (2006: 160) chama "separações" aos fenómenos provocados pelas diversas deslocações de migrantes do território de origem para o de chegada, depois ao inverso, ao retorno em direção ao ponto de partida. Estes movimentos deixam traços físicos e mentais muito complexos, traços da primeira "separação", imediatamente visíveis no espaço estrangeiro em direção ao qual se efetua o deslocamento. Os primeiros vestígios destes transportes de seres humanos são audíveis e mesmo visíveis através da necessidade de utilizar uma língua desconhecida e das dificuldades de se apropriar dela, numa busca de reprodução que minorasse a aparência de "estrangeiridade". ${ }^{1}$

\section{O que é que falar quer dizer naquele país?}

É evidente que cada língua possui uma musicalidade, um ritmo e uma acentuação próprias. Sem mesmo conhecermos as línguas estrangeiras, basta pormo-nos à escuta nas nossas cidades, feitas

1 O termo existe em português do Brasil e é a tradução do conceito em francês, define os diferentes encontros com o estranho, em particular o que se apresenta oriundo do corpo e em relação com o desconhecido que provém do mundo exterior. Relaciona-se com o que tem o carácter específico de estranheza $e$ distingue-se do que é meramente "étrange" (estranho) ou "étranger" (estrangeiro). 
de numerosas outras línguas e culturas, para percebermos a diversidade de partituras que nem sempre identificamos e cujos sons, por vezes, nos soam estranhos porque estrangeiros. Afogamento: tal foi a minha sensação ao desembarcar em Paris; a mesma sensação quando alguns anos mais tarde me atiraram para uma piscina sem pé a fim de aprender a nadar. Primeiro, o pânico, de seguida a procura instintiva de sinais para sobreviver, e com alguma generosidade, um nadador salva-vidas estendeu-me da berma a sua vara para que eu não me afogasse. Em contrapartida, não havia portões de segurança à saída na estação ferroviária: havia a imensidão de uma cidade após o espaço circunscrito da pequena aldeola, o anonimato e o acanhamento acentuados pelo desconhecimento de uma língua que me deixava em alto mar sem boia nem foguete com para-quedas. Sempre me perguntei se esta não seria a sensação de um bebé quando sai do ventre da mãe para a imersão total num ambiente tão estrangeiro como desmesurado. Nada, nenhum som amigo para me situar nesta linguagem, que, para minha surpresa, crianças bem mais pequenas do que eu manejavam com facilidade. Aprendi às minhas custas o sentido de "língua materna" e, mais tarde, o do bilinguismo, quando finalmente, depois de muitos pirolitos, passei dos bruços ao crawl, e atirava-me voluntariamente do trampolim de uma língua em que acabei por me deliciar.

Lembro-me claramente da minha surpresa quando os meus pais me informaram que havia "outras línguas". Não percebi: Porque é que havia pessoas que falavam "línguas" em vez de falarem simplesmente como nós? Para mim o português era a "fala".

(Barreno, 2010: 10) ${ }^{2}$.

2 Note-se que «fala» significa em português tanto palavra, voz, elocução como linguagem enquanto discurso, diálogo, conversa. 
Esta confissão de Maria Isabel Barreno tranquilizou-me ao longo de numerosos segredos que era preciso guardar por prudência: sempre o medo de não ser como os outros e de ter ar de ignorante. Então não estava sozinha, outros tinham vivido as mesmas coisas.

\section{Escutar e calar-se, escutar e baixar os olhos}

Sim, mas este "mesmo" nunca é o mesmo, já que o íntimo, a sensação individual, comporta elementos particulares muitas vezes não exprimidos e por vezes reprimidos. O lugar que se abandona cobre um espaço geográfico, um tempo coletivo igualmente ligado a uma temporalidade pessoal que caracteriza a história de vida. Assim, o Portugal do Estado Novo de Salazar deixou marcas. O que é que queria dizer falar naquele país? As interações com os outros estavam condicionadas pela situação ditatorial e a escola era o lugar onde os comportamentos, as ideias, o verbo do regime eram ditados, ou antes, impostos. O diálogo era uma noção desconhecida, comunicar fazia-se em sentido único: absorver um discurso unívoco sem resposta possível. Escutar e calar-se, escutar e baixar os olhos. Não se cruzar com o olhar do adulto, do professor ou professora da primária. Concordar, ao invés de se exprimir. Submeter-se à ordem imposta: ordem social, ordem moral, ordem política. Cada um no seu lugar. Não aspirar a nenhuma mudança, satisfazer-se com o que se tem, estar de acordo com o modelo, o conformismo é o ideal. A estas imposições corresponde uma linguagem corporal e vocal que induz o "sim" e a cabeça baixa. Os agrupamentos públicos são procissões religiosas ou desfiles festivos canalizados para os ideais do poder, com vista à exibição de uma festa a qualquer preço, a de um povo para quem se organiza uma alegria obrigada. Trata-se de uma organização assente num dispositivo que condiciona os corpos e os espíritos; a língua associada à linguagem é incorporada e 
a fala e o comportamento são heranças destinadas a tornarem-se automatismos.

Tratando-se de rememoração da língua transmitida nestas condições, não são vocábulos que me ocorrem, é antes uma imagem ostentada nas paredes da escola, a da "Lição de Salazar", que se inscreveu na minha retina e que retorna de maneira obsessiva.

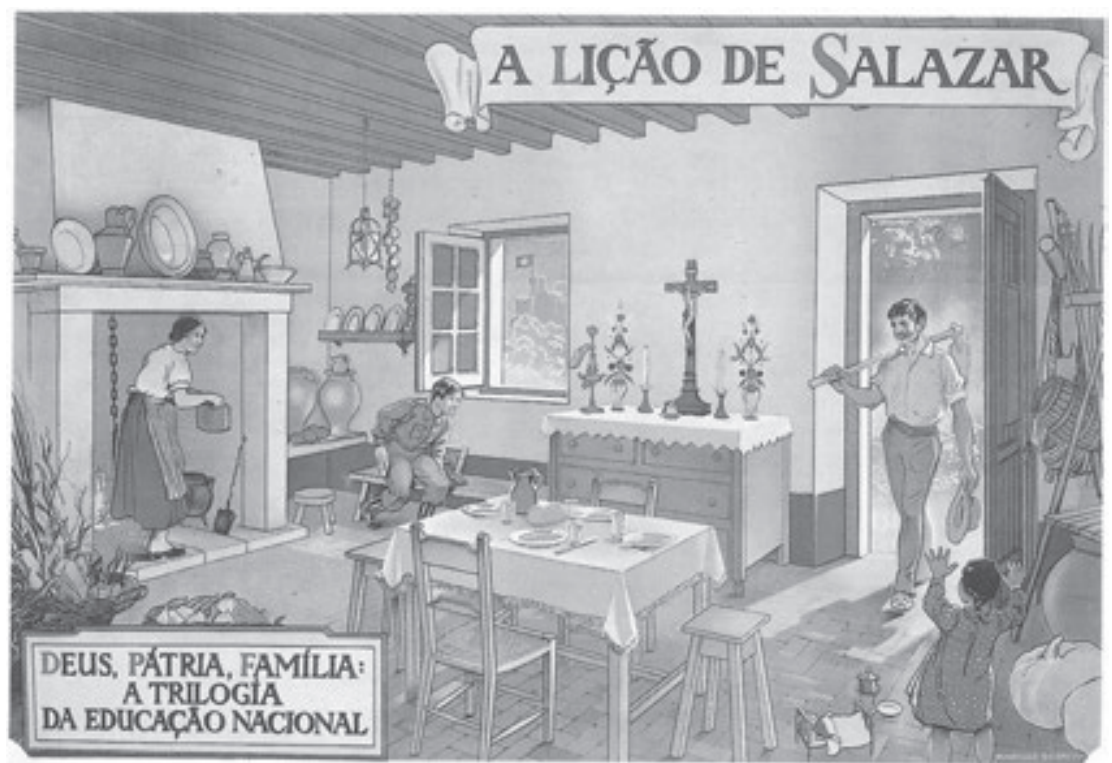

Fig. 1 Um dos cartazes da série "A lição de Salazar", difundidos a partir de $1938 .{ }^{3}$.

"Lição" e "educação" são as palavras-chave que indicam a finalidade desta pedagogia diretiva incontornável que determina os

3 Em 1938, foi editada uma coleção de cartazes (desenhados por Martins Barata) intitulada "A escola portuguesa", que figurava nas paredes das escolas da época. $\mathrm{Na}$ série, esta "lição de Salazar" resume bem o que se pretendia inculcar: idealiza-se a ruralidade, a família cujos membros têm papéis imutáveis de acordo com idade e género (veja-se que a mulher, que Salazar queria confinada ao lar, encontra-se aqui literalmente na lareira), promove-se a religião católica como fundamento indispensável. 
papéis de cada um, como se atores fossem de uma peça cujo final é imutável. Na verdade, esta representação iconográfica é como um quadro de uma cena em que as personagens têm lugares marcados; são as representações sociais bem como de género e onde a ruralidade é levada ao apogeu. A minha língua materna está maculada por esse passado; evocar o património linguístico que herdei é também convocar, no momento da primeira "separação", essa realidade. Trata-se de um sistema de evidências sensíveis condicionadas por um contexto,

uma partilha do sensível que fixa ao mesmo tempo um comum partilhado e partes exclusivas [...] A partilha do sensível faz ver quem pode partilhar o comum em função do que faz, do tempo e do espaço em que essa atividade se exerce. Ter esta ou aquela profissão define assim competências ou incompetências em comum [...] É uma divisão do tempo e dos espaços, do visível e do invisível, da palavra e do ruído que define simultaneamente o lugar e o desafio da política como forma de experiência. A política incide no que se vê e no que se pode dizer, em quem tem competência para ver e qualidade para dizer, nas propriedades dos espaços e possibilidades do tempo.

(Rancière, 2000: 13).

Aquando da primeira deslocação física operada após a emigração clandestina do meu pai, não tinha qualquer capacidade de formular estas "evidências sensíveis". Ora, as posições e os movimentos do corpo, as funções da palavra, as repartições do visível e do invisível desse tempo, estando embora contaminados pela propaganda do regime, misturavam-se numa forma de património comunitário imaterial legado. A língua intercala-se numa herança patrimonial cultural imaterial que se perpetua de maneira consuetudinária, e sabemos o quanto os serviços do Estado Novo interferiram na manipulação 
de certas práticas culturais populares, ao procederem a um tipo de folclorização da cultura (dos Santos, 2008).

\section{O corpo como vetor semântico}

Reapropriar-se deste património, aí detetando os automatismos impostos pela situação ditatorial, permite constituir uma lista de "mentefacts" , álbum de recordações coletivas e individuais, indispensáveis para prosseguir na existência. Este desafio permanente permite ir ao encontro da linguagem perdida, sendo "tudo o que a espécie humana que vive no planeta conseguiu inventar para superar os limites que a sua estrutura mental e material lhe impõe - tantas formas, gestos, sons, tentativas de superação ou de revolta às quais se atribui o nome de imaginário" (Duvignaud, 2004: 13).

Mas este caminho para trás apenas é possível depois da tomada de consciência da ligação entre língua e poder. A chegada do migrante ou do exilado ao país que se dizia então "de acolhimento", caracteriza-se pela demonstração da dissemelhança entre si próprio e o novo contexto de vida. A passagem em direção à outra língua é também a incorporação da língua do outro, é colocar-se numa postura de imitação da alteridade, é pôr o seu corpo (audição, respiração, aparelho fonador), modelado por uma língua primeira, na disposição de reproduzir o idioma desconhecido e que se torna como um intruso numa organização física e mental previamente adquirida.

Existir significa, em primeiro lugar, mover-se num espaço e numa duração, transformar o seu meio graças a uma soma de gestos eficazes, selecionar e atribuir um significado e um valor aos estímulos incontá-

${ }^{4}$ No âmbito do património imaterial, o conceito de "mentefact" define o conjunto de produções espirituais ou intangíveis constituindo a parte imaterial do património etnológico. Por outro lado, o "artefact" é o objeto fabricado ou transformado pelo homem. Estes termos criados em língua inglesa costumam permanecer nesta língua. 
veis do meio graças a atividades percetíveis, fornecer um reportório de gestos e mímicas, um conjunto de ritualidades corporais que contam com a adesão dos outros.

(Le Breton, 2010: 4).

O que está em causa aqui são as representações físicas de cada ser humano, decorrentes de sistemas simbólicos, são constituídas por referências culturais que abrem mais amplamente para o teatro da vida e as suas realizações. A existência é antes de tudo corporal, e o contexto social modela o corpo que se torna um "vetor semântico" a demonstrar a sua relação com o mundo, a partir de elementos que vão da expressão de sentimentos, de etiquetas de ritos de interação, a encenações da aparência. Quer seja emissor ou recetor, o corpo produz portanto perpetuamente sentido e insere o homem num dado espaço social e cultural.

Os sociólogos e os antropólogos analisaram bem esta construção social que constitui a linguagem do corpo e a investigação sobre estas questões está longe de estar encerrada. Marcel Mauss, em particular, quando define as "técnicas do corpo como as maneiras através das quais os homens, de sociedade para sociedade, de uma maneira tradicional, sabem servir-se dos seus corpos" (Mauss, 1950: 365); o que interessa ao investigador é ver como a educação e a tradição imprimem marcas culturais indeléveis no corpo (Jacquet, 2001: 12). Outras correntes sociológicas interessaram-se mais pelas diferenças sociais e sexuais que moldam os esquemas corporais. Assim, Pierre Bourdieu, que perceciona o corpo como um produto sócio-cultural e, para quem, "a relação com o corpo não provém diretamente da imagem dele que os outros nos devolvem, mas para certos modelos do corpo "legítimo" que regem a avaliação desta imagem em função da posição do sujeito na estrutura social" (Maisonneuve, Bruchon-Schweitzer, 1981: 84). Por seu lado, Merleau-Ponty acentua o facto de que "a organização anatómica do corpo deixa aberta uma quan- 
tidade de possibilidades de maneira que o seu manual de utilização não é entregue de maneira definitiva, Turnkey, mas é inventado, tal como a língua, devendo assim ser decifrado" (Jacquet, 2001: 188). Noam Chomsky e Michel Foucault evocam, por seu lado, o desenvolvimento de uma natureza humana como conceito biológico, e as investigações sobre a linguagem ganham uma grande importância, como se pode verificar com Claude Hagège, que concetualiza o homem como um enunciador psicossocial. Esta reflexão sobre o comportamento humano e sobre o lugar do corpo na sociedade é também enriquecida pelo desenvolvimento das ciências cognitivas, em particular pelas neurociências.

\section{A partilha do sensível, passar de uma língua à outra}

O conceito de "mentefact" permite reagrupar todas as manifestações imateriais produzidas pelo homem, mas a definição estabelecida pelo Observatório da cultura e das comunicações do Quebeque convém particularmente ao meu propósito: "os saberes e as proficiências de uma coletividade, tais como o património linguístico, a toponímia, o património científico, o património áudio-visual e património de expressão" (Blanchet-Robitaille, 2012). Englobando a língua/património tanto do ponto de vista linguístico como físico e comportamental, consegue aproximar a partilha do sensível (Rancière, 2000) já evocada e que está no centro da reflexão ligada à minha atividade profissional e artística. Atriz e encenadora bilingue francês/ português, pude testar a passagem de uma língua à outra de uma maneira muito concreta, em primeiro lugar no palco, depois como professora. É evidente que a prática do teatro leva a uma tomada de consciência do corpo portador de uma articulação, de uma voz, utensílios indispensáveis para o bom domínio de uma língua, permitindo aí rastrear todas as suas potencialidades. Tirando partido 
da prática do palco e de atividades ligadas às artes do espetáculo, trabalho sobre os dois idiomas, procuro as suas comunicações e dou cursos de língua oral na forma de atelier bilingue (dos Santos, 2012). A partir de uma língua matriz (na maioria das vezes, o francês), propõe-se um caminho até, pelo menos, um outro idioma. Trata-se de sugerir uma outra abordagem/experiência da noção de língua tanto na linguística como no teatro. Os ateliers são assim o lugar de eclosão de capacidades muitas vezes desconhecidas e das quais cada um é portador; esta descoberta individual é acompanhada por um percurso em comum, no seio do grupo constituído.

O objetivo é, também, que cada um tome consciência da sua própria maneira de falar a/da sua língua. É, simultaneamente, uma forma de introspeção do indivíduo, analisando o seu corpo portador de voz e fala, e já um trabalho sobre a precisão, a observação, e a seguir sobre a capacidade de formular estes elementos de si subitamente liberados. O atelier desempenhará plenamente o seu papel: antes de evocar a palavra articulada, é preciso compreender a respiração, a voz e mais amplamente o corpo e os lugares fundamentais que impelem o ar para as cordas vocais. $O$ ator compreende então que todo o seu corpo abarca e impele a sua voz, as suas palavras, a sua língua... O papel do grupo constituído em atelier é fundamental: o indivíduo ao nosso lado perceciona as características do nosso ser exteriorizadas, de maneira mais imediata e aguda; ele remete-nos para nós próprios, formula esse outro ser dissimulado em nós. Por vezes, esta observação dos outros torna-se também propícia ao espelho. $\mathrm{O}$ ator bilingue torna-se revelador de forças, de vozes até então escondidas; tendo partido à procura do outro em si próprio, revela a alteridade humana de maneira quase mágica. É já o teatro, o espetáculo: dar a quem olha a visão cénica doutros "eles mesmos" numa representação da vida. Pois trata-se também de abrir à imaginação, ao que Édouard Glissant (2010: 53) chama o imaginário das línguas, falar a língua aberta ou fechada, afirma, apelando ao imaginário das humanida- 
des. Não se trata mais de ser bilingue, mas multilingue: "A palavra está ligada a uma paisagem, a um tempo, mas ela tenta encontrar todas as paisagens e todos os tempos do mundo" (Glissant, 2010: 63).

"O à vontade está ligado à adequação ao papel, à convicção que se está bem no seu lugar, que o papel, retomando a terminologia interacionista, é validado pelas normas em vigor" (Goffman, 1973: 56), mas este à vontade implica uma reflexão, um retorno sobre si próprio que o trabalho em atelier permite desencadear, favorecendo um comportamento autónomo e consciente.

O professor não pode sair do seu etnocentrismo linguístico e cultural para descobrir que a língua que utiliza espontaneamente nas suas aulas é a de uma classe social sem se aperceber ao mesmo tempo que a língua que os alunos falam espontaneamente deve o essencial das suas características, aprovadas ou condenadas, à origem social deles.

(Bourdieu, Passeron, 1965: 463).

O objetivo é tornar explícitos todos estes pressupostos e chegar a uma transmissão aberta que revele as opacidades admitidas (as evidências invisíveis). Muitos dos meus estudantes, na universidade, são filhos ou netos de imigrantes portugueses em França, e os ateliers realizados são a ocasião para questionamentos e descobertas favorecidas por uma experimentação em direto, uma reflexão sobre a linguagem física e linguística, bem como sobre as heranças e os automatismos incorporados, que a língua e a voz refletem.

"Aprender é, indissociavelmente, adquirir saberes e adquirir o saber do código no qual esses saberes são suscetíveis de serem adquiridos" (Bourdieu, Passeron, 1065: 462). Esta definição coloca indiretamente a questão da norma linguística ensinada; esta é determinada por instruções oficiais que definem uma norma que reflete as preocupações linguísticas próprias de um período. Parece importante ultrapassar as tais normas impostas a fim de não ensinar 
uma língua estagnada, bem como dar o seu sentido próprio à "língua viva", quer dizer, dar aos alunos a possibilidade de a ouvir nas suas variações. Se seguirmos a lógica do processo seguido no atelier de língua em movimento, trata-se de assegurar que cada um possa apoderar-se do objeto linguístico ensinado, a fim de o tornar seu. No quadro do ensino bilingue, incita-se também os alunos a produzirem metadiscursos sobre as duas línguas. "Aprender uma língua ou duas ou três, escrevê-la, é negociar sem parar, consigo mesmo, com a sua sensibilidade, com a sua personalidade, com a sua cultura. É passar a dominá-la" (Lapeyre-Desmaison, 2011). À pergunta "o que é que é aprender uma língua", junta-se "que língua"? Um modelo ou as possibilidades infinitas dessa língua? Esta pergunta não pode obter uma resposta unívoca ou assente. Se cada locutor se encontra perante a obrigação de se servir da sua língua, esta não deveria ser um simples utensílio funcional de comunicação, mas algo que faça parte de si próprio; certos alunos podem mesmo encontrar-se como estrangeiros perante a língua por eles falada. Assim, no que diz respeito ao ensino do português, é preciso evitar ostracizar as abordagens à língua que fogem à norma do "bem falar" em Portugal e que excluem qualquer articulação da língua de Camões que não seja a de Lisboa ou de Coimbra. Esta conotação social associada à fala e à sua incorporação, tenho-a rastreado com a companhia de teatro Cá e Lá, desde há mais de 30 anos.

\section{O teatro como lugar para tomar a palavra}

Em abril de 1980, foi apresentado um espetáculo com um título provocador que iria dar que falar: $O$ cu entre duas cadeiras $^{5}$, repre-

5 Em francês, a expressão "Le cul entre deux chaises» (que deu o título original à primeira peça de teatro da companhia Cá e Lá) também podia ser traduzida por "sentado entre duas cadeiras" e significa estar dividido entre dois espaços, duas escolhas. 
sentado por um grupo de jovens da chamada «segunda geração de imigrantes" portugueses em França. Esta terminologia, então habitual para referir os filhos dos que se tinham exilado em países mais propícios a permitirem-lhes sustentar-se bem, como às suas famílias, iria ganhar uma coloração militante após a eleição de François Mitterrand, no ano seguinte e, mais particularmente, com a Marcha pela Igualdade e contra o Racismo, em 1983. O êxito da "Marcha" (100 000 pessoas em Paris), igualmente denominada "Marcha dos Beurs"6 pelos média, não satisfaria totalmente os seus protagonistas, que iriam continuar a luta através da organização da "Convergência 84 ", desta vez com trajetos de motorizada até Paris, passando por numerosas cidades do país. Os membros do grupo de teatro, que se chamaria Cá e Lá precisamente a partir desse ano, e constituído essencialmente por raparigas, figuraram entre os poucos jovens de origem portuguesa a terem participado nestes movimentos reivindicativos. Muitos dos manifestantes davam os primeiros passos numa ação coletiva reivindicativa. O que os unia era a necessidade de tomar a palavra na primeira pessoa, com uma vontade de afirmação enquanto sujeitos políticos fora de grupos ou de partidos organizados. Tornando-se uma companhia profissional, Cá e Lá cumpriu 30 anos em 2013, mas decidiu que a única celebração seria continuar a sua atividade atípica.

É na universidade que se encontram estas jovens mulheres que sentem uma necessidade visceral de exprimirem a dupla cultura que é a delas. Estudantes de letras e de línguas, encontram-se num processo de busca de aprofundamento da origem, desejando

6 A denominação «beurs" é uma forma de neologismo que designa os jovens de origem magrebina nascidos ou a viver em França. O termo foi criado através da prática do que é designado em França por "verlan" (tipo de calão), isto é falar ao contrário (à l'envers); assim, a palavra a-ra-beu deu beu-ra-a, depois beur assim como Rebeu, que tem o mesmo sentido; o termo aparece ligado primeiro a uma rádio associativa (Rádio Beur, 1982) e, em seguida, populariza-se até que entra no dicionário Le Robert em 1985. 
desenvolver os seus conhecimentos para melhor afirmarem a sua dupla identidade já bastante assumida. O lugar do seu encontro não é, como tal, irrelevante; a reflexão, a redefinição perpétua dos termos usados, a vontade de construir uma arquitetura própria para o pensamento estrutura-se com o ensino recebido na universidade, onde elas procuram os elementos intelectuais para a sua formulação. Inicialmente, o teatro parece-lhes ser o espaço propício para uma tomada de palavra representativa, tanto da sua individualidade como do género que elas formam. Trata-se de exprimir a particularidade de uma situação em que a dupla pertença era reivindicada como uma cultura em si, afirmando uma identidade feminina: evocar existências complexas e bipolares; a duas línguas respondem duas culturas e dois modos de vida, por vezes antagónicos, a que era chamada de "cultura de origem" face à "cultura de acolhimento".

Desenvolveram-se então estudos sociológicos que abordavam estas problemáticas identitárias com muitas estatísticas, entrevistas, testemunhos e outras histórias de vida. A primeira criação de Cá e Lá, O cu entre duas cadeiras tornou-se, de imediato, objeto de investigação. Peça resultante de um trabalho coletivo, exprime bem o famoso mal-estar identitário da segunda geração. Via-se ali a vida de família em França, em que os pais queriam perpetuar um modelo comportamental português desfasado do que se vivia no exterior do lar. Assim, à amiga francesa de visita, que é surpreendida pelo cheiro do jantar a ser preparado (bacalhau com grão), a jovem Maria responde que também ela gostaria de comer de vez em quando "gratin dauphinois"; a comida aparecia aqui como a melhor maneira de simbolizar a separação entre estes dois mundos que compunham a vida da protagonista. Os dois atos da peça destacam também a diferença de papéis atribuídos segundo a identidade

7 Prato típico francês genuíno da região de Oisans (Alpes franceses) confecionado com batatas, manteiga, creme e queijo, gratinados no forno. 
sexual, apresentando um esquema familiar próximo do modelo patriarcal herdado do Portugal dos anos 60. Um modelo inculcado pelo salazarismo, em que o pai dispõe de toda a autoridade, à qual se submete a mulher dedicada ao lar e a filha obediente e resignada.

A estética e a escolha da encenação adotadas pela companhia dão a estas situações um ponto de vista desfasado, optando pelo humor corrosivo, uma forma de rir de si próprio que exagera o traço e que dá uma visão dilatada da realidade apresentada de forma arrasadora. A crítica contundente não se detém apenas na "cultura de origem", visa também a de "acolhimento" e o famoso discurso dos sociólogos, que podem ser representados em palco de capacete colonial a tomar apontamentos em papel higiénico, uma maneira clara de recusar qualquer interpretação "de cima para baixo" ou qualquer análise especializada de uma situação que os atores querem continuar a controlar. "Cá e Lá optou por um certo teatro, escolheu a sua noção de cultura contando as vidas triviais de pessoas humildes frequentemente ignoradas, estas vidas de nada, estas histórias esquecidas para que não sejam olvidadas", assim é dito no programa de Sudexpress, a segunda criação da companhia, precisando que se trata de falar de "anónimos, de gente sem história que todavia tem uma". Este espetáculo em sete quadros enumera os episódios da vida no quotidiano de personagens femininas que, da professora à patroa, da funcionária do ANPE (Centro de Emprego, em Portugal) ou do Consulado, passando pela mulher da limpeza, espelham diferentes facetas da vida de mulheres que cada uma por seu turno aguenta, tentando desconstruir um sistema que não as ilude.

Passando do português para o francês, toda a atividade artística da companhia é fundada na experimentação permanente da noção de passagem de uma língua para a outra; cada espetáculo possui uma versão dupla e pode ser representado numa língua ou noutra. Para o ator, a consciência física desta passagem é muito sensível. O seu corpo, a sua respiração, a sua voz modificam-se consoante 
a língua a articular. A carga afetiva, bem como o conteúdo social, diferem segundo os idiomas. Assim, os atores de Cá e Lá investigaram particularmente o sotaque como fator de identificação social. $\mathrm{O}$ ator, formado na imitação, modula aqui as suas personagens segundo os níveis de língua, exercita-se nas articulações do padrão como nas que são mais rudes e, muitas vezes, culturalmente menos respeitadas. Utiliza-se deliberadamente a mistura do português e do francês, uma forma de metalíngua utilizada nas comunidades imigrantes, o "françoguês", frequentemente desprezado. A estética dos espetáculos de Cá e Lá construiu-se ao longo desta pesquisa centrada na noção de cultura desvalorizada, em particular a do migrante português. A representação cénica integra deliberadamente signos que fazem referência "ao sujo", ao que é socialmente desvalorizado e que pode ser identificado como uma cultura "bastarda". O corpo em palco aparenta-se ao corpo grotesco definido por Bakhtine. Aproximamo-nos aqui dos festejos do Carnaval, que mais do que espetáculos, eram antes exibições amalgamadas, estranhas ao distanciamento e à apropriação só pelo olhar (Le Breton, 2000: 30). Um teatro de mãos sujas, declararam as atrizes de Cá e Lá de maneira deliberada.

\section{A forma híbrida ou a onomatopeia aproxima-se da palavra}

Bernard Lahire evoca as distinções culturais e a luta de si contra si, e que leva a detestar a parte popular de si.

Enquanto esquema de perceção, a oposição do tipo nobre/popular ou legítima/ilegítima (e toda a série de oposições associadas ou equivalentes: alto/baixo, digno/indigno, culto/inculto, inteligente/parvo, etc) aplica-se também à diversidade de práticas e preferências de muitos indivíduos. Diferenças entre classes, de facto - com o "povo" como figura contraposta da qual é preciso se demarcar custe o que custar mas também diferenças de si para si (entre um estado atual de si e um 
estado anterior de si ou entre estados paralelos de si), estas últimas podendo mesmo dar lugar a lutas de si (legítimo) contra si (ilegítimo). (Lahire, 2005: 138)

E constata que os indivíduos com perfis culturais heterogéneos ou dissonantes são frequentemente, eles mesmos, arena de uma luta de classificações. "A figura do "povo" (urbano ou rural) assombra [...] implícita ou explicitamente muitos juízos desqualificadores: música de supermercado, programa para broncos, humor popularucho, é pimba" (Lahire, 2005: 138). Este povo, do qual é preciso demarcar-se, toma aqui a figura do imigrante gozado em Portugal e pela elite portuguesa no estrangeiro. A tomada da palavra de Cá e Lá situa-se precisamente na vontade de reabilitação destes desterrados das montras das representações oficiais.

Divididas entre duas culturas e dois meios sociais, as atrizes de Cá e Lá entendem-se a si próprias como indivíduos de perfis culturais heterogéneos e dissonantes. Estas estudantes, que através dos estudos iam aceder a um outro meio social, tinham acesso a uma linguagem que lhes permitiria resolver este possível afastamento da origem, encenando a condição de vida dos seus pais, assim como a sua.

Quando as instituições, obras ou práticas culturais são hierarquizadas socialmente, então associar-se ao grande, ao nobre, ao elevado e ao respeitável é uma maneira boa de se engrandecer, de se enobrecer, de se elevar ou de se fazer respeitar. Por contraste, ao se virar para atividades ou produtos entendidos como vulgares, pequenos, baixos ou comuns, baixa-se, regride-se, deteriora-se ou cai-se para mais baixo. (Lahire, 2005: 138).

Ao se identificar com a figura do emigrante e da sua descendência, em vez de adotar um repertório ligado à literatura portuguesa unanimemente reconhecida, as atrizes da companhia correm deli- 
beradamente o risco de serem ostracizadas pela grande cultura ou pela alta cultura. Este posicionamento é vivido como uma reivindicação, uma maneira de militar, e transforma-se numa forma de arte popular que se torna libertadora.

"Modalidade espetacular que, paralelamente ao teatro institucionalizado, escolhe os lugares públicos - fábricas, lojas, meios de transporte - com o objetivo de mudar de vida" (Corvin, 2008: 718): Cá e Lá entra parcialmente nesta definição de "teatro de intervenção", tendo já representado em todos esses lugares. Esta forma de teatro, ligada a um espaço preciso e à atualidade, baseia-se numa relação de trocas entre um grupo de atores e um meio, colocando mais ênfase no processo de produção do que num produto terminado e fixo; articulando-se em torno de formas breves, situa-se como evento e não no domínio do repetitivo. As formas adotadas pela companhia bilingue, primeiro sketchs, assim como performances e colocações em espaços diversos, incorporam bem esta descrição. Estes modelos evoluíram entretanto e peças como Mulher ao mar ou Debaixo da oliveira adotam formatos mais clássicos, mantendo um tom propositadamente desfasado e cáustico. Note-se que, ao fim de 30 anos de existência, Cá e Lá segue o movimento natural dos grupos de teatro de intervenção que nos anos 80 se virou para a animação de rua, depois para o teatro de rua e a performance, escolhendo domar a cidade e mudar o olhar de um público desejado o mais vasto possível. A estética dos espetáculos também ela evoluiu a partir de Sudexpress, com a escolha da máscara branca que insinua a mímica, a expressão gestual que permite a compreensão da fábula para lá da palavra articulada. As numerosas tournées internacionais da companhia, a partir de 1983, são também possíveis através da superação do problema da compreensão linguística. Mas não são espetáculos mudos, trata-se antes de uma forma híbrida em que a onomatopeia se aproxima da palavra, em que o corpo é signo primordial, acompanhado pela voz no tempo e pelo rosto, 
cujas expressões relembram tanto o cinema mudo como as máscaras mortuárias ou o nô contemporâneo, mas também o palhaço.

Como dar a uma forma estética a eficácia espetacular capaz de fundar uma adesão a uma mensagem politicamente reconhecível? Como os artistas, quaisquer que sejam, podem adaptar, desviar, transformar esta forma permitindo que um público não convencido seja tocado, apanhado, conduzido pela sua efetivação?

(Biet, Neveux, 2007: 10).

Estas questões que o teatro militante coloca, se não foram conscientes desde os primeiros anos de atividade da companhia, instintivas de uma certa maneira, tornaram-se constitutivas da sua evolução e operantes num processo de libertação dos constrangimentos; salvadoras porque portadoras de autonomia e de superação de si. "No caso da autodidática ou de mobilidades sociais ascendentes, o hiato de si para si é um hiato entre um si passado, que aprecia as coisas mais populares [...] e um si presente mais evoluído" (Lahire, 2005: 139). O trabalho cénico realizado por Cá e Lá provém de um processo de formulação individual e coletiva que faz com que a separação do legítimo e do ilegítimo deixe de ser vivida como uma divisão interna que, noutros casos, dá lugar a lutas de si contra si.

\section{Património, língua e poder}

"Não se trata de desenraizar, trata-se de conceber a raiz menos intolerante, menos sectária: uma identidade-raiz que não mata à sua volta mas que, pelo contrário, estende os seus ramos até aos outros" (Lahire, 2005: 139). Assim, Cá e Lá tem tentado constantemente abrir o seu horizonte, concentrando-se doravante num trabalho pluridisciplinar que inclui ciclos de formação de atores plurilingues que vão 
dar à luz Perfumes de Lisboa, um festival de urbanidades cruzadas entre Lisboa e Paris ${ }^{8}$. A iniciativa partiu, em 2007, do encontro de um grupo de artistas, um bairro, lugares e parceiros que acreditaram logo neste projeto tão local como internacional, reflexo da cidade cosmopolita em que o bairro não é um paradoxo pois, mantendo-se particular, abraça as línguas e as culturas dos que o compõem. O trabalho da companhia, como o que levo a cabo na universidade, procedem de uma reflexão teórica, bem como de uma prática artística em que a relação com a língua é considerada tanto do ponto de vista da expressão linguística como do corpo; trata-se do corpo físico, assim como do corpo social, e qualquer comunicação, qualquer diálogo, envolve uma forma ampla de linguagem que implica uma partilha do sensível, em que a língua é "mentefact" que reflete um património imaterial em ligação com a história coletiva e o

8 Cá e Lá é uma companhia bilingue francês/português sediada na região parisiense. Tudo começa em 1979 com a necessidade urgente de uma tomada de palavra reivindicativa que logo faz manchetes face a interlocutores sempre binários: a sociedade francesa que as jovens mulheres de origem imigrante e fundadoras do grupo interpelam e o campo cultural português aqui definido em ligação com o Portugal dos seus pais como com a sua representação no território francês (o meio associativo português, as diversas estruturas privadas ou de Estado identificadas com a cultura portuguesa em França). O tom provocador, a linguagem física e vocal, o repertório, inicialmente proveniente da criação coletiva, chamam a atenção do público ou de sociólogos perante um grupo feminino muito atípico e que rompe com a imagem da imigração portuguesa em França, a de uma comunidade silenciosa, dócil e trabalhadora. A participação na "Marcha" ao lado dos "beurs"é o reflexo desta postura de pôr em causa os estereótipos e de uma reivindicação através do teatro. Companhia profissional a partir de 1983, Cá e Lá vai desenvolver uma atividade cada vez mais visível no âmbito internacional: numerosas tournées da Escandinávia a Portugal e peças que chegaram às 300 representações em França. A partir dos anos 90, a componente formação vai desenvolver-se em torno do trabalho de Graça Dos Santos e de ateliers de prática centradas na questão do bilinguismo no teatro. A criação, em 2007, de "Perfumes de Lisboa - Festival de urbanidades cruzadas entre Lisboa e Paris" vem confirmar a particularidade do percurso de uma companhia de teatro cuja atividade se centra no diálogo entre línguas e culturas. A pluridisciplinaridade do festival, a diversidade de lugares abertos a todos os públicos, são reflexo de um movimento incessante, elaborado e sempre portador de uma palavra que interpela. Para mais informação: http://www.caela.net/ e http://parfumsdelisbonne.com ou então consultar o sítio internet do Museu da História da Imigração em Paris: http:// www.histoire-immigration.fr/search/apachesolr_search/ca\%20e\%201a. 
percurso individual. Assim, formular estes temas implica o "forum" tanto como o "domus", um "eu" e um "nós".

A língua é uma legislação, a língua é um código. Não vemos o poder que está dentro da língua, porque esquecemos que qualquer língua é uma classificação e que qualquer classificação é opressiva. [...] A partir do momento em que é proferida, ainda que na intimidade mais profunda do sujeito, a língua entra ao serviço de um poder.

(Barthes, 1978: 14).

Todo o meu percurso consiste, assim, na tomada de consciência de automatismos e, em seguida, na sua superação. Pois falar remete para a origem da aprendizagem primordial: a da escola, decerto, que nas nossas sociedades é regulamentada a partir do exterior, mas ainda antes desta existe a herança, transmitida pelo círculo familiar, uma herança que, diria, começa no útero e depois a do círculo social, que também deixa a sua marca. São diferentes estratos gravados na memória física e mental que refletem um ou dois modelos que pertencem ao íntimo e ao coletivo. Esta bagagem patrimonial é um entrelaçamento de elementos adquiridos, frequentemente percecionados como inatos, mas cuja relação com o poder e o molde imposto é audível na elocução e visível nos gestos e na postura física. A relação entre património e língua não pode ser pensada sem o discurso do poder que se inscreve de maneira inapagável na linguagem. "Falar, e mais ainda discursar, não é comunicar, como se repete frequentemente, é subjugar: qualquer língua é uma regência generalizada" (Barthes, 1978: 13). 


\section{Referências bibliográficas:}

ABDelilaH-BAUER, Barbara (2006), Le défi des enfants bilingues. Grandir et vivre en parlant plusieurs langues. Paris: Editions La Découverte, 186.

BARRENO, Maria Isabel (2010), “A fala”, JL, Jornal de letras artes e ideias, n. ${ }^{\circ} 1033,5-18,16$.

BIET, Christian; NEveuX, Olivier (dir.) (2007), Une histoire du spectacle militant. Théâtre et cinéma militants 1966-1989. Paris: L'Entretemps Editions, 321.

BLANCHET-ROBITAILle, Ariane (2012), "Le mentefact au musée: la mémoire mise en scène”, Muséologies: les cabiers d'études supérieures, vol. 6, n. ${ }^{\circ}$ 1, 55-75. Consultável em: http://id.erudit.org/iderudit/1011532ar, DOI: $10.7202 / 1011532$ ar.

BOURDiEU, Pierre; PASSERON, Jean-Claude (1965), "Langage et rapport au langage dans la situation pédagogique", Les temps modernes, n. ${ }^{\circ} 232$, 435-466.

BRAUNSTEIN, Florence; PÉPIN, Jean-François (1999), La place du corps dans la culture occidentale. Paris: Presses Universitaires de France.

CORVIN, Michel (dir.) (2008), Dictionnaire encyclopédique du théâtre à travers le monde. Paris: Édition Bordas/SEJER.

DeTreZ, Christine (2002), La construction sociale du corps. Paris: Editions du Seuil.

CROM, Nathalie (entrevistadora), "Il était une fois... Jean Claude Ameisen, chercheur en biologie, passionné de science, de philo et de poésie”, consultado a 24.03.2015, em http://www.telerama.fr/radio/il-etait-unefois-jean-claude-ameisen-chercheur-en-biologie-passionne-de-sciencede-philo-et-de-poesie, 106868.php

DOS SANTOS, Graça (2008), "La fête à tout prix: le corps mis en scène par l'Etat Nouveau de Salazar", Plural Pluriel, revue des cultures de langue portugaise, $\mathrm{n} .{ }^{\circ} 2$, Le spectacle de l'histoire, le spectacle dans l'histoire. Em inglês, consultável em: www.pluralpluriel.org. 
DOS SANTOS, Graça (2012), "Passages du corps à la voix, à la recherche de l'autre: vers l'acteur bilingue”, Plural Pluriel, revue des cultures de langue portugaise, $\mathrm{n} .{ }^{\circ} 10$, Imaginaires de la voix. Em inglês, consultável em: www.pluralpluriel.org.

DOS SANTOS, Graça (2013), “"Je est un autre». L'expérience du bilinguisme et du théâtre pour enseigner et apprendre une langue”, Langages, n. ${ }^{\circ} 192,111-117$.

DOS SANTOS, Graça (2014), "Cá e Lá, un pont de corps et de voix: le parcours d'une compagnie de théâtre en quête d'imaginaire multilingue (1983-2013)", Les langues Néo-Latines, $108^{\mathrm{e}}$ année, n. ${ }^{\circ} 368$, 85-93.

DOS SANTOS, Graça (2014), "La reconnaissance de soi à travers le corps de l'autre: quand un cours de langue orale ouvre sur le théâtre de la vie", in Gilles Louys e Emmanuelle Sauvage (dir.), De la singularité dans la communication interculturelle: approches transdisciplinaires. Paris: L'Harmattan, 175-182.

DUVIGNAUD, Jean (2004), "Le langage perdu", in Internationale de l'imaginaire, $\mathrm{n}^{\circ} 17$, Le patrimoine culturel immatériel, les enjeux, les problématiques, les pratiques, Babel Maison des cultures du monde, 11-15.

ERARD, Yves (2000), "Faire entendre sa voix", in Multitudes, n. ${ }^{\circ} 42$, 190-197.

FLEISCHER, Alain (2005), L'accent une langue fantôme. Paris: Editions du Seuil, 171.

GinZBurg, Carlo (2008), “L'œil de l'étranger”, L'Homme, 2008/3, n. 187$-188,33-39$.

GLISSANT, Édouard (2010), L'imaginaire des langues, entretiens avec Lise Gauvin (1991-2009). Paris: Gallimard.

GofFMAN, Erving (1973), La mise en scène de la vie quotidienne. Paris: Éditions de Minuit.

HUSTON, Nancy (1999), Nord perdu. Arles: Actes Sud, 130.

LAHIRE, Bernard (2005), "Distinctions culturelles et lutte de soi contre soi: "Détester la part populaire de soi»", in Hermès, "Peuples, populaire, populismes". Paris: CNRS Éditions, n. ${ }^{\circ} 42,137-143$. 
LAPEYRE-DESMAISON, Chantal; POUlin, Isabelle; ROGER, Jérôme (2011), "Sens de la langue, sens du langage", Modernités, n. ${ }^{\circ} 32$. Bordeaux: Presses Universitaires de Bordeaux.

LE BREton, David (2000), Anthropologie du corps et modernité. Paris: PUF, coll, "quadrige".

LE BRETON, David (2010), "La sociologie du corps" (1992), Que sais-je. Paris: Presses Universitaires de France.

MAISONNEUVE, Jean; BRUCHON-SCHWEITZER, Marilou (1981), Modèles $d u$ corps et psychologie esthétique. Paris: Presses Universitaires de France.

MAUSS, Marcel (1950), "Les techniques du corps", Sociologie et anthropologie. Paris: Presses Universitaires de France.

RANCIÈRE, Jacques (2000), Le partage du sensible esthétique et politique. Paris: La Fabrique éditions.

SAYAD, Abdelmalek (2006), L'immigration ou les paradoxes de l'altérité, 1. L'illusion du provisoire, 2. Les enfants illégitimes. Paris: Éditions Raisons d'agir.

STEIGER, André (2001), "Le jeu comme transparence", in Josette Féral, Les chemins de l'acteur, former pour jouer. Montréal: Editions Québec Amérique, 113-121.

ZÉKRI-HURSTEL, Régine (2001), Un nouveau regard sur l'élève, langage, gestes postures. S. L.: Editions du Rouergue, 219. 
(Página deixada propositadamente em branco) 


\section{TERRITÓRIOS E REDES NA HISTORIOGRAFIA}

A história não apresenta aos homens uma coleção de fatos isolados. Ela organiza esses fatos. Ela explica-os, e portanto, para os explicar, transforma-os em séries, a que não presta igual atenção. Porque, quer queira quer não - é em função das suas necessidades presentes que ela recolhe sistematicamente, e em seguida classifica e agrupa os fatos passados. É em função da vida que ela interroga a morte. (Lucien Febvre, 1977: 225-226)

Não se trata aqui de conceituar aquilo que já vem sendo conceituado noutros capítulos deste livro: património, influência, matriz, memória, identidade, herança, tradução... Portanto, a historiografia a que se refere o título deste capítulo abordará conexões, trocas, influências, sempre mútuas, entre súditos, sociedades, culturas e territórios que, por terem sido conquistados pelos portugueses, se foram por eles influenciados também os influenciaram. Trataremos da historiografia do império português - com sensível destaque para o Brasil -, que pode nos auxiliar a discutir o contexto no qual surgiu um património comum e compartilhado.

\section{Centros e periferias}

Em coletânea publicada em 2002, Negotiated Empires. Center and Peripheries in the Americas, os historiadores Amy Turner Bushnell e 
Jack Philip Greene utilizam os conceitos de centro e periferia para analisar o relacionamento entre os Estados europeus e seus territórios ultramarinos. Na introdução ao livro discutem a obra de Immanuel Wallerstein, O Moderno Sistema Mundial, publicada entre 1974 e 1989. Os conceitos de centro e periferia de Wallerstein foram muito usados para entender o sistema mundial colonial e mercantilista nos tempos modernos. Na sua perspetiva, um núcleo europeu composto de Estados centrais, com máquinas estatais poderosas, integrava culturas nacionais e complexas economias, que crescentemente incorporaram e dominaram áreas periféricas com Estados fracos ou não existentes - economias simples baseadas na mineração, na agricultura, em vários tipos de exploração de recursos, utilizando-se de trabalho compulsório. Nesse esquema, o centro sempre dominava a periferia, embora ele próprio não fosse necessariamente estável, uma vez que mecanismos estruturais da "economia mundo" poderiam empurrar alguns Estados-centro para um status periférico ou semiperiférico (Wallerstein, 1774-1989).

De acordo com Bushnell e Greene, apesar de Wallerstein ter desenvolvido essas categorias para facilitar a análise do processo que teve as suas origens na época moderna, e embora historiadores da América Latina tenham utilizado a sua perspetiva de sistema-mundial em combinação com a teoria da dependência para explicar o subdesenvolvimento, essa conceituação específica do relacionamento centro-periferia não tem sido fulcral nos argumentos de uma nova historiografia. O esquema de Wallerstein confere muito poder aos núcleos europeus, é exclusivamente focado na criação dos sistemas de comércio internacionais, apresentando uma visão bastante generalista para ser proficuamente aplicada à análise da história das múltiplas e complexas estruturas imperiais que emergiram das monarquias europeias nos tempos modernos (Bushnell e Greene, 2002).

Em um dos artigos que assina no mesmo livro, Greene critica o uso indiscriminado de um modelo coercitivo e centralizado de 
organização imperial, no qual poderosos Estados-nações exploravam colônias e cuja autoridade fluía de cima para baixo, do centro sobre as populações sujeitas nas distantes e distintas periferias. Assim como as monarquias compósitas, os impérios da época moderna podiam espelhar uma soberania fragmentada, além de considerável autoridade poder ser mantida pelas periferias. Em suma, a formação dos hoje chamados impérios coloniais nos tempos modernos pressupôs a construção de novos centros - ultramarinos - igualmente detentores de autoridade, por meio de complexos mecanismos de negociação (Greene, 2002).

Não nos podemos esquecer, como nos ensina Lucien Febvre na epígrafe deste capítulo, de que o historiador é um sujeito do seu tempo e as questões que coloca ao seu objeto de estudo - e às fontes que escolhe analisar - não estão dissociadas da conjuntura política, social, económica e cultural na qual nos inserimos. O que temos vivenciado nas últimas décadas são movimentos de explosão - ou de implosão - das antigas nacionalidades e a emergência de outras identidades, locais, regionais, religiosas, étnicas... Sobre elas se vem pautando um profundo rearranjo da geografia, da política e do próprio conceito que tínhamos até então de Europa. Por outro lado, a Europa - e não só ela - tem presenciado, em termos económicos e políticos, o desenvolvimento de organizações supranacionais. Tais processos levam, necessariamente, a um exercício de reinterpretação histórica daquilo que há cerca de cinquenta anos atrás era visto e sentido como dado e, quiçá, imutável.

Novos recortes do objeto historiográfico, assim como novos conceitos e novas metodologias de análise, foram sendo desenvolvidos a partir dos anos 80 e 90 do século passado, sobretudo pela historiografia anglo-saxónica e, principalmente, nos Estados Unidos. A História Atlântica (Atlantic History) é uma delas. Em obra coletiva sobre este novo método, Jack Greene e Philip Morgan afirmam ser a História Atlântica uma construção analítica e uma categoria da 
análise histórica que os historiadores inventaram para ajudá-los a organizar o estudo de alguns dos mais importantes movimentos da idade moderna: a emergência, no século XV, e o subsequente desenvolvimento do complexo banhado pelo oceano atlântico - incluindo a Europa, a África e as Américas do Norte, do Sul e todas as ilhas adjacentes - como uma extensa região de trocas demográficas, económicas, sociais, culturais, etc. Como a definiu John Elliott, a História Atlântica envolve o estudo da criação, destruição e recriação de comunidades como resultado do movimento através e em torno do oceano Atlântico, de pessoas, bens materiais, práticas culturais e valores (apud Greene e Morgan, 2009: 3). Da mesma forma, a História Global (Global History), outra categoria analítica muito em voga atualmente, enfatiza o estudo de processos que transcendem regiões, Estados, nações; processos que incluem o colonialismo e o imperialismo, as relações internacionais, as religiões, as ideologias, as migrações, as diásporas, a partir de uma perspetiva planetária, transnacional. ${ }^{1}$

O que tem sido a linha de argumentação aqui desenvolvida é que novas questões, assim como um outro recorte metodológico - e,

1 Cf., entre outros, o site do Centre for Global History, criado em 2011 no departmento de História da Universidade de Oxford, no qual se lê: "Global History in Oxford is defined broadly as the global movement of people, goods and ideas and the consequences that flow from them. Chronologically, it extends across all historical periods from Ancient to Late Modern. The Centre is particularly keen to encourage cooperation between historians of different periods, as well as places, in the study of themes of global significance, including: the dialogue between imperial, transnational and comparative history; the different meanings of the concept 'global', including the balance in the dialogue between cultures in different historical periods; the global history of rights, and the history of global governance; cross-cultural and transnational histories of varieties of representative government and of public spheres (including attitudes to public ethics and the global history of corruption); the development of economic interdependence, including its relation to technological transfer and scientific interchange; the movement of peoples as against the movement of ideas and practices; the history of regions seen in a global context, and the study of intersecting local societies; the roles of linguas francas in history, including the practices of translation and their cultural significance". (http://global.history.ox.ac.uk/) 
portanto, uma diferente perspetiva historiográfica - vêm-se impondo nas últimas décadas. A estabilidade e a coerência, por exemplo, dos conceitos de Estado e de nação, convencionalmente tomados como uma criação da "modernidade" europeia, não são mais tão evidentes quanto foram há meio século atrás. Pode-se dizer que, diante da "crise" do conceito de Estado-nação, os estudos históricos vêm tomando outras direções e privilegiando outras categorias (Cardim, 1998; Schaub, 2005/1).

Em 1992, num artigo já hoje clássico, "A Europe of Composite Monarchies", John Hall Elliott discutiu a sobrevivência da interpretação historiográfica que surgiu no século XIX, numa conjuntura de fortalecimento dos Estados Nacionais e que, voltada para a compreensão desse processo, projetou retroativamente as suas origens para as nascentes monarquias em formação nos primórdios dos tempos modernos. Para Elliott, se por um lado a Europa no século XVI era constituída por monarquias compósitas, coexistindo com uma miríade de unidades territoriais e jurisdicionais independentes, por outro, estas monarquias não deveriam ser entendidas como um meio-caminho necessário, embora incompleto e insatisfatório, no lento e sempre contínuo processo de formação de Estados unitários (Elliott, 1992). Se o Estado-nação não deve ser visto como o resultado final de um processo histórico iniciado na época moderna, torna-se necessário refletir sobre as estruturas mais amplas no seio das quais situamos as nossas pesquisas especializadas.

Não podemos, antes disso, deixar de invocar dois autores e duas obras que marcaram profundamente a tradição historiográfica brasileira. O ensaio "O sentido da colonização", de Caio Prado Júnior, publicado em 1942, formou gerações de historiadores no Brasil. Apesar de todos os méritos, que não são poucos, a sua análise, marxista, é tributária de uma perspetiva histórica nacionalista. Ao analisar a constituição do Estado e da nação no Brasil e na América 
Latina, traça, por um lado, uma linha mestra de evolução e desenvolvimento, entendendo-a, por outro, como decorrência ou manifestação interna de processos estruturais - como o desenvolvimento do capitalismo - ocorridos externamente, nos centros dinâmicos da Europa ocidental (Prado Júnior, 1977). A historiadora Maria Odila Leite da Silva Dias afirma que o impasse da contradição entre o vir a ser da nacionalidade e as relações sociais de dependência colonial, levaram Caio Prado a defender a tese da anomia dos oprimidos, da construção de uma sociedade inorgânica e da sua incapacidade de articulação política (Dias, 1989: 389-390).

Se o sentido comercial da colonização é desenvolvido por Caio Prado Jr., o livro de Fernando Novais, Portugal e Brasil na Crise do Antigo Sistema Colonial (1777-1808), publicado na década de 1970, formula um novo conceito: o de Antigo Sistema Colonial, que relaciona a dependência da colónia à metrópole, a organização das atividades produtivas e das relações de produção coloniais ao processo de acumulação primitiva de capital na Europa, de acordo com as práticas mercantilistas então em voga (Novais, 1979). Se, por um lado, essa visão praticamente nega aos atores engendrados na dinâmica do processo de colonização possibilidades múltiplas de escolha e de negociação das suas estratégias individuais e sociais, tornando-os mais objetos do que sujeitos de uma "política colonial", e, portanto, de seus destinos históricos; minimiza, igualmente, as diversidades e singularidades regionais e temporais do que se convencionou chamar de "Brasil-colónia".

Embora pouco influente nos anos de 1960 e 70, a contribuição anglo-saxónica foi-se impondo no cenário historiográfico brasileiro a partir da década de 1990, assim como a noção de império, que teve em Charles Ralph Boxer - O Império Marítimo Português (Boxer, 2000) e Salvador de Sá. A Luta pelo Brasil e Angola (Boxer, 1973) - o seu maior expoente. A sua obra discute a construção da soberania portuguesa em áreas tão distintas e distantes, do Maranhão a Macau, 
conjugando atividades comerciais, incursões missionárias, campanhas militares e administração imperial. Esta abordagem fez escola, distinguindo alguns de seus discípulos, como Anthony John Russell-Wood, cujo livro, Um Mundo em Movimento. Os Portugueses na África, Ásia e América, é uma contribuição fundamental para se pensar na dinâmica imperial portuguesa (Russell-Wood, 1998). Na mesma década, em Portugal, a coleção História da Expansão Portuguesa, obra de fôlego, gigantesco e bem sucedido projeto editorial em cinco volumes, coordenado por Francisco Bethencourt e Kirti Chaudhuri, analisou, sob o conceito de Expansão, tão caro à historiografia portuguesa, as conexões entre Portugal e os territórios ultramarinos, a partir não só dos sistemas económicos, mas também da apropriação dos espaços, da reorganização dos territórios, da disseminação das gentes, das dinâmicas sociais, das configurações do império e das práticas de identidade (Bethencourt e Chaudhuri, 1997, vols 1-3).

Os estudos sobre as articulações imperiais dos portugueses frutificaram e, em certa medida, especializaram-se nos seus diferentes circuitos geográficos. É o caso da obra de Sanjay Subrahmanyam, em particular O Império Asiático Português, 1500-1700. Uma História Política e Econômica (Subrahmanyam, 1995) e Comércio e Conflito. A Presença Portuguesa no Golfo de Bengala, 1500-1700 (Subrahmanyam, 1994); ou ainda do livro De Ceuta a Timor, de Luís Filipe Thomaz (Thomaz, 1994). Consolidou-se, assim, uma nova chave interpretativa com a qual os historiadores brasileiros passaram a dialogar. E essa chave interpretativa forjou novos conceitos.

\section{Redes imperiais}

Um deles é o conceito de rede ou redes imperiais. No capítulo "Estrutura Política e Administrativa do Estado da Índia no Século XVI", Luís Filipe Thomaz afirma que 
a expressão 'Estado da Índia' designava, no século XVI, não um espaço geograficamente bem definido, mas o conjunto dos territórios, estabelecimentos, bens, pessoas, e interesses administrados pela Coroa portuguesa no Oceano Índico.

\section{E continua:}

Daí que, quando confrontado com a noção corrente de império, o Estado Português da Índia se nos apresente como algo de original e, por vezes, desconcertante. [...] A razão é que, normalmente, os impérios representam a estruturação política de determinados espaços geográficos, enquanto o Estado da Índia é na sua essência uma rede, isto é, um sistema de comunicação entre vários espaços. (Thomaz, 1994: 207-208)

Num trabalho sobre a administração portuguesa em Angola na segunda metade do século XVIII, Catarina Madeira Santos afirma que é legítimo desobjetivar a noção de Estado em rede, de Luís Filipe Thomaz, e usá-la como categoria analítica, sobretudo no caso da África, onde a descontinuidade territorial se articula com o pluralismo institucional, jurídico e jurisdicional. Segundo a autora:

Em Angola, a relação que o Estado colonial sustentava com o território traduzia-se na construção de uma espécie de rede. As formas de presença no território - os presídios - eram satelizadas, reticuladas a partir de um centro, mas sem justaposição. (...) O objetivo da presença colonial não passava pela conquista de espaços vazios de rotas comerciais e mercadorias, mas antes pela apropriação da rede comercial existente, através de fortalezas, feitorias e feiras. Nessa perspectiva, o essencial para os colonizadores e os seus agentes não seria 'fazer território' mas, antes, aceder e intensificar a serventia de uma rede. (Santos, 2005: 109).

A autora vai além das conotações espaciais do conceito de rede, utilizando-o na análise do cruzamento de culturas políticas. A seu 
ver, o conceito operatório de Estado em rede deve ser entendido não só como lugar de trocas comerciais, mas também institucionais, ideológicas e políticas, na medida em que a teia das relações interafricanas se tecia paralelamente à malha administrativa portuguesa. Essa configuração, dotada de uma grande plasticidade, gerava equilíbrios que resultavam na coexistência de diferentes mundos e lógicas políticas, permitindo que um poder colonial, embora frágil, sobrevivesse por longo tempo (Santos, 2005: 111-112).

Num trabalho pioneiro na historiografia brasileira, publicado em 1968, José Roberto Amaral Lapa chama a atenção para o papel da cidade da Bahia na conexão entre a carreira da Índia e o comércio atlântico de escravos. Amaral Lapa foi um dos primeiros a estudar as rotas mercantis que ligavam diferentes regiões do império, conectando o Índico e o Atlântico. Era comum que os navios provenientes da Índia parassem pela Bahia e lá fizessem negócios (Lapa, 2000 [1968]). No que diz respeito à importância do tráfico negreiro na formação do complexo atlântico português, Pierre Verger (Verger, 1988 [1968]), Luiz Felipe de Alencastro (Alencastro, 2000) e Alberto da Costa e Silva (Silva, 2003) deram contribuições inestimáveis para um novo recorte espacial, com implicações económicas, políticas e culturais, calcado na profunda interdependência entre Brasil e África. No prefácio de O Trato dos Viventes. A Formação do Brasil no Atlântico Sul, Alencastro afirma: "nossa história [do Brasil] colonial não se confunde com a continuidade do nosso território colonial", pois "a colonização portuguesa, fundada no escravismo, deu lugar a um espaço econômico e social bipolar, englobando uma zona de produção escravista situada no litoral da América do Sul e uma zona de reprodução de escravos centrada em Angola". A intenção do autor é demonstrar "como essas duas partes unidas pelo oceano se completam num só sistema de exploração colonial" (Alencastro, 2000: 9). 
Mas não só. Na sua argumentação, o tráfico negreiro surge como a "alavancagem do Império [português] do Ocidente", responsável pela transmutação da escravatura em escravismo colonial, sistema que extrapola simples "operações de compra, transporte e venda de africanos para moldar o conjunto da economia, da demografia, da sociedade e da política da América portuguesa”. Ao voltar-se para o território africano dos séculos XVI e XVII, Alencastro discute a geografia comercial, ainda medieval, trans-saariana, aos poucos suplantada pela abordagem marítima portuguesa. Vitoriosas sobre as caravanas, as caravelas navegavam empurradas por "ventos negreiros". Interesses económicos e justificações ideológicas-cristãs fundem-se em O Trato dos Viventes, descortinando-nos os múltiplos significados da grande transmigração, de acordo com as palavras do padre António Vieira: o transporte contínuo de africanos ao Brasil através do Atlântico Sul. África e América não podem ser pensadas uma sem a outra (Alencastro, 2000).

Já em Um Rio chamado Atlântico, Alberto da Costa e Silva tenta relembrar-nos o que foi, durante tanto tempo, tão óbvio quanto esquecido:

Que não se pode escrever a história do Brasil durante seus quase quatro séculos de regime escravista, sem levar em conta o que se passava no outro lado do Atlântico, em cada uma daquelas áreas de onde o país recebia a mão-de-obra forçada com que ocupava a sua geografia. O que esperamos, nós, os leitores de livros de história, é que os seus autores nos digam de que áreas daquele continente vieram, em cada momento, os que mudaram o perfil humano de grande parte deste outro continente [da América], e porque foram esses e não aqueles. (Silva, 2003: 80)

Roquinaldo Ferreira retomou a questão na sua tese de doutoramento, recentemente publicada, Cross-Cultural Exchange in the Atlantic World (Ferreira, 2012). A sua minuciosa pesquisa constata 
o aumento da demanda no Brasil por escravos, a partir de finais do século XVII, tanto para suprir as necessidades das regiões açucareiras da Bahia, de Pernambuco e do Rio de Janeiro, quanto para dar conta das importações destinadas à região mineradora, recém descoberta no final daquela centúria. O início da produção aurífera tornou o porto do Rio de Janeiro estratégico para a entrada e distribuição de escravos para as Minas Gerais. Além da Bahia e de Pernambuco - praças que tradicionalmente enviavam navios diretamente para Angola, o Rio de Janeiro tornou-se, no século XVIII, num dos principais portos importadores de escravos africanos - não para traficar escravos na rede triangular Rio-Angola-Buenos Aires, como demonstrou Alencastro para o século XVII, nem tampouco para alimentar exclusivamente os seus engenhos de açúcar, mas sim para suprir a demanda dos estabelecimentos mineradores.

Ainda segundo Ferreira, entre 1736 e 1770, as três principais praças mercantis brasileiras - Salvador, Recife e Rio de Janeiro negociavam diretamente com Luanda. Os seus navios respondiam por cerca de $85 \%$ de toda a movimentação daquele porto africano, enquanto apenas $15 \%$ dos navios que chegavam a Luanda eram de origem portuguesa, ou seja, provenientes do reino. Na segunda metade do século XVIII, Alexandre Elias da Silva Corrêa escrevia que os poucos navios provenientes de Portugal que apareciam no porto de Luanda para carregar escravos "eram contrabandistas dos interesses brasílicos, e por conseguinte nocivos [àquela] conquista" (apud Ferreira, 2001: 345). A chave do sucesso "brasileiro" achava-se nas mercadorias que financiavam a compra de escravos na África: inicialmente a cachaça ou geribita, produzida nos engenhos da Bahia, de Pernambuco e do Rio de Janeiro e, cada vez mais, os panos asiáticos - curiosamente chamados de "fazendas de negros" - trazidos pela carreira das Índias ao porto da Bahia e, posteriormente, também ao do Rio de Janeiro: 
Boa parte das rotas mercantis do Império eram controladas a partir de áreas supostamente periféricas - primeiramente Bahia, e fundamentalmente, Rio de Janeiro. (...) Sob o comando dos negociantes do Brasil, o comércio de panos asiáticos interligou diferentes áreas do Império português - Brasil, África e Ásia - colocando-as em rota de colisão com os administradores lisboetas. Em 1772, a inversão de papéis era tal que levou os conselheiros ultramarinos a escreverem que "não parece Portugal o país dominante das suas Américas, mas são elas que representam o país dominante de Portugal" (Ferreira, 2001: 345-346).

Já no século XVIII, percebe-se a incontestável consolidação económica e social das conquistas atlânticas portuguesas, forjando-se comunidades de mercadores residentes em diferentes regiões do ultramar. Eram frequentes as procurações de cunho mercantil passadas por moradores do Rio de Janeiro para Angola. Da mesma forma, era comum que os arrematadores dos direitos dos escravos de Angola tivessem representantes no Rio de Janeiro e na Bahia. Estes dados reforçam o argumento sobre a existência de redes mercantis ligando as duas partes do Atlântico Sul.

Porém, não só o Atlântico era perpassado por redes e rotas comerciais que interligavam as conquistas portuguesas entre si. Em artigo denominado "Nichos e redes: interesses familiares e relações comerciais luso-brasileiras na África Oriental (1752-1808)”, Luís Frederico Antunes afirma que ao longo do século XVII e durante a primeira metade do XVIII, embora de forma esparsa e com pequenas margens de lucro, os navios da carreira da Índia, por necessidade de refresco ou para conserto dos estragos causados pelas intempéries, tocavam, na torna-viagem, o porto de Moçambique e se proviam de escravos que abasteciam o mercado brasileiro.

A presença sistemática dos primeiros comerciantes brasileiros na costa oriental africana ocorreu a partir de meados do século XVIII, no âmbito da política ultramarina de Pombal, destacando-se a 
separação de Moçambique do Estado da Índia, em 1752, e a instauração da liberdade de comércio para todos os súditos portugueses da Ásia, América e Europa em Moçambique, em 1761. Na mesma altura, António Lopes da Costa e João Antunes de Araújo e Lima, dois dos mais influentes homens de negócio da praça do Rio de Janeiro constituíram uma sociedade para os tratos que desenvolviam em diversos portos da costa brasileira, em Moçambique e na Índia. Pensada para o resgate de escravos de longa distância, esta sociedade instalou-se em Moçambique e ficou conhecida pelo nome de Casa do Rio de Janeiro. Os navios da Casa do Rio de Janeiro foram autorizados a participar na navegação de cabotagem em Moçambique, contribuindo para o desenvolvimento do comércio interno daquela região da África portuguesa. Participaram também no socorro aos soldados envolvidos na expedição a Mombaça, em 1769, envolvendo-se ainda no tráfico de escravos com as ilhas francesas no Índico (Antunes, 2005: 199-218).

Por outro lado, falar de comunidades mercantis cujos negócios atravessavam os diferentes quadrantes do império, é ter em mente outra dinâmica do Antigo Regime português: as redes de reciprocidade e a formação de clientelas que cruzaram e uniram as diferentes conquistas ultramarinas. Era extremamente difícil, para uma casa comercial setecentista, manter uma rede de comércio que envolvesse distantes regiões e diferentes produtos - como era o caso do tráfico atlântico de escravos - sem o recurso a relações de reciprocidade e casamentos entre famílias de sócios (Fragoso e Gouvêa, 2005: 83-111; Osório, 2001 e 2007). Portanto, o império aparece, igualmente, como espaço de circulação de famílias empresariais, a exemplo da experiência dos Loureiro, estudados por Ernestine Carreira, portugueses com conexões e negócios no Brasil e na Índia. O interessante é que tais relações, ao tecerem as intrincadas redes que integravam e constituíam o império, criavam, no mesmo movimento, as condições para a transformação de algumas destas 
famílias em representantes das elites económicas, nessas distantes regiões ultramarinas (Carreira, 1998: 77-120).

O que João Fragoso e Maria de Fátima Silva Gouvêa chamaram de "mercado imperial", principalmente ao longo dos setecentos, tornou-se cada vez mais vital para a produção material das relações sociais do Brasil escravista; portanto, para a própria existência da economia escravista na América portuguesa (Fragoso e Gouvêa, 2005: 83-111). Assim como o tráfico atlântico de almas foi essencial na reprodução e ampliação das sociedades e hierarquias sociais angolanas (Florentino, 1997: 82-100); da mesma maneira, as importações feitas pelos portos brasileiros e o comércio de cativos foram importantes para a manutenção da estrutura da antiga sociedade portuguesa, para usar um conceito de Magalhães Godinho (Godinho, 1975); e, ainda, para as produções têxteis indianas e o seu grupo mercantil como elite regional, como nos demonstram os estudos de Sanjay Subrahmanyam (Subrahmanyam, 1995: 258-266).

\section{Histórias conectadas e autoridades negociadas: eurocentrismo ou protagonismo dos agentes locais?}

Em Connected Histories: notes towards a reconfiguration of Early Modern Eurasia, Sanjay Subrahmanyam faz algumas reflexões críticas sobre o método comparativo utilizado por historiadores que estudam o período moderno. Critica a "ditadura", "camisa-de-força" ou "imposição" do modelo da trajetória europeia para análises de outras realidades, como a asiática, por exemplo. Ou seja, procura escapar de uma noção de modernidade que hierarquiza os espaços e as sociedades de acordo com um processo histórico que parte sempre da Europa.

A época moderna significou mais, em termos económicos, do que o avanço do comércio europeu, da conquista, da exploração. 
O próprio comércio não era unidirecional, não navegava sempre - e apenas - do Índico para o Atlântico, ao encontro dos portos ditos metropolitanos. Segundo Subrahmanyam, seria mais interessante estudar o comércio global nas suas múltiplas dimensões e implicações, tanto para consumidores, quanto para produtores. Romper-se-ia, assim, com um modelo eurocêntrico que perpassa, não raramente, a perspetiva dos historiadores ocidentais - mesmo daqueles dedicados a estudar as sociedades asiáticas e africanas -, modificando as questões priorizadas, os objetos recortados e a forma de recortá-los, assim como as conclusões a que chegam.

De acordo com o autor, o exercício da comparação baseia-se em grandes modelos explicativos, nos quais as características de um determinado objeto de estudo acabam por se adequar, ou não, a estes modelos. Em suma, o método comparativo produz especialistas que buscam um encaixe de peças num grande quebra-cabeça pré-concebido. Propõe, em vez do modelo comparativo - e do eurocentrismo que ele implica - o conceito de connected histories. O método de conectar histórias baseia-se não em modelos, mas sim numa relação entre o local e o regional. Local e regional definiriam os níveis micro e macro da análise histórica. Subrahmanyam sugere partir do local e, no geral, encontrar as singularidades e multiplicidades que caracterizariam traços comuns, partilhados por diferentes culturas ou diferentes noções universais de império: Mongol, Chinês, Espanhol, Otomano, Português, Inca, Asteca, do Daomé ou do Monomotapa. Resgatar tais noções - que os contemporâneos possuíam na época moderna e foram obscurecidas pela historiografia calcada na perspetiva do Estado-nação - seria chegar mais perto da cultura política, ou das diferentes culturas políticas que coexistiram e se enfrentaram nos tempos modernos (Subrahmanyam, 1999: 289-316).

Caminhando para a conclusão, voltemos ao autor que mencionamos logo no início deste ensaio historiográfico: Jack Greene, porém, no seu célebre livro, Negociated Authorities. Essays in Colonial Poli- 
tical and Constitutional History (Greene, 1994). No intuito de examinar as dinâmicas de governo dos impérios ultramarinos europeus - sob a luz da nova historiografia acerca da formação dos Estados modernos - Greene defende que o modelo de Estado centralizado, do qual emanaria uma política imperial baseada exclusivamente na coerção, mostra-se impróprio e a-histórico. Propõe, ao contrário, um modelo consensual que enfatize a importância da negociação e o significativo papel dos poderes e dos agentes locais - ou seja, coloniais - na construção da autoridade central.

Critica os conceitos de colônia e de colonos, cunhados a partir da noção de sujeição, subordinação, dependência, dominação, inferioridade, incapacidade, profunda alteridade. Contrapõe-se à perspetiva segundo a qual colônias teriam constituído territórios e colonos teriam representado populações sobre as quais os Estados-nação europeus exerceram um controle hegemónico. Os historiadores que defendem esta tese aplicam retrospectivamente, a seu ver, um modelo de organização imperial coercitivo e centralizado, muito mais afeito ao imperialismo contemporâneo dos séculos XIX e XX, à dinâmica política sobre a qual se baseou a estruturação dos impérios ultramarinos na época moderna.

Dialogando com a historiografia sobre o império espanhol, ou seja, as Índias ocidentais de Castela, Greene desenvolve o argumento de que, até às reformas bourbónicas em meados do século XVIII, as elites criollas da América hispânica foram hábeis em reter um amplo controlo sobre questões ligadas ao governo local. Por intermédio dos seus órgãos municipais, do princípio da consulta às periferias ao longo do processo legislativo do monarca, e do movimento de creolização da burocracia real, conquistaram, segundo Elliott, um grau substancial de autogoverno, mesmo que sob o comando e a direção da coroa (Elliott, 1989). Certamente, a coroa deteve sempre uma larga autoridade para tomar toda a sorte de medidas referentes ao império. No entanto, ao implementar tais medidas, os funcio- 
nários régios nas conquistas adaptaram-nas às variadas circunstâncias definidas pelos agentes e pelos interesses locais. Em suma, o poder de barganha entre coroa e colonos, produziu um ajuste e uma combinação de autoridade negociada, que parece ter sido uma das características dos impérios atlânticos nos tempos modernos.

Capacidade similar de negociação - e de incorporação - dos súditos coloniais tem sido tema recorrente da historiografia sobre a América portuguesa. Anthony John Russell-Wood, em artigo sugestivamente intitulado "Centro e periferia no mundo luso-brasileiro, 1500-1808", afirma que:

a noção de um governo metropolitano centralizado, a formulação de políticas impermeáveis à realidade colonial e implementadas ao pé da letra por agentes da Coroa, de uma Coroa insensível e de atitudes metropolitanas rígidas voltadas para o Brasil, demanda revisão" (Russell-Wood, 1998: 202).

Insiste no potencial de negociação dos agentes locais - sejam senhores de engenhos, comerciantes, lideranças indígenas, e até mesmo escravos - ao afirmar que:

a história do Brasil colonial fornece numerosos exemplos de como os colonos foram capazes de exercer suficiente pressão sobre as autoridades metropolitanas no sentido de evitar ou modificar totalmente as políticas propostas, de atrasar a implementação de ações prescritas, ou de negociar um acordo menos ofensivo aos interesses coloniais (Russell-Wood, 1998: 206).

Por fim, uma das coisas que tentamos discutir neste balanço historiográfico acerca do império português na época moderna com base no que nos ensina Lucien Febvre na epígrafe acima -, é a dificuldade atual de, simplesmente, contrapor segmentos que se definem unicamente pelo facto de se terem constituído enquanto 
colonos ou colonizadores. Esperamos ter conseguido defender o argumento de que, por intermédio de uma intrincada teia de relações económicas, político-administrativas e clientelísticas, as elites locais em diferentes regiões do Atlântico, e até mesmo do Índico, foram capazes de construir a soberania do rei de Portugal, por intermédio, das suas redes e alianças e pelo exercício de autoridades negociadas. Estas elites, dos mais diferentes calibres, souberam tornar-se não apenas objeto de uma política ou de uma influência constituída de cima para baixo, do centro para as periferias, da Europa para os trópicos; mas foram, ao contrário, sujeitos do seu próprio devir histórico, e souberam, sem dúvida, influenciar e modificar o centro num constante jogo de mão-dupla. O Antigo Regime português não teria sido o que foi sem o seu império, assim como Portugal, hoje, não seria o mesmo. Além disso, não estaríamos aqui, neste livro, a discutir conceitos como influência, matriz, memória, identidade, herança, tradução e património, sempre compartilhados, e jamais uma via de mão única.

\section{Referências bibliográficas}

AlenCASTRO, Luiz Felipe de (2000), O Trato dos Viventes. A Formação do Brasil no Atlântico Sul. São Paulo: Companhia das Letras.

ANTUNES, Luís Frederico Dias (2005), "Nichos e redes: interesses familiares e relações comerciais luso-brasileiras na África Oriental (1752-1808)”, in Maria Fernanda Bicalho e Vera Lúcia Ferlini (orgs.), Modos de Governar. São Paulo: Alameda, 199-218.

BICAlHo, Maria Fernanda (2003), A Cidade e o Império. O Rio de Janeiro no século XVIII. Rio de Janeiro: Civilização Brasileira.

BOXER, Charles Ralph (1973), Salvador de Sá e a Luta pelo Brasil e Angola (1602-1686). São Paulo: Editora Nacional, Editora da Universidade de São Paulo. 
Bushnell, Amy Turner e GreEne, Jack Philip (2002), "Peripheries, Centers, and the Construction of Early Modern American Empires", in Christine Daniels e Michael Kennedy (eds.), Negotiated Empires. Centers and Peripheries in the Américas, 1500-1820. New York/London: Routledge, 1-14.

CARDIM, Pedro (1998), "Centralização política e Estado na recente historiografia sobre o Portugal do Antigo Regime”. Nação e Defesa, n. ${ }^{\circ}$ 87, 2. ${ }^{a}$ série, 129-158.

CARREIRA, Ernestine (1998), "La correspondance de Francisco Gomes Loureiro, un négociant portugais au Gujarat", in Ernestine Carreira (dir.), Sources Européennes sur le Gujarat. Paris: L'Harmattan, 77-120.

DIAS, Maria Odila Leite da Silva (1989), "Impasses do Inorgânico", in Maria Ângela D'incao (org.), Ensaios sobre Caio Prado Júnior. São Paulo: Editora Brasiliense, Ed. UNESP, Secretaria de Estado da Cultura.

ELLIOTT, John Hall (1989), The Role of the State in British and Spanish Colonial America. Philadelphia: Philadelphia Center for Early American Studies.

ELliOTT, John Hall (1992), A Europe of Composite Monarchies. Past and Present, n. 137, 48-71.

FEBVRE, Lucien (1977), "Caminhando para uma outra História”, in Combates pela História II. Lisboa: Editorial Presença.

FERreIRA, Roquinaldo (2012), Cross-Cultural Exchange in the Atlantic World. Angola and Brazil during the Era of the Slave Trade. Cambrigde: Cambridge University Press.

Florentino, Manolo (1997), Em Costas Negras. São Paulo: Companhia das Letras.

FRAGOSO, João Fragoso; GOUVÊA, Maria de Fátima (2005), "Vitorino Magalhães Godinho et les réseaux impériaux", Arquivos do Centro Cultural Calouste Gulbenkian, vol. 50, 83-109.

Godinho, Vitorino Magalhães (1975), A Estrutura da Antiga Sociedade Portuguesa. Lisboa: Arcádia. 
GreENE, Jack Philip (1994), Negotiated Authorities. Essays in Colonial Political and Constitutional History. Charlottesville and London: The University Press of Virginia.

GRENNE, Jack Philip (2002), "Transatlantic Colonization and the Redefinition of Empire in the Early Modern Era. The British-American Experience", in Christine Daniels e Michael Kennedy (eds.), Negotiated Empires. Centers and Peripheries in the Américas, 1500-1820. New York/London: Routledge, 267-282.

Grenne, Jack; MORgan, Philip (eds.) (2009), Atlantic History. A Critical Appraisal. Oxford: Oxford University Press.

JúNIOR, Caio Prado (1977), Formação do Brasil Contemporâneo. (1942), São Paulo: Editora Brasiliense.

LAPA, José Roberto do Amaral (2000), A Babia e a Carreira da Índia. (1966). São Paulo: Hucitec/Ed. Unicamp.

MAURO, Frédéric (1988), Portugal, o Brasil e o Atlântico, 1570-1670. Lisboa: Estampa.

NOVAIS, Fernando (1979), Portugal e Brasil na crise do antigo sistema colonial (1777-1808). São Paulo: Hucitec.

OSÓRIO, Helen (2001), "As elites econômicas e a arrematação dos contratos reais: o exemplo do Rio Grande do Sul (século XVIII)", in João Fragoso; Maria Fernanda Bicalho e Maria de Fátima Gouvêa (orgs.), O Antigo Regime nos Trópicos. A dinâmica imperial portuguesa (séculos XVI-XVIII). Rio de Janeiro: Civilização Brasileira, 107-137.

OSÓRIO, Helen (2007), O Império Português no Sul da América: Estancieiros, Lavradores e Comerciantes. Porto Alegre: Editora da UFRGS.

RUSSELL-WOOD, Anthony John (1998), Um Mundo em Movimento. Os Portugueses na África, Ásia e América (1415-1808). Lisboa: Difel.

RUSSELL-WOOD, Anthony John (1998a), "Centro e periferia no mundo luso-brasileiro, 1500-1808" in Revista Brasileira de História, vol. 18, n. ${ }^{\circ} 36,187-249$.

SANTOS, Catarina Madeira (2005), "Arredondar Angola: do Estado em rede à territorialização do Estado", in Um governo "polido" para Angola. Recon- 
figurar dispositivos de domínio (1750-c.1800). Tese de doutoramento. Lisboa/Paris: FCSH/UNL/l'École des Hautes Études en Sciences Sociales. SCHAUB, Jean-Frédéric (2005/1), "La notion d'État Moderne est-elle utile? Remarques sur les blocages de la demarche comparatiste en histoire", Cabiers du monde russe, vol. 46, 51-64.

Subrahmanyam, Sanjay (1994), Comércio e Conflito. A Presença Portuguesa no Golfo de Bengala, 1500-1700. Lisboa: Edições 70.

Subrahmanyam, Sanjay (1995), O Império Asiático Português, 1500-1700. Uma História Política e Econômica. Lisboa: Difel.

SUBRAHMANYAM, Sanjay (1999), "Connected Histories: Notes Towards a Reconfiguration of Early Modern Eurasia”, in Victor Lieberman, (ed.). Beyond Binary Histories. Re-imagining Eurasia to c. 1830. Michigan: University of Michigan Press, 289-316.

Thomaz, Luís Filipe (1994), De Ceuta a Timor. Lisboa: Difel.

VERGER, Pierre (1998), Fluxo e Refluxo do tráfico de africanos entre o Golfo do Benin e a Babia de todos os Santos nos séculos XVII e XIX. São Paulo: Currupio.

WALLERSTEIN, Immanuel (1974-1989), The Modern World-System, 3 vols. New York: Academic Press. 
(Página deixada propositadamente em branco) 


\section{DOS DOCUMENTOS À HISTÓRIA}

\section{E AOS ARQUivos}

A História, diz-se, faz-se com documentos. Sem eles e sem as técnicas necessárias para os criar e para os conservar, não há História, quer dizer, não há conhecimento do passado através da investigação. Era essa, pelo menos, a convicção sincera dos eruditos europeus dos séculos XVIII e XIX, que queriam libertar a disciplina do peso da retórica e da cronística e que aspiravam legitimá-la pelo recurso a documentos objetivos e inquestionáveis. ${ }^{1}$ Para eles, os diplomas autênticos eram os únicos com que se podia resgatar a verdadeira história, aquela que as crónicas e os textos literários e narrativos não contavam, ou que ocultavam por baixo dos propósitos memorialísticos, dos desígnios políticos e da subjetividade dos seus autores. Como se sabe, isso suscitou um interesse maior pela conservação daquelas antiguidades, ${ }^{2}$ acompanhado pela edição dos auxiliares de pesquisa mais diversos, e, sobretudo, pela seleção e publicação

\footnotetext{
${ }^{1}$ António Henrique de Oliveira Marques (org.) (1974-1975), Antologia da Historiografia Portuguesa, 2 vols. Mem Martins: Europa-América, vol. I, 17-35; José Mattoso (2002), "A publicação de fontes documentais e o progresso da ciência histórica em Portugal" (1985), in A Escrita da História, vol. 10 das Obras Completas de José Mattoso. Lisboa: Círculo de Leitores, 125-129; Luís Reis Torgal, José Amado Mendes, Fernando Catroga (1996), História da História em Portugal. Lisboa: Círculo de Leitores, 19-23; para o panorama europeu, Guy Bourdé e Hervé Martin (1990), As Escolas Históricas. Mem-Martins: Europa-América, 61-81.

${ }^{2}$ Em agosto de 1721, um alvará régio (cf. Luís Reis Torgal, José Amado Mendes, Fernando Catroga, A História da História..., 21), ordenava às Câmaras Municipais a conservação de todas as antiguidades. Para alguns resultados dessa iniciativa. Alberto
} 
de grandes coleções documentais. ${ }^{3}$ No caso português, tal esforço coube à Academia de História, e, depois, à Academia das Ciências, que organizou, entre outras, a edição dos Livros inéditos (1790), do Quadro Elementar (1842) e dos Portugaliae Monumenta (1856) e que se havia de igual modo empenhado no inventário dos cartórios monásticos e concelhios e na recolha dos diplomas neles conservados. ${ }^{4}$ A criação dos arquivos nacionais foi, por isso mesmo, outra consequência do trabalho destes eruditos. À imagem das bibliotecas e, mais tarde, dos museus, o arquivo nacional português foi criado em 1823 a partir do antigo arquivo da Coroa, 5 tendo depois incorporado os acervos dos organismos e das instituições extintas pelo regime liberal.

Para os eruditos europeus do século XIX, que haviam convertido a história numa atividade racional e que haveriam de a profissionalizar, fazendo-a entrar nas Universidades, ${ }^{6}$ os documentos de arquivo tinham valor instrumental. Desde que a sua autenticidade fosse aferida pela crítica textual, ou crítica histórica, às quais competia verificar a conformidade dos diplomas com o tempo e com o espaço, distinguindo os verdadeiros dos falsos, só se interessavam pelo seu conteúdo. Para eles, era essa a forma de conhecer o passado, de

Iria (1947), Os arquivos municipais do Algarve e a Academia Real de História Portuguesa (1729-1732), Sep. de Anais das Bibliotecas e Arquivos, vols. 17 e 19, Lisboa.

${ }^{3}$ Além dos estudos mencionados na primeira nota, Saul António Gomes (2011), "The Editions of Archival Sources and Documents", in José Mattoso (dir.), The Historiography of Medieval Portugal c. 1950-2010. Lisboa: IEM,15-42.

${ }^{4}$ Os resultados dessa recolha, em parte dirigida por João Pedro Ribeiro, Santa Rosa Viterbo e Joaquim de Santo Agostinho, estão hoje arrumados entre os manuscritos da série Azul da biblioteca da Academia das Ciências de Lisboa, onde podem ser consultados. Entre outros, vejam-se os manuscritos n. ${ }^{\circ}$ 402-404, 406-413, 582-585, 653.

${ }^{5}$ Luís Reis Torgal, José Amado Mendes e Fernando Catroga (1996), A História da História..., 162-164; Fernanda Ribeiro (2012), "Antes e para além do Aquivo Nacional: ruturas e continuidades”, in Maria de Lurdes Rosa (org.), Arquivos de Família, séculos XIII-XX: Que Presente, que Futuro?. Lisboa: IEM, 45-58.

${ }^{6}$ Antologia da Historiografia..., 33-34; Luís Reis Torgal, José Amado Mendes, Fernando Catroga (1996), A História da História..., 26-27, 166-170, 180-192. 
esclarecer as leis e os costumes e descrever o funcionamento das instituições, ou de listar os responsáveis políticos ou religiosos que as haviam governado, de estabelecer, em suma, os factos seguros e objetivos, essenciais para determinar a verdade e afastar os mitos do passado. Tal desinteresse pelas restantes dimensões dos documentos, que se reduziam, assim, à condição de textos, materializava-se, aliás, no estatuto subalterno de disciplinas como a arquivística e a paleografia, ou a diplomática, a heráldica e a sigilografia, todas classificadas como ciências auxiliares da história. ${ }^{7}$ Só a esta cabia a investigação do passado, reduzindo-se as restantes a técnicas neutras e objetivas. Era o que sucedia com os arquivos e com os arquivistas, vistos aqueles como simples depósitos e estes como meros guardiães dos documentos lidos e aproveitados pelos historiadores. ${ }^{8}$

Os eruditos que pretendiam fundar a história sobre factos verdadeiros, estabelecidos a partir de documentos autênticos, tinham uma crença ingénua na capacidade de estes lhes revelarem as realidades do passado. Acreditavam, no fundo, que eles eram objetos naturais, reflexos genuínos dos homens e das instituições que os tinham criado. Tomavam, assim, o documento pelo sentido original do termo, como aquele que mostra, ou ensina, facto que se revelava igualmente, e de forma mais significativa, através da classificação dos documentos como fontes históricas, como se o conhecimento do passado delas pudesse brotar naturalmente. Tal crença apoiava-se, em boa parte, na natureza dos acervos arquivísticos, em regra formados

\footnotetext{
${ }^{7}$ Entre outros, António Henrique de Oliveira Marques (1988), Guia do Estudante de História Medieval Portuguesa (1964). Lisboa: Estampa, 131-149.

${ }^{8}$ Fernanda Ribeiro (2012), "Antes e para além do Aquivo Nacional...", 50 e ss.; Terry Cook (2012), "Ghosts in the Family: Historians, Archivists, and the Documentary Past", in Maria de Lurdes Rosa (org.), Arquivos de Família..., 34-40; Terry Cook (2013), "Evidence, memory, identity, and community: four shifting archival paradigms", Archival Science, vol. 13, 100, 106 e 107. Para um bom panorama, Maria de Lurdes Rosa (2011), "Arquivos de Família - O que são, para que servem, como preservá-los e estudá-los?”, Casa Nobre: Um Património para o Futuro. Atas do $3 .^{\circ}$ Congresso Internacional. Arcos de Valdevez: C. M. de Arcos de Valdevez, 316-319.
} 
por documentação de natureza oficial, produzida pelos organismos da Coroa e pelos institutos do Antigo Regime e que se arrumava em respeito pela sua origem, em fundos que reproduziam a orgânica das instituições. ${ }^{9}$ Por estarem essencialmente votados à preservação dos registos públicos, aqueles que mais interessavam à história da Nação, os arquivos não se preocuparam com documentos doutras tipologias, como aqueles que se haviam acumulado nos arquivos familiares e nos espólios pessoais. ${ }^{10}$ Estes últimos reservavam-se, em contrapartida, para as bibliotecas nacionais, mas apenas quando neles se reconhecia algum interesse cívico, científico, ou literário, capaz de suscitar a sua conservação.

Como seria de esperar, a história produzida nestas condições tinha uma enorme preocupação factológica e uma feição política e institucional muito acentuada. ${ }^{11} \mathrm{~A}$ escola positivista acentuaria, de resto, estas características, ora ao circunscrever a história à tarefa de estabelecer factos objetivos, reservando à sociologia a interpretação da sociedade e a definição de leis científicas, ora ao postular, sobretudo, a neutralidade do historiador e a evidência dos factos por ele determinados. ${ }^{12}$ Mesmo quando a sua prática era diversa, era nisso que acreditavam os melhores espíritos da época, quando reduziam o trabalho do investigador à determinação dos dados históricos, por

9 Terry Cook (2012), "Ghosts in the Family...", 37-39; Terry Cook (2013), "Evidence, memory...", 106; Maria de Lurdes Rosa (2012), "Arquivos de Família, o que são...", 318-319.

10 Sobre a valorização tardia destes arquivos, Olga Gallego (1993), Manual de Archivos Familiares. Madrid: ANABAD; Manuel Gonçalves, Paulo Guimarães e Pedro Peixoto (1996), Arquivos de Família. Organização e Descrição. Vila Real: UTAD. Para uma visão mais atual, Maria de Lurdes Rosa (2012), "Arquivos de Família: para um roteiro de temas e problemas", in Maria de Lurdes Rosa (org.), Arquivos de Família...", 15-30.

11 Guy Bourdé e Hervé Martin (1990), As Escolas Históricas..., 101-105, 112, 121-122; Peter Burke (1992), A Revolução Francesa da Historiografia: A Escola dos Annales (1929-1989). São Paulo: UNESP, 12-15. Para Portugal, Antologia da Historiografia..., 36-45; José Mattoso (2002), "A publicação de fontes..., 130.

12 Além dos trabalhos citados na nota anterior, Luís Reis Torgal, José Amado Mendes e Fernando Catroga (1996), A História da História..., 95 e ss. 
estarem certos que estes falavam por si próprios. A perspetiva era cândida e esquecia as opções tomadas para estabelecer os factos, ou os conceitos com que se lhes fixava o sentido, mas esta preocupação com o detalhe e com o rigor, com a definição precisa do tempo e do espaço, ou com a recolha exaustiva dos testemunhos do passado, deu uma legitimidade acrescida àquelas que eram as principais exigências do ofício do historiador.

Tudo isto teve consequências da maior importância. Um pouco por toda a parte, deu lugar à multiplicação de inventários de arquivos e de reportórios de fontes, à organização de biografias, de catálogos, de dicionários e doutros instrumentos de trabalho, com informações seguras e concentradas. Suscitou de igual modo, sobretudo nos países europeus, um interesse renovado pela publicação de conjuntos documentais completos e bem delimitados, como os documentos e as chancelarias régias, as atas de cortes, os textos hagiográficos e narrativos, os tratados, a legislação, os cadastros de bens, os cartórios dos conventos e mosteiros mais importantes, ou os diplomas pontifícios, após a abertura do arquivo do Vaticano em finais do século XIX. ${ }^{13} \mathrm{O}$ aperfeiçoamento da crítica histórica, por meio da crítica dos testemunhos e das proveniências, permitiu revalorizar, por outro lado, os textos literários e narrativos, ${ }^{14}$ até então menosprezados pelos eruditos. O maior conhecimento dos textos e dos autores, das datas e dos locais em que tinham vivido e dos públicos

13 Antologia da Historiografia..., 36-40; Luís Reis Torgal, José Amado Mendes, Fernando Catroga (1996), A História da História..., 192-215. Para um inventário, António Henrique de Oliveira Marques (1988), Guia do Estudante de História..., 151-186, 238-239. Luís Miguel García Mora (1998), Fuentes manuscritas para la Historia de Portugal. Guía de instrumentos de investigación. Madrid: Fundación Histórica Tavera; Bernardo Vasconcelos e Sousa (dir.) (2005), Ordens Religiosas em Portugal: Das Origens a Trento. Guia Histórico, Lisboa.

14 As biografias de trovadores construídas por Carolina Michaëlis de Vasconcelos (1990), Cancioneiro da Ajuda, reimp. da edição de Halle. Lisboa: INCM, vol. II, 289-584; Yara F. Viera et al. (orgs.) (2004), Glosas Marginais ao Cancioneiro Medieval Português de Carolina Michaëlis de Vasconcelos. Coimbra: Imprensa da Universidade, são particularmente significativas. 
a que se dirigiam, era indispensável, na verdade, para reconstituir os seus contextos de produção e de circulação, para circunscrever, em suma, a subjetividade que se atribuía a essas fontes e poder dar um sentido objetivo às intenções dos seus autores. ${ }^{15}$ As lendas e as narrativas, ou mesmo algumas crónicas menos fiáveis, que até então se relegavam para o campo da ficção e da literatura, podiam assim começar a serem resgatadas como testemunhos históricos da maior importância. ${ }^{16}$

Seja como for, isso encerrava o historiador dentro de limites demasiado técnicos e demasiado estreitos. A abertura de novos e mais vastos horizontes foi, como se sabe, o programa dos fundadores dos Annales, em 1929. Mais conscientes do papel do historiador na seleção e na interpretação dos dados, pretendiam afastar a disciplina do território do político e do institucional, articulando-a com o estudo das realidades económicas e sociais. ${ }^{17}$ Acercavam-na, assim, das outras ciências sociais, onde buscavam os modelos de norma e de estrutura, de conflito e de revolução, indispensáveis para selecionar, avaliar e dar sentido aos testemunhos do passado. Tal proximidade levou, por outro lado, a que se multiplicassem os objetos de estudo, alargando a investigação aos domínios da cultura, das ideologias e das mentalidades. Ao mesmo tempo, promoviam-se os primeiros ensaios de "história total», em regra a partir de monografias regionais, esperando que a acumulação de dados e de

\footnotetext{
15 Sobre esta metodologia de análise, José Mattoso (2002), "Investigação histórica e interpretação literária de textos medievais", in A Escrita da História..., 134-142.

16 Para alguns exemplos, José Mattoso (2002a), "João Soares Coelho e a gesta de Egas Moniz", in Portugal Medieval. Novas interpretações, vol. 8 das Obras Completas de José Mattoso. Lisboa: Círculo de Leitores, 301-320; Luís Krus (1994), "Uma variante peninsular do mito de Melusina: a origem dos Haros no Livro de Linhagens do conde D. Pedro de Barcelos", Passado, memória e poder na sociedade medieval portuguesa. Estudos. Redondo: Patrimonia, 171-195 [republ. in A Construção do Passado Medieval. Textos inéditos e publicados, Lisboa, IEM, 2011].

17 Guy Bourdé, Hervé Martin (1990), As Escolas Históricas..., 119-135; Peter Burke (1992), A Revolução Francesa da Historiografia..., 16-30. Para o caso português, José Mattoso (2002), "Novos rumos da historiografia", in A Escrita da História..., 31-40.
} 
estudos resultasse num maior conhecimento do passado. Apesar de alguns trabalhos brilhantes, como o de Duby sobre a região de Mâcon, o de Garcia de Cortázar sobre o domínio de S. Millan de la Cogolla, ou o de Pierre Toubert sobre o Lácio, os resultados ficaram muito aquém das expectativas, quando não deram lugar à repetição mecânica das ideias e dos esquemas verificados noutras regiões. ${ }^{18} \mathrm{Em}$ parte devido às críticas do pós-modernismo, com a desconfiança em relação aos grandes temas e às grandes narrativas, ${ }^{19}$ que admitiam o caráter unitário do saber histórico, os desenvolvimentos posteriores da disciplina levaram a uma pulverização dos temas de pesquisa, por vezes até quase ao absurdo. ${ }^{20}$ No lugar de uma "história total», de base quantitativa e serial, desenvolveu-se, em particular depois dos anos setenta do século XX, uma pluralidade de pontos de vista, de estudos de caso, de microbiografias e de prosopografias, com a revalorização do qualitativo, do político e do individual.

Mesmo sem discutir estas novidades, nem avaliar o seu sentido, torna-se evidente a enorme transformação do ofício do historiador. De colecionador de factos e de personagens, o historiador ganhou consciência do seu papel como observador científico das sociedades do passado, atento às tendências do presente e às teorias e aos modelos das outras ciências sociais. Nos dias de hoje, em que se

\footnotetext{
18 Gorges Duby (1953), La Société aux XI et XII siècles dans la région Mâconnaise. Paris: A. Colin; José Ángel García de Cortázar (1969), El dominio del monasterio de San Millán de la Cogolla (siglo X-XIII). Introduccion a la Historia Rural de Castilla Altomedieval. Salamanca: Universidade de Salamanca; Pierre Toubert (1973), Les Structures du Latium médiéval: Le Latium méridional et la Sabine du IXe à la fin $d u X I I^{e}$ siècle, 2 vols. Paris/Roma: Ecole française de Rome. Para uma análise crítica, e por vezes muito mordaz, dos estudos regionais, Alain Guerreau (2001), L'Avenir d'un passé incertain. Quelle histoire du Moyen Âge au XXI' siècle?. Paris: Le Seuil.

19 Para algumas observações, Fredric Jamesen (1998), The Cultural Turn. Selected workings on the Postmodern, 1983-1998. Londres: Verso, sobretudo 1-32, 50-92.

20 Para estas tendências, Guy Bourdé e Hervé Martin (1990), As Escolas Históricas..., 144-152, 193-197; Peter Burke (1992), A Revolução Francesa da Historiografia..., 56-76; Carlo Ginzburg (1992), A micro-história e outros ensaios. Lisboa: Difel. Para uma apreciação crítica, José Mattoso (2002), “A História hoje: que História ensinar?", in A Escrita da História..., 89-100.
} 
torna cada vez mais evidente o carácter discursivo, isto é, construído, das suas representações do passado, vê-se confrontado com a perda do monopólio da investigação sobre esse mesmo passado, por via da concorrência que lhe é movida por outros profissionais, como os antropólogos e os sociólogos, os estudiosos da cultura e da literatura e os arquivistas, ou até os jornalistas. Como já foi sublinhado, a situação convida a repensar as regras do ofício e a frequentar os conceitos com maior assiduidade, para usar a feliz expressão de Alain Guerreau ${ }^{21}$. Sem essa reflexão, o historiador corre o risco de ver diluir-se aquilo que lhe era essencial, quer dizer, a atenção aos tempos e aos lugares, a preocupação com o detalhe e com o rigor, e, sobretudo, o exame crítico de todas as mediações (desde os diplomas e os testemunhos, às teorias e aos conceitos), tarefas indispensáveis para não perder de vista a coerência dos conjuntos sobre os quais trabalha e que procura reconstituir.

No decurso deste processo, os dados de base do ofício do historiador, ou seja, os documentos, também mudaram de estatuto. De janela aberta sobre o passado, ganharam limites e tornaram-se parciais. Para extrair deles dados realmente significativos sobre as realidades económicas e sociais, houve que reunir grandes massas documentais, organizá-las em séries o mais completas que fosse possível e proceder a trabalhos de quantificação. Para os fazer falar, por outro lado, sobre os valores e os costumes, ou sobre as ideologias, houve que determinar aquilo que calavam e interrogá-los das formas mais diversas, confrontando-os com outros indícios, ou com a informação conhecida sobre a época, os coletivos, ou os indivíduos a que diziam respeito. ${ }^{22}$ Se o documento inédito e isolado, que era o encanto dos eruditos, perdeu assim importância, em benefício das

21 Alain Guerreau (2001), L'Avenir d'un passé..., 251-274.

22 Sobre esta metodologia de análise, Georges Duby (1977), "História social e ideologia das sociedades", Fazer História 1: Novos Problemas. Lisboa: Bertrand, 173-195; Georges Duby e Guy Lardreau (1980), Dialogues. Paris: Flammarion. 
séries e dos grandes conjuntos, a investigação deitou mão entretanto a outros testemunhos do passado. A par das narrativas e dos textos literários, ou dos materiais que eram objeto das antigas ciências auxiliares, os gestos, as imagens e os símbolos, as tradições técnicas e os monumentos, ou os vestígios arqueológicos, passaram a merecer a atenção do historiador, tal como sucederia com os dados do terreno e da paisagem, ${ }^{23}$ imprescindíveis para perceber como as sociedades organizavam o espaço e desenhavam os territórios.

Foi talvez mais importante o reconhecimento da dimensão monumental dos documentos, para retomar uma designação há muito consagrada por J. Le Goff. ${ }^{24}$ Não apenas pela descoberta das memórias que neles se queriam fixar e das intenções que moviam os seus organizadores, mas por se valorizarem os rituais, as solenidades e os procedimentos que lhes garantiam a preservação, isto é, a recordação e o futuro. Por demonstrarem, em suma, que a criação de um documento e a organização de um arquivo, ou a conservação das espécies aí depositadas, nada tinha de acidental, ou de natural, mas que resultava, pelo contrário, da vontade expressa de criar uma determinada leitura do passado e de a impor aos presentes e aos vindouros. Para o verificar, basta talvez evocar o modo como a afirmação da primazia de Braga, ou dos direitos dos bispos de Coimbra e do Porto, dependeu de uma criteriosa seleção e classificação dos diplomas transcritos para o Liber Fidei, para o Livro Preto

${ }^{23}$ José Ángel García de Cortázar (org.) (1985), Organización social del espacio en la España medieval: La Corona de Castilla en los siglos VIII a XV. Barcelona: Ariel; Construction de l'Espace au Moyen Âge: pratiques et représentations, XXXVII Congrès de la SHMES. Paris: Sorbonne, 2007; Stéphane Boissellier (ed.) (2010), De l'espace aux territoires. La territorialité des processus sociaux et culturels au Moyen Âge. Actes de la table ronde des 8-9 juin 2006, CESCM (Poitiers). Turnhout: Brepols; Iria Gonçalves (coord) (2005-2013), Paisagens Rurais e Urbanas. Fontes, Metodologias, Problemáticas, 5 vols. Lisboa: CH-UNL.

${ }^{24}$ Jacques Le Goff (1984), "Documento/Monumento", Enciclopédia Eunaudi, vol 1, Memória-História. Lisboa: INCM, 95-106. Veja-se, também, do mesmo autor a entrada "Memória", ibidem, 11-50. 
e para o Censual do Cabido. ${ }^{25} \mathrm{O}$ modo como Zurara reformou a Chancelaria de Pedro I, que foi posta em destaque por Luís Krus, ${ }^{26}$ é também revelador dos mesmos processos, por dar testemunho do desejo de criar uma memória régia do passado, o qual levou a que muitos diplomas fossem abreviados e outros só copiados em parte, mas que destruiu igualmente vários outros, por estes, à época, já não terem utilidade e não interessarem a ninguém. Como recordava Marc Bloch na sua defesa do ofício do historiador, ${ }^{27}$ a existência de documentos e a organização de arquivos não é um acidente, nem o resultado de um desígnio dos deuses, mas um facto social da maior importância, que importa esclarecer com todo o cuidado.

Apesar da renovação recente de algumas disciplinas como a filologia e a diplomática, com uma maior atenção aos suportes, aos escribas e às cópias 28 e com o estudo dos cartulários, dos cartórios e das chancelarias, ${ }^{29}$ nas quais os livros e os diplomas são tomados

25 José Mattoso (1987), "Os arquivos oficiais e a construção social do passado", in A Escrita da História..., 118-119; Luís Krus (1994a), A Concepção Nobiliárquica do Espaço Ibérico (1280-1380). Lisboa: FCG/JNICT, 95-96, nota 159.

${ }^{26}$ Luís Krus (1985), "Recensão a "Chancelarias Portuguesas. D. Pedro I (13571367)"” (1984), in António Henrique de Oliveira Marques (org.), Ler História, n. ${ }^{\circ}$ 5. Lisboa: I.N.I.C., 143-147.

27 Marc Bloch (1952), Apologie pour L'Histoire ou Métier D'Historien. Paris: A. Colin, 29-30.

${ }^{28}$ Pierre Chastang (2008), "L'archéologie du texte médiéval. Autour de travaux récents de l'écrit", Annales. Histoire, Sciences Sociales, vol. 63, n. ${ }^{\circ}$ 2, 247-256; Stephen G. Nichols (2014), "Reflections on The New Philology", in R. Howard Bloch et al. (ed.), Rethinking the New Medievalism. Baltimore: John Hopkins, 12-38; Jacqueline Cerquiglini-Toulet (2014), "Conceiving the Text in the Middle Ages", ibidem, 151-161.

${ }^{29}$ Entre outros, Olivier Guyotjennin, Laurent Morelle, Michel Parisse (ed.) (1993), Les Cartulaires. Actes de la table-ronde organisée par l'École nationale des chartres. Paris: École nationale des chartes; Pierre Chastang (2006), "Cartulaires, cartularisation et scripturalité médiévale: la structuration d'un nouveau champ de recherche", in Cahiers de civilisation médiévale, vol. 49, 21-31; Pierre Toubert, Pierre Moret (ed.) (2009), Remploi, citation, plagiat. Conduites et pratiques médiévales (XIe-XII siècles). Madrid: Casa de Velazquez; Maria Helena Coelho et al. (2001), Estudos de Diplomática Portuguesa. Lisboa: Colibri; Saul António Gomes (2007), In Limine Conscriptionis. Documentos, chancelaria e cultura no Mosteiro de Santa Cruz de Coimbra. Viseu: Palimage. 
como objetos sociais e não apenas como fontes, tem sido menor o interesse pelas restantes dimensões materiais dos documentos. Se essa materialidade pode ser invocada através da análise dos contextos de registo e de circulação, ela também se revela por meio dos usos sociais dos documentos, ou pelo percurso destes após terem sido arrumados nos arquivos, ${ }^{30}$ problema que só raras vezes recebeu a consideração dos historiadores. Em parte, isso deveu-se à redução inconsciente dos documentos à condição de textos, que se podiam interpretar assim sem olhar aos suportes, mas, também, à desvalorização dos arquivistas, vistos como técnicos neutros e auxiliares ${ }^{31}$. A visão dos arquivos como depósitos estáticos, que vingou até à segunda metade do século $\mathrm{XX},{ }^{32}$ não favorecia o desenvolvimento, por outro lado, de uma história social dos procedimentos de registo, de classificação e conservação, indispensável para se compreender o arquivo como um espaço de poder sobre o passado e a memória. Como bem preveniu Thomas Cook, a interpretação desse mesmo passado não começa quando se escolhe o tema e se selecionam e analisam as fontes, mas inicia-se, muito pelo contrário, com a organização do arquivo e com a escolha dos documentos que hão- de ser destruídos, ou conservados. ${ }^{33}$ Uma advertência decisiva, que obriga a ter na devida conta os múltiplos efeitos que a constituição

${ }^{30}$ Joseph Morsel (2000), "Ce qu'écrire veut dire au Moyen Âge. Observations préliminaires à une étude de la scriptrualité médiévale”, in Mimini. Travaux et documents de la Société des études médiévales du Québec, 4, 3-43; Pierre Chastang (2008), "L’archéologie du texte médiéval....", 245-270; Joseph Morsel (2008), "Du texte aux archives le problème de la source", in Bulletin du centre d'études médiévales d'Auxerre (BUCEMA), hors série n. ${ }^{\circ} 2$ (disponível em http://cem.revues.org/index 4132. html); Maria de Lurdes Rosa (2012), "Arquivos de Família: para um roteiro...", 22-23.

${ }^{31}$ Fernanda Ribeiro (2012), "Antes e para além do Aquivo Nacional...”, 50 e ss.; Terry Cook, "Ghosts in the Family:...", 34-40; Maria de Lurdes Rosa (2012), "Arquivos de Família: para um roteiro...", 21-22; Terry Cook, "Evidence, memory...", 100, 106 e 107.

32 Fernanda Ribeiro (2012), "Antes e para além do Arquivo Nacional..., 55-57; Terry Cook, "Evidence, memory...”, 107-109.

33 Terry Cook (2012), "Ghosts in the Family:...", 36. 
do arquivo e o trabalho dos arquivistas produzem na atividade dos investigadores e na construção do saber histórico.

Mesmo sem desenvolver estes problemas em pormenor, nem avançar com soluções satisfatórias, importa fazer duas observações. A primeira delas respeita ao lugar e aos usos da escrita na sociedade medieval. Não tanto para evocar a sua íntima relação com o poder, que tem sido mais trabalhada e foi há muito objeto de um notável artigo de Luís Krus, ${ }^{34}$ mas para sublinhar que os documentos então produzidos não se reduzem ao seu conteúdo, aos textos que neles foram lavrados. Como sabe todo o aprendiz de historiador, as cartas emitidas pelos reis, ou por outros senhores, não foram escritas só para serem lidas e ouvidas, mas também para serem vistas. Era a necessidade de as exibir em público que justificava, aliás, alguns dos seus atributos materiais: o uso do pergaminho, um material mais nobre e resistente, o destaque dado ao selo, ou ao sinal com as armas respetivas, a caligrafia e a disposição do texto em linhas contínuas, quando há muito os livros se dispunham em duas, ou mais colunas, ${ }^{35} \mathrm{ou}$, por fim, a forma de as enrolar, ou de as dobrar segundo regras próprias, ${ }^{6}$ facto que garantia tanto o seu transporte, como a sua conservação.

Como objeto material, a carta tornava presente, isto é, representava, a voz do senhor que a emitira, permitindo a comunicação numa sociedade maioritariamente iletrada, onde as relações entre o visível e o invisível tinham uma importância decisiva. Uma carta não era, portanto, um fetiche, mas um objeto indispensável à compreensão das vozes invisíveis, através da qual se podiam materializar,

${ }^{34}$ Luís Krus (1994), "Escrita e Poder. As Inquirições de Afonso III", Passado, memória..., 35-57 [republ. in A Construção do Passado Medieval..., 41-58].

35 Joseph Morsel (2008), "Du texte aux archives...", 5-6, n. ${ }^{\circ}$ 17; Joseph Morsel (2000), “Ce qu'écrire veut dire..”, 34.

36 António Ribeiro Guerra (2003), Os Diplomas Privados em Portugal dos séculos IX a XII: gestos e atitudes de rotina dos seus autores materiais. Lisboa: Universidade de Lisboa, 235-252; Saul António Gomes (2007), In Limine Conscriptionis..., 264-270. 
de resto, outras ausências. Nas transações, a carta então produzida era, por vezes, misturada com a terra do prédio a que respeitava, para que assim a captasse, antes de passar da mão do antigo para o novo possuidor. ${ }^{37}$ Por isso, era frequente que a transmissão de um prédio estivesse acompanhada pela transferência de um pequeno arquivo, em regra formado pelas cartas dos antigos proprietários, 38 havendo muitas vezes o cuidado de assinalar que as outras cartas, as que se haviam perdido, ou que não haviam sido entregues por esquecimento, perdiam todo o seu valor, ficando mortas e caducas. ${ }^{39}$ Mais que um instrumento jurídico, ou apenas utilitário, as cartas eram, pois, um objeto simbólico, ${ }^{40}$ cuja manipulação ritual era imprescindível para garantir a eficácia de qualquer transação. Talvez essa dupla dimensão, simultaneamente simbólica e material, possa explicar por que foram as cartas objeto de tantas falsificações na época medieval ${ }^{41}$, ou por que são elas, como já foi recordado, ${ }^{42}$

\footnotetext{
37 Aron Gurevitch (1990), As Categorias da Cultura Medieval. Lisboa: Caminho, 204.

38 Apesar de a identificação desses conjuntos não ser fácil, dada a classificação cronológica das espécies, a integração na Ordem de Avis dos bens de certo proprietário/Iria Gonçalves (1999), "Um pequeno proprietário rural de Trezentos: Rodrigo Anes Chim, de S. Vicente da Beira", in Media Aetas. Revista de Estudos Medievais, n. ${ }^{\circ} 2,49-78$.) foi acompanhado por um pequeno arquivo, composto quer por várias cartas de aquisição, quer pelos diplomas pertencentes aos antigos proprietários. Para estes últimos, ANTT, Mesa da Consciência e Ordens, Ordem de Avis/Convento de S. Bento, Cx. 3, Mç. 2, n. ${ }^{\circ}$ 181, 182, 187, 197, 199, 202, 209, 217, 218.

39 Joseph Morsel (2000), "Ce qu'écrire veut dire...", 33.

40 Aron Gurevitch (1990), As Categorias..., 204; Joseph Morsel (2000), "Ce qu'écrire veut dire..., 24 e ss. O primeiro destes autores fez notar a dimensão simbólica revelada pelo hábito de enviar cartas em branco, sem texto, portanto, mas capazes de garantir que a voz do emissor era escutada. Para a emissão de cartas em branco no reino de Castela, Joseph O'Callaghan (1961), "The Earliest 'Difiniciones' of the Order of Calatrava, 1304-1383", in Traditio, vol. XVII, 272, n. ${ }^{\circ} 18$ [republ. in The Spanish Military Order of Calatrava and its Affiliates, Londres, 1975, n. ${ }^{\circ}$ VII].

41 Aron Gurevitch (1990), As Categorias..., 207-208; Ruy de Azevedo (1935), Documentos Falsos de Santa Cruz de Coimbra (séculos XII e XIII). Estudos de Diplomática Portuguesa. Lisboa: José Fernandes Júnior; Falsos y falsificaciones de documentos diplomáticos en la Edad Media (1991), ed. da Comissão internacional de Diplomática. Zaragoza: Real Sociedad Económica de Amigos del País.
}

42 Joseph Morsel (2000), "Ce qu'écrire veut dire...", 20. 
os documentos que se conservam em maior número nos arquivos, quando desapareceram muitos outros diplomas de natureza técnica, doméstica, ou pessoal.

A segunda série de observações tem a ver com a necessidade de olhar os arquivos como espaços de poder, quer dizer, como lugares de construção de um discurso sobre o passado. 43 Como se sabe, a organização de um arquivo tinha uma óbvia dimensão prática, criada pela necessidade de recuperar os diplomas que atestavam a validade dos títulos, das honras, dos privilégios e dos direitos de propriedade. ${ }^{44}$ Servia, pois, propósitos sociais muito concretos, que justificavam a construção de índices e de inventários, ou a seleção e a cópia das escrituras neles conservados para tombos e cartulários. Mas estes processos de inventário, de cópia e de classificação, não eram técnicas neutras e objetivas e criavam, por vezes, outros sentidos, ou davam lugar a novas intertextualidades. Para além das cópias adulteradas, como o caso daquele foral de Tomar que esteve em vigor entre 1318 e $1410,{ }^{45}$ era o que se verificava com alguns índices de arquivo do século XVIII ${ }^{46}$ que, associando sumários a dados genealógicos e a cópias de outros arquivos, construíam narrativas sobre o prestígio e a antiguidade de certas famílias. Mas essas narrativas também se podiam materializar numa reorganização das espécies conservadas. Foi o que sucedeu com alguns cartórios senho-

43 Joseph Morsel (2008), "Du texte aux archives...", 7-11, n. ${ }^{\circ}$ 23-38; Maria de Lurdes Rosa (2012), "Arquivos de Família: para um roteiro...”, 21-23; Terry Cook (2013), "Evidence, memory...”, 99, 102-103, 109 e ss.

${ }^{44}$ Luís Krus (1985), "Recensão a "Chancelarias Portuguesas...", 144; Luís Filipe Oliveira (2001), "O arquivo dos condes de Marialva num inventário do século XVI", in Filipe Themudo Barata (org.), Elites e redes clientelares na Idade Média. Lisboa: Colibri, 222-225; Saul António Gomes (2007), In Limine Conscriptionis..., 248-262.

${ }^{45}$ Luís Filipe Oliveira (2012), "Duas Memórias em confronto: a Ordem de Cristo e o concelho de Tomar", in José Carreiras e Giulia Vairo (orgs.), I Colóquio Internacional Cister. Os Templários e a Ordem de Cristo. Da Ordem do Templo à Ordem de Cristo. Os Anos da Transição. Atas. Tomar, 249-252, 254.

46 Maria de Lurdes Rosa (2012), “Arquivos de Família, o que são...”, 321. 
riais alemães do século $\mathrm{XV}$, rearranjados então segundo princípios linhagísticos, que se impuseram depois às escrituras dos séculos anteriores, e, por extensão, aos indivíduos e aos grupos familiares neles mencionados, que assim se convertiam em antepassados. ${ }^{47}$ A observação é importante e deve ser sublinhada. Por sugerir que a noção de linhagem foi uma invenção tardia, com impacto na organização dos cartórios senhoriais dos séculos anteriores, ela traz, de facto, um contributo decisivo para o debate sobre a mutação das estruturas de parentesco da nobreza, tema com enorme relevância na historiografia europeia e, também, na portuguesa. ${ }^{48}$

Os procedimentos de inventário e de classificação não eram alheios, por outro lado, à conservação das escrituras, e, portanto à preservação do passado e da memória. Sirva de exemplo o arquivo dos antigos condes de Marialva, que foi inventariado em 1565 por um clérigo da casa de D. António, o prior do Crato. ${ }^{49} \mathrm{O}$ inventário foi seletivo e nele apenas se sumariaram e classificaram cerca de trezentos diplomas relativos às igrejas do padroado dos condes, cujos direitos pertenciam então ao prior do Crato. O restante acervo do arquivo não suscitou, em contrapartida, a mesma atenção, sendo tratado de forma mais rápida, com a arrumação das espécies em quatro maços, as quais nem sempre foram descritas e contadas por serem consideradas de pouca utilidade. Ao contrário dos primeiros, que ainda hoje podem ser consultados na Torre do Tombo, aquelas

\footnotetext{
${ }^{47}$ Joseph Morsel (2004), "Le médiéviste, le lignage et l'effet de réel. La construction du Geschlecht par l'archive en Haute-Allemagne à partir de la fin du Moyen Âge", Révue de Synthèse, 83-110 [disponível em https://halshs.archives-ouvertes. fr/halshs-00289558]; Joseph Morsel, "La production circulaire d'un concept: le Geschlecht (lignage). Contribution à l'approche critique de la Beggriffgeschicte", in Bernard Lacroix, Xavier Landrin (dir), L'Histoire sociale des concepts. Signifier, classer, représenter $\left(X V I^{e}-X X^{e}\right.$ siècle). Paris: PUF (no prelo).

48 Didier Lett (2000), Famille et aparenté dans l'Occident médiéval $\mathrm{V}^{e}-X V^{e}$ siècle. Paris: Hachette, 23-65; José Mattoso (2011), "The Medieval Portuguese Nobility", in José Mattoso (dir.), The Historiography of Medieval..., 401-423.

${ }^{49}$ Luís Filipe Oliveira (2001), "O arquivo dos condes....", 221-260.
} 
últimas foram objeto de menores cuidados de conservação e viriam a desaparecer quase por completo. Como dizia Zurara a propósito de algumas cartas da chancelaria de Pedro I, ${ }^{50}$ também elas já não aproveitavam a ninguém, facto que as tornava dispensáveis, consentindo um extravio, ou até uma eventual destruição. Muito longe de ser um depósito estático, alheio às preocupações da vida, o arquivo era, portanto, um espaço em movimento, em articulação permanente com a história dos indivíduos, dos grupos e das sociedades que os haviam organizado e que deles sabiam tirar proveito.

A organização de um arquivo e a conservação das espécies que nele se arrumavam estavam longe de ser, portanto, aqueles atos neutros, objetivos e racionais, tão do agrado dos eruditos europeus e, depois, dos historiadores e dos arquivistas mais tradicionais. Muito pelo contrário, eram instrumentos sociais da maior importância, indispensáveis para garantir a memória escrita do passado e para ocultar memórias e passados alternativos, assegurando a identidade social dos seus detentores, quer dizer, os estatutos, os privilégios e os poderes de quem os tutelava e deles se servia. Nas sociedades europeias dos finais da Idade Média, quando a lei escrita se converteu num dos esteios da ordem política e da legitimidade social, a constituição de um senhorio, de uma comunidade, ou de outro qualquer corpo social, traduzia-se por norma na formação de um arquivo. ${ }^{51}$ Era rara a instituição sem uma chancelaria, ou um cartório,

\footnotetext{
50 Luís Krus (1985), “Recensão a "Chancelarias Portuguesas...”, 143-145.

51 Para a importância do arquivo na legitimação e na atividade das comunidades concelhias, Monique Bourrin (1993), "Les solidarités villageoises et l'écrit: La formalisation de l'années 1150-1250. L'exemple languedocien”, in Cofradías, Gremios y Solidariedades en la Europa Medieval (atas de las XIX Semana de Estudios Medievales de Estella, 20-24 de julio de 1992). Pamplona: Gobierno de Navarra, 31-49; Ana Filipa Roldão (2006), Escrita e Poderes Urbanos nos concelhos de Coimbra, Santarém e Lisboa (1179-1325), dissertação de mestrado em História apresentada à Faculdade de Letras da Universidade de Lisboa; Ana Filipa Roldão (2011), A memória da cidade. Administração urbana e práticas de escrita em Évora (1415-1536), dissertação de doutoramento apresentada à Faculdade de Letras da Universidade de Lisboa.
} 
ou que não detivesse, pelo menos, uma arca com escrituras, pois disso dependia a salvaguarda dos direitos e dos poderes exercidos sobre o espaço e os homens. A geografia da produção, e, sobretudo, da conservação documental, acompanhava de perto a geografia dos poderes, ${ }^{52}$ aspeto que se atesta, de resto, pela circunstância de os territórios pior documentados serem quase sempre espaços marginais, mais distanciados dos centros de poder e pouco procurados pelos grupos sociais mais influentes. Talvez mais que um lugar de memória e de identidade, o arquivo era uma expressão do poder da comunidade, do senhor da terra e, sobretudo, dos príncipes e dos monarcas.

Tal relação com o poder e com os processos de domínio do espaço e dos homens permite compreender, por outro lado, por que os arquivos europeus se transformaram nos principais repositórios de informação documental sobre o mundo. A partir de inícios do século XV, neles acumulou-se, na verdade, uma grande massa documental, 53 com diferentes proveniências e as tipologias mais diversas, em resultado da formação dos impérios europeus e do domínio e da colonização de várias regiões do globo. Com a posterior organização dos arquivos do império, ou do ultramar, essa documentação daria lugar a uma outra forma de domínio das

\footnotetext{
52 Para a análise dos processos de organização e de conservação do arquivo de um território, José Mattoso, Luís Krus, Amélia Andrade (1989), O Castelo e a Feira: A terra de Santa Maria nos séculos XI a XIII. Lisboa: Estampa, 29-67; Amélia Andrade e Luís Krus (coords.) (2000), Valdevez Medieval. Documentos: I. 950-1299. Arcos de Valdevez: C. M. de Arcos de Valdevez, 9-22.

53 Para alguns exemplos, Guia de Fontes Portuguesas para a História de África, ed. do Instituto Português de Arquivos. Lisboa: INCM, 1991; Guia de Fontes Portuguesas para a História da América Latina, ed. do Instituto dos Arquivos Nacionais-Torre do Tombo. Lisboa: INCM; 1997; Guia de Fontes Portuguesas para a História da Ásia, ed. do Instituto dos Arquivos Nacionais-Torre do Tombo. Lisboa: INCM, 1998; Barbara Harlow, Mia Carter (ed.) (2003-2004), Archives of Empire, 2 vols.. Durham: Duke University Press. Para a documentação relativa ao Brasil, conservada em diversos arquivos europeus, consultem-se os resultados do Projeto Resgaste, disponiveis em: http://www.cmd.unb.br/resgate_index.php.
} 
antigas colónias, graças à difusão dos critérios de prova, de autoria e de verdade documental, desenvolvidos pelos eruditos europeus, e à ocidentalização da sua história e do seu passado. Os processos tradicionais de guardar memórias e de contar histórias, ou de lidar com as questões da prova e da verdade, perdiam assim o seu antigo prestígio e toda a sua eficácia social, podendo ser relegados para os territórios da lenda e do costume. Para todos os excluídos daquele mundo, pouco mais restava, portanto, que o esquecimento, à margem da história e da civilização.

\section{Referências bibliográficas}

ANDrade, Amélia; Krus, Luís (coords.) (2000), Valdevez Medieval. Documentos: I. 950-1299. Arcos de Valdevez: C. M. de Arcos de Valdevez, 9-22. AZEVEDO, Ruy de (1935), Documentos Falsos de Santa Cruz de Coimbra (séculos XII e XIII). Estudos de Diplomática Portuguesa. Lisboa: José Fernandes Júnior.

AZEvedo, Ruy de (1991), Falsos y falsificaciones de documentos diplomáticos en la Edad Media, ed. da Comissão internacional de Diplomática. Zaragoza: Real Sociedad Económica de Amigos del País.

BLOCH, Marc (1952), Apologie pour L'Histoire ou Métier D'Historien. Paris:

A. Colin, 29-30.

BOISSELlier, Stéphane (ed.) (2010), De l'espace aux territoires. La territorialité des processus sociaux et culturels au Moyen Âge. Actes de la table ronde des 8-9 juin 2006, CESCM (Poitiers). Turnhout: Brepols.

BOURDÉ, Guy; MARTin, Hervé (1990), As Escolas Históricas. Mem-Martins: Europa-América.

BOURRIN, Monique (1993), "Les solidarités villageoises et l'écrit: La formalisation de l'années 1150-1250. L'exemple languedocien", in Cofradias, Gremios y Solidariedades en la Europa Medieval (atas de las XIX Semana 
de Estudios Medievales de Estella, 20-24 de julio de 1992). Pamplona: Gobierno de Navarra, 31-49.

BURKE, Peter (1992), A Revolução Francesa da Historiografia: A Escola dos Annales (1929-1989). São Paulo: UNESP, 12-15.

Cerquiglini-Toulet, Jacqueline (2014), "Conceiving the Text in the Middle Ages", in R. Howard Bloch et al. (eds.), Rethinking the New Medievalism. Baltimore: John Hopkins, 151-161.

CHASTANG, Pierre (2006), "Cartulaires, cartularisation et scripturalité médiévale: la structuration d'un nouveau champ de recherche”, Cabiers de civilisation médiévale, vol. 49, 21-31.

Chastang, Pierre (2008), "L'archéologie du texte médiéval. Autour de travaux récents de l'écrit", Annales. Histoire, Sciences Sociales, vol. 63, n. ${ }^{\circ} 2,247-256$.

Coelho, Maria Helena et al. (2001), Estudos de Diplomática Portuguesa. Lisboa: Colibri.

COOK, Terry (2012), "Ghosts in the Family: Historians, Archivists, and the Documentary Past", in Maria de Lurdes Rosa (org.), Arquivos de Família, séculos XIII-XX: Que Presente, que Futuro?. Lisboa: IEM.

COOK, Terry (2013), "Evidence, memory, identity, and community: four shifting archival paradigms", Archival Science, vol. 13, 100, 106 e 107.

DUBY, Gorges (1953), La Société aux XI et XII siècles dans la région Mâconnaise. Paris: A. Colin.

DUBY, Georges (1977), "História social e ideologia das sociedades", in Fazer História 1: Novos Problemas. Lisboa: Bertrand, 173-195.

Duby, Georges; LARDREAU, Guy (1980), Dialogues. Paris: Flammarion.

GAllego, Olga (1993), Manual de Archivos Familiares. Madrid: ANABAD.

GARCía DE CORTÁZAR, José Ángel (1969), El dominio del monasterio de San Millán de la Cogolla (siglo X-XIII). Introduccion a la Historia Rural de Castilla Altomedieval. Salamanca: Universidade de Salamanca.

GARCía DE CORTÁZAR, José Ángel (org.) (1985), Organización social del espacio en la España medieval: La Corona de Castilla en los siglos VIII a XV. Barcelona: Ariel. 
GINZBURG, Carlo (1992), A micro-história e outros ensaios. Lisboa: Difel. GOMES, Saul António (2007), In Limine Conscriptionis. Documentos, chancelaria e cultura no Mosteiro de Santa Cruz de Coimbra. Viseu: Palimage. Gomes, Saul António (2011), "The Editions of Archival Sources and Documents", in José Mattoso (dir.), The Historiography of Medieval Portugal c. 1950-2010. Lisboa: IEM, 15-42.

GONÇALVES, Iria (1999), "Um pequeno proprietário rural de Trezentos: Rodrigo Anes Chim, de S. Vicente da Beira”, in Media Aetas. Revista de Estudos Medievais, n. ${ }^{\circ}$ 2, 49-78.

GONÇALVES, Iria (coord.) (2005-2013), Paisagens Rurais e Urbanas. Fontes, Metodologias, Problemáticas, 5 vols. Lisboa: CH-UNL.

GonÇAlves, Manuel; Guimarães, Paulo; PeiXoto, Pedro (1996), Arquivos de Família. Organização e Descrição. Vila Real: UTAD.

GUERrA, António Ribeiro (2003), Os Diplomas Privados em Portugal dos séculos IX a XII: gestos e atitudes de rotina dos seus autores materiais. Lisboa: Universidade de Lisboa, 235-252.

GUERREAU, Alain (2001), L'Avenir d'un passé incertain. Quelle bistoire du Moyen Âge au XXI siècle?. Paris: Le Seuil.

Guia de Fontes Portuguesas para a História de África (1991), ed. do Instituto Português de Arquivos. Lisboa: INCM.

Guia de Fontes Portuguesas para a História da América Latina (1997), ed. do Instituto dos Arquivos Nacionais-Torre do Tombo. Lisboa: INCM.

Guia de Fontes Portuguesas para a História da Ásia (1998), ed. do Instituto dos Arquivos Nacionais-Torre do Tombo. Lisboa: INCM.

Gurevitch, Aron (1990), As Categorias da Cultura Medieval. Lisboa: Caminho, 204.

Guyotjennin, Olivier; MORElle, Laurent; PARISSE, Michel, et al. (eds.) (1993), Les Cartulaires. Actes de la table-ronde organisée par l'École nationale des chartres. Paris: École nationale des chartes.

HARLOW, Barbara; CARTER, Mia (eds.) (2003-2004), Archives of Empire, 2 vols. Durham: Duke University Press. 
IRIA, Alberto (1947), Os arquivos municipais do Algarve e a Academia Real de História Portuguesa (1729-1732), Sep. de Anais das Bibliotecas e Arquivos. Lisboa, vols. 17 e 19.

JAMESEN, Fredric (1998), The Cultural Turn. Selected workings on the Postmodern, 1983-1998. Londres: Verso.

KRUS, Luís (1985), "Recensão a "Chancelarias Portuguesas. D. Pedro I (1357-1367)»" (1984), in António Henrique de Oliveira Marques (org.), Ler História. Lisboa: I.N.I.C., n. ${ }^{\circ} 5,143-147$.

KRUS, Luís (1994), "Uma variante peninsular do mito de Melusina: a origem dos Haros no Livro de Linhagens do conde D. Pedro de Barcelos", Passado, memória e poder na sociedade medieval portuguesa. Estudos. Redondo: Patrimonia, 171-195 [republ. in A Construção do Passado Medieval. Textos inéditos e publicados, Lisboa, IEM, 2011].

KRUS, Luís (1994a), A Concepção Nobiliárquica do Espaço Ibérico (12801380). Lisboa: FCG/JNICT, 95-96, nota 159.

LE GOFF, Jacques (1984), "Documento/Monumento" e "Memória”, Enciclopédia Eunaudi. Memória-História. Lisboa: INCM, vol 1.

LETT, Didier (2000), Famille et aparenté dans l'Occident médiéval $V^{e}-X V^{e}$ siècle. Paris: Hachette, 23-65.

MARQUeS, António Henrique de Oliveira (org.) (1974-1975), Antologia da Historiografia Portuguesa, 2 vols. Mem Martins: Europa-América.

MARQUES, António Henrique de Oliveira (1988), Guia do Estudante de História Medieval Portuguesa (1964). Lisboa: Estampa.

MATTOSO, José; KRUS, Luís; ANDrAde, Amélia (1989), O Castelo e a Feira: A terra de Santa Maria nos séculos XI a XIII. Lisboa: Estampa, 29-67. MATTOso, José (2002), "A publicação de fontes documentais e o progresso da ciência histórica em Portugal" (1985), in A Escrita da História: teoria e métodos, Obras Completas de José Mattoso. Lisboa: Círculo de Leitores, vol. 10 .

MATTOSO, José Mattoso (2002a), “João Soares Coelho e a gesta de Egas Moniz", in Portugal Medieval. Novas interpretações, Obras Completas de José Mattoso. Lisboa: Círculo de Leitores, vol. 8, 301-320. 
MORA, Luís Miguel García (1998), Fuentes manuscritas para la Historia de Portugal. Guía de instrumentos de investigación. Madrid: Fundación Histórica Tavera.

MORSEL, Joseph (2000), "Ce qu'écrire veut dire au Moyen Âge. Observations préliminaires à une étude de la scriptrualité médiévale”, in Mimini. Travaux et documents de la Société des études médiévales du Québec, 4, 3-43. MORSEL, Joseph (2004), "Le médiéviste, le lignage et l'effet de réel. La construction du Geschlecht par l'archive en Haute-Allemagne à partir de la fin du Moyen Âge”, Révue de Synthèse, 83-110 [disponível em https:// halshs.archives-ouvertes.fr/halshs-00289558].

MORSEL, Joseph (2008), "Du texte aux archives le problème de la source", in Bulletin du centre d'études médiévales d'Auxerre (BUCEMA), hors série n. ${ }^{\circ} 2$ (disponível em http://cem.revues.org/index4132.html).

MORSEL, Joseph, "La production circulaire d'un concept: le Geschlecht (lignage). Contribution à l'approche critique de la Beggriffgeschicte”, in Bernard Lacroix e Xavier Landrin (dirs.), L'Histoire sociale des concepts. Signifier, classer, représenter ( $X V I^{e}-X X^{e}$ siècle). Paris: PUF (no prelo). NICHOLS, Stephen (2014), "Reflections on The New Philology", in R. Howard Bloch et al. (eds.), Rethinking the New Medievalism. Baltimore: John Hopkins, 12-38.

O'CALlaGHAN, Joseph (1961), "The Earliest 'Difiniciones' of the Order of Calatrava, 1304-1383", in Traditio, vol. XVII, 272, n. ${ }^{\circ} 18$ [republ. in The Spanish Military Order of Calatrava and its Affiliates, Londres, 1975, n. $\left.{ }^{\circ} \mathrm{VII}\right]$.

OliveirA, Luís Filipe (2001), "O arquivo dos condes de Marialva num inventário do século XVI", in Filipe Themudo Barata (org.), Elites e redes clientelares na Idade Média. Lisboa: Colibri, 222-225.

OliveirA, Luís Filipe (2012), "Duas Memórias em confronto: a Ordem de Cristo e o concelho de Tomar", in José Carreiras e Giulia Vairo (orgs.), I Colóquio Internacional Cister. Os Templários e a Ordem de Cristo. Da Ordem do Templo à Ordem de Cristo. Os Anos da Transição. Atas. Tomar, 249-252, 254. 
RIBEIRO, Fernanda (2012), "Antes e para além do Aquivo Nacional: ruturas e continuidades", in Maria de Lurdes Rosa (org.), Arquivos de Família, séculos XIII-XX: Que Presente, que Futuro?. Lisboa: IEM.

ROLDÃO, Ana Filipa (2006), Escrita e Poderes Urbanos nos concelhos de Coimbra, Santarém e Lisboa (1179-1325), dissertação de mestrado em História apresentada à Faculdade de Letras da Universidade de Lisboa. ROLDÃO, Ana Filipa (2011), A memória da cidade. Administração urbana e práticas de escrita em Évora (1415-1536), dissertação de doutoramento apresentada à Faculdade de Letras da Universidade de Lisboa.

RosA, Maria de Lurdes (2011), "Arquivos de Família - O que são, para que servem, como preservá-los e estudá-los?", in Casa Nobre: Um Património para o Futuro. Atas do $3 .^{\circ}$ Congresso Internacional. Arcos de Valdevez: C. M. de Arcos de Valdevez.

SOUSA, Bernardo Vasconcelos e (dir.) (2005), Ordens Religiosas em Portugal: Das Origens a Trento. Guia Histórico. Lisboa.

Torgal, Luís Reis; MEndes, José Amado; CATrogra, Fernando (1996), História da História em Portugal. Lisboa: Círculo de Leitores.

TOUBERT, Pierre (1973), Les Structures du Latium médiéval: Le Latium méridional et la Sabine du IXe à la fin du XII ${ }^{e}$ siècle, 2 vols. Paris/Roma: Ecole française de Rome.

TOUBERT, Pierre; MORET, Pierre (eds.) (2009), Remploi, citation, plagiat. Conduites et pratiques médiévales (XIe-XII siècles). Madrid: Casa de Velazquez.

VASCONCELOS, Carolina Michaëlis de (1990), Cancioneiro da Ajuda, reimp. da edição de Halle. Lisboa: INCM, vol. II, 289-584.

VIERA, Yara et al. (eds.) (2004), Glosas Marginais ao Cancioneiro Medieval Português de Carolina Michaëlis de Vasconcelos. Coimbra: Imprensa da Universidade. 
(Página deixada propositadamente em branco) 


\section{7 \\ PRÁTICAS E MATERIALIDADES, ETNOGRAFIAS EANTROPOLOGIA}

No final do século XIX e início do século XX, face à aflição teórica decorrente das críticas ao evolucionismo, foram apresentadas e desenvolvidas novas propostas metodológicas na antropologia britânica (Stocking, 1983). As recolhas apressadas de objetos e folclore ou os inquéritos conduzidos por não etnógrafos, de acordo com as categorias de Notes and Queries dos antropólogos de gabinete, foram dando lugar ao trabalho intensivo de campo de etnógrafos especializados, assente na residência prolongada numa comunidade, no conhecimento da língua nativa, na atenção a conversas informais ou "espontâneas", na observação direta de todos os detalhes concretos da vida quotidiana, em conversas demoradas com os nativos dotadas de "simpatia" e "tato" e, com Malinowski, na participação no dia a dia das populações estudadas. O trabalho de campo, com observação-participante tornar-se-ia no método inquestionável da antropologia durante grande parte do século XX. O propósito era resgatar cada cultura particular nos seus próprios termos e desfazer pré-noções baseadas em comparações apressadas com outras culturas ou com a do próprio investigador. Procurava-se obter um significado mais profundo de cada cultura, não inteiramente resgatável através de recolhas de relatos verbais.

Em meados dos anos 70 do século $\mathrm{XX}$, o trabalho de campo foi fortemente criticado pelo pós-modernismo e um pouco mais 
tarde pelos estudos pós-coloniais, enquanto "laboratório" ou lugar de descoberta de uma antropologia geopoliticamente assente num centro euro-americano (Clifford, 1997; Robben e Sluka, 2007). A crescente atenção à relação entre conhecimento e poder daria origem a um conjunto de tendências reflexivas e a novas modalidades de investigação e escrita etnográfica mais colaborativas e polifónicas. A descolonização da disciplina exigia a reformulação das relações de poder na investigação. Por outro lado, a compressão do espaço-tempo decorrente das novas tecnologias de transporte e comunicação, a transformação da geografia da distância e da diferença em contextos pós-coloniais, a multiplicação de lugares suscetíveis de serem abordados etnograficamente e a entrada de académicos "indígenas", "diaspóricos" ou "pós-coloniais" na antropologia, tornaram cada vez mais complexa a circunscrição do terreno. A oposição entre antropólogo nativo e não nativo e, assim, entre interior e exterior, identidade e diferença é questionada, já que qualquer antropólogo pertence em simultâneo a diferentes comunidades e a múltiplos e complexos lugares de identificação. Neste novo contexto de questionamento, a antropologia tem procurado reinventar e redefinir o trabalho de campo, pois é um dos poucos elementos de distinção disciplinar que lhe resta (Clifford, 1997). Como defende James Clifford (1997), a antropologia nos EUA está sobretudo preocupada em demarcar uma fronteira com os estudos culturais. A reconfiguração do trabalho de campo permite à antropologia distinguir-se da crítica literária e da semiótica textualista, apenas centradas em "discursos", "narrativas", "representações", daí também a recente rejeição da chamada antropologia pós-moderna. Em Portugal, a antropologia, ao aproximar-se dos estudos pós-coloniais, também fez questão de demarcar a fronteira entre "textos" e "experiências de intersubjetividade", entre estudos culturais e antropologia (Almeida, 2000; Roque, 2006; Sanches, 2006). No entanto, os estudos culturais da escola de Birmingham também têm uma tradição de trabalho etnográfico 
e várias pesquisas antropológicas contemporâneas, dificilmente se distinguem dos estudos culturais, ao articularem observação-participante, crítica cultural e análise do discurso e dos média (Appadurai, 2000; Marcus, 1998). A antropologia tem vindo, progressivamente, a reconhecer (não sem conflitos, disputas e negociações internas) novas práticas etnográficas, mas permanece a exigência de uma pesquisa intensiva, prolongada e profunda, atenta às práticas quotidianas e ao conhecimento informalmente produzido e transmitido, decorrente de uma relação de envolvimento, proximidade e diálogo com o sujeito etnográfico. Porém, James Clifford (1997: 63) pergunta: quão descentrado se pode tornar o trabalho de campo antes de ser reconhecido como apenas um entre um conjunto de métodos etnográficos e históricos utilizados pela disciplina em diálogo com outras disciplinas?

Ao aproximar-se da história, dos estudos culturais, da crítica literária, dos estudos de imagem e ao passar também a analisar textos, discursos, fotografias, desenhos, arquivos, a antropologia tem vindo a destacar a materialidade das representações, mostrando as práticas a elas associadas e como também elas estão inseridas no campo das interações sociais. Em Photographs Objects Histories, Elizabeth Edwards e Janice Hart referem as qualidades performativas da fotografia, os seus múltiplos contextos (pessoais e/ou institucionais) de produção, troca, uso e significado e propõem, como métodos de investigação da materialidade da fotografia, o estudo da biografia social dos objetos fotográficos e uma etnografia das práticas fotográficas em várias partes do mundo. Também as recentes propostas de etnografias de arquivo (Comaroff e Comaroff, 1992; Porto, 2002; Cunha, 2004; Valentim, 2014) têm procurado resgatar a sua materialidade, mostrando como foram constituídos, alimentados e mantidos por pessoas, grupos sociais e instituições e como integram as relações de poder que entre eles se tecem. Falaremos aqui destas propostas etnográficas que, centradas na materialidade 
das imagens, textos e documentos, reformulam a tradição metodológica da antropologia.

\section{Perspetivas pós-coloniais e antropologia}

Abordar os possíveis contributos da antropologia para um aprofundamento da reflexão teórica e metodológica sobre "Patrimónios de Influência Portuguesa" passa, num primeiro momento, por evocar os recentes debates sobre estudos coloniais e pós-coloniais, pois grande parte desses "patrimónios" foram produzidos em zonas de contacto (Pratt, 1992) e de encontro colonial, frequentemente marcadas quer por processos de coerção, desigualdade e conflito, quer por colaborações e negociações. Os estudos pós-coloniais, associados nos anos 80 do século $\mathrm{XX}$ aos estudos culturais e à crítica literária, foram criticados pelas ciências sociais e, em particular, pela antropologia por se centrarem sobretudo em textos, discursos e representações e negligenciarem a complexidade e multiplicidade de práticas, contextos e interações coloniais (Cooper e Stoler, 1997; Almeida, 2000; Roque, 2006; Sanches, 2006).

Porém, os estudos pós-coloniais não se propõem apenas analisar as diferentes formas de poder e de conhecimento do colonialismo, mas a fazê-lo de um modo crítico, com o objetivo de transformar o nosso entendimento do presente. As suas abordagens procuram transcender os legados culturais e ideológicos do império e as representações, relações e práticas coloniais que ainda hoje se mantêm, apresentando-se assim como um domínio político-intelectual. Eles configuram uma possibilidade de se repensar o modo pelo qual as diferentes disciplinas criaram a sua autoridade e as suas categorias de conhecimento, analisando os discursos e as representações coloniais como ponto de partida para questionar o conhecimento ocidental. No entanto, essa abordagem não necessita de assentar 
em grandes oposições, como colonizador/colonizado ou metrópole/ colónias, nem em noções abstratas, redutoras e monolíticas dos aparelhos coloniais, que ignoram os conflitos internos, incoerências e as tensões ou alianças com as autoridades indígenas. Como destacam Cooper e Stoler (1997), as possibilidades políticas também residem num olhar mais subtil e empiricamente sustentado sobre as múltiplas, contraditórias e fortuitas práticas de obtenção de poder e produção cultural. Ainda segundo estes autores, o aparelho colonial europeu não era monolítico nem coerente, mas composto por vozes dissonantes, narrativas divergentes, conflitos de interesse entre os diferentes agentes do império (missionários, colonos, homens de negócios, empresas comerciais europeias, oficiais locais, políticos metropolitanos, donos de plantações), políticas e conhecimentos incompletos e fragmentados e inúmeras discussões sobre os procedimentos a seguir pelo Estado colonial. Os regimes coloniais não eram consensuais e nem sempre tiveram a adesão da população metropolitana, tal como frequentemente não tinham da população local, sendo constantemente levados a reavaliar as suas estratégias face a resistências várias, quer internas, quer por parte das pessoas que procuravam subjugar. Cooper e Stoler (1997) sugerem assim que, em vez de partirmos da dicotomia traçada pelos regimes coloniais entre colonizador e colonizado, devemos procurar compreender como as fronteiras culturais foram sendo construídas e mantidas, mas também contestadas e negociadas, através de processos dinâmicos de encontro colonial, sendo essa a principal tensão do império. Por isso, Miguel Vale de Almeida (2000) e Manuela Ribeiro Sanches (2006) defendem que as perspetivas pós-coloniais devem assentar em trabalhos de pesquisa empírica, nomeadamente historiográficos e antropológicos, atentos à diversidade de práticas e contextos coloniais, a fontes escritas menores ou esquecidas, às vicissitudes e contingências das representações culturais. Para Vale de Almeida, existe uma área de sobreposição entre os estudos pós-coloniais e 
uma prática antropológica mais descentrada, colaborativa e polifónica, reflexiva e autocrítica em relação à bagagem conceptual que herdou do colonialismo, mas enquanto os estudos pós-coloniais se centram na análise de textos e representações, o método da antropologia assenta em experiências intersubjetivas. Podemos, no entanto, perguntar se as duas abordagens não se poderão articular e complementar, se o reforçar da diferença entre representações e práticas ou experiências quotidianas não se deve a um mecanismo de distinção e sobrevivência disciplinar, e se a tradição metodológica da antropologia não poderá contribuir para ampliar e renovar as teorizações pós-coloniais.

\section{"Viragem Material"}

As investigações antropológicas sobre representações e processos coloniais poderão ajudar a resgatar não apenas as práticas quotidianas dos agentes sociais, mas também a materialidade dessas representações. Nas décadas de 70 e sobretudo 80, a antropologia, que havia abandonado o estudo dos artefactos com receio de ser acusada de fetichismo, passou a enfatizar as formas materiais como constitutivas dos mundos sociais (Miller, 1998; Edwards e Hart, 2004). Através desta "viragem material", a antropologia tem vindo a estudar a existência social mundana dos objetos e o seu papel na produção de significados e relações sociais. Alguns autores, como Bruno Latour (2005) ou Alfred Gell (1998), referem-se mesmo aos objetos como atores sociais ou actantes, no sentido em que não apenas significam mas influenciam o campo da ação social de um modo que nunca aconteceria se eles não existissem. O importante não é, então, averiguar qual o significado que as formas materiais adquirem, mas o que elas fazem, quais os seus efeitos sociais. Para Latour (2005), qualquer objeto que faça a diferença no decurso da 
ação de um outro agente ou que modifique o estado de coisas é um actante. Se desenvolver uma determinada atividade que, com ou sem esse objeto for exatamente igual, então ele desaparece do campo da ação social. Mas os objetos não são a causa, nem determinam a ação humana, eles apenas autorizam, permitem, encorajam, sugerem, influenciam, bloqueiam, tornam possível, proíbem e por aí adiante (Latour, 2005: 72). Os estudos de cultura material permitem assim, segundo Miller (1998), resgatar processos culturais anteriormente negligenciados pela antropologia, associados à materialidade e às representações visuais, ao mesmo tempo que questionam uma abordagem centrada nos textos e na linguagem verbal.

Elizabete Edwards e Janice Hart (2004: 4) defendem também que existe um quadro metodológico e teórico comum aos estudos da cultura material e da cultura visual, ambos interessados nas formas materiais e na ação social. Em Photographs Objects Histories, as autoras falam da fotografia não apenas como uma imagem bidimensional, mas também como um objeto material, tridimensional, com volume e textura, que existe no espaço e no tempo e, assim, na experiência social e cultural. Por isso, falar da fotografia como objeto não é cair no fetichismo, mas destacar a relação complexa e dinâmica entre pessoas e objetos, traduzindo uma fotografia abstrata e representacional numa fotografia cuja mudança contínua de significado depende da sua biografia social, da sua passagem por diferentes lugares e contextos de produção, distribuição, troca, consumo, uso, destruição e reciclagem. Através de intervenções materiais sobre a superfície da fotografia e de práticas aditivas, como colorir, escrever ou dobrar a fotografia, ao ordenarem as fotografias, inserindo-as e retirando-as de álbuns fotográficos ou em determinados espaços da casa, as pessoas apropriam-se e conferem um significado particular a fotografias produzidas em massa, tornando-as suas e tornando-se também, através do uso que delas fazem, os seus autores. Resgatar a materialidade da fotografia é assim, para Edwards e Hart, resgatar 
também o seu lugar nas interações sociais e fazer depender o seu significado social daqueles que a utilizam, contrariando assim as abordagens que se centram na visão do fotógrafo e na receção e consumo passivo da fotografia.

Esta "viragem material”, que abarcou uma atenção renovada à cultura material e à cultura visual, surgiu, entretanto, num período marcado pela eclosão de um olhar crítico sobre a história da disciplina, particularmente atento aos enlaces entre a antropologia, a construção ocidental da alteridade e o fenómeno colonial. Promovido no âmbito da crítica pós-moderna da antropologia - mas também no contexto de uma renovada história da antropologia desenvolvida na esteira do trabalho de G. W. Stocking -, este olhar mostra-se desde cedo atento ao modo como, ao longo dos séculos XIX e XX, a antropologia foi sendo praticada nos museus, através da constituição de coleções e da organização de exibições, e também da criação de imagens fotográficas e fílmicas. São exemplos pioneiros desta orientação o livro Objects and Others. Essays on Museums and Material Culture, organizado por George W. Stocking, (1985) e Predicament of Culture de James Clifford (1988). Os ensaios compilados por Stocking abordam os acervos de objetos etnográficos na sua relação com a construção de diferentes teorias antropológicas e enquanto resultado dos processos de dominação colonial (Stocking, 1985b: 4-5). A sua leitura é particularmente reveladora dos processos de descontextualização e recontextualização a que os artefactos Outros foram sujeitos nos museus ocidentais: oriundos de sociedades e culturas distantes, eram muitas vezes desgarrados dos usos e significados que aí detinham, para, não raramente, ilustrar a alegada superioridade da "civilização ocidental»: no capítulo dedicado às coleções etnográficas organizadas na Inglaterra oitocentista por Pitt Rivers, por exemplo, William Chapman mostra como os princípios do evolucionismo social organizavam a aquisição e o arranjo expositivo dos objetos, transmitindo a ideia de que as «sociedades 
aborígenes» contemporâneas seriam representantes vivas de um estádio pré-histórico da evolução humana, ao qual teriam ficado aprisionadas (Chapman, 1985:31).

Em The Predicament of Culture, James Clifford propõe uma abordagem mais ampla às apropriações ocidentais da cultura material de outras sociedades: atento às práticas etnográficas que, durante o século XX, atravessaram os campos da antropologia, da literatura e das artes, James Clifford devota uma parte substancial do seu livro à obsessão ocidental em "colecionar o mundo". Neste sentido, analisando exibições etnográficas e, sobretudo, exposições de "arte primitiva", mostra como os artefactos não ocidentais foram sujeitos a diferentes processos de reclassificação, acompanhados, em muitos casos, pela completa rasura dos sentidos que os mesmos detinham nos seus contextos de origem. Esta demonstração é bem nítida na análise que Clifford (1988: 189-214) oferece da conhecida exposição "Primitivism in the $\mathrm{XX}^{\text {th }}$ century", organizada em 1984 pelo Museum of Modern Art, em Nova Iorque (MoMA). Como explica o autor, para além de aludirem à descoberta da "arte primitiva" por parte dos pintores modernistas, os organizadores desta mostra teriam reduzido o significado dos artefactos nativos às ideias que os modernistas projetaram nos mesmos, transformando-os numa prova tangível da sensibilidade artística da vanguarda do princípio do século XX; como se a existência de tais artefactos só fizesse sentido à luz da história de arte ocidental. A exposição realizada no MoMA teria sido, acima de tudo, uma celebração do modernismo e da sua descoberta da "arte tribal», uma história que deixaria de fora as outras histórias por um lado, a história e os contextos culturais dos objetos expostos antes de chegarem à Europa, por outro, a história, e as circunstâncias políticas e ideológicas, da própria apropriação modernista dos artefactos nativos. Como afirma Clifford, "[...] a lógica subjacente à "descoberta" da arte tribal tem subjacente assunções hegemónicas do Ocidente enraizadas na época colonial e neocolonial." (1988:197). 
Ao longo dos anos 90, esta orientação diversifica-se, vindo a abarcar outros campos de análise, como o do amplo universo das imagens e da sua circulação: imagens produzidas por antropólogos, fotógrafos e cineastas amadores e profissionais que invadem a modernidade ocidental de retratos da alteridade, através da publicidade, das revistas e dos postais ilustrados ou do cinema. Seguindo um rumo já traçado por James Clifford, tais pesquisas encaram as ideias produzidas no âmbito da antropologia académica em conjunto com outras instâncias de construção do Outro não ocidental. Em períodos em que as fronteiras da produção e da divulgação científica eram manifestamente fluidas, a etnografia profissional cruzava-se com as artes e com a literatura - como o demonstrou Clifford -, mas também com os produtos da cultura de massas, configurando, assim, aquilo a que se pode chamar uma "antropologia popular». A importância desta perspetiva não é de menosprezar: como defende Robert Gordon (1997), não é possível entender as representações do Outro, que circulam na sociedade ocidental, sem estudar as modalidades dessa antropologia «de massas». No seu estudo sobre a «Expedição Africana de Denver» de 1925 - expedição que envolveu jornalistas, cineastas, gente de negócios e cientistas em busca do "povo mais primitivo ainda existente" - Gordon mostra, precisamente, como as fotografias dos bosquímanes, produzidas nesse âmbito, foram responsáveis pela construção da imagem «idealizada» de um povo à margem da modernidade, evidenciando também que foi esse o retrato que permaneceu até à atualidade, com consequências claramente funestas para tais populações.

\section{Circulação de textos e objetos antropológicos em contextos coloniais: dois estudos de caso}

Certas leituras dos contributos de Stocking e de Clifford correm, no entanto, o risco de promover uma visão redutora da relação 
entre processos coloniais e representações do Outro, esquecendo as contingências e a pluralidade de práticas e configurações materiais associadas a tais representações. Como defende Ricardo Roque (2006), a relação cúmplice entre antropologia e os projetos coloniais europeus foi frequentemente assumida e afirmada no interior da própria disciplina, sobretudo nas décadas de 1960 e 1970, mas nem sempre foi objeto de investigação, questionamento e problematização.

No seu texto "Colonialidade equívoca: Fonseca Cardoso e as origens da antropologia colonial portuguesa”, Roque propõe então investigar esta relação através de uma história prática da antropologia, centrada nos contextos de produção, circulação e receção do conhecimento antropológico. Fá-lo perseguindo a história e o percurso de um texto, "O Indígena de Satari. Estudo antropológico" de 1896-97, e do seu autor, Artur da Fonseca Cardoso (18651912), celebrado no I Congresso de Antropologia Colonial de 1934, enquanto fundador da antropologia colonial portuguesa. A associação entre Fonseca Cardoso e antropologia colonial é, no entanto, equívoca e só pode ser compreendida pelo modo como o texto "O indígena de Satari" foi recebido e estrategicamente apropriado por uma posterior geração de antropólogos, ligados à Universidade do Porto e a António Mendes Correia (1888-1960), com o objetivo de promover, com o apoio do Estado, as suas próprias carreiras científicas enquanto estudiosos das populações coloniais (Roque, 2006: 105-6). Quando morre, em 1912, Fonseca Cardoso era conhecido como um estudioso das populações portuguesas e não como um antropólogo colonial. Na verdade, e como demonstra Ricardo Roque, a sua antropologia estava associada a um projeto de regeneração nacional no qual as populações ultramarinas não estavam presentes. O seu trabalho antropométrico no distrito de Satari decorreu, por isso, de um acidente e de um imprevisto que interrompeu o seu projeto antropológico metropolitano. A sua carreira militar obrigou Fonseca Cardoso a partir para Goa para participar nas "campanhas 
de pacificação da Índia de 1895-1896". As campanhas de "pacificação" em Goa não correram de feição para os militares portugueses. Estes confrontaram-se com tropas inimigas móveis e invisíveis, dificilmente derrotáveis. Apesar da relação de poder entre portugueses e indígenas não ter sido favorável para a prática antropológica, Fonseca Cardoso conseguiu, através do aprisionamento equívoco de trabalhadores ao serviço do Estado Colonial, tirar partido da conexão material momentânea e contingente entre situação colonial e o seu próprio trabalho antropométrico. Ao seguir a trajetória do texto "O Indígena de Satari", pensado como um artefacto, pelos seus diferentes contextos de produção, circulação e receção, Roque demonstra então que, neste caso, as ligações materiais entre antropologia e colonialismo foram efémeras e transitórias, contrariando assim as leituras que assumem, como um dado inquestionável e não problemático, que a antropologia, sobretudo na tradição da antropologia física, foi utilizada como um instrumento ao serviço da construção do império. Como conclui Ricardo Roque (2006: 110), "As des/conexões entre a antropologia e o colonialismo foram sendo elaboradas e reelaboradas pelas práticas dos atores, constituindo um resultado imprevisível, instável e ambivalente. Por vezes a antropologia de Fonseca Cardoso foi colonial; mas outras vezes tal não acontecia".

Num outro texto, Roque (2009/10) procura reconstituir historicamente as práticas materiais de aquisição no terreno da coleção de crânios de Timor da Universidade de Coimbra, mas também a circulação do documento oficial escrito pelo seu coletor, o reverendo António Joaquim de Medeiros, para acompanhar esta coleção enviada de Timor para a metrópole em 1881-82. Através deste texto (Roque, 2009/10: 268), ficamos a saber que o governador de Timor, Hugo de Lacerda, nomeou, em abril de 1879, uma Comissão, presidida pelo Superior da Missão Católica em Timor, o missionário Medeiros, para a formação de coleções de produtos timorenses dignos de apresentação no Museu Colonial de Lisboa, conforme 
ordem superior recebida do governo provincial de Macau. Esta Comissão foi extinta abruptamente, em fevereiro de 1881, pelo novo governador de Timor, Augusto Cardoso de Carvalho, então em contenda política com a Missão Católica. Medeiros foi então obrigado a entregar todos os materiais até aí recolhidos, enviando para Carvalho as caixas com as peças empacotadas à pressa e de improviso, uma carta oficial, um ofício e um catálogo das coleções. Neste ofício, o Ofício n. ${ }^{\circ} 15$, é referido que os 35 crânios, listados com o N. ${ }^{\circ} 1 .^{\circ}$ no catálogo, eram de homens e mulheres decepados por guerreiros timorenses ao serviço do governo colonial durante a guerra de Laleia de 1878 a 1879, marcada por uma violenta campanha contra o rei ou régulo timorense deste reino, D. Manuel Salvador de Remédios. Neste ofício é também assinalado que estes crânios foram posteriormente entregues pelas forças timorenses auxiliares do governo aos missionários, que os receberam, conservaram e classificaram como objetos de valor científico e antropológico. De acordo com Ricardo Roque, esta descrição transforma os missionários portugueses em recetores passivos das práticas timorenses de decapitação, ocultando o papel ativo que aqueles tiveram na guerra de Laleia e nas ações militares que deram origem à caça de cabeças, e permite também transformar simbolicamente um conjunto de objetos associados à violência cerimonial timorense, potencialmente poluidora, numa coleção de significado antropológico a enviar para os museus em Lisboa. Esta coleção é, no entanto e como demonstra Roque, o resultado de conexões materiais entre a violência da guerra desencadeada pelo governo colonial português em Timor, a Missão Católica que, ao mesmo tempo que participa na guerra de Laleia contra o régulo Remédios, é nomeada pelo então governador Hugo de Lacerda para a Comissão científica de recolha de produtos timorenses, e a violência ritual exercida durante a guerra pelas forças nativas, referidas como "auxiliares do governo". Por isso e como conclui Ricardo Roque: 
[...] a obtenção de objectos indígenas pelos europeus no período colonial não deve ser vista como um processo monolítico e homogéneo, mas como uma série de actividades relativas a diferentes projectos e interacções coloniais,[...] na qual a agência dos povos nativos deve ser tida em conta (Roque, 2009/10: 278).

Mas, até agora, apenas nos temos centrado no contexto de recolha ou de aquisição da coleção de crânios de Timor da Universidade de Coimbra. No seu trajeto até esta universidade, muitos outros atores e processos materiais entraram em jogo. Começamos por lembrar que o conjunto de crânios foi empacotado à pressa, em conjunto com outros produtos recolhidos, e enviado, em 1881, para o novo governador de Timor, na sequência da alteração das relações políticas entre a Missão e o governo colonial. Nesse mesmo ano, todos esses materiais foram enviados para Macau (Martins e Amaral, 2011). As remessas enviadas para Macau foram aí recebidas, reorganizadas e embaladas (para seguirem até Lisboa) pelo Secretário-Geral do governo provincial de Macau e Timor, José Alberto Homem da Cunha Corte-Real (Martins e Amaral, 2011). Medeiros não tinha intenção de as enviar para Coimbra, mas apenas para o Museu Colonial de Lisboa e, eventualmente, uma parte para o projetado museu de Dili (Roque, 2009/10). No entanto, a entrada, em 1882, da coleção de crânios de Timor no Museu Botânico e, posteriormente, no Museu de História Natural da Universidade de Coimbra (Martins e Amaral, 2011), pode ser explicada pela correspondência trocada, pelo menos desde 1879, entre Corte-Real e Júlio Henriques, então diretor do Jardim e Museu Botânico de Coimbra, sobre os produtos de Timor e Macau a recolher (ver Corte-Real, carta para Júlio Henriques, 25 de fevereiro de 1879). O trabalho de reorganização dos objetos a remeter para a metrópole, coordenado por Corte-Real, não foi guiado por interesses antropológicos, mas exclusivamente comerciais e industriais (Roque, 2009/10; Martins e Amaral, 2011); talvez por 
isso, o Ofício n. ${ }^{\circ} 15$ e o catálogo produzido pelo seu coletor nunca tenham chegado a Coimbra (Roque, 2009/10). Segundo Roque, é provável que Macau tenha sido o último destino destes documentos e, desde então, a coleção de crânios de Timor ficou separada das palavras do reverendo e, assim, do seu contexto de aquisição, adquirindo novos sentidos. O contexto colonial e de guerra, no qual os crânios timorenses foram recolhidos, foi deste modo ocultado, tal como aconteceu, sobretudo a partir do século XVIII, com muitas outras coleções científicas (ver Miller, 1996; Schiebinguer, 1998). Os documentos hoje existentes nos arquivos da Universidade de Coimbra, relativamente aos produtos então enviados de Timor e Macau para a metrópole, estão assinados por Corte-Real (Martins e Amaral, 2011). Tal como referem Maria do Rosário Martins e Ana Rita Amaral (2011), estes objetos passaram, desde então e ao longo da sua trajetória, por diferentes processos de inventariação e classificação, contendo, ainda hoje, alguns vestígios materiais deste percurso nas etiquetas a eles associadas, mas as interações coloniais, através das quais eles foram adquiridos no terreno, foram apagadas. (Fig. 1).

Como é que Ricardo Roque então acedeu ao Oficio $n .^{\circ} 15$, de modo a poder reconstituir historicamente o contexto de recolha da coleção de crânios de Timor, ainda hoje pertencente à Universidade de Coimbra? Roque encontrou este documento de um modo algo inesperado, integrado num outro arquivo colonial, historicamente desligado do trajeto da coleção. Depositado no Arquivo Histórico Ultramarino em Lisboa, o Ofício n. ${ }^{\circ} 15$ surge inserido no vasto conjunto de correspondência trocada durante o conflito institucional e público entre o Estado colonial em Timor, na altura liderado por Carvalho, e os missionários. É neste contexto que o reverendo Medeiros escreve uma longa carta enviada em junho de 1881 ao Bispo de Macau, por este reencaminhada para o Ministro dos Negócios da Marinha e Ultramar, na qual procura mostrar a importância da Missão para o estabelecimento colonial, referindo também os 


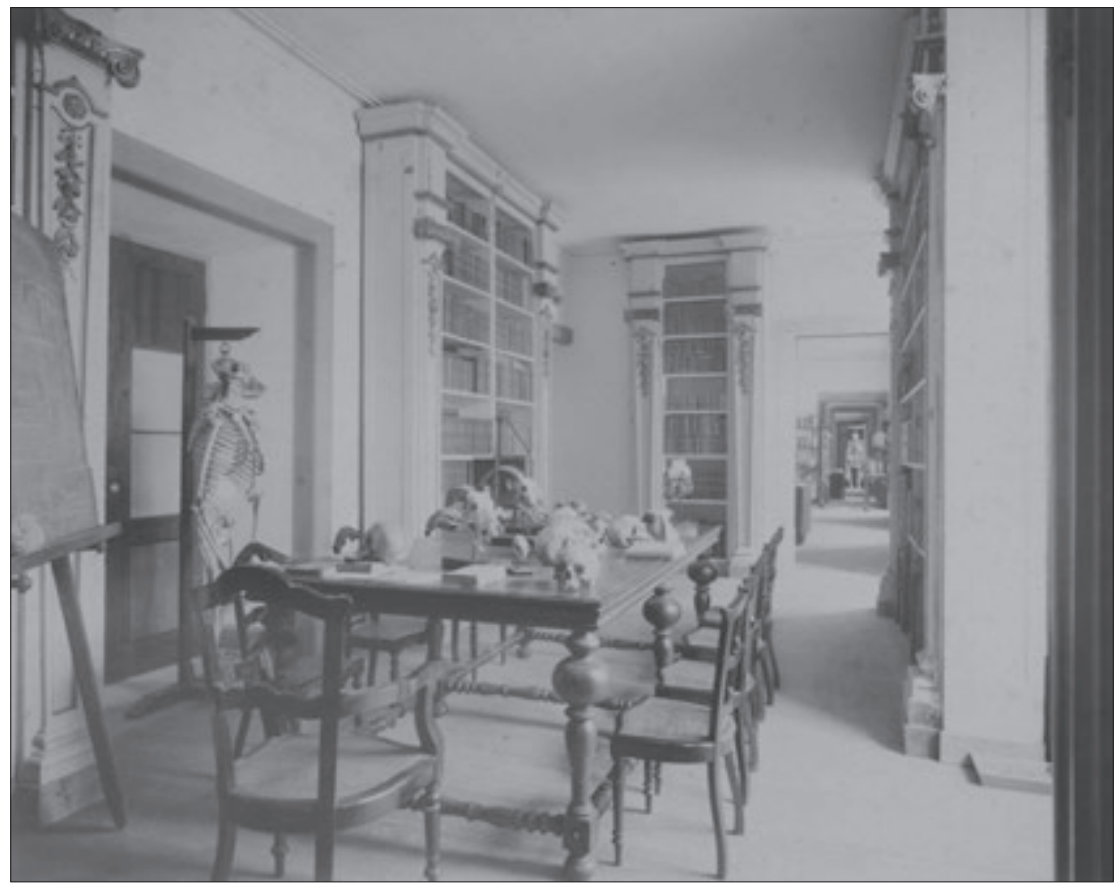

Fig. 1 Secção de Antropologia do Museu de História Natural da Universidade de Coimbra. Augusto Bobone, 1899.

serviços prestados à ciência através da Comissão oficial de recolha de produtos timorenses, transcrevendo aqui, integralmente, o Ofício $n .^{\circ} 15$. Este documento, no qual se descrevem as práticas de aquisição no terreno da coleção de crânios timorenses, adquiriu por isso visibilidade pública, surgindo hoje, no arquivo colonial, como um modo de interferir na resolução do conflito político entre os missionários e o governador da colónia e seus aliados. Como defende Ricardo Roque:

[...] as acções de recolha de cabeças humanas, tanto quanto a acção de tornar públicas essas práticas de recolha, constituíram elementos dinâmicos na resolução de conflitos entre diferentes colectivos em Timor, colectivos compostos de alianças variáveis entre portugueses e timoren- 
ses, que expressavam também fracturas internas à própria comunidade de colonizadores (Roque, 2009/10: 278-9).

Roque destaca, portanto, a materialidade do arquivo, procurando resgatar o modo como os documentos oficiais foram produzidos, transmitidos e utilizados, participando nos processos dinâmicos de configuração e reconfiguração de interações sociais, categorias culturais, formas de conhecimento e relações de poder entre os diferentes agentes do império e entre estes e as populações colonizadas, cuja voz e agência não está ausente dos arquivos coloniais. Vários outros antropólogos também têm vindo a sublinhar tal materialidade, através de uma metodologia que tem vindo a ser designada por etnografia de arquivo (Comaroff e Comaroff 1992; Porto 2002; Cunha 2004; Valentim 2014).

\section{Considerações Finais}

A "viragem material" que temos vindo a comentar aproxima, entretanto, a antropologia das abordagens que têm vindo a ser desenvolvidas no âmbito dos estudos sobre arquitetura e urbanismo coloniais e pós-coloniais. Anthony King (2004: 48) refere que os estudos materiais, espaciais, arquitetónicos e da geografia urbana poderão ajudar a desenvolver e a reforçar as teorias pós-coloniais baseados na literatura. Segundo King (2004: 57), os estudos pós-coloniais ignoraram, até ao fim da década de 90, o domínio do urbanismo colonial e do espaço construído e, ao ignorarem as realidades físicas, espaciais, arquitetónicas e urbanas nas quais muitos dos discursos coloniais se desenvolveram, apagaram as condições materiais, sem as quais outras práticas culturais e formas de representação, como a escrita, cartografia, etnografia, filme, fotografia, pintura, não teriam sido possíveis. Anthony King não pretende, no entanto, estabelecer 
uma oposição entre o mundo material e o das representações, pois as formas materiais são também textuais e vice-versa (2004:58); pretende apenas combinar abordagens provenientes de diferentes áreas disciplinares, de modo a incluir nas críticas pós-coloniais a análise das práticas materiais, dos espaços e políticas reais (2004: 45-6). Tal como Anthony King, também Jane Margaret Jacobs (1996) considera que as perspetivas pós-coloniais são essenciais ao entendimento das cidades contemporâneas, supostamente pós-imperiais ou pós-coloniais, mas precisam de se envolver mais com as geografias materiais do império. Também ela considera que a economia e a política do colonialismo não podem ser separadas dos processos culturais, pois as hierarquias de poder nas colónias e as relações desiguais entre os seus habitantes são formuladas através de categorias culturais de raça, classe, comunidade e género, construídas e reconstruidas, mantidas e contestadas através de geografias simultaneamente imaginadas e materiais. Em Edge of Empire, Jacobs (1996: 3) propõem-se falar sobre aquilo que designa por geografias "reais" do colonialismo e do pós-colonialismo, não porque elas possam ser claramente separadas das geografias imaginadas, mas porque foram negligenciadas pelos estudos pós-coloniais.

Poderemos então dizer que, quer a antropologia quer os estudos sobre arquitetura e urbanismo, têm vindo a destacar a materialidade dos processos e representações coloniais. Tal, porém, não significa abandonar o legado dos estudos pós-coloniais mais associados aos estudos culturais e à crítica literária, ignorando o papel que os discursos e representações tiveram na política da diferença do colonialismo. Significa apenas que também podemos resgatar, através do olhar e da metodologia da antropologia, os contextos materiais através dos quais formas de representação, como a fotografia, o cinema ou a literatura, foram produzidas, distribuídas, recebidas e utilizadas e, assim, a complexidade, limites, contingências e contradições dos seus efeitos sociais. Torna-se assim possível questionar o 
modo pelo qual as diferentes disciplinas criaram a sua autoridade e as suas categorias de conhecimento, essencial para a descolonização da ciência e, nomeadamente, da antropologia, sem nos centrarmos, como aconteceu na esteira das propostas de Edward Said, na análise do discurso e na crítica internalista dos textos coloniais.

Seguindo a trajetória de diferentes "patrimónios" herdados dos impérios, e em particular do império colonial português, - como textos, arquivos, coleções científicas, fotografias, formas urbanas e arquitetónicas, entre outros - através de uma etnografia atenta aos seus contextos e processos materiais de produção, circulação e utilização, torna-se possível resgatar a complexidade de práticas e relações coloniais e pós-coloniais a eles associadas. Revelando estas histórias e não esquecendo a voz e a agência das populações colonizadas nestes processos, a antropologia poderá contribuir de um modo significativo para descolonizar estes "patrimónios", questionando, através de uma etnografia descentrada, colaborativa e polifónica, as formas de poder e conhecimento herdadas do império e, simultaneamente, as grandes oposições traçadas pelos regimes coloniais entre colonizador/colonizado ou metrópole/colónias. Este poderá ser um dos contributos da antropologia para o estudo dos "Patrimónios de Influência Portuguesa".

\section{Referências bibliográficas}

ALMEIDA, Miguel Vale de (2000), Um Mar Cor da Terra: raça, cultura e política da identidade. Oeiras: Celta Editora.

APPADURAI, Arjun (2000), Dimensões Culturais da Globalização. Lisboa: Editorial Teorema.

CHAPMAN, William Ryan (1985), "Abranging Ethnology: A. H. L. Pitt Rivers and the Typological Tradition", in George W. Stocking, Jr. (ed.), Objects 
and Others. Essays on Museums and Material Culture. Madison e Londres: The University of Wisconsin Press, 15-48.

CLIFFORD, James (1988), The Predicament of Culture. Twentieth Century Ethnography, Literature, and Art. Cambridge, Massachusetts: Harvard University Press.

CLIFFORD, James (1997), Routes: travel and translation in the late twentieth century. Londres: Harvard University Press.

COMAROFF, John; COMAROFF, Jean (1992), Ethnography and the Historical Imagination. Oxford: Westview Press.

COOPER, Frederick; STOLER, Ann Laura (eds.) (1997), Tensions of Empire: Colonial Cultures in a Bourgeois World. Londres: University of California Press.

CUNHA, Olívia Maria Gomes da (2004), “Tempo Imperfeito: uma etnografia de arquivo", MANA, 10(2), 287-322.

EDWARDS, Elizabeth; HART, Janice (2004), "Introduction: photographs as objects", in Elizabeth Edwards e Janice Hart (eds.), Photographs Objects Histories: on the materiality of images. Londres: Routledge, 1-15.

GELL, Alfred (1998), Art and Agency: An Anthropological Theory. Oxford: Clarendon Press.

GORDON, Robert (1997), Picturing Bushmen. The Denver African Expedition of 1925. Athens, Ohio: Ohio University Press.

JACOBS, Jane Margaret (1996), Edge of Empire. Postcolonialism and the city. Londres: Routledge.

KING, Anthony (2004), Spaces of Global Cultures. Architecture Urbanism Identity. Londres: Routledge.

LATOUR, Bruno (2005), Reassembling the Social: An introduction to Actor-Network-Theory. Nova Iorque: Oxford University Press.

MARCUS, George (1998), "Ethnography in/of the world system: the emergence of multisited ethnography", Annual Review of Anthropology, 24, 95-117. MARTINS, Maria do Rosário; AMARAL, Ana Rita (2011), "História e atualidade das coleções de Timor na Universidade de Coimbra”, Atas do Colóquio Timor: Missões Científicas e Antropologia Colonial, AHU. Consultado a 
29.11.2014, em http://www.historyanthropologytimor.org/wp-content/ uploads/2012/01/05-MARTINS_MR-AMARAL_AR.pdf.

MILlER, Daniel (1998), "Why some things matter", in Daniel Miller (ed.), Material Cultures: Why some things matter. Londres: University College London Press, 3-21.

MILlER, David Philip (1996), "Joseph Banks, empire, and 'centers of calculation' in late Hanoverian London”, in David Miller e Reill Peter (eds.), Visions of Empire: voyages, botany and representations of nature. Cambridge: Cambridge University Press, 21-37.

PORTO, Nuno (2002), "O museu e o arquivo do Império", in Cristiana Bastos et al. (coords.), Trânsitos Coloniais - diálogos críticos luso-brasileiros. Lisboa: Instituto de Ciências Sociais, 117-132.

PRATT, Mary Louise (1992), Imperial Eyes: travel writing and transculturation. Londres: Routledge.

ROBBEN, Antonius; SLUKA, Jeffrey (eds.) (2007), Ethnographic Fielwork: an anthropological reader. Oxford: Blackwell Publishing.

ROQUE, Ricardo (2009/10), “A Missão em guerra: a história oculta da colecção de crânios de Timor da Universidade de Coimbra”, in Antropologia Portuguesa, 26/27, 259-283.

ROQUE, Ricardo (2006), "Colonialidade equívoca: Fonseca Cardoso e as origens da Antropologia Colonial Portuguesa”, in Manuela Sanches (org.), Portugal Não é um País Pequeno: contar o "império" na pós-colonialidade. Lisboa: Livros Cotovia, 83-111.

SANCHES, Manuela (2006), "Introdução”, in Manuela Sanches (org.), Portugal Não é um País Pequeno: contar o "império" na pós-colonialidade. Lisboa: Livros Cotovia, 7-21.

SCHIEBINGUER, Londa (1998), "Lost Knowledge, Bodies of Ignorance, and the Poverty of Taxonomy as Illustrated by the Curious Fate of Flos Pavonis, an Abortifacient", in Caroline Jones e Peter Galison (eds.), Picturing Science, Producing Art. New York: Routledge, 125-144.

STOCKING, George (ed.) (1983), Observers Observed: essays on ethnographic Fieldwork. Wisconsin: University Wisconsin Press. 
STOCKING, George (org.) (1985), Objects and Others. Essays on Museums and Material Culture. Madison e Londres: The University of Wisconsin Press. STOCKING, George (1985a), "Essays on Museums and Material culture", in Objects and Others. Essays on Museums and Material Culture. Madison e Londres: The University of Wisconsin Press, 3-14.

VALENTIM, Cristina Sá (2014), “O(s) pó(s) do arquivo: Uma etnografia em arquivo colonial numa pesquisa pós-colonial”, in Cabo dos Trabalbos, 10. Consultado a 29 de novembro, em http://cabodostrabalhos.ces.uc.pt/ n10/documentos/7.1.2_Cristina_Sa_Valentim.pdf.

Manuscrito:

Corte-Real, José Alberto H. C., carta para Júlio Henriques, 25 de fevereiro de 1879. Consultado a 29 de novembro, em http://almamater.uc.pt/ wrapper.asp? $\mathrm{t}=\% 5 \mathrm{BCarta} \% 5 \mathrm{D} \% 2 \mathrm{C}+1879+\mathrm{Fev} \% 2 \mathrm{E}+25 \% 2 \mathrm{C}+\mathrm{Macau} \% 2 \mathrm{C}$ $+\mathrm{a}+\mathrm{J} \% \mathrm{FAlio}+$ Henriques $\% 2 \mathrm{C}+\mathrm{Coimbra} \& \mathrm{~d}=\mathrm{http} \% 3 \mathrm{~A} \% 2 \mathrm{~F} \% 2 \mathrm{Fbibdigital}$ \%2Ebot\%2Euc\%2Ept\%2Fobras\%2FUCFCTBt\%2DJH\%2DConDa242\%2D CORREA\%2DJA1\%2FglobalItems\%2Ehtml. 


\section{CINEMA：TEMPOS E MOVIMENTOS}

Every thought, however original it may be, is to some extent shaped by the questions that it is asked.

(PAULIN J. HOUNTONDJI)

\section{Introdução}

A tentativa de apreensão do discurso imagético sempre foi problemática. É importante perceber que a necessidade de desvendar completamente a imagem, de encontrar uma interpretação iluminadora, é típica da modernidade. O que não pode ser interpretado não pode ser dominado pelo homem-intelecto que necessita apreender o mundo racionalmente. Domado o inefável, destrói-se o mito e tudo fica no terreno do compreensível. "Le temps de l'image est venu!", disse um dos pioneiros do cinema francês, Abel Gance, ainda nos anos 20. Estamos, mais do que nunca, mergulhados nas imagens que nos interpelam a todo instante.

O cinema encontra-se hoje atravessado por novos textos e contextos e pela quase omnipresença da imagem digital. Somos expostos, diariamente, a milhares de imagens que se multiplicam nos mais diversos ecrãs, e todas elas são, de alguma maneira, devedoras da linguagem que o cinema construiu, ao longo da sua centenária 
existência, e continuam a emanar o cunho ontológico que a imagem produzida mecanicamente, através da câmara e com o auxílio da luz, imprimiu à imagem cinematográfica desde os seus primórdios. Compreender que a imagem cinematográfica não é inocente e que é fonte inesgotável de significações é uma arma eficaz contra o embotamento dos sentidos e contra a absorção cega dos significados, engendrada por um dispositivo que se transforma e se adequa a novas realidades, mas que mantém intacta a sua capacidade de sedução pela imagem.

O cinema é a arte do espaço e do tempo - de um espaço que se arrasta no tempo e de um tempo feito de uma espacialidade muito própria - um tempo construído de fragmentos. Como a psicanálise, coloca em evidência o sujeito e é através dele que se constitui enquanto instrumento de compreensão ou de sedução da mente humana: o sujeito passa a se reconhecer como lugar originário do sentido. Há, no entanto, uma distância entre o sujeito e a imagem que o cinema tentou, diversas vezes, ultrapassar. Para os realizadores, quanto menor a fronteira entre sujeito/espectador e objeto/ filme, melhor.

Os filmes destinados ao grande público procuram ocultar a sua condição de arte da representação e pretendem ser absorvidos como um dispositivo de "apresentação", um simulador do real, um espelho hiperdimensionado que reflete, inocentemente, o mundo que o circunda. A nossa relação com o cinema assenta no seguinte paradoxo: de um lado temos a sensação de penetrar na realidade mas, de outro, reconhecemos as limitações do nosso campo de visão, circunscrito pelo enquadramento. Convertemo-nos em voyeurs e, como tal, espreitamos fragmentos do mundo tangível. O cinema simula, ou emula, uma efetividade que assumimos como passível de ser visitada e habitada por cada um de nós.

Apesar da predominância do modelo hollywoodiano, existe uma cinematografia divergente, muitas vezes periférica, que seguiu outros 
caminhos, na tentativa de converter o cinema num lugar possível da poesia e do encontro com a História, muitas vezes invisível, dos países que não ocupam o centro das narrativas ocidentais, caso do cinema africano de língua portuguesa. Às cinematografias divergentes é-lhes dado o epíteto de World Cinema, como se o mundo fossem os outros e como se este cinema fosse subsidiário de um discurso tão implantado na lógica quotidiana, que nem sequer é pensado como discurso. No caso da cinematografia africana acrescenta-se ainda o peso da etnografia, tão contestada por pensadores como o filósofo beninense Hountondji que argumenta, no que diz respeito à filosofia, que esta não pode depender da chamada etnofilosofia. Pensar o cinema da África é evitar o lugar-comum que, ora esquece que o substrato inconsciente, ou atávico, que está sob a camada de toda e qualquer cultura, não se deve impor sobre aquilo que a cultura contemporaneamente apresenta e aquilo que efetivamente produz, ora defende que o cinema feito fora do circuito ocidental, reproduz sem refletir, as imagens que o discurso dominante produziu e divulgou sobre eles.

\section{Cinema africano: um possível necessário olhar}

O filósofo beninense Hountondji, ao longo da sua vida, tem-se debatido à procura de uma verdadeira filosofia africana, que fuja do modelo imposto pela etnofilosofia defendida por Placide Tempels e Alexis Kagame. Para Hountondji, a proposta de Tempels e Kagame reproduz a visão que o Ocidente tem da África, imputando-lhe um pensamento que nega a subjetividade e defendendo a manutenção de traços comunitários e tradicionais, baseados num conjunto de saberes transmitidos oralmente. A etnofilosofia seria mais um braço da antropologia e, sem refutar os valores culturais por ela valorizados, Hountondji prefere defender uma filosofia que não ignore 
o sujeito e que não ignore que a filosofia, para existir, necessita inscrever-se, e ser escrita, num texto reflexivo que não consegue sobreviver apenas da tradição oral, pois esta tem uma função primeva: preservar a memória. E se estamos preocupados em não nos esquecermos daquilo que foi transmitido, sobra pouco ou nenhum espaço para a reflexão. Assim, o texto fixado "liberates the memory, and permits it to forget its acquisitions, provisionally to reject or question them because it knows that it can at any moment recapture them if need be." (Hountondji, 2002: 103-104)

A necessidade de fixação do texto não é a principal ideia defendida pelo filósofo mas, para mim, é um ponto de partida para aquilo que pretendo fazer sobre e com o cinema africano. Por um lado reconheço, como o filósofo, que é necessário deixar de pensar África como o paraíso da etnografia, como um lugar unificado e estanque, aprisionado pela tradição e, mais ainda, pela visão do outro sobre os que ali estão. Como se os africanos fossem "members of a herd-like mob, devoid of the capacity to think as independent individuals" (Ochieng, 2010: 25). Pensar o continente africano, independentemente de sermos ou não africanos, é não nos esquecermos de que o substrato inconsciente ou atávico, que está sob a camada de toda e qualquer cultura, não deve impor-se sobre aquilo que a cultura contemporaneamente nos apresenta e aquilo que ela, efetivamente, produz.

Para Hountondji é impensável falarmos de uma álgebra ou de uma geometria inconscientes. A modernidade é um facto, mesmo que distribuída de forma desigual pelo planeta, determina regras para a aceitação e para a respeitabilidade de condutas teóricas. A modernidade estabeleceu um modelo discursivo que não aceita outras formas de pensamento que não a sua, como único modelo válido para enfrentar a barbárie. E a barbárie são os outros, cujas ideias advêm de uma massa inconsciente e informe e que pode ser tratada, livremente, por quem dela conseguir apoderar-se. Daí a 
necessidade de lutar com as armas do inimigo, dentro do seu campo. África, para o filósofo, deve abandonar o lugar de objeto e ocupar o lugar de sujeito. O que não é, definitivamente, uma tarefa fácil.

Há alguns anos, o diretor do Centre National de la Cinématographie Française, Dominique Wallon, foi questionado sobre a sua opção pelo cinema africano, ao que ele respondeu que a França não deveria baixar a cabeça ao "bulldozer" americano da uniformização cultural. A cultura desejável não seria a da aceitação e da uniformização, mas a que assumisse a difícil tarefa de aceitar, e difundir, a pluralidade. No caso do cinema, é começar uma guerra entre o cinema industrial e as cinematografias independentes, entre o cinema produzido nos EUA e o que é feito no resto do mundo. Sem nos esquecermos de que, por trás de tudo ou à frente, há a questão económica. O modelo de cinema que se impõe escapa às razões éticas ou estéticas. Responde, sobretudo, à imposição dum modelo de discurso universalizante e hegemónico que incorpora os discursos outros convertendo-os todos no discurso do mesmo. Talvez seja uma guerra perdida. Em 2001, Jean-Marie Messier, então diretor do Canal+, declara que a exceção cultural franco-francesa estava morta. Para Olivier Barlet: "Une production cinématographique ne contribue à l'exception culturelle que lorsqu'elle se détache du classicisme ou du dogmatisme progressiste, que si elle affirme un regard autre, celui d'une modernité en perpétuelle redéfinition" (Messier, 2002: 3), (Fig. 1).

Para mim o problema não é a batalha entre uma cinematografia hegemónica e as que não conseguem, por razões várias, destacar-se. O problema reside na própria ideia da necessidade de estabelecermos exceções, sejam elas culturais ou não. A ideia de exceção é já, à partida, uma ideia condescendente: há que proteger uma cultura, uma tradição, uma cinematografia, porque ela não pode, sozinha, sobreviver. E cabe a nós, Ocidente, este papel. É a mesma atitude dos etnofilósofos que por respeito à cultura alheia, preferem pre- 
servá-la e cultuá-la e, assim, ela permanecerá a mesma, não poderá expandir-se, adaptar-se, modificar-se e, inclusive, negar-se a si mesma num dado instante. É a manutenção da exceção que confirma a regra, que confirma o discurso hegemónico, que confirma a manutenção de um modelo.

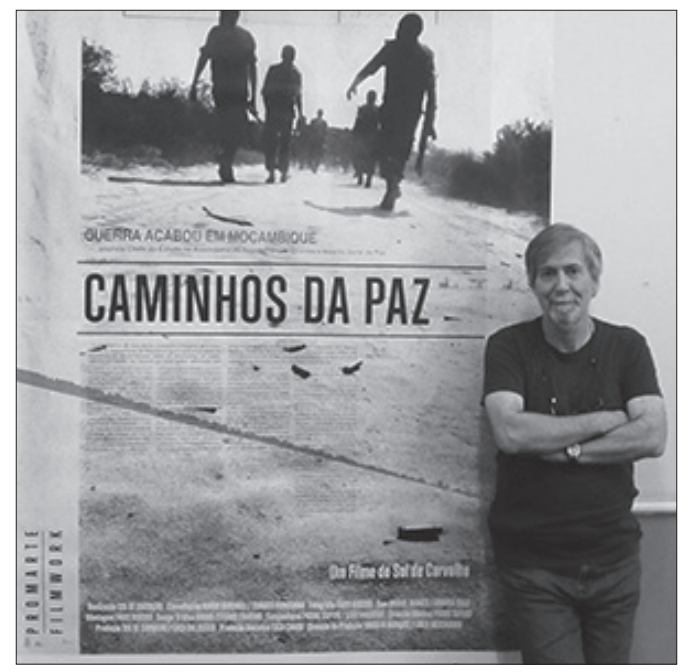

Fig. 1 Cineasta moçambicano Sol de Carvalbo.

\section{Cinema e perceção}

Hugo Munsterberg escreveu a obra que é considerada a primeira teoria do cinema: The Photoplay - A Psychological study, publicada em 1916. Neste livro, o psicólogo alemão radicado em Harvard, estuda o fenómeno da imagem em movimento, desde as suas origens até ao cinema narrativo, que já se realizava naquela altura. Em dado momento ele questiona: “(...) do the moving pictures bring us an independent art, controlled by esthetic laws of its own, working with mental appeals which are fundamentally different from those of the theater, with a sphere of its own and with ideal aims of its own?" (1916, Parte I). 
A resposta a esta inquietação é dada ao longo do livro, em que Munsterbeg escrutina minuciosamente o cinema, comparando-o com outras artes, como o teatro e a literatura, e concluindo que não só o cinema cria leis próprias, baseadas numa estética particular, como ainda, de todos os meios narrativos anteriormente criados pelo homem, é o primeiro que efetivamente incorpora, na sua conceção, os mesmos mecanismos que regulam a perceção humana. Ou seja, o cinema resulta porque estruturalmente funciona de maneira semelhante ao nosso aparelho percetivo: vemos filmes como percebemos o mundo à nossa volta, usando os mesmos mecanismos mentais.

Munsterberg reconhece ainda (apesar de ter escrito a sua obra no momento em que o cinema começava a organizar o relato e a criar, de facto, uma linguagem) que os fotogramas em movimento, que convocam a nossa atenção, memória, imaginação e emoções, não são suficientes para cativar o público. A novidade esgota-se muito rapidamente e é necessário que se criem estratégias para não entediar os espectadores. $\mathrm{E}$ a melhor estratégia que o cinema possui é a capacidade intrínseca de contar histórias, cujo modelo vai buscar à literatura do séc. XIX, folhetinesca e burguesa, realista e fantasiosa, psicológica e emotiva:

Uma das marcas desse modo de contar era certa linearidade obtida pelo entrelaçamento meticuloso das subtramas. A linearidade das narrativas dá uma falsa sensação de controle: o homem-ciência, que quer competir com o criador, torna-se demiurgo a partir do instante em que controla o fluxo de uma história que escorrega, inexorável, para o fim. Uma metáfora do curso da vida e da morte que espreita. Mas um curso desviado de seu caminho natural e aprisionado em uma fórmula controlada. Sei quando acaba. E sei como acaba. (Tavares, 2008, 39-40).

O processo de identificação no cinema dá-se através do reconhecimento de uma alteridade, o espectador ocupa o lugar do outro: 
En su parte documental - que es la marca de su nacimiento y la condición de su invención -, el cine no hace más que abrir el diafragma de una lente, la sensibilidad de una emulsión (...) a la presencia luminosa del otro, más o menos, es todo el asunto, de ese otro que viene hacia la cámara tanto como ésta va hacia él. (Comolli, 2007: 46).

Para Comolli, o outro que vemos no ecrã, que é capturado pela câmara, é um corpo que reconhecemos como diverso e igual. E é na associação entre o que vê e o que é olhado, na crença do milagre efetuado pela luz que imprime o real no fotograma, que se estabelece uma relação de poder. O espectador ocupa, normalmente, o lugar do morto, não é ele quem conduz a narrativa mas é sim conduzido por ela.

O número de espectadores que o cinema norte-americano conseguia atrair nos seus primórdios foi crescendo, à medida que crescia também a capacidade deste dispositivo de se tornar mais próximo do real, e paradoxalmente, mais distante. O som sincrónico e mais tarde o aparecimento da cor, ajudaram o cinema a aproximar-se do mundo extraecrã transformando os seus artifícios em elementos de realidade, ou seja, cada novo efeito, ajudava os realizadores a criarem no público a sensação efetiva de estar diante de uma janela aberta para o mundo. Ao contrário daquilo que as Vanguardas Históricas preconizaram, ou realizaram com o cinema, os filmes caminham em direção à normatização e à organização da mise en scène a favor da duplicação do real e não da criação de novas possibilidades de leitura do mundo, o que reforça ainda mais o poder do cinema de criar e difundir modelos identitários.

O cinema clássico escamoteia o discurso, ou melhor, escamoteia a sua condição de discurso, permitindo ao sujeito identificar-se com o que vê mais do que em qualquer outra arte do espetáculo. Apesar de reconheceremos o duplo vínculo da imagem cinematográfica, aquilo que vemos parece repousar num estatuto ontológico do 
pré-pensamento: eu vejo, logo existe. No entanto, não nos podemos esquecer que o cogito ergo sum cartesiano continua a dominar a esfera da apreensão do mundo, e daquilo que é produzido no mundo, que é o que acontece com as imagens. Eu vejo, mas o meu "ver" já está impregnado do que penso sobre o que vejo. Aquilo que nos é dado como orgânico, adquirido ou natural - a capacidade de reconhecer as imagens/representações do mundo é, na verdade, parte de um processo complexo. Nem o ato fisiológico de ver é neutro, porque não vemos com os olhos, mas com a mente. O que significa que vemos o resultado de um processo físico-químico-psíquico-afetivo. A imagem não é neutra, nem como dar-se a ver, nem como representação.

Ao acompanhar o processo de criação de imagens artísticas no ocidente, deparamo-nos com o ideal greco-romano que gerou, posteriormente, um modelo de representação. Observamos que o cânone ocidental assenta numa base político-ideológica e que este modelo conseguiu permanecer na História porque se tratava, aparentemente, do modo mais natural e/ou mimético, de se representar o mundo. Assim, uma imagem é fruto da consciência de uma dada realidade somada ao desejo de retratá-la/torná-la imortal. A partir do instante em que ela se cristaliza, torna-se visível e compartilhável. A criação de um modelo de representação da figura humana no mundo ocidental fez surgir um modelo ideal da própria humanidade, que queria sentir-se incluída e ver-se representada.

A ideia de mimese das imagens greco-romanas invadiu o imaginário coletivo e tornou-se um cânone, cuja predominância afastava qualquer outro modelo que não lhe correspondesse. E todos os que não se encaixavam (o resto do mundo) passaram a ser vistos como o outro. A alteridade, conferida aos que não comungavam o modo de representação ocidental, não se cingiu, porém, ao campo da imagem, tornando-se muito mais vasta ao ponto de transformar uma cultura, ou modelo cultural, no único e desejável cânone. 
No caso do cinema, o modelo canónico é aquele aperfeiçoado por Griffith e reiterado ao longo da história do séc. XX, através do close up das estrelas que povoaram, e que ainda povoam, o imaginário mundial, gerando modelos desejosamente especulares, mas que são frustrados quando confrontados com a realidade de cada espectador ou do público em geral. No prefácio do livro Ver $y$ Poder de Jean-Louis Comolli, Eduardo A. Russo enumera alguns conceitos do teórico francês e ressalta a ideia que este defende da afinidade documentário-ficção: "Ambivalencia del cine. La dualidad de deseos y de miedos está en el mismo punto de partida de la oposición ficción/documental; es ella quien al mismo tiempo la funda y la agota." (Comolli, 2007: 24). Comolli vê o espectador como um ser ambíguo que deseja, simultaneamente, a imagem do cinema e o seu oposto, ou seja, a sua existência enquanto coisa no mundo real. O público de cinema quer "(...) la cosa, su imagen y el contrario de su imagen." (idem: ibidem). Como na tese do duplo vínculo batesoniana, aqui o espectador reconhece e rechaça a falta de densidade, de corpo, que a imagem possui. Mas não deixa de desejar ver-se representado por aquela sombra projetada no ecrã.

O universo simbólico e ideológico, construído pelos estúdios de cinema em Hollywood, perpetuou um modelo de corpo a ser imitado, um modelo de sociedade a ser copiado, porque o público desejava estar representado no ecrã, desejava reconhecer-se naquilo que o cinema apresentava. $\mathrm{O}$ modelo perpetua-se, também, porque se adapta aos tempos, às modas e às novas tecnologias.

\section{Apontamentos sobre um cinema outro}

Jean-Claude Carrière, no seu livro Linguagem secreta do cinema, conta que o cinema foi levado para o continente africano pelos 
colonizadores europeus como mais uma arma na sua bagagem já tão carregada. Não é de estranhar este facto se pensarmos que, também a igreja, nos primórdios do cinema, utilizou filmes como parte da homilia. A imagem serviu vezes sem conta fins pedagógicos - fossem os ensinamentos uma forma de ampliar o conhecimento do outro ou uma forma de dominá-lo, pura e simplesmente. E a imagem cinematográfica não fugiu à regra. Prestou-se, em diversas ocasiões, a ser instrumento de cognição e de dominação. Pela sua ligação ao real, o cinema serviu para criar e reforçar ideologias; para impor modelos e sugerir padrões de comportamento, (Fig. 2).

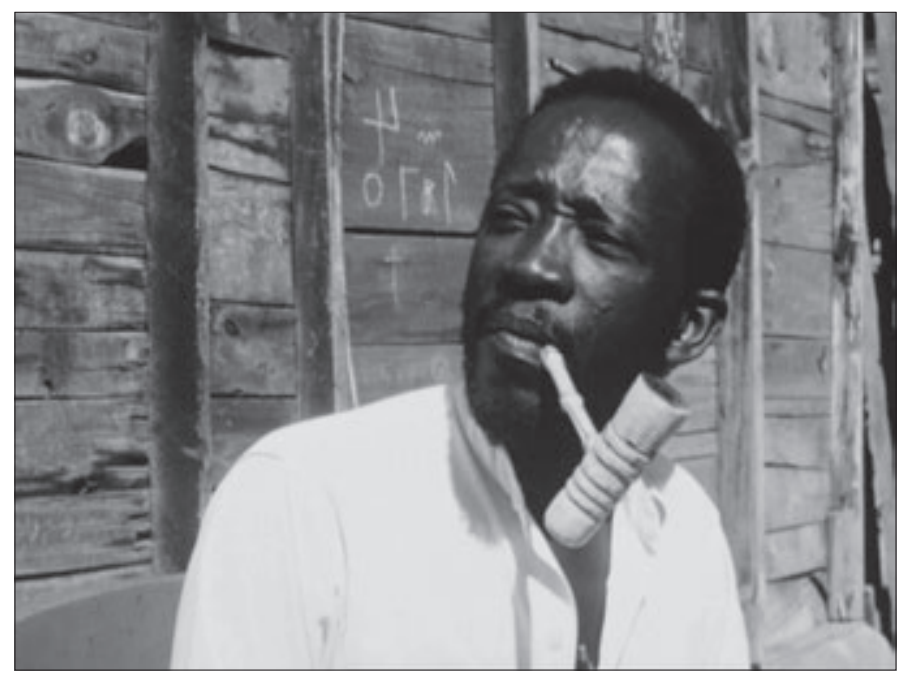

Fig. 2 Cineasta Ousmane Sembène.

Ousmane Sembène, realizador senegalês, considerado o "pai do cinema africano", disse numa entrevista que o cinema, para ele, tinha uma finalidade muito específica: educar as pessoas. Os seus filmes eram conscientemente pedagógicos e o cinema era apenas um veículo para o seu discurso. A imagem é um meio poderoso em lugares onde a língua é múltipla e o espaço é dominado pela 
heteroglossia - a fala é socialmente construída e nem todos dominam a língua oficial do seu próprio país. De uma maneira geral, é este também o panorama do cinema africano de língua portuguesa: filmes de ficção produzidos por entidades autónomas, normalmente ONGs, que cumprem uma função social importante e apresentam, através de um discurso apreensível, questões fulcrais para o país, como o desenraizamento das pessoas, a pobreza, e o VIH.

Ao estudar a cinematografia dos países africanos de língua portuguesa, deparei-me com textos diversos, cujo tom é o da etnografia. Nada contra a matéria em si, mas poucos são os que olham para a cinematografia destes países como uma cinematografia, com características próprias e muitas características em comum com o cinema mundial. O que é bastante óbvio: o cinema é um texto nascido e criado no ocidente, uma narrativa ocidental que foi transplantada para o continente africano aquando dos processos de colonização. Por exemplo, o cinema chega a Angola pouco depois da instalação da República em Portugal. O primeiro filme rodado neste país data de 1913, O Caminho de Ferro de Benguela, de Artur Pereira. Em Cabo Verde, o cinematógrafo entra no país por esta altura, mas a realização de filmes só começa, efetivamente, nos anos 50.

Em Moçambique e na Guiné-Bissau, a produção cinematográfica começa nos anos 60. Encontramos referência à produção de um filme nos anos 70 em S. Tomé e Príncipe, onde o cinema chega tardiamente. Da cinematografia desses países, interesso-me por aquela que começa a ser realizada após a independência. Grande parte do que foi realizado anteriormente é constituído por filmes de propaganda do regime, documentários de caráter pedagógico e/ou político e muitos documentos filmados pelos Serviços Cartográficos do Exército. O cinema, desde muito cedo - e não só nos países africanos - cumpriu um papel fundamental na construção do imaginário moderno. 
Flora Gomes, cineasta da Guiné-Bissau, repete muitas vezes que fazer cinema é bastante difícil e fazer cinema em África é uma insanidade total. Após a independência, Moçambique investiu na produção cinematográfica como forma de propaganda do novo regime, na tentativa de criar uma imagem do país para ser consumida por uma nação fragmentada. De todos os países africanos de língua portuguesa é o que possui, desde 1975, a filmografia mais variada e um conjunto de realizadores com características diversas que continuam, até hoje, a produzir, apesar de o Estado cedo se ter retirado do papel de mecenas. Na Guiné-Bissau, Flora Gomes foi um dos pioneiros e é um dos poucos realizadores do país, tendo alguns de seus filmes contado com o apoio do Estado e quase todos eles terem sido galardoados em festivais internacionais. Mas não existe qualquer estrutura de produção na Guiné-Bissau e nunca foi criado um Instituto Nacional do Cinema, como ocorreu em Angola e Moçambique. Cabo Verde começa por se constituir como um país de cinéfilos e é a atividade cineclubista que vai dar impulso à criação cinematográfica. Hoje, o país conta com festivais e várias coproduções com países como Portugal, França e Brasil, além da produção nacional.

Flora Gomes e Sana Na N'Hada estudaram em Cuba e o ideário por trás da formação dos institutos nacionais de cinema em Angola e Moçambique era originário dos países socialistas e tinha a função clara de contribuir para reforçar o regime e criar uma identidade nacional. Passada a fase inicial da independência, diminuiu o apoio do Estado e o cinema passa a ser verdadeiramente um cinema de resistência, ou, como disse Flora Gomes, um ato de insanidade. Os que resistiram, e que resistem, como cineastas nesses países, fazem-no por pura teimosia ou vontade de continuar a contar uma história que não pode ser contada por outros. Porque é a história deles e é a sua maneira de se inscreverem na história dos outros, que somos nós. 
A História contemporânea constitui-se como um discurso aberto à interpretação e, nisso, o seu estatuto não difere do estatuto de qualquer outra espécie de discurso narrativo. O discurso do outro, e sua história, podem ser desvendados através da arte, através do cinema, arte-indústria, que nasce como narrativa ocidental, e que cedo se espraia pelo mundo fora, convertendo-se numa espécie de espelho opaco para onde converge o desejo de imagens do mundo, partilhado por todos. Para conhecer melhor o outro e tentar perceber o seu lugar na construção de uma nova narrativa, mais adequada ao necessário esbatimento das fronteiras culturais atuais, precisamos apreender o seu discurso sobre os outros, que somos nós. Neste contexto, coloca-se esta questão: de que maneira as sociedades africanas absorveram, transformaram ou rejeitaram o modelo de narrativa ocidental da modernidade?

\section{A cidade no cinema moçambicano}

Partindo da premissa que o cinema, como forma visível, não é apenas uma forma cultural e/ou artística, mas também uma maneira de se organizar e de se refletir sobre o mundo, este medium constitui-se assim como um veículo que poderá ajudar-nos a compreender as culturas africanas dos países de língua portuguesa. Como defende Hountondji, para haver filosofia, contemporaneamente, é preciso haver um texto que liberte a memória para que se possa chegar a episteme e deixar que a doxa ocupe o lugar que lhe cabe. O Cinema tornou-se um dos mais importantes repositórios de imagens a que podemos ter acesso. Não só pelo que mostra, mas também por aquilo que ele diz. Assim, se o filme tem servido, desde o início, para organizar a nossa experiência do mundo, e a nossa experiência no mundo, é legítimo recorrer a ele para entender melhor a construção do imaginário de um povo ou de uma nação, (Fig. 3). 


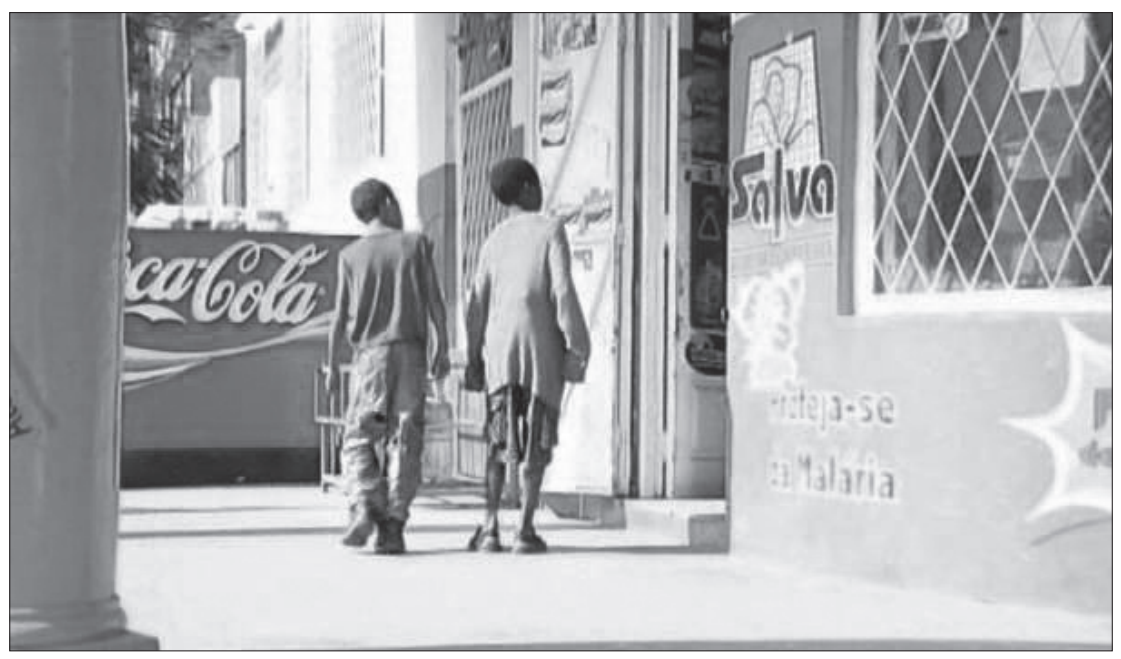

Fig. 3 Cena do filme de Licínio de Azevedo O Grande bazar.

Mama Këita, realizador senegalês, disse numa entrevista: "Les jeunes Guinéens de Conakry écoutent la même musique que ceux de Paris. A moins d'être dans un trou perdu. Il y a aujourd'hui une culture dominante qui affecte toutes les couches de la population." (Bartlet, 2002). Para Këita, o mundo vai a todos os lugares, impondo um modelo de cultura que torna todos os outros modelos clandestinos. A única maneira de deixar a clandestinidade é criar um modelo alternativo, ou disjuntivo. Um modelo que ponha em causa o conceito moderno de unidade e de modelo.

A cidade ocidental e o cinema chegaram quase que em simultâneo a Moçambique. Lourenço Marques é concebida como uma metrópole, no sentido etimológico do termo: cidade mãe de uma ideia de ocidente, modelo de uma civilização que se deveria espraiar por todo o país e, quiçá, pelo continente vastíssimo. É interessante reter que um dos primeiros institutos criados por Samora Machel, logo a seguir à independência, foi o INC - Instituto Nacional do Cinema. A função principal deste instituto era a de realizar atualidades cine- 
matográficas, pequenos documentários - Kuxakanema - que eram distribuídos por todo o país. O que nos dá a dimensão da importância pedagógica e propagandística que este meio teve durante a primeira fase da independência de Moçambique. E dá-nos também a dimensão documental que vai vincar fortemente o cinema deste país.

Não havia televisão e o cinema assume o papel de criar a imagem do novo governo e do novo país. Para além das atualidades, vários filmes, principalmente curtas e médias metragens, foram sendo produzidos. Em 1991, um incêndio destruiu quase todo o acervo de filmes produzidos pós-independência, restando apenas uma parte que está a ser catalogada e restaurada com a ajuda da Cinemateca Portuguesa. A nós interessa mais o cinema de ficção, mesmo que a produção deste seja bem mais escassa, porque acreditamos, como Barthes, que é na pose que nos revelamos. É através da ficção que os realizadores conseguem mostrar de que maneiras se apropriaram do cinema e da cidade, escrevendo com suas próprias palavras estes dois textos que foram ali implantados (Fig. 4).

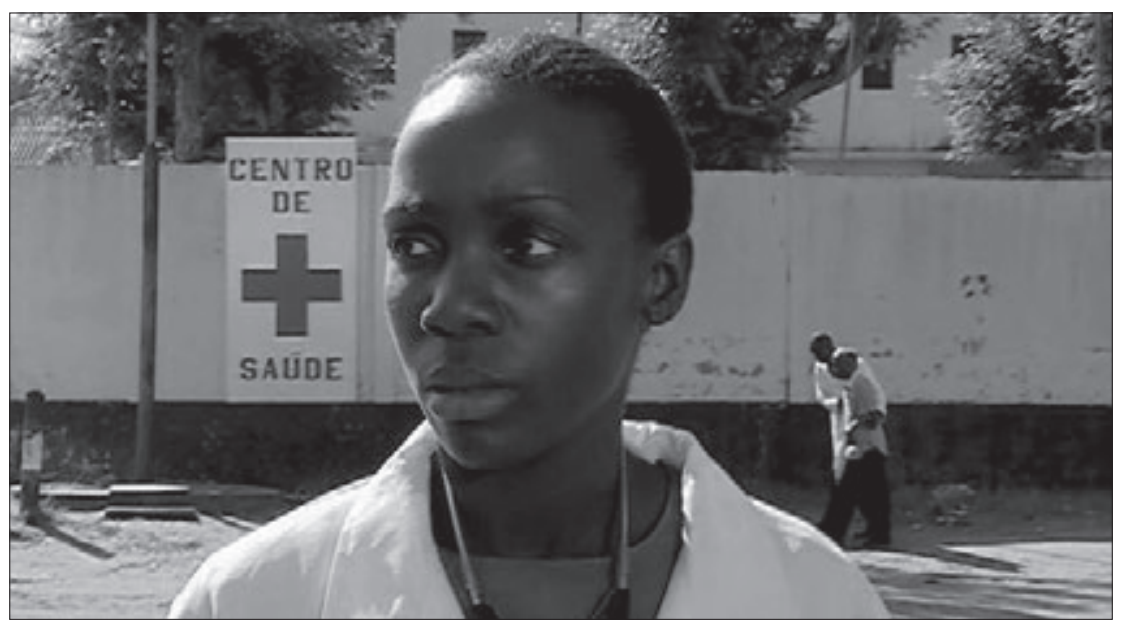

Fig. 4 Cena do filme de Sol de Carvalho O Jardim de outro bomem. 
A cidade, nestes filmes, ora é personagem, ora é pano de fundo. E a sua ausência, como o carretel do jogo freudiano, é apenas uma presença ocultada. Ela aparece como um caminho, e são os caminhos de ferro que ligam as personagens ao espaço urbano no filme de Licínio de Azevedo, O Grande Bazar. São as ruas da cidade de Maputo que dividem a cidade em várias, como no filme Jardim d'Outro Homem, de Sol de Carvalho. No filme As Pitas, também de Licínio de Azevedo, o universo juvenil é apresentado, tendo como pano de fundo a cidade, Tete. As jovens falam de amores e desamores, veem TV e vestem-se como raparigas ocidentais. É o espaço envolvente e a recorrência a um tabu ocidental, a feitiçaria, que dão ao filme uma cor e tom locais.

A cidade, ou as cidades, nestes filmes, aparece fragmentada, desmontada, rearranjada. É a mesma cidade mas são múltiplos os espaços e, mais diversos ainda, os usos de cada edifício, de cada recanto. A cidade moçambicana é a mesma, mas é outra. A sua fragmentação não obedece ao raccord do cinema ocidental, a sua lógica interna é feita de apropriações, devidas ou indevidas, do espaço público e das representações do espaço privado neste. A análise das sequências das imagens da cidade não se constrói apenas da materialidade física dos espaços, mas sim a partir do que se faz e do que se passa na cidade, a partir dos seus habitantes. Neste sentido, a cidade transparece mais nos corpos que a povoam do que na organização dos cenários que propõe.

Uma cidade é um espaço dialógico e este diálogo é capturado pela câmara dos realizadores de uma ficção muito próxima do docu-drama, matriz de um cinema ainda em construção, de um cinema inacabado, como as cidades que retrata. É uma escolha, consciente ou inconsciente, de um espaço que não se quer confinar, construído por betão e vidro. Sobretudo construído por pessoas. É esta massa humana que faz da cidade aquela cidade. E é sobre esta cidade de 
pessoas que fala um cinema cuja voz ainda se ouve muito pouco nestas cidades do lado de cá.

A relação de identificação com o cinema não se dá apenas através da (falsa) especularidade dos corpos, mas também ocorre quando uma cinematografia apela a sentimentos arquetípicos, propondo ao espectador um lugar ativo na história. O que só ocorre, verdadeiramente, no cinema que podemos chamar de "divergente", de não canónico. Mas este tipo de cinema ainda atinge um público pequeno diante dos muitos milhões que consomem o modelo norte-americano e que, como tal, continuam a desfrutar do gozo perverso do duplo vínculo, do saber-se não representado mas continuar acreditando que se vê no ecrã, replicando comportamentos e modelos que ocultam uma ideologia específica e que suscita, paulatinamente, a normatização dos comportamentos e cria uma sensação real, embora distorcida, de pertença.

\section{Conclusão}

A modernidade trouxe consigo um novo conceito de espaço e um novo modelo de visão. A nova espacialidade racional e teleológica pretendia substituir o labirinto e os descaminhos, pretendia iluminar os becos e convertê-los em largas avenidas. Mais do que um conceito espacial, é um modelo ideológico que só aceitava como certo aquilo que a ele correspondia. Todo o resto era a barbárie. O novo espaço (co) respondia a uma nova realidade, teoricamente destinada a tornar o mundo um lugar melhor para se viver. Este foi o modelo que os colonizadores do século XX levaram com eles quando assumiram o controlo das terras para além das fronteiras europeias. Este é o modelo que falhou, mas que persiste em continuar como uma referência incontornável. Este é o modelo que vê o 
resto como etnografia, que vê o outro não como sujeito, mas como outro, simplesmente.

Do percurso trilhado pela humanidade em busca do domínio pleno de uma forma de representação que satisfizesse o nosso aparelho percetivo, inventou-se o cinema e a figura humana voltou assim a assumir um papel central na hierarquia das representações. "Desde um ponto de vista psicológico, a tendência "cêntrica" representa a atitude egocêntrica que caracteriza a forma de ver as coisas e as motivações próprias do ser humano no começo da vida". Esta tendência acaba, segundo Arnheim, por se transformar num "poderoso impulso" ao longo da vida adulta (Arnheim, 1998: 10).

As crianças veem-se a si mesmas como o centro do mundo que as rodeia e todo o resto age em função das suas próprias necessidades e desejos. Mais tarde, como adultas, são forçadas a admitir que há outros centros com os quais têm de interagir para encontrar um ponto de equilíbrio possível entre estas forças internas e externas que, ora se atraem ora se repelem. Para Arnheim, toda e qualquer manifestação artística que não incorpore esta disputa e não aceite o desafio de equilibrar estas forças antagónicas resultará sempre insuficiente. "Nem o egocentrismo absoluto, nem a rendição incondicional aos poderes externos, podem constituir uma imagem aceitável das motivações humanas" (Arnheim, 1998: 11).

A imagem cinematográfica buscou, ao longo de sua história, não ferir as leis da perceção nem ir ao encontro das tendências naturais que constituem a nossa subjetividade. Só no cinema marginal é que é possível encontrar-se formas disruptivas de representação que não repliquem o cânone e que consigam, efetivamente, refletir e provocar a reflexão sobre o que se vê, sobre o que é visto e sobre quem se vê. O modelo de cinema que se impõe escapa às razões éticas ou estéticas. Responde, sobretudo, à imposição dum modelo de discurso universalizante e hegemónico que incorpora os discursos outros, convertendo-os todos no discurso do mesmo, (Fig. 5). 


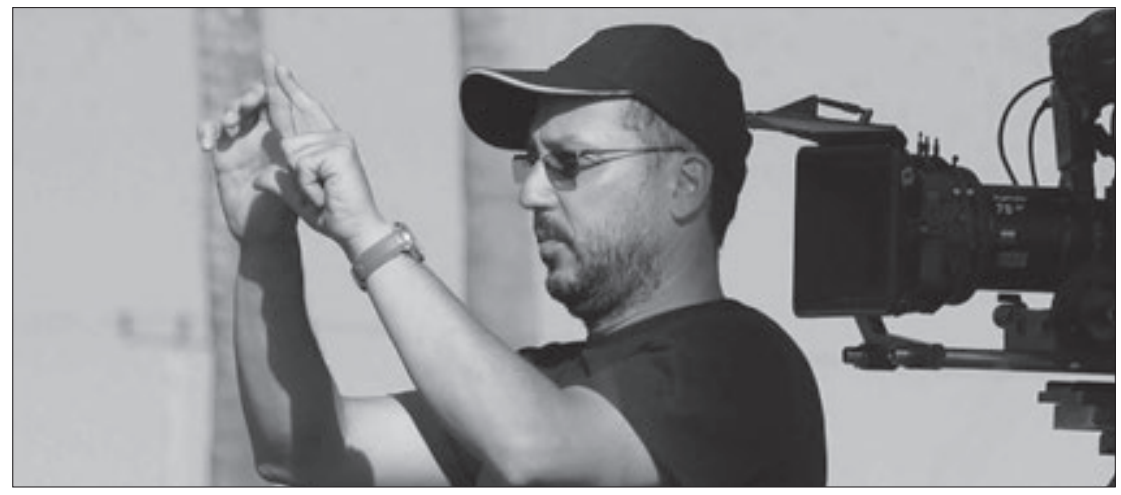

Fig. 5 Cineasta João Ribeiro.

Se a imagem do cinema é um constructo artístico, contingente, social e ideológico, somente através da conceção de novos discursos, que reflitam sobre a condição de alteridade do resto do mundo e que desmistifiquem o cânone ocidental, é que se pode reverter a tendência dominante de vermos o outro como o mesmo. Tomemos como exemplo o realizador moçambicano João Ribeiro, cujo cinema é composto basicamente de adaptações da obra de Mia Couto: ele usa o enquadramento e a morfologia do cinema para conceber um discurso apreensível dentro do seu país ao mesmo tempo que universal. No filme Fogata (1993), o realizador apropria-se dos recursos morfológicos convencionais do cinema industrial para criar uma atmosfera simbólica que remete para o espaço que origina a história, e para o tempo a que ela se refere, que é o tempo mítico dos contos que perduram na memória e que são repassados através das gerações:

(...) a montagem é feita através de raccords simples, que dão continuidade à narrativa ao mesmo tempo que usam a imagem como metáfora. Os planos são fechados e o uso da película ajuda a revelar os matizes do espaço que os rodeia. Um espaço pobre, vazio, preenchido por aqueles dois corpos, quase anónimos. (Tavares, 2012:170). 
O cinema constituiu-se, ao longo da sua história, como um património imagético e conceptual responsável, em diversos momentos, pela criação e difusão de mitos identitários. Dada a sua capacidade de, através dos seus mecanismos, provocar a identificação e do pacto que realiza com os seus espectadores de suspension of disbilief, (que permite o gozo escopofílico), os filmes foram usados em diversos momentos da História para reforçar e inventar identidades nacionais. Pelo facto de ser sustentado por imagens que são consideradas um espelho do real, o cinema ocupa, muitas vezes, o lugar de "discurso da verdade". Um dispositivo que nunca foi um mero reprodutor da realidade, sempre usou a realidade como discurso, um discurso que se apresenta como um espelho aperfeiçoado que, não só reflete, mas reelabora as imagens do mundo, tornando-o mais compreensível e ordenado segundo padrões ideais. A única forma de combater este discurso do mundo visível é produzir outros discursos, que irrompam de dentro da lógica do dispositivo, que é que acontece com filmes como Fogata e muitos mais, produzidos fora do circuito industrial, por isto rotulados de world cinema, o que paradoxalmente os remete, não ao lugar de representantes do cinema do mundo, mas de produtores de um tipo de cinema específico, marginal, quase etnográfico.

Quando Hountondji defende uma filosofia africana não etnográfica, está a defender o direito de difusão de vozes divergentes através do mesmo modo de produção do discurso dominante. Não quer, com isto, transformar o pensamento africano num pensamento europeu, mas sim, dar espaço à produção contemporânea, que emerge no continente, de se expressar da forma que melhor the aprouver e de promover um movimento contrário: são os outros, neste caso, que se apropriam do discurso dominante para que a sua voz seja ouvida. O mesmo se dá no cinema produzido nos países africanos de língua portuguesa: não se quer propor uma nova forma de fazer filmes, quer-se utilizar os recursos que o cinema dispõe para cons- 
truir com eles novos discursos e dar a ver aquilo que, de um modo geral, se oculta ou se estereotipa. Como, aliás, João Ribeiro consegue fazer ao transportar a literatura de Mia Couto para o seu cinema e transformar "a história (...), através das imagens, naquilo que efetivamente é, um conto tradicional, que pertence a uma cultura, que pertence a um povo, que se revela na forma de falar e de viver a morte." (Tavares, 2012:170). E é deste espaço e das histórias que os rodeiam que são feitos os filmes. E é esta voz, vinda destes espaços, e são estas imagens que refletem esta realidade documentada ou ficcional que devemos ver e que é tão difícil de chegar até nós. Porque o bulldozer cultural americano, ou europeu, não dá espaço para mais nada além do seu próprio discurso. Estou ainda no princípio de um processo que deve ser longo. Podia falar de listas de filmes, de datas, de nomes. Mas para já, prefiro começar por falar de uma atitude. De uma escolha. Quero desenhar o meu percurso conforme as perguntas que o meu corpus me coloque cada vez que estejamos frente a frente. Para já, começo por rejeitar um modelo. Só posso ter a pretensão de entrar no discurso do outro com o seu assentimento e no seu espaço, diverso, complexo, impenetrável talvez. Só posso ter a pretensão de ver o cinema do outro se não quiser que ele seja o reflexo de um modelo, se não pretender que ele seja apenas o resultado de um processo de colonização. Mas um texto legitimamente escrito por pessoas que querem deixar a questão da memória resolvida e tratar do presente e da necessária ação sobre uma realidade que se transforma e que escapa, como toda realidade que se preze, a um modelo que tente aprisioná-la.

\section{Referências Bibliográficas}

ARNHEIM, Rudolf (1998), Arte e percepção visual: uma psicologia da visão criadora. São Paulo: Pioneira. 
BARLET, Olivier (2002), “Modernité de l'exception”, Africultures, n. ${ }^{4} 45$, Fev. 2002.

BARLET, Olivier (2002), "Notre génération a une chance historique - entretien avec Mama Këita”, Africultures, n. ${ }^{\circ}$ 45, Fev./2002.

BURCH, Noël (1995), El tragaluz del infinito (1991). Madrid: Cátedra.

CAnevacCI, Massimo (1990), Antropologia da Comunicação Visual. São Paulo: Brasiliense.

CARRIÈre, Jean-Claude (1995), A linguagem secreta do cinema. Rio de Janeiro: Nova Fronteira.

COMOLLI, Jean-Louis (2007), Ver y Poder - La inocencia perdida: cine, televisión, ficción, documental. Buenos Aires: Aurelia Rivera.

CRARY, Jonathan (2004), "A visão que se desprende: Manet e o observador atento no fim do século XIX”, in Leo Charney e Vanessa Schwartz (orgs.), O Cinema e a invenção da vida moderna. São Paulo: Cosac \& Naify, 67-94.

DEBRAY, Régis, (1994), Vida e Morte da Imagem. Petrópolis: Editora Vozes. DONDIS, Donis A. (1999), Sintaxe da Linguagem Visual. São Paulo: Martins Fontes.

HOUNTONDJI, Paulin (2002), The Struggle for Meaning: Reflections on Philosophy, Culture and Democracy in Africa. Ohio: Ohio University Press. Munsterberg, Hugo (1916), The Photoplay - A Psychological Study, The Project Gutenberg EBook, em http://www.gutenberg.org/files/15383/ 15383-h/15383-h.htm

OCHIENG, Omedi (2010), “The African intellectual: Hountondji and after", Radical Philosophy, n. ${ }^{\circ}$ 164, Nov/Dez 2010. Londres.

TAVARES, Mirian (2015), "Film and the city in Mozambican Cinema", International Journal of Humanities and Social Science, Vol. 5, n. ${ }^{\circ}$, January 2015, 134-138.

TAVARES, Mirian (2012), "Cartografias do desejo: a cidade como o espaço do outro (e alguns apontamentos sobre a cidade no cinema moçambicano)" in Helena Pires e Teresa Mora (orgs.), Encontro de Paisagens, em: (http://www.lasics.uminho.pt/ojs/index.php/encontro_paisagens/ issue/view/76/showToc). 
TAVARES, Mirian (2012), "O Cinema na Literatura de Mia Couto", in Petar Petrov; Pedro Quintino de Sousa; Roberto López-Iglésias Samartim e Elias Torres Feijó (orgs.): Avanços em Literaturas e Culturas Africanas e em Literatura e Cultura Galegas. Santiago de Compostela - Faro: Associação Internacional de Lusitanistas - Através Editora, 163-172. TAVARES, Mirian (2008), "Cinema digital: novos suportes, mesmas histórias", ARS (São Paulo). São Paulo: v. 6, n. 12, dezembro 2008.

XAVIER, Ismail (1996), O Cinema no século. Rio de Janeiro: Imago.

\section{Filmografia}

As Pitas

País: Moçambique

Ano: 1998

Género: Ficção

Duração: $52 \mathrm{~min}$

Realizador: Licínio Azevedo

O Grande Bazar

País: Moçambique

Ano: 2005

Género: Drama

Duração: 56 min

Realizador: Licínio Azevedo

O Jardim do Outro homem

País: Moçambique

Ano: 2006

Género: Drama

Duração: $100 \mathrm{~min}$

Realizador: Sol de Carvalho

Pregos na Cabeça

Ano: 2004 
2. ${ }^{a}$ PARTE: DisCursos E PERCURSOS

Género: Drama

Duração: $32 \mathrm{~min}$

Realizador: Sol de Carvalho.

\section{Fogata}

Ano: 1993

Género: Drama

Duração: $17 \min 50$

Realizador: João Ribeiro 
(Página deixada propositadamente em branco) 
FOTOGRAFIA PÚBLICA E PODER

Desde as últimas décadas do século XIX a perceção visual do mundo foi marcada pela utilização de dispositivos técnicos para a produção das imagens. A demanda social de imagens foi-se ampliando ao longo do século XX, a ponto de podermos contar a sua história através das imagens técnicas, notadamente, a fotografia. A ampliação dos usos e funções da imagem fotográfica esteve associada à natureza realista de sua representação, dos retratos em modelo carte-de-visite às paisagens de lugares exóticos, incluindo-se aos usos científicos, a imagem fotográfica decalcou-se ao seu referente ao ponto de com ele se confundir. Entretanto, entre o sujeito que olha e as imagens que elaboram, existe um conjunto de mediações técnicas e estéticas, fazendo da fotografia uma escolha, num conjunto de escolhas possíveis. Sendo assim, as imagens técnicas, na sua dimensão de documentos e monumentos da história contemporânea, devem ser trabalhadas a partir da ampliação da noção de testemunho, à maneira de Bloch. ${ }^{1}$

Há que se considerar, portanto, os usos e funções da fotografia no contexto dos processos de produção de sentido na sociedade contemporânea, com destaque para os seguintes aspetos: o papel desempenhado pela tecnologia; a definição do circuito social da

1 Marc Bloch (2006), Apologia da História ou ofício do Historiador. Rio de Janeiro: Ed. Jorge Zahar. 
produção de imagens técnicas, enfatizando historicidade dos regimes visuais; o papel dos sujeitos sociais como mediadores da produção cultural, compreendendo que a relação entre produtores e recetores de imagens se traduz numa negociação de sentidos e significados; e, por fim, a capacidade narrativa das imagens técnicas, discutindo-se aí a dimensão temporal das imagens, os elementos definidores de uma linguagem eminentemente visual e por fim, o diálogo estabelecido entre imagens técnicas e outros textos, tanto de caráter verbal, como não verbal, a partir do princípio de intertextualidade.

A título de orientação para as reflexões que se seguem, vale indicar quatro princípios metodológicos para se trabalhar com a fotografia na perspetiva do património histórico e cultural. O primeiro, remete-se à questão da produção, em que se concebe o ato fotográfico como uma mediação cultural entre o sujeito que olha e a imagem que elabora. Através dessa atividade de olhar, dá-se a manipulação de um dispositivo de caráter tecnológico, que possui determinadas regras, definidas historicamente. O segundo, relaciona-se com a questão da receção, que se associa ao valor atribuído à imagem pela sociedade que a produz, mas também recebe. Em que medida este valor está mais ou menos balizado pelos efeitos de realismo da imagem, apontará para a conformação histórica de um certo regime de visualidade. Portanto, se a questão da relação da imagem com o seu referente e o grau de iconicidade dessa imagem é uma questão estética, o seu julgamento (ou apropriação) tem a ver com as condições de receção e como, através dessa receção, se atribui valor à imagem: informativo, artístico, íntimo, etc. O terceiro princípio volta-se para a questão do produto, resultado da objetivação de trabalho humano numa relação social de produção de sentido. A fotografia, como produto, implica a capacidade da imagem potencializar a matéria em si mesma, e, então, poder ser apropriada pelas trocas sociais, notadamente de caráter simbólico. Compreendida como resultante de uma relação entre sujeitos, 
a imagem fotográfica engendra uma capacidade narrativa que se processa numa dada temporalidade. Estabelece, assim, um diálogo de sentidos com outras referências culturais de caráter verbal e não verbal. As fotografias contam-nos histórias, atualizam memórias, inventam vivências, recriam a história. O quarto, por fim, diz respeito à problemática do agenciamento da imagem fotográfica, relaciona-se aos percursos delineados pela biografia das imagens desde a sua produção, passando pelas estratégias de publicação, arquivamento e guarda, finalmente, chegando às possíveis interpretações históricas sugeridas pelos novos contextos de apropriação das fotografias mensagem e objeto - texto e suporte material.

\section{Fotografia pública, um conceito em construção}

O circuito social da fotografia nos séculos XIX e XX foi caracterizado pelo advento daquilo que se denomina de fotografia pública. ${ }^{2}$ A noção de fotografia pública associa-se à configuração da ação do poder público, por meio da produção de registros de situações, processos e sujeitos, que se associam à ação do Estado e criam a memória visual da ação do poder público. Paralelamente, procura ampliar a noção de documento visual, por entender que qualquer fotografia, ao mesmo tempo em que apresenta e representa o mundo visível, por meio de uma linguagem, é também o resultado de uma prática social e de uma experiência histórica. Utiliza-se o termo "fotografia pública" para incluir, dentro da análise de fotografias, as dimensões de seu circuito social, quer seja definindo a dimensão do

2 Ana Maria Mauad (2013), "Fotografia Pública e cultura visual em perspetiva histórica", in Revista Brasileira de História da Mídia, vol.2, n. ${ }^{\circ}$ 2, http://www.uni centro.br/rbhm/ed04/dossie/01.pdf 
espaço público visual, quer seja pela configuração de um público que visualiza essas imagens.

A produção histórica da fotografia pública, ao longo do século $\mathrm{XX}$, associou-se, por um lado, à constituição da sociedade burguesa, liberal e democrática, e, por outro, ao apoio à propaganda de regimes ditatoriais e fascistas. A sua prática constitui-se no âmbito de circuito social, proveniente da cultura dos meios e das mediações, composto pelas agências de produção das imagens governamentais (órgãos ligados ao Estado que possuem a função de registro e arquivo da sua ação sobre o espaço público; bem como as assessorias de imprensa e propaganda, que cumprem a função de publicizar a ação do Estado como o principal organizador das relações sociais no espaço público); pelas agências da grande imprensa e pelas agências independentes que operam conjuntamente aos movimentos sociais.

Portanto, conjugamos dentro desta rubrica, um conjunto de imagens publicadas em jornais e revistas, mas também veiculadas em catálogos de exposições e coletâneas de fotógrafos resultantes da sua prática fotográfica: documental e artística. Assim, a noção de fotografia pública vem complementar aquela relativa ao espaço doméstico e da intimidade, reservada à esfera privada das relações sociais. O fundamental é perceber os aspetos dessa comunidade de imagens que estruturam uma linguagem visual comum, migrando de campos de produção visual para outros, a partir de um processo de apropriação e rearticulação dos elementos significantes.

Em compasso com a configuração de uma cultura visual plural e diversificada, ao longo do século XX, a questão social emergiu na cena pública de distintas maneiras e em diferentes locais, alimentada pelos movimentos sociais e políticos de procedências e tendências também variadas: do movimento operário às demandas de liberdade sexual, passando pelas lutas por direitos civis, guerras pós-coloniais, etc. Tudo isto, captado por profissionais atentos ao calor dos acontecimentos. Tais imagens, compõem um catálogo, no 
qual surge uma história redefinida pelo estatuto técnico próprio ao dispositivo da representação: a câmara fotográfica. Nesse outro tipo de escrita da história, o local de sua produção (as agências de produção da imagem: família, Estado e imprensa) e o sujeito da narrativa (os fotógrafos), dividem com os institutos históricos e as academias literárias, a tarefa de imaginar a nação e instituir os lugares de sua memória. Assim, a experiência fotográfica de novecentos redefiniu as formas de acesso aos acontecimentos históricos e a sua inscrição na memória pública, a ponto de podermos contar a história do século XX através de suas imagens. Ao mesmo tempo, a produção de imagens fotográficas voltadas para o registro de processos, situações e sujeitos históricos, contribuiu significativamente para a configuração dos sentidos atribuídos ao espaço público na contemporaneidade.

Vale ressaltar que todo o processo de produção de sentido pela fotografia, bem como o seu valor autoral, envolve dois movimentos por parte do sujeito-fotógrafo: inscrição e atribuição. ${ }^{3}$ Pela dimensão da inscrição reconhece-se o investimento por parte do sujeito-fotógrafo em produzir uma imagem que provoque ressonância no campo social, no qual desenvolve a sua experiência fotográfica. Esse investimento é o resultado de um trabalho social de produção de sentido, definido pela relação entre o sujeito e o mundo visível, com apoio dos recursos, técnicas e conceções do meio do qual provém. ${ }^{4}$ Pelo lado da atribuição, identificam-se as relações sociais que sustentam a eficácia da imagem fotográfica e estão diretamente relacionadas ao regime visual, do qual procedem. Assim, uma fotografia adquire valor histórico, tanto pela sua capacidade de responder às demandas visuais do circuito social (produção, circulação, consumo

\footnotetext{
3 Oliver Lugon (2006), "L'anonymat d'auter", in Le statut de l'auteur dans l'image documentaire: signature du neuter. Paris: Jeau de Paume, Document 3, 4-13.

4 Siegfried Kracauer (1980), "Photography", in Trachetenberg, Alan (ed.), Classic Essays on Photography. New Haven: Leete's Island Books, 245-268.
} 
e agenciamento) organizados por diferentes instâncias da cena pública (imprensa, mercado, estado, movimento social, etc.), como pelos recursos técnicos e estéticos utilizados para esse trabalho.

A fotografia pública, ao longo do século XX, pode ser compreendida segundo dois rumos: o da prática artística e o da prática documental. ${ }^{5}$ No primeiro caminho, o da prática artística, a fotografia, entre várias tendências, foi pensada, por um lado, como expressão autoral ligada ao pictorialismo e aos padrões clássicos de representação artística, de outro lado, associada às vanguardas contemporâneas, colocou em questão o próprio princípio realista. Assim, a fotografia pública, na sua dimensão de prática artística, esteve tanto comprometida com a pedagogia do sujeito e o cultivo do olhar, quanto com o engajamento de públicos à perceção crítica do mundo visível. No segundo caminho, como registro documental, a fotografia pública esteve associada às agências governamentais, à imprensa ilustrada e a produção das notícias, agindo como janelas que se abriam para o mundo, figurando-o da forma mais realista. Ainda nesse segundo rumo ou tendência, a produção fotográfica novecentista associou-se às práticas de registro de social, servindo para documentar as condições de vida de diferentes setores sociais, os deslocamentos humanos, conflitos e situações limite.

Ambas as modalidades de fotografia pública integram o património ${ }^{6}$ das sociedades históricas. Entretanto, há que se considerar

\footnotetext{
5 Idem, ibidem.

${ }^{6}$ Desde os anos 1990, a discussão sobre a noção de patrimônio superou os seus limites materiais, bem como as dicotomias tradicionais entre cultura popular e erudita, associou-se às políticas de construção das identidades plurais próprias às sociedades complexas e, assim, incorporou ao seu debate, as noções de conflito e disputa pela memória. A noção de patrimônio passou, nos últimos 30 anos ganhou novos foros de debate, reflexão e ação social. No panorama dos debates sobre patrimônio na e para a sociedade contemporânea enfatiza-se o estudo sobre os agentes, seus discursos e estratégias de ação. Para um mapeamento do campo de debates cf. Nestor Garcia Canclini (1994), "O patrimônio Cultural e a construção imaginária do nacional”, in Revista do Patrimônio Histórico e Artístico. Rio de Janeiro: IPHAN, n. ${ }^{\circ} 23,95-115$.
} 
a fotografia, simultaneamente como imagem/documento e como imagem/monumento. Como imagem/documento, considera-se a fotografia como marca de uma materialidade passada, que nos informa sobre determinados aspetos desse passado: condições de vida, moda, infraestrutura urbana ou rural, condições de trabalho, etc. Como imagem/monumento, a fotografia é um símbolo, aquilo que, no passado, a sociedade estabeleceu como imagem a ser perenizada para o futuro. Como documento e monumento, a fotografia informa e também conforma visões de mundo. ${ }^{7}$

$\mathrm{Na}$ sequência do texto, com o objetivo de operacionalizar o conceito de fotografia pública, apresenta-se um estudo de caso - a produção sobre o catálogo da Exposição de Angola, de 1938 - em que se procura inventariar as imagens e suas histórias, num possível exercício de biografar objetos e imagens fotografadas.

\section{Álbuns fotográficos como arenas da memória pública}

Foi publicada uma foto no suplemento de "Cultura", no sábado cinco de abril de 2014, no Jornal Público de Lisboa, que ilustrava a matéria intitulada, Luanda, um olhar desconbecido, assinada por Sergi B. Gomes. A notícia apresentava ao público português a exposição que se organizava em torno da descoberta do Álbum comemorativo da exposição-feira de Angola, realizada em Luanda, em 1938, pelo galerista Alexandre Pomar, na Pequena Galeria, em Lisboa. A imagem que ilustrava a matéria, bem como a apresentação do significado da descoberta do álbum para diferentes domínios da

7 Ana Maria Mauad; Marcos Felipe de Brum Lopes (2013), "História e Fotografia”, in Ciro Cardoso e Ronaldo Vainfas (orgs.), Novos Domínios da História. Rio de Janeiro: Ed. Elsevier-Campus. 
pesquisa social chamou-me a atenção e iniciei uma breve pesquisa para desvendar a história dessa descoberta (Fig. 1).

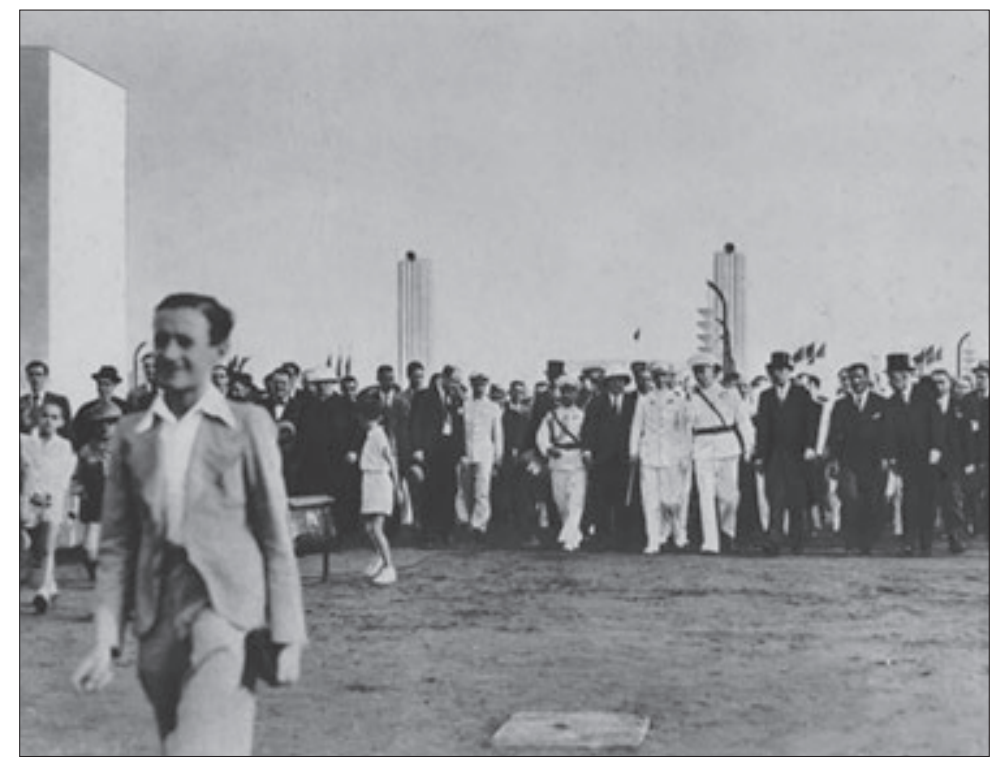

Fig. 1 Inauguração da exposição.

Álbum comemorativo da exposição-feira de Angola.

Em tempos de pesquisa on-line, o acesso ao blog de Alexandre Pomar, jornalista e crítico de arte permitiu-me retraçar o percurso feito pelo investigador desde 2011. Inicia-se a descoberta do Álbum da feira de Alfarrabistas na Rua Anchieta, em agosto de 2011, mencionado no post do dia 28/08:

Adenda, ou autocomentário. O meu exemplar do álbum (comprado ontem na feira dos alfarrabistas da R. Anchieta) tem um interessante carimbo da Biblioteca da Universidade de Lisboa - Faculdade de Direito, e depois um outro que justifica o seu itinerário histórico: "Oferta da Biblioteca da Faculdade de Direito de Lisboa”. Lá dentro, um cartão que refere o envio gracioso de Luanda. Depreendo que não foi no tempo maoista do 
nosso presidente Durão Barroso que a Biblioteca se desfez do catálogo (não se poriam carimbos nas urgências da revolução), mas já antes, quando "o regime" se desfazia do passado colonial, ou do seu passado, apenas. Ou, ainda, mais simplesmente, será só um outro exemplo da tara das bibliotecas (não só nacionais...) se desfazerem dos seus bens? De qualquer modo, paguei-o, e é uma peça preciosa. ${ }^{8}$

A descoberta relatada acima, levaria o investigador à busca de outros exemplares nos arquivos e bibliotecas, registrando a existência de mais cinco exemplares distribuídos na Biblioteca Nacional, no Centro de Intervenção para o Desenvolvimento Amílcar Cabral (CIDAC), na Biblioteca da Universidade de Coimbra, na Sociedade de Geografia de Lisboa e, finalmente, na Biblioteca de Arte da Fundação Calouste Gulbekian (entregue pelo próprio investigador). As suas descobertas e identificação dos locais de guarda do álbum foi acompanhada pela surpresa do investigador em não encontrar referências sobre a sua existência, tampouco a da própria exposição de 1938, na historiografia especializada. O que o levaria a fazer uma verdadeira arqueologia da peça, colocando-a em perspetiva em relação às práticas de propaganda e de registro documental pelo Estado Português da política colonial. Implementada nos anos 1930, essa política estaria fortemente apoiada no lema, atribuído ao político pró-salazarista Henrique Galvão: "Sabe-se que os homens que nasceram num país pequeno querem hoje, firmemente, morrer dentro dum império".

Lema que traduzia a tendência colocada em prática, a partir de 1931, quando Armindo Monteiro (1896-1955) se torna Ministro das Colónias. A partir de então, o Estado Novo procuraria lançar uma campanha de propaganda com o objetivo de consolidar, externamente, a ideia do Império Colonial Português, e, internamente, de

\footnotetext{
8 http://alexandrepomar.typepad.com/, acesso em 31/05/2014.
} 
mostrar aos portugueses a ideia de um Portugal Imperial espalhado pelo Mundo, grande, uno e indivisível, que marcará o regime (e o país) nas décadas seguintes.

O procedimento de análise do álbum, acompanhado pelas postagens no blog do investigador, vai-se tornando cada vez mais minucioso, com a descoberta de indícios sobre produção do objeto (confeção do álbum e destino dos negativos); os seus artífices-editores, fotógrafo, editora e os resultados políticos esperados. Finalmente, em oito de maio de 2014, relatou-se o resultado da investigação detalhada sobre a trajetória do álbum, o seu conteúdo visual e função política, iniciada em 2011.

No Álbum de 1938 as fotografias (c. 140) são atribuídas a C. Duarte, que é muito provavelmente Firmino Marques da Costa (1911-1992). Acompanhou a visita de Carmona às colónias, em 1938, e a ele atribuiu António Sena a autoria principal das imagens dos cinco álbuns fotográficos que a Agência Geral das Colónias publicou em 1939-40 [...] O segundo destes álbuns refere a intenção do Governo de Angola produzir um volume dedicado à Exposição-Feira, o que se cumpriu - algumas fotografias publicadas nessas edições são 'contíguas', mas não as mesmas: uma colecção de negativos teria seguido para a Agência Geral das Colónias e outra ficou em Luanda (é o que se pode depreender). [...] Será possível atribuir a edição a Vasco Vieira da Costa, cuja presença se reconhece também no grafismo da revista 'Actividade Económica de Angola' onde as mesmas fotografias se publicam. [...] O certame realizado durante o governo do coronel António Lopes Mateus (1935-39) foi totalmente levado a cabo por técnicos e artistas de Angola, o que é sublinhado em muitas circunstâncias. Foi inaugurado por ocasião da visita de Carmona a 15 de Agosto (dia da Restauração de Angola, após a ocupação holandesa) e decorreu até 18 de Setembro, precedida pelo anúncio da criação do Fundo de Fomento de Angola com um empréstimo de 115 milhões de escudos. É possível que o início da II Guerra 
tenha alterado profundamente as expectativas então abertas, levando ao esquecimento da Exposição. Dois anos depois realizou-se a Exposição do Mundo Português. 9

Na sua avaliação, Pomar projeta o objeto-álbum fotográfico em perspetiva histórica - diferenciando-o do Álbum da Exposição Colonial Portuguesa de 1934, associado à propaganda do regime salazarista e à defesa do domínio colonial como parte da ideologia "Portugal não é um país pequeno"; enquanto o de 1938, adiantaria o perfil da Expo de 1940, em Lisboa, assumindo a centralidade dos espaços coloniais no jogo de representação do Império Português.

O relato sobre a descoberta do álbum, a sua produção e o destino das suas imagens relevam aspetos interessantes sobre as tensões que perpassam a economia visual do período. O Álbum de 1938 e a narrativa visual nele proposta, valorizavam a projeção arquitetónica no espaço colonial. A escolha pelo estilo arte déco, em consonância com os padrões estabelecidos pela cultura ocidental hegemónica, bem como a valorização dos espaços expositivos, sem a presença dos visitantes (embora se tenha a indicação que cerca de 70 mil pessoas visitaram a expo), concederam à Exposição uma dimensão cénica, apoiada numa espécie de imaginação futurista do que poderiam ser as colónias. Espaço criado artificialmente para ser destruído, teria nas fotografias publicadas no álbum a garantia da sua perenidade e de monumentalização de um mundo pós-colonial imaginado.

O álbum da exposição de Luanda, em 1938, apresenta um lugar criado para ser fotografado. O partido adotado pelo fotógrafo comissionado pelas autoridades locais, priorizou a composição e o enquadramento, em que se retirou do espaço público de Luanda o que esse teria de próprio e de singular - o que lhe daria direito à

9 http://doportoenaoso.blogspot.com.br/2014/02/o-porto-dos-anos30a-exposi cao-colonial.html, acesso em 31/05/2014. 
cidade e aos seus habitantes à cidadania -, e projeta-o no espaço público das colónias uniformizadas pela política colonial.

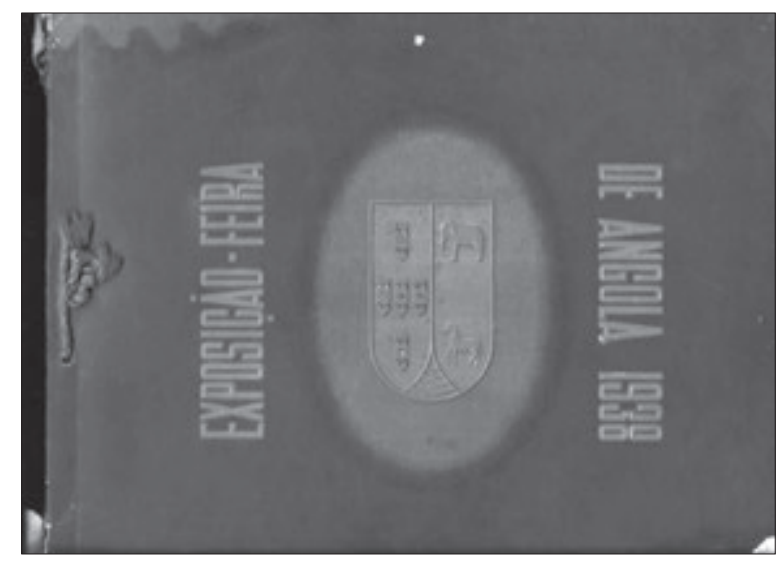

Fig. 2 Capa do Álbum comemorativo da exposição-feira de Angola.

A sequência abaixo recompõe, resumidamente, o padrão narrativo apresentado no Álbum comemorativo da exposição-feira de Angola, com destaque para a monumentalidade das edificações, valorizadas pelas tomadas noturnas em que a iluminação realça a perspetiva ascendente, reforçada pela imagem em diagonal (Fig. 3). Valoriza-se, também, o registro das áreas internas, em que os objetos de decoração compõem a ambientação ilusória de um espaço próprio à exibição dos valores de cada lugar. Investimento, esse, reforçado pelo uso de mapas, fotografias e gráficos incluídos na exposição como índices de uma realidade que lhe é exterior, mas complementar (Fig. 4). Completa a narrativa, as fotografias diurnas da exposição, em que apresenta com mais detalhe as opções arquitetónicas dos pavilhões, divididos de forma temática (Fig. 5), cuja tipologia de letras e grafismo, notadamente arte déco, contrasta como etnografia da temática figurada; ou ainda, fotografias que apresentam o plano geral da exposição (Fig. 6), em que se destacam a amplitude do espaço expositivo, os símbolos da modernização colonial e das 
marcas de poder da metrópole. Uma narrativa que elege o ordenamento dos ângulos retos e da distribuição equilibrada dos planos como marcas da projeção visual do espaço colonial.
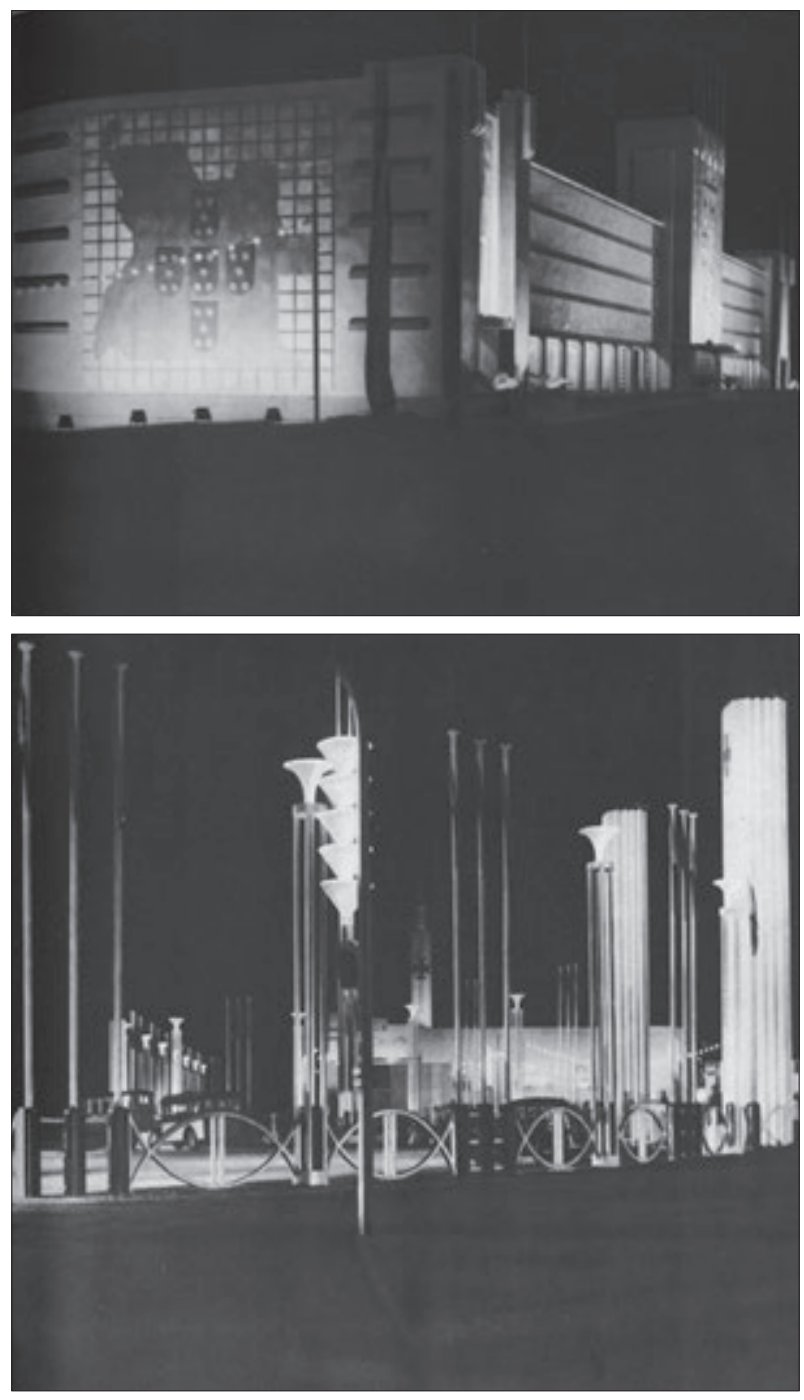

Fig. 3 Imagem noturna de um dos pavilhões, uma novidade para a época | Área Central da Exposição. Álbum comemorativo da exposição-feira de Angola. 

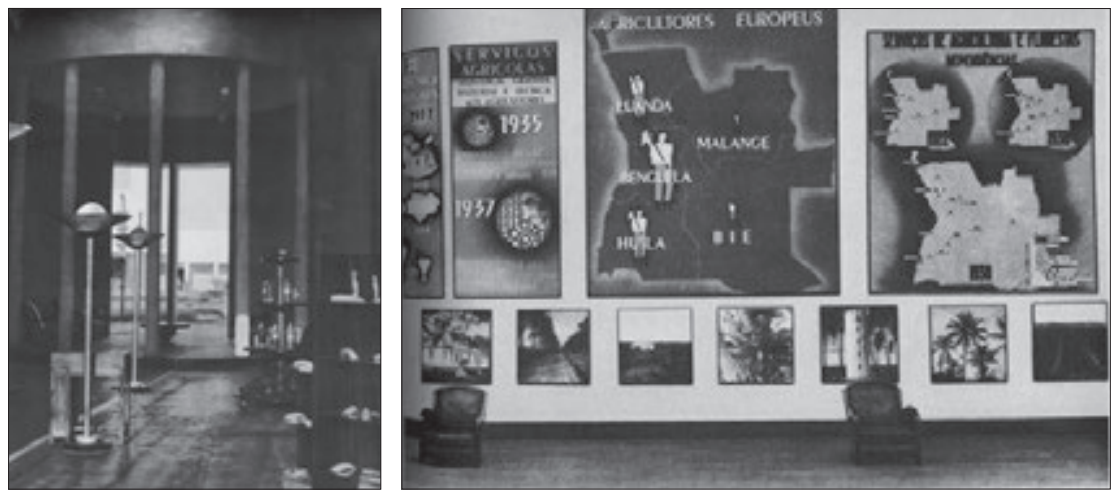

Fig. 4 Interior do pavilhão da Província de Luanda | Pavilhão da Agricultura. Álbum comemorativo da exposição-feira de Angola.

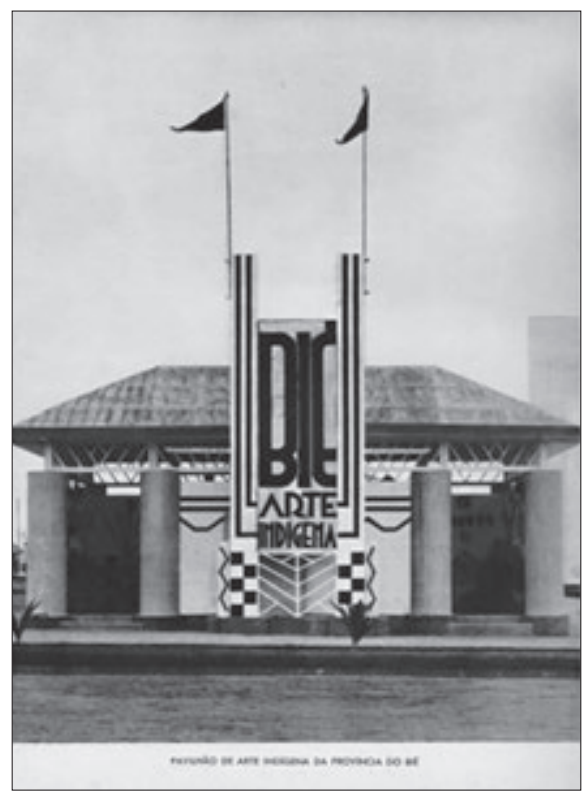

Fig. 5 Destaque para o Pavilhão de Arte Indígena. Álbum comemorativo da exposição-feira de Angola.

Observa-se ainda, que a composição do Álbum como objeto (Fig. 2), seguiu os padrões dos álbuns de família, com capa dura em cor escura, páginas reunidas por um cordel de cor azul, mas 

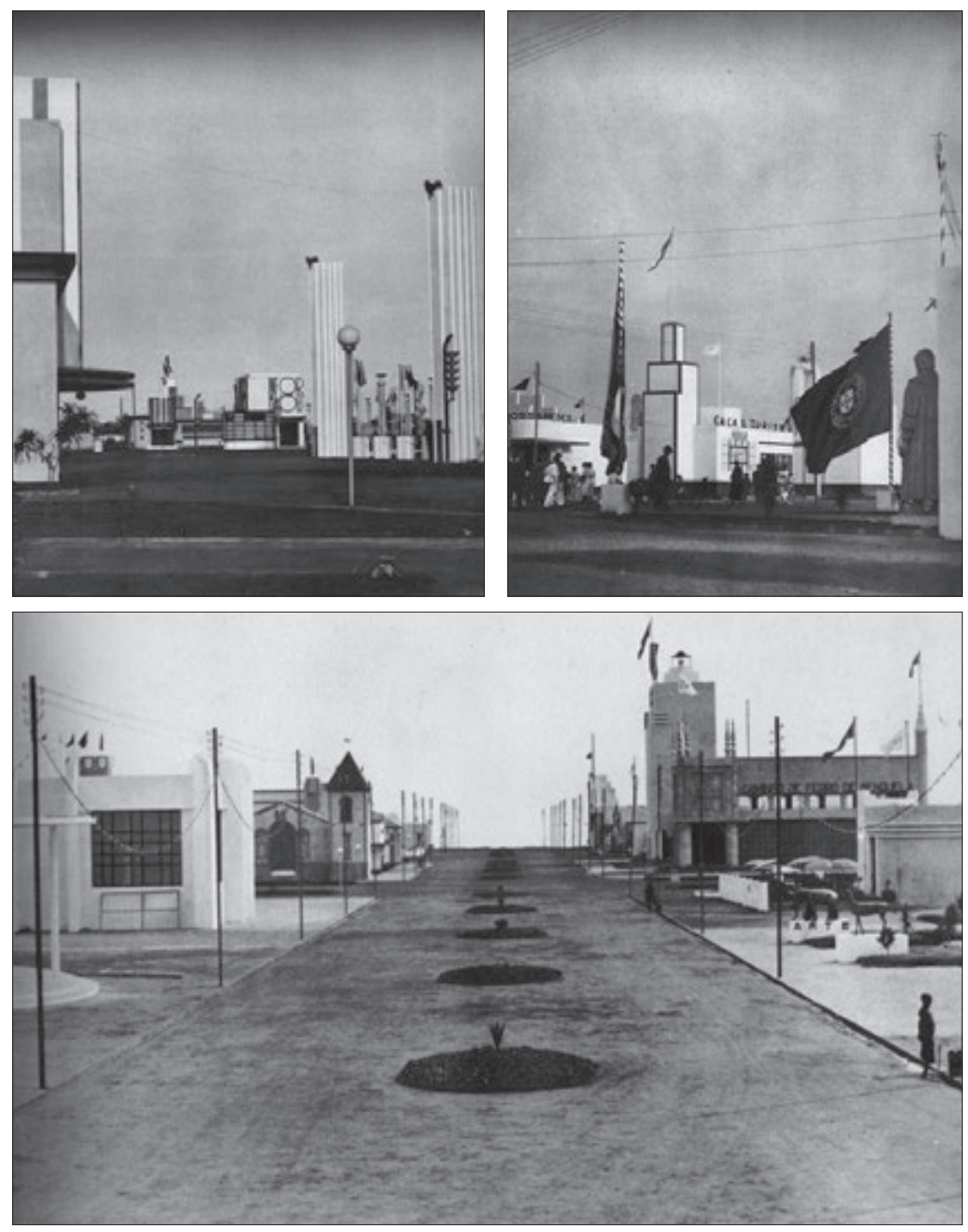

Fig. 6 Vista geral | Pavilhão de Caça e Turismo | Avenida Central da exposição. Álbum comemorativo da exposição-feira de Angola.

as letras douradas e o brasão não indicam mais a família a quem as imagens recompõem a memória, mas o país cuja memória será monumentalizada nas páginas do álbum. A opção por reunir o 
registro documental na modalidade álbum de fotografias e doá-lo como se identifica na mensagem da Fig. 7, ao invés da publicação de uma revista, revestiu a iniciativa de um dever de memória e o próprio registro fotográfico torna-se monumento, materialização da memória em património.

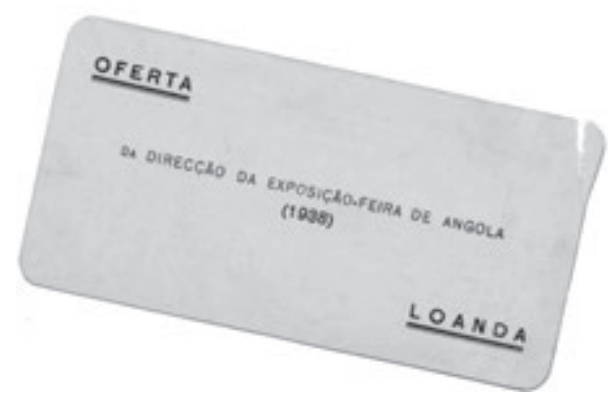

Fig. 7 Indicativo da distribuição do Álbum comemorativo da exposição-feira de Angola.
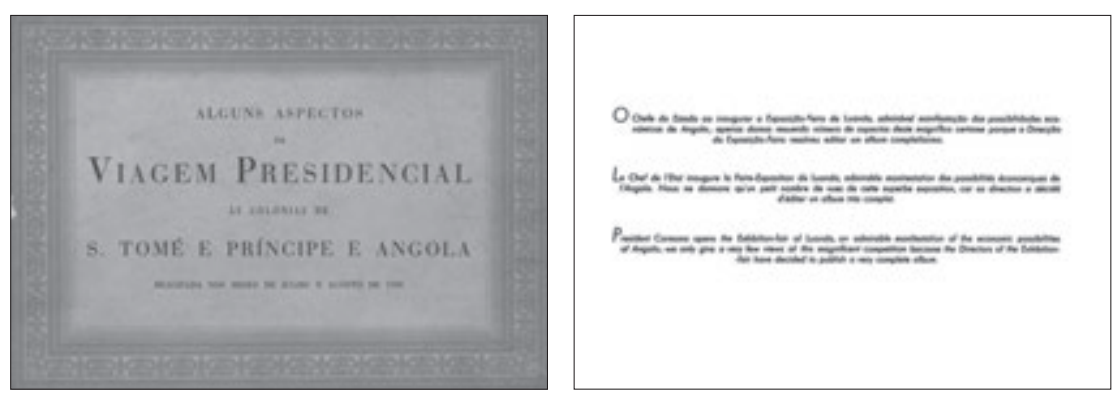

Fig. 8 Capa do Álbum da viagem presidencial | Abertura em três idiomas.

Tendência confirmada pelas fotografias que apresentam a cobertura da visita do presidente Oscar Carmona a Luanda, com destaque para o evento de abertura da exposição, compondo um álbum suplementar, com imagens também feitas pelo fotógrafo 
Firmino Marques da Costa, comissionado pela Agencia Geral de Colônias para integrar a Missão cinegráfica de 1937 e 1938, que registrou o périplo do presidente pelas colónias africanas. O repórter fotográfico compôs a representação do poder em cena no álbum da visita presidencial, por meio de imagens que dialogavam com as tendências contemporâneas do fotojornalismo de cobertura de eventos, em que se revelavam os dignitários do poder como protagonistas da narrativa de acolhimento da multidão que os acompanhava (Fig. 8).

O Álbum intitulado "Alguns aspectos da viagem presidencial às colónias de S. Tomé e Príncipe e Angola realizada nos meses de julho e agosto de 1938", introduz-se pela seguinte nota:

Chefe do Estado ao inaugurar a Exposição-Feira de Luanda, admirável manifestação das possibilidades ecanómicas de Angola; apenas damos resumido número de aspectos deste magnífico certame porque a Direcção da Exposição-Feira resolveu editar um album completíssimo.

Observa-se, por essa nota, que a mesma cobertura fotográfica serviu para dois objetivos distintos: a inauguração da exposição e a visita presidencial. Por um lado, as autoridades locais de Angola já haviam planeado a edição de um álbum completo; por outro, a visita presidencial não se limitaria à abertura da exposição, incluindo-se outras atividades e lugares a visitar. Entretanto, a nota acima reproduzida, não deixa de indicar que a escolha de somente colocar algumas imagens do "magnífico certame", não foi por parte da administração central, que realmente estaria interessada em garantir como sua as "possibilidades econômicas de Angola". A disputa pelo espaço fotografado revela uma tensão política extra fotográfica que se evidencia nos combates pela memória. 

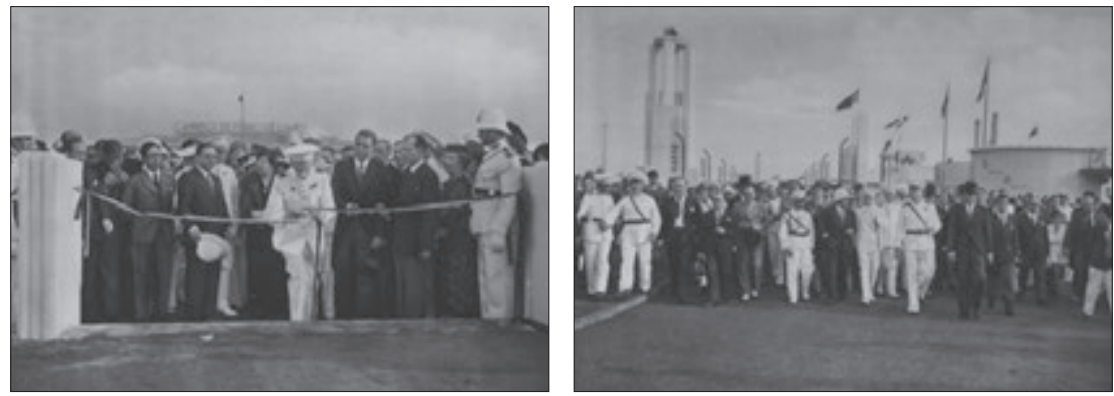

Fig. 9 Inauguração da Exposição de Luanda pelo presidente Oscar Carmona.

A Fig. 9 coloca os personagens da trama oficial em plena performance do poder - corte da faixa de inauguração da exposição pelo presidente devidamente paramentado com o seu uniforme; seguida pela imagem do grupo abrindo a visita pública e identificando os distintos públicos que percorreriam a feira, tanto pela indumentária quanto pela sua posição mais próxima ou distante do poder. As duas sequências (Fig. 10) foram montadas pelos historiadores da fotografia que pesquisaram a vida do fotógrafo Firmino Marques da Costa, e apresentadas no blog de Alexandre Pomar, como uma série complementar com o título "Imagens fugazes". Interessante notar que, nessas duas sequências, o conjunto de vivências, personagens e lugares registrados é bem mais amplo que a do Álbum da Exposição, pois inclui a viagem do presidente às colónias de São Tomé e Angola. O que se identifica nessas imagens, que demandam uma análise que não cabe aqui neste texto, é a afluência maciça de um público desidentificado e do destaque para o poder paramentado - exército e igreja.

Vale ainda comentar que, a foto que havia ilustrado a reportagem do jornal Público (Fig. 1), integra o álbum da exposição de 1938. Trata-se de uma foto que foge ao padrão das demais, pois por ela se cria uma pausa na narrativa da exibição dos espaços expositivos, para trazer os dignitários do poder para o centro da fotografia, como 
atores principais da mise-en-scène da fotografia oficial. Entretanto, na tomada da foto, emerge o público, em forma de um sujeito com trajes de passeio levemente desfocado que, na lateral esquerda da imagem foge do quadro central, projetando-se para o espaço extra fotográfico em direção oposta ao objeto central da fotografia - a comitiva presidencial. Essa imagem pode suscitar múltiplas interpretações, entretanto, todas seriam exercícios de imaginação.

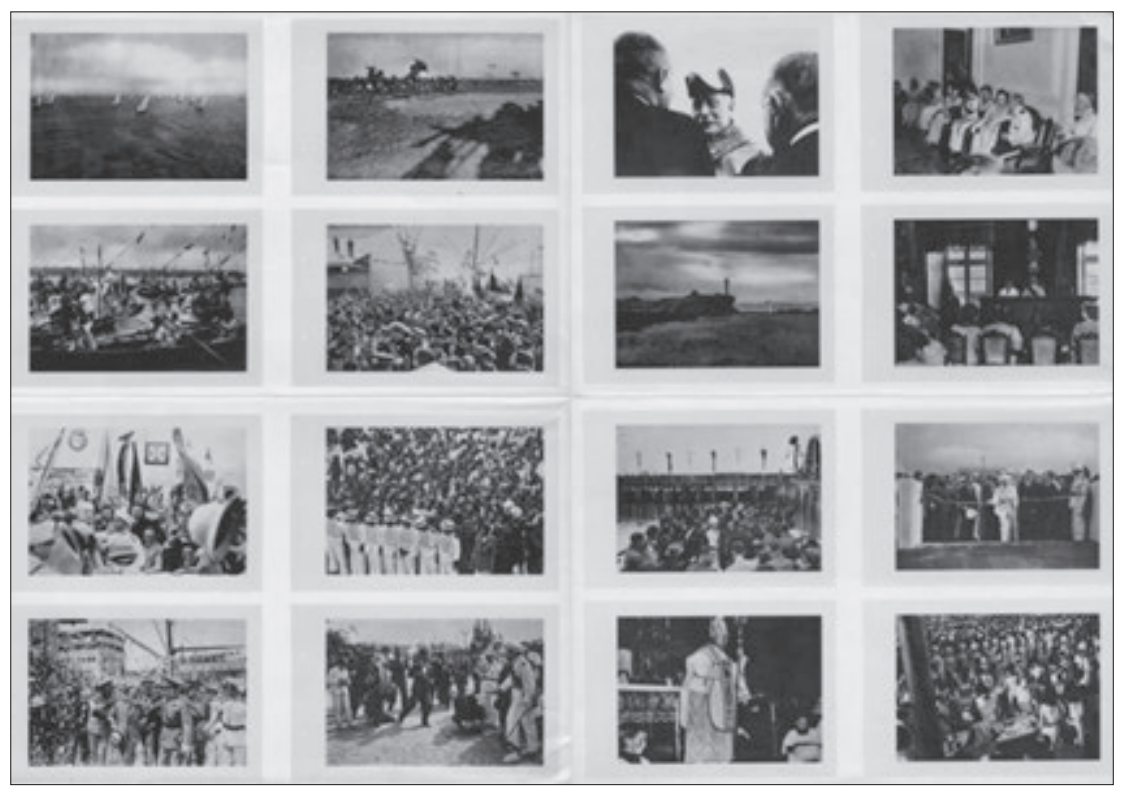

Fig. 10 Périplo pelas províncias do presidente Oscar Carmona, com destaque para as celebrações desportivas, religiosas e concentrações militares.

O que cabe indagar é o porquê de se manter, na narrativa do álbum da exposição, uma imagem que foge ao padrão das anteriores e cria uma tensão visual pelo desequilíbrio entre o centro e a extremidade da foto, deslocando o olhar para o sujeito e subtraindo da comitiva presidencial a força da presença. Uma hipótese factível 
coloca essa imagem como a ponte entre os dois álbuns, e indica que o segundo foi feito concomitante ao primeiro, reservando à edição o papel de distribuição das imagens feitas pelo mesmo fotógrafo. A montagem de uma narrativa voltada para interesses diferentes, mas complementares, permitiria que cada tipo de memória fosse acionada de forma independente: a memória monumental do primeiro álbum serviria às elites coloniais locais a valorização do espaço colonial de Angola para o seu domínio; ao passo que a cobertura da visita presidencial, tema do segundo álbum, responderia às demandas de confirmação da presença do governo central nas metrópoles.

Colocados em perspetiva comparativa, os dois álbuns - da exposição de 1938 e da visita presidencial - apresentam-se como arenas de disputa da memória pública colonial: a primeira associada à promoção de Angola, pelo governador António Lopes Mateus, que expressa a tendência de se criar nas colónias um grande Portugal. A contratação do fotógrafo para produzir uma série especial de fotografias, exclusivamente voltada para valorização do espaço projetado na exposição por meio de signos arquitetónicos, em que se expressaria a modernidade ocidental incorporada ao espaço colonial; e uma segunda que, como fica clara na abertura do álbum da visita presidencial, seria complementar, pois adotar-se-ia uma outra abordagem: a de reportagem de eventos oficiais. Entretanto, o que se apresentou na série de imagens de registro da visita presidencial, foi a ocupação do espaço, deixado vazio nas imagens anteriores, pela presença maciça do público saudando as autoridades, e o consequente fortalecimento do poder de representação da metrópole na colónia. Aqui cabe uma nota metodológica, segundo Hart e Edwards, ao se considerar a materialidade das fotografias, individualmente ou em série, organizadas num álbum e associadas a uma narrativa visual ou isoladas em unidades, é fundamental tomar os objetos como meios pelos quais se traduzem as experiências sociais, comportamentos e modos de ser. Assim, os objetos fazem parte das ações humanas 
e devem ser concebidos como meios de ação, não simplesmente como acessórios da experiência social. Como consequência dessa aproximação concetual, desenvolve-se uma abordagem metodológica que explora a trajetória das fotografias, separadas ou seriadas, como forma de compreender por meio das suas biografias os discursos que as fundamentam como suportes de práticas sociais. ${ }^{10}$

Em que pese, a tese defendida por Pomar, do sentido singular e diferenciado da Exposição de 1938 face às demais, o que se observa é a confirmação do imaginário colonial, incluindo o futuro pós-colonial, representado pelo progresso construtivo de Angola o arquiteto e a equipa que montou a exposição eram angolanos. Afirma-se a lógica da dominação por meio de imagens que evocam a autonomia do espaço construído e os atributos arquitetónicos de progresso. Assim, em complementação à cultura visual colonialista do exótico, confirmada pela iconografia das exposições coloniais (Figs. 11 e 12), bastante popular nos anos 1930 e 1940, afirma-se o pós-colonial, imaginado pelas edificações em estilo arte déco e espaços expositivos planificados e artificiais, sem a presença do público e do direito à cidade.

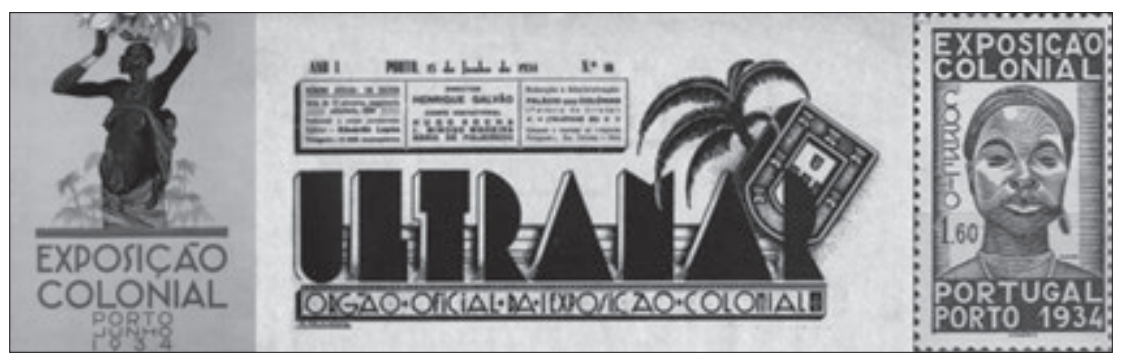

Fig. 11 1. ${ }^{\mathrm{a}}$ Exposição Colonial Portuguesa na cidade do Porto, 1934. Selo comemorativo.

10 Elizabeth Edwards; Janice Hart (2004), "Introduction: photographs as objects", in Photographs Objects Histories. New York: Routledge. 


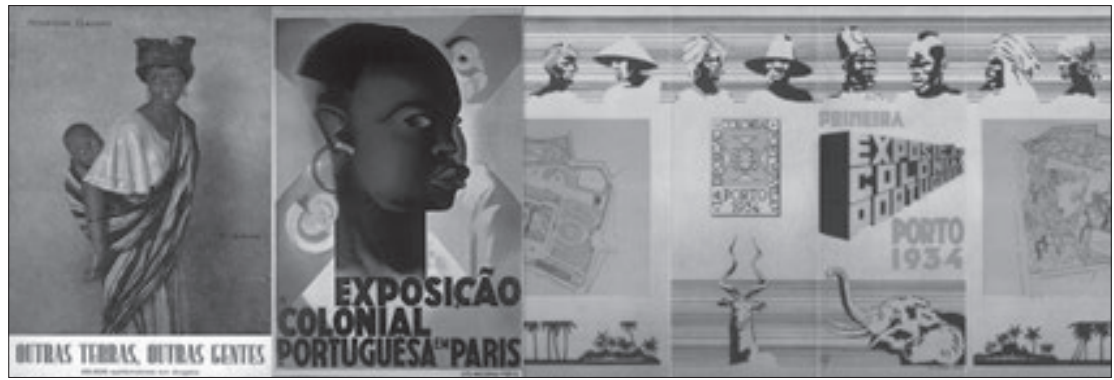

Fig. 12 Capa da obra de Henrique Galvão | Cartaz de divulgação da Exposição Colonial Portuguesa em Paris | Cartaz de divulgação da 1. ${ }^{a}$ Exposição Colonial Portuguesa na cidade do Porto.

A associação entre património cultural e fotografia pública, possibilita que se considere, na perspetiva de Canclini, a pluralidade dos discursos que fundamentam o imaginário das identidades nacionais (coloniais e pós-coloniais) forjadas nos processos históricos. De acordo com esse autor,

Aquilo que se entende por cultura nacional muda de acordo com as épocas. Isto demonstra que, mesmo existindo suportes concretos do que se concebe como nação (o território, a população e seus costumes, etc.) em boa parte o que se considera como tal é uma construção imaginária [...]. O imaginário discursivo contribuiu para formar o sentido do nacional, selecionando e combinando suas referências emblemáticas, dando-lhe até o presente uma unidade e uma coerência imaginárias. Chamo-os assim pelo caráter de construção desses textos e imagens, e porque informam tanto sobre feitos altamente significativos quanto sobre o modelo ideal de nação dos que os elaboram. [...] À medida que esses discursos alcançam uma eficácia social, ou seja, que são partilhados e contribuem para formar uma concepção coletiva da nação, se constituem em patrimônio (tradição objetivada). [... $]^{11}$

11 Nestor Garcia Canclini (1994), "O patrimônio Cultural e a construção imaginária do nacional", in Revista do Patrimônio Histórico e Artístico. Rio de Janeiro: IPHAN, n. ${ }^{\circ}$ 23, 98. 
Observa-se, portanto, que a produção das fotografias, quanto os seus possíveis usos, são factos políticos de uma história que não se conta por eventos, mas que se elabora por problemas. A relação entre imagem fotográfica e política está na base da condição histórica do dispositivo fotográfico, como um importante meio de representação social, e da fotografia como prática de produção de sentido social. Assim, é pública, não é somente a fotografia publicada, mas aquela que se refere ao espaço público como tema e que tem no espaço público o seu lugar de referência política. A fotografia pública organizada em álbuns, publicadas em revistas ou dispostas em séries de arquivos, apresenta-se como arena de disputa da memória pública. As trajetórias e rumos que essas imagens, nas suas biografias percorrem, deixam o rastro das ressignificações que o passado assume a cada presente.

Vale, por fim, destacar o valor dos patrimónios visuais para as políticas de memória, sobretudo a memória pública. As fotografias produzidas na exposição de 1938 e no périplo presidencial, foram organizadas em álbuns que, depositados em arquivos, ficaram inertes até cobrarem vida numa outra exposição, em Lisboa, muitos anos depois. Ao recompormos a biografia dessas imagens, indagamos sobre os circuitos sociais, os agentes envolvidos na sua produção, circulação, consumo, e questionamos o seu posterior arquivo como registro documental neutro de uma história que já havia passado. Entretanto, esse trabalho de escavar os extratos do tempo que cobriam o álbum e as suas imagens, foi-lhe atribuindo um novo valor de documento/monumento da empresa colonial portuguesa. De registro factual a património visual, as imagens revelam-se pela operação histórica. 


\section{Referências bibliográficas}

BLOCH, Marc (2006), Apologia da História ou ofício do Historiador. Rio de Janeiro: Ed. Jorge Zahar.

CANCLINI, Nestor Garcia (1994), "O patrimônio Cultural e a Construção imaginária do nacional", Revista do Patrimônio Histórico e Artístico. Rio de Janeiro: IPHAN, N. ${ }^{\circ}$ 23, 95-115.

EDWARDS, Elizabeth; HART, Jenice (2004), "Introduction: photographs as objects”, in Photographs Objects Histories. New York: Routlege.

KRACAUER, Siegfried (1980), "Photography", in Alan Trachetenberg (ed.), Classic Essays ou Photography. New Haven: Leete's Island Books, 245-268.

LUGON, Oliver (2006), "L'anonymat d'auter", in Le Statut de l'auter dans l'image documentaire: signature du neuter. Paris: Jean de Paune, Document 3, 4-13.

MAUAD, Ana Maria (2013), "Fotografia pública e cultura Visual em perspetiva histórica”, Revista Brasileira de História da Mídia, vol. 2, n. ${ }^{\circ}$ 2, http:// www.unicentro.br/rbhm/ed04/dossie/01.pdf

MAUAD, Ana Maria; LOPES, Marcos Felipe de Brum (2013), "Hitória e Fotografia”, in Ciro Cardoso e Ronaldo Vainfas (orgs.), Novos Domínios da História. Rio de Janeiro: Ed. Elsevier-Campus. 


\section{DESENHO: DISCURSO E INSTRUMENTO}

\section{Recortes e contextos:}

Além de património em si, a imagem desenhada ocupa na investigação em Patrimónios um lugar relevante enquanto instrumento, particularmente sensível nas áreas da arquitetura e do urbanismo. Neste sentido, o presente texto propõe-se tratá-la sob dois enfoques: a imagem desenhada como fonte de conhecimento; o desenho como ferramenta de investigação.

Começando pelo primeiro ponto - o potencial informativo da imagem desenhada - a enorme abrangência do tema obriga-nos a delimitar o campo de análise, recorrendo a um exercício concreto, limitado no tempo e no espaço, mas cuja metodologia de análise e considerações podem (e devem) ser aplicadas a muitos outros contextos geográficos e temporais. Ou seja, a especificidade inerente ao estudo de caso, não compromete a sua potencial representatividade.

Assim, os séculos XV e XVI constituem o recorte escolhido, ${ }^{1}$ entre outros aspetos, por coincidirem com a realização dos primeiros con-

1 No âmbito dos Patrimónios de Influência Portuguesa e concretamente no que toca ao património urbano, outras cronologias e espaços são particularmente ricos em fontes iconográficas. Veja-se, a título de exemplo, a vasta coleção de representações do território brasileiro coligida e estudada por Nestor Goulart Reis intitulada Imagens de Vilas e Cidades do Brasil Colonial. São Paulo: Editora da Universidade de São Paulo-Imprensa Oficial do Estado/ Fapesp, 2000. 
juntos expressivos de desenhos conhecidos. Tal é não apenas uma prova inequívoca da instrumentalização do desenho, aspeto que nos interessa explorar particularmente, como também da codificação e teorização sobre os processos de execução, o significado e a técnica. Quanto aos limites espaciais, a circunscrição da amostragem é mais difusa, englobando regiões diversas, com destaque para os territórios portugueses (continentais e insulares), mas também aqueles em que se verificou algum tipo de ação portuguesa - fosse por ambições territoriais ou simples contactos comerciais - ou outros que, por múltiplas razões (curiosidade, desejo de atualização ou emulação), suscitaram interesse durante esse mesmo período ao estreito círculo da encomenda portuguesa.

A esta delimitação acresce uma outra, decisiva para o alcance do texto: a da categoria da imagem. Assumindo imagem como ideia e representação $o^{2}$ de um qualquer ser ou objeto, mental ou real, limita-se, neste caso, o âmbito à que elegeu como tema a cidade (ou parte dela), contextualizada num território mais ou menos vasto. Escolha que se justifica, entre outras razões menos relevantes, por dois aspetos fundamentais: se por um lado a cidade é o objeto mais completo da civilização, o mais rico e por isso mesmo o mais difícil de representar, por outro a sua representação surge numa escala intermédia, entre a particularização do objeto individual e a vastidão territorial, aspeto que, apesar das especificidades de leitura que exige, congrega um conjunto de mecanismos de análise

\footnotetext{
2 Do latim imago, corresponde ao eidos grego, étimo de ideia. Se para Platão era "ideia da coisa" ou projeção da mente, para Aristóteles significou a representação mental de um objeto real. Hans Belting e Bernard Stiegler resumem a perspetiva aqui adotada: se para o primeiro "as imagens não existem apenas na parede, nem existem somente nas nossas cabeças" sendo pelo contrário o resultado de um incessante vaivém em "que as imagens endógenas reagem às imagens exógenas", para o segundo "nunca houve imagens físicas (images object) sem a participação de imagens mentais, já que imagem é por definição a que se vê (é de facto apenas aquela que se vê)" (apud Belting, 2014:13).
} 
transversais a qualquer das representações anteriores, sendo assim o mais representativo para um texto desta natureza.

Nesta definição de contornos, resta, por último, definir o significado de desenho, de acordo com a cronologia escolhida. Assim, e seguindo a proposta de Francisco de Holanda [1517-1585], não se tratará aqui do desenho como exercício mental a priori, ato de inventar e ideia criada, mas como representação gráfica propriamente dita, à época designada por termos como debuxo ${ }^{3}$, pintura, risco, traça, prataforma, ou, seguindo a sistematização de raiz vitruviana (Vitrúvio, 2006: 37), usada pelo mesmo Holanda, ichnografia, ortographia e scaenographia. Simplificando, plantas, alçados e vistas em perspetiva.

Em síntese, e por forma a balizar o exercício, a reflexão sobre a imagem desenhada como fonte de conhecimento incidirá sobre a representação gráfica de cidades portuguesas ou realizadas por portugueses, no decorrer dos séculos XV e XVI.

\section{Forma e natureza da representação gráfica de cidades}

Representação de cidades, portanto. Ora, de acordo com a raiz etimológica, representação é a conjugação de re e praesens, ou seja, repetir e tornar presente. Por outras palavras, a representatio torna presente de novo, no caso vertente, traz novamente à vista lugares e cidades, retratos de um território. É justamente essa qualidade de vencer distâncias físicas e temporais, de repetir o que já se viu ou ver o que apenas outros viram, vantagens que Georg Braun realçava na introdução à obra Civitates orbis terrarum, que justifica a dimensão instrumental que tão frequentemente lhe esteve associada ${ }^{4}$.

3 (Holanda, 1985: 20ss) Progressivamente o termo debuxo cairá em desuso, passando desenho a englobar os vários termos e aceções (Bueno, 2011: 31 e ss.).

4 Neste âmbito específico da instrumentalização do desenho (sobretudo de arquitetura) é essencial a consulta de Pereira: 2011 e Pereira: 2013. 
$\mathrm{Na}$ realidade, até que a pintura de paisagem se constituísse em género artístico individualizado, as vistas foram, desde o século XV e em toda a Europa Ocidental, eminentemente corográficas ${ }^{5}$, no sentido de descreverem um local ou região específica. Não admira por isso que as mais antigas que conhecemos, materialmente ou apenas por referência documental, cumpram uma função essencialmente demonstrativa. São debuxos ou pinturas fecit ad vivum ou, como à época se dizia em português, tirado naturall ${ }^{6}$. Não de memória ou por interposta representação, mas realizadas frente ao objeto físico ${ }^{7}$, característica normalmente valorizada porque supostamente indicativa de um elevado grau de "precisão", uma quase garantia de obrigação mimética. Ao suposto rigor associava-se a verosimilhança, de acordo com as duas aceções do termo latino: ad vivum significava simultaneamente "ao vivo", com o observador/debuxador presente, e "como vivo", como o observador vê (Ballon e Friedman, 2007:688)8.

5 Do grego choros, sítio, local. Na escala de Ptolomeu, cosmografia, geografia e corografia, a esta última competia fixar e descrever as particularidades de um local específico. Não por acaso, o termo paisagem, de origem francesa em finais do século XV e com uma primeira menção oficial em 1549 no dicionário latim-francês de Robert Etienne, tem o seu étimo em pays sendo, por isso, paisagem entendida como "uma pintura de um país" (Roger, 1997:19).

6 Expressão utilizada em muitos outros idiomas na mesma época: "au vif", "al vivo", "vere figure".

7 Para convencer o observador que a representação fora efetivamente feita ad vivum, adotaram-se vários estratagemas sendo dos mais comuns a inclusão de figuras humanas trajadas de acordo com a região (nas estampas de Braunio, por exemplo) ou a representação do próprio artista no ato de desenhar a cidade, como pode ver-se na famosa vista de Florença, conhecida por "Pianta della Catena", pintada c. 1470 , por Rosselli.

8 O significado de "como vivo" percebe-se melhor por oposição a um ponto de vista imaginário, como o que é necessário para uma projeção ortogonal, abstrata. Refira-se que o al vivo foi para a cultura italiana do Renascimento mais até do que um ponto de partida, um ponto de chegada (Nuti, 2000: 135) sobretudo associado à procura sistemática de uma representação holística da cidade. Por isso, entre a planta e a perspetiva linear, a primeira demasiado abstrata, a segundo demasiado limitada, por não permitir ver o que está por detrás dos objetos representados em primeiro plano, os homens do Renascimento elegeram a vista "a voo de pássaro" (Jacopo de' Barbari foi o primeiro a utilizá-la, em 1500, numa representação de Veneza) como o compromisso ideal: elevando-se o vantage point e mantendo a tridi- 
Ora, aspetos como precisão e verosimilhança permitem introduzir uma primeira questão das muitas que se colocam quando uma imagem debuxada é usada como fonte de conhecimento para a reconstituição da aparência de uma cidade num determinado momento histórico: a da verdadeira natureza da representação, a urbs ou a civitas 9 ? Os dois termos foram utilizados desde a Antiguidade para nomear a cidade mas referenciando aspetos diferentes: urbs associado à materialidade física; civitas à comunidade humana. Pela boca de Nícias, no discurso dirigido às suas tropas, ficaria famosa a afirmação de Tucídides de que Atenas era o conjunto de atenienses, não as muralhas ou os seus edifícios (Tucídides, 2001: 468). Ideia que, relançada por Isidoro de Sevilha nas Etimologias (Sevilla, 2004: 1059), atravessaria com grande fortuna toda a Idade Média e Moderna (cf. Kagan, 2000: 9 ss).

Pese embora a inequívoca prevalência da civitas, as suas virtudes e valores não deixariam, todavia, de se refletir na grandeza dos seus edifícios. Esta correspondência - de que a nobreza da civitas se espelha diretamente na estatura da urbs - para além de defendida e difundida pelos tratadistas de arquitetura do Renascimento (cabendo a Alberti um papel fundamental), traduzia na verdade um sentimento que se tornava corrente e generalizado, quase vulgar, no decurso do século XV. Repare-se como no caso português, onde só perto dos meados do século XVI a tratadística moderna faria a sua aparição, a justificação apresentada ao rei pela esmagadora maioria dos pedidos quatrocentistas de apoio à construção de edifícios concelhios - paços do concelho, açougues ou fangas - se baseava já

mensionalidade, representou-se a cidade de cima, de uma forma quase aérea, "como imaginavam que Deus a via". Sobre estes aspetos, relacionados com o sucesso que, à época, teve a vista "a voo de pássaro", veja-se Ballon e Friedman, 2007:687 e ss.

9 Conceitos particularmente discutidos e aplicados por Richard Kagan ao mundo hispânico. Cf. Kagan, 2000. 
num novo e inadiável sentimento de defesa e promoção da "honra e nobreza da villa" (Trindade, 2013: 642).

$\mathrm{Na}$ verdade, como realçou Kagan, a distinção entre civitas e urbs, por mais ténue que seja, é fundamental para entender o modo como as cidades foram representadas, ora colocando a tónica na forma corográfica e descritiva, como um retrato particularizado, ora tentando capturar os valores da comunidade, a genius loci, enfatizando não o espaço mas o lugar, o "lugar de memória", ainda que naturalmente ancorado numa realidade física minimamente reconhecível (Kagan, 2000: 17).

$\mathrm{E}$ aqui reside o primeiro perigo, a armadilha em que facilmente se cai perante uma qualquer representação urbana: a da aferição da sua fiabilidade, da verosimilhança e objetividade, aspetos tanto mais procurados e valorizados quando o que está em causa é a tentativa de recuperar uma materialidade urbana para a qual os outros tipos de fontes são particularmente omissos ou vagos, senão mesmo incapazes de a descrever. Na verdade, mesmo quando o objeto perseguido foi assumidamente a urbs, ou seja, a tangibilidade urbana, e mesmo quando esta foi desenhada presencialmente ou tirado naturall, o resultado nunca foi, ou pôde ser, uma cópia fiel do que a vista alcançava. Por muito que o seu autor o desejasse e a encomenda o exigisse, a representação não foi nunca (apenas) uma repetição, capaz de trazer para o presente uma determinada visão passada, tornando visível uma ausência. O desenhar de uma vista ou paisagem é sempre o resultado de um sem-número de escolhas, algumas de relevo e por isso assumidas, outras ínfimas e amiúde inconscientes, por vezes apenas da responsabilidade do autor, por vezes veiculadas ou impostas por outros. $\mathrm{E}$, contudo, o facto de qualquer representação ser uma construção não a torna necessariamente menos "verdadeira". O colocar da tónica na verdade ou rigor de uma imagem urbana é normalmente o resultado de um posicionamento incorreto, de uma questão mal colocada: a "veracidade" ou verosi- 
milhança é um valor relativo, apenas operativo quando entendido no quadro mais vasto do seu potencial demonstrativo, ou seja, da sua função e dos seus contextos individuais (Kagan, 2000: 9). Ou seja, assumindo-se como premissa que a representação isenta ou neutra do real é uma utopia, e que qualquer figuração é o resultado da interação entre imagem, corpo e meio (Belting, 2014), o que aqui releva é o binómio intenção/função que, com maior ou menor intensidade e consciência, acresce e amplia a premissa enunciada.

Dois aspetos particularmente comuns, mas nem por isso devidamente valorizados, ilustram o que atrás foi dito: em primeiro lugar, a necessidade que, perante a complexidade do objeto, o autor da representação sentiu de transmitir o máximo de detalhe e volume de informação, sem com isso comprometer a coerência global do objeto. Assim, tornou-se um artifício corrente a utilização conjunta de mais do que um ponto de vista ou captação, a par de diferentes angulações ou tipos de visibilidade. Simplificando, "a partir do naturall" construía-se uma imagem outra, capaz de garantir simultaneamente a visibilidade das partes e a inteligibilidade do todo. Na prática, associavam-se numa mesma representação pontos de vista distintos, a voo de pássaro, à cavaleira, oblíqua, perfil ${ }^{10}$, conseguindo-se pela (e apesar da) sua junção um resultado "profundamente real" a partir de uma composição "profundamente falsa". O segundo aspeto refere-se ao porquê da encomenda, ao que na origem ditou a sua execução. O móbil é a chave para a descodificação do processo seletivo que inevitavelmente esteve na base da realização: excluindo ou esbatendo determinados factos em função de outros que, assim realçados, se tornam os grandes protagonistas. Todo o desenho é, ainda que em graus diferentes, temático e retórico (e como tal per-

10 Sobre a terminologia associada aos diferentes tipos de vistas e suas características, cf. Kagan, 2000: 2 e ss. 
suasivo), sobretudo o que resulta de encomenda e obedece a um propósito específico.

É tempo de passar a um elenco concreto que permita visualizar melhor algumas das questões elencadas, com particular destaque para o processo de instrumentalização do desenho. Recorrer-se-á, para isso a dois temas diferentes escolhidos pela sua clara articulação com a questão da representação da urbs e da civitas:

- A imagem desenhada como instrumento demonstrativo, de cariz essencialmente utilitário, no sentido de veicular informação para a tomada de decisões, ao exercício do poder e ao controlo de um espaço-território;

- A imagem desenhada eminentemente simbólica.

\section{O caráter utilitário das imagens}

Remetendo-nos aos limites inicialmente estabelecidos - a representação gráfica de cidades portuguesas ou realizada por portugueses, no decorrer dos séculos XV e XVI - trata-se de um elenco curto, na realidade. Não que o uso do desenho fosse novo na cronologia em causa. Não restam hoje dúvidas de que desenhos de vários tipos foram utilizados em toda a Europa no decorrer da Idade Média, particularmente a partir do século XIV ${ }^{11}$ : a planta do mosteiro de Saint Gaal12, da primeira metade do século IX, o plano técnico do sistema de águas do complexo monástico de Canterbury ${ }^{13}$, de mea-

11 Um elenco circunstanciado de desenhos conhecidos para os séculos XII a XIV na Europa (mapas itinerários, mapas de regiões, planos de cidades ou simples limites de propriedades), pode ser lido em Morse, 2007, 38 e ss.

12 Plano do Mosteiro de Saint Gaal, c. 816-837, Codex Sangallensis, Stiftsbibliothek, S. Gaal.

13 Eadwine Psalter, c.1150, Catedral de Canterbury Trinity College Library, Cambridge. Conhece-se um outro documento desta mesma natureza: trata-se do desenho do sistema de águas da abadia de Waltham, em Wormley no Hertfordshire, 
dos do século XII, ou o levantamento da vila de Talamone ${ }^{14}$, já de 1306, para referir apenas alguns dos mais antigos, são disso prova. A verdade é que os poucos que chegaram até nós serão sempre uma amostragem muito reduzida do que realmente terá existido. Em muitos casos, terá sido justamente o seu caráter instrumental e o seu manuseamento frequente que ditou o desgaste e perda. Uma menor valorização da autoria também não terá ajudado à sua conservação, nem mesmo das grandes peças feitas a partir de vários pergaminhos cosidos.

Remetendo-nos apenas aos séculos XV e XVI e ao panorama português, continental e de Além-mar, são vários os indícios documentais que atestam o uso de debuxos como instrumentos de obra. Vejamos alguns dos exemplos mais substantivos, começando pelos anos do governo de D. João II: o plano que em 1480, acompanharia os apontamentos para a reforma das muralhas de Ceuta15; os quinze desenhos de Safim (Marrocos) que António Carneiro teria em sua posse (Carita, 1999: 48), a pintura do Chafariz del Rey, em Lisboa, que serviria ao monarca para pôr fim à discussão com o concelho, mandando acabar a obra sem delongas (Cid, 2007: 368) e, finalmente, a "pintura" da rua Nova dos Mercadores (Lisboa), peça com cerca de 6 metros de comprimento, a partir da qual o rei e sua entourage discutiam o processo de calcetamento e modernização da que era então a mais importante artéria da capital (Cid, 2007: 359).

Para o período de governação de D. Manuel, não só as referências escritas são mais numerosas - caso da "mostra e pimtura..." da

sendo particularmente relevante que se diga explicitamente no cartulário em que se inscreve, que a sua maior utilidade se prende com a memória da localização das nascentes e percurso subterrâneo das condutas. British Museum, Harl MS 391 ff5b, 6.

14 Planta do castelo de Talamone, 1306, Siena, Archivio di Stato, Caleffo nero, 3 , cc. $25 \mathrm{v}-26 \mathrm{r}$

15 No texto diz-se “... Esta fortaleza avera tres portais nos muros de fora nos $l u$ guares omde vam emlegidos...” Dias, 1999: 21. 
cerca de Alfaitaes ${ }^{16}$, dos desenhos expressamente encomendados para poder decidir-se o partido da nova praça de Elvas (Cabeças, 2008:38) ou dos que de Azamor (Marrocos) foram enviados ao rei por D. Jaime (Pereira, 2012: 607) -, como se tornam efetivamente tangíveis: o projeto da couraça de Alcácer Ceguer (Marrocos) ${ }^{17}$, realizado por Boitaca em 1502, o plano da Alfândega de Safim (Marrocos) ${ }^{18}$, de 1516, ou o desenho da torre de Cananor (Índia), ${ }^{19}$ também da segunda década, são disso bons exemplos.

Todos os referidos ${ }^{20}$, reportam, sem exceção, a uma função específica: a de demonstração. Debuxos soltos, reproduzem objetos vários e realidades de escala diversa: um chafariz, um edifício civil ou uma estrutura militar, caso dos últimos três, todos eles de cariz arquitetónico, mas também uma rua, o perímetro de uma muralha, partes de cidade. Têm em comum o facto de servirem de suporte à discussão das soluções a adotar, acompanhando relatos e vistorias num vaivém de informação e opiniões várias carreadas por diferentes agentes para a corte, de onde, finalmente, emanava a ordem de execução. E este foi efetivamente um dos principais desígnios da imagem pintada e debuxada, do traço e da prataforma. "Que loguo a mamdes debujar o majs no çerto que poderdes" 21 escrevia

16 Datado de 1520, integra o contrato em que Martim Teixeira assume a construção da cerca de Alfaiates "per omde lhe for enligido e dado per mostra e pimtura...", Viterbo, 1922: vol. III, 84.

17 Projeto de couraça e cubelos em Alcácer-Ceguer, IAN-TT, Gavetas XV, maço 18, n. ${ }^{\circ} 26$, fl. 3 .

18 Plano de construção da Alfândega de Safim, da autoria de Nuno Gato. IAN-TT, Corpo Cronológico, Parte I, maço 20, doc. 71 (publicado em Correia, 2008: 286).

19 ANTT, Cartas Missivas, maço 4, caixa 1, n. ${ }^{\circ}$ 26. Publicado em A Arquitetura Militar na Expansão Portuguesa, 1994: 93.

20 Para um elenco destes e outros desenhos, bem como para a leitura das cartas que testemunham a sua circulação no contexto dos reinados de D. João II e D. Manuel, cf. Cid. 2007: 105 ss; Bueno, 2011: 53ss.

21 Carta régia, Lisboa, 28 de outubro de 1514. AHME, Livro primeiro, das proprias Provizões, Alvarás, Cartas, e ordens Régias, fl. 581. Publicado por Cabeças, 2008: 15 e doc. 9 . 
D. Manuel acerca da praça de Elvas, denunciando uma atitude de proximidade e intervenção direta que a documentação relativa a muitos outros casos, como o Funchal ou Vila do Conde (Carita, 1999: 49-50 e Ferreira, 1923: 21-22), corrobora.

\section{Para a descodificação da imagem: o móbil}

Não há, porém, exemplo mais elucidativo da funcionalidade do desenho como resposta a uma encomenda específica que o "episódio Duarte de Armas": o escudeiro de D. Manuel, talvez com o cargo de rei de armas, para seguirmos a convincente argumentação de Paulo Pereira (Pereira, 2012:794), por duas vezes incumbido pelo monarca para o desempenho de tarefas centrais à administração e definição da estratégia militar do reino: em 1507, no Norte de África ${ }^{22}$; em 1509, na fronteira interior do reino.

Se da primeira encomenda apenas se sabe o que Damião de Góis brevemente noticia - que o "grande pintor" seguira na armada capitaneada por D. João de Meneses com a missão de traçar e debuxar as entradas dos rios e a situação da terra de Larache, Salé e Azamor (Góis, 1566: parte II, cap. XXVII, fl. 45) - da segunda, pelo contrário, ficou o Livro das Fortalezas, nas versões de Madrid e Lisboa ${ }^{23}$.

22 Como foi já defendido por vários autores (Correia, 2008:42 e Pereira, 2011: 763) pode equacionar-se se as representações de parte das cidades da costa do Norte de África do volume I, do Civitates Orbis Terrarum de Braun e Hogenberg, editado em 1572, terão tido por base um desenho original português de cerca de 1505-1515. Se assim foi, então Duarte d'Armas terá excedido a incumbência régia. A verdade é que uma análise circunstanciada das vistas de Tânger, Safim, Ceuta, Arzila e Salé confirma semelhanças de conceção e de convenções representacionais, podendo indiciar uma origem comum. Como argumenta P. Pereira, a tal, acresce uma similitude de processos de representação com os debuxos do Livro das Fortalezas.

23 Lisboa, Arquivo Nacional da Torre do Tombo, Códices e documentos de proveniência desconhecida, n. ${ }^{\circ}$ 159. Duarte de Armas e o Livro das Fortalezas foram já objeto de vários trabalhos. Muito superior, porém, é o número de textos que recorrem ao seu conteúdo, seja numa perspetiva corográfica, seja como fonte para o 
Trata-se de um álbum, com um total de 139 fólios, em que se inclui o "retrato" das principais vilas da raia portuguesa, entre Castro Marim e Caminha, num total de 55 povoações, dedicando a cada uma delas duas vistas panorâmicas "tirada(s) naturall", a partir de dois pontos cardeais, ou "bandas" diferentes. A esmagadora maioria dos casos é acompanhada da planta do respetivo castelo.

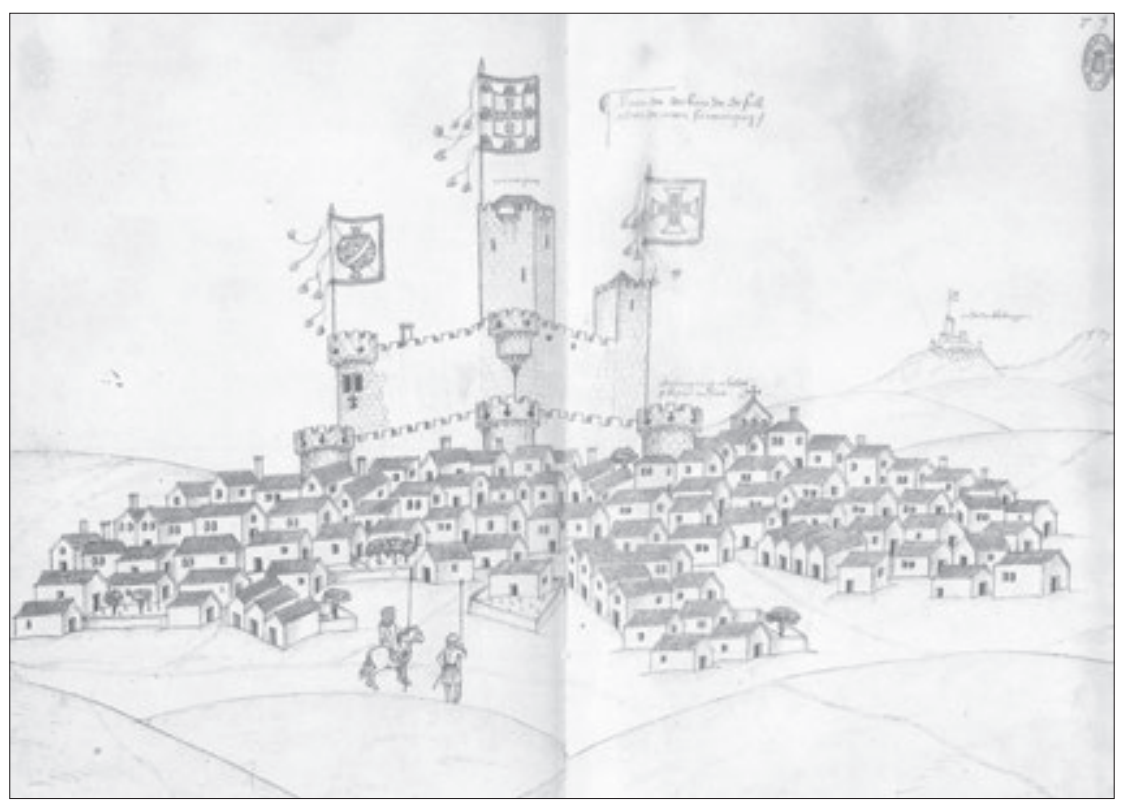

Fig. 1 Castelo de Almeida. Duarte de Armas, Livro das Fortalezas, 1509. Lisboa, Torre do Tombo, Ms.159, fl. 73.

estudo de muitos dos diversos aspetos representados ou correlativos, das formas de habitação aos caminhos, de aspetos demográficos e urbanísticos até equipamentos como fontes, pontes, forcas, etc, passando pelas estruturas defensivas (construção, forma, função), temática que surge, como seria expectável, em primeiro lugar. Na impossibilidade de referenciar em extensão todos esses estudos, elencam-se apenas alguns dos trabalhos onde, mais recentemente, foi discutido o que se sabe sobre o tema. Para além da edição fac-similada do Livro das Fortalezas (versão de Lisboa), trazida a público em 1997 por Manuel da Silva Castelo Branco, com destaque para o estudo introdutório que a acompanha, veja-se Cid, 2005 e, sobretudo, Pereira, 2011: 562-810. Em Gameiro, 2014, é possível confrontar os dois códices, o de Madrid e o de Lisboa, em toda a sua extensão. 
Neste caso, se dúvidas houvesse, o objeto e âmbito da encomenda é expressamente declarado pelo próprio autor no primeiro fólio: "Este livro he das fortalezas que são situadas no estremo de portugall e castella" e cumpre uma função que anos mais tarde Francisco de Holanda explicaria de forma particularmente sugestiva: "Sirva-se Vossa Alteza do Desenho da pintura nas coisas da guerra pois esta é vencida se o desenho vai bem desenhado, perdida, se o desenho vai descomposto" 24 .

O móbil militar, na realidade, traduz-se em toda a representação (Fig. 1). No detalhe das estruturas defensivas, muros, torres, barbacãs e fossos, nas breves notas que especificam alturas, espessuras, estado de conservação, bem como na marcação dos mecanismos próprios para o uso de artilharia. À data em que os desenhos foram realizados, coincidindo com um dos períodos mais ricos da história da arquitetura militar comummente designado como "estilo de transição", esta seria, porventura, a informação mais relevante, traduzindo-se no conhecimento do número, estado e localização das fortalezas (ainda) com valia em caso de guerra. É esse propósito que explica a razão por que Duarte de Armas dedicou uma especial atenção à marcação precisa de troneiras, aos grandes cubelos que então se erguiam, às barbacãs novas já adaptadas à instalação de bocas de fogo. Mas o objetivo militar vai mais longe. Se o que está em causa é o conhecer a resistência de um território, então não basta expor as virtudes e fragilidades das fortalezas: é necessário assinalar as atalaias que complementam a linha defensiva, a relação de cada fortaleza com o território e destas com os castelos do reino vizinho. Os caminhos e as pontes, o seu estado e o tempo

${ }^{24}$ Holanda, 1985: 31. Várias décadas antes já o mesmo conselho integrava a Arte da Guerra de Maquiavel, (Machiavelli, 2005:159) bem como o Cortesão de Castiglione, onde se destaca como da pintura "provêm muitas utilidades, em especial na guerra para desenhar aldeias, regiões, rios, pontes, penedias, fortalezas e coisas similares, as quais, embora se conservassem na memória o que, porém, é assaz difícil, não podem ser mostradas aos outros." (Castiglione, 1997: 75). 
que demoram a percorrer ou até mesmo a generosidade ou aridez dos campos, aspeto fundamental às necessidades de abastecimento das tropas, são outros aspetos igualmente tidos em conta. Mas o que releva neste caso é a dimensão e coerência da encomenda, a lógica de álbum enquanto método de recolha sistematizada de um conjunto de informações veiculadas essencialmente (mas não só25) de forma gráfica. O que patenteia, de forma inequívoca, uma instrumentalização regular do desenho.

Este tipo de uso, permitindo aos governantes conhecer e, por essa via, mais facilmente defender e dominar - territórios e súbditos - esteve na base de algumas encomendas de cortes europeias ${ }^{26}$, cronologicamente muito próximas à de D. Manuel. Podemos integrá-los num tipo de levantamentos que John Hale ${ }^{27}$ definiu como "cartografia de defesa", por oposição à "cartografia de ataque", bastante mais rara desde logo porque essencialmente dirigida a territórios estrangeiros que se pretendiam conquistar. Foi efetivamente esse primeiro género, orientado para os próprios domínios e incidindo sobretudo em cidades fortificadas ou fortificações costeiras e de fronteira que fez evoluir a cartografia de vocação militar. A utilização cada vez mais intensa e eficaz das armas de fogo, obrigando a uma alteração profunda das estruturas militares, originou uma intensa corrente de registos gráficos entre os monarcas e os seus pintores

25 Para além das inúmeras notas que acompanham os desenhos, o álbum integra uma "Tavoada" no final, seguindo a tradição dos itinerários escritos que durante séculos guiaram exércitos, peregrinos ou mercadores. A esses registos, também chamados de "cartografia escrita", associava-se a "cartografa oral", veiculada pelos naturais da região ou por guias e escutas que, antecipadamente, avançavam pelo território. Métodos que continuaram em uso durante muito tempo, sobretudo enquanto os mapas foram pouco precisos.

26 Outros exemplos poderiam ser aduzidos como a encomenda feita ao pintor Hans Baldung, em 1522, para registar os castelos da Ordem de S. João, em Rodes ou os que Henrique VIII mandou fazer dos castelos erguidos em 1539 na região de Kent Downs (Inglaterra).

27 Sobre a relação entre guerra e cartografia é imprescindível a consulta de Hale, 2007. 
ou debuxadores, progressivamente substituídos, no decorrer da Época Moderna, por mestres, engenheiros e arquitetos. Sublinhe-se, todavia, que essa mesma cartografia não teve, pelo menos no decorrer do século XVI, um propósito exclusivamente militar, nem constituiu um género claramente individualizado. Pelo contrário, o seu carácter descritivo respondeu de múltiplas formas (território, propriedade, fiscalidade, população, recursos, equipamentos, etc.) ao apetite dos governantes por informação vária, indispensável aos impulsos centralizadores de toda a administração moderna (Hale, 2007: 736 ss).

Um primeiro caso é o armorial que em meados do século $\mathrm{XV}$, Carlos I, Duque de Bourbon, encomendou a Guillaume Revel (Fig. 3). Embora o alvo principal fosse o registo das armas de toda a nobreza dos domínios ducais, Revel desenhou igualmente os castelos de cada família, num total de 54, no que constitui apenas uma pequena parte da encomenda original. Com um protocolo de representação muito próximo ao de Duarte de Armas, Revel, porém, não concedeu ao território a mesma importância, o que é compreensível atendendo ao objetivo central: os castelos são remetidos a ilustrações de poder, reservando-se para os brasões a parte fundamental de cada um dos fólios ${ }^{28}$.

Um outro caso particularmente próximo de Duarte de Armas, é o livro dos Castelos do Sul do Tirol e Friaul ${ }^{29}$ realizado, também em 1509, por ordem de Maximiliano I, filho do imperador Frederico III e de Leonor de Portugal (Fig. 2). Como no álbum português, a atenção centrou-se nas estruturas defensivas, ainda que não tanto ao nível do detalhe, mas sobretudo no seu enquadramento físico,

28 "Registre d'armes» ou "Armorial d'Auvergne, Forez et Bourbonnais». Bibliothèque Nationale de France, Département des manuscrits Français 22297. Álbum completo em http://gallica.bnf.fr/ark:/12148/btv1b8470455b

29 Befestigungen in Südtirol und Friaul. Österreichischen National-bibliothek, ÖNB, Cod. 2858. Obra completa em http://data.onb.ac.at/rec/AL00167875 


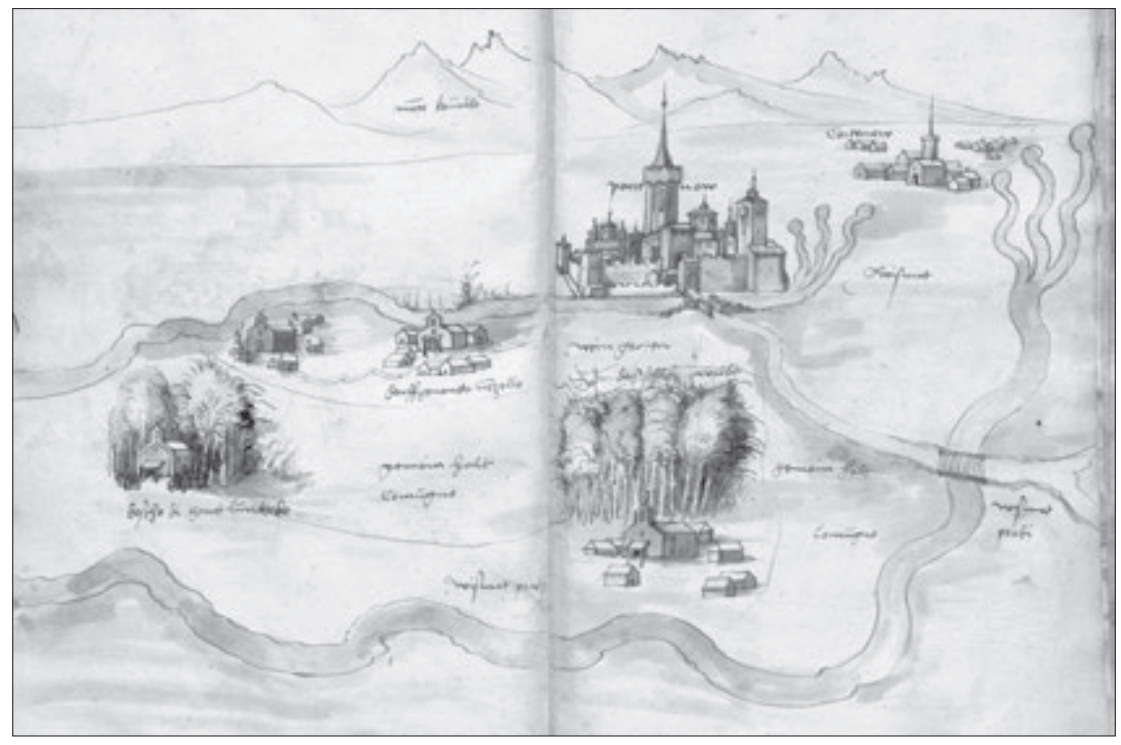

Fig. 2 J. Kölderer, Befestigungen in Südtirol und Friaurevell, 1508. Wien, ÖNB, Cod. 2858, fl.24-25.
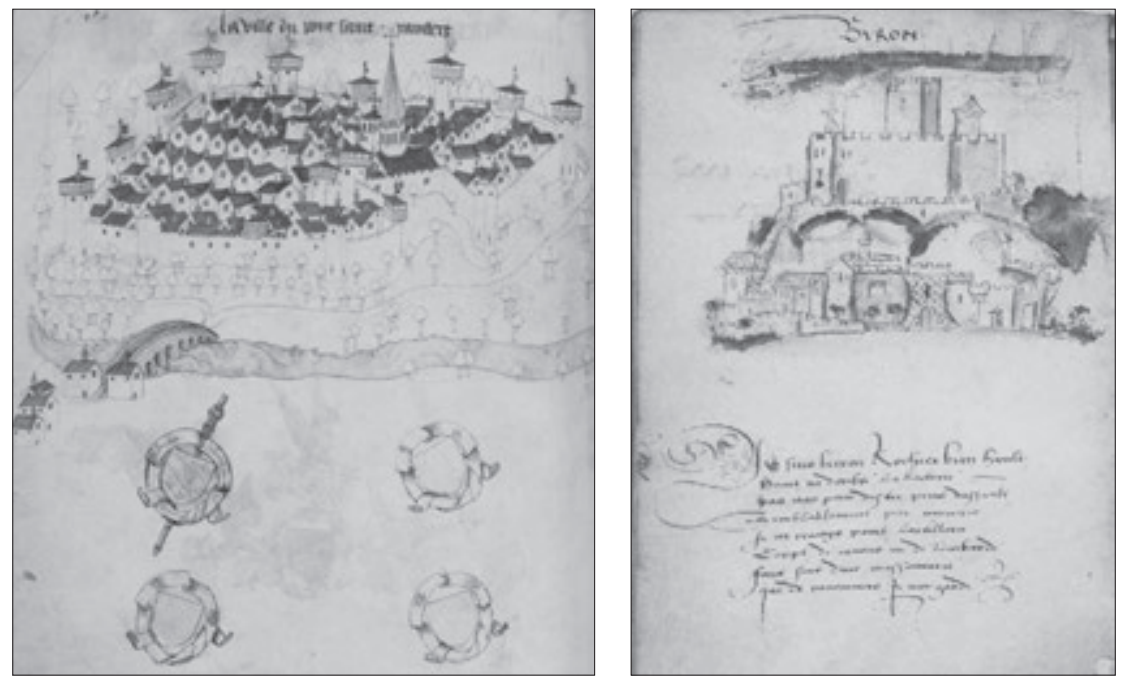

Fig. 3 Saint Rambert sur Loire. G. Revel, Registre d'Armes ou Armorial d'Auvergne dédié par le héraut Guillaume Revel au roi Charles VII", c. 1450. Paris, BnF, DépartFig. 4 J. Lemaire de Belges, Génealogie de Madame Anne de la Tour, princesse de l'Ecosse, 1518. The Hague, KB, 74 G 11, fl. 56v. ment des manuscripts, Français 22297, f1. 462 . 
concretamente na relação destas com as estradas e a topografia. Dar a conhecer o território ao imperador - admirado entre os contemporâneos pelos seus conhecimentos cartográficos e supostamente capaz de desenhar de memória qualquer lugar dos seus vastos domínios (Vann, 1992: 156) - parece ter sido, em todos os 23 desenhos, a grande preocupação do pintor da corte Jörg Kolderer, seu autor. Próximo no tema e na época mas profundamente diferente no propósito, refira-se, por último, o manuscrito mandado realizar em 1518 por Anne de la Tour, condessa da Auvergne e Boulogne (Fig. 4). Trata-se do elenco dos bens que constitui a sua herança e, entre eles, de 13 castelos da Auvergne, pelo que as representações podem ser muito mais esquemáticas do que as anteriores, valendo pelo todo mais do que pelo detalhe. ${ }^{30}$

Quando explicitados os objetivos, os elementos presentes no desenho ganham legibilidade permitindo uma consciencialização do valor que a cada um podemos atribuir. Voltando ao caso de Duarte de Armas, veja-se como o edificado corrente cumpre tão só a missão de reproduzir as manchas de ocupação em torno das fortalezas, essa sim uma informação crucial à estratégia militar, sendo por isso genericamente tipificado e como tal de uso limitado na reconstituição do concreto de cada localidade. É portanto uma construção codificada, aquela que nos oferece das vilas e castelos do extremo do Portugal quinhentista, mas que satisfaz eficientemente a sua função, trazendo à presença do rei uma realidade distante, que, supostamente, através da sua representação, se torna mais compreensível do que a própria realidade.

30 Jean Lemaire de Belges, Genealogie de Madame Anne de la Tour, princesse de l'Ecosse. The Hague, Koninklijke Bibliotheek, 74 G 11. Consultável em http:// manuscripts.kb.nl/show/images_text/74+G+11 


\section{A imagem no controlo dos territórios. Encomenda régia}

Na verdade, o Livro das Fortalezas seria apenas um dos primeiros, seguindo-se muitos outros de função idêntica, ainda que dedicados a outros espaços, agora ultramarinos, cuja distância mais agudizava a necessidade de representações desenhadas:

Eu folgaria de ver o debuxo das principais fortalezas que tenho nessas partes pelo que vos encomendo muito que se lá houver alguma pessoa que o saiba bem fazer me envieis cada uma delas e assim a cidade ou lugar em que estiver (apud Garcia, 2009: 12).

Esta determinação de D. João III em conhecer por debuxos os territórios que a Oriente iam dando corpo ao Império, transformando-os nos "olhos do rei", na expressão feliz de Jorge Flores (Flores, 2001), foi cumprida nos anos seguintes por D. João de Castro ${ }^{31}$ e Gaspar Correia32. Mas como foi já questionado (Pereira, 2011), é difícil que registos deste género não existissem já e que os desenhos de Gaspar Correia fossem os primeiros que a corte e o rei viam dos territórios orientais. A questão é tanto mais pertinente quanto, como atrás se viu, parece cada vez mais firme a ideia de que no reinado de D. Manuel I o desenho foi uma ferramenta correntemente utilizada no círculo do rei. Como explicar então que, durante mais de duas décadas, um reinado que usou a cultura visual como um dos principais veículos de propaganda régia e um rei que associou à sua titulação as menções a África, Guiné, Etiópia, Arábia, Pér-

31 São um total de 15 tavoas incluídas nos seus famosos roteiros: o "Roteiro de Lisboa a Goa" (1538), o Roteiro de Goa a Diu (1538-1539) e o Roteiro do Mar Roxo (1540), Cf. Castro, 1968-1982.

32 Trata-se de um conjunto de folhas soltas, com vistas cavaleiras das cidades e fortalezas, inseridas por Gaspar Correia nos manuscritos das Lendas da Índia (1550-1563), desenhos, ao que tudo indica, realizados em resposta ao pedido de D. João III. Correa, 1858-1863. 
sia e Índia, não procurasse registos visuais das conquistas que, a Oriente, iam construindo o Império? Indícios seguros dessa prática de representação encontram-se pelo menos em duas situações: as "pinturas feitas pelo natural" que Duarte Pacheco Pereira, entre 1505 e 1508, diz explicitamente incluir no Esmeraldo de Situ Orbis, destinadas a descrever os principais portos e acidentes da costa africana, provavelmente até feitas com base em representações mais antigas (Daveau, 1997:17); o espaço em branco existente na página do diário de bordo de Álvaro Velho em que se descreve a aproximação da armada de Vasco da Gama à Ilha de Moçambique, nesse ano de 1498. Espaço que apenas se justifica por nunca ter recebido o desenho que seguramente lhe estava destinado (Garcia, 2009: 12). Se a estes indícios juntarmos o episódio de Duarte de Armas em Larache e a hipótese de as representações das cidades publicadas no volume I do Civitates Orbis Terrarum de Braun e Hogenberg, editado em 1572, terem tido por base desenhos portugueses de cerca de 1505-1515,33 o recuo da prática de fixar em desenho as conquistas ultramarinas, pelo menos desde os inícios de quinhentos, parece ganhar bases sólidas.

De forma sistemática, saciando a curiosidade e respondendo às necessidades político-administrativas dos monarcas seguintes, com destaque para os da Casa da Áustria, é no século XVII que as descrições figuradas do Império ganham força: Barreto de Resende, Erédia ou Mariz Carneiro, ${ }^{34}$ entre outros, seriam os "olhos do rei",

\footnotetext{
33 Veja-se supra nota 22.

34 Livro das Plantas de Todas as Fortalezas, cidades e povoações do Estado da Índia Oriental, de c. de 1635, composto por António Bocarro e Pedro Barreto de Resende, com cinquenta e duas plantas de fortalezas e cidades desenhadas da autoria do último e hoje pertencente ao espólio da Biblioteca Pública de Évora, Inv. ${ }^{\circ}$ n. ${ }^{\circ}$ Cód. CXV/2-1, (ed. por CID, 1992); Lyvro de Plantaforma das Fortalezas da Índia, atribuído a Manuel Godinho de Erédia, 1630-1640, CEME, Forte de S. Julião da Barra, Oeiras, Inv. ${ }^{\circ}$ n. ${ }^{\circ} 805$, (ed. por Carita, 1999); de cerca de 1633-1641, o $L i$ vro das plantas das fortalezas, cidades e Povoações do Estado da Índia Oriental, à guarda da Biblioteca do Paço Ducal de Vila Viçosa, Fundação da Casa de Bragança,
} 
dando corpo a uma longa genealogia de álbuns de vistas de cidades (Fig. 5). Num processo que, aliás, fez da cópia uma prática corrente e legítima. De facto, a autoridade de um mapa ou vista ancorou-se muito frequentemente na sua fidelidade à representação tradicional, ou seja, às que antes dela estabeleceram uma identidade para um determinado local e assim um cânone. Em muitas situações tal foi mais importante do que a tentativa de proximidade ao real (Ballon e Friedman, 2007: 691), o que levanta questões de outra natureza ao observador contemporâneo, obrigado a descodificar os tempos do objeto representado e da representação propriamente dita. Reconhecer a existência de um cânone anterior e, idealmente, identificá-lo, permite aferir o hiato ou distância entre os dois momentos em causa e assim compreender o processo de cristalização da imagem.

Mas voltando aos meados do século XVI e ao poder demonstrativo da imagem, importa reconhecer o que terá sido um enorme investimento na representação do território, tanto mais relevante quanto o desenvolvimento das técnicas de desenho possibilitava a partir da planimetria, uma visão mais apurada da "verdade dos chãos", para citar de novo Francisco de Holanda (Holanda, 1984: 69). Na verdade, a quase totalidade destes levantamentos tem em comum dois aspetos fundamentais: a angulação ortogonal ou em planta, que se divulga justamente nesta época (recorde-se como o plano de Imola, realizado por Leonardo da Vinci em 1502, é normalmente tido como o primeiro do género), e o desígnio de uma grande proximidade formal ao existente, comprovável ainda hoje pelo confronto com o que subsiste. Em conjunto, meio e representação, pressupõem uma

Ms. Res. 21 (ed. por Silveira, 1991); e, finalmente, de António de Mariz Carneiro e de cerca de 1639, a Descrição da fortaleza de Sofala e das mais da Índia, BNL, Inv. ${ }^{\circ}$ n. ${ }^{\circ}$ IL 149, (pub. por Dias, 1990). Fundamental para o estudo da iconografia do Império é a obra de Luís da Silveira, vinda a público em 1956 e intitulada Ensaio de Iconografia das cidades portuguesas do Ultramar (4 volumes). 


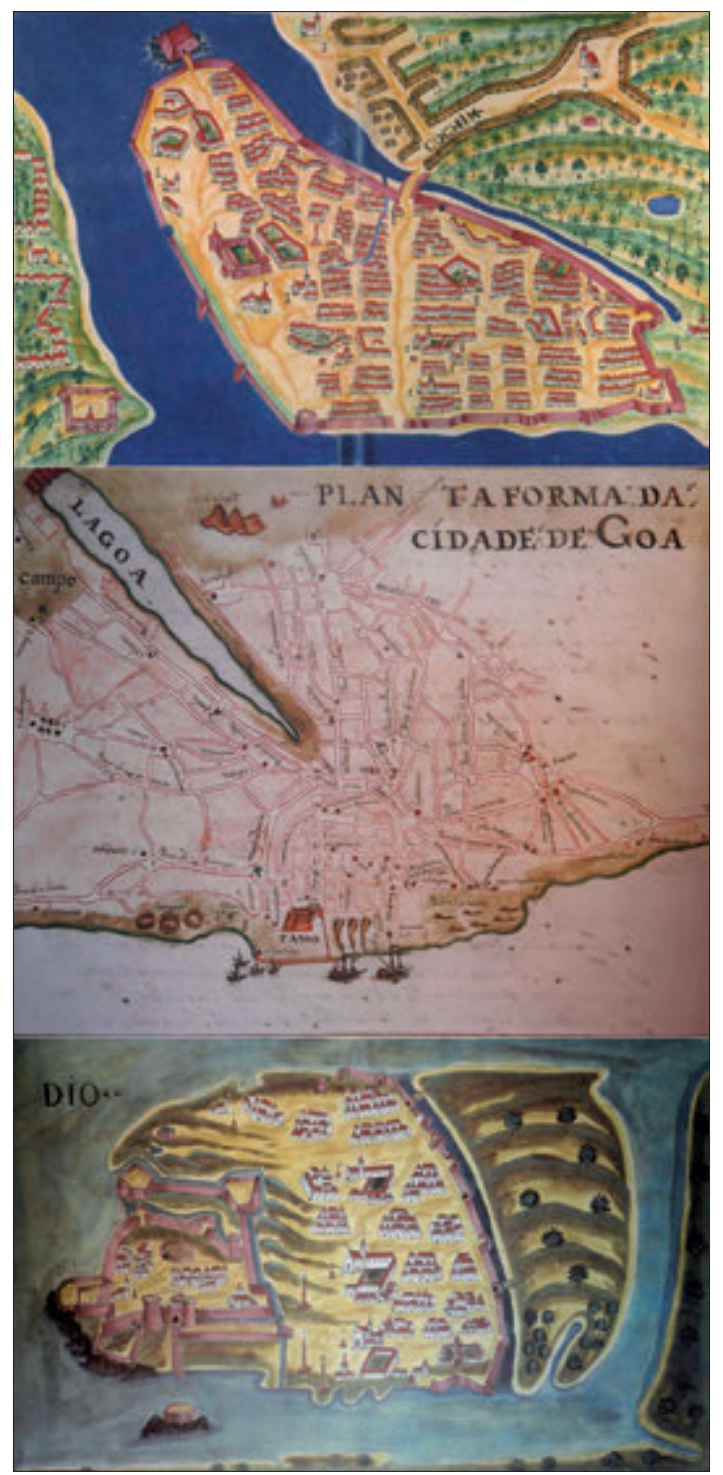

Fig. 5 Cochim. António Bocarro e Pedro Barreto de Resende, Livro das Plantas de Todas as Fortalezas, cidades e povoações do Estado da Índia Oriental, c. de 1635. Biblioteca Pública de Évora, Inv. ${ }^{\circ}$ n. ${ }^{\circ}$ Cód. CXV/2-1; Goa. Atribuído a Manuel Godinho de Erédia, Lyvro de Plantaforma das Fortalezas da Índia, 1630-1640. CEME, Forte de S. Julião da Barra, Oeiras, Inv. ${ }^{\circ}$ n. ${ }^{\circ} 805$; Diu. António de Mariz Carneiro, Descrição da fortaleza de Sofala e das mais da Índia, 1639. BNL, Inv. ${ }^{\circ}$ n. ${ }^{\circ}$ IL 149. 
encomenda que tem como objetivo o conhecimento da urbs, da materialidade específica e identificadora de um locus.

Que a encomenda terá sido significativa e geograficamente abrangente prova-o o conjunto de levantamentos hoje à guarda do arquivo Militar de Estocolmo ${ }^{35}$ e da Biblioteca Nacional do Rio de Janeiro ${ }^{36}$ : Tavira (Fig. 6), Lagos e Castro Marim, por um lado, Funchal, Sesimbra (Fig. 7), Vila do Conde, o castelo Velho da Mina, o conjunto de oito desenhos dedicados aos Açores (Fig. 8), ${ }^{37}$ Guimarães $^{38}$ e

35 Trata-se do manuscrito intitulado "Plantas de diferentes plazas de España, Italia, Flandes y las Indias", encomendado em 1650 ao pintor italiano Leonardo de Ferrari pelo marquês de Heliche, ministro de Filipe IV, localizado em 2001 no Arquivo Militar de Estocolmo (secção Handritade Kartverk, vol. 25). Sánchez Rubio et al, 2002. No caso das três plantas portuguesas, a descoberta é tanto mais relevante quanto a sua crítica interna permite aventar a hipótese de terem sido feitas com base em outras, mais antigas, datadas de cerca de 1542-68 (sobre Tavira cf. Fraga, 2008).

36 Para além do álbum referido na nota anterior e dos levantamentos de Guimarães e Lisboa (na margem do Tejo), recentemente identificados no Rio de Janeiro, também no decorrer de 2000, em Viena, foi "encontrada" a obra Descrição de Espanha das costas e portos dos seus reinos. Datada de 1630, inclui um vasto conjunto de portos portugueses, de Caminha a Tavira, levantados por Pedro Teixeira, cosmógrafo português, a mando de Felipe IV. As inúmeras descobertas recentes, a última das quais retratando a Rua Nova de Lisboa, a que adiante voltaremos, permitem acalentar a esperança de que muitas mais possam aparecer.

37 Cidade do Funchal, BNRJ, ARC.016,09,003on Cartografia (Carita, 1983); A vila de Sezimbra, c. 1570, BNRJ, ARC.016,08,0040n Cartografia; De Vila do Conde, c. 1570, BNRJ ARC.016,09,001 on Cartografia; Castelo Velho da Mina, cart1079089; BNRJ, A ilha do Pico, ARC.016,09,010on Cartografia; Ilha do Fayal, ARC.016,09,011on Cartografia; Chorographia de toda a ilha de sam Iorie, ARC.016,09,008on Cartografia; Ilba Terceira, ARC.016,09,007on Cartografia; Ylheo de Vila Franca na Ilba de São Miguel ARC.016,09,006on Cartografia; Ilha Graciosa ARC.016,09,009 on Cartografia; Ilha de Santa Maria, ARC.016,09,004on Cartografia; Fortaleza que se faz na Ilha de São Miguel, na cidade de Ponta Delgada, ARC.016,09,005on Cartografia, todas elas datadas de c. de 1570, a do Funchal assinada por Mateus Fernandes, mestre das obras de el-Rei na Ilha da Madeira, justamente entre 1567 e 1570. Sobre este conjunto de plantas (Funchal, Sesimbra, Açores e Mina), cf. Bueno 2001: 278-279 e Bueno, 2011: 80-82. No conjunto dedicado aos Açores, seis representações, Santa Maria, Terceira, Graciosa, Faial, S. Jorge e Pico são efetivamente um misto de voo de pássaro e vista ortogonal, a última das quais com a angulação mais baixa.

38 De Guimarães, c. 1570, BNRJ, ARC.016,09,012on Cartografia. Divulgada em 2005 por Maria Dulce de Faria. Cf. Faria, 2014; Fernandes, 2009. 


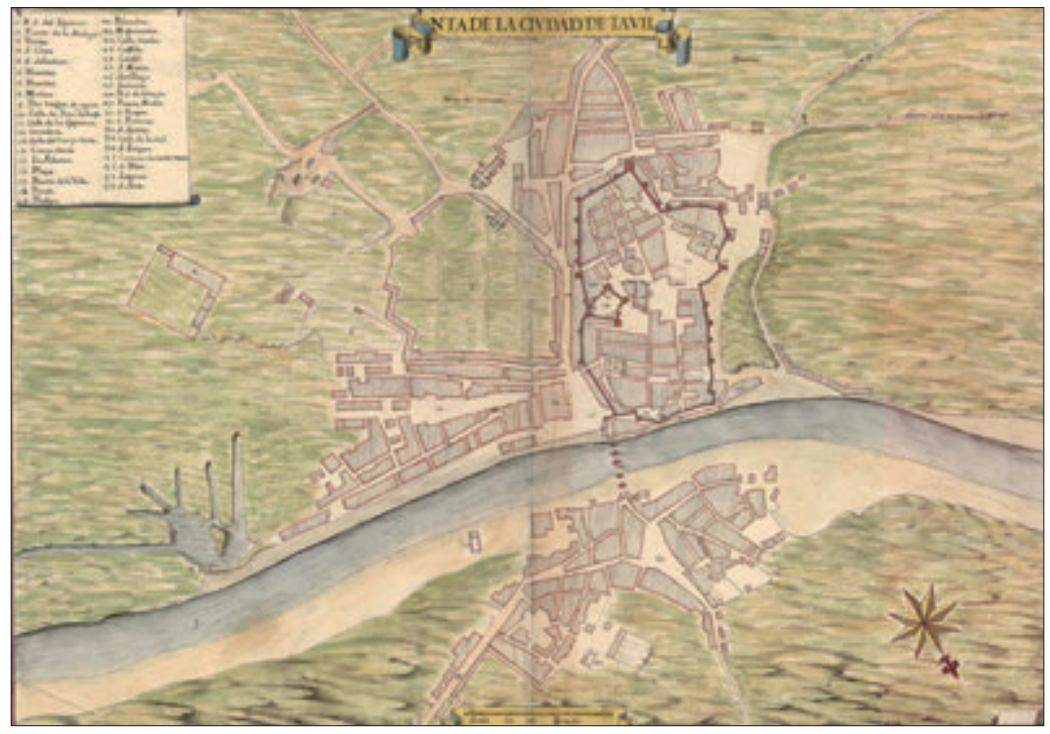

Fig. 6 Planta da cidade de Tavira (cópia de um original de 1542-1568). Leonardo de Ferrari, Plantas de diferentes plazas de Espania, Italia, Flandes, los Indias (Atlas do marquês de Heliche), c. 1645. Estocolmo, Krigsarkivet, SE/KrA/0414/0025/0011.

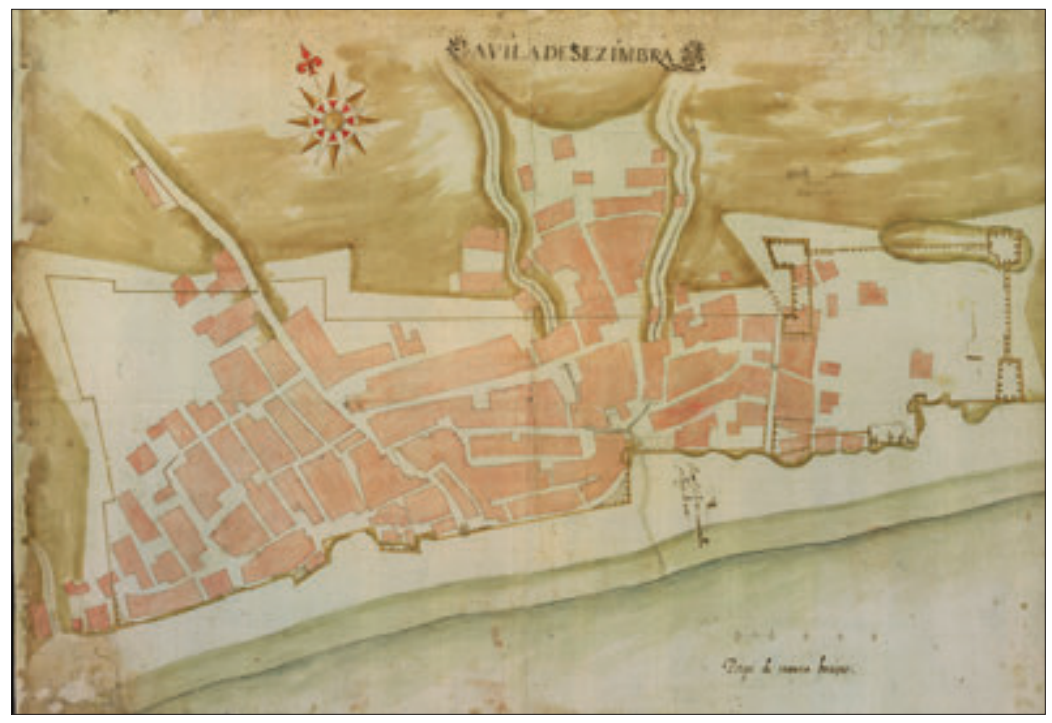

Fig. 7 Vila de Sezimbra, c. 1570. Biblioteca Nacional do Rio de Janeiro, ARC.016,08,004on Cartografia. 
Lisboa, ${ }^{39}$ por outro. Todas elas da segunda metade do século XVI ${ }^{40}$ e algumas indiscutivelmente da mão de um mesmo autor, provam o vincado interesse da coroa no conhecimento detalhado do território continental, nas Ilhas Atlânticas e em África, com particular destaque para as cidades e vilas do litoral. Recorde-se como a defesa da costa ocupou lugar central na política de D. Sebastião, ordenando, justamente em 1569, a fortificação de todos os portos do reino. $\mathrm{O}$ peso determinante que em muitos destes levantamentos tem a componente militar, construída ou a construir, caso do Funchal, Ponta Delgada, Vila Franca, Lagos, Sesimbra e Mina ${ }^{41}$ - onde as velhas cercas medievais, as novas muralhas abaluartadas e as fortalezas surgem bem demarcadas - permite pensar que seriam exatamente a resposta a essa estratégia de aggiornamento da capacidade defensiva do reino. Guimarães, todavia, a última a ser identificada e incontestavelmente da mesma mão que desenhou Vila do Conde, obriga a equacionar se o interesse seria apenas esse. Pelo seu número e contemporaneidade não parecem ser levantamentos desconexos mas antes, como o conjunto dedicado aos Açores parece indiciar, o reflexo de uma política sistemática e de uma forte cultura de representação do território. Aliás, as raízes dessa prática poderão, porventura, recuar até à primeira metade do século, a comprovar-se a existência de um mapa de todo o reino realizado ainda antes de $1540,{ }^{42}$ data particularmente precoce no universo europeu (Parker, 1992:133) ou dos minuciosos mapas

39 BNRJ, Cartografia Arm.014,01,018. Cf. Rossa, 2015: 59-79.

40 Os planos ortogonais foram relativamente raros no decorrer do século XVI, sobretudo na sua primeira metade. Para um elenco dos mais importantes cf. Ballon e Friedman, 2007:686.

${ }^{41}$ E em tantas outras desaparecidas como as amostras que Luís Dias enviou de Salvador ao rei.

42 Mapa de Portugal que pode ter servido de carta-padrão ao de Álvares Seco publicado em 1561 e divulgado em 1570, ao ser incorporado no Theatrum Orbis Terrarum de A. Ortelius. Cf. Daveau e Galego, 1995:89 e Alegria e Garcia, 1995: 56. 
regionais datáveis do reinado de D. João III e que, pelo menos na literatura, deixaram memória (representando, por exemplo, a região de Peniche, Sacavém, Cascais e Sintra) (Daveau e Galego, 1995:89).

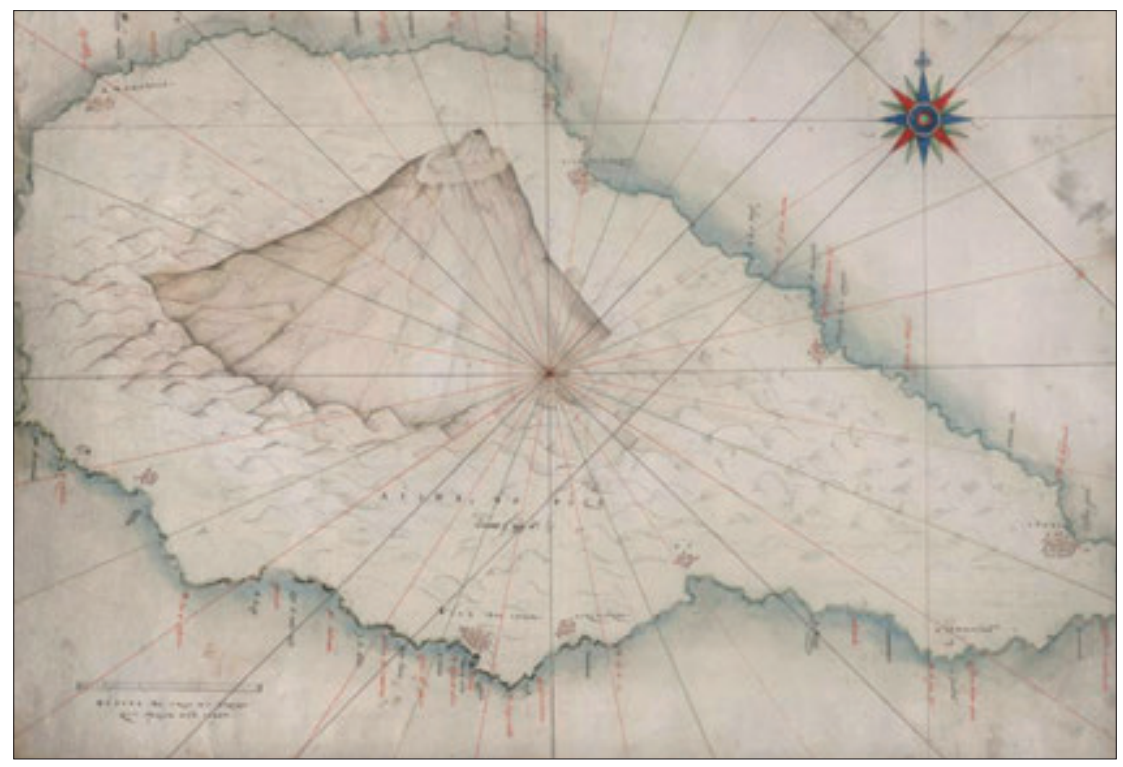

Fig. 8 A Ilha do Pico (Açores). Biblioteca Nacional do Rio de Janeiro, ARC.016,09,010on Cartografia.

Na verdade, até pela forma como a maioria destes levantamentos abarca a escala urbana, e representa em detalhe ruas e edificado, pode pensar-se se não estaria em causa o desejo e a necessidade de fixar as principais cidades e vilas portuguesas, no seu todo ${ }^{43}$. No

43 Uma das maiores vantagens da representação ortogonal foi a de, adotando um número infinito de hipotéticos pontos de vista, perpendiculares à superfície da terra, captar a forma global da cidade. Ao fazê-lo de forma plana, contudo, obrigava a prescindir da representação em três dimensões, limitação que no século XVI foi contornada através do uso de abas articuladas, como as que vemos, por exemplo, na planta de Guimarães, no Paço dos duques de Bragança. 
que constituiria, afinal, o corolário natural desse eventual intento de representação do território: a seguir ao reino e às regiões, a cidade ou vila. E, de facto, todos os exercícios efetuados sobre eles traduzem essa intenção de um registo formal "preciso", da materialidade específica e identificadora de um lugar concreto, certamente a resposta a ordens como a que há pouco vimos de D. Manuel, inequívoca no tom e no propósito: “... que a mandes debujar o majs no çerto que poderdes" ${ }^{4}$. Debuxos que seriam cada vez mais incontornáveis e cuja existência explica o nível de conhecimento atingido na corte. A pormenorização espacial que, em 1502, surge numa carta que o mesmo monarca envia para as obras da praça da igreja de Vila do Conde, só pode assentar num registo desenhado:

... a porta principal dará para defronte dumas casas que se hão de derribar [...] e ao redor da igreja e da Capella ficarão despejadas 6 braças para adro [...] e defronte da porta principal se fará uma praça quadrada de 15 braças de lado, e a rua irá ter ao meio ${ }^{45}$.

Diretivas, aliás, que a planta realizada na segunda metade de quinhentos, atrás referida, já representa como concretizadas (Fig. 9).

\section{A representação ortogonal e a suposta "verdade dos chãos"}

Mas neste ponto importa chamar de novo a atenção para um aspeto fundamental e que é válido tanto para as representações ortogonais, como para os mapas: a necessidade de matizar essa "verdade dos chãos" ou "carácter preciso", tendo em conta o que

44 Carta régia, Lisboa, 28 de outubro de 1514. AHME, Livro primeiro, das proprias Provizões, Alvarás, Cartas, e ordens Régias, fl. 581. Cabeças, 2008: 15 e doc. 9.

45 Ferreira, 1923: 21-22; Trindade, 2013: 593. 


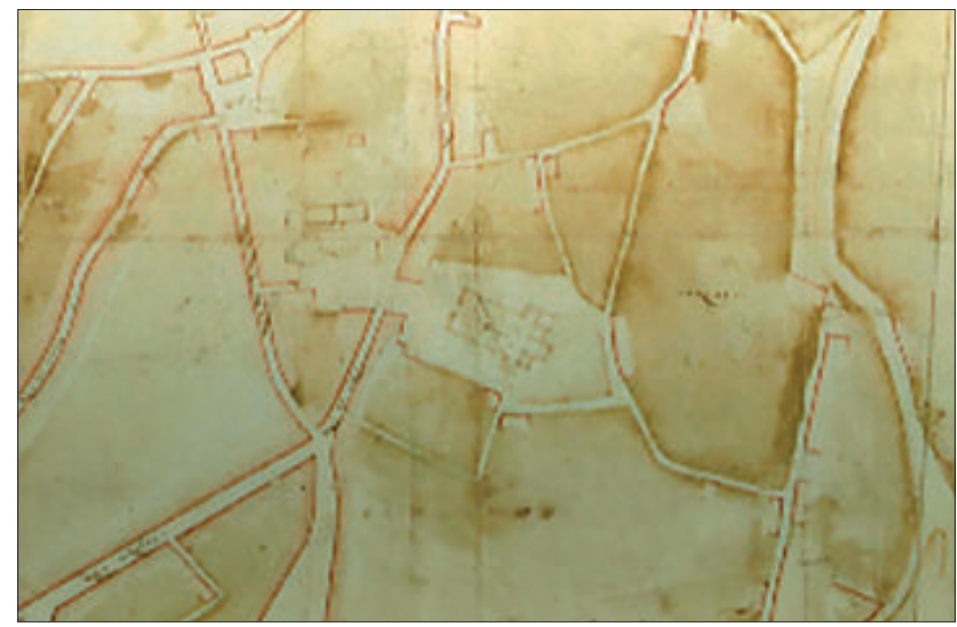

Fig. 9 Pormenor da planta De Vila do Conde, Biblioteca Nacional do Rio de Janeiro, ARC.016,09,001on Cartografia.

J. B. Harley apontou como "discurso cartográfico" (Harley, 2001: 54) e Carl Sauer como "eloquência dos mapas" (Sauer, 1956:289). $\mathrm{Na}$ realidade, ao contrário das vistas, onde a subjetividade é normalmente aceite (quase até expectável) os mapas e as plantas, ao serem identificados com processos científicos, fugiram (e fogem ainda) à categoria de objetos retóricos e persuasivos que na realidade também são. Quer a cartografia quer os levantamentos ortogonais foram, durante muito tempo, apanágio das elites dominantes desde logo porque, como argumentava Floriano Dal Buono, autor da vista de Bolonha de 1636, a essência da cidade só podia ser captada por uma imagem que a representasse tal como se vê a partir de um determinado ponto (pictural portanto); a sua planta, pelo contrário, em toda a sua abstração e caráter científico, estranha à perceção empírica, só poderia interessar a alguém que a quisesse atacar ou fazer uma igual (Ballon e Friedman, 2007:687). Cartografia e levantamentos ortogonais foram, por isso, mas também pela complexidade da sua realização, quase sem exceção linguagem de 
poder, transmitindo, de forma quase impercetível, realidades social e politicamente comprometidas. Quando, depois de reproduzidas chegaram ao grande público, transformam-se em instrumentos de disseminação e fortalecimento dos valores e crenças que se pretendiam dominantes. Como sublinhou Harley, "Seeing was believing in relation to the territorial hierarchies expressed in maps" (Harley: 2001, 62). Efeitos que, no concreto, se materializam em omissões, distorções propositadas, sublinhados ou, por exemplo, no chamado "síndrome de omphalos", isto é, na reivindicação de um posicionamento central por parte da entidade representada.

A verdade é que, mesmo utilizando métodos matemáticos e científicos, os autores dessas imagens raramente decidiram em plena autonomia, livres de quaisquer constrangimentos. A moldura técnica partilhou sempre o seu domínio com a moldura político-social. "Maps are never value-free images" (Harley: 2001, 53), por vezes em aspetos quase tão impercetíveis quanto a manipulação da escala, o âmbito representado, o tamanho e local onde surgem os símbolos e inscrições que identificam o promotor ou, tão simplesmente, nas cores escolhidas para os diferentes elementos.

Tudo o que fica dito expressa bem a necessidade de uma crítica interna atenta, ao mesmo tempo que vinca como o desenho foi, e é, instrumento de quem decide, e nesse sentido, instrumento de poder.

\section{A imagem como símbolo: o potencial discursivo}

Instrumento do poder também por via do poder da imagem, aspeto que nos permite fazer a ponte para o segundo tipo de representação: aquela em que a civitas sobreleva a urbe.

Lisboa é o exemplo possível para a cronologia e espaço em causa, como fica claro pelo elenco das representações panorâmicas de cidades portuguesas que dessa centúria chegaram até nós. Com efeito, 
à exceção da iluminura de Santarém que ocupa o pé de página de um dos fólios da Genealogia dos Reis de Portugal ou da vista de Évora, que Duarte de Armas debuxou para o frontispício do foral manuelino 46 e deixando à margem as vistas integradas no Civitas Orbis terrarum ${ }^{47}$, pelo conceito inteiramente diferente da obra, só Lisboa, ou parte dela, é representada. Repetidamente, aliás, o que, por si só, é já muito significativo ${ }^{48}$.

Desde os finais da primeira década de Quinhentos assiste-se à consolidação daquela que virá a ser a vista da cidade com maior fortuna, de base corográfica, sem dúvida, mas a que acresce um enorme potencial retórico, a um tempo simbólico e propagandístico. Lisboa a partir do rio, que é, aliás, como alegoricamente a retrata Francisco de Holanda em 1571: uma figura feminina emergindo das

46 Vista de Santarém de António de Holanda, integrada na Genealogia dos Reis de Portugal, (1530-1534), Ms. 12531 da British Library, Londres e a iluminura do foral manuelino da cidade de Évora, da autoria de Duarte de Armas, c. 1501, Arquivo Municipal de Évora.

47 Lisboa e Cascais, surgem no volume I da Civitates Orbis Terrarum, editado em 1572; Coimbra, Braga e novamente Lisboa no volume V, de 1594. A primeira vista de Lisboa (1572) terá tido por base um desenho mais antigo, de cerca de 1513, como assinala Nuno Senos, pois ainda nela figura a Torre da Escrivaninha, demolida em 1517 para a construção da Igreja da Misericórdia. Senos, 2002: 64-65.

48 Vista de Lisboa, Crónica de D. João I, de Fernão Lopes, Crónicas 8, IAN-TT, Lisboa; Vista de Lisboa de António d'Holanda e Simon Bening incluída na Genealogia do Infante Dom Fernando de Portugal, 1530-1534, fol. 8, Ms. 12531, British Library, Londres; do Livro de Horas (dito) de D. Manuel, também atribuído a António de Holanda e hoje no Museu Nacional de Arte Antiga, destaca-se a iluminura do fl. 25; a vista de Lisboa, novamente da autoria de António d'Holanda, inserida na Crónica de D. Afonso Henriques, de Duarte Galvão, de cerca de 1540, na Casa-Museu Condes de Castro Guimarães, Cascais; a Ulisiponae Pars, de Simão de Miranda, realizada em 1575, do Arquivo do Estado de Turim e, finalmente, a vista panorâmica de Lisboa, de autor desconhecido, realizada em torno de 1570, da Biblioteca da Universidade de Leiden, Coleção Bodel Nijenhuis. Para o estudo das diferentes vistas de Lisboa veja-se França, 1996: 136 ss; Senos, 2002 e, de forma particularmente aprofundada, Pereira, 2011: 865 e ss. Uma outra vista, da autoria de Francisco de Holanda e incluída na Fábrica que Falece à Cidade de Lisboa, obra escrita em 1571, é neste âmbito uma exceção já que a cidade aí retratada, precisa no perfil, esquemática no pormenor, obedece a um objetivo muito preciso: a demonstração da cerca abaluartada, que, do lado de terra e do lado do mar, falta à capital de D. Sebastião. Elementos defensivos que, emoldurando a panorâmica, ocupam $2 / 3$ do fólio e denunciam, sem equívocos, o móbil do desenho. (Holanda, 1584: fl8v-9r). 
águas (Holanda, 1984: fl2v) (Fig. 10). Trata-se, efetivamente, da vista captada a partir de uma das muitas caravelas e carracas fundeadas no estuário do Tejo, cuja presença é, por si só, crucial na caracterização da Lisboa Quinhentista, cidade portuária onde, por via fluvial e marítima, confluíam gentes e mercadorias de todo o mundo, velho e novo (Fig. 11). ${ }^{49} \mathrm{Se}$ as colinas e a velha alcáçova, se as torres da Sé e os grandes conventos contribuem decididamente para o fácil reconhecimento da cidade, o protagonismo é sem dúvida reservado ao contacto da cidade com o rio, fazendo da Ribeira o espaço de referência. E essa Ribeira seria, a partir de 1505, definitivamente marcada pelo novo Paço Real, cuja composição atravessaria toda a Idade Moderna.

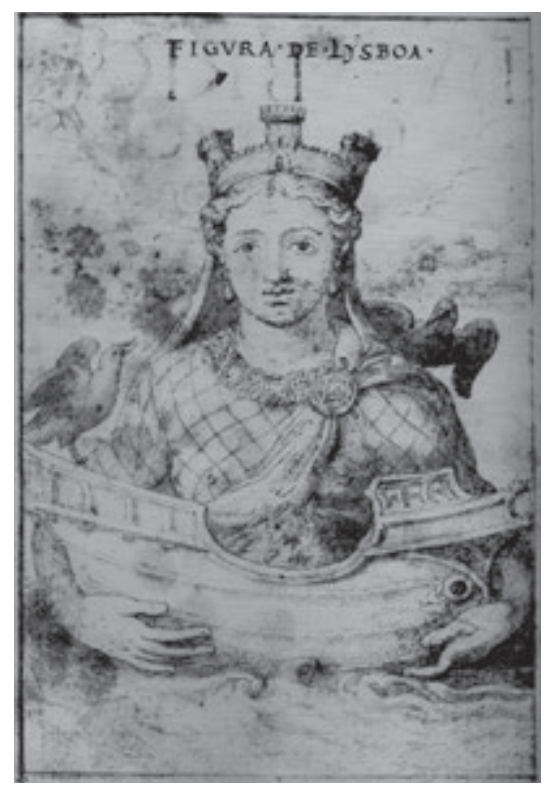

Fig. 10 Figura de Lisboa, Francisco de Holanda, Da Fábrica que Falece à Cidade de Lisboa, Fl. 2v.

49 Outras cidades do Império, terão uma vista-tipo idêntica, caso de Goa ou do Rio de Janeiro. 


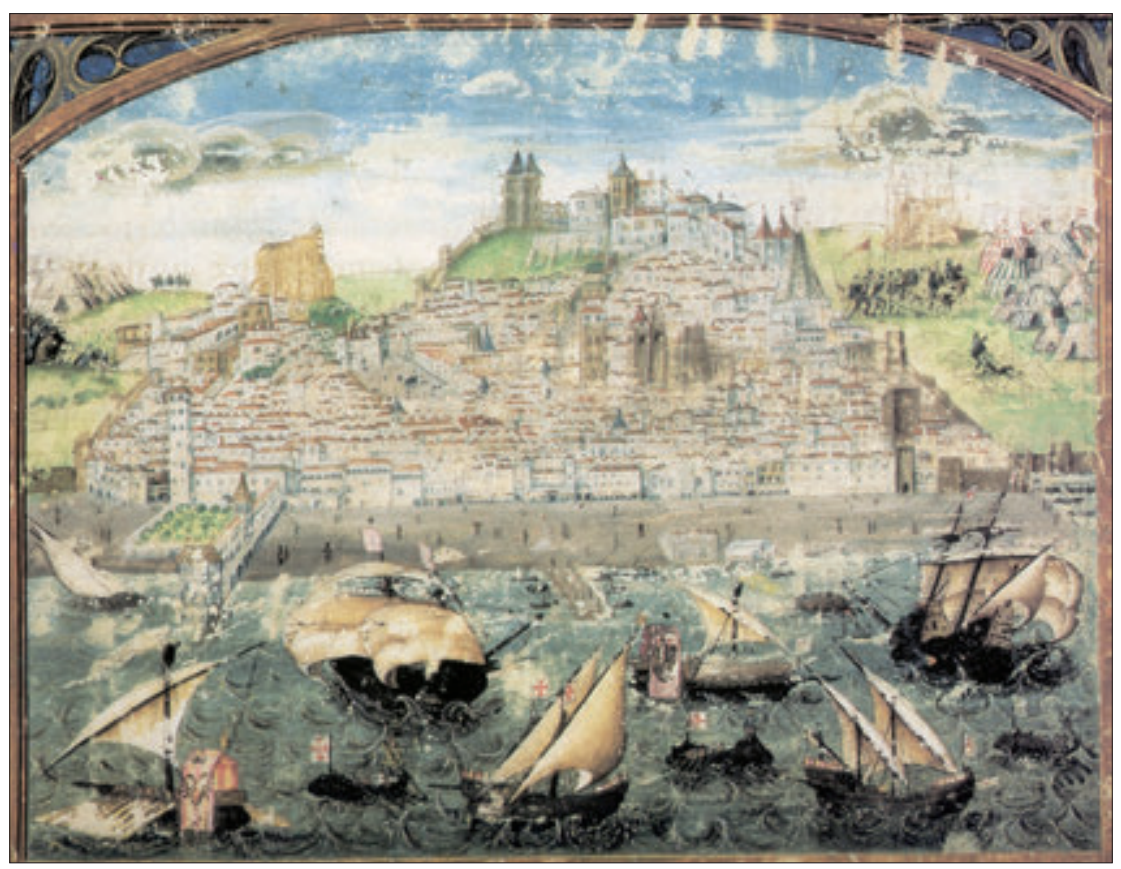

Fig. 11 Vista de Lisboa. António de Holanda, Crónica de D. Afonso Henriques, de Duarte Galvão. Cascais, Museu Condes de Castro Guimarães, Inv. 14.

De forma geral, em todas as representações é possível reconhecer a vontade de representar o existente, senão no detalhe, pelo menos em termos de volumes e posição relativas aspeto que, aliás, permite acompanhar as alterações que vão sendo sucessivamente introduzidas na residência régia. 50

Nesse paço, concretamente no piso térreo do núcleo residencial, situava-se a Casa da Índia e Mina, centro nevrálgico do trato comercial que o rei monopolizava. ${ }^{51}$ Ora, como Nuno Senos (2002:

50 As diferentes representações do Paço em toda a iconografia de Lisboa do século XVI podem ser vistas em Garcia, 2008: 24-25.

51 Exemplo bem elucidativo da imagem ao serviço do poder, recorde-se como era nesse espaço, embora então ainda Casa da Guiné e da Mina, que, por entre enorme secretismo, se guardava a carta de grandes dimensões, o chamado Padrão Real, que ao velho mundo conhecido acrescentava não só a América recém desco- 


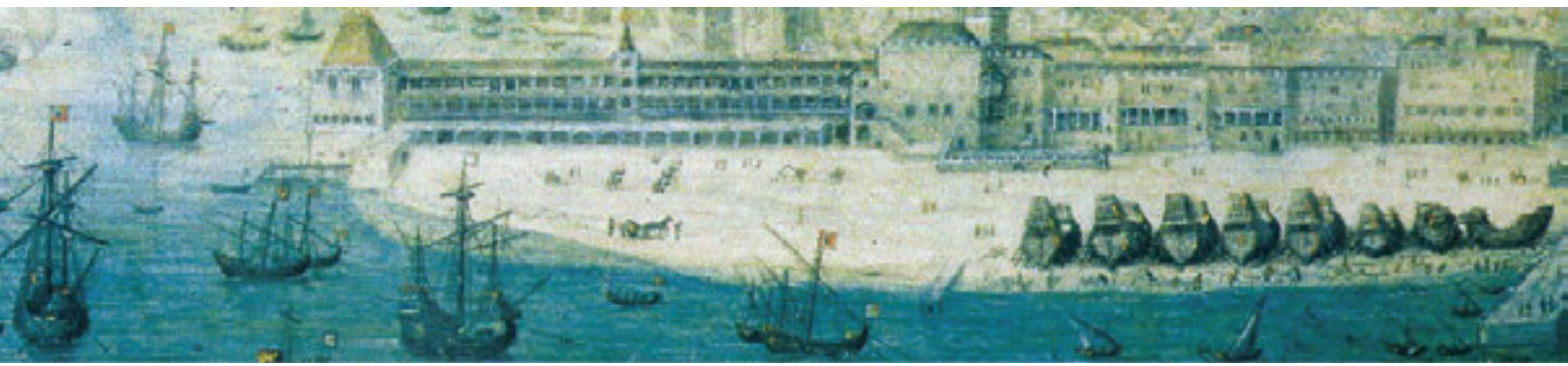

Fig. 12 Paço da Ribeira, em Lisboa. António de Holanda, Livro de Horas dito de D. Manuel [detalhe]. Lisboa, Museu Nacional de Arte Antiga, Inv. 14, fl. 25v.

217) e Paulo Pereira (2006: 8 e 2012: 875) têm destacado, esse edifício sintetizava, na sua lógica arquitetónica e funcional, a ideia da indissociabilidade entre o império marítimo e comercial e a dinastia de Avis-Beja. O rei de Portugal era, afinal, também Senhor da Conquista, Navegação e Comércio... da Etiópia, Arábia, Pérsia e Índia.

Em síntese, quando a casa do rei literalmente se alicerçava na casa da Índia, e quando o Paço, ou pelo menos a parte mais emblemática - a "ponte" ou "varandas dos paços" - literalmente avançava sobre o rio, num contacto quase físico com caravelas e naus, afirmava-se de forma perene a natureza e geografia do Império e D. Manuel como dominus mundi (Fig. 12). Tanto quanto o rinoceronte, o elefante, a onça e o cavalo persa que segundo Damião de Góis abriam o cortejo régio nas ruas da cidade (Góis, 1566: IV, Cap. 84, fl.105), 52 o paço manuelino, na sua ala mais visível e simbólica, cristalizava a escala mundializante do império. Desta feita, a urbs transformava-se em civitas. E a imagem em discurso político. 53

berta como uma África de contornos atualizados (Domingues: 2006, 12). A mesma que, em 1502, seria clandestinamente copiada por Cantino e que hoje se encontra na Biblioteca Estense, de Módena.

52 Sobre o papel dos animais exóticos na construção da mitografia manuelina, cf. Gschwend, 2009: 35 e ss.

53 Reforçando essa ideia da utilização da força da imagem por D. Manuel em geral (de que a heráldica aposta em todas as obras régias será sempre o primeiro 


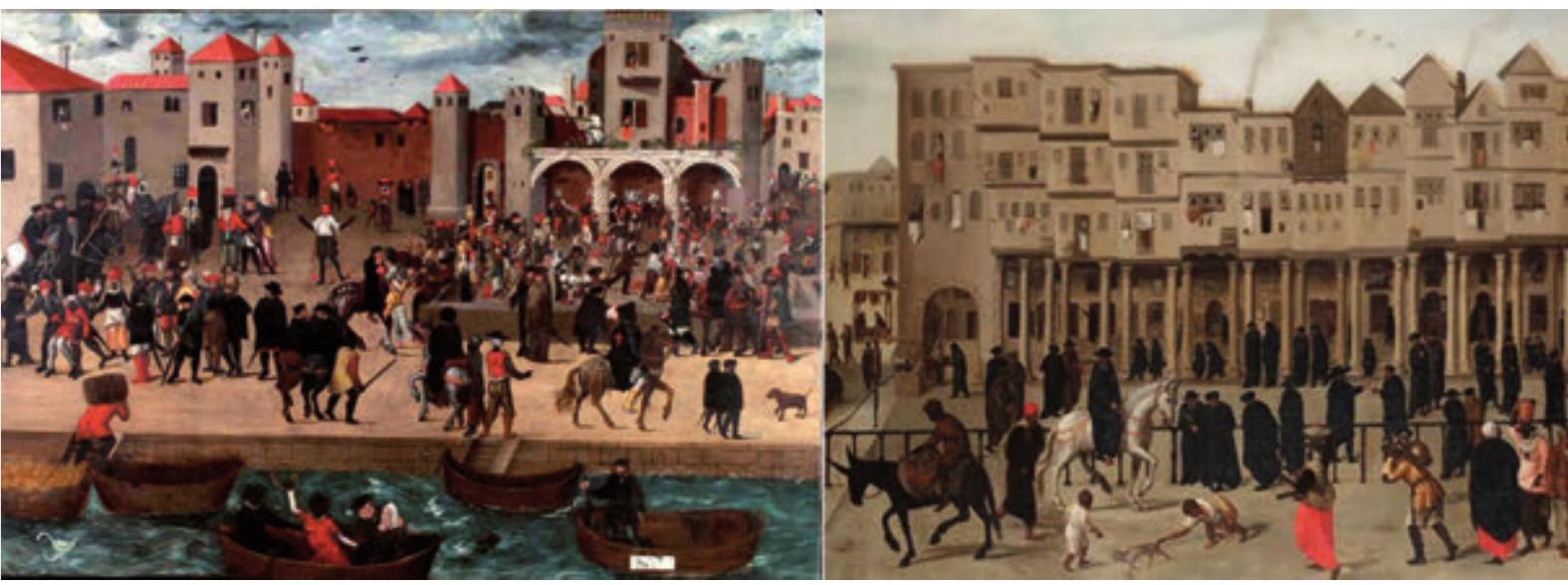

Fig. 13 Chafariz d'el Rey em Lisboa. Autor anónimo, c. 1570-80. Coleção Berardo. Rua Nova dos Mercadores em Lisboa. Autor anónimo, c. 1570-1590. Londres, Kelmscott Manor Collection - Society of Antiquaries of London.

Ainda que em grau menor, o potencial discursivo da vista panorâmica captada a partir do Tejo foi disputado por outras partes da zona ribeirinha ou com ela confinantes. Efetivamente, tanto a vista da Rua Nova incluída no fl.130 do Livro de Horas (dito) de D. Manuel como a pintura do Chafariz d'el Rey ${ }^{54}$ (Fig. 13) não descrevem apenas paisagens construídas e humanas de uma determinada realidade. As casas que sobem aos céus, no dizer de Zurara, as arcadas e esteios onde diariamente se vendiam os produtos oriundos de todo o império, o concurso de "desvairadas gentes", missionários, escravos e mercadores estrangeiros, funcionam como instrumentos de persuasão capazes de convencer qualquer

\footnotetext{
e mais alargado registo), e no Paço da Ribeira em particular, mas agora apenas para aqueles que aí tinham entrada, recorde-se, como indissociável da construção da ideia de império globalizante, o ciclo de 26 tapeçarias descrevendo a "Conquista da Índia" encomendado pelo monarca, em 1510, para revestir a Sala Grande, espaço de referência para o cerimonial da corte.

54 Respetivamente Livro de Horas (dito) de D. Manuel, Museu Nacional de Arte Antiga, 14, fl. 130 e Chafariz d'el Rey em Lisboa, c. 1570-80, de autor anónimo e pertencente à Coleção Berardo.
} 
observador do carácter cosmopolita da cidade retratada. ${ }^{55}$ São eles os atores principais que, pela urbs, remetem para a vivência diferenciadora da civitas.

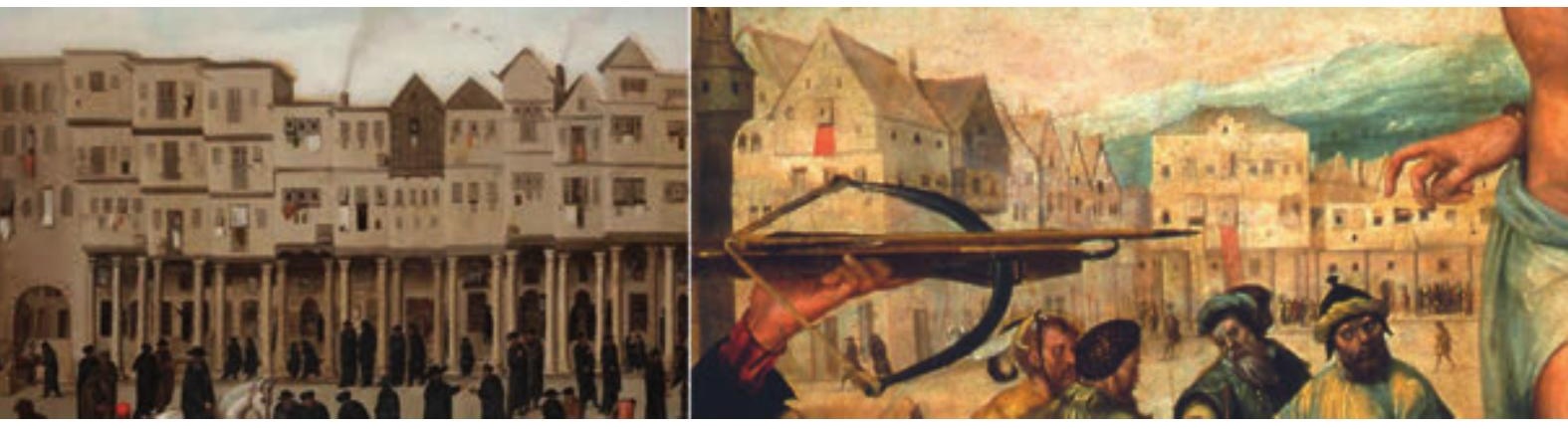

Fig. 14 Rua Nova dos Mercadores em Lisboa. Autor anónimo, c. 1570-1590. Londres, Kelmscott Manor Collection - Society of Antiquaries of London. Martírio de S. Sebastião (pormenor). Gregório Lopes, Museu Nacional de Arte Antiga, Inv. 80 Pint.

Também nesse âmbito os exemplos conhecidos representarão apenas uma ínfima parte do que terá existido, noção fundamental na análise da produção da época e que obriga a um cuidado acrescido no que toca às conclusões. Neste âmbito de um universo truncado, é bem elucidativa a descoberta mais recente e que constitui, para a cronologia em causa, uma verdadeira joia da coroa: refiro-me à pintura da Kelmscott Manor Collection (Fig. 13), vinda a público em novembro de 2010, no âmbito de uma exposição de marfins cingaleses do século XVI realizada no Museu Rietberg de Zurique e identificada por Annemarie Jordan Gschwend, curadora da exposição. ${ }^{56}$

55 A famosa Rua dos Leilões, em Goa, é representada com idêntico espírito cosmopolita por Jan Huygen van Linschoten, em 1596.

56 Tendo pertencido a Dante Gabriel Rossetti, integra hoje a Kelmscott Manor Collection, proprietária da Sociedade de Antiquários de Londres, que os cedeu para a referida exposição. Gschwend e Beltz, 2010. 
Datável dos anos de 1570-1590 e de autor desconhecido, o quadro, hoje cortado em dois, representa a Rua Nova dos Mercadores, em Lisboa. Mais do que uma análise circunstanciada da obra, importa aqui referir como o ângulo representado, uma vista frontal do casario, corrobora e, sobretudo, acrescenta, ${ }^{57}$ o que a vista em escorço e "a voo de pássaro" do Livro de Horas dava a conhecer. A ponto de permitir identificar uma outra representação do mesmo espaço que tem, até agora e tanto quanto sabemos, passado despercebida. Trata-se do pano de fundo que compõe uma das mais famosas obras de Gregório Lopes: o Martírio de S. Sebastião (Fig. 14), pintado para a Charola do Convento de Cristo em Tomar. Se o icónico edifício de planta centrada, que embora não identificado confere à cena do martírio o seu referencial geográfico romano, tem sido o foco da atenção dos estudiosos, a verdade é que a "cidade anónima" que, em último plano, ocupa a parte central da superfície pintada pode, doravante, aceitar-se como mais uma representação dessa importante artéria da Lisboa quinhentista, nas palavras de Damião de Góis "mais ampla que as outras ruas, ornada de ambos os lados de belíssimos edifícios (e onde) se juntam à compita, todos os dias, comerciantes de todas as partes e povos do mundo" (Góis, 1988:54). Uma representação "de memória", mais do que um retrato fiel, já que os edifícios, fugindo ao plano linear da rua e sujeitando-se ao esquema compositivo geral, desenham a praça onde decorre o martírio.

\footnotetext{
57 Repare-se, por exemplo, na guarda de ferro que definia (e protegia) a área dos cambistas (e que justificava o topónimo de Rua Nova dos Ferros atribuído a esta parte da rua) representada no Ofício dos Mortos do Livro de Horas de forma pouco nítida e pormenorizada e que agora surge quase em primeiro plano na pintura flamenga. Um testemunho circunstanciado da Rua Nova dos Mercadores, em pleno século XVI, foi deixado por João Brandão (Brandão, 1990: 97 e ss). Sobre a rua veja-se igualmente Gonçalves, 1996: 66-67 e Matos; Paulo, 2013: 38 obra, aliás, em que surgem publicadas as duas pinturas da Kelmscott Manor Collection.
} 
A proximidade entre ambas as representações, a de Gregório Lopes, de finais da década de 1530 e a do pintor flamengo dos anos seguintes a 1570, é evidente a vários níveis: nos edifícios de vários pisos dotados de galeria térrea com mezanino; no revestimento parcial das frontarias com madeira, os chamados "fromtaes de tavoado" ou nos ressaltos das fachadas, soluções a que D. Manuel tentara pôr fim; na diferente altura dos edifícios ou, sobretudo, na tipologia das janelas, fechadas por portadas de madeira basculantes, muitas delas dotadas de aberturas centrais, certamente destinadas a deixar passar alguma luz. No conjunto, a inspiração parece inequívoca. No que é, aliás, um procedimento comum a Gregório Lopes como chamou já a atenção Paulo Pereira: na Degolação de S. João Baptista, de cerca de 1536, ficam bem patentes dois dos edifícios reais que inspiraram o autor na constituição do cenário onde situa o episódio: a Galeria do Paço da Ribeira, em Lisboa, e a parte superior da fachada da igreja da Graça, em Évora (Pereira, 2013: 101).

\section{O desenho como ferramenta de investigação}

As questões até agora desenvolvidas integram-se no âmbito do referido exercício de análise da imagem desenhada. Um processo de descodificação que, como terá ficado explícito pelos exemplos aduzidos, resulta da interseção de múltiplas técnicas e ciências, aspeto que remete, necessariamente, para a exigência de um quadro interdisciplinar de suporte. No conjunto desses saberes de natureza diferente, da Literatura à Geografia, da História à Arqueologia e História da Arte, um há que importa agora destacar: o próprio desenho. Qualquer imagem desenhada de uma cidade, pela própria capacidade (e densidade) de síntese do desenho, incorpora um imenso volume de informação. A essa, que podemos designar como endógena, associamos, no decorrer do processo de análise, um outro volume 
significativo de dados exógenos. Ora a organização de todo esse manancial de informação e a sua conversão num quadro sinóptico, obriga a recorrer de novo, à capacidade de síntese do desenho. Em suma, no âmbito disciplinar da História urbana, do urbanismo e da urbanística, o desenho constitui-se como instrumento da própria investigação. 58

$\mathrm{Na}$ verdade o uso do desenho revela-se uma quase necessidade imperativa em estudos que têm por objeto a cidade: a sua dimensão e complexidade ou a transformação ininterrupta a que é sujeita, dificulta particularmente a sua perceção global. Abarcar o todo implica o recurso a abstrações: ortofotomapas, plantas, vistas, para enumerar apenas as principais. E se os meios usados são abstrações, o resultado a que chegamos também só o pode ser, no que não é uma especificidade da História do Urbanismo: remetido ao passado, o objeto da História do Urbanismo já deixou de existir, permanecendo apenas o seu resíduo - ativo ou não - na realidade contemporânea.

\section{$O$ cadastro na base do método}

Por entre os vários tipos de representação desenhada da cidade, do ponto de vista instrumental, o levantamento do cadastro é o que apresenta maiores potencialidades. ${ }^{59}$ De acordo com a própria significação do termo - do grego "linha por linha" -, o cadastro é transcrição gráfica detalhada e rigorosa de toda a propriedade: regista a localização, configuração e área de todo o edificado e, pelo confronto entre cheios e vazios, os espaços de uso e domínio

58 Tema particularmente estudado na "Escola de Coimbra" com vários textos a ele dedicados. Rossa, 2001, Rossa e Trindade, 2006; Trindade, 2013, Rossa, 2015a; Rossa, 2015b.

59 Merlin, 1988; Betran Abadía, 1994. 
público. Ora é sobre esta base cadastral que, no decorrer do processo investigativo, de forma simultânea e interativa, se realizam duas operações fundamentais, apenas aparentemente contraditórias: uma de montagem, outra de desmontagem.

No primeiro caso, é sobre o desenho do cadastro que se verte ou monta toda a informação mobilizada pelo cruzamento do maior número de fontes disponíveis: ${ }^{60}$ do documento escrito ao iconográfico, da cartografia (histórica e atual) à fotografia (antiga, aérea, ortofotomapas) dos dados veiculados pela arqueologia urbana aos recolhidos na própria cidade que, na sua expressão contemporânea, guarda de forma mais ou menos aparente o registo material das etapas anteriores.

De forma organizada, o cadastro permite a síntese de toda essa trama de informação (Fig. 15). Mas não antes de proceder à sua crítica interna, individualmente e por confronto. Como foi já abordado, o que as fontes ocultam ou acentuam, o que distorcem propositadamente em função do destinatário ou do objetivo, ou que involuntariamente é determinado pela técnica ou circunstâncias de produção, são apenas alguns dos vetores que tornam absolutamente essencial um processo de crítica rigoroso. A convergência da informação assim recolhida e a sua conversão em desenho, permite criar novas imagens onde as lacunas possam idealmente ser substituídas por continuidades, naturalmente que evidenciando de forma inequívoca o que resulta dos factos e o que decorre de hipóteses e interpretações novas.

O caso da desmontagem torna-se mais claro se pedirmos emprestado às ciências ditas "duras", o conceito de reverse engineering ou processo de compreender os princípios de funcionamento de um objeto ou sistema, através da análise da sua estrutura e modo de operar. Por outras palavras, inverte-se o processo de produção

60 Rossa e Trindade, 2005; Trindade, 2013: 99 e ss; Arizaga Bolumburu, 2014. 
desmontando um produto acabado, retrocedendo progressivamente, identificando cada componente e o seu papel, até recuperar o código original, entretanto esquecido. No caso presente, recuando no tempo através do desenho, pode acompanhar-se a estruturação urbana e perceber como num dado momento se fez e pensou a cidade.

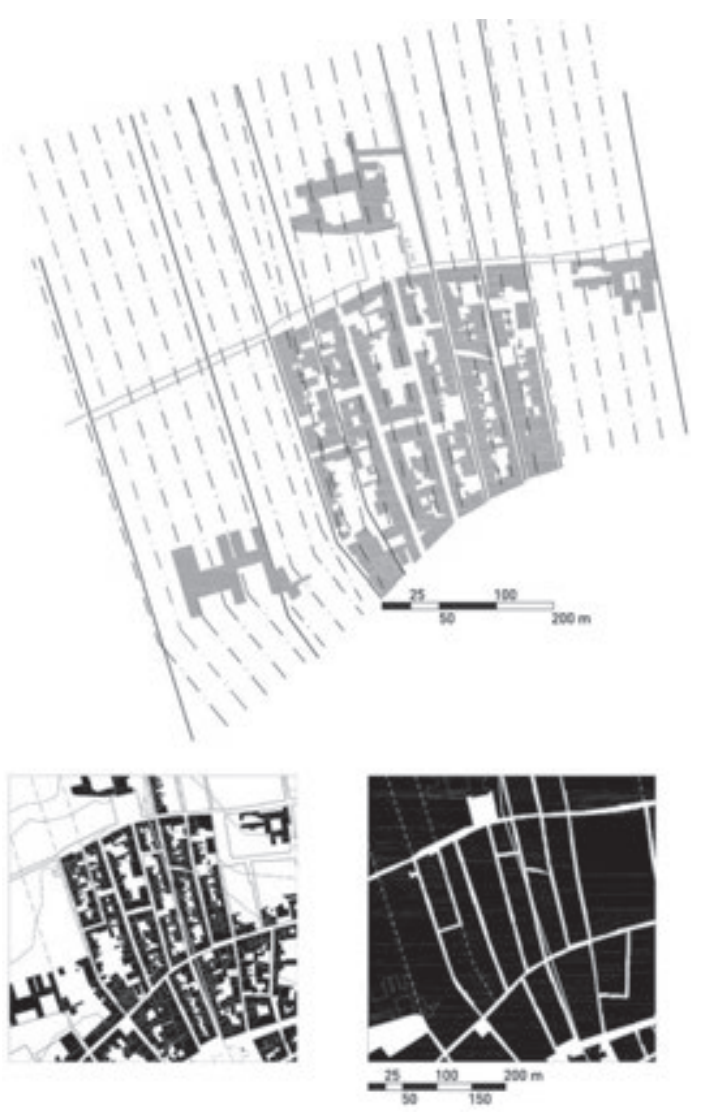

Fig. 15 Ponta Delgada. Antonieta Reis Leite, Açores, cidade e território: quatro vilas estruturantes. Angra do Heroísmo: Instituto Açoriano de Cultura, 2014.

Fundamental ao processo interpretativo, o desenho permite individualizar elementos, limpar o ruído envolvente, reconhecer unidades morfológicas ou troços de cidade cuja homogeneidade 
referencia uma origem comum ou ritmos e processos de expansão (Fig. 16). A leitura atenta do cadastro é uma fonte preciosa de informações revelando, por exemplo, alterações da propriedade como a junção ou divisão de parcelas ou a sua expansão sobre o espaço público, ao mesmo tempo que torna evidentes cicatrizes deixadas por acidentes naturais como as linhas de água ou artificiais, caso das muralhas, que o tempo obliterou. ${ }^{61}$ Por outro lado, quando a partir do registo cadastral se consegue identificar o uso de sistemas compositivos proporcionais é possível, a partir da planta, repor alçados e volumes. Quando a esta volumetria se conseguem associar ritmos de fenestração, de intensidade ou repetibilidade de determinados elementos arquitectónicos, "montam-se" troços de cidade, potenciando o estabelecimento de paralelos, a identificação de rotinas e métodos, tipos e séries.

\section{Operações e processamento dos dados}

Em termos práticos opera-se quer através do tratamento da imagem, quer do desenho vetorial. No primeiro caso, o mais elementar, ${ }^{62}$ é possível a partir de um conjunto de operações simples como o ajuste do brilho, contraste ou saturação de cor, ou de forma mais complexa pela sobreposição de imagens ou desenho, realçar, distinguir e assim reconhecer alguns dos múltiplos dados representados. No segundo caso, o desenho assistido por computador (CAD) proporciona a reconstituição do objeto de estudo em 2 e 3 dimensões, a realidade aumentada (Fig. 16)63 ou a realidade virtual com

61 Veja-se um exemplo prático em Trindade, 2005.

$62 \mathrm{Um}$ dos programas de tratamento de imagem mais utilizados é o photoshop.

63 A realidade aumentada é uma ferramenta fundamental da investigação: simplificando, trata-se da construção de um ambiente onde o mundo real é combinado com imagens virtuais geradas por computador ou simplesmente desenhadas sobre 
animação, ${ }^{64}$ aspetos particularmente interessantes ao permitirem uma divulgação mais acessível e apelativa dos resultados da pesquisa.

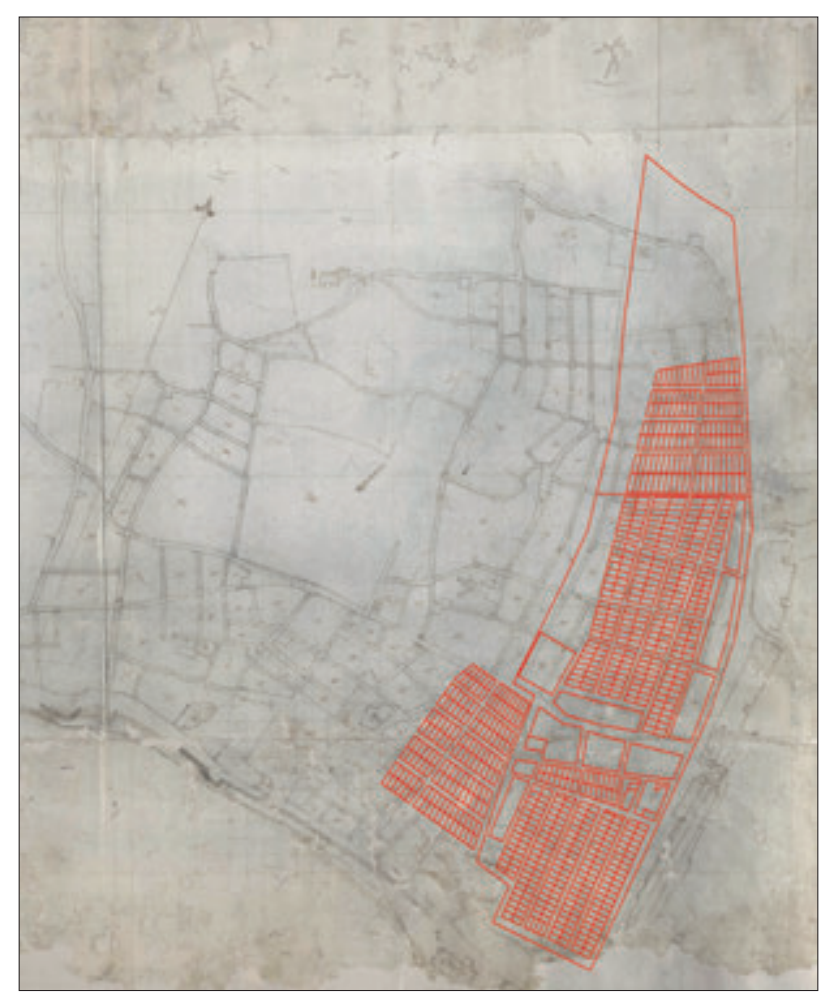

Fig. 16 Walter Rossa e Vera Domingues, Colagem digital da modelação 30x60 palmos do Bairro Alto em parte da Planta da cidade de Lisboa, na margem do Rio Tejo: desde o Bairro Alto até Santo Amaro, c.1581-1590. Biblioteca Nacional do Rio de Janeiro, Cartografia, Arm. 014,01,018.

Particularmente importante é que todo este processo de investigação seja constituído num sistema de informação geográfica (SIG), ou seja, que toda a informação disponível e entre ela a produzida

ele. A realidade é modificada ou mediada por forma a aumentar a perceção do observador sobre um determinado aspeto.

64 Veja-se como exemplo a Recriação Virtual da Alta de Coimbra pré-1942, acedido a 2 de fevereiro de 2015 em https://www.youtube.com/watch?v=wPCwEnjJLdk. 
ou desenhada, tenha coordenadas geográficas de referência. De forma simples, trata-se de um sistema que relaciona a informação armazenada em bases de dados de naturezas diferentes (textos escritos, fotografia, cartografia, iconografia, desenhos, vídeos, registos de som, etc.) segundo a sua referência geográfica disponibilizando essa informação nos mais variados suportes, designadamente representações geográficas georeferenciadas como por exemplo o google earth, o maps, ortofotomapas, etc. ${ }^{65}$ É essa a melhor forma de processar e gerir de forma integrada num único suporte e num número infinito de layers toda a informação de que dispomos sobre a evolução do território em estudo. Não no sentido tradicional de palimpsesto, em que a escrita de uma nova camada determina a eliminação aparente da anterior, mas num conceito próximo da hipertextualidade em que, a um mesmo tempo, surgem interconectadas informações de natureza, origem e época diferente. Repare-se que as fontes não surgem apenas lado a lado mas cruzadas entre si, sendo particularmente importante para o nosso exercício sobre cidades antigas a resolução das tão frequentes discrepâncias entre representações diferentes, através da sobreposição e ajuste de plantas antigas à realidade atual. Em síntese, gerar sinergias entre os diferentes materiais, conseguindo-se, no final, que o todo seja bem mais do que a soma das partes.

Note-se ainda, como a apresentação dos resultados da investigação a partir deste sistema e tipos de suporte, intensifica a operatividade do conhecimento histórico, facilitando o diálogo entre

65 Rossa, 2006 e 2015a. Cf. igualmente Bombay Before the British: the Indoportuguese layerhttp://en.wikipedia.org/wiki/Bombay_Before_the_British:_the_Indoportuguese_layer, acedido em julho de 2014. Vários exemplos do uso do desenho como instrumento da investigação podem ser vistos na obra Património de Origem Portuguesa no Mundo: Arquitetura e Urbanismo, José Mattoso (dir.), 4 vols. Lisboa: Fundação Calouste Gulbenkian, 2010, bem como em WWW.HPIP.org., evolução dessa mesma obra para um sítio em linha. Veja-se, a título de exemplo, o caso de Baçaim acedido em fevereiro de 2015 em http://www.hpip.org/Default/pt/Conteudos/ Navegacao/NavegacaoGeograficaToponimica/Localidade?a=567 
áreas científicas distintas e por regra de costas viradas: entre os que produzem o conhecimento teórico e os que "no terreno" intervêm em processos de salvaguarda e reabilitação urbana.

\section{Concluindo}

Património artístico, histórico, técnico e cultural em si mesmas, as imagens são também um meio para outros fins, com destaque para o (re)conhecimento de realidades desaparecidas. São extraordinárias e potentes formas de representação e divulgação e, também por isso, perigosas, pois veiculam como realidade olhares da realidade conduzidos por quem as produziu ou reproduziu, mas também por quem as vê. Uma vez feitas ficam ainda e para sempre sujeitas aos perigos e ao fascínio da manipulação, o que pode ocorrer pelo contexto, pela truncagem, pela edição e montagem.

Enquanto património as imagens têm, pois, uma extraordinária dimensão ativa, vida. Por tudo isso, qualquer discurso sobre imagem é um risco, começando pela dispersão. Por outro lado, descritivas ou simbólicas, as imagens, designadamente as que representam espaços urbanos, são sempre insinuantes, ainda que por vezes nem o seu criador, menos ainda o universo dos potenciais leitores, esteja consciente disso mesmo. O seu uso, qualquer que seja o âmbito da investigação é, por isso, um processo de descodificação, de identificação dos diferentes cruzamentos e níveis de leitura.

É significativo que a codificação dos sistemas de representação desenhada por processos que podemos caraterizar como "artesanais", a sua divulgação e utilização maciça tenham ocorrido com o extraordinário salto epistemológico que foi o Renascimento, designadamente a par com o aparecimento do livro, a primeira globalização, a autonomização da profissão do arquiteto em relação ao mestre pedreiro, a elevação do estatuto social do artista, etc. E é 
também curioso ver como, com o segundo passo da civilização ocidental, a Revolução Industrial disponibilizou os contextos e meios científicos e tecnológicos para o surgimento de outras formas de produção de imagens, em concreto a fotografia ou, mais tarde, o cinema, a rádio e a televisão, a autonomização da produção artística da encomenda direta e o surgimento de um mercado da arte, as coleções e os museus, etc. Vive-se agora uma outra revolução, uma outra mudança, em que as imagens têm outros meios de produção e divulgação e surgem completamente massificadas, comunicando-se tanto por imagem quanto por texto.

Todos esses processos, porém, foram essencialmente aditivos e integradores, uma vez que nenhuma dessas conquistas substituiu ou diminuiu a relevância das preexistentes. O mesmo aconteceu com os métodos de olhar e analisar. As representações em imagens que hoje possamos produzir sobre factos ou materialidades passadas não serão nunca mais exatas que as que foram feitas nesses momentos. Não as atualizamos, mas atualizamos o olhar sobre elas.

Neste texto refletimos sobre as imagens enquanto património, mas também e sobretudo em como as utilizar para a investigação em patrimónios, ou seja, incidindo sobre outras expressões patrimoniais. Pelas razões alinhadas, as visões e métodos lançados sobre os casos do século XVI português nos territórios do Império são, mutatis mutandis, válidas para outras cronologias e espaços, sempre que referentes a imagens "artesanais", as únicas originais que temos para o estudo dos patrimónios de influência portuguesa do $1 .^{\circ}$ Império.

Por fim, discorremos brevemente sobre as potencialidades que outras formas e ambientes de desenhar nos dão de manipular imagem, desconstruída e reconstruída por nós, sobre ou a partir de imagens criadas por outros, por vezes até apenas em texto: é a imagem tornada ferramenta do processo de investigação, clarificando as dinâmicas de génese e transformação, organizando e armazenando dados, divulgando os resultados a públicos diferenciados. 
No meio de tudo ficará a noção da imensa potencialidade das imagens para a investigação em patrimónios, até de como parece ser um universo inesgotável, com permanentes surpresas e descobertas. Mas ficará também a noção do fascínio que exercem e do risco que tal representa, a ponto de poderem manipular os resultados do que a partir delas construímos.

\section{Referências bibliográficas}

AlegriA, Maria Fernanda, et al (2007), "Portuguese Cartography in the Renaissance", in David Woodward (ed.), The History of Cartography Volume 3 (Part 1), Cartography in the European Renaissance. University of Chicago Press, 2007, 993-994.

ALEGRIA, Maria Fernanda; GARCiA, João Carlos (1995), "Aspetos da evolução da cartografia portuguesa (séculos XV a XIX)", in Maria Helena Dias (coord.), Os Mapas em Portugal da tradição aos novos rumos da cartografia. Lisboa: Edições Cosmos.

ARMAS, Duarte de (1997), Livro das Fortalezas (1509-1510), Manuel da Silva Castelo Branco (intr.). Lisboa: Arquivo Nacional da Torre do Tombo Edições Inapa, [Fac-símile do Ms. 159 da Casa Forte do Arquivo Nacional da Torre do Tombo].

BAllon, Hilary; FRIEDMAN, David (2007), Portraying the City in Early Modern Europe: Measurement, Representation, and Planning, in David Woodward (ed.), Cartography in the European Renaissance. The History of Cartography, Volume 3 (Part 1). University of Chicago Press.

Belting, Hans (2014), Antropologia da Imagem (2001), João Francisco Figueira e Vítor Silva (org.). Lisboa: KKYM+EAUM.

BETRAN ABADÍA, Ramón (1994), "Las huellas del tiempo: parcelario, tipo y propiedad", Aragón en la Edad Media. Paisajes rurales y paisajes urbanos: Métodos de análisis en Historia Medieval. Zaragoza.

BRANDÃO, João (1990), Grandeza e abastança de Lisboa em 1552. Lisboa: Livros Horizonte. 
BUENo, Beatriz Piccolotto Siqueira (2001), "De quanto serve a ciência do desenho no serviço das obras de el-Rei”, in Walter Rossa; Renata Araújo; Helder Carita (coords.), Actas do Colóquio Internacional Universo Urbanístico Português 1415-1822. Lisboa: CNCDP.

BuEno, Beatriz Piccolotto Siqueira (2011), Desenho e desígnio: o Brasil dos engenheiros militares (1500-1822) (2001). São Paulo: EdUSP e FAPESP. CABEÇAS, Mário Henriques (2008), Festas, Urbanismo e Arquitectura: A Praça Nova de Elvas, Trabalho realizado no âmbito do Seminário Estudos de Urbanismo do Curso de Mestrado em Arte, Património e Teoria do Restauro, Faculdade de Letras da Universidade de Lisboa [policopiado].

CARITA, Helder (1999), Lisboa Manuelina e a formação de modelos urbanísticos da Época Moderna (1495-1521). Lisboa: Livros Horizonte.

CARITA, Rui (1983), A Planta do Funchal de Mateus Fernandes (c.1570). Coimbra: Centro de Estudos de Cartografia Antiga.

CAstelo-Branco, M. da Silva (1994), "O Livro de Duarte de Armas", in Francisco Faria Paulino (coord.), A Arquitectura Militar na Expansão Portuguesa. Lisboa: CNCDP, 101-105.

CAStiglione, Baldassare (1997), O Cortesão (1528), Carlos Nilson Moulin Louzada (trad.), Eduardo Brandão (rev.). São Paulo: Martins Fontes.

CASTRO, Dom João de (1968-1982), Obras Completas (1538-1541), Armando Cortesão e Luís de Albuquerque (edição crítica), 4 vols. Coimbra: Academia Internacional da Cultura Portuguesa.

CID, Pedro de Aboim Inglez (2005), "Castelo de Vide e o álbum de Duarte de Armas: algumas notas”, Estudos/Património, 8. Lisboa: IPPAR - Instituto Português do Património Arquitectónico, 108-119.

CID, Pedro de Aboim Inglez (2007), A Torre de S. Sebastião de Caparica e a arquitectura militar no tempo de D. João II (1998). Lisboa: Edições Colibri/ Instituto de Historia da Arte da FCSH - UNL.

- Civitates Orbis Terrarum (1594), [liber] quintum, Georgius Braun, Franciscus Hogenbergius. Coloniae: Typis Bertrami Buchholtz.

CORREIA, Gaspar (1858-1863), Lendas da Índia (1550), Rodrigo José de Lima Felner (dir.). Lisboa: Academia Real das Sciencias. 
CORREIA, Jorge (2008), Implantação da cidade portuguesa no Norte de África. Porto: Faup.

DAVEAU, Suzanne (1997) "Lugares e regiões em mapas antigos", in Joaquim Romero de Magalhães et al. (coords.), Lugares e regiões em mapas antigos. Lisboa: CNCDP.

DAVEAU, Suzanne; GALEGO, Júlia (1995), ”Difusão e ensino da cartografia em Portugal”, in Maria Helena Dias (coord.), Os Mapas em Portugal da tradição aos novos rumos da cartografia. Lisboa: Edições Cosmos. Descrição da fortaleza de Sofala e das mais da Índia (1990) (1639), Pedro Dias (nota introdutória e legendas). Lisboa: Fundação Oriente, [facsímile do códice de 1639].

DiAs, Pedro (1999), História da Arte Portuguesa no Mundo (1415-1822), O Espaço do Atlântico. Lisboa: Círculo de Leitores.

DOMINGUES, Francisco Contente (2006), "Navegar em novos mares e representar os novos mundos. Náutica e cartografia nas navegações portuguesas" Novos Mundos - Neue Welten. Portugal e a Época dos Descobrimentos, Deutsches Historisches Museum, Berlim [Versão eletrónica consultada a 13.07.2014 em http://www.dhm.de/archiv/ausstellungen/neue-welten/ pt/docs/Francisco_Contente_Domingues.pdf

FARIA, Maria Dulce de (2014), A planta de Guimarães no atlas factício de Diogo Barbosa Machado BNDigital Brasil. Versão eletrónica consultada a 13.01.2015 em http://bndigital.bn.br/artigos/ ?taxonomia=artigos_autor\&tv=maria-dulce-de-faria

FERNANDES, Mário Gonçalves (2009), As plantas "De Guimarães" e "De Vila do Conde", da Biblioteca Nacional do Brasil. III Simpósio Luso-Brasileiro de cartografia histórica, anais. Belo Horizonte: Universidade Federal de Minas Gerais. Versão eletrónica consultada a 15.10.2014 em https:// www.ufmg.br/rededemuseus/crch/fernandes_as-plantas-de-guimaraese-de-vila-do-conde.pdf

FERrEIRA, Augusto (1923), Villa do Conde e o seu alfoz. Origens e monumentos. Porto. 
FLORES, Jorge Manuel (2001), Os olbos do rei. Desenhos e descrições portuguesas da Ilha de Ceilão $(1624,1638)$. Lisboa: CNCDP.

FRANÇA, José Augusto (1996), "Le imagini di Lisbona, 1505-1755", in Città d'Europa. Iconografia e vedutismo dal XV al XVIII secolo, Cesare de Seta (a cura di). Electa Napoli.

GAMEIRO, Pedro de Matos, (2014), O semblante original das Fortalezas Medievais de Portugal. Granada: Escuela de Posgrado de la Universidad de Granada [policopiado].

GARCIA, José Manuel (coord.) (2008), Lisboa do século XVII: A mais deliciosa terra do mundo. Imagens e textos nos quatrocentos anos do Padre António Vieira. Lisboa: Gabinete de Estudos Olisiponenses.

GARCIA, José Manuel (2009), Cidades e Fortalezas do Estado da Índia. Séculos XVI e XVII. Lisboa: Quidnovi.

GÓIS, Damião de (1566-1567), Chronica do Felicissimo Rei Dom Emanuel. Lisboa. [versão eletrónica consultada em 01.06.14 em Biblioteca Nacional Digital res-22-a]

GONÇALVES, Iria (1996), "Na ribeira de Lisboa em finais da Idade Média”, Um olhar sobre a cidade medieval. Cascais: Patrimonia.

GSCHWEND, Annemarie Jordan (2009), “A procura portuguesa por animais exóticos", in Jessica Hallett (coord.), Cortejo triunfal com girafas: animais exóticos ao serviço do poder. Lisboa: Fundação Ricardo do Espírito Santo Silva, 32-42.

GSCHWEnd, Annemarie Jordan; BELTZ, Johannes (2010), Elfenbein aus Ceylon. Luxusgüter für Katharina von Habsburg (1507-1578). Zürich: Museum Rietberg.

HALE, John (2007), Warfare and Cartography, ca. 1450 to ca. 1640, in David Woodward (ed.), Cartography in the European Renaissance. The History of Cartography Volume 3 (Part 1). University of Chicago Press. HARLEY, J. Brian (2001), "Maps, knowledge and power" (1988), in J. Brian Harley (author), Paul Laxton (ed.), J.H. Andrews (introd.), The New Nature of Maps. Essays in the History of Cartography. Baltimore and London: The John Hopkins University Press, 52-81. 
HOLANDA, Francisco de (1984), Da Fábrica que falece à cidade de Lisboa (1571), José da Felicidade Alves (introd., notas e comentário). Livros Horizonte.

HolandA, Francisco de (1984), Da Pintura Antiga (1548), Ángel González Garcia (ed.). Lisboa: IN-CM.

HolandA, Francisco de (1985), Da Ciência do Desenho (1571), José da Felicidade Alves (introd., comentário e notas). Lisboa: Livros Horizonte. KAGAN, Richard (2000), Urban Images of the Hispanic World, 1493-1793. Yale University Press.

LINSCHOTEN, John Huyghen van (1997), Itinerário, Viagem ou Navegação de... para as Índias Orientais ou Portuguesas (1596). Lisboa: Comissão Nacional para as Comemorações dos Descobrimentos Portugueses.

Livro das plantas das fortalezas, cidades e povoações do Estado da índia Oriental com as demonstrações do marítimo dos Reinos e Províncias onde estão situadas e outros portos principais daquela partes: contribuição para a história das fortalezas dos portugueses no Ultramar (1991) (1650), Luís Silveira (ed. e pref.). Lisboa: Instituto de Investigação Científica Tropical.

Livro das plantas de todas as fortalezas, cidades e povoações do estado da Índia Oriental (O) (1992), (1634-1635), Isabel Cid (transcrição, estudo histórico, codicológico, paleográfico e índices). Lisboa: Imprensa Nacional-Casa da Moeda.

Livro de Plantaforma das Fortalezas da Índia (O) (1999), (1612?/1635?), Rui Carita (estudo). Lisboa: Ministério da Defesa Nacional e Edições Inapa, S.A.

MACHIAVELLI, Niccolò (2005), A arte da guerra (1519-1520), David Martelo (trad. estudo, int. e notas). Lisboa: Sílabo.

MATOS, J. Sarmento de; PAUlo, Jorge Ferreira (2013), Um Sítio na Baixa: A Sede do Banco de Portugal. Lisboa: Museu do Dinheiro-Banco de Portugal. MILler, Naomi (1992), Mapping the city: Ptolemy's Geography in the Renaissance, in David Buisseret (ed.), Envisioning the city. Six studies in urban cartography. Chicago and London: University of Chicago Press. 
MOREIRA, Rafael, Arquitectura Militar na Expansão Portuguesa (A) (1994). Porto: CNCDP.

MORSE, Victoria (2007), The Role of Maps in Later Medieval Society: Twelfth to Fourteenth Century, in David Woodward (ed.), Cartography in the European Renaissance. The History of Cartography. Chicago: University of Chicago Press, vol. 3 (Part 1).

NUTI, Lucia (2000), Ritratti di citta: Visione e memoria tra Medioevo e Settecento (1996). Venezia: Marsilio Editore.

PARKER, Geoffrey (1992), "Maps and ministers: the Spanish Habsburgs”, in David Buisseret (ed.), Monarchs, ministers and maps. The emergence of cartography as a toll of government in Early Modern Europe. Chicago: University of Chicago Press.

PEREDA, Felipe et al. (eds.) (2002), El Atlas del Rey Planeta: La "descripción de España y de las costas y puerto de sus reinos" de Pedro Teixeira (1634). San Sebastian: Nerea.

PEREIRA, Paulo (2006), "Lisboa (séculos XVI-XVII)”, Novos Mundos - Neue Welten. Portugal e a Época dos Descobrimentos. Berlin: Deutsches Historisches Museum. [versão eletrónica consultada em julho de 2014 em http://www.dhm.de/archiv/ausstellungen/neue-welten/pt/docs/ Paulo_Pereira.pdf.]

PEREIRA, Paulo (2011), A Fábrica Medieval - Concepção e Construção da Arquitectura Portuguesa (1150-1550). Dissertação de doutoramento apresentada à Faculdade de Arquitetura da Universidade de Lisboa [Policopiado].

PEREIRA, Paulo (2013), "A Arquitetura enquanto metáfora. Iconografia da arquitetura (séculos XII-XVI)” in A. F. Pimentel (coord.), A Arquitetura imaginária. Pintura, escultura, artes decorativas. Lisboa: MNAA-INCM. REIS, Nestor Goulart (2000), Imagens de Vilas e Cidades do Brasil Colonial. São Paulo: Editora da Universidade de São Paulo-Imprensa Oficial do Estado/Fapesp.

ROGER, Alain (1997), Court Traité du paysage. Paris: Gallimard. 
RossA, Walter (2006), "Bombay Before the British: the indo-portuguese layer", in Rahul Mehrotra et al. (orgs.), Mumbai Reader. Mumbai: Urban Design Research Institute, 262-269.

ROSSA, Walter (2015a), "Património urbanístico: (re)fazer cidade parcela a parcela" (2013). Fomos condenados à cidade: uma década de estudos sobre património urbanístico. Coimbra: Imprensa da Universidade, 97-131. RossA, Walter (2015b), "História(s) do património urbanístico" (2012), Fomos condenados à Cidade. Uma década de estudos sobre património urbanístico. Coimbra: Imprensa da Universidade de Coimbra, 59-79. ROSSA, Walter; TRINDADE, Luísa (2005), "Questões e antecedentes da cidade portuguesa: o conhecimento sobre o urbanismo medieval e a sua expressão morfológica”, Murphy. Revista de História e Teoria da Arquitectura e do Urbanismo. Coimbra: Departamento de Arquitetura da Faculdade de Ciências e Tecnologia da Universidade de Coimbra, 70-109. ROSSA, Walter; TRINDADE, Luísa (2006), "O desenho e o conhecimento do urbanismo medieval português", in Beatriz Arízaga Bolumburu, Jesus Solórzano Telechea (eds.), El Espacio Urbano en la Europa Medieval, Nájera. Encuentros Internacionales del Medievo. Logroño: Gobierno de La Rioja-Instituto de Estúdios Riojanos, 191-207.

ROSSA, Walter; TRINDADE, Luísa (2013), "Il sistema urbanistico della Rua de Francos (via dei Franchi) a Coimbra: evidenze e ipotesi, evoluzione e permanenza, in Marco Cadinu (a cura di) I Catasti e la storia dei luoghi. Cagliari. Storia dell’Urbanistica 4/2012, Edizione Kappa, 247-260.

SÁNCHEZ Rubio, Rocío et al. (eds.) (2004), Imágenes de un Imperio Perdido: el Atlas del Marqués de Heliche - Plantas de diferentes Plazas de España, Italia, Flandes y las Indias. Mérida: Presidencia de la Junta de Extremadura.

SAUER, Carl (1956), "The education of a Geographer", Annales of the Association of American Geographers, 46.

SENOS, Nuno (2002), O Paço da Ribeira: 1501-1581. Lisboa: Editorial Notícias. 
SEVILlA, San Isidoro de (2004), Etimologías (627-630), J. Oroz Reta y M.-A. Marcos Casquero, (texto latino, versão espanhola y notas). Madrid: Biblioteca de Autores Cristianos.

SILVA, Luís Fraga da (2008), Uma planta inédita de Tavira, do séc. XVI. Campo Arqueológico de Tavira.

SILVEIRA, Luís da (1956), Ensaio de Iconografia das cidades portuguesas do Ultramar, 4 vols. Lisboa: Junta de Investigações do Ultramar.

TRINDADE, Luísa (2005) "A Praça e a Rua da Calçada segundo o Tombo Antigo da Câmara de Coimbra (1532)" Media Aetas, Paisagens Medievais I. Ponta Delgada: Universidade dos Açores, vol. I da 2. ${ }^{a}$ Série, 121-157. TRINDADE, Luísa (2013), Urbanismo na composição de Portugal (2009). Coimbra: Imprensa da Universidade.

TuCíDIDEs (2001), História da Guerra do Peloponeso (431 a.C.), Mário da Gama Kury (trad.). Brasília: Editora Universidade de Brasília, Instituto de Pesquisa de Relações Internacionais; São Paulo: Imprensa Oficial do Estado de São Paulo.

VANN, James (1992), "Mapping under the Austrian Habsburgs", in David Buisseret (ed.), Monarchs, ministers and maps. The emergence of cartography as a tooll of government in Early Modern Europe. Chicago: University of Chicago Press.

VITRÚVIO (2006), Tratado de Arquitectura (27-16 a.C.), Justino Maciel (tradução, introdução e notas). Lisboa: IST PRESS. 
JOSÉ PESSÔA

11

A ARQUITETURA COMO DOCUMENTO

A arquitetura foi o objeto principal com que foram sendo constituídos no ocidente os patrimónios históricos nacionais a partir do século XIX. Na Europa oitocentista a noção de monumento histórico estava atrelada àquela de arquitetura erudita do passado, fossem as ruínas da antiguidade, fossem as igrejas, castelos e palácios medievais e renascentistas. Camillo Boito, em 1893, identificava três qualidades principais para os monumentos arquitetónicos: a importância arqueológica, a aparência pitoresca e a beleza arquitetónica (Boito, 1989: 115). Segundo este, todo monumento arquitetónico tinha em si uma destas qualidades, preponderante sobre as outras. Eram estas qualidades que definiam três possíveis abordagens de restauro, vinculadas cada uma delas a um distinto período da história da arte. O restauro arqueológico seria aplicado às ruínas da antiguidade com ações de consolidação; o restauro pictórico voltado para os monumentos medievais valorizados pela sua aparência pitoresca; e o restauro arquitetónico, no qual se previa uma intervenção mais completa, dedicado a restabelecer a beleza arquitetónica dos edifícios renascentistas. Há na proposta do italiano Camillo Boito uma valorização no tratamento dos monumentos do renascimento em relação aos medievais, reflexo da importância desses na cultura italiana. O fenómeno não foi exclusivo da visão de Boito sobre o património arquitetónico. As escolhas na seleção do que seriam os 
monumentos históricos refletiam a busca da origem e grandeza das nações. Os monumentos arquitetónicos do passado guardavam em si um valor cognitivo (Choay, 2001: 128), que expressava a história e a identidade das nações.

No contexto de uma reflexão sobre Patrimónios de Influência Portuguesa, interessa pensar como edificado e paisagem traduzem a história e a identidade dos povos que os construíram. Arquitetura, cidade e território são, nessa perspetiva, documentos patrimoniais que registram a história dos homens.

Que documentos são esses?

Para compreender melhor esse ponto de vista podemos pegar emprestada a metáfora das "belas conchas" referidas por Levi-Strauss em uma entrevista, poucos anos antes de morrer. Quando lhe foi indagado qual seria ainda o seu interesse no estudo dos homens, ele respondeu que tinha por estes o mesmo apreço que pelos moluscos, seres sem maior importância, mas que depois de suas passagens pela Terra deixavam conchas magníficas.

Se não fosse ofender a dignidade do homem, eu compararia de bom grado os nossos estudos nesse domínio aos do especialista em moluscos e mariscos. Nos mariscos há duas coisas, um animal informe e viscoso que secreta um objeto admirável por suas proporções matemáticas, sua dureza, sua estabilidade, suas cores, e que é a própria concha. As instituições humanas, as crenças e os ritos são bem mais fugazes que a concha dos moluscos, mas possuem um rigor comparável. O etnólogo, diferentemente talvez do psicólogo ou do sociólogo, se interessa menos pela lesma e mais pela concha. (Levi Strauss, 2009).

Fazendo analogia com as crenças e os ritos de Levi-Strauss, a arquitetura e a paisagem transformada pelo homem são as conchas do trabalho do Património. Entendê-las e decifrá-las é a tarefa dos estudiosos envolvidos com a proteção, conservação e restauro do 
património edificado. Os monumentos arquitetónicos são, além de objetos notáveis do ponto de vista plástico, fonte de informação sobre a passagem do homem na terra. Cabe aqui também indagar se a informação contida em pedra, barro, cal e madeira, transformados em casas, igrejas, fortalezas, ruas e vilas, nos territórios em que brasileiros, cabo verdianos, angolanos, goeses, moçambicanos, portugueses, etc., edificaram ao longo dos últimos séculos constitui um património comum.

\section{Arquitetura como documento e a produção do conhecimento}

Pensar os monumentos edificados como documentos históricos implica compreender o trabalho de restauro e conservação destes monumentos como um processo de produção de conhecimento. Documento deriva do latim docere, que significa ensinar, informar, mostrar. É, portanto, uma dimensão inerente ao trabalho da proteção e restauro do património arquitetónico que relaciona a preservação da memória com a produção do conhecimento. A capacidade dos monumentos arquitetónicos de informar relaciona-se com a afirmação da sua identidade e autenticidade. Os edifícios históricos têm, portanto, um valor informativo, mas também têm um valor sensorial e expressivo, que é o seu valor artístico ou de imagem. Este valor é mutável, ao longo dos séculos, e faz com que a apropriação dos monumentos históricos seja um processo continuado de reinterpretação dos seus valores artísticos. A qualidade plástica, assim como a informação histórica contidas na arquitetura é que irá qualificar esta como monumento histórico. A qualidade plástica teve na história dos patrimónios ocidentais uma relevância maior nas escolhas do que proteger, se comparada com o valor histórico dessas arquiteturas. A história da arte, mais do que a história dos homens será o fio condutor na seleção do que seria passível de proteção. 
Dito isso é necessário ressalvar que o suporte material e a informação nele contida não são necessariamente indissociáveis. Muito pelo contrário, é parte fundamental do trabalho de proteção a transcrição para outro suporte da informação contida no monumento arquitetónico. É o conhecimento produzido nas transcrições do que está registrado em barro e pedra, para o papel, meio digital ou outro, que permite a reflexão e o entendimento necessário para decifrar os sentidos da linguagem arquitetónica dos monumentos. Não é apenas o trabalho de conservação da matéria concreta de que são feitos os monumentos que garante a transmissão das informações contidas nela, para as gerações futuras. Conservar significa principalmente produzir conhecimento e registrar este, em suportes diversos da pedra, barro e madeira de que são feitas as arquiteturas. A conservação da matéria concreta deve-se relacionar com um processo de nova apropriação voltado à reflexão e ao entendimento das matrizes culturais que geraram aquelas formas. No entanto, a prática da conservação dos monumentos arquitetónicos pressupôs na maior parte da história dos patrimónios dos diferentes países ocidentais a crença que a conservação da informação relativa ao monumento estaria garantida com a conservação rigorosa da materialidade das edificações. Mais que isso, essa informação ganhava um valor de veneração através da mística evocativa da autenticidade das obras antigas, respaldada na teoria da aura de Walter Benjamin (Benjamin, 2014).

Ora, é necessário aqui questionarmos a crença de que a conservação da informação no documento, monumento edificado, se dá apenas pelos instrumentos da manutenção da matéria. Principalmente questionarmos a ideia cara aos operadores do restauro do património arquitetónico de que este é uma ciência neutra, a qual tem como objetivo devolver a verdade histórica dos monumentos. Essa verdade nunca é enunciada claramente, mas está sempre presente por trás de axiomas como o chamado "falso histórico" nas intervenções de 
restauro dos edifícios históricos. Ora, se existe um falso é porque haveria também um verdadeiro, negando a ideia da história como um permanente processo de interpretação do passado.

As primeiras ações de proteção e conservação do património arquitetónico existente assumiram para si um enorme desafio, recuperar a imagem do passado dessas construções que se encontravam bastante modificadas pelas adições que a história havia lhes dado. As informações gravadas na pedra dos monumentos formam um verdadeiro palimpsesto, com escritas superpostas, ausência de trechos, sinais das linguagens arquitetónicas, mas insuficiente para a reconstituição dos discursos anteriores. Para suprir a ausência destas informações, o restauro voltou-se inicialmente para o estudo estilístico, a analise tipológica, a generalizantes caracterizações construtivas do passado (Carbonara, 2000). Os estudos permitiram o acúmulo de conhecimento sobre a arquitetura do passado até então inédito, mas também foram a base para a busca de uma inexistente originalidade perdida dos monumentos arquitetónicos. É em torno da possibilidade ética do refazimento da originalidade perdida dos edifícios, que vai se dar o debate e as diferentes linhas de abordagem do restauro dos monumentos no século XIX e primeira metade do século XX. Entre reconstituir uma imagem que pode nunca ter existido, ou contextualizar, mas sem ser igual, procura-se uma objetividade histórica inexistente. No Brasil no início da atividade de proteção do património histórico, os operadores do restauro dos monumentos vão procurar através das informações ainda existentes nos edifícios, dos registros da história da arte e da analogia com edifícios semelhantes, a originalidade perdida.

Na figura 1 vemos o registro fotográfico, feito em 1937, provavelmente pelo arquiteto Carlos Leão, responsável pelo restauro da Igreja de São Francisco Xavier. Na imagem temos a fachada sem a argamassa de revestimento, com padres e operários posando de forma circunspecta, mostrando a vitória obtida com o trabalho de 
prospeção. A igreja de São Francisco Xavier está localizada numa pequena colina numa enseada da baía de Guanabara, na cidade de Niterói. Fora construída pelos jesuítas na segunda metade do século XVII, depois que estes compraram aquelas terras e implantaram uma fazenda de gado. A igreja havia passado por uma reforma em 1905 que havia "modernizado" em vários aspetos a fachada frontal, pisos e forros do interior. As outras fachadas, porém, mantinham o aspeto da construção primitiva.

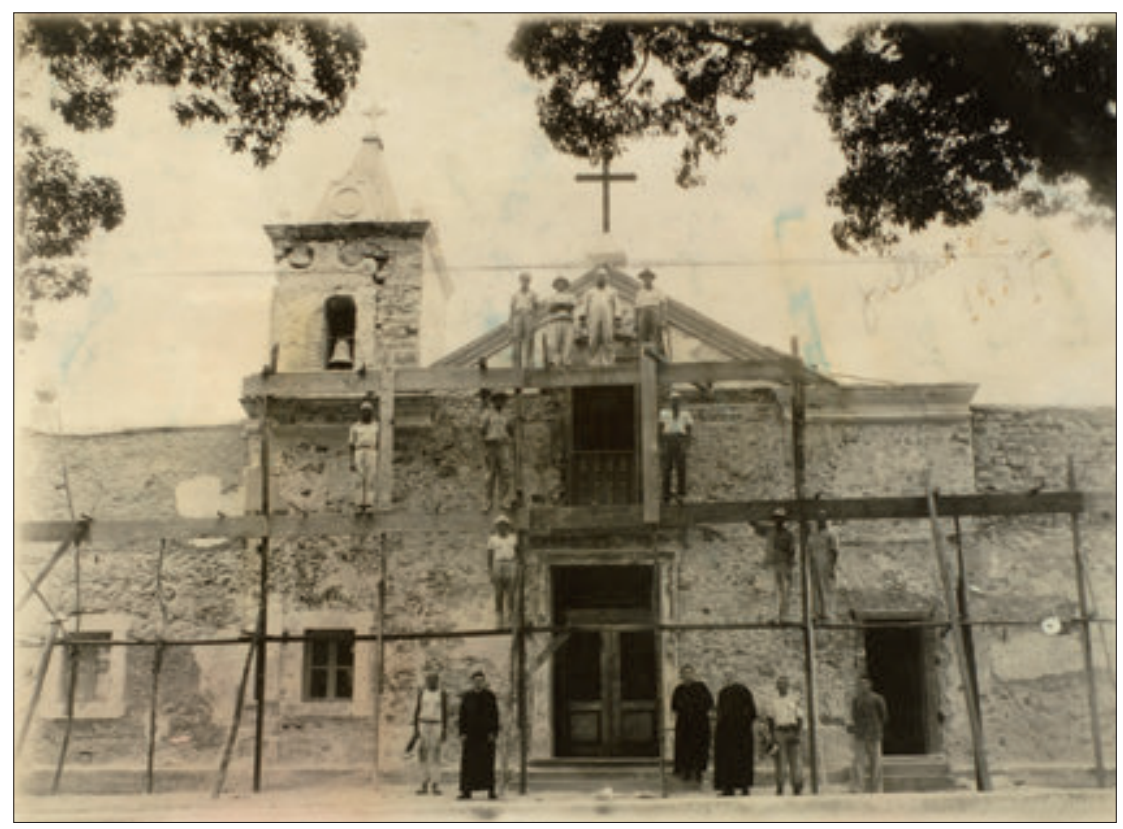

Fig. 1 Igreja de São Francisco Xavier, Niterói, 1937, Arquivo Central do IPHAN.

As obras de restauro, as primeiras realizadas pelo recém-criado Serviço do Patrimônio Histórico e Artístico Nacional [SPHAN] ${ }^{1}$, são

${ }^{1}$ Criado para reconhecer e proteger federalmente o património histórico e artístico brasileiro teve vários nomes ao longo da sua história: Serviço do Patrimônio Histórico e Artístico Nacional, SPHAN, de 1937 à 1946; Diretoria do Patrimônio 
iniciadas a pedido do padre responsável pela igreja que queria recuperar o aspeto primitivo do velho templo. A retirada da argamassa de revestimento da fachada frontal iria trazer informações desconhecidas sobre o edifício primitivo. É descoberta a sineira primitiva envolvida pela torre do início do século $\mathrm{XX}$, e a altura original dos corpos laterais da igreja na fachada principal. A prospeção na fachada principal permitiu identificar em linhas gerais o buscado feitio primitivo desejado pelo padre e pelo SPHAN. As informações registradas na fachada não são, porém, suficientes para a reconstituição pretendida. A janela rasgada do coro, feita em 1905, não permitia afirmar como seria a solução original. A procura de modelos semelhantes iria encontrar na igreja dos jesuítas em São Pedro da Aldeia, no Estado do Rio de Janeiro, a solução de uma janela iluminando o coro (Fig. 2), nesse caso reproduz-se o padrão de janelas com cercaduras de pedra que ainda existiam na fachada, preocupando-se em distinguir as pedras novas introduzidas: "Tivemos o cuidado de procurar pedra cuja contextura e aspeto muito se aproximassem das primitivas, sem contudo, serem iguais. Dessa forma nada se perdeu em cor e aspeto e ficaram caracterizados os novos elementos." 2

No Brasil do início da atuação do Serviço do Patrimônio Histórico e Artístico Nacional a busca da originalidade perdida se dava pelo restauro baseado nas fontes documentais, apoiada na história dos estilos sempre que fosse necessário (Fig. 3). O debate entre a busca da originalidade dos monumentos e a compreensão destes como testemunhos de um processo de transformação ao longo da história

Histórico e Artístico Nacional, DPHAN, de 1946 a 1970; Instituto do Patrimônio Histórico e Artístico Nacional, IPHAN, de 1970 à 1979; Secretaria do Patrimônio Histórico e Artístico Nacional, SPHAN, de 1979 à 1990; Instituto Brasileiro do Patrimônio Cultural, IBPC, de 1990 à 1994; Instituto do Patrimônio Histórico e Artístico Nacional, IPHAN, desde 1994.

2 Informação do técnico Carlos Leão, 1937, Igreja de São Francisco, Niterói, Pasta de Obras, Arquivo Central do IPHAN. 


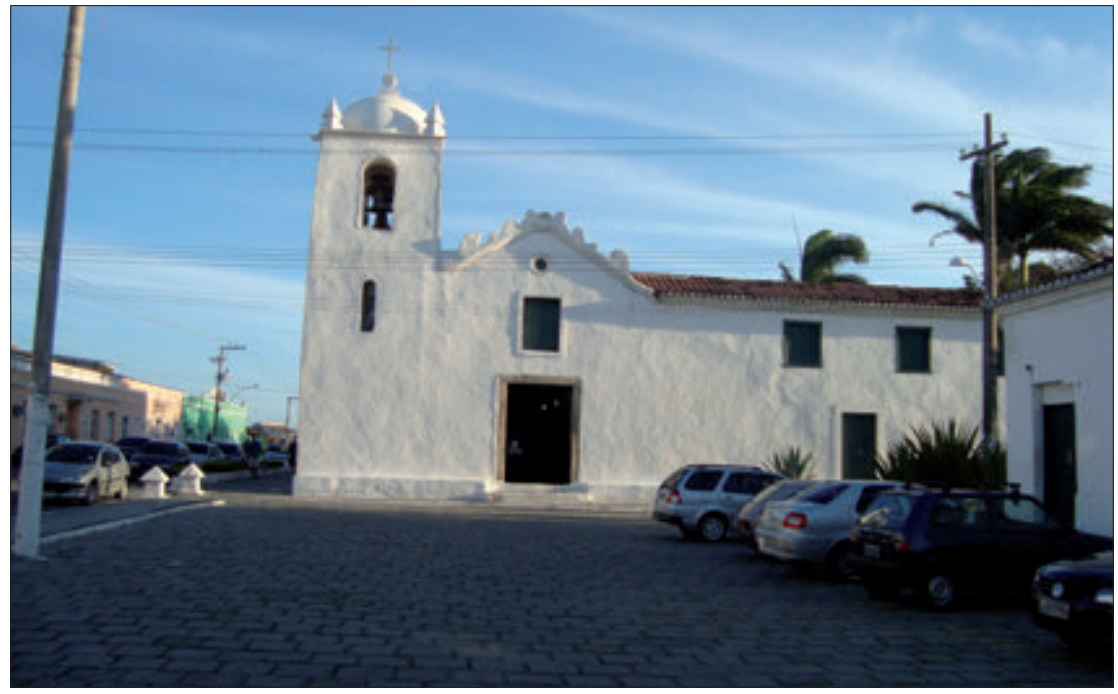

Fig. 2 Igreja Jesuíta de São Pedro d'Aldeia, Rio de Janeiro, 2009.

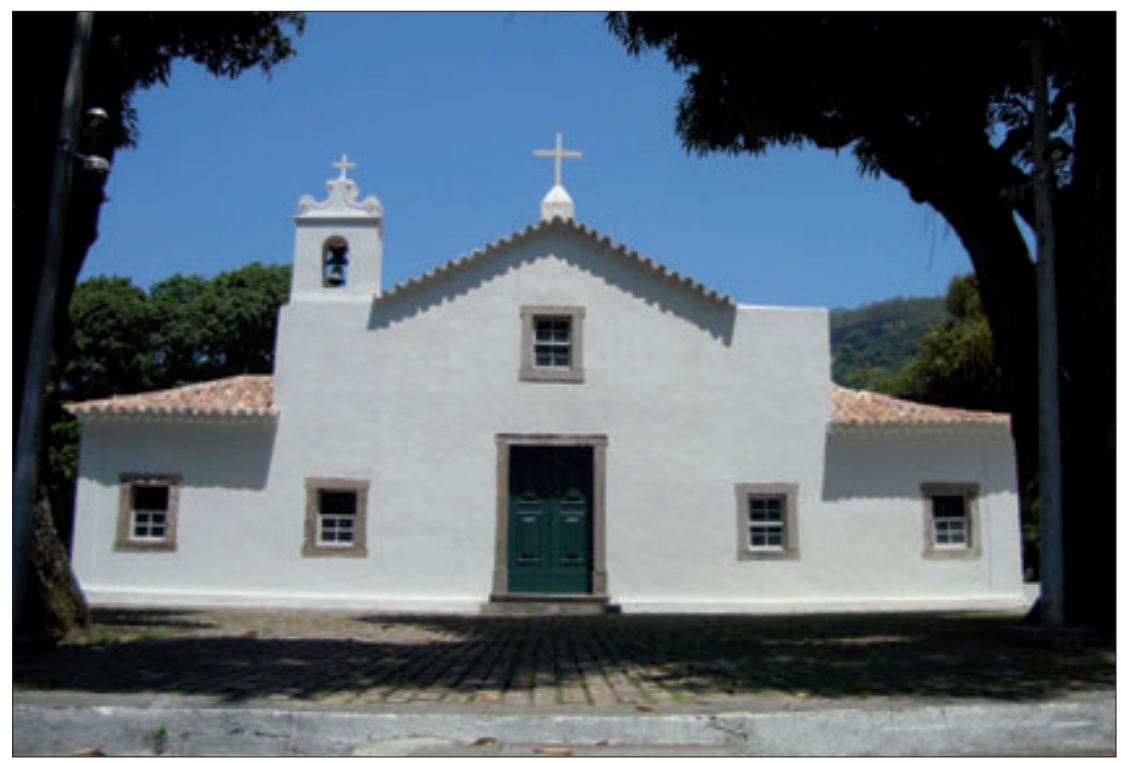

Fig. 3 Igreja de São Francisco Xavier, Niterói, 2009. 
estará presente nas chamadas cartas patrimoniais, documentos internacionais que pretendem ser normativas para a atuação de restauro. Se analisarmos os principais documentos internacionais veremos que houve sempre uma preponderância no sentido de pensar os monumentos arquitetónicos como resultado das diferentes adições feitas ao longo da sua história, em detrimento da ideia da busca de uma originalidade perdida. O documento da Sociedade das Nações, em Atenas, em 1931, propunha "que se respeite a obra histórica e artística do passado, sem prejudicar o estilo de nenhuma época" (Cury, 2000: 13). Em 1964, aquela que até os dias atuais é considerada a principal referência internacional para a disciplina do restauro, a Carta internacional sobre a conservação e restauro de monumentos e sítios, denominada Carta de Veneza, propõe a ampliação do conceito de monumento histórico, passando da arquitetura erudita para os sítios urbanos e rurais. Defende a inseparabilidade entre matéria e significado "o monumento é inseparável da história de que é testemunho" (Idem: 93). Reafirma a importância da história na compreensão dos monumentos arquitetónicos, "as contribuições válidas de todas as épocas para a edificação do monumento devem ser respeitadas, visto que a unidade de estilo não é a finalidade a alcançar no curso de uma restauração" (Ibidem: 93). A Carta de Veneza considera que não só a arquitetura erudita deve ser objeto da proteção patrimonial, mas também aquela chamada de vernacular, as obras modestas que registram a linguagem arquitetónica das diferentes culturas. A arquitetura vernacular tem um papel fundamental na compreensão do património dos países de língua portuguesa. No Brasil desde a criação do Serviço do Patrimônio Histórico e Artístico Nacional a arquitetura que expressava a linguagem do povo foi considerada como objeto de proteção. A ideia de uma norma generalizante presente nos diversos textos produzidos nos encontros internacionais de especialistas de restauro e conservação (Lopes e Brito, 2014), contraria a compreensão do restauro como um ato cultural. 


\section{Lembrar e inventar: o restauro na história da arquitetura}

O restauro é uma forma de reinterpretação do passado através da consolidação de uma determinada imagem arquitetónica das construções. Portanto todo restauro é uma recriação. A história da arquitetura escrita a partir do século XIX é devedora das informações que os processos de restauro e conservação trouxeram à luz a partir desse mesmo período.

Os monumentos do património edificado são os testemunhos que alimentam a memória coletiva dos povos. A conservação do seu suporte material e o restauro da sua imagem são os processos que reavivam as lembranças neles contidas. Ora é necessário aqui prevenir que não podemos lembrar sem inventar. A construção de nossas memórias individuais e coletivas é devedora da invenção.

A experiência de proteção do património edificado teve desde o seu início a necessidade da imediata restauração dos edifícios. Uma considerável parte desse acervo edificado encontrava-se descaracterizada por modificações sucessivas, tendo a proteção visado não só a sua preservação mas também o seu restauro. No caso brasileiro, e ele não é único nesse sentido, vários eram os problemas implicados nessa ação e poucos eram os estudos sobre os sistemas construtivos tradicionais utilizados no território brasileiro e sobre a linguagem arquitetónica colonial, além de raras serem as imagens documentais das nossas cidades anteriores ao século XIX. O esforço inicial foi o do desenvolvimento das pesquisas que preenchessem essas lacunas. Seriam identificadas características comuns dos diferentes programas arquitetónicos - casas de câmara e cadeia, sedes de engenho, igrejas conventuais, etc. - das diferentes regiões - as minas gerais, a região do açúcar em Pernambuco, o recôncavo baiano, a guanabara, o planalto paulista, etc. - e dos diferentes períodos - casas dos séculos XVI e XVII, casas do XVIII, casas de fins do XVIII e começo do XIX, casas de meados do XIX. O restauro então era, via 
de regra, resultado das informações desses estudos e da análise dos monumentos, através do trabalho de prospeção de paredes, pisos e tetos. O objetivo, então, era o de recuperar a feição colonial dos monumentos, o que naquele momento inicial podia ter dois tipos de solução: ou a recuperação fidedigna de uma determinada época do edifício, quando as prospeções e a documentação assim o permitiam; ou a recuperação de uma imagem idealizada daquele edifício a partir da analogia com edifícios similares.

Essas obras restauradas iriam subsidiar, às vezes de modo bastante acrítico, a história da arquitetura brasileira. Um caso exemplar dessa relação entre restauro e história é o da capela do Padre Faria, em Ouro Preto, Minas Gerais. Considerada um dos primeiros templos erguido naquela região, encontrava-se em meados do século XX com formas provavelmente adquiridas em inícios do XIX. A opção de garantir a imagem idealizada dos primeiros templos da ocupação das Minas Gerais vai dar o aspeto atual da igreja e seria incorporado, apenas dois anos terminado o seu restauro, como exemplo da tipologia inicial das fachadas de capelas da região no meticuloso trabalho de Paulo Santos, A arquitetura religiosa de Ouro Preto (Santos, 1951). O restauro realizado a partir de 1945 teve como principais modificações a demolição do corpo lateral onde se encontrava a escada para o púlpito e a transformação do frontão barroco numa empena simples com arremate de beira e bica. O modelo para o novo frontão arcaico é inegavelmente a capela de São João Batista, que era considerada a mais antiga de Ouro Preto e apresentava essa mesma solução. Toda a discussão ocorrerá a partir da descoberta no início de 1945, pelo representante do Serviço do Patrimônio, Sylvio de Vasconcellos, de uma foto antiga do século XIX (Fig. 4) da capela na qual o corpo lateral era apenas um telheiro e as janelas do coro eram em verga reta, ao invés do arco abatido que apresentava no momento. No edifício haviam fragmentos dos antigos cunhais nas fachadas laterais, indicando ser a fachada frontal atual um avanço 


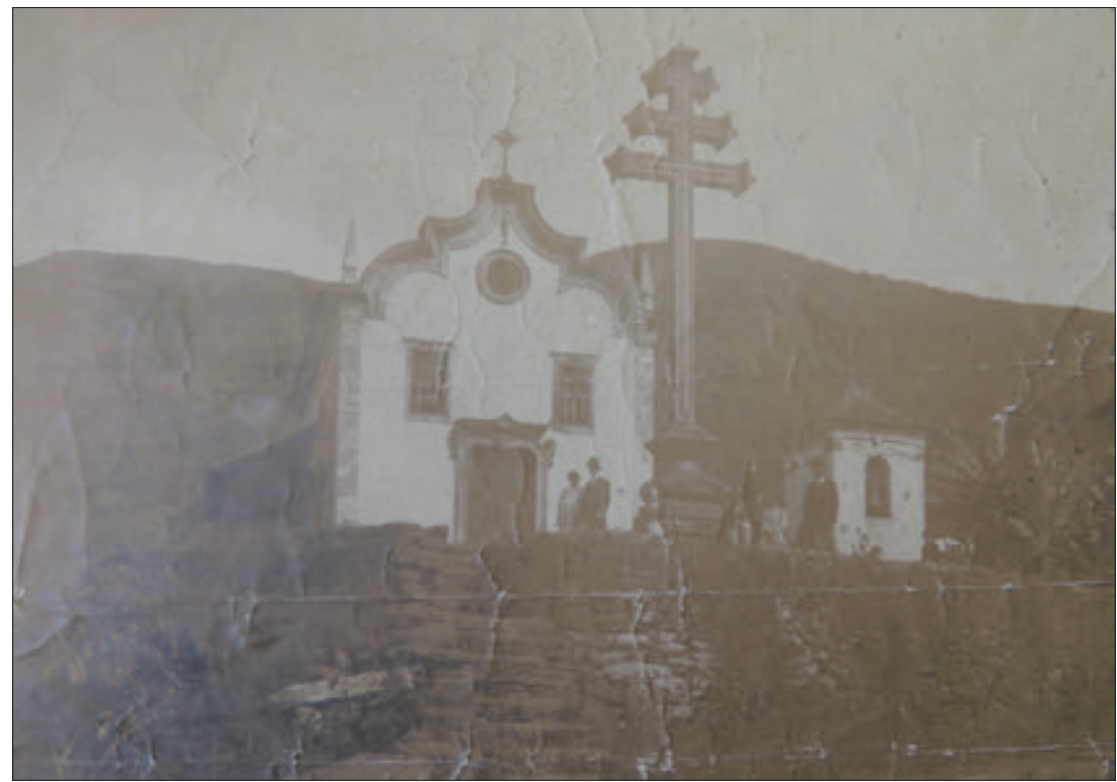

Fig. 4 Capela do Padre Faria, Ouro Preto, Minas Gerais, sem data, Arquivo Regional do IPHAN, Minas Gerais.

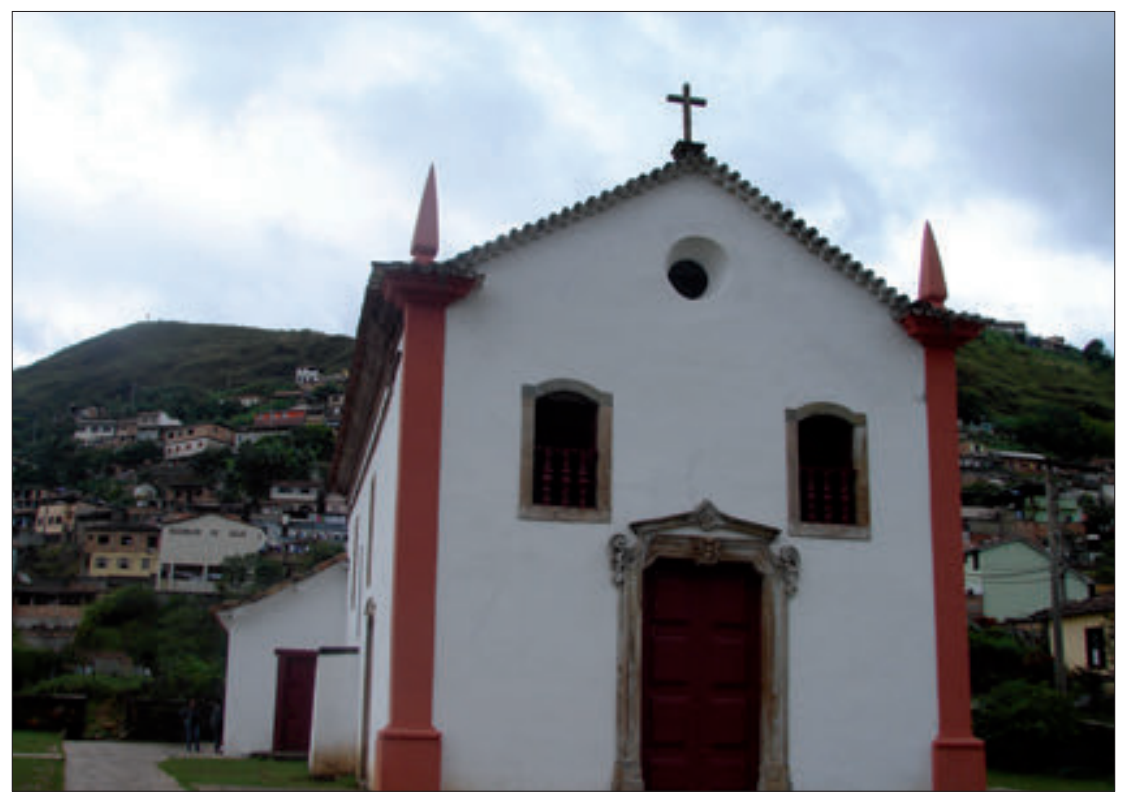

Fig. 5 Capela do Padre Faria, Ouro Preto, Minas Gerais, 2012. 
de 1,50 metros feito para a criação/ampliação do coro. Sylvio de Vasconcellos sustentava que a foto retratava a fachada antes da ampliação do corpo da nave. Lucio Costa, então um dos diretores do Serviço do Patrimônio, acreditava que a foto, por já apresentar o frontão barroco, corresponderia a um período posterior ao avanço feito. $\mathrm{O}$ argumento de Lucio Costa estava baseado no fato de que as cimalhas laterais existentes no edifício eram de pedra, e portanto, o mesmo deveria ocorrer originalmente em relação aos arremates da fachada principal, enquanto cunhais e o frontão na fotografia antiga eram nitidamente em massa pintada a escaiola.

A demolição do corpo lateral ocorreu claramente em razão da foto encontrada por Sylvio de Vasconcelos, já o frontão foi nitidamente uma opção tipológica, contrariando a regra geral utilizada pelo Serviço do Patrimônio nos seus anos iniciais de restauro histórico com as recomposições sempre baseadas na existência de documentação iconográfica. A Capela do Padre Faria (fig. 5), pela sua antiguidade, vai reproduzir o modelo da sua contemporânea capela de São João Batista. O arremate do frontão em beira e bica é cópia da capela de São João (Fig. 6). As transformações feitas pelo restauro da capela seriam imediatamente assimiladas pela história da arquitetura. Paulo Santos ao escrever em 1951 o livro A Arquitetura Religiosa em Ouro Preto, apresenta a igreja do Rosário de Padre Faria com a configuração da fachada recém feita, identificando como parte inicial de um processo tipológico de transformação das fachadas das capelas mineiras (idem: 159). Não menciona em momento algum que a configuração do frontão reto era resultado de uma operação recente de restauro, que retirou as curvas e contracurvas do frontão de gosto barroco que adornava a igreja na época do seu restauro.

Além do pioneiro trabalho de Paulo Santos, teremos também no caso brasileiro os textos de Lucio Costa (Costa, 1995) e Sylvio de Vasconcellos (Vasconcellos, 1979) que buscam criar uma espécie de síntese generalizante das características da arquitetura colonial 


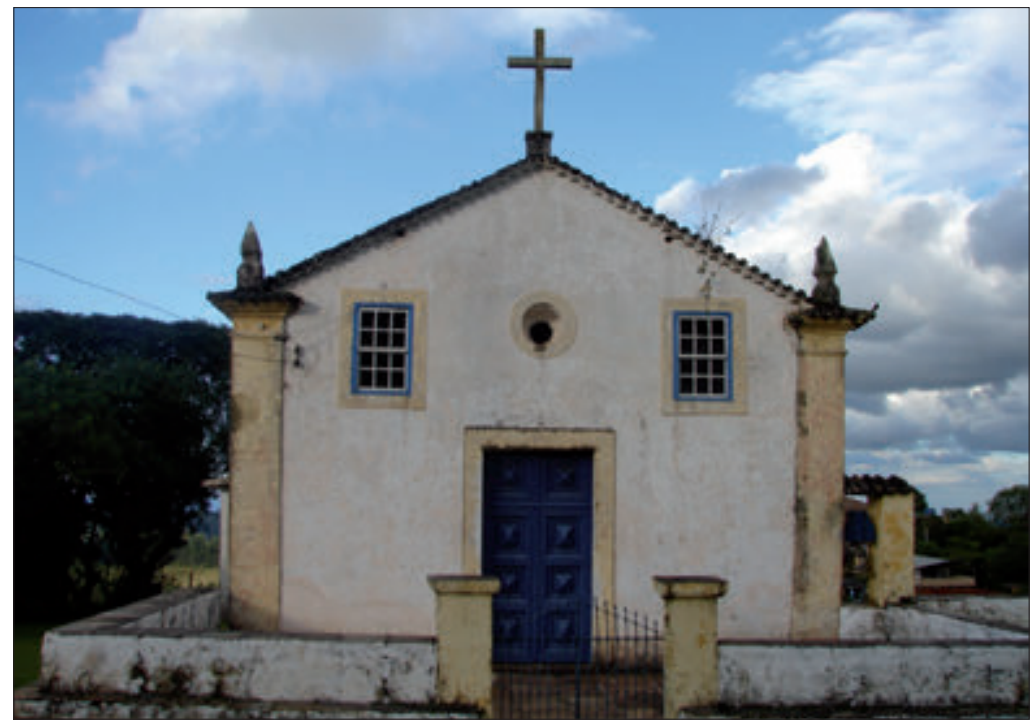

Fig. 6 Capela de São João Batista, Ouro Preto, Minas Gerais, 2012.

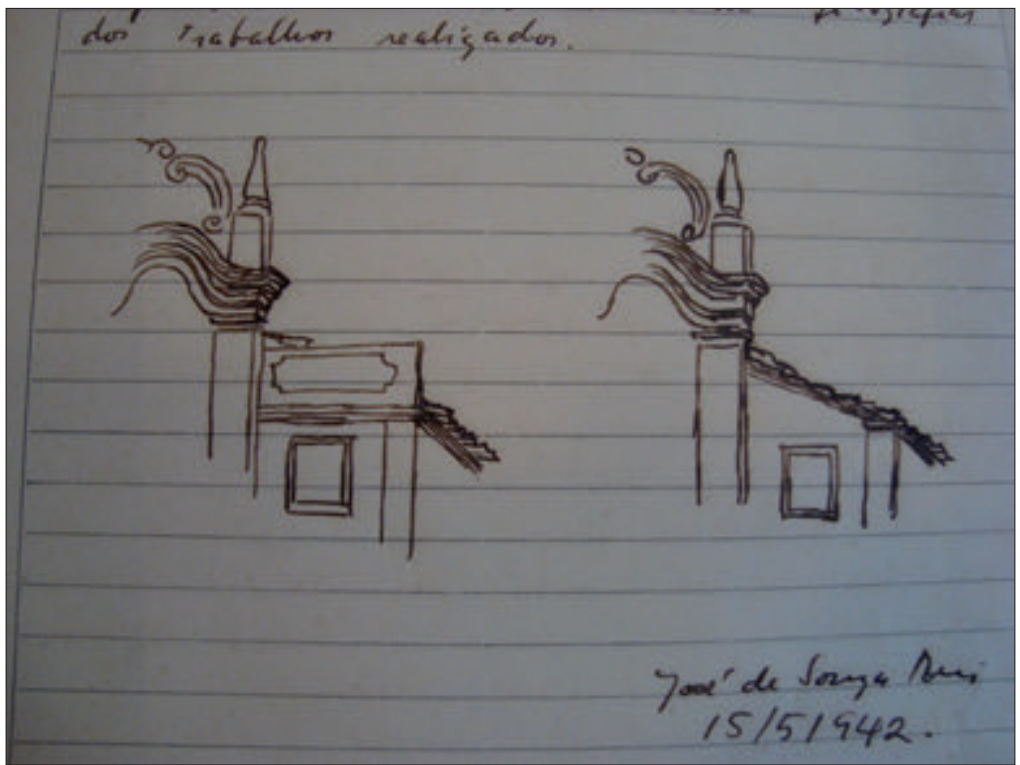

Fig. 7 Estudos para substituição de platibanda lateral na Igreja de São Cosme e Damiao, Igaraçu, Pernambuco, Arquivo Central IPHAN. 
brasileira. No caso de Lucio Costa essa busca é permeada pela preocupação de caracterizar regionalmente as situações identificadas, enquanto Sylvio de Vasconcellos quando recorre à identificação regional de um dado elemento, é para confirmar a ideia de uma linguagem arquitetônica comum.

A generalização proposta por Sylvio de Vasconcellos era operada nas ações de restauro pelos vários técnicos do Património. Exemplo disso é a solução proposta por José de Souza Reis para o arremate da empena do corpo lateral da Igreja de São Cosme e Damião, em Igarassu, Pernambuco, que devia ser, na sua opinião, uma espécie de cornija rampante simplificada, solução esta que ele já havia proposto para a igreja jesuítica de Nossa Senhora do Rosário em Embu, São Paulo, a partir do desenho da fachada de outra igreja paulista, a de Nossa Senhora da Escada, em Guararema. Para Reis a solução utilizada em São Paulo poderia perfeitamente ser transplantada para Pernambuco (Fig. 7). Apesar do valor que tiveram e ainda têm esses estudos iniciais, é necessário reconhecer a urgência com que deve ser disseminada a prática de novos estudos que decodifiquem e compreendam a informação contida nas arquiteturas e cidades do período colonial brasileiro.

\section{Origem ou influência: a circulação de formas nos territórios de língua portuguesa}

Falarmos de um património arquitetónico comum aos países de língua portuguesa implica discutir a questão da origem ou da influência na configuração deste património espalhado pelos continentes. No Brasil a questão se enunciava quando da criação do SPHAN numa relação de origem, isto é, na procura de identificar as formas com que se expressava a linguagem arquitetónica do nosso passado colonial, com a identificação de possíveis matrizes em Portugal. 
Lucio Costa apresentará a questão em outros termos a partir de uma viagem de estudos que realizou em 1948 por Portugal. O objetivo da viagem fora o de buscar as origens e modelos da arquitetura colonial brasileira na metrópole. O resultado dessa viagem, registrado em um relatório, é apresentado por ele como um aparente fracasso. "Fracasso" no intento de identificar matrizes e suas derivações no contexto da arquitetura luso-brasileira, pois na realidade, segundo ele, influência e autonomia conviviam e se misturavam. E mais importante ainda é que essa influência era mútua.

Cabe pois concluir que a importância adquirida pelo desenvolvimento da arquitetura portuguesa na colônia foi de tal ordem e se processou de forma tão irregular e especial que as suas manifestações não podem ser consideradas apenas como decorrência de determinados regionalismos metropolitanos, mas como um complexo em cujo todo intervieram variadas filiações e caprichosas interferências retificadoras ou desintegradoras, e que nas várias províncias brasileiras a arquitetura portuguesa desenvolveu-se algumas vezes idêntica aos padrões metropolitanos, outras vezes diferente, da mesma forma como se desenvolveu igual ou diferenciada nas províncias do próprio reino, cada qual portuguesa à sua moda; e as nossas modas de o ser - pois, que houve várias -, foram sempre brasileiras. Assim, portanto, mesmo quando o estilo é o mesmo, como ocorre no caso das igrejas do mosteiro de S. Bento e da Ordem Terceira de São Francisco, no Rio de Janeiro, ou do convento de São Francisco e do antigo Colégio dos Jesuítas, na Bahia, os monumentos devem ser considerados originais, pois tem personalidade própria, embora concebidos e executados ao gosto e segundo os preceitos reinóis então correntes, e como tal são tão autênticos e legítimos como os de lá.

Por onde se vê, finalmente, que tanto é incorreta a atitude dos que estão sempre a pretender descobrir na arquitetura colonial brasileira a "copia" ou a "imitação" de modelos portugueses todas as vezes que aquela semelhança se torna mais viva, como a dos que atribuem a maior 
parte senão todas as suas características a imposições de ordem funcional ou mesológica. Pois que, de uma parte, os portugueses estavam aqui na sua própria casa e, portanto, ao idealizarem e construírem a morada ou a capela à sua maneira não estavam a copiar coisa alguma senão a fazer muito naturalmente a única coisa que de fato lhes cabia, da mesma forma como ao falar português não arremedavam ninguém, - falavam a própria língua.

Enquanto, por outro lado, se nos países europeus a formação das várias modalidades de arquitetura regional se processou passo a passo, como decorrência lógica da função a que se destinavam e das imposições do meio físico e social, nos países americanos o processo foi inverso: os colonizadores trouxeram soluções já prontas que se tiveram de ajustar como roupa feita - ou, para ser-se mais verdadeiro, de "meia-confecção", como agora se diz -, ao corpo de nova terra. (Costa, 1995: 456).

O projeto da viagem de 1948 é retomado quatro anos depois numa segunda viagem a Portugal. Desta viagem ficou um conjunto de desenhos conservados em cinco blocos que registram a ideia da autonomia e a mútua influência, e foram recentemente publicados (Pessôa e Costa, 2012). As escolhas das arquiteturas desenhadas estão carregadas dessa visão, bem como das anotações à margem dos desenhos, tais como a bela igreja mineira dos franciscanos em Viseu, ou o baldaquino baiano da igreja de bom Jesus de Braga. Apesar disso, a hipótese da autonomia e mútua influência entre a arte da colónia e a do reino, levantada por Lucio Costa, ia contra a corrente do pensamento de história da arte dominante no período, permanecendo quase absolutamente inédita, mesmo dentro do próprio Instituto do Patrimônio Histórico e Artístico Nacional. Um bom exemplo disso foi quando eu trabalhava no IPHAN na década de 1980 e fui encarregado de estudar para redigir o parecer de tombamento de uma igreja do século XVIII em Minas Gerais. O primeiro conselho recebido na ocasião, foi o de procurar identi- 
ficar em Portugal uma igreja que tivesse possivelmente servido de modelo ao caso que estava estudando. A dialética entre autonomia e mutua influência proposta no relatório de 1948 que iria conduzir o olhar de Lucio Costa nos riscos feitos da arquitetura portuguesa em 1952, ainda está a pedir muitos estudos que fundamentem hipóteses, identifiquem tipologias e principalmente estabeleçam os laços de circulação entre as arquiteturas desse nosso universo de territórios de língua portuguesa.

Alguns tipos arquitetónicos que afirmam a autonomia defendida por Lucio Costa foram objeto de estudos, como as casas de taipa de pilão do planalto paulista nos séculos XVII e XVIII, com sua característica varanda entalada, ou os engenhos do século XVIII na baía de Guanabara, com suas varandas em colunas toscanas e o grande telhado quadrado (Fig. 8). Nestes exemplos a adaptação das soluções trazidas de Portugal vai resultar numa nova criação arquitetónica. Noutros casos pode-se identificar processos de circulação que ainda pedem estudos mais aprofundados, como os engenhos pernambucanos do século XVII, registrados pelos pintores holandeses, especialmente Franz Post, que estiveram na região na época. Não existem mais exemplares deste tipo de arquitetura em Pernambuco, mas são inegáveis as semelhanças entre suas formas e um certo tipo de arquitetura rural do Norte de Portugal, especialmente do Minho. Teriam ido do Minho para Pernambuco, ou o processo ter-se-ia dado de maneira oposta, levando a solução pernambucana do Novo Mundo para a Europa?

Desse segundo movimento há casos já identificados como as igrejas em Portugal com varandas na frente e laterais (Fig. 9) que, segundo Kubler, seriam originadas das igrejas rurais alpendradas do nordeste brasileiro (Kubler, 1988: 164). A circulação de formas não se dava somente entre Portugal e os seus antigos territórios de além mar. Entre Ásia, África e Brasil a circulação de formas também seria fundamental para a consolidação da linguagem arquitetónica 


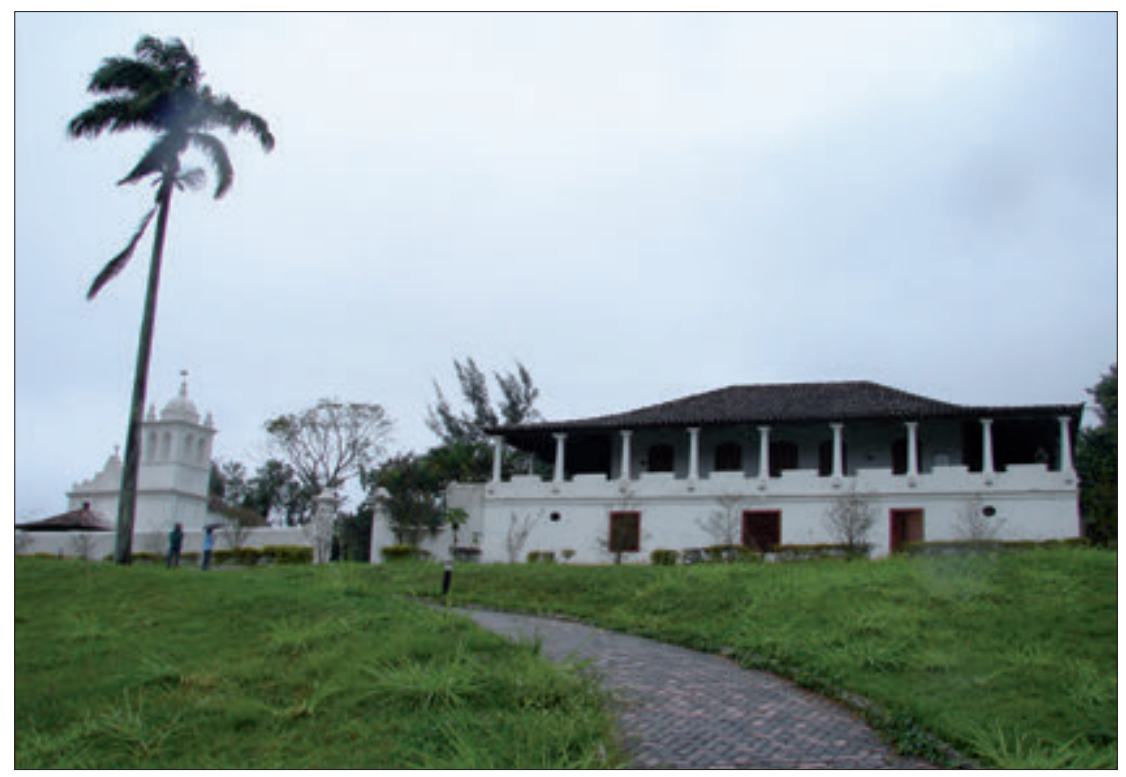

Fig. 8 Fazenda Colubandê, São Gonçalo, Rio de Janeiro, 2012.

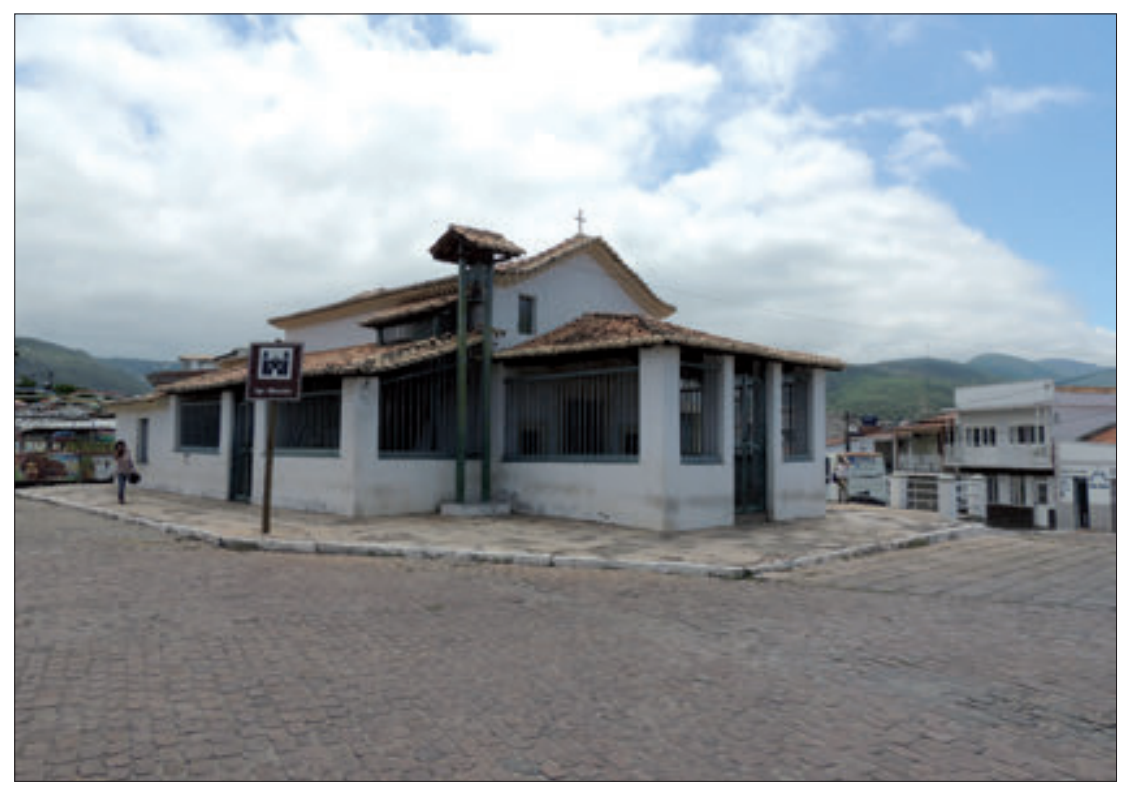

Fig. 9 Igreja Missão, Jacobina, Bahia, 2014. 
destes territórios. Alguns casos ainda são hipóteses que precisam de estudos mais aprofundados que possam verificar o quanto houve de influência, por exemplo, nas formas dos grandes cruzeiros de pedra dos conventos franciscanos do nordeste brasileiro e das igrejas do sul da Índia. Outros, como as mesquitas "brasileiras" do Benin, têm sido objeto de interesse dos estudiosos no Brasil e na África, e documentam o retorno de africanos e seus descendentes no século XIX, trazendo consigo a linguagem da arquitetura baiana do período (Fig. 10).

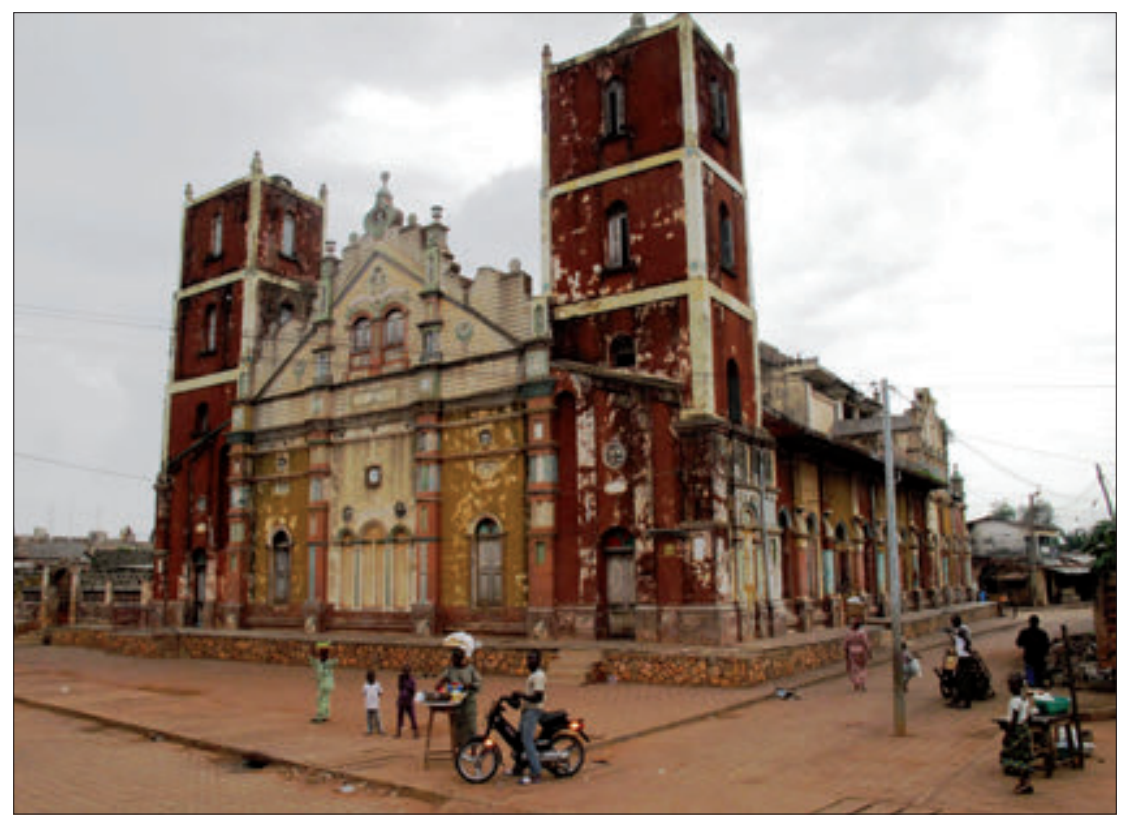

Fig. 10 Grande Mesquita. Porto Novo, Benin, 2012. Foto Milton Guran.

\section{O legado desse património no mundo}

A valorização da arquitetura colonial inicia-se no Brasil com a criação do SPHAN. Os primeiros monumentos a serem protegidos e os estudos decorrentes desta proteção, centravam a sua abor- 
dagem no valor plástico da arquitetura popular luso-brasileira, e se contrapunham ao pensamento de arte dominante na época no Brasil, para o qual os portugueses "trouxeram de suas aldeias o tipo desproporcionado e sombrio das velhas construções" (Costa, 1937: 31). A arquitetura popular portuguesa tinha para o SPHAN muito maior interesse do que a arquitetura erudita. Como afirma Lucio Costa no seu "Documentação necessária", "sem o ar afetado e por vezes pedante de quando se apura, aí, à vontade, ela se desenvolve naturalmente, adivinhando-se na justeza das proporções e na ausência de "make up", uma saúde plástica perfeita." (Costa, idem).

Outro aspeto da valorização desse legado é o da urbanística. Sintomático disto é o expressivo conjunto de cidades de fundação portuguesa elevadas à categoria de património da humanidade. No Brasil, numa ação pioneira do SPHAN, um conjunto de cidades fundadas no século XVIII em Minas Gerais foi protegido em 1938 Ouro Preto, Mariana, São João del Rey, Tiradentes, Serro, Diamantina - através da inscrição no Livro do Tombo das Belas Artes. A prática de conservação destes sítios históricos urbanos propõe o desafio, ainda não devidamente enfrentado, de abordar a relação entre os monumentos e a arquitetura vernacular e o papel desta última para a conceituação dos centros históricos. A ideia de vernáculo serve aqui para definirmos a arquitetura civil urbana em um contexto semelhante à relação que as palavras têm com a língua, no nosso caso, a cidade. Os indivíduos arquitetónicos são as palavras que articulam a língua geral da cidade.

A uniformidade tipológica da arquitetura civil luso-brasileira, referida em textos históricos como as cartas de Vauthier (Vauthier, 1943) ou nos trabalhos de historiadores como Robert Smith (Smith, 1969) ou Nestor Goulart Reis (Reis, 1995), nos faria prevenir contra um uso abusivo do termo vernacular, pensado em sua aceção original de regionalismo, e nos levaria a aproximar-nos dos termos arquitetura menor ou arquitetura popular, menos usados no Brasil. 
Essa linguagem precisa de novos estudos que contribuam para o conhecimento da história das formas arquitetónicas, sua circulação e os processos de mútua influência, revendo os discursos de matrizes arquitetónicas e da transmissão destas da metrópole para os outros territórios, e repensando os processos de circulação dos vocábulos arquitetónicos no conjunto de territórios da língua portuguesa. É essa linguagem comum das nossas formas arquitetónicas, e dos espaços e traçados das nossas cidades que fazem delas, apesar de acrescentadas, modificadas e transformadas em cada uma das regiões, portanto, criações locais sempre singulares, parecerem-nos absolutamente familiares. O que permite a cada um de nós, olhar o outro, seja o Brasil, Portugal, Cabo Verde, Moçambique, etc, com olhos da sua terra. Descobrindo em cada um dos sítios sinais do seu próprio país.

\section{Referências bibliográficas}

BENJAMIN, Walter (2014), A obra de arte na era da sua reprodutibilidade técnica. Porto Alegre: L\&PM Editores.

BOITO, Camillo (1989), Il nuovo e l'antico in architettura. Milão: Jaca Book. CARBONARA, Giovanni (2000), Avvicinamento al restauro. Napoles: Liguori Editore.

CARITA, Helder (2008), Arquitectura Indo-Portuguesa na região de Cochim e Kerala. Lisboa: Transbooks.

CARSAlADE, Flavio de Lemos (2014), A pedra e o tempo: arquitetura como patrimônio cultural. Belo Horizonte: Editora UFMG.

CHOAY Françoise (2001), A alegoria do patrimônio. São Paulo: Estação Liberdade.

COSTA, Lucio (1937), "Documentação Necessária" in RPHAN, n. ${ }^{\circ} 1$, Rio de Janeiro: Ministério da Educação e Saude, 31-39. 
CostA, Lucio (1995), Lucio Costa: registro de uma vivência. São Paulo: Empresa das Artes.

CURY, Isabelle (2000), Cartas Patrimoniais. Rio de Janeiro: IPHAN.

KUBLER, George (1988), A arquitetura portuguesa chã. Entre as Especiarias e os Diamantes, 1521-1706. Lisboa: Vega.

LEVI STRAUSs, Claude (2009), "Claude Lévi-Strauss por Françoise Héritier" in Estudos Avançados, vol. 23, n. 67, São Paulo.

LOPES, Flávio e CORREIA, Miguel Brito (2014), Património cultural: critérios e normas internacionais de proteção. Lisboa: Livros Horizonte.

PEssôA, José; COSTA, Maria Elisa (2012), Bloquinhos de Portugal: a arquitetura portuguesa no traço de Lucio Costa. Rio de Janeiro: Funarte.

REIS, Nestor Goulart (1995), Quadro da arquitetura no Brasil. São Paulo: Perspectiva.

SANTOS, Paulo (1951), A arquitetura religiosa em Ouro Preto. Rio de Janeiro: Livraria Kosmos.

SMITH, Robert (1969), "Arquitetura civil do período colonial”, in RPHAN, n. ${ }^{\circ}$ 17. Rio de Janeiro: Ministério da Educação e Cultura, 27-125.

VASCONCELlOS, Sylvio (1979), Arquitetura no Brasil: sistemas construtivos. Belo Horizonte: UFMG.

VAUTHIER, Louis Léger (1943), "Casas de residência no Brasil”, in RPHAN, n. ${ }^{\circ}$ 7. Rio de Janeiro: Ministério da Educação e Saude, 128-208. 
(Página deixada propositadamente em branco) 


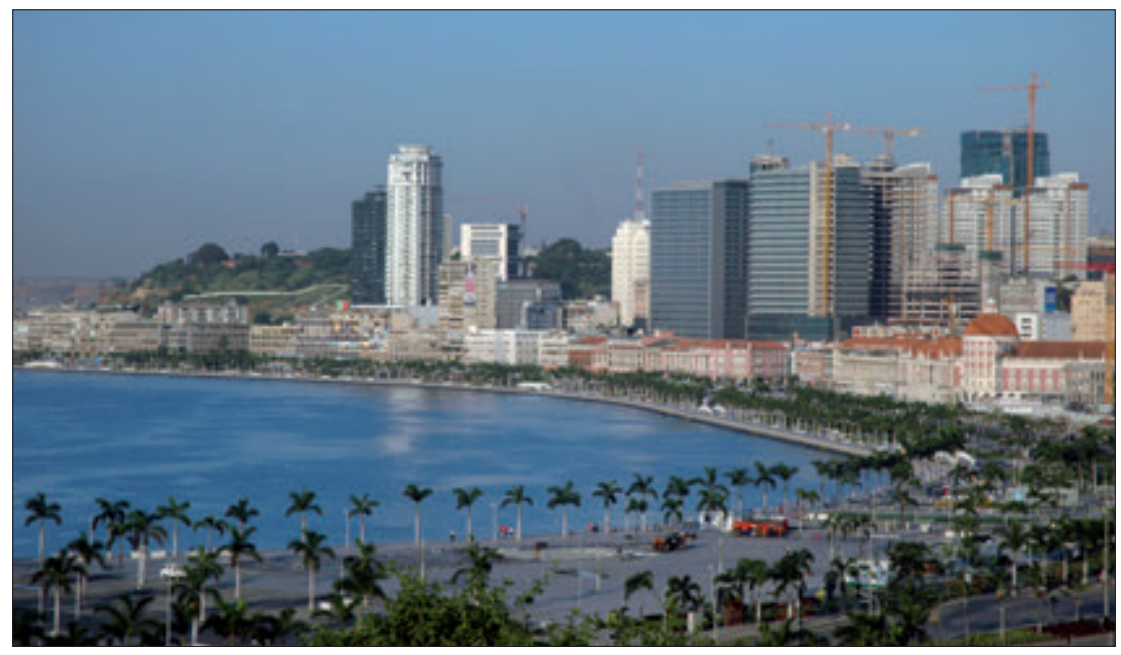

Fig. 1 Paisagem urbana da baía de Luanda, 2014.

\section{Fascínio}

Tal como o território que integra, a cidade é resultado da interação dos grupos humanos que a compõem (comunidades) com o ambiente físico no qual as suas vidas se desenrolam (habitats). Se ontológica e conceptualmente pessoas e espaço físico são itens de natureza absolutamente diversa, na sua discussão epistemológica são indissociáveis. Basta invocar o quanto as origem, etimologia e semiologia da palavra cidade se baseiam no reconhecimento da organização da diversidade, complexidade e complementaridade 
funcionais de uma comunidade, a polis. O que desde logo não só nos conduz à natureza política da cidade, como também a invocar a pulsão gregária que leva o ser humano a viver em grupos além do seu ciclo familiar, ou seja, e já num estádio avançado, ser cidadão de uma cidade e nela e para ela desempenhar e regular o exercício dos seus receios, anseios e poder. Se há coisa que a história da humanidade nos permite afirmar com segurança, é que só as culturas urbanas perseveram.

Foi, contudo, uma tendência de afirmação extraordinariamente lenta, pois só em 2008 mais de metade da população mundial passou a ser urbana, embora quase $1 / 4 \mathrm{em}$ favelas. $\mathrm{O}$ fenómeno da urbanização global é de afirmação exponencial, pois se nas primeiras décadas de Oitocentos esse rácio era de apenas $2 \%$ e $10 \%$ um século depois, as projeções atuais apontam para que dentro de 15 anos atinja os $60 \%$, 70\% em 2050, ${ }^{1}$ o que constituirá o confirmar da condenação (Rossa, 2002-2013) definitiva da humanidade à situação urbana. Será um dado particularmente expressivo ao coincidir com as décadas em que também se deverá confirmar a desaceleração global, já em curso, do crescimento demográfico. Esses indicadores globais - urbanização e abrandamento demográfico - seguem agora na Ásia e em África o padrão já há algum tempo confirmado nas regiões-comunidades do globo mais desenvolvidas, constituindo-se, também assim, em indicadores de desenvolvimento, pelo menos de acordo com os descritores e padrões comummente aceites para tal, o que mais uma vez confirma a cidade como objetivo da humanidade, e também as enormes assimetrias globais em termos de desenvolvimento e urbanidade.

Uma assimetria significativa é constituída pelo facto de parte desse percurso da humanidade para a cidade, por vezes numa dramática

${ }^{1}$ Estes dados encontram-se disponíveis em muitas publicações e sítios em linha, sendo contudo centrais os que a Divisão de População da ONU vai atualizando no endereço: http://www.un.org/en/development/desa/population/ 
procura de refúgio e condições de sobrevivência, estar a ser feito com a explosão de grandes concentrações urbanas (metrópoles, conurbações, mega e metapolis, etc.), as quais pela sua dimensão, policentrismo, aglutinação em sprawl sobre núcleos preexistentes, diluição da perceção dos limites e das identidades desafiam o conceito de cidade revisto e consolidado para a era industrial, entretanto finada. Não se trata da post-city age pioneiramente proposta por Melvin Webber (1920-2006) (Webber, 1968) ou da substituição das cidades por "um mundo urbanizado sem" elas, como questionou Manuel Castells (1942-) (Castells, 2004), pois, recorrendo agora a François Ascher (1946-2009), "o fim das cidades não está na ordem do dia" (Ascher, 2001)² e a história do urbanismo tem demonstrado como na cidade, além das pessoas nada se perde, tudo se regista e decanta em camadas de palimpsesto (Corboz, 2000 e 2001) e relações de hipertextualidade-hiperforma-hipercidade, que diacrónica, sincrónica e resilientemente integram a cidade contemporânea (Rossa, 2002-2013: 1. ${ }^{a}$ parte).

Trata-se de uma alteração de paradigma determinado pelas novas dinâmicas da terceira modernidade emergente, a segunda revolução nas formas de transporte e armazenamento de bens, informação e pessoas. ${ }^{3}$ Todavia, a dinâmica para a concentração urbana é paradoxal, pois ocorre quando se esperava que a facilidade de comunicação gerasse a dispersão, até aliciasse uma neoruralização cuja

2 Trata-se, mais precisamente, do subtítulo na edição original: Les nouveaux principes de l'urbanisme. La fin des villes n'est pas à l'ordre du jour. Todo o título é uma clara oposição a proposições como, por exemplo, as de Webber ou as assumidamente utópicas de William J. Mitchell (1944-2010) (Mitchell, 1995 e 1999). $\mathrm{Na}$ última destas o prólogo tem precisamente como título "Réquiem por la ciudad".

3 Aquilo que Ascher designa "sistema BIP", precisamente de bens, informação e pessoas (Ascher, 2001). Segundo ele, é nas transições estruturais entre tempos que claramente se identificam mudanças, também estruturais, nesse sistema. Ocorreu com a passagem da medievalidade para a $1 .^{a}$ idade moderna; com o período das revoluções (industrial, francesa, das independências americanas, etc.) e a consequente instalação da $2 .^{a}$ modernidade; e está a ocorrer agora sem que ainda possamos ter uma perceção definitiva das suas caraterísticas e implicações. 
urbanidade em rede seria digitalmente garantida (Mitchell, 1995 e 1999). A verdade é que a tendência da agregação acentuou-se, com densidades e formas diversas, é certo, mas conglomerada. O desafio atual é, precisamente, encontrar a forma de constituir esse todo urbano como um sistema, fazendo-o evoluir, mais uma vez, ${ }^{4}$ do estádio protoarcaico de aglomeração, e com isso florescer uma nova conceptualização de cidade. Urge fazer com que o urbano fragmentário de hoje volte a ser, em moldes novos e ajustados, o ecossistema ideal para a humanidade. A história e o património, uma cultura do território, podem ajudar.

Confirma-se, pois, que só num ambiente de cidade, com a assunção de uma determinada identidade urbana - uma cultura de território - o ser humano realiza em plenitude as capacidades com que a natureza o distinguiu das demais espécies vivas conhecidas, as quais, entre muitas outras coisas, o conduzem à produção de conhecimento e, também, ao desenvolvimento cultural, um dos quatro pilares da sustentabilidade. A cultura e o conhecimento têm como lugar de enunciação esmagadoramente preferencial a cidade, sendo a partir dela que olhamos e refletimos sobre o que nos rodeia, como se e de certa forma a humanidade, além de ter construído a cidade como seu habitat natural, também o tenha feito para poder observar o resto, os $97 \%$ de superfície terrestre que existem além dela, mas também o cosmos. Observação que é necessariamente exercício de poder com vista ao conhecimento e organização desses territórios desurbanizados, mas crescentemente humanizados, em função e complemento da polis. Numa integração crescente, os sistemas territoriais e urbanos são cada vez mais indissociáveis e globais.

Mais ou menos densa, no bom e mau sentido, a cidade é assim cada vez mais concentração e capital de humanidade, um extraor-

${ }^{4}$ A passagem da cidade tardo-medieval para a do renascimento é um bom paralelo. 
dinário organismo vivo exigindo atenção correspondente sobre os mais variados aspetos da sua vitalidade e materialidade. Contudo, os esforços desenvolvidos nesse sentido nem sempre são conduzidos segundo a visão holística que a natureza da cidade impõe. É necessário fazê-lo segundo a visão de um todo que é impossível de abarcar, ou seja, no exercício da busca da utopia do conhecimento limite que cada investigador deve procurar dentro da sua especialidade. A complexidade do fenómeno de cidade é, pois, total, sendo interessante verificar como o próprio termo cidade se usa para nos referirmos a um caso ou ao todo. De facto e como fui sugerindo no parágrafo anterior, mais do que indissociáveis, território e cidade são um dos mais extraordinários holons (Koestler, 1967), ou seja, simultaneamente sistema em si e parte de sistemas. Só em visões parciais focadas nos sistemas territoriais e de cidade, mas que integrem uma ambição prospetiva sobre o sistema geral (o tal ecossistema), se podem construir plataformas narrativas para o seu entendimento e discussão. Talvez isso ajude a compreender a ancestral necessidade de fazer falar a cidade.

Basta refletir um pouco como evoluiu cumulativamente o próprio sistema de representação, a imagem simbólica da cidade e/ou de cada uma delas. Logo nas primeiras civilizações encontramos figurações quase abstratas que, no essencial, remetem para a ideia de limite muralhado e acessos, bem como para os conceitos de ordem e centralidade (cruz, círculo, quadrado) (Fig. 2), de entre as quais se impõe referir o caso especial das mandalas, onde energias do sagrado, terreno e cosmos confluem (Fig. 3). ${ }^{5}$ Surgem depois

5 No quinto capítulo, "The Parallels", da obra seminal de Joseph Rykwert (1926-) dedicada ao estudo do caso de Roma, é feita uma listagem e caracterização de formas equivalentes à mandala em outras culturas (Rykwert, 1963: 163-187). Noutra obra incontornável, Giorgio Muratore (1946-) dedicou-se a demonstrar a relevância da mística e simbolismo da cosmologia oriental na génese conceptual e formal da cidade moderna ocidental (Muratore, 1975). 

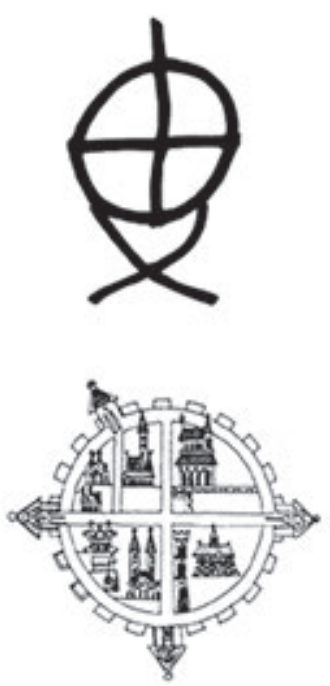
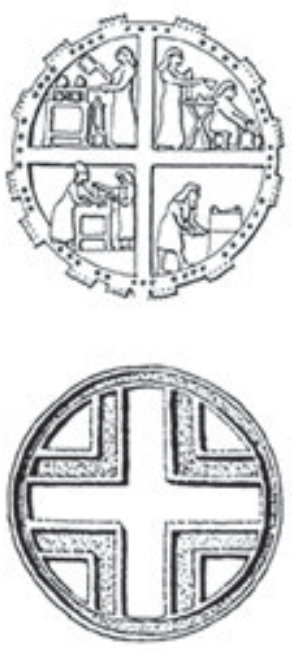

Fig. 2 Reprodução de quatro representações de cidade in Norman Crowe (1995), Nature and the Idea of a Man-Made World... Chicago: MIT Press. No sentido dos ponteiros do relógio, a contar do canto superior esquerdo: ideograma chinês (c. 1300-612 BC); baixo relevo assírio (palácio de Nimrud, c. 1600 BC); hieróglifo egípcio para cidade (c. 3110-2884 BC); desenho islandês da Jerusalém Celeste (séc. XIII).

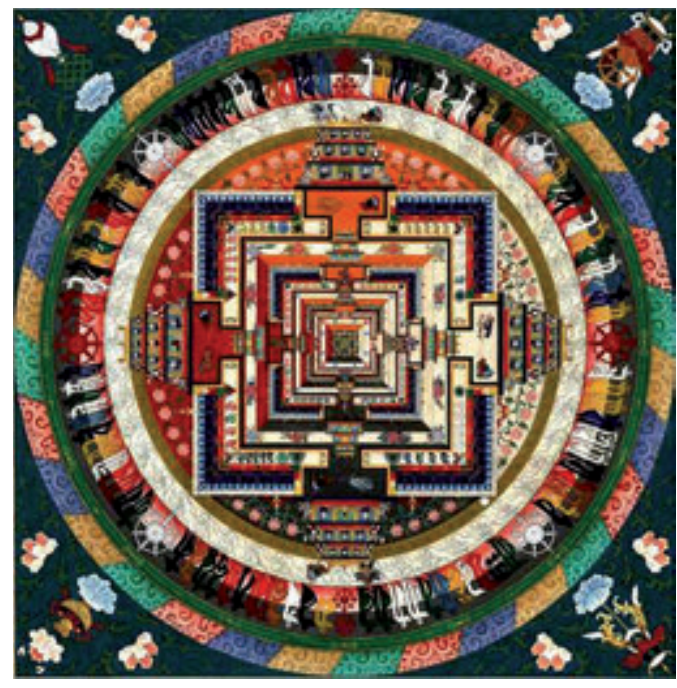

Fig. 3 Mandala budista de areia. 
alegorias antropomórficas lembrando as imagens dos deuses (Fig. 4), a par de brasões onde, uma vez mais, no coronel se vê a muralha que, consoante o número de torres, para alguns países, como Portugal, exprime o estatuto administrativo de freguesia, vila ou cidade. No escudo figura algo de invocativo, quase invariavelmente figurativo. Contudo, à medida que a capacidade de representação direta do real e a sua reprodução surgiram e evoluíram, as cidades passaram a também ser vistas em retratos das suas materialidade e espacialidade, tendo-se então constituído estereótipos e séries a partir deles, da xilogravura à fotografia tridimensional de hoje. ${ }^{6}$ Assim se faz o lento e ainda curto caminho para a leitura direta na cidade do que ela tem para dizer de si própria.

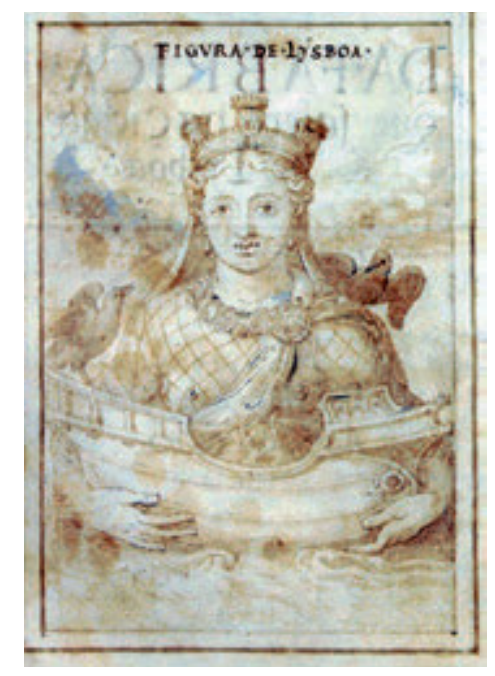

Fig. 4 "Figura de Lysboa". In Francisco d'Holanda (1571), Da fabrica que falece... Lisboa, Biblioteca Nacional da Ajuda.

${ }^{6}$ Ver neste livro o texto de Luísa Trindade e, do autor, o exercício para o caso de Lisboa (Rossa, 2015b). 


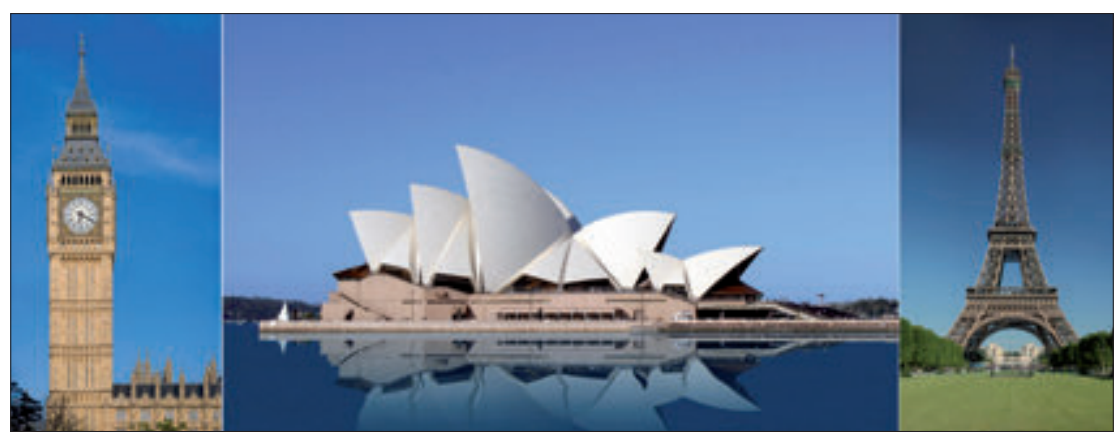

Fig. 5 Big Ben (Londres), Ópera de Sidney; Torre Eiffel (Paris).

Esse momento do surgimento das representações do real por processos baseados no desenho foi também o da alvorada das descrições, muitas delas poéticas, seguido do da literatura de viagens, os quais até hoje foram registando profundas mutações, mas que na origem ergueram e desenvolveram, por vezes sem qualquer base verosímil, mitos extraordinários sobre a fundação, ritos e fundadores heroicos, justificações toponímicas e episódios gloriosos ${ }^{7}$. A comparação com arquétipos reais, como Roma, ou míticos, como a Jerusalém Celeste, surgiu também com frequência, competição que, com expressões e sofisticações muito diversas, hoje se desenvolve frenética e globalmente segundo diversas hierarquias com estratégias e meios avultados ${ }^{8}$. Constroem-se nomes, rácios, slogans, logos, mas nunca se funciona sem a associação a imagem(s), a paisagem(s) ativadas por texto ou desenho, já não através das expressões clássicas contemplativas mais elaboradas da poesia e da pintura, mas,

7 Trata-se de um assunto muito explorado e, assim, com uma vasta bibliografia. Sendo talvez Roma o caso mais paradigmático, uma referência fundamental é o já referido clássico de Joseph Rykwert de 1963.

8 Esta questão é, aliás, um dos mais evidentes reflexos da globalização, e surgiu teorizada com grande impacto por Saskia Sassen (1949-) em duas obras, ambas com significativas alterações nas edições mais recentes (Sassen, 1991 e 1994). 
no fundo, sempre em busca e construção da aura do objeto artístico coletivo por excelência que a cidade é.

Além dos símbolos, figurações e alegorias, hoje identificamos mentalmente as cidades por imagens da sua paisagem urbana consolidada, nas quais têm de figurar alguns bens diferenciadores, por detalhes com carga simbólica, ícones, ou, se assim o quisermos, imagens de marca (Fig. 5). A isso somamos um conjunto de experiências alheias (descrições, músicas, reportagens, comentários) que se esvanecem quando logramos visitá-las presencialmente com o exercício de todos os nossos sentidos, 9 para depois ressurgirem misturando e relativizando as verdades da nossa experiência, manipulando a nossa memória e os nossos sonhos, a nossa forma de interagir com a realidade.

Em suma, pese embora o facto de as mais diversas formas de expressão cultural e artística terem nos seus reportórios inúmeras invocações e representações de cidades, é na imagem das suas materialidade e espacialidade que nos detemos e investimos construindo a síntese que delas temos em mente. Alinhar alguns dispositivos conceptuais e metodológicos para a recolha e edição desse discurso é a utopia deste texto, necessariamente submisso ao enorme fascínio, por vezes inconsciente e sempre baseado em abstrações da realidade, exercido pela miríade de facetas estruturais, formais e epidérmicas do sistema urbano e da sua extraordinária e permanente dinâmica de transformação. Discurso que, só por si, é uma genuína expressão patrimonial das comunidades condenadas a cada cidade, muitas com influência portuguesa, o que pode ser um veículo de ligação e reforço das suas identidades.

9 O conceito comum de paisagem, em especial quando se refere "experiência de paisagem", apela precisamente à integração de todas as sensações e não as meramente visuais. 


\section{Urbanismo, paisagem, cultura do território, história, patri- mónio urbanístico}

Regressando à primeira frase deste texto, reconheçamos então no ambiente físico da cidade o habitat humano, a espacialidade do urbano, a qual é, nem mais, urbanismo. É um termo novilatino, cunhado com o florescimento da disciplina nas últimas décadas de Oitocentos a partir do étimo urbis da cultura clássica. ${ }^{10}$ Como Françoise Choay (1925-) o foi destacando (Choay, 1992: 135-157),11 o urbanismo surgiu e desenvolveu-se a par, ou por vezes por confronto, ${ }^{12} \mathrm{com}$ a sua própria historiografia e a formação de consciência sobre o caráter patrimonial do urbano, o que resultou no facto de, no essencial, o seu corpus teórico se confundir com a sua história. A natureza do objeto assim o impôs, pois a cidade não é uma invenção, mas uma recriação permanente. Durante muito tempo manteve-se, contudo, a confusão entre urbano e urbanismo, ou mais precisamente, entre património urbano e património urbanístico, aliás tal como persiste sobre outras declinações do étimo em glosa.

Ao invés de cidade, urbe não reporta preferencialmente às pessoas, e as suas várias e tardias declinações têm levado tempo a afirmar-se, primeiro na sua geografia linguística de origem, depois noutros âmbitos, designadamente o anglo-saxónico, o que é relevante em reflexões comparativas e na teorização disciplinar que

10 Considera-se que surgiu na Teoría general de la urbanización... (Cerdá, 1867) de Ildefonso Cerdá (1815-1876), ou seja, a partir da palavra que designa o processo e não a coisa em si.

11 É neste capítulo "L'invention du patrimoine urbain" da sua obra seminal sobre património, que Choay o formula de forma clara. Contudo, esse é o corolário de um percurso onde a cultura urbanística, como teoria e história, foram dissecadas, designadamente em L'Urbanisme, utopies et réalités de 1965 e La règle et le modèle. Sur la théorie de l'architecture et de l'urbanisme de 1980.

12 "L'histoire des doctrines de l'urbanisme et de leurs applications concrètes ne se confond nullement avec l'invention du patrimoine urbain historique et de sa protection" (Choay, 1992: 139). 
não cabem no escopo deste texto (Rossa, 1989-2001: 13-22). Essas declinações não só definem o que é o objeto da sua existência, urbanismo, como o processo da sua construção, urbanização, ${ }^{13} \mathrm{e}$ teorização, urbanística, aqui num desvio em relação ao que seria linguisticamente mais correto, urbanologia. ${ }^{14}$ Teorização que necessariamente inclui, como laboratório empírico, a formulação de planos e projetos de urbanização, pelo menos aqueles em que a discussão teórica os encabeça e é claramente assumida.

Coloca-se contudo a questão da natureza do urbanismo, já acima considerado "ambiente" e "espacialidade" o que nos remete para uma imaterialidade. Contudo a cidade concretiza-se e transforma-se continuamente por processos de (re)urbanização, ou seja de construção e transformação física e respetiva ocupação e vivência por pessoas com usos e funções. ${ }^{15}$ Essa construção concretiza objetos edificados de natureza arquitetónica no seu sentido mais lato, sejam eles edifícios, espaços públicos (incluindo os verdes de utilização colectiva), vias e barreiras, entre outros. É o sistema formado pela interação do seu conjunto com as caraterísticas endógenas do sítio, a sua articulação e espacialidade resultantes, o que constitui o urbanismo e é uma demonstração simples da sua já referida natureza imaterial. Imaterialidade que na sua corporização em construção e/ou arquitetura, além de se conformar como uma realidade abstrata, assume dimensões que constituem um sistema em tríade, o

13 Camillo Sitte (1843-1903) é autor de outra obra de fundação da disciplina (Sitte, 1889), na qual verificamos como, tal como para Cerdá, foi a perceção da existência de um processo de construção da cidade (städte-bau) que presidiu à sua redação, precisamente para melhor o determinar e, assim, qualificar. Claro que urbanização tem ainda a dimensão semântica da passagem de selvagem ou rural a urbano, aliás usada no segundo parágrafo deste texto.

14 Foi um processo de estabilização não assumido, no qual a hegemonia da teorização urbanística italiana das décadas de 1960 a 1980 acabou por ser determinante.

15 Nesta oração é fundamental terem-se em conta os processos parciais e, em alguns casos, quase quotidianos de reurbanização, reconstrução e/ou renovação, refuncionalização, reabilitação, etc. 
qual temos vindo a testar empiricamente nas mais comuns ações de análise urbanística: estrutura, forma e imagem. ${ }^{16}$

Além da significação óbvia de cada um desses termos, assim constituídos nas componentes analíticas do urbanismo, importa referir como se organizam segundo uma hierarquia de mutabilidade - da mais volátil imagem, à mais perene estrutura - e visibilidade - da invisível estrutura, à evidente imagem. No meio a forma, que materializa a estrutura e se reveste com a imagem, a qual, nas correntes metodológicas vincadamente formalistas, é confundida com o todo (Figs. 6 e 7). ${ }^{17} \mathrm{Na}$ perceção do discurso de uma cidade é fundamental distinguir estas três componentes e mapear e caracterizar as suas articulações. Claro que numa perspetiva de tempo longo e de riqueza nos âmbitos de ação mais comuns em património (identificação, inventariação, salvaguarda, gestão, etc.), é essencialmente na estrutura que nos devemos focar, pois é nela que estão sistematizadas as invariantes, ou seja, o que é simultaneamente durável e seminal, genético. Ao invés, a volatilidade da imagem e a inevitável evolução gradual da forma, num tempo longo desagregam as respetivas componentes identitárias. E, contudo, é sobre forma e, essencialmente, pela imagem que se constitui a paisagem urbana, conceito que, como é evidente, surgiu com a apropriação pelo urbano da ideia de fixação contemplativa de vistas do não urbano pelas artes do desenho e poesia. ${ }^{18}$

16 É essencialmente em "Património urbanístico: (re)fazer cidade parcela a parcela" (Rossa, 2002-2013: 97-131), que (numa perspectiva operativa) até aqui melhor discuti este assunto.

17 Recorrendo ao corpo humano como analogia para uma explicação (excessivamente) simples desta tríade, temos o esqueleto como item essencialmente estrutural, os tecidos musculares e adiposos como constituintes da forma, e a pele, cabelos, vestuário e adereços como determinantes da imagem. Tratando-se de um sistema, fica pois implícita a integração e interação de cada um dos elementos.

18 Mais com um enfoque interventivo no desenho urbano e espaço público, que com uma abordagem meramente teórico-crítica, foi com Paisagem Urbana de Gordon Cullen (Cullen, 1961) que foi lançado o termo-conceito. 


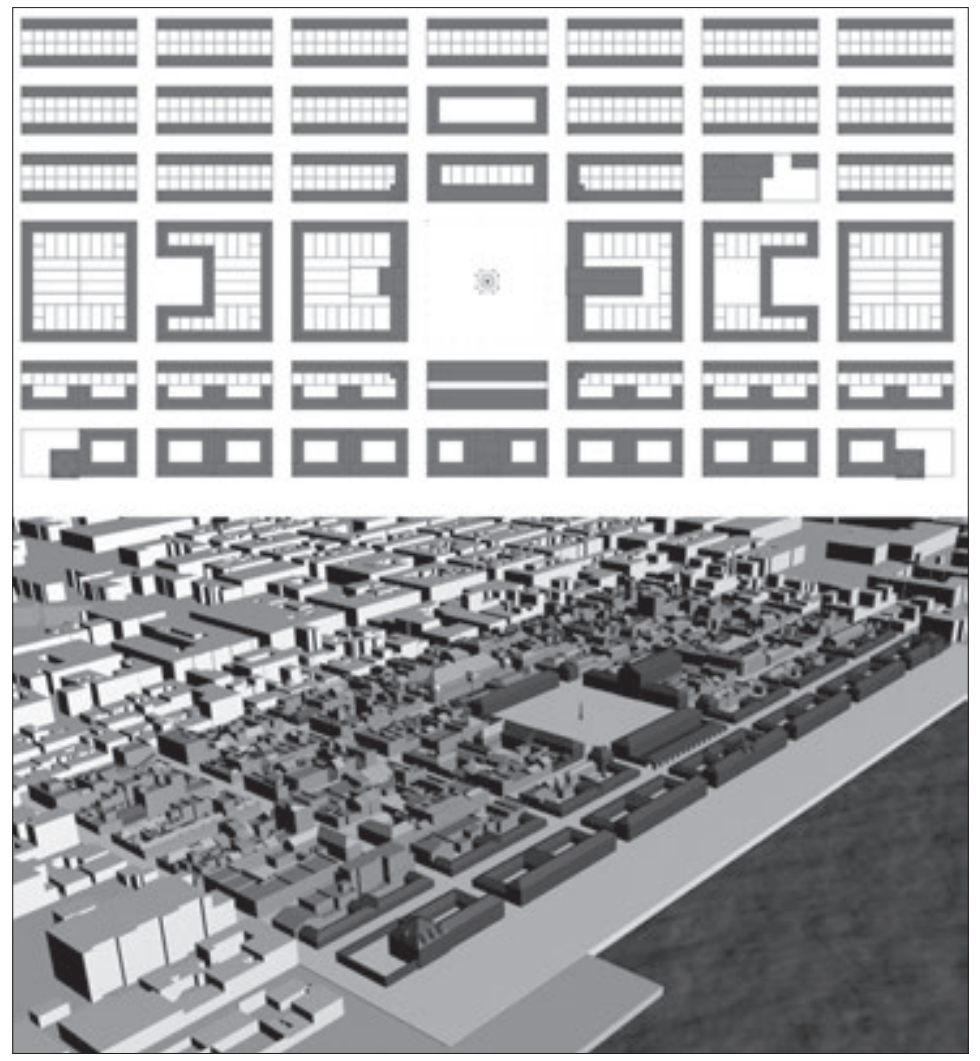

Fig. 6 Estrutura e forma do centro de identidade de Vila Real de Santo António. In Walter Rossa e Adelino Gonçalves (coord.). Plano de Pormenor de Salvaguarda do Núcleo Pombalino, 2005.

De facto o termo-tema-conceito paisagem tem vindo, também ele, a ser declinado e desenvolvido, por vezes ao ponto de se perder quase em absoluto a referência semântica original - o que se contempla no território humanizado, no pays - e rapidamente evoluiu para a dupla artialização da natureza e da cultura (Roger, 1997: 11-30).19 Claro que o que se vê é a imagem, a epiderme de

19 É complementar e sugestiva a abordagem sintética e do ponto de vista do projeto em Franco Zagari (2006), Questo è paesaggio: 48 definizioni. Roma: Mancosu. 


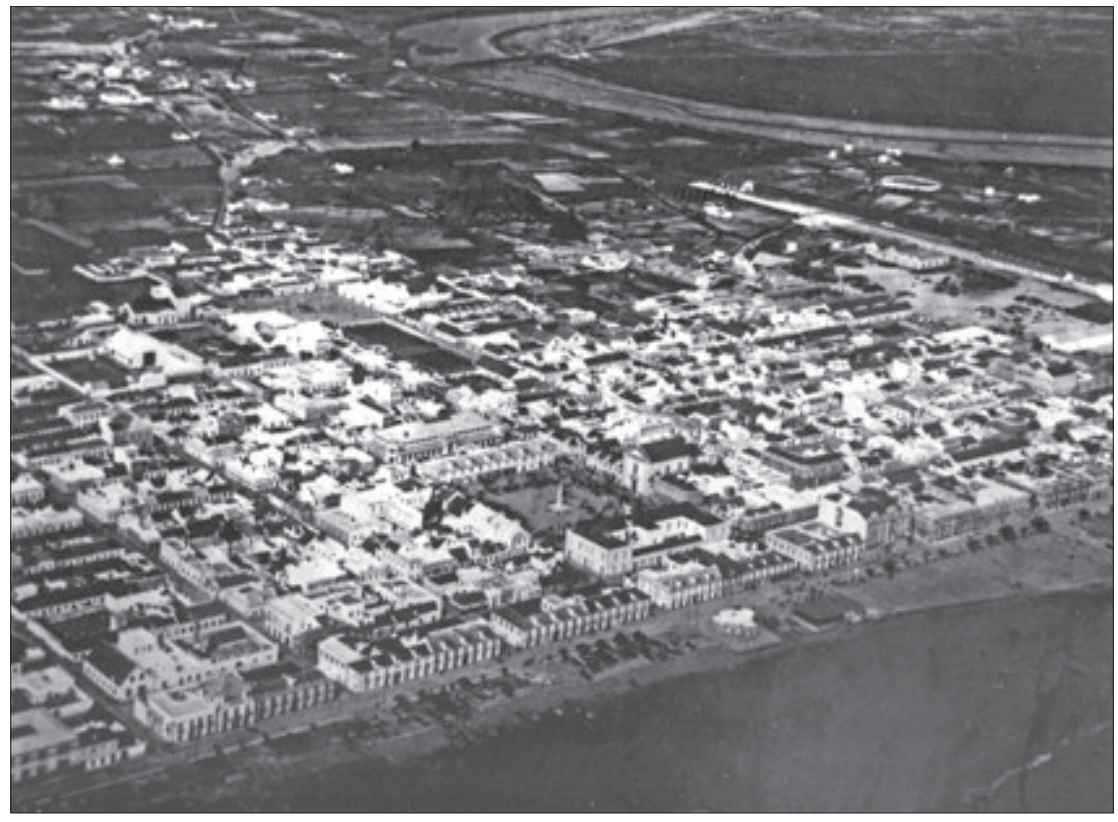

Fig. 7 Imagem do centro de identidade de Vila Real de Santo António em meados do século XX.

formas estruturadas no território, vista garantida e influenciada pelo espaço que medeia entre quem vê e o que vê. Essa imagem, ou melhor, a paisagem é, pois, resultante de todo um processo de construção, - no caso da paisagem urbana urbanização - o qual é espacial e cronologicamente contínuo. Por tal razão há muito que o conceito de paisagem tem implícita a construção e significação do que se vê no território, por conseguinte dinamizando a referida articulação estética entre natureza e cultura. ${ }^{20}$ Em suma, na sua vertente urbana o conceito de paisagem aproximou-se do conceito

20 O conceito-categoria de paisagem cultural foi particularmente valorizado e desenvolvido no mundo anglo-saxónico, contando com uma vasta bibliografia dedicada, dentro da área de estudos sobre património, onde se destacam vários números e artigos do International Journal of Heritage Studies. 
de urbanismo. São ambos de uma ampla área (inter)disciplinar urbanismo, planeamento e ordenamento do território - que tem vindo a ser alvo de uma proliferação taxonómica, não só geradora de um grande ruído, como nem sempre precedida de uma cuidadosa escolha das palavras e construção das respetivas declinações.

Um bom reflexo de tudo isso, até pelo protagonismo central que assume na teoria-ação sobre património cultural, é a forma como a UNESCO $^{21}$ tem vindo a utilizar e desenvolver o conceito paisagem no âmbito da aplicação da Convenção para a proteção do Património Mundial, Cultural e Natural, ${ }^{22}$ o documento fundador, em 1972, do conceito património mundial e assim da respetiva Lista. As categorias de classificação são duas: sítio natural e sítio cultural, sendo admitida a classificação mista sítio cultural e natural. Esta matéria, necessariamente prevista na referida convenção, está desenvolvida em diversos documentos oficiais, de entre os quais o mais relevante são as Orientações Técnicas para aplicação da Convenção do Património Mundial, frequentemente atualizadas "to reflect the evolution of the World Heritage concept itself". ${ }^{23}$ Entre diversas disposições, designadamente processuais, contém a definição dos critérios de seleção, mas também uma especificação dos tipos de bens passíveis de ser integrados na Lista do Património Mundial.

Enquanto na Convenção do Património Mundial, paisagem surge apenas uma vez e isolada, nas Orientações Técnicas... foi proliferando com diversas combinações de revisão em revisão. Desde 1992 passaram a ser reconhecidos vários tipos de bens como paisagem cultural, o que foi ocorrendo a par dos tipos cidades históricas, centros históricos, canais do património e rotas do património, tudo dentro da categoria de sítios culturais ou mistos culturais e naturais,

\footnotetext{
21 United Nations Educational, Scientific and Cultural Organization.

22 É mais comum a designação abreviada Convenção do Património Mundial.

23 Disponível em linha (http://whc.unesco.org/archive/opguide13-pt.pdf).
} 
mas nunca meramente naturais. De declinação em declinação, dentro das paisagens culturais foram ainda identificadas três categorias intencionalmente concebida e criada pelo homem; essencialmente evolutiva; cultural associativa - que aqui não importa caracterizar. Importa, porém, saber em concreto o que nesse contexto normativo se entende ser uma paisagem cultural (Orientações Técnicas..., §47): As paisagens culturais são bens culturais e representam as "obras conjugadas do homem e da natureza" a que se refere o artigo $1 .^{\circ}$ da Convenção. Ilustram a evolução da sociedade humana e a sua consolidação ao longo do tempo, sob a influência das condicionantes físicas e/ou das possibilidades apresentadas pelo seu ambiente natural e das sucessivas forças sociais, económicas e culturais, externas e internas.

Não teria sido complicado fazer evoluir essa redação, ou mesmo espelhá-la, de forma a integrar explicitamente o urbano. Já o mesmo não poderia ter sido feito ao que parece mais próximo, as cidades ou centros históricos, pois a doutrina da UNESCO consolidada para estes não é sensível à importância crucial da dinâmica urbana para o fenómeno cultural que é a cidade. Basta ver nos $\$ 14$ e $\$ 15$ do Anexo 3 das Orientações Técnicas... a barreira de reservas levantadas à inscrição da categoria cidades históricas habitadas, mais ainda à das cidades novas do século $X X$ - cujo "exame destes dossiês deverá ser diferido, salvo circunstâncias excecionais" - por contraposição à das cidades não habitadas, as únicas onde o critério básico da autenticidade é considerado garantido. ${ }^{24} \mathrm{~A}$ redação, elíptica, vai toda no sentido de

${ }^{24}$ A questão da autenticidade, no âmbito do património cultural, suscita, há décadas, um intenso e frutífero debate aqui impossível de caracterizar, o qual se tem feito entre extraordinários textos de síntese (Waterton e Watson, 2015). Nesta última, além do texto de abertura dos organizadores e de várias referências em muitos outros, há um capítulo que lhe é dedicado: "Heritage and Authenticity", por Helaine Silverman. Notem-se ainda as relações óbvias que o debate tem com as questões da "invenção da tradição" levantadas por Hobsbawn e Trevor Ropes e das "comunidades imagnadas" de Anderson, curiosamente ambas de 1983. 
considerar que o facto de haver vida urbana põe em risco a autenticidade (um dos requisitos fundamentais para o Património Mundial), a qual tem de ser garantida à base de conservação e restauro, não de uma leitura de evolução. O que é uma aberrante contradição com a condição de sítio cultural, a designação chapéu para a inscrição deste tipo de bens. Se uma cidade é, por definição, um sítio cultural, deve-o à autenticidade da vida que a faz pulsar e não à ruína arqueológica em que potencialmente se poderá transformar, congelando apenas vestígios de uma autenticidade defunta. $O$ urbano não regride, uma cidade não se restaura e sem pessoas é um fantasma.

Independentemente da sua qualidade técnica e genérica atualidade, os documentos doutrinários da UNESCO são particularmente significativos, ${ }^{25}$ porque só são assumidos ao cabo de longos processos de consensualização, não por determinação de quaisquer vanguardas científicas ou culturais, e porque facilmente se convertem em clichés que os decisores políticos e os agentes económicos e culturais adotam sem questionar. Constituem-se, pois, em posições culturalmente cristalizadas e linhas mestras de ação legitimadas e prosseguidas ao mais alto nível. Devem assim ser mantidas sob escrutínio e pressão permanentes de modernização por parte de quem reflete e investiga, não apenas pelo que implicam para os bens listados, mas pela cultura patrimonial que ferram na comunidade.

Pelo menos no que diz respeito ao património urbanístico e territorial-paisagístico, urge dar um salto epistemológico, que crie e difunda uma teoria de património que descole dos conceitos e teorias da conservação e restauro para bens artísticos autónomos (no início, aliás, apenas os monumentais) dos pioneiros oitocentistas Eugène Viollet-le-Duc (1814-1879), John Ruskin (1819-1900),

25 Para uma visão global desses documentos, ver International charters for conservation and restoration: monuments and sites I. Munique: JCOMOS. 2004; e uma outra recolha, em Lopes e Brito, 2014. 
Alois Riegl (1858-1905) e Camillo Boito (1836-1914) a Cesare Brandi (1906-1988), que, no fundo, estão na base do pensamento patrimonial ainda hegemónico do qual a UNESCO, pese embora todos os esforços em contrário, é um espelho (Lopes e Correia, 2014). Teorias que não só não foram concebidas com a cidade em mente, como entretanto se desajustaram, pois a era industrial foi suplantada por outra, uma $3 .^{\mathrm{a}}$ modernidade onde tudo quanto está relacionado com o cognitivo ganha protagonismo nos mais diversos setores de atividade (Ascher, 2001). São necessários novos paradigmas conceptuais que conduzam à determinação de novas linhas de atuação sobre o património cultural, as quais têm de se conformar em torno de visões integradas como as que a cidade exige.

Será esse o sentido da ação movida dentro da UNESCO para a implantação e desenvolvimento do conceito-ação - abordagem como tem vindo a ser vincado especificamente para este caso - Paisagem Urbana Histórica [HUL] ${ }^{26}$. Foi um processo iniciado em 2005 e que, após seis anos de debates e grande polémica, acabou consagrado (apenas) como recomendação. ${ }^{27} \mathrm{~A}$ dificuldade é simples de identificar: "the acceptance of change as an inherent part of the urban condition" (Bandarin e Oers, 2012: 198). A definição aprovada para a "HUL approach" 28 é a seguinte:

- The historic urban landscape is the urban area understood as the result of a historic layering of cultural and natural values and attributes, extending beyond the notion of "historic centre" or "ensemble" to include the broader urban context and its geographical setting.

26 Historic Urban Landscape, HUL.

27 Recommendation on the Historic Urban Landscape, adoptada na $36 .^{a}$ sessão da Conferência Geral da UNESCO de 10 de novembro de 2011.

28 Como portal de entrada na "HUL approach" ver a brochura New life for historic cities: the historic urban landscape approach explained editada pela UNESCO (descarregar em: http://whc.unesco.org/uploads/news/documents/news-1026-1. pdf) e, fundamentalmente, Bandarin e Oers, 2012 e Bandarin e Oers (ed.), 2015. 
- This wider context includes notably the site's topography, geomorphology, hydrology and natural features, its built environment, both historic and contemporary, its infrastructures above and below ground, its open spaces and gardens, its land use patterns and spatial organization, perceptions and visual relationships, as well as all other elements of the urban structure. It also includes social and cultural practices and values, economic processes and the intangible dimensions of heritage as related to diversity and identity.

- This definition provides the basis for a comprehensive and integrated approach for the identification, assessment, conservation and management of historic urban landscapes within an overall sustainable development framework.

- The historic urban landscape approach is aimed at preserving the quality of the human environment, enhancing the productive and sustainable use of urban spaces, while recognizing their dynamic character, and promoting social and functional diversity. It integrates the goals of urban heritage conservation and those of social and economic development. It is rooted in a balanced and sustainable relationship between the urban and natural environment, between the needs of present and future generations and the legacy from the past.

- The historic urban landscape approach considers cultural diversity and creativity as key assets for human, social and economic development, and provides tools to manage physical and social transformations and to ensure that contemporary interventions are harmoniously integrated with heritage in a historic setting and take into account regional contexts. - The historic urban landscape approach learns from the traditions and perceptions of local communities, while respecting the values of the national and international communities.

A transcrição integral dos seis parágrafos da recomendação que são a definição da Paisagem Urbana Histórica, ${ }^{29}$ justifica-se por não

29 A recomendação tem 30 parágrafos além de considerandos, introdução, apêndices e glossário. 
ser mais do que uma síntese da teoria-agenda da urbanística contemporânea, em especial quando dirigida a áreas urbanas existentes, consolidadas ou não. ${ }^{30} \mathrm{O}$ mesmo se verifica nas recomendações sobre as políticas, métodos e instrumentos. Na realidade, apenas se compreende a necessidade de ser introduzida mais uma designação-conceito (HUL) pelo desafio de encontrar e afirmar, num ambiente conceptual e ideologicamente reacionário, uma nova bandeira, ou melhor, uma nova marca, a qual vai muito para além do que pode ser contido pelos conceitos de paisagem urbana ou paisagem cultural. Hostilidade que advém de uma visão cristalizadora do património (conservacionista e restauracionista), legítima para tipos de bens sem organicidade, ou seja, sem relação de nexo com o território e a cidade. Pena é que se tenha recorrido ao já conceptualmente estirado conceito de paisagem, confundindo irreversivelmente vários conceitos e níveis de análise, intervenção e gestão patrimonial e urbana, e não tenha sido possível afirmar aquilo de que realmente se trata: património urbano em geral, urbanístico quando o enfoque é sobre o habitat humano, a espacialidade da cidade que é o foco deste texto.

A explicação, com exemplificação, do que se entende por património urbanístico foi já publicada em alguns textos (Rossa, 2002-2013: 1. ${ }^{\mathrm{a}}$ parte). ${ }^{31}$ De forma sintética pode dizer-se que consiste no

30 Não será mera coincidência o facto de um dos principais proponentes da HUL ser o holandês Ron von Oers, e ser evidente a inspiração que aquele tem no Belvedere Memorandum, a policy document examining the relationship between cultural history and spartial planning, anunciado em 1997, pelos Minister of Education, Culture and Science, the Minister of Public Housings Spatial Planning and the Environment and the Minister of Agriculture, Nature Management and Fisheries holandeses (Janssena et al., 2014).

31 Aqui fica um dos parágrafos:

“O Património Urbanístico [...é] património imaterial virtualmente corporizado pelo conjunto de edifícios de um núcleo, nele se destacando o edificado anónimo ou genérico - até há bem pouco tempo designado de acompanhamento - e não só os elementos notáveis, sejam eles monumentos, edifícios ou espaços públicos. No fundo é um sistema de relações formais estáveis sobre o qual a urbe se cria e 
conjunto de características estruturais, com implicações construtivas, espaciais ou arquitetónicas, que garantem as caraterísticas centrais da identidade urbanística de um conjunto urbano, deixando espaço para um desenvolvimento harmonioso da forma e da imagem com as preexistências. Por outras palavras, é o sistema de valores que têm de ser instituídos como invariantes para garantir que a incontornável, por vezes desejável, evolução decorra sem se perder o que conecta o espaço com a sua comunidade e a sua cultura. Até ao momento a melhor analogia é a do genoma, um código para o crescimento e vida sem perda do eu. Como o genoma, o património urbanístico é uma abstração com uma corporização tão evidente que com ela facilmente se confunde. No limite a invariante é o que em património é ou contém um discurso consolidado, por contraste com conjuntos de palavras soltas ou frases truncadas e/ou sem nexo (Figs. 8 e 9).

De uma forma prosaica, insuficiente e meramente ilustrativa, podem integrar-informar o património urbanístico de uma cidade, de um conjunto de cidades ou até de cidades territorialmente separadas, mas unidas por laços culturais como as de influência portuguesa: o sistema primário de divisão da propriedade (parcelário) e das suas relações com os espaços públicos e de poder, em especial se ele revelar padrões; relações tipificáveis do edificado com a parcela em que se insere e, assim, com o espaço público, vizinhos e logradouros $;^{32}$ sistemas construtivos determinados pelas

\footnotetext{
recria num contínuo recurso à arquitetura, transformando cores, anúncios, perfis de arruamentos, trânsito, árvores e plantas, etc. O património urbanístico é o sistema imaterial residente - resistente, se quisermos - da vida urbana e da sua evolução e transformação sem soluções de continuidade. A sua resultante é a paisagem urbana e a sua função central consiste na estruturação física da vida, ou se quisermos, da ecologia urbana."

Ver também Gonçalves, 2011, em especial a rubrica "Será o património urbanístico um conceito útil?"

32 Lotes estreitos e compridos em regra determinam não só implantações do edifício à frente com logradouro atrás, como também sistemas de traçado em ruas e travessas, que por sua vez se relacionam com maior frequência com quarteirões retangulares ou alongados.
} 


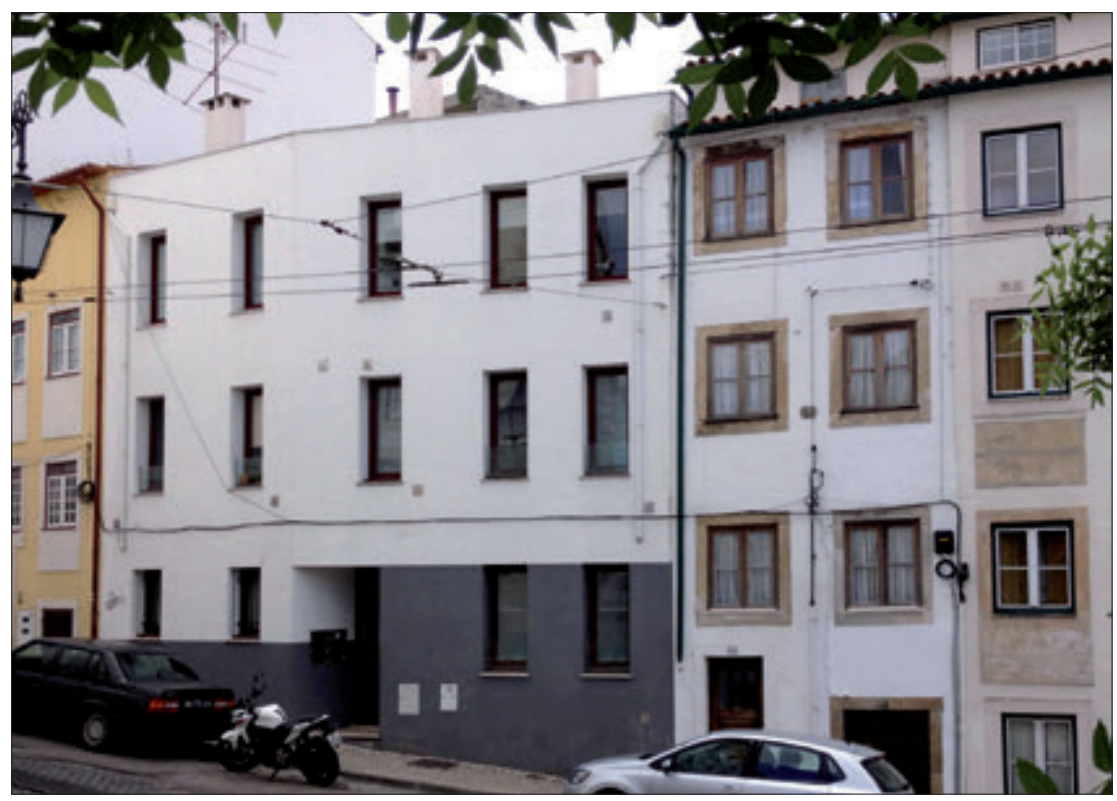

Fig. 8 Rotura do sistema proporcional-compositivo de um dos lados da Rua Padre António Vieira (Coimbra).

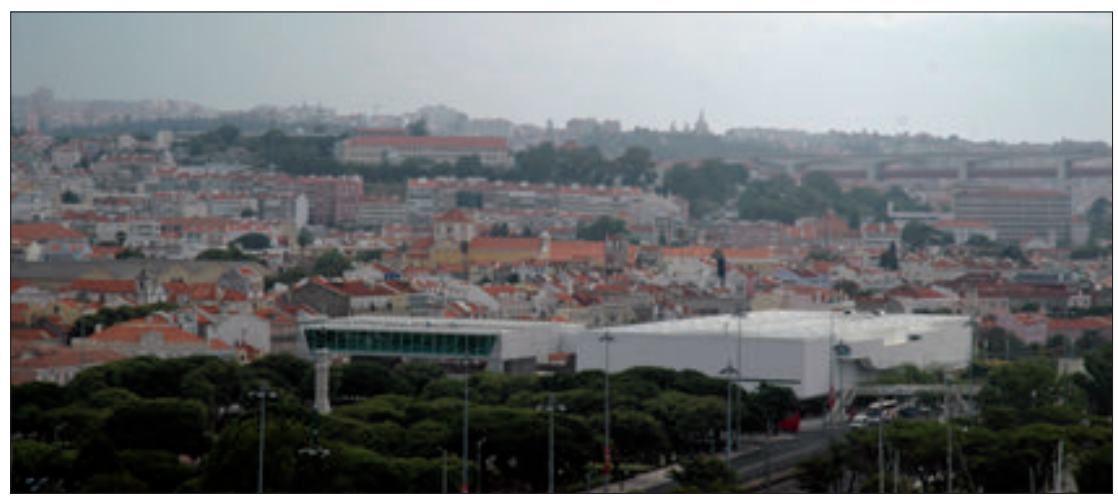

Fig. 9 Rotura, por alteração da estrutura e das regras de composição e escala da forma, nas caraterísticas do património urbanístico da zona de Belém-Junqueira pelo novo edifício do Museu Nacional dos Coches (Lisboa). 
caraterísticas climatéricas, geológicas e de recursos naturais do território; ${ }^{33}$ sistemas compositivos determinados, por exemplo, por maiores ou menores luminosidade (tamanho dos vãos) e pluviosidade (proteção com alpendres), o que é extensível às soluções mais comuns para a realização, forma (planas, terraço, inclinadas), escolha de materiais (chapa, telha, vegetal) e remate das coberturas e da relação destas com os alçados (platibanda, beirado); de tudo isso depende a proporção entre cheios e vazios como os vãos, mas também influi a cultura de maior ou menor zelo pela privacidade, no que a religião tem um papel fundamental; dessa linha advêm também regras para as formas de relação entre público e privado (o que tem tradução, por exemplo, nas formas de vedação), mas também a forma como fisicamente se relacionam funções básicas como a habitação e o comércio. Trata-se, em suma, do vasto elenco de caraterísticas que num tempo longo se decantaram da relação mais natural, equilibrada e sustentável entre a(s) comunidade(s) e o(s) seu(s) habitat(s).

Ao invés do que outros conceitos que as ditas ciências do património determinam, o património urbanístico de uma cidade ou área urbana deve ser passível de catalisar e informar um plano integrado de desenvolvimento urbano ou, por outras palavras, cumprir os princípios da "HUL approach". A visão e abordagem holística e integradora, ativando a participação e, assim, o compromisso de todos nesse processo de planeamento de salvaguarda em desenvolvimento, ${ }^{34}$ é um instrumento único para o relançamento da

33 Um território onde escasseia a pedra ou esta é de má qualidade, tende a determinar para o grosso do seu edificado a construção em tijolo, adobo ou madeira, o que por sua vez tem implicações na relação entre edifícios adjacentes. Se a isso acrescentarmos questões como, para o caso da construção em tijolo ou adobo, a existência ou não de materiais que possibilitem a realização de rebocos, ficamos com uma ideia clara de como aquilo que pode parecer uma mera opção de imagem pode ter como base necessidades que na realidade são estruturais.

34 Esta é outra expressão que temos vindo a utilizar (Gonçalves, 2011; Rossa, 2002-2013: 1. ${ }^{\mathrm{a}}$ parte). 
relação proactiva dos cidadãos com o seu ecossistema, fundamental para a integração das problemáticas do património na cultura e no dia a dia dos cidadãos, potenciando o desenvolvimento dos seus sentimentos de pertença e identidade. Na construção em curso da terceira modernidade, a sustentabilidade é já algo do conhecimento comum e empenhamento de muitos. A cultura está consagrada como um dos seus quatro pilares, ${ }^{35}$ a par com o ambiente, a economia e a sociedade, e nela o património desempenha um lugar central. Ou seja é algo que está em afirmação como determinante para a vida de cada um, e no seu eixo tudo quanto tenha a ver com o seu habitat, a sua esfera urbana. 36

Desde sempre e como já antes referi, o centro é uma das questões fulcrais do fenómeno urbano. Centros que têm necessariamente de ter coroas em seu redor, as quais quando perdem a sua solidez urbana (densidade, continuidades, funcionalidades, etc.) são consideradas periferias. Ao invés do que sucedia antes da era industrial, as periferias - que, conforme as culturas, até então se designavam, por exemplo, arrabalde ou faubourg, e até hoje subúrbio - são agora muito maiores que a parte consolidada, central. Isso fez com que esse espalhar do urbano dito "em mancha de óleo", ou sprawl, fosse atingindo e aglutinando-se com os de outros centros, originando contínuos urbanos (conurbações) pontuados, até toponimicamente, por esses centros (Solà-Morales i Rubió, 1993) (Fig. 10). No fundo é uma mera ampliação do que sempre aconteceu, mesmo a partir de pequenos núcleos sobre outros ainda mais pequenos, aldeias. Hoje a expressão deste fenómeno simples e de tempo longo pode

35 Entre múltiplas alternativas, o Creative economy report 2013... é uma extraordinária demonstração do papel que a cultura, as cidades e o património podem desempenhar no desenvolvimento humano.

36 A cultura está a tornar-se, cada vez mais, o fulcro da atividade e economia urbanas, o tema objeto das estratégias de planeamento urbano (Monclous e Guardia, 2006). 
constituir a estrutura básica da forma urbana de uma pequena ou média cidade, ou de uma enorme metrópole.

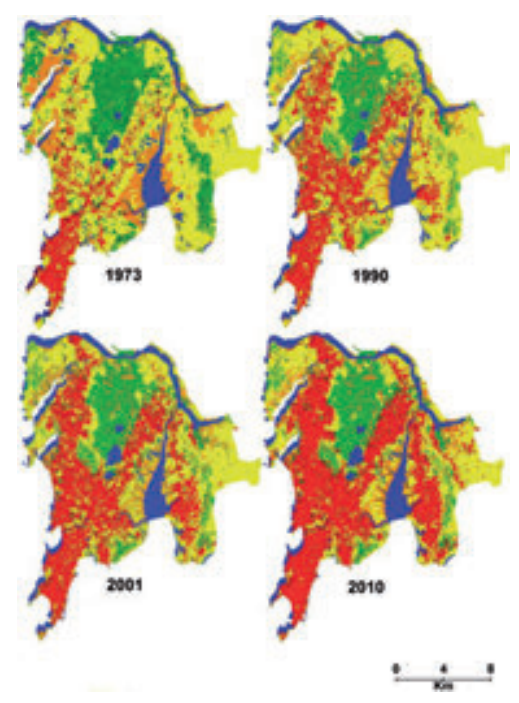

Fig. 10 Sprawl de Mumbai sobre território com centros urbanos consolidados preexistentes, que se transformam em centralidades metropolitanas. In http://udconnect.net/mumbai-urban-sprawl-urbanization/

Esses centros, distribuídos em rede pelos territórios urbanizados, desempenham um papel simultaneamente magnetizador, dinamizador e difusor de urbanidade. Há casos em que recebem o epíteto de centro bistórico, o que já há muito venho pondo em causa, preferindo o mais operativo e integrador de centro de identidade (Rossa, 1989-2001: 18-19). O seu potencial de conjunto para a reconfiguração do conceito de cidade é tão grande, quanto são cruciais no reformular e garantir da sustentabilidade cultural, em rede, dessas comunidades urbanas alargadas. Todos esses centros têm história, todos são matéria contemporânea, todos são património urbano significante, um arquivo discursivo de expressões urbanas e, desig- 
nadamente, urbanísticas. E se tudo isso é verdade numa realidade urbana territorialmente contínua, por que não aplicá-lo também de forma interpolada, ou seja, entre comunidades distantes, mas com afinidades culturais como as de influência portuguesa?

\section{Gramática urbanística}

No âmbito mais estrito, mas fundamental, do património urbanístico, a dimensão técnica e disciplinar requerida pela determinação das suas invariantes ou caraterísticas estruturais - o seu vocabulário e regras de composição - não deve ser transformada numa tecnopacidade que demagogicamente vede o seu conhecimento e gestão aos cidadãos. A elevação do nível da cultura do território de uma sociedade é um objetivo alcançável desde que politicamente assumido, ou seja, desde que uma vez desejado se transforme em ação política, por exemplo com reflexos nos diversos níveis de ensino. As ferramentas básicas são simples e o seu relacionamento intuitivo, embora requeiram uma mentalidade, um pensamento matemático rudimentar, sendo tão importante a sensibilidade quanto o conhecimento de partida e o desígnio cidadão de democratização da gestão territorial.

Nessa linha passemos então a um breve exercício que, com o recurso a uma atrevida analogia, poderá ajudar a tornar um pouco mais claros os procedimentos básicos da análise urbanística. O ponto de partida é este: ao admitirmos, como é axioma base deste texto, que os elementos urbanos que têm vindo a ser referidos e as respetivas relações constituem uma linguagem, então estamos implicitamente a aceitar que o seu sistema de regras, a sua estrutura, constitui uma gramática. No sistema clássico de organização das atividades e conhecimento, a gramática surge integrada nas sete Artes Liberais. A subdivisão destas em dois grupos, apartava no Trivium 
a gramática, a lógica e a retórica (processadoras da comunicação e estimuladoras do espírito), e no Quadrivium (relacionado com a compreensão da matéria) a geometria (teoria do espaço), aritmética (teoria dos números), astronomia (aplicação da geometria) e música (aplicação da aritmética). Curiosamente, a linguagem urbanística configura-se, assim, como algo transversal a tudo isso, ou seja e estabelecendo um exercício de pura analogia, na sua materialidade espacial a cidade resulta do exercício contínuo das artes liberais pela sua comunidade ao longo do tempo, em suma é, por excelência, a “arte inconsciente da comunidade.".37

Intuir que os elementos de base, as palavras e frases que urbanisticamente conformam uma cidade são a praça, a rua, o quarteirão, a parcela, o edifício, o parque, o largo e as diferentes imagens e sociabilidades que induzem, não deve ser transformado em algo complexo e opaco, até porque o não é. Também deve ser assumido, sem qualquer complexidade, que a sua composição em textos, no fundo consiste nas relações daqueles elementos entre si no território que lhes serve de suporte, produzindo padrões estruturais e formais cuja taxonomia surgiu da apropriação da dos têxteis (traçado, tecido, malha, padrão), e que isso não só pode ser facilmente representado através de esquemas de desenho simples, como produz espacialidades diversas, por vezes únicas. ${ }^{38}$ Tudo se complica um pouco mais quando, progredindo pela complexidade dos sistemas urbanísticos, queremos introduzir o suporte, o território que - com o seu relevo, linhas de água, pontos marcantes como os topos dos montes e a sua ocupação - é a principal infraestrutura da cidade (o papel onde

37 Subtítulo do texto, "História do urbanismo e identidade: a arte inconsciente da comunidade" (Rossa, 1989-2001: 13-22).

38 Este assunto, ao qual voltarei adiante, tem uma sistematização já muito variada e consolidada (Lynch, 1960) (Kostof, 1991 e 1992) (Coelho, 2013), desde o primeiro momento incluindo pesquisa sobre a forma como as pessoas percecionam o espaço do seu habitat, e também sobre como lhes fazer chegar informação sobre isso mesmo. 
se inscreve o discurso), a primeira e principal condicionante do seu desenho. Já não será qualquer um a fazê-lo, mas com os meios hoje existentes (SIG, ${ }^{39}$ 3D, ${ }^{40}$ realidade virtual), é fácil disponibilizar suportes com registo simultaneamente rigoroso e de fácil perceção.

Estendendo a analogia, o mesmo pode ser assumido em relação a outros aspetos, onde os sistemas de composição e proporção internos de cada um dos elementos (edifícios, espaços públicos, parcelário etc.) e as suas relações também compositivas e proporcionais com os demais, uma vez sistematizados são dados indispensáveis para a caraterização do discurso urbanístico de uma unidade urbana consolidada. No fundo é tudo uma questão de escala, de leitura de processos e relações, pois nada de novo há para inventar no que diz respeito aos conceitos e métodos de leitura e interpretação urbanísticas. Todavia é necessário clarificar, encontrando novas formas de recolha, interpretação e explicação, no que o aumento exponencial da capacidade de processamento e relacionamento de dados vetoriais e de imagem proporcionados pela informática é estimulante e determinante. A principal dificuldade reside na extraordinária complexidade de relações e hierarquias, na natureza de holon acima referida que a cidade corporiza.

As circunstâncias deste texto não proporcionam lugar nem competência para agora progredir pela evolução e relações da linguística para a semiótica (no fundo a interpretação do meio ambiente), e daí continuar a extrair expressivas analogias para os meus argumentos. Mas se admitimos axiomaticamente que o urbanismo é uma linguagem, então está implícito que se constitui como um sistema de signos. Por isso nos interessa o conceito gramática, ou seja, não na perspetiva descritiva ou normativa como mais habitualmente é

39 Sistema de Informação Geográfica.

40 "3 dimensões", mais concretamente representação dinâmica da tridimensionalidade em suporte bidimensional que, por norma, é o ecrã de um computador. 
utilizado em linguística, mas como alegoria simplificativa, numa perspetiva comparativa e estruturante, para podermos estudar expressões que não são língua, mas são linguagens, sistemas de signos. Em suma, gramática como sistema, nunca como lista de regras, instrumento e objetivo.

Sistema que no seu mundo próprio, o da linguística, contém um número considerável de categorias de análise, das quais, continuando a explorar a analogia, nos interessam apenas algumas: ${ }^{41}$ Morfologia e sintaxe dizem respeito a aspetos estruturais e por isso têm sido já muito usadas e (con)fundidas na nossa área disciplinar, o urbanismo; de forma muito simples, pode-se dizer que na sintaxe vemos como os elementos (p.e. edifícios) se organizam para formar frases (p.e. ruas), composições que à escala urbana são primárias, e na morfologia o que resulta como forma e a regras da sua estruturação; ambas são, pois, cruciais para o reconhecimento de duas das três dimensões que constituem a tríade da análise urbanística, ou seja, a forma e a estrutura, deixando de lado a imagem. O que já não acontece com o par analogicamente relevante constituído pela fonologia e semântica, pois têm tudo a ver com a transmissão, a performance, ou seja, a imagem, a terceira dimensão daquela tríade. Influenciadas por múltiplos fatores, incluindo a moda, brilho, cor, textura, lettering, por exemplo, são a última e mais volátil-mutável camada do discurso urbanístico. Por último a pragmática, que em linguística é a sugestiva expressão usada para o que de forma mais simples se pode designar por usos da linguagem, ou seja, o sítio e a sua relação com o território e com outros discursos urbanísticos ou, forçando um pouco mais, os contextos.

Como acima disse morfologia e sintaxe já há muito que foram apropriadas pela investigação em arquitetura e urbanismo, a primeira

41 Ficam de fora, por exemplo, a fonologia, a lexicologia, a terminologia, a etimologia, a estilística, a filologia. 
fundamentalmente como morfologia urbana, a segunda como sintaxe espacial. Há vários grupos de investigadores, projetos, associações, publicações e reuniões científicas regulares que não é viável listar e caraterizar, até porque estabeleceram linhas de trabalho diversas com variações sensíveis que também se refletem na taxonomia. Todavia, talvez se possa indicar o ISUF ${ }^{42}$ e as suas extensões nacionais como a referência básica, o mais concorrido e abrangente ponto de encontro para todos eles. Os interesses vão da análise empírica pura e simples com meios de observação rudimentares, mas não necessariamente imprecisos, ${ }^{43}$ à automação do projeto e planeamento, passando também pelo património arquitetónico e urbanístico, e os métodos do mais elementar desenho às mais sofisticadas e dedicadas ferramentas informáticas. Importa, porém, deixar claro como por trás das expressões morfologia urbana e sintaxe espacial, a investigação produzida vai muito além do que ambas as designações redutoramente possam induzir, até porque seria absolutamente impossível estudar, de forma cabal e produtiva, forma sem contexto e sintaxe, sintaxe sem semântica e forma e por aí fora.

Um bom exemplo das limitações conceptuais que toda essa taxinomia sobre o discurso urbanístico induz é, precisamente, o facto de nela estar ausente a pragmática ou usos da linguagem, do que, em última análise, resultam as relações, as influências, as séries formais (Kubler, 1962) que são o objeto central do estudo da cidade como património cultural comum a diversas comunidades, como as de influência portuguesa. Para tal é crucial a introdução do conceito de

42 International Seminar on Urban Form. Criado em 1994, publica a revista Urban Morphology, realiza uma reunião anual e mantém ativo o site http://www. urbanform.org (Moudon, 1997).

43 Dois dos pioneiros mais conhecidos são M.R.G. Conzen (1907-2000), com uma abordagem histórico-geográfica inspirada pela realidade anglo-saxónica (Conzen, 1960 e 1968) e Saverio Muratori (1910-1973) e Gianfranco Cannigia (1933-1987), entre alguns outros, com uma abordagem tipológico-processual em linha com as preocupações do projeto arquitetónico e urbano (Marzot, 2002). 
bipertexto na análise do discurso urbanístico, ou seja, das relações que trechos ou mesmo a totalidade do discurso urbanístico de uma cidade estabelecem com os de outras e, simultaneamente, com o seu próprio passado (Corboz, 2000 e 2001; Rossa, 2002-2013: 81-95). $\mathrm{Na}$ realidade, mais do que um palimpsesto (que remete para uma leitura arqueológica) as cidades são discursos em carateres azuis que nos remetem para outras, criando redes urbanas cujas relações são necessariamente património cultural.

Levanta-se assim, uma vez mais, o problema que a área disciplinar tem com a utilização de taxonomias etimológica e semanticamente corretas, suscetíveis de uma imediata conversão interdisciplinar, bloqueando, pelo menos parcialmente, o implícito e potencialmente rico contrabando metodológico. Mesmo dentro da disciplina a não distinção entre a forma e a estrutura provoca distorções da análise. Um exemplo simples: o parcelário (ou divisão da propriedade), elemento seminal na composição urbanística, condiciona a forma, mas não o é, é estrutura. O uso da forma para tudo leva a que seja usada extensivamente, inclusive como gramática da forma, ${ }^{44}$ uma linha de investigação de vanguarda na área da computação gráfica, com resultados de extraordinário alcance teórico e operativo, mas que tem na designação uma evidente redução do seu verdadeiro nexo. Porque não, pura e simplesmente, gramática urbanística?

Terminologia à parte, o que aqui acabo de expor sob o conceito genérico de gramática urbanística será suficiente para fazer entender, ou pelo menos intuir, as razões pelas quais a matéria central da teoria do urbanismo é a manipulação analítica, interpretativa e prospetiva de um discurso da cidade, o qual é uma reescrita per-

${ }^{44}$ A shape grammar foi cunhada e inicialmente desenvolvida por George Stiny na década de 1970, tendo como inspiração os estudos sobre gramática generativa do filósofo e linguista Noam Chomsky (1928-), designadamente o livro Syntactic structures de 1957 (Stiny e Gips, 1972; Stiny, 1980). 
manente da sua história e, assim, património. Também por isso em urbanismo a história se confunde com a teoria.

\section{Urbanismo(s) de influência portuguesa}

No universo cultural da influência portuguesa, a construção da consciência sobre a relevância cultural do património urbanístico teve como base o desenvolvimento da história do urbanismo, que por sua vez teve como ponto de partida o interesse, autónomo, de historiadores de arte e geógrafos portugueses e de arquitetos e geógrafos brasileiros nas décadas 1950-60 (Rossa, 2002-2013: 168-170). Independentemente de uma ou outra mais precoce inventariação e classificação como património cultural de alguns conjuntos urbanos em Portugal e no Brasil, aquela construção só adquiriu expressão nas duas últimas décadas do século passado, o que, no fundo, coincide no tempo com o que sucedeu noutras culturas. Coincide também com um significativo alargamento do número de investigadores dedicados às temáticas da história e do património urbanísticos, bem como ao estabelecimento de interação científica entre especialistas trabalhando nas diversas geografias (Araujo e Carita (org.), 1982-1997; Rossa et al (org.), 1999). Surgiram então as primeiras propostas de leitura geral, ou seja, para toda a geografia da urbanística de influência portuguesa (Fernandes, 1987; Rossa, 1995). Tinham, porém, como âmbito cronológico o $1 .^{\circ}$ Império, ${ }^{45} \mathrm{O}$

45 Considero $1 .^{\circ}$ Império Português o sistema colonial que se desenvolveu desde as ações de descobrimento e expansão do século XV até à independência do Brasil em 1822, e $2 .^{\circ}$ Império a recomposição colonial produzida com base nos territórios africanos desde então, a qual teve o seu fim na descolonização formalizada em 1975. Rejeito assim a proposta implícita em Gervase Clarence-Smith (1985), The third Portuguese empire: 1825-1975: a study in economic imperialism. Manchester University Press, a qual tem como base uma perceção errada, porque fragmentadora, do sistema colonial português que precedeu o período que trata, do qual o autor é 
que bem se conjuga com as suas visões nacionalistas, aliás patentes nos trabalhos setoriais que os precederam no Brasil e em Portugal.

Com graduação diversa, essa visão tinha como princípio que os modelos urbanísticos com os quais se produziu a urbanização de novos territórios, transpunham além-mar um casticismo português que ia da espontaneidade ao racionalismo da engenharia militar, passando por um variado leque de expressões, nas quais foram sempre destacados os aspetos conducentes a uma especificidade portuguesa. Entre outras razões é necessário ter em conta que o desenvolvimento dessas visões decorreu a par com o estudo e valorização, também de pendor nacionalista, do urbanismo hispânico, de maior expressão e impacto, mas essencialmente de mais imediata perceção e leitura. $\mathrm{O}$ facto de na cronologia do $1 .^{\circ}$ Império a produção urbana colonial ser essencialmente ibérica, favorecia não só essa surda discussão a dois, como também a exclusão de dois factos óbvios: os processos, modelos e territórios da colonização portuguesa e espanhola são muito diversos; a cultura urbanística ibérica é, antes do mais, europeia, com tudo o que isso contém de raízes da Antiguidade Clássica e, assim, de mediterrânico (Rossa, 2014). Iludia ainda um outro facto: ainda que de forma ténue, essa urbanística foi sendo matizada por influências do que colonizava e dos próprios processos de colonização. Não é a mesma coisa urbanizar ex-novo e ex-nibilo na América ou a par na Índia.

Haveria, pois, uma cidade portuguesa, expressão que desde logo contém o já denunciado pecado original de se confundir cidade com urbanismo, e tende a veicular a ideia de que as ações urbanísticas são sempre centralmente determinadas, o que não leva em conta um sem fim de matizes que dependem de culturas de território com tanto de difuso quanto de arreigado. O desenvolvimento de

especialista. Sobre este livro ver a recensão de Valentim Alexandre "Um imperialismo económico?" (Alexandre, 2000: 141-145). 
novos estudos monográficos e/ou sínteses parcelares, e decorrente florescimento de novas metodologias como as que acima ficaram enunciadas, bem como o estabelecimento de fluxos de estímulo interdisciplinar (de que o projeto e programa de doutoramento Patrimónios de Influência Portuguesa são um expoente), catalisaram a inevitável revisão do conceito, o que considero vertido no relatório significativamente intitulado (des)Construção da cidade portuguesa... (Rossa, 2012). Revisão que, além de propor a renovação do olhar sobre as realidades e os antecedentes medievais no seu contexto europeu, integrou a necessidade de se desenvolverem estudos sobre a produção urbanística do $2 .^{\circ}$ Império, bem como das comunidades emigradas. Porém, para uma visita aos casos, a síntese mais completa e atual será a contida na obra coletiva dirigida por José Mattoso sob a forma de dicionário-enciclopédia, Património de Origem Portuguesa: arquitetura e urbanismo (Mattoso, 2010).

Procurar a projeção colonial de uma expressão cultural europeia é diferente de pretender encontrar formas de expressão comuns de um conjunto de culturas com matrizes diversas. Desde logo no primeiro caso o objeto de pesquisa são as regras e/ou o modelo fundador, no segundo o que é que eles induziram de comum na cidade contemporânea, o que necessariamente implica valorizar todas as contaminações. Persiste, todavia, um vício de partida: a ideia de cidade (Rykwert, 1963) que preside à nossa observação é a cunhada e desenvolvida a partir das culturas clássicas do Mediterrâneo, também ela a seu tempo (Idade Média) influenciada por culturas do norte, o caso cristão-europeu, ou do médio-oriente, o caso islâmico. Temos tido muita dificuldade em reconhecer outras, o que é dificultado pela existência de estudos que as identifiquem e estudem com a profundidade com que tem sido estudados esses dois ramos do que pode ser considerado um modelo, uma ideia de partida, a da cidade da civilização do Ocidente. Em suma como identificar a presença de influências diferentes quando não conhe- 
cemos as suas linguagens, menos ainda os seus discursos? É uma questão com a qual teremos de continuar a conviver com o cuidado de não esquecer.

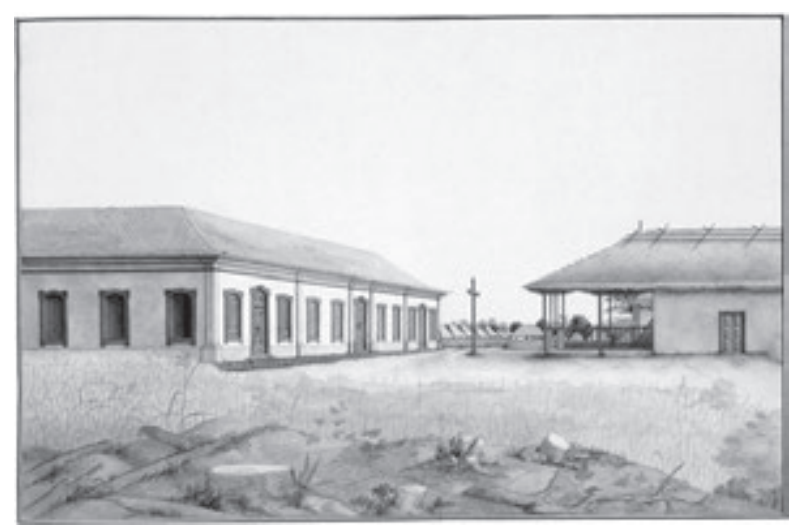

Fig. 11 Prospecto da Villa de Borba a Nova..., c.1790, Museu Botânico Bocage (Lisboa). Notem-se os contrastes.

No caso português esse problema coloca-se com intensidades muito diferentes, pois entre o Brasil e Índia, por exemplo, as expressões urbanísticas endógenas eram muito diversas, como diverso foi o investimento do processo colonial na criação de cidades e redes urbanas. Em tudo isso é também necessário conjugar os diferentes graus de intervenção do Estado, pois em alguns casos foram outros os agentes a catalisar e desenvolver processos de urbanização, de que Macau será o exemplo mais expressivo e durável. Assim se afirmaram discursos urbanísticos portugueses em territórios onde o português mal chegou a ser língua franca. Contudo, à medida que se avançava no tempo era inevitável caminhar-se para um monopólio do poder central na determinação e gestão dos processos de urbanização, o que se já aconteceu com o período iluminista (Fig. 11), foi a rotina ao longo do $2 .^{\circ}$ Império, ou seja, em África. Entretanto já se dera a extraordinária mudança de paradigma ocorrida com 
a era das revoluções, a passagem da $1 .^{a}$ para a $2 .^{a}$ modernidade. A comparação com o império espanhol fora substituída pelas dos sistemas coloniais inglês e os demais consubstanciados pela Conferência de Berlim (1984-85).

Com efeito, a discussão sobre as complexas diferenças e convergências entre os diversos modelos e sistemas do colonialismo moderno, é uma área de debate científico extenso, intenso e prolixo, sendo que o caso português não é, de forma alguma, uma exceção. ${ }^{46}$ Arrisco, porém, considerar que, por entre as suas grandes diferenças de fundo, têm especial relevância para a urbanística a pobreza do país, o antecedente (Portugal foi a única potência colonial moderna com um antecedente colonial estruturado e de âmbito global) e o caráter confessional do seu sistema (bem para além da vinculação Estado-Igreja que, aliás, teve períodos de acentuada intermitência). Os três remetem para dinâmicas de tempo longo, continuidade e invariantes que, como fomos vendo, são cruciais na cultura do território das comunidades. Por alguma razão os colonos portugueses emigravam para as colónias com a perspetiva clara de se fixar definitivamente, o que teve uma tradução evidente na expressão consolidada da arquitetura e urbanismo, no discurso urbanístico e territorial.

A isso foi correspondendo o Estado, em especial a partir da década de 1950, precisamente quando os processos de descolonização de todas as outras potências coloniais ganhavam curso. É então muito significativo que, enquanto a arquitetura e o urbanismo modernistas foram assumidos como a linguagem da utopia das independências de países como o Ghana, o Senegal, o Quénia, a Zambia ou a Costa do Marfim (Kultermann, 1963 e 1999; Hers, 2015), também o sejam para a construção das utopias brancas das

46 Face à dificuldade de indicar algo claramente de síntese, remeto para o texto de Miguel Bandeira Jerónimo neste livro. Do ponto de vista da perceção de alguns fenómenos mais diretamente influentes nas questões territoriais e urbanas, vejam-se ainda Alexandre, 1998, 2000 e 2001 e Jerónimo, 2008. 
colónias (então eufemisticamente províncias ultramarinas) portuguesas e da África do Sul (Haarhoff, 2011), ou seja, elementos centrais do discurso urbanístico do segregacionismo racial (Njoh, 2007). Nas colónias africanas portuguesas consolidam-se, pois, pelas décadas de 1950 a 1970, cidades com um urbanismo dual que, apesar da absoluta interdependência entre a cidade do betão ou do asfalto e o musseque ou o caniço (Fig. 12), apenas tinham reconhecidas como cidade as áreas resultantes dessa utopia moderna, situação que as descolonizações ocorridas em 1975 transformaram num desafio ainda por responder, talvez porque ainda não foi estudado e compreendido de forma cabal e integrada (Viegas, 2015; Rossa, 2015a). Tudo era e é, porém, uma cidade, nos casos mais expressivos, como Luanda ou Maputo, com dimensões metropolitanas e, por conseguinte, animadas por diversos centros de identidade com identidades nem sempre diversas.

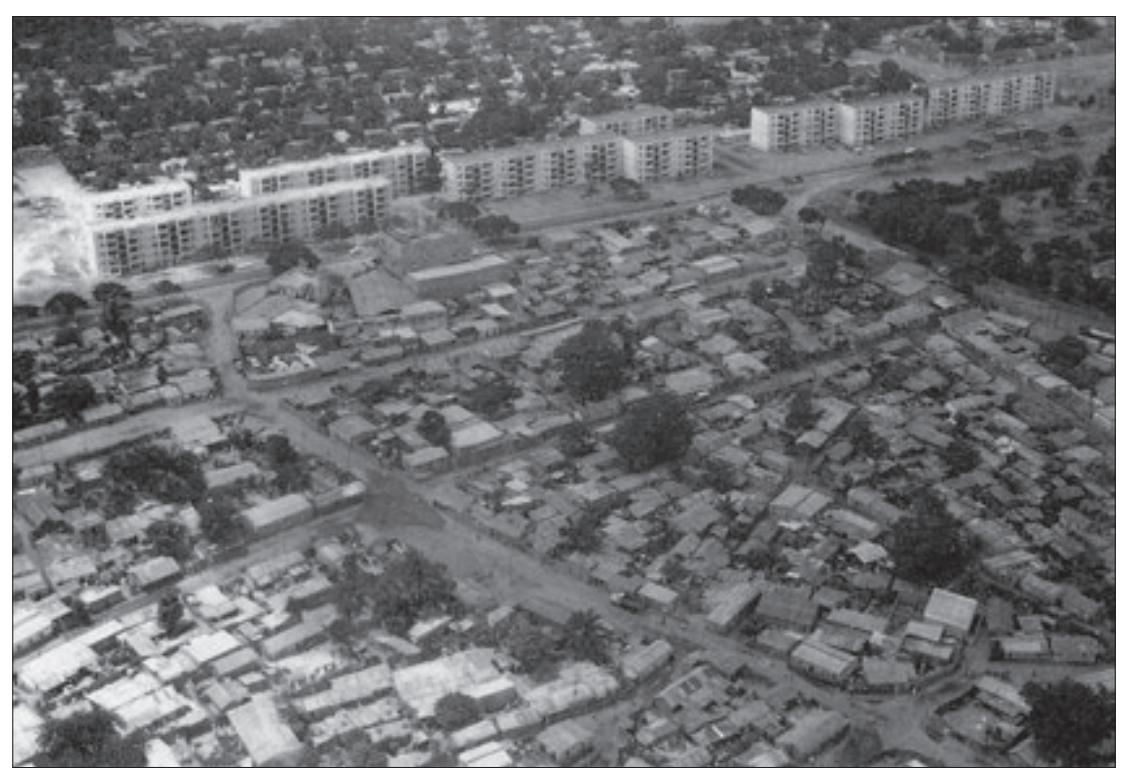

Fig. 12 Urbanismo dual betão-asfalto vs. musseque-caniço em Luanda. In Sebastian Kasak (1996), "Os musseques de Luanda: problemas do desenvolvimento urbano”, Garcia da Orta: série geografia. Lisboa: n. ${ }^{\circ}$ 1, vol. 15: 65-78. 
Os urbanismos de influência portuguesa apresentam-se, assim, de formas extraordinariamente variadas, abrindo múltiplas linhas de investigação e de conexão com outras expressões patrimoniais e culturais, para as quais aqui fica resumidamente proposto o quadro temático, teórico e metodológico que agora concluo. É um diálogo interno de uma potencial comunidade alargada que se pode identificar nessa influência, mas também fora dela, ou não houvesse mais territórios com discursos de cidade com influência portuguesa do que com palavras em Português.

\section{Referências bibliográficas}

ALEXANDRE, Valentim (1998), "Ruptura e estruturação de um novo império" e "Configurações políticas" in História da Expansão Portuguesa. Francisco Bethencourt e Kirti Chaudhuri (dir.). Lisboa: Círculo de Leitores. vol. 4, 9-211.

ALEXANDRE, Valentim (2000), Velho Brasil novas Áfricas: Portugal e o Império (1808-1975). Porto: Afrontamento.

ALEXANDRE, Valentim (2001), "O império português (1825-1890): ideologia e economia”, Análise Social. Lisboa, 2004: ICS. n. ${ }^{\circ}$ 169, vol. XXXVIII, 959-979.

ARAUJO, Renata; CARITA, Helder (org.) (1982-1997), Colectânea de Estudos: Universo Urbanístico Português 1415-1822. Lisboa, 1998: Comissão Nacional para as Comemorações dos Descobrimentos Portugueses.

ASCHER, François (2001-2008), Novos princípios do urbanismo [e] Novos compromissos urbanos: um léxico. Lisboa, 2010: Livros Horizonte.

BANDARIN, Francesco; OERS, Ron von (2012), The historic urban landscape. Oxford: Wiley-Blackwell.

BANDARIN, Francesco; OERS, Ron von (ed.) (2015), Reconnecting the City: the Historic Urban Landscape approach and the future of urban heritage. Oxford: Wiley-Blackwell. 
CASTElls, Manuel (2004), "Un mundo urbanizado sin ciudades?", La Vanguardia. Barcelona: 2004/05/09.

CERDÁ, Ildefonso (1867), Teoría general de la urbanización, y aplicación de sus principios y doctrinas a la reforma y ensanche de Barcelona. Madrid, 1968: Instituto de Estudios Fiscales, 3 vol.

CHOAY, Françoise (1992), L'allégorie du patrimoine. Paris: Éditions du Seuil. COElHo, Carlos Dias (coord.) (2013), Cadernos de morfologia urbana 1: os elementos urbanos. Lisboa: Argumentum.

CONZEN, M.R.G. (1960), Alnwick, Northumberland: a study in town-plan analysis. London, 1969: Institute of British Geographers.

CONZEN, M.R.G. (1968), "The Use of Town Plans in the Study of Urban History" in The Study of Urban History. London: H. J. Dyos (ed.), Edward Arnold, 113-130.

CORBOZ, André (2000), "La Suisse comme hyperville", Le Visiteur. Paris: Société française des architectes \& Éditions de l'Imprimeur, n. ${ }^{\circ} 6$.

CORBOZ, André (2001), Le Territoire comme palimpseste et autres essais. Paris: L'Imprimeur.

Creative economy report 2013 special edition: widening local development pathways. Paris, 2013: UNDP e UNESCO.

Cullen, Gordon (1961), Paisagem Urbana. Porto, 1984: Edições 70.

DEMISSIE, Fassil (ed.) (2012), Colonial Architecture and Urbanism in Africa: Intertwined and Contested Histories (Design and the Built Environment). Burlington: Ashgate.

Fernandes, José Manuel (1987), "O Lugar da Cidade Portuguesa." Povos e Culturas, Lisboa: Centro de Estudos de Povos e Culturas de Expressão Portuguesa da Universidade Católica Portuguesa, n. ${ }^{\circ}$ 2, 79-112.

GONÇAlves, Adelino (2011), Património urban(ístic)o e planeamento da salvaguarda. Coimbra: dissertação de doutoramento apresentada à Faculdade de Ciências e Tecnologia da Universidade de Coimbra.

Graham, Brian; HOWARD, Peter (ed.) (2008), The Ashgate Research Companion to Heritage and Identity. Aldershot: Ashgate. 
HAARHOFF, Errol J. (2011), "Appropriating modernism: apartheid and the South African township", A|Z, Journal of the Faculty of Architecture. Istanbul: Istanbul Technical University, n. ${ }^{\circ}$ 1, vol. 8, 184-195.

HERS, Manuel (ed.) (2015), African Modernism: The Architecture of Independence. Ghana, Senegal, Kenya, Zambia, Côte d'Ivoire. Chicago: University of Chicago Press.

International charters for conservation and restoration: monuments and sites I. Munique, 2004: ICOMOS.

JANSSENA, Joks; LuiTenB, Eric; RENESC, Hans; ROUWEN DALC, Han (2014), "Heritage planning and spatial development in the Netherlands: changing policies and perspectives", International Journal of Heritage Studies. Routledge, $n .^{\circ} 20,1: 1-21$.

Jerónimo, Miguel Bandeira (2008), A diplomacia do império. Política e religião na partilha de África (1820-1890). Lisboa, 2012: Edições 70.

KUltermanN, Udo (1963), New architecture in Africa. New York: Universe Books.

KUltermanN, Udo; FRAMPTON, Kenneth (orgs.) (1999), World Architecture 1900-2000: a critical mosaic. Central and Southern Africa, vol. 6. New York: Springer.

KOESTLER, Arthur (1967), The Ghost in the Machine. London, 1990: Arkana. KOSTOF, Spiro (1991), The city shaped: urban patterns and meanings through bistory. London: Thames and Hudson.

KOSTOF, Spiro (1992), The city assembled: the elements of urban form through bistory. London: Thames and Hudson.

KUBLER, George (1962), The shape of time, remarks on the history of things. New Haven, 1967: Yale University Press.

LOPES, Flávio; CORREIA, Miguel Brito (2014), Património cultural: critérios e normas internacionais de proteção. Lisboa: Livros Horizonte.

LOWENTHAL, David (1999), "Authenticity: Mock of faith or quicksand quagmire?", Newsletter. The Guetty Conservation Institute, n. ${ }^{\circ}$ 14, 3: 5-8.

LYNCH, Kevin (1960), A imagem da cidade. Porto, 1982: Edições 70. 
LYNCH, Kevin (1972), De qué tiempo es este lugar?. Barcelona, 1975: Gustavo Gili.

MARZOT, Nicola (2002), "The study of urban forma in Italy", Urban Morphology. 6(2): 59-73.

MAtToso, José (dir.) (2010), Património de Origem Portuguesa no Mundo: arquitetura e urbanismo. Lisboa: Fundação Calouste Gulbenkian, 3 vol. MiTCHELL, William J. (1995), City of bits: space, place, and the infobahn. Cambridge: MIT Press.

MitChell, William J. (1999), E-topía: "vida urbana, Jim; pero no la que nosotros conocemos.” Barcelona, 2001: Gustavo Gili.

MONCLOUS, Javier; GUARDIA, Manuel (ed.) (2006), Culture, urbanism and planning. Burlington: Ashgate.

MOUDON, Anne Vernez (1997), "Urban morphology as emerging interdisciplinary field", Urban Morphology, 1: 3-10.

MURATORE, Giorgio (1975), La ciudad renascentista. Madrid, 1980: Instituto de Estudios de Administration Local.

$\mathrm{NJOH}$, Ambe J. (2007), Planning power: town planning and social control in colonial Africa. London: UCL.

ROGER, Alain (1997), Court traité du paysage. Paris: Gallimard.

ROSSA, Walter; ARAUjO, Renata; CARITA, Helder (org.) (1999), Colóquio Internacional Universo Urbanístico Português 1415-1822. Lisboa, 2001: atas, Comissão Nacional para as Comemorações dos Descobrimentos Portugueses.

RossA, Walter (1995), A cidade portuguesa, História da Arte Portuguesa. Lisboa: Círculo de Leitores, vol. III, 233-323.

ROSSA, Walter (1989-2001), A urbe e o traço: uma década de estudos sobre o urbanismo português. Coimbra, 2002: Almedina.

ROSSA, Walter (2002-2013), Fomos condenados à cidade: uma década de estudos sobre património urbanístico. Coimbra, 2015: Imprensa da Universidade.

ROSSA, Walter (2012), (des)Construção da cidade portuguesa: urbanização e conceito. Coimbra 2013: relatório da unidade curricular apresentado 
à Universidade de Coimbra para a obtenção do grau de Agregado em Arquitetura.

ROSSA, Walter (2014), "Stone Raft, allegory on the spread of European urbanistics in Early Modern times”, Joelbo. Coimbra: Departamento de Arquitetura da Universidade de Coimbra. n. ${ }^{\circ}$ 6, no prelo (também em https://www.academia.edu/9706967/Stone_Raft_allegory_on_the_ spread_of_European_urbanistics_in_Early_Modern_times)

RossA, Walter (2015a), “A fénix do património colonial”, Público. Lisboa: 2015/01/15.

ROsSA, Walter (2015b), "Lisboa: da busca de imagem de capital", Rossio, estudos de Lisboa. Lisboa: Gabinete de Estudos Olisiponenses. n. ${ }^{\circ} 5$. RYKWERT Joseph (1963), The Idea of a Town: the anthropology of urban form in Rome, Italy and the Ancient World. Cambridge/London, 1988: MIT Press.

SASSEN, Saskia (1991), The global city. Princeton, 2001: University Press. SASSEN, Saskia (1994), Cities in a world economy. Thousand Oaks, 2012: Sage. SITTE, Camillo (1889), Der Städte-Bau nach seinen Künslerischen Gründsätzen. Viena.

SOLÀ-MORALES I RUBIÓ, Manuel de (1993), Las formas de crecimento urbano. Barcelona, 1997: UPC.

STINY, George; GIPS, James (1972), "Shape grammars and the generative specification of painting and sculpture", Information Processing, 71: 1460-1465.

STINY, George (1980), "Introduction to shape and shape grammars", Environment and Planning B: Planning and Design, 7(3): 343-351.

WATERTON, Emma; WATSOn, Steve (ed.) (2015), The Palgrave handbook of contemporary heritage research. Basingstoke: Palgrave.

WEBBER, Melvin M. (1968), "The post-city age”, Daedalus. Boston: MIT Press, n. ${ }^{\circ}$ 97-4: 1091-1110.

ZAGARI, Franco (2006), Questo è paesaggio: 48 definizioni. Roma: Mancosu. TERÁN, Fernando de (2009), El pasado activo: del uso interesado de la bistoria para el entendimiento y la construcción de la ciudad. Madrid: Akal. 
2. ${ }^{a}$ PARTE: DisCursos E PERCURSOS

VIEGAS, Sílvia Leiria (2015), Luanda, cidade (im)previsível? Lisboa: dissertação de doutoramento apresentada à Faculdade de Arquitetura da Universidade de Lisboa. 
(Página deixada propositadamente em branco) 
NOTAS BIOGRÁFICAS 
(Página deixada propositadamente em branco) 


\section{NOTAS BIOGRÁ FICAS}

\section{ANA MARIA MAUAD}

Ana Mauad é doutorada em História do Brasil pela Universidade Federal Fluminense (1990) e pós-doutorada na área de História da Imagem e especialidade de Fotografia, no Museu Paulista da Universidade de São Paulo. É professora do Departamento de História, Coordenadora do Programa de Pós-Graduação em História e Pesquisadora do Laboratório de História Oral e Imagem da Universidade Federal Fluminense (desde 1992), do Conselho Nacional de Desenvolvimento Científico e tecnológico (desde 1996) e Cientista do Nosso Estado Faperj (desde 2013). Possui vários artigos sobre temas ligados à História visual, História cultural e História da Memória (especialmente fotografia), destaque para as publicações: Poses e Flagrantes: Dicionário histórico-biográfico da fotografia e dos Fotógrafos no Brasil (com Ana Serrano e Clarissa Castro) (2013).

\section{ANTÓNIO SOUSA RIBEIRO}

António Sousa Ribeiro é professor catedrático da Secção de Estudos Germanísticos do Departamento de Línguas, Literaturas e Culturas da Faculdade de Letras da Universidade de Coimbra. Entre outros cargos, foi, nesta Faculdade, presidente do Conselho Científico e diretor do Departamento de Línguas, Literaturas e Culturas. É também investigador sénior do Centro de Estudos Sociais da UC, a cujo Conselho Científico presidiu entre 2003 e 2007 e onde é presentemente coordenador da direção e coordenador do programa de doutoramento em Pós-Colonialismos e Cidadania Global. Foi, entre 1991 e 2008, responsável pela Revista Crítica de Ciências Sociais. 
Publicou extensamente sobre diferentes tópicos no âmbito dos Estudos Germanísticos (em particular sobre Karl Kraus e a modernidade vienense), da Literatura Comparada, da Teoria da Literatura, dos Estudos Culturais, dos Estudos Pós-Coloniais, dos Estudos de Tradução e dos Estudos sobre a Violência. Tem-se dedicado igualmente à tradução literária.

\section{EDUARDO LOURENÇO}

Eduardo Lourenço, ensaísta e crítico literário, lecionou em várias universidades: Coimbra, Hamburgo, Heidelberg, Montpellier, Baía, Grenoble e Nice, até à jubilação (1988). É administrador não executivo da Fundação Calouste Gulbenkian desde 2002. Da sua vasta obra, destacam-se livros marcantes no pensamento português e europeu: Heterodoxia I (1949); O Labirinto da Saudade - Psicanálise Mítica do Destino Português (1978); Nós e a Europa ou as Duas Razões (1988); A Europa Desencantada: para uma Mitologia Europeia (1994); Fernando Pessoa Rei da nossa Baviera (1997); Portugal como destino, seguindo a Mitologia da saudade (1999); A morte de Colombo: metamorfose e fim do Ocidente como mito (2005); Do colonialismo como nosso impensado (2014). Têm-lhe sido atribuídos muitos prémios nacionais e internacionias, destacando-se Prémio Europeu de Ensaio Charles Veillon (Lausanne, 1988), Prémio Camões (1996), o Prémio Pessoa (2011). Recebeu o título de Doutor Honoris Causa por diversas universidades entre as quais Bolonha em 2007, onde foi criada a cátedra com o seu nome. Foi ainda condecorado pelos governos português e francês.

\section{FRANCISCO BETHENCOURT}

É Professor Charles Boxer no Departamento de História do King's College London e investigador associado do Centro de Estudos Sociais da Universidade de Coimbra. Licenciado pela Universidade de Lisboa, mestre pela Universidade Nova de Lisboa e doutorado pelo Instituto Universitário Europeu, Florença. Foi diretor da Biblioteca Nacional entre 1996 e 1998, e diretor do Centro Cultural Gulbenkian em Paris entre 1999 e 2004. Dos seus interesses de investigação, destaque para a história dos territórios de 
língua portuguesa; história do racismo; identidade portuguesa; história comparada da expansão europeia; história da Inquisição (Portugal, Espanha, Itália e colónias ibéricas). Trabalha agora na historia da desigualdade. Das suas publicações, destaque para: O Imaginário da Magia (1987); A Memória da Nação (org. com Diogo Ramada Curto, 1991); L'Inquisition à l'époque moderne: Espagne, Portugal, Italie, $X V^{e}-X I X^{e}$ siècles (1995, com versões em português, espanhol, sérbio; revisto e atualizado para inglês, 2009); História da Expansão Portuguesa (org. com Kirti Chaudhuri, 1998); Correspondence and Cultural Exchange in Europe, 1400-1700, (org. com Florike Egmond, 2007); L'empire portugais face aux autres empires, (org. com Luiz Felipe de Alencastro, 2007); The Portuguese Oceanic Expansion, 1400-1800 (org. com Diogo Ramada Curto, 2007, traduzido para português, 2010), Frontières religieuses dans le monde moderne (org. com Denis Crouzet, 2013); Racisms: From the Crusades to the Twentieth Century (2013).

\section{FRANCISCO NOA}

Francisco Noa é doutorado em Literaturas Africanas de Língua Portuguesa (2001), pela Universidade Nova de Lisboa. Ensaísta e professor de Literatura Moçambicana na Universidade Eduardo Mondlane, Maputo, é também investigador associado na Universidade de Coimbra. Atualmente, Reitor da Universidade Lúrio (UniLurio), foi diretor e investigador do Centro de Estudos Sociais Aquilo de Bragança (CESAB). Professor convidado, orientador e examinador de teses em universidades nacionais e no estrangeiro, assumiu ainda vários cargos de gestão em instituições de ensino superior. A sua pesquisa atual debruça-se sobre os temas de colonialidade, nacionalidade e transnacionalidade literária, a literatura como conhecimento e o diálogo intercultural no Oceano Índico, a partir da literatura. Entre as suas publicações, destaque para: Literatura Moçambicana: Memória e Conflito (1997); A Escrita Infinita (1998); Império, Mito e Miopia. Moçambique como Invenção Literária (2002); A Letra, a Sombra e Água. Ensaios E Dispersões (2008); Perto do Fragmento, a Totalidade. Olhares sobre a literatura e o mundo (2012); A escrita Infinita. Ensaios sobre literatura moçambicana, 2. ${ }^{a}$ ed., (2013). 


\section{GRAÇA DOS SANTOS}

Graça dos Santos é docente na Universidade Paris Ouest Nanterre La Défense, onde é investigadora no CRILUS; é investigadora associada no Centre d'Histoire Culturelle des Sociétés Contemporaines, onde codirige desde 2001 com Jean-Claude Yon o seminário de investigação "Histoire du spectacle vivant XIX ${ }^{\mathrm{e}}$ et $\mathrm{XX}^{\mathrm{e}}$ siècles", na Société d'Histoire du Théâtre, Bibliothèque Nationale de France, Paris; e também no IELT (Instituto de Estudos de Literatura Tradicional - FCSH-UNL). Os seus trabalhos analisaram em particular a ditadura salazarista e a censura. Encenadora, atriz e professora de teatro, escreve sobre as noções de corpo físico/corpo social, sobre as representações cénicas do corpo e do povo. Publicou artigos sobre a história do espetáculo europeu e sobre o teatro português; publicou Le spectacle dénaturé, le théâtre portugais sous le règne de Salazar 1933-1968 (2002). é autora no Dictionnaire encyclopédique du théâtre à travers le monde (Dir. Michel Corvin, 2008). Cofundadora da companhia Cá e Lá (Compagnie bilingue français/portugais) tem desenvolvido um trabalho sobre o ator bilingue e sobre as conexões teatro e ensino das línguas. É diretora de Parfums de Lisbonne - Festival d'urbanités croisées entre Lisbonne et Paris.

\section{HELDER MACEDO}

Helder Macedo é doutorado em Letras pela Universidade de Londres, King's College, onde foi Camoens Professor of Portuguese e é atualmente Professor Catedrático Emérito. Foi Diretor Associado do Instituto de Estudos Românicos da Universidade de Londres e o diretor fundador da revista Portuguese Studies (Prémio da Conference of Editors of Learned Journals, EUA). A sua vasta obra ensaística inclui livros sobre poesia medieval, Bernardim Ribeiro (Prémio da Academia das Ciências de Lisboa), Luís de Camões, Cesário Verde, a coletânea de ensaios sobre autores portugueses e brasileiros Trinta Leituras e, em colaboração com Fernando Gil, Viagens do Olhar: Visão, Retrospecção e Profecia no Renascimento Português, também publicado nos EUA (Prémios do PEN Clube Português e da Associação 
Internacional dos Críticos Literários). É autor de seis livros de poesia e de seis romances publicados em Portugal e no Brasil e com traduções em várias línguas.

JOSÉ PESSÔA

José Pessôa é arquiteto e doutor em planejamento urbano e regional pelo Istituto Universitario di Architettura di Venezia, Itália. Professor associado da Escola de Arquitetura e Urbanismo da Universidade Federal Fluminense, Niterói/RJ, onde leciona Projeto de Restauração e Teoria e História da Arquitetura. Professor convidado das universidades: UNIROMA 3 (Italia,2007); Universidade Nova de Lisboa (Portugal, 2007 e 2010); Universidade do Algarve (Portugal, 2007); Instituto Superior Técnico de Lisboa (Portugal, 2007, 2010, 2013); Universidade Eduardo Mondlane (Moçambique, 2012); Universidade de Évora (Portugal, 2013); Université Aix Marseille (França, 2013, 2015). Conselheiro da Fundação Oscar Niemeyer. Membro do Conselho Executivo e Científico do portal interativo piHip-portuguese influenced Heritage, que integra o projeto Património de Origem Portuguesa no Mundo - Arquitetura e Urbanismo da Fundação Calouste Gulbenkian, Portugal. Pesquisador do CNPq, é autor de livros, ensaios e artigos publicados no Brasil e no exterior, entre os quais Atlas de Centros Históricos do Brasil (Casa da Palavra, 2007), The Telephone on the Eighteenth-Century Table: How Brazilian Modern Architects conceived the Preservation of Historic City Centers (Future Anterior, 2010), Bloquinhos de Portugal: a arquitetura portuguesa no traço de Lucio Costa (Funarte, 2012).

\section{LUÍS FILIPE OLIVEIRA}

Luís Filipe Oliveira é docente no Departamento de Artes e Humanidades da Universidade do Algarve e do curso de Doutoramento Patrimónios de Influência Portuguesa, do Instituto de Investigação interdisciplinar - Centro de Estudos Socias da Universidade de Coimbra. Doutorou-se em História Medieval pela Universidade do Algarve (2007), sendo membro do Instituto de Estudos Medievais da Universidade Nova de Lisboa e colaborador do 
CEHR da Universidade Católica e do Campo Arqueológico de Mértola. Entre os seus trabalhos, destacam-se A Casa dos Coutinhos: Linhagem, Espaço e Poder (1360-1452), Cascais, Editora Patrimonia, 1999; e A Coroa, os Mestres e os Comendadores: As Ordens Militares de Avis e de Santiago (13301449), Faro, Universidade do Algarve, 2009. Tem colaborações dispersas (Alan Murray (dir.), The Crusades. An Encyclopedia, 4 vols. Santa Barbara, 2006; N. Bériou e Ph. Josserand (dirs.), Prier et Combattre. Dictionnaire européen des ordres militaires au Moyen Âge, Paris, 2009), e foi responsável com Philippe Josserand e Damien Carraz pela edição de Élites et Ordres Militaires au Moyen Âge. Rencontre autor D'Alain Demurger, Madrid, Casa de Velázquez, 2015.

\section{LUÍSA TRINDADE}

Luísa Trindade é doutorada em História da Arte pela Universidade de Coimbra (2010), em cujo departamento de História, Estudos Europeus, Arqueologia e Artes leciona desde 1996. Coordenadora da licenciatura em História da Arte, é responsável pela lecionação de várias disciplinas do $10^{\circ}$ ciclo de estudos (entre as quais Cidade Portuguesa e História do Urbanismo), bem como do mestrado em Arte e Património. É desde 2008 Investigadora do Centro de Estudos Sociais e, desde 2010, professora no Programa de Doutoramento Patrimónios de Influência Portuguesa (III-CES). Participou em vários projetos europeus sobre o ensino e investigação da História, sendo atualmente responsável científica do projeto Castelos e Muralhas do Mondego. Com inúmeras conferências proferidas em Portugal e no estrangeiro, destacam-se, no âmbito das publicações dedicadas à História do Urbanismo, A Casa urbana em Coimbra. Dos finais da Idade Média aos inícios da Época Moderna (2002) e Urbanismo na composição de Portugal (2013).

\section{MARGARIDA CALAFATE RIBEIRO}

Margarida Calafate Ribeiro é investigadora-coordenadora no Centro de Estudos Sociais, Universidade de Coimbra, docente e coordenadora, com Walter Rossa, do programa de Doutoramento, "Patrimónios de Influência 
Portuguesa“ e, com Roberto Vecchi, da Cátedra Eduardo Lourenço, Camões/ Universidade de Bolonha. Em 2015 ganhou uma bolsa do Conselho Europeu de Investigação. Das suas publicações destacam-se Uma história de regressos: Império, Guerra Colonial e Pós-colonialismo (2004), África no feminino: as mulheres portuguesas e a Guerra Colonial (2007) e a organização de vários livros: Fantasmas e fantasias imperiais no imaginário português contemporâneo (e Ana Paula Ferreira, 2003); Moçambique: das palavras escritas (e Paula Meneses, 2008); Lendo Angola (e Laura Padilha, 2008); Literaturas da Guiné-Bissau: cantando os escritos da história (e Odete Semedo, 2011); Antologia da memória poética da Guerra Colonial (e Roberto Vecchi, 2011).

\section{MARIA FERNANDA BICALHO}

Maria Fernanda Bicalho é licenciada em História pela PUC-RJ (1981), mestre em Antropologia Social pelo Museu Nacional-UFRJ (1988), doutora em História Social pela USP (1997), pós-doutoranda pelo ICS da Universidade de Lisboa (2007 e 2013). É Professora Associada no Departamento de História da Universidade Federal Fluminense, na qual foi coordenadora do Programa de Pós-Graduação em História entre 2010 e 2013. Foi professora convidada na Université de Provence Aix Marseille (desde 2009) e na École des Hautes Études en Sciences Sociales (em 2014). Em 2015 passou a integrar o corpo docente do Doutoramento Patrimónios de Influência Portuguesa. Dedica-se à História do Brasil colonial, do Rio de Janeiro nos séculos XVII-XIX, das dinâmicas e redes de poder e administração no império português. Entre suas publicações e obras coletivas destacam-se O Antigo Regime nos Trópicos (com João Fragoso e Maria de Fátima Gouvêa, 2001); A Cidade e o Império. O Rio de Janeiro no Século XVIII (2003); Modos de Governar (com Vera Ferlini, 2007); O Governo dos Povos (com Laura de Mello e Souza e Júnia Furtado, 2009).

\section{MIGUEL BANDEIRA JERÓNIMO}

Miguel Bandeira Jerónimo é investigador Auxiliar do Instituto de Ciências Sociais da Universidade de Lisboa (ICS-UL). Doutor pelo King's College London, foi Professor Visitante na Universidade de Brown (EUA) (2011 e 
2012). É docente nos programas de Doutoramento do CES/III, "Patrimónios de Influência Portuguesa", e do ICS, "Programa Interuniversitário de Doutoramento em História: mudança e continuidade no mundo global”. Os seus interesses de pesquisa centram-se na História Global e Comparada do Imperialismo e do Colonialismo (Sécs. XVIII-XX). Em 2010, publicou Livros Brancos, Almas Negras: A "Missão Civilizadora" do Colonialismo Português, c. 1870-1930. Em 2012, publicou A Diplomacia do Império. Política e Religião na Partilha de África e editou O Império Colonial em Questão. Recentemente, coeditou Portugal e ofim do Colonialismo. Dimensões internacionais (2014), publicou The "Civilizing Mission" of Portuguese Colonialism (1870-1930) e coeditou The Ends of European Colonial Empires: Cases and comparisons (ambos na Palgrave-Macmillan, em 2015). É coordenador do projeto internacional Internationalism and Empire: The Politics of Difference in the Portuguese Colonial Empire in Comparative Perspective (1920-1975) e é coeditor da coleção HistóriaESociedade nas Edições 70.

\section{MIRIAN TAVARES}

Com formação académica nas Ciências da Comunicação, Semiótica e Estudos Culturais (doutorou-se em Comunicação e Cultura Contemporâneas, na Universidade Federal da Bahia), tem desenvolvido o seu trabalho de investigação e de produção teórica em domínios relacionados com o Cinema, a Literatura e outras Artes, bem como nas áreas de estética fílmica e artística. Como professora da Universidade do Algarve, participou na elaboração do projeto de licenciatura em Artes Visuais, do mestrado e doutoramento em Comunicação, Cultura e Artes e do doutoramento em Média-Arte Digital. Atualmente é Coordenadora do CIAC (Centro de Investigação em Artes e Comunicação - http://www.ciac.pt/ e Diretora da Faculdade de Ciências Humanas e Sociais da Universidade do Algarve.

\section{RENATA ARAUJO}

Renata Malcher de Araujo é professora do Departamento de Artes e Humanidades da Faculdade de Ciências Humanas e Sociais da Universidade do 
Algarve e Investigadora Integrada do CHAM (Centro de História d'Aquém e d'Além Mar UNL-FCHS/UA. Licenciada em Arquitetura e Urbanismo, é Mestre e Doutora em História da Arte (UNL-FCSH, 1992 e 2001). Tem desenvolvido investigação especialmente na área da história do urbanismo colonial, sendo extenso o número de publicações e palestras apresentadas, assim como a sua integração em atividades profissionais e projetos científicos.

Entre as suas publicações, destacam-se: As Cidades da Amazónia no século XVIII: Belém, Macapá e Mazagão (1998) (Prémio José de Figueiredo); Actas do Colóquio internacional Universo Urbanístico Português 1415-1822, (co-coord. científica) (2001); Património de Origem Portuguesa no Mundo: arquitetura e urbanismo: América do Sul, (et. Al.) (2010).

\section{ROBERTO VECCHI}

Roberto Vecchi é professor catedrático de Literatura Portuguesa e Brasileira e de História da cultura portuguesa na Universidade de Bolonha. É diretor do Departamento de Línguas, Literatura e Culturas Modernas desta Universidade e coordenador da Cátedra Eduardo Lourenço. Em Portugal, é investigador associado do Centro de Estudos Sociais da Universidade de Coimbra e no Brasil, é pesquisador CNPq. É Honorary Professor (2012-2015) of Lusophone Studies at the School of Cultures, Languages and Area Studies na Universidade de Nottingham. É presidente (2014-2017) da AIL, a Associação Internacional de Lusitanistas. Entre as suas publicações, Excepção atlântica. Pensar a literatura da guerra colonial (Porto, 2010), a organização, com Margarida Calafate Ribeiro, da Antologia da memória poética da guerra colonial (Porto, 2011) e, sempre com Margarida Calafate Ribeiro, a organização do volume de Eduardo Lourenço, Do colonialismo como nosso impensado (Lisboa, 2014).

\section{SANDRA XAVIER}

Sandra Xavier é antropóloga e docente no Departamento de Ciências da Vida da Universidade de Coimbra, assim como no Programa de Doutoramento "Patrimónios de Influência Portuguesa" (III/CES). Tem publicado em 
revistas nacionais e internacionais, bem como divulgado a sua investigação em eventos científicos, sobre antropologia em articulação com estudos de imagem, arte, ciência, paisagem e arquitetura. No âmbito do Centro em Rede de Investigação em Antropologia (CRIA), tem como produções mais relevantes: "Para lá da oposição entre arquitectura erudita e arquitectura sem arquitectos”, in Sandra Xavier, Paulo Providência e Luís Quintais (Orgs.), Intersecções: Antropologia e Arquitectura (2011); "Em diferentes escalas: a arquitetura do Hospital-Colónia Rovisco Pais sob o olhar do médico Fernando Bissaya Barreto (1886-1974)”, História, Ciências, Saúde - Manguinhos (2013); "Imagem, ruína, fragmento", in Sandra Xavier, Paulo Providência (orgs.), Leprosaria Nacional: Modernidade e Ruína no Hospital-Colónia Rovisco Pais (2013).

SÍLVIO RENATO JORGE

Sílvio Renato Jorge é doutorado em Letras (Letras Vernáculas) pela Universidade Federal do Rio de Janeiro (1999). Desenvolveu estágios de Pós-Doutoramento na Universidade de São Paulo (2004) e no Centro de Estudos Sociais da Universidade de Coimbra (2009), com bolsa CAPES (Coordenação de Aperfeiçoamento de Pessoal de Nível Superior). É professor Associado da Universidade Federal Fluminense, onde atua como docente desde 1995, e pesquisador do CNPq (Conselho Nacional de Desenvolvimento Científico e Tecnológico) nível 1D. Das suas publicações, destacam-se: Sobre mulheres e estrangeiros: alguns romances de Olga Gonçalves (2009); África, escritas literárias: Angola, Cabo Verde, Guiné-Bissau, Moçambique, São Tomé e Príncipe (org. com Carmem Lúcia Tindó Secco e Maria Teresa Salgado, 2010); Literaturas Insulares; leituras e escritas de Cabo verde e São Tomé e Príncipe (org. com Margarida Calafate Ribeiro, 2011).

(http://lattes.cnpq.br/3744848219239914)

\section{VERA MARQUES ALVES}

Vera Marques Alves nasceu em Lisboa no dia 16 de maio de 1969. Em 1993, licenciou-se em Antropologia Social no ISCTE e, em 2008, doutorou-se, pelo 
mesmo Instituto, com a tese "Camponeses Estetas" no Estado Novo: Arte Popular e Nação na Política Folclorista do Secretariado da Propaganda Nacional. Colaborou em diversas obras coletivas: Vozes do Povo. A Folclorização em Portugal (2003), Enciclopédia da Música em Portugal no século XX (2010) e Como se faz um Povo (2010). É investigadora do CRIA (Centro em Rede de Investigação em Antropologia) e, desde 2011, Professora Auxiliar Convidada na Faculdade de Ciências e Tecnologia da Universidade de Coimbra, onde leciona diversas cadeiras na Licenciatura em Antropologia e no Mestrado em Antropologia Social e Cultural.

\section{WALTER ROSSA}

Walter Rossa (1962). Arquiteto pela Universidade Técnica de Lisboa (1985), mestre em História da Arte pela Universidade Nova de Lisboa (1991), doutor e agregado em Arquitetura pela Universidade de Coimbra (2001 e 2013). Docente do Departamento de Arquitetura, investigador no Centro de Estudos Sociais e, com Margarida Calafate Ribeiro, coordenador do programa de doutoramento "Patrimónios de Influência Portuguesa" na Universidade de Coimbra. Leciona teoria e história do urbanismo e do território. Investiga em teoria e história do urbanismo, em especial nos domínios da urbanística, da cultura do território e do património de influência portuguesa. Deu aulas, cursos e conferências no Brasil, Cabo Verde, Espanha, Estados Unidos da América, França, Holanda, Índia, Itália, Macau, México, Moçambique, Portugal, Singapura e Uruguai; comissariou eventos e exposições; dirigiu projetos editoriais e de investigação; tem textos ou livros publicados em Português, Inglês, Espanhol e Italiano. 
(Página deixada propositadamente em branco) 
Walter Rossa (1962). Arquiteto pela Universidade Técnica de Lisboa (1985), mestre em História da Arte pela Universidade Nova de Lisboa (1991), doutor e agregado em Arquitetura pela Universidade de Coimbra (2001 e 2013). Docente do Departamento de Arquitetura, investigador no Centro de Estudos Sociais e, com MargaridaCalafate Ribeiro, coordenador do programa de doutoramento "Patrimónios de Influência Portuguesa" na Universidade de Coimbra. Leciona teoria e história do urbanismo e do território.

Investiga em teoria e história do urbanismo, em especial nos domínios da urbanística, da cultura do território e do património de influência portuguesa. Deu aulas, cursos e conferências no Brasil, Cabo Verde, Espanha, Estados Unidos da América, França, Holanda, Índia, Itália, Macau, México, Moçambique, Portugal, Singapura e Uruguai; comissariou eventos e exposições; dirigiu projetos editoriais e de investigação; tem textos ou livros publicados em Português, Inglês, Espanhol e Italiano.

Margarida Calafate Ribeiro é investigadora-coordenadora no Centro de Estudos Sociais, Universidade de Coimbra, docente e coordenadora, com Walter Rossa, do programa de Doutoramento, "Patrimónios de Influência Portuguesa" e, com Roberto Vecchi, da Cátedra Eduardo Lourenço, Camões/Universidade de Bolonha. Em 2015 ganhou uma bolsa do Conselho Europeu de Investigação.

Das suas publicações destacam-se Uma história de regressos: Império, Guerra Colonial e Pós-colonialismo (2004), África no feminino: as mulheres portuguesas e a Guerra Colonial (2007) e a organização de vários livros: Fantasmas e fantasias imperiais no imaginário português contemporâneo (e Ana Paula Ferreira, 2003); Moçambique: das palavras escritas (e Paula Meneses, 2008); Lendo Angola (e Laura Padilha, 2008); Literaturas da Guiné-Bissau: cantando os escritos da história (e Odete Semedo, 2011); Antologia da memória poética da Guerra Colonial (e Roberto Vecchi, 2011). 


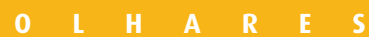

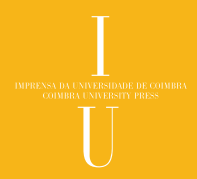

FUNDAÇÃO

YPA CALOUSTE

Eduff

GULBENKIAN 